551.49

Un 342kw

no. $88-4046$

\title{
CUMULATIVE POTENTIAL HYDROLOGIC IMPACTS OF SURFACE COAL MINING IN THE EASTERN POWDER RIVER STRUCTURAL BASIN, NORTHEASTERN WYOMING
}

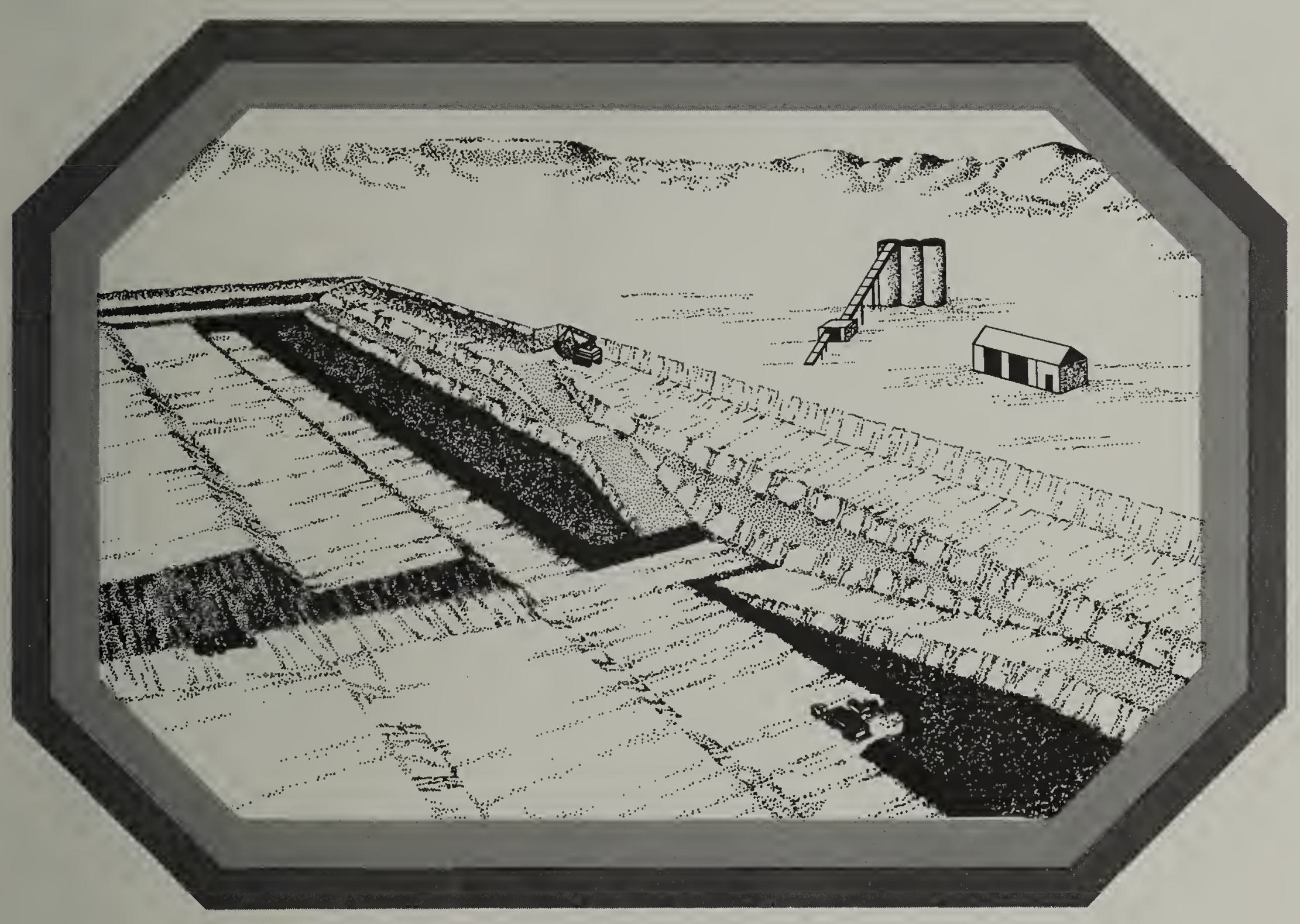

U.S. GEOLOGICAL SURVEY

Water-Resources Investigations Report 88-4046

Prepared in cooperation with the

WYOMING DEPARTMENT OF ENVIRONMENTAL QUALITY and the

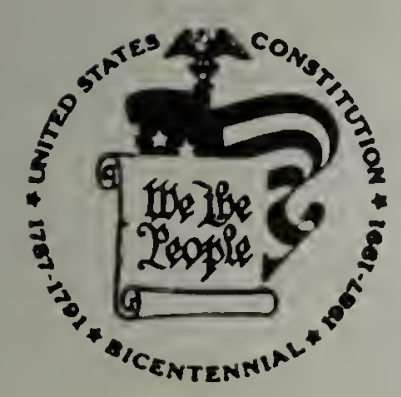

U.S. OFFICE OF SURFACE MINING

DEPPSITORY

JUL 151988

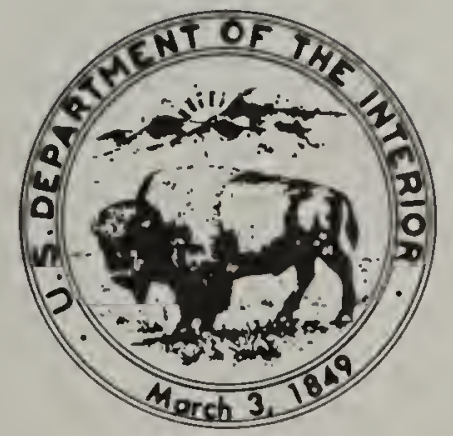



CUMULATIVE POTENTIAL HYDROLOGIC IMPACTS OF SURFACE COAL MINING

IN THE EASTERN POWDER RIVER STRUCTURAL BASIN, NORTHEASTERN WYOMING

By Lawrence J. Martin, David L. Naftz, H.W. Lowham, and J.G. Rankl

U.S. GEOLOGICAL SURVEY

Water-Resources Investigations Report 88-4046

Prepared in cooperation with the

WYOMING DEPARTMENT OF ENVIRONMENTAL QUALITY and the

U.S. OFFICE OF SURFACE MINING

Cheyenne, Wyoming

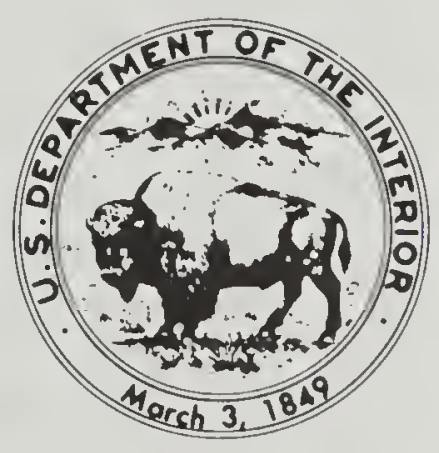


DEPARTMENT OF THE INTERIOR

DONALD PAUL HODEL, Secretary

U.S. GEOLOGICAL SURVEY

Dallas L. Peck, Director

For additional information write to:

District Chief

U.S. Geological Survey

2120 Capitol Avenue

P.0. Box 1125

Cheyenne, WY 82003
Copies of this report can be purchased from:

U.S. Geological Survey Books and Open-File Reports Federal Center, Building 810 P.0. Box 25425

Denver, CO 80225 


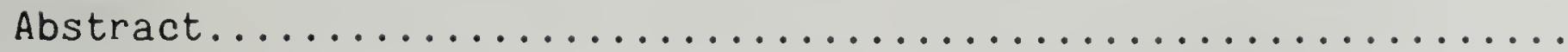

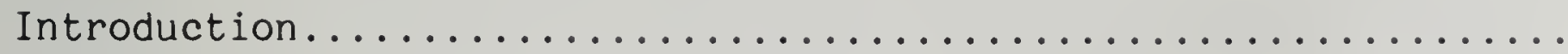

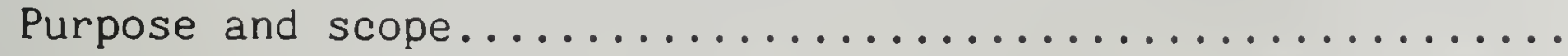

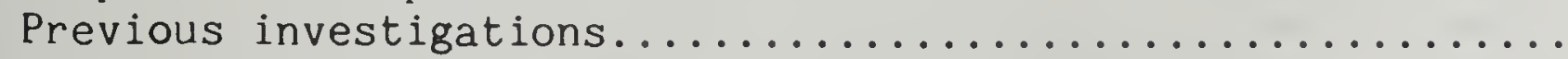

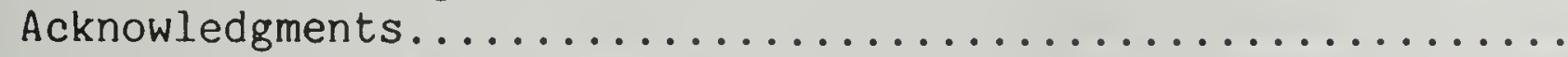

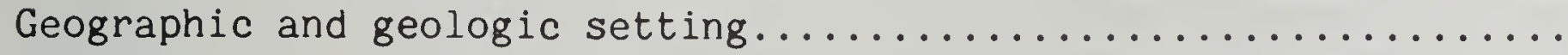

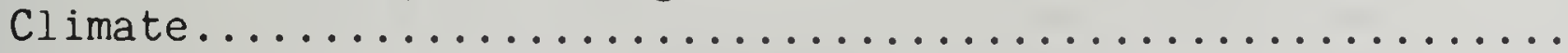

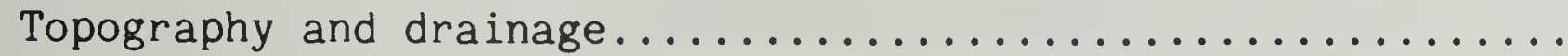

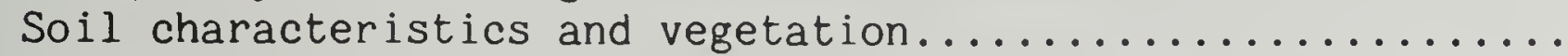

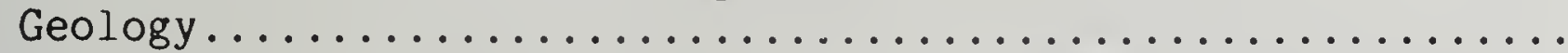

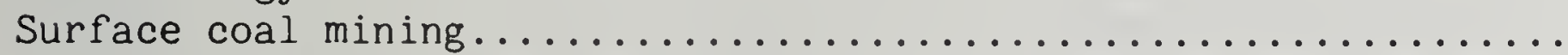

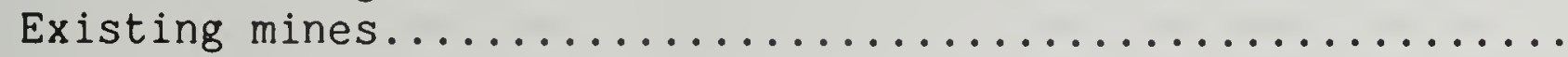

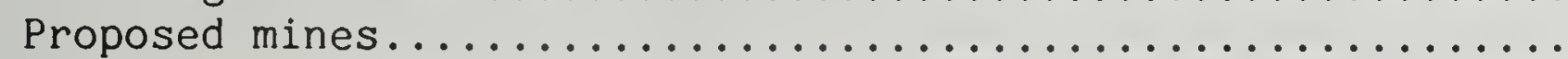

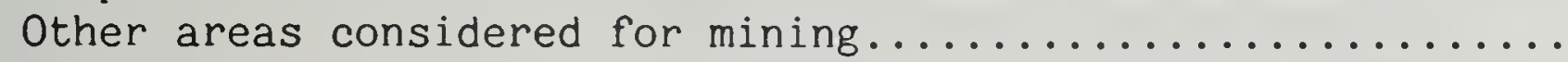

Definition of "all anticipated mining".................

Hydrogeology.

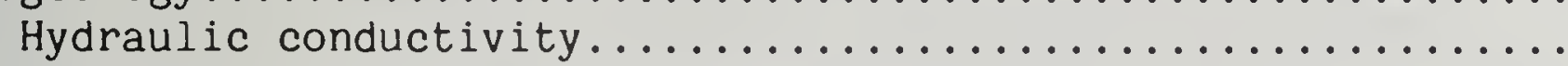

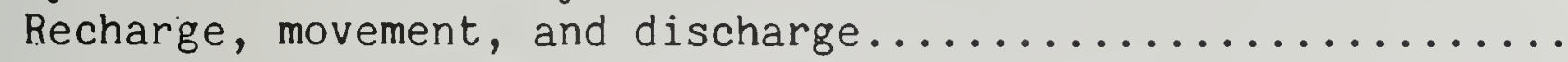

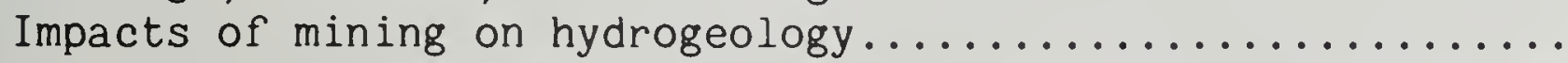

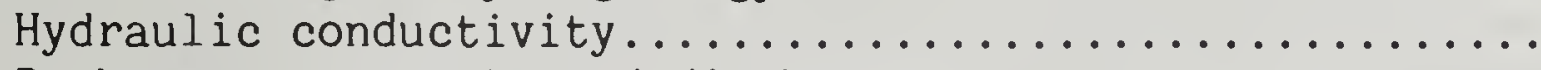

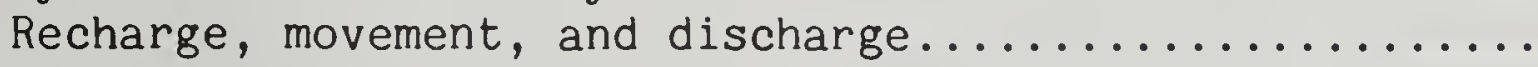

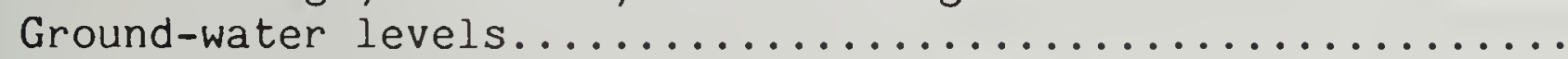

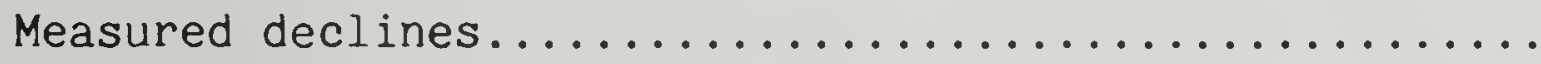

Predicted areal extent of declines resulting from

individual existing and proposed mines............ 26

Predicted areal extent of cumulative declines

resulting from all existing and proposed mines.......

Predicted areal extent of cumulative declines

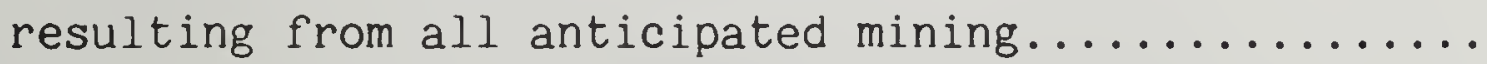

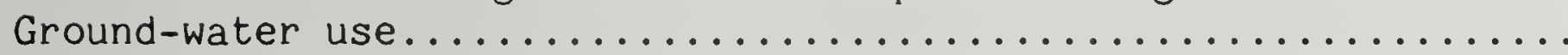

Impacts of water-level declines on ground-water use.........

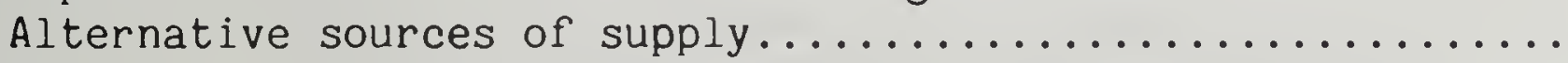

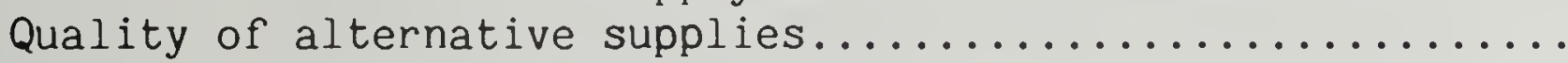

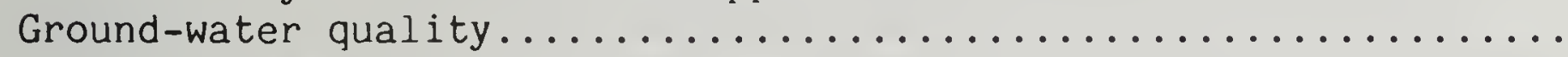

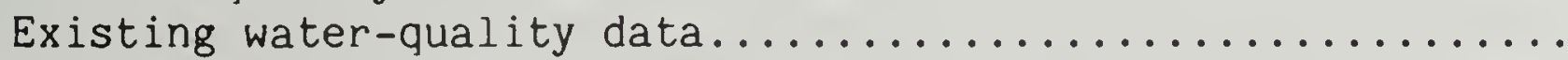

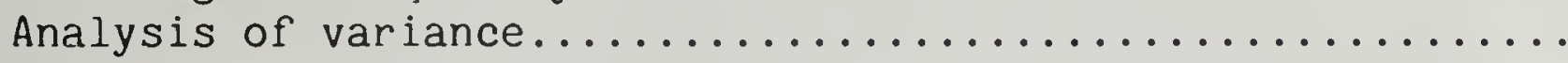

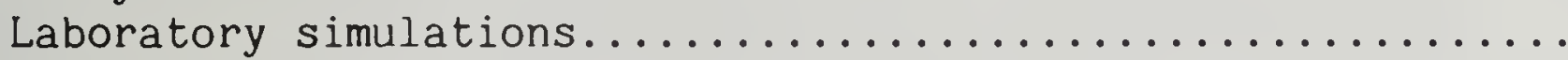

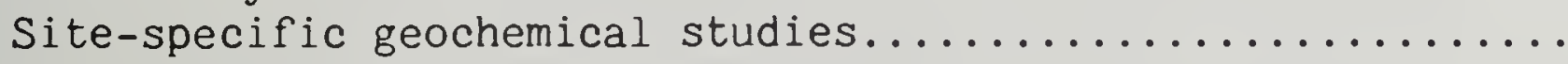

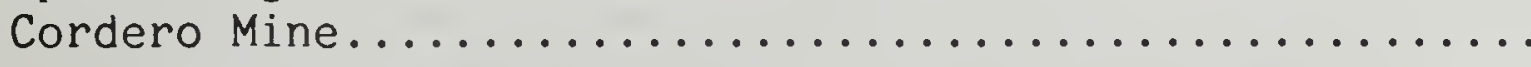

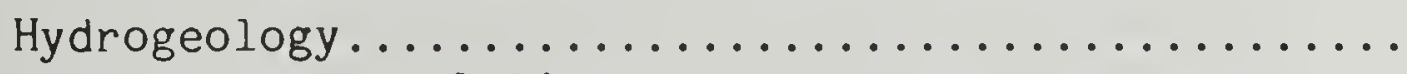

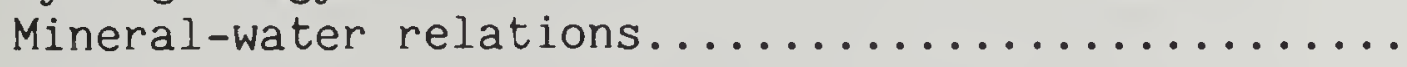

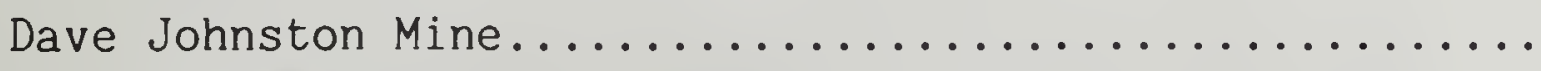

Hydrogeology .........................

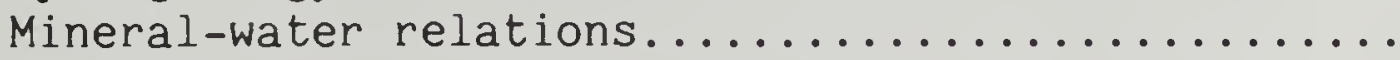

Possible offsite water-quality changes in the Wyodak coal

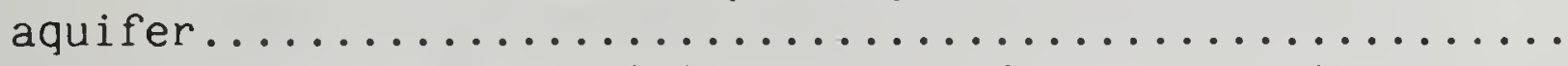

Impacts of surface coal mining on ground-water quality......

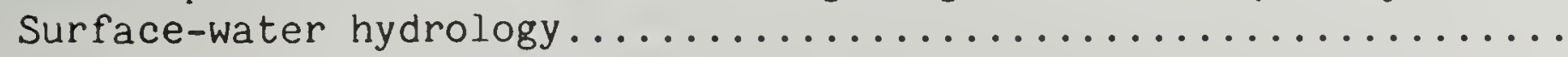

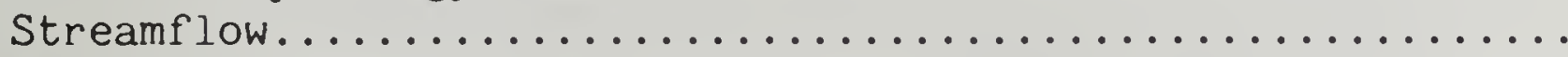

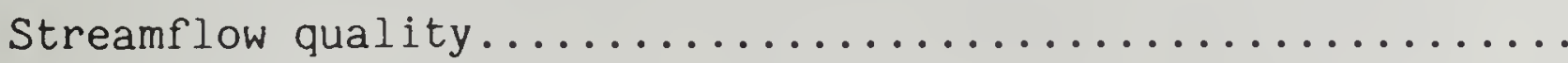

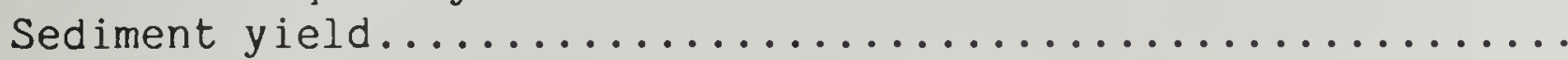

Water rights. 
Impacts of surface coal mining on surface-water hydrology....

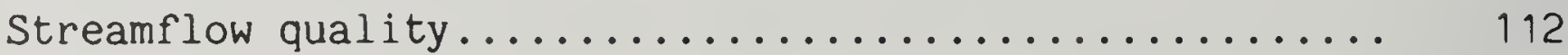

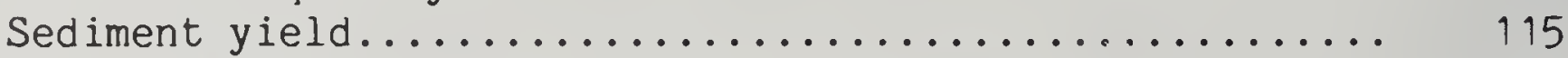

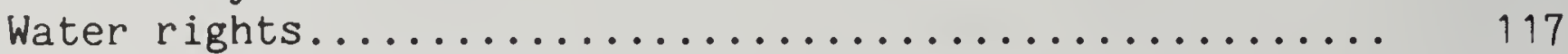

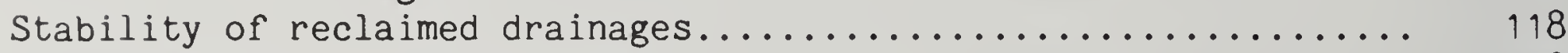

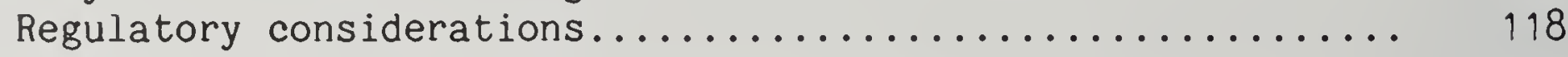

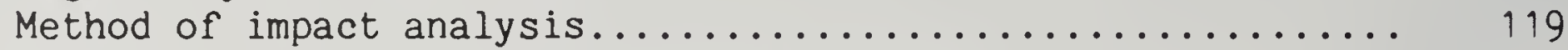

Characteristics of natural drainage basins.............. 122

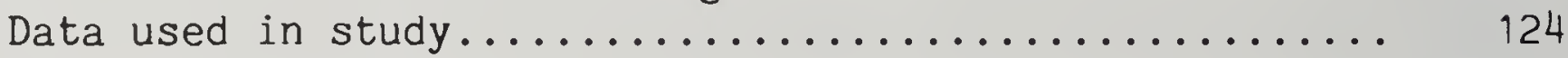

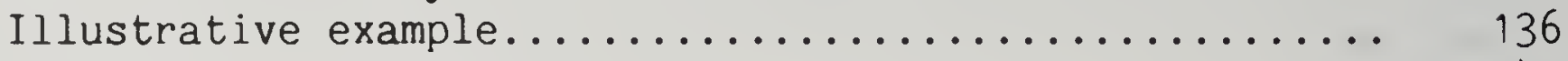

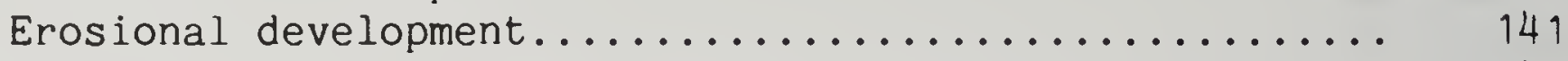

Impacts of surface coal mining on drainage-basin stability... 141

Characteristics of postmining drainage basins.......... 145

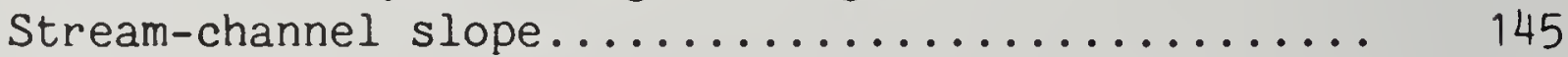

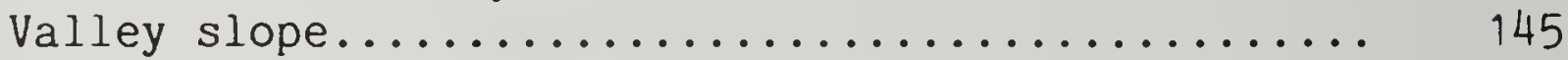

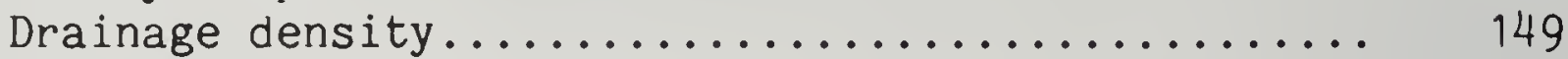

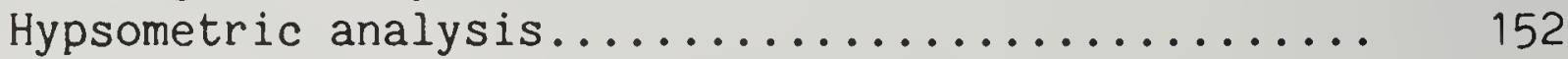

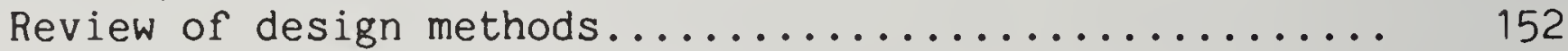

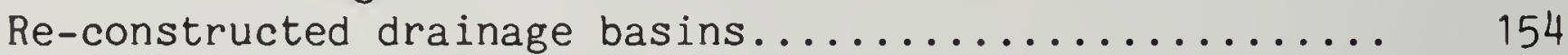

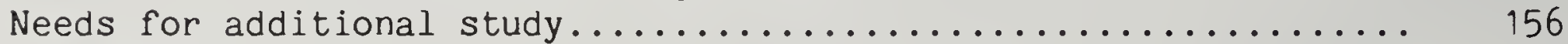

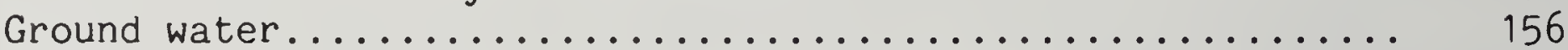

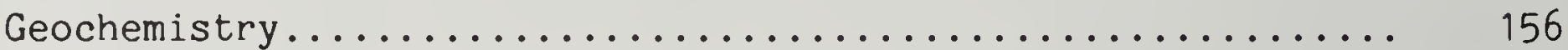

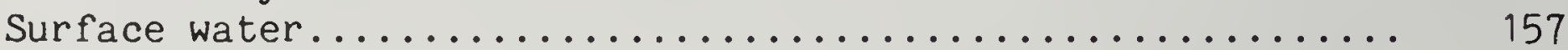

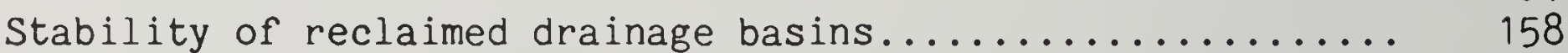

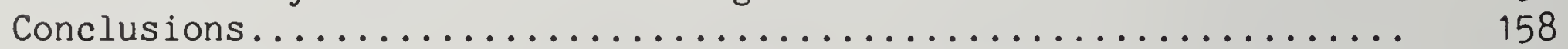

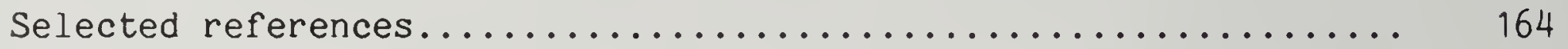

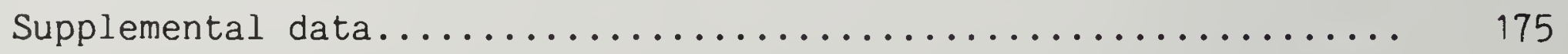

\section{PLATES}

Plate 1. Map showing status of coal leasing, 1987, and overburden thickness, eastern Powder River structural basin, northeastern Wyoming........... In pocket

2. Map showing predicted extent of water-level declines in the Wyodak coal aquifer and areas of all anticipated coal mining, eastern Powder River structural basin, northeastern Wyoming...........

In pocket

3. Map showing location of water-supply wells completed in the Wasatch aquifer and Wyodak coal aquifer in the area of water-level decline resulting from all anticipated coal mining, eastern Powder River structural basin, northeastern Wyoming.......... In pocket

4. Map showing projected maximum disturbed areas, location of streamflow-gaging stations and drainage-basin boundaries, eastern Powder River structural basin, northeastern Wyoming.......... In pocket

5. Map showing coal-lease areas and surface-water rights, eastern Powder River structural basin, northeastern Wyoming................... In pocket 


\section{FIGURES}

Figure 1. Map showing location of the study area and the

Powder River structural basin in Wyoming.........
Map showing surficial geology within and adjacent

2. Map showing surficial geology within and adjacent

3. Sketch of typical mining and reclamation

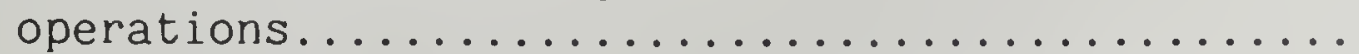

4. Diagram showing relation of stratigraphic units to hydrogeologic units...................

5-7. Graphs showing:

5. Frequency distribution of the logs of hydraulic-conductivity values from aquifer tests of the Wasatch aquifer..............

6. Frequency distribution of the logs of hydraulic-conductivity values from aquifer tests of the Wyodak coal aquifer...........

7. Comparison of probability distribution of the logs of hydraulic-conductivity values for the Wyodak coal aquifer for three subareas

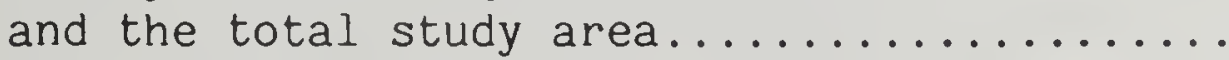

8. Map showing location of sampling sites for which water-quality data are available for water samples from aquifers in Upper Cretaceous

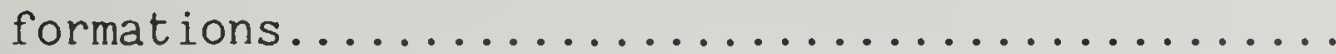

9. Histograms of selected water-quality constituents in water samples from aquifers in Upper

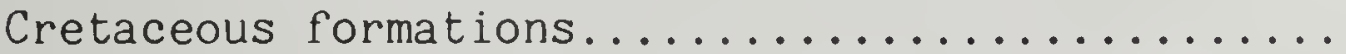

10. Map showing location of surface coal mines where data for determining the water quality in aquifers and the chemical composition of constituents in overburden were collected........

11. Graphs showing changes in the dissolved-solids, sulfate, and nitrate concentrations, as a function of time, in water samples from wells completed in the spoil aquifers at selected

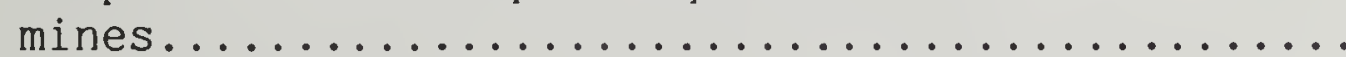

12. Graphs showing changes in the chromium and selenium concentrations, as a function of time, in water samples from wells completed in the

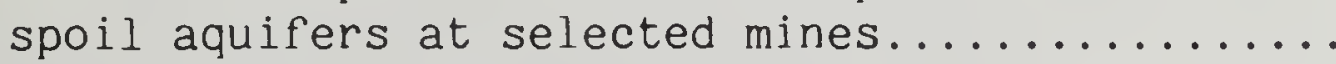

13. Diagram showing design of unbalanced analysis of variance used for water-quality data sets for the Wyodak coal aquifer and spoil aquifers.......

14. Graph showing the variance ratio that can be used to approximate the number of random water samples needed from each unit area in order to describe the gross differences among a number

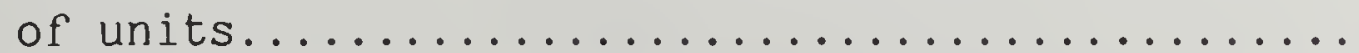

15-20. Graphs showing:

15. Comparison of concentrations in batch-extract water to actual concentrations of alkalinity, calcium, sodium, and sulfate in water from the spoil aquifer sampled during July 1984 at the Cordero Mine....... 
16. Comparison of dissolved-solids concentration

in water derived from selected column-

leaching tests to the number of pore

volumes of water leached through the

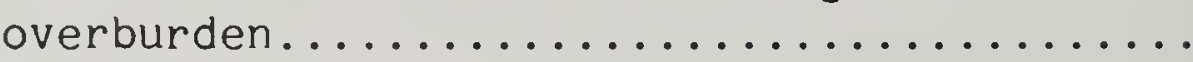

17. Comparison of dissolved-nitrate

concentration in water derived from

selected column-leaching tests to the

number of pore volumes of water leached

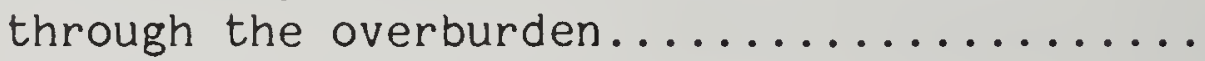

18. Comparison of dissolved-selenium

concentration in water derived from

selected column-leaching tests to the

number of pore volumes of water leached

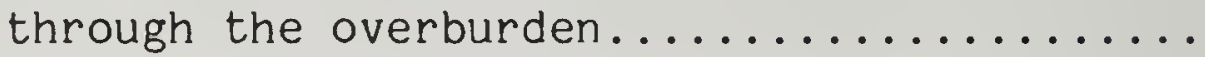

19. Dissolved-solids and nitrate concentrations

in the first effluent from selected

column-leaching tests in relation to the

specific conductance and extractable-

nitrate content in the overburden

material used in the tests...............

20. Total-selenium content in overburden and coal samples from the Caballo and Keeline

Mines...........................

21. Map showing potentiometric surface of the Wyodak coal aquifer during December 1981 and location of water-quality sampling sites, Cordero Mine....

22. Diagrammatic geologic section of the Wyodak coal bed of the Tongue River Member of the Fort Union Formation and associated strata, and the spoil aquifer after mining, Cordero Mine........

23-25. Graphs showing:

23. Comparison of the isotopic composition of ground-water samples from the Cordero Mine to the isotopic composition of North

American continental precipitation..........

24. Correlation of $\delta^{18} 0$ composition of continental precipitation compared to the average monthly temperature from continental stations superposed with the $\delta^{18} 0$ composition of ground-water samples from the Cordero Mine...................

uantity of dissolved calcite in relation

to quantity of dissolved pyrite predicted to dissolve in water under equilibrium conditions superposed with the quantities of dissolved calcite and pyrite predicted by reaction models 1 and 3 , Cordero Mine....

26. Diagrammatic geologic section showing the Badger and School coal beds of the Wasatch Formation, and associated strata after mining, Dave Johnston Mine......................... 
27. Map showing potentiometric surface of the School coal aquifer during December 1981 and location of water-quality sampling sites, Dave Johnston

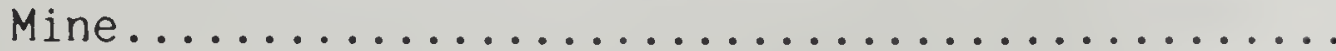

28-32. Graphs showing:

28. Comparison of the isotopic composition of ground-water samples from the Dave Johnston Mine to the isotopic composition of North American continental

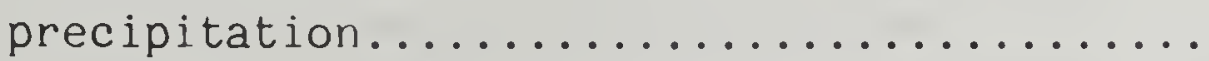

29. Correlation of $\delta^{18} 0$ composition of continental precipitation compared to the average monthly temperature from continental stations superposed with the $\delta^{18} O$ composition of ground-water samples from the Dave Johnston Mine..............

30. Tritium concentration in ground-water samples in relation to the distance downgradient from well DSP-1 completed in the spoil aquifer, Dave Johnston Mine.......

31. Actual dissolved-solids concentrations in wells DSP-1, DCO-30, and DCO-37, and the calculated dissolved-solids concentration based on isotopic ratios for well DCO-30....

32. Changes in concentrations of calcium, alkalinity, sulfate, and dissolved solids in relation to the reaction increments using the reaction-path geochemical model PHREEQE.....................

33. Map showing location of streamflow-gaging stations and drainage basins used in surface-

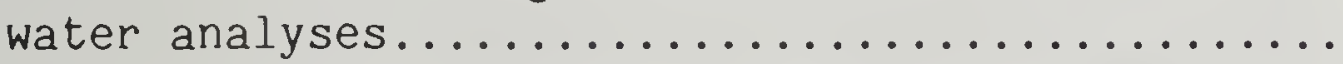

34. Map showing typical drainage basin used for analysis of runoff and an example of runoff

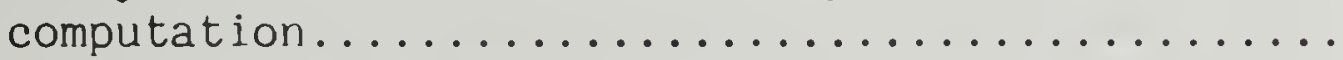

35-39. Graphs showing:

35. Relation of total sediment load to peak discharge for storm runoff, Coal Creek

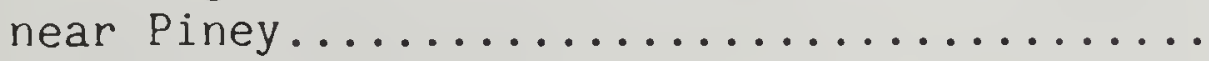

36. Average percentage difference between infiltration rates for natural and reclaimed soils at the Belle Ayr Mine.......

37. Sensitivity analysis for hypothetical changes in runoff in Black Thunder Creek....

38. Analysis of runoff and change in runoff for storm of May 27-28, 1981, Coal Creek near

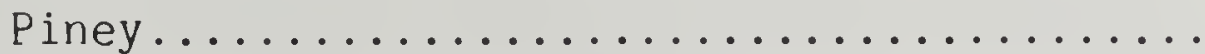

39. Relation between sediment accumulation in reservoirs and drainage area, upper Cheyenne River basin..................

40. Photograph showing example of discontinuous gully with slowly advancing headcuts as part of a

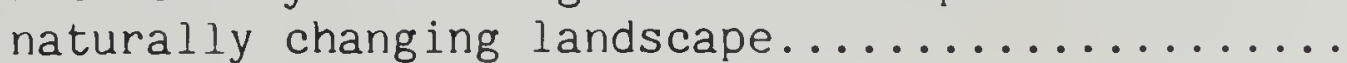


41. Sketch of a drainage network with a dendritic pattern in a third-order drainage basin showing first-, second-, and third-order streams........

42. Map showing location of drainage basins used to determine physical characteristics...........

43-45. Graphs showing relation(s) of:

43. Drainage-basin order to drainage area........ 136

44. Number of stream channels to drainage area.... 137

45. Stream-channel and valley slopes to

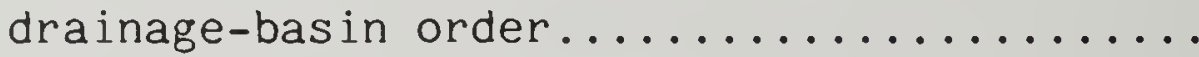

46-48. Graphs showing average hypsometric curve for:

46. Second-order drainage basins.............. 142

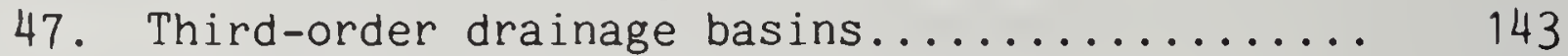

48. Fourth-order drainage basins............... 144

49. Graph showing comparison of stream-channel slopes

for natural and postmining drainage basins......

50. Graph showing comparison of valley slopes for natural and postmining drainage basins..........

51. Sketch showing effects of drainage density and relief on hillslope inclination and length......

52. Sketch showing end-of-mine reclamation problem resulting from shortage of material to re-construct small drainage basins............

\section{TABLES}

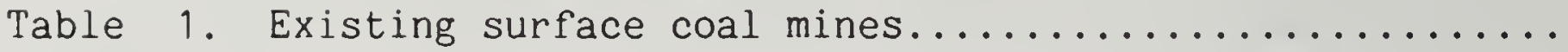

2. Proposed surface coal mines including mines that have been granted permits, but that have not been

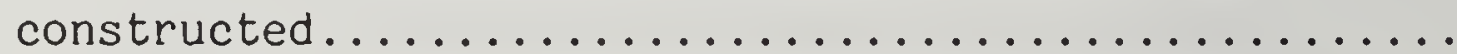

3. Selected Coal Tracts and Preference Right Lease

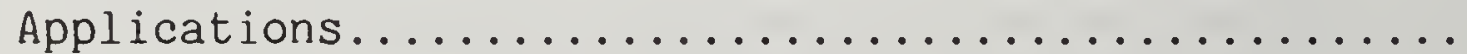

4. Percentage of samples with concentrations exceeding State standards and statistical summary of selected constituents in water samples from the Wasatch aquifer, Wyodak coal aquifer, and spoil aquifers from selected coal mines................

5. Summary of dissolved-solids concentrations in water from the Wasatch aquifer, Wyodak coal aquifer, and

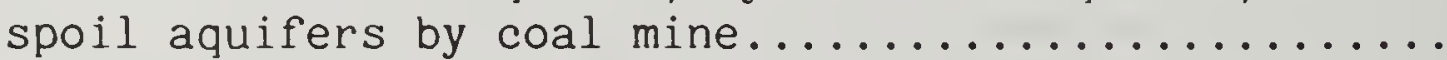

6. Comparison of estimated logarithmic variance components for selected chemical properties and constituents in samples of water from the Wyodak

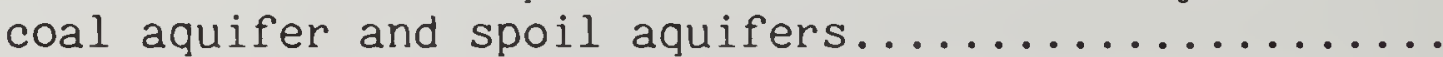

7. Isotopic ratios or activities of isotopes in groundand surface-water samples collected at Cordero Mine..

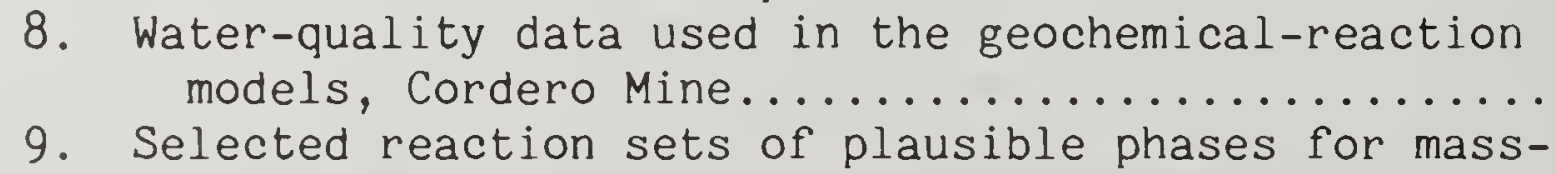

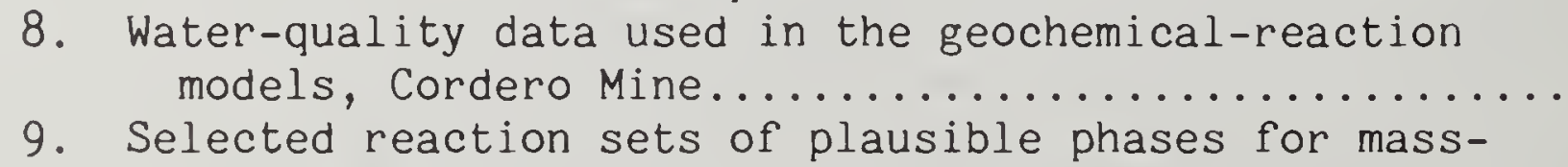
balance calculations, Cordero Mine...............

10. Pertinent chemical reactions...................... 
11. Results of mass-balance calculations for water from the well completed in the clinker aquifer and from

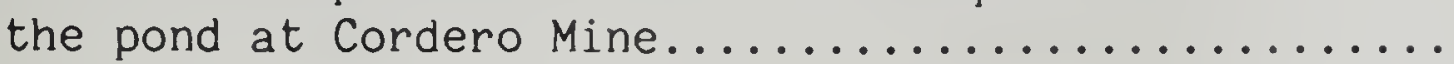

12. Isotopic ratios or activities of isotopes in groundwater samples collected at Dave Johnston Mine.......

13. Chemical analyses of water samples collected from pressure-vacuum lysimeters at Dave Johnston Mine.....

14. Streamflow-gaging stations operated by the U.S.

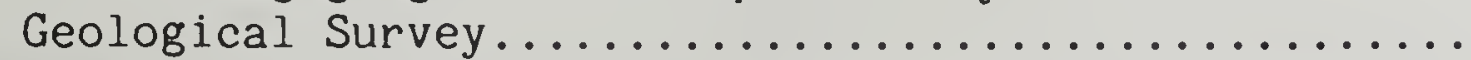

15. Average annual runoff from drainage basins upstream from streamflow-gaging stations with more than 5

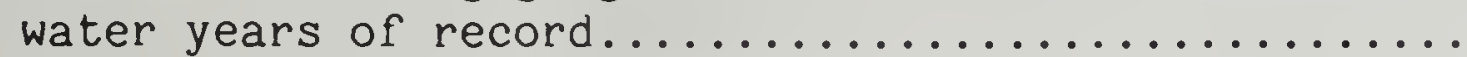

16. Sediment data for three sediment-sampling stations in the Belle Fourche River basin................

17. Summary of rainfall-simulator tests comparing infiltration rates for natural and reclaimed soils...

107

18. Projected maximum areas of drainage basins to be disturbed during mining of selected existing and proposed mines, and increases in runoff in major

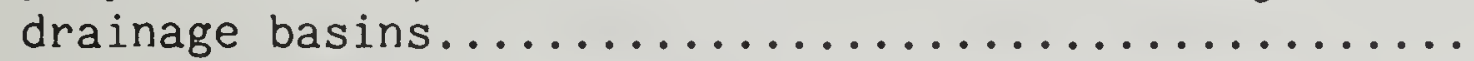

19. Projected maximum areas of drainage basins to be disturbed during all anticipated mining and increases in runoff in major drainage basins........

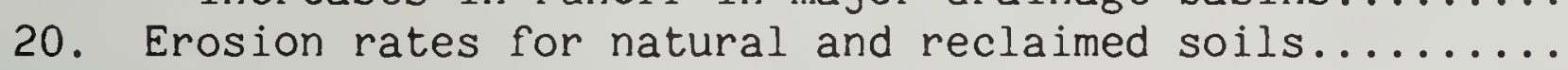

21. Characteristics measured in drainage-basin-stability

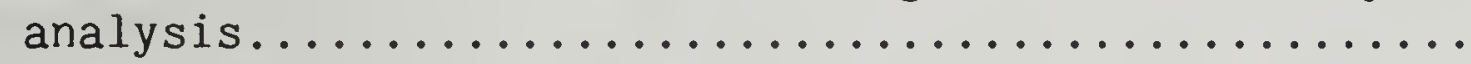

22. Physical characteristics for second-, third-, and

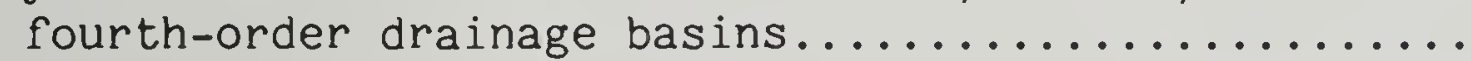

23. Physical characteristics for first-order drainage

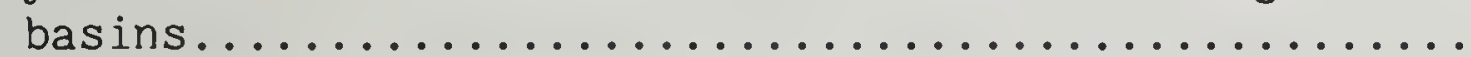

24. Statistical properties for first-order drainage

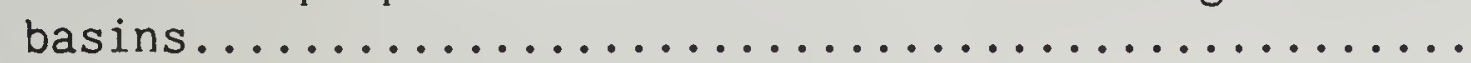

25. Statistical properties for second-order drainage

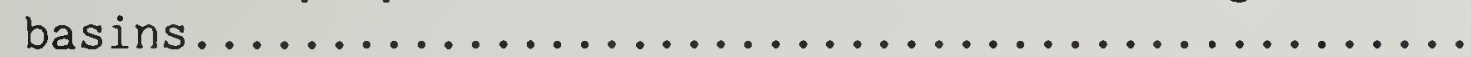

26. Statistical properties for third-order drainage

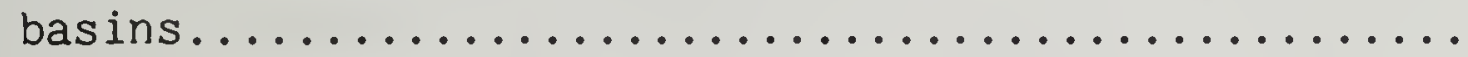

27. Statistical properties for fourth-order drainage

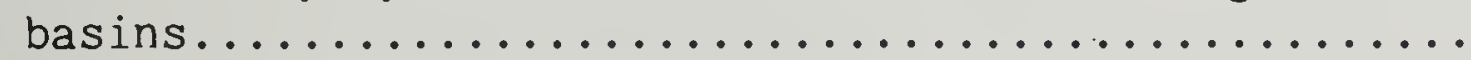

28. Summary of correlation analysis of physical characteristics for drainage basins..............

29. Summary of regression analysis...................

30. Physical characteristics for example drainage basin....

31. Physical characteristics for sample of postmining

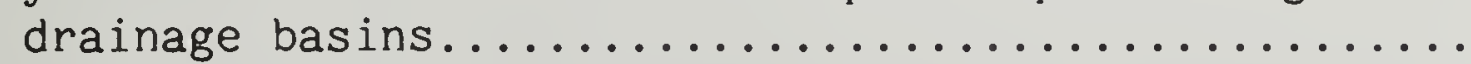

32. Privately owned water-supply wells in the area of potential cumulative water-level declines...........

33. Surface-water data network operated by coal-mining

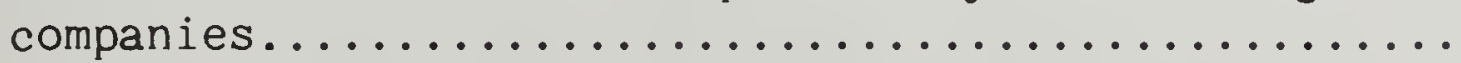




\section{CONVERSION FACTORS}

For use of readers who prefer to use metric (International System) units, rather than the inch-pound units used in this report, the following conversion factors may be used:

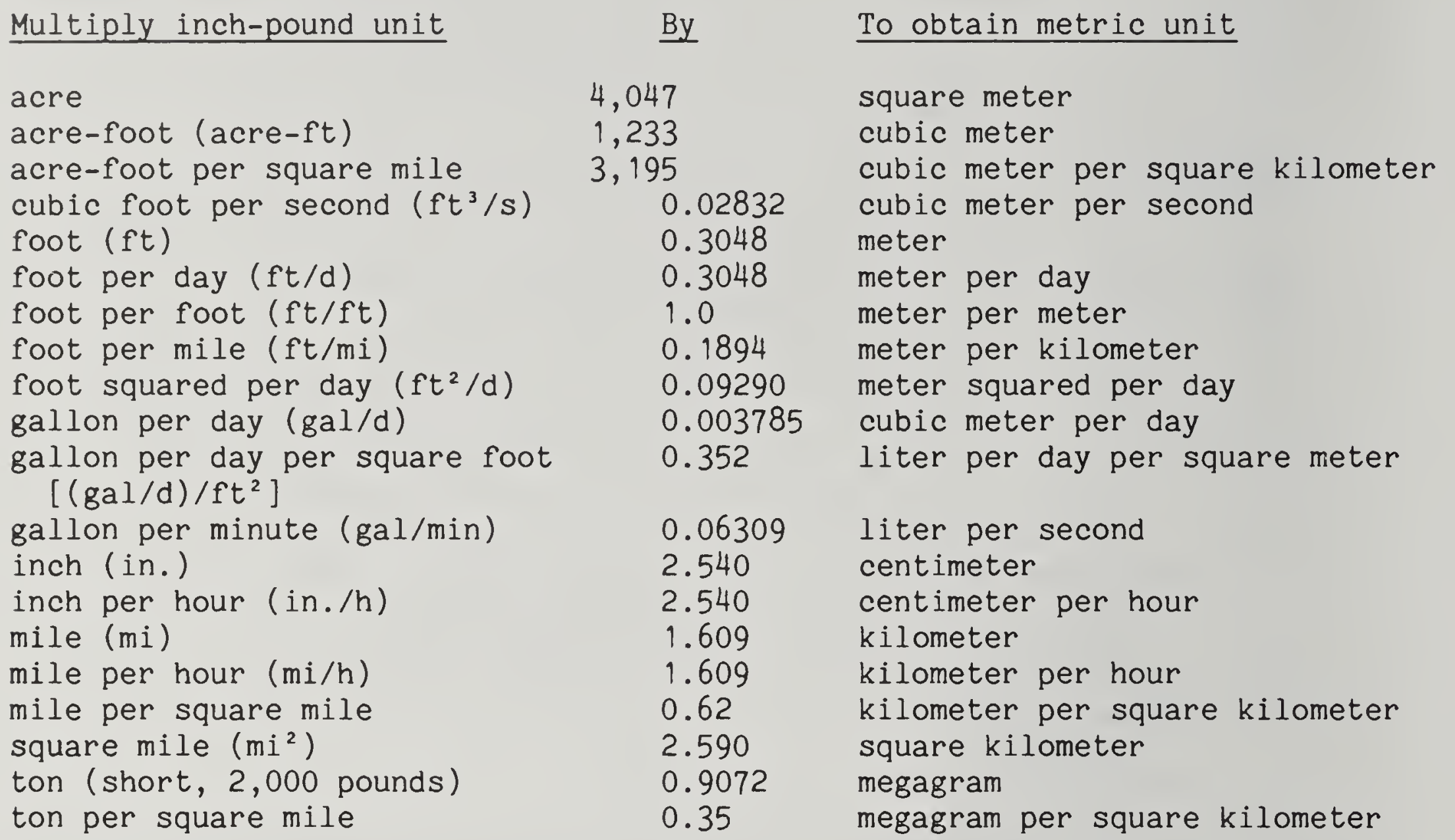

Temperature in degrees Fahrenheit $\left({ }^{\circ} \mathrm{F}\right)$ and degrees Celsius $\left({ }^{\circ} \mathrm{C}\right)$ can be converted by the following equations:

and

$$
{ }^{\circ} \mathrm{F}=9 / 5\left({ }^{\circ} \mathrm{C}\right)+32
$$

$$
{ }^{\circ} \mathrm{C}=5 / 9\left({ }^{\circ} \mathrm{F}-32\right) \text {. }
$$


IN THE EASTERN POWDER RIVER STRUCTURAL BASIN, NORTHEASTERN WYOMING

By Lawrence J. Martin, David L. Naftz, H.W. Lowham, and J.G. RankI

\section{ABSTRACT}

There are 16 existing and 6 proposed surface coal mines in the eastern Powder River structural basin of northeastern Wyoming. In addition to the areas already developed for surface coal mines or being considered for mining, there are large tracts remaining that have thick deposits of coal suitable for extraction by surface-mining methods. Coal-mining companies predict water-level declines of 5 feet or more in the Wasatch aquifer to extend from about 1,000 to about 2,000 feet beyond the mine pits. The predicted 5-foot water-level decline in the Wyodak coal aquifer generally extends 4 to 8 miles beyond the lease areas.

About 3,000 wells are in the area of potential cumulative water-level declines resulting from all anticipated mining. of these 3,000 wells, about 1,200 are outside the areas of anticipated mining: about 1,000 wells supply water for domestic or livestock uses, and about 200 wells supply water for municipal, industrial, irrigation, and miscellaneous uses. The 1,800 remaining wells are used by coal-mining companies. According to well logs and completion reports for these wells, about 580 wells are completed in the Wasatch aquifer, about 100 in the Wyodak coal aquifer, and about 280 in aquifers below the wyodak coal bed. Stratigraphic location of the completion interval could not be determined for about 260 wells because of lack of information on the well-completion report. Alternative sources of water that could replace the wells significantly impacted by mining operations are the Tongue River-Lebo aquifer (Fort Union Formation) for domestic and livestock supplies, and either the Tullock (Fort Union Formation) or Lance-Fox Hills (Upper Cretaceous) aquifers for uses requiring a larger yield. Although the quality of water from these alternative sources does not always meet the standard for domestic water supplies prescribed by the Wyoming Department of Environmental Quality, the quality of water approximates the quality of water currently (1987) being used for domestic supplies.

On the basis of the compiled premining (Wasatch aquifer and Wyodak coal aquifer) and postmining (spoil aquifers) water-quality data, the majority of current and future postmining water will be of suitable quality to meet the State standard for livestock watering. Future surface coal mining probably will result in postmining ground water of similar quality to that currently present in the study area. Column-leaching-test results compiled from three mines in the study area are variable depending on the type of water used in the columns (deionized versus actual ground 
water) and the chemical composition of the overburden. Decreases in the concentrations of dissolved solids, nitrate, and selenium in future postmining water are predicted based on the columnleaching-test results.

Geochemical data collected at the Cordero and Dave Johnston Mines were used to predict future ground-water-quality changes and to identify reclamation methods that could minimize future postmining water-quality degradation. Isolation of overburden material with large soluble-salt contents to areas above the postmining ground-water table in conjunction with decreasing the rates of surface-water infiltration in the spoil aquifer could minimize increases in dissolved-solids concentrations in future reclaimed areas. Furthermore, isolation of spoil material with large soluble-salt contents from clay-rich and organic-rich strata during backfilling also could minimize increases in dissolvedsolids concentrations in postmining ground water.

By use of geochemical-modeling techniques, the results of a hypothetical reaction-path exercise indicate the potential for marked improvements in postmining water quality because of chemical reactions as a postmining ground water with a large dissolved-solids concentration (3,540 milligrams per liter) moves into a coal aquifer with relatively small dissolved-solids concentrations ( $910 \mathrm{milligrams}$ per liter). Results of the modeling exercise also indicate geochemical conditions that are most ideal for large decreases in dissolved-solids concentrations in coal aquifers receiving recharge from a spoil aquifer.

Infiltrometer studies indicate that reclaimed soils have, on the average, a 29-percent slower infiltration rate than that of undisturbed soils. In addition, the data indicate a trend for the infiltration rates to return to premining rates. For the purpose of computing the effective change in infiltration, it was assumed that runoff had an inverse corresponding rate. The computation of runoff using disturbed areas for all anticipated mining is a worst-case condition and indicates a maximum increase in runoff of 7.6 percent for Coal Creek and 5.3 percent for Little Thunder creek. The remainder of the drainage basins analyzed for the worst-case condition had increases in runoff of less than 5 percent.

Analyses of changes in sediment yield are limited due to a lack of data; therefore, predictions of cumulative changes in sediment yield are subjective. The larger sediment yield from reclaimed soils probably will not be conveyed to the streams in the basins due to sediment deposition as a result of flatter slopes on re-constructed hillsides and sediment entrainment by sediment-settling ponds.

Postmining drainage networks and stream channels have been and are being designed with attention to existing geomorphic conditions and accepted engineering principles. In general, re-constructed stream and valley slopes are and will be consistent 
with natural conditions for the area; however, re-constructed drainage basins have and will have fewer streams than natural basins. Although additional first-order channels likely will form in the reclaimed basins, the practice of re-constructing only higher-order major channels is believed to have advantages of: (1) Allowing flatter hillslopes with resulting greater re-vegetation success, and (2) providing smaller sediment yields than if drainage networks were fully re-constructed to premining densities.

\section{INTRODUCTION}

The Wyoming Department of Environmental Quality, Land Quality Division, in cooperation with the U.S. Office of Surface Mining, Department of the Interior, is required to assess the probable cumulative impacts of current and anticipated mining on the ground-and surface-water systems each time a mine-permit application is made. The assessment is required by the Surface Mining Control and Reclamation Act of 1977 (Public Law 95-87) and Wyoming Department of Environmental Quality, Land Quality Division, Rules and Regulations (Wyoming Department of Environmental Quality, 1986).

The Wyoming Dedartment of Environmental Quality is assessing the potential cumulative impacts of surface coal mining in the eastern Powder River structural basin (hereinafter referred to as the eastern Powder River basin). In order to provide the hydrologic information needed to assess the cumulative impacts of all anticipated mining in sufficient detail, the U.S. Geological Survey, in cooperation with the Wyoming Department of Environmental Quality and the U.S. Office of Surface Mining, conducted a study of the hydrology of the eastern Powder River basin.

\section{Purpose and Scope}

The purpose of this report is to describe the cumulative effects of all current (1987) and anticipated surface coal mining on the hydrologic system in the eastern Powder River basin, Wyoming (fig. 1). Specific objectives of the study, which was conducted during 1986-87, included the following:

1. Determine the potential, cumulative ground-water-level declines in the overburden (Wasatch aquifer) and the coal (Wyodak aquifer) as a result of surface coal mining at existing (1987) and proposed mines and the effects of declines on ground-water use.

2. Determine the availability and quality of alternative groundwater supplies not disturbed by surface coal mining.

3. By use of existing data from surface coal mines in the study area, define the current premining (Wasatch aquifer and Wyodak coal aquifer) and postmining (spoil aquifer) ground-water quality, identify chemical constituents that exceed water-use criteria, and evaluate future ground-water-quality monitoring needs. 


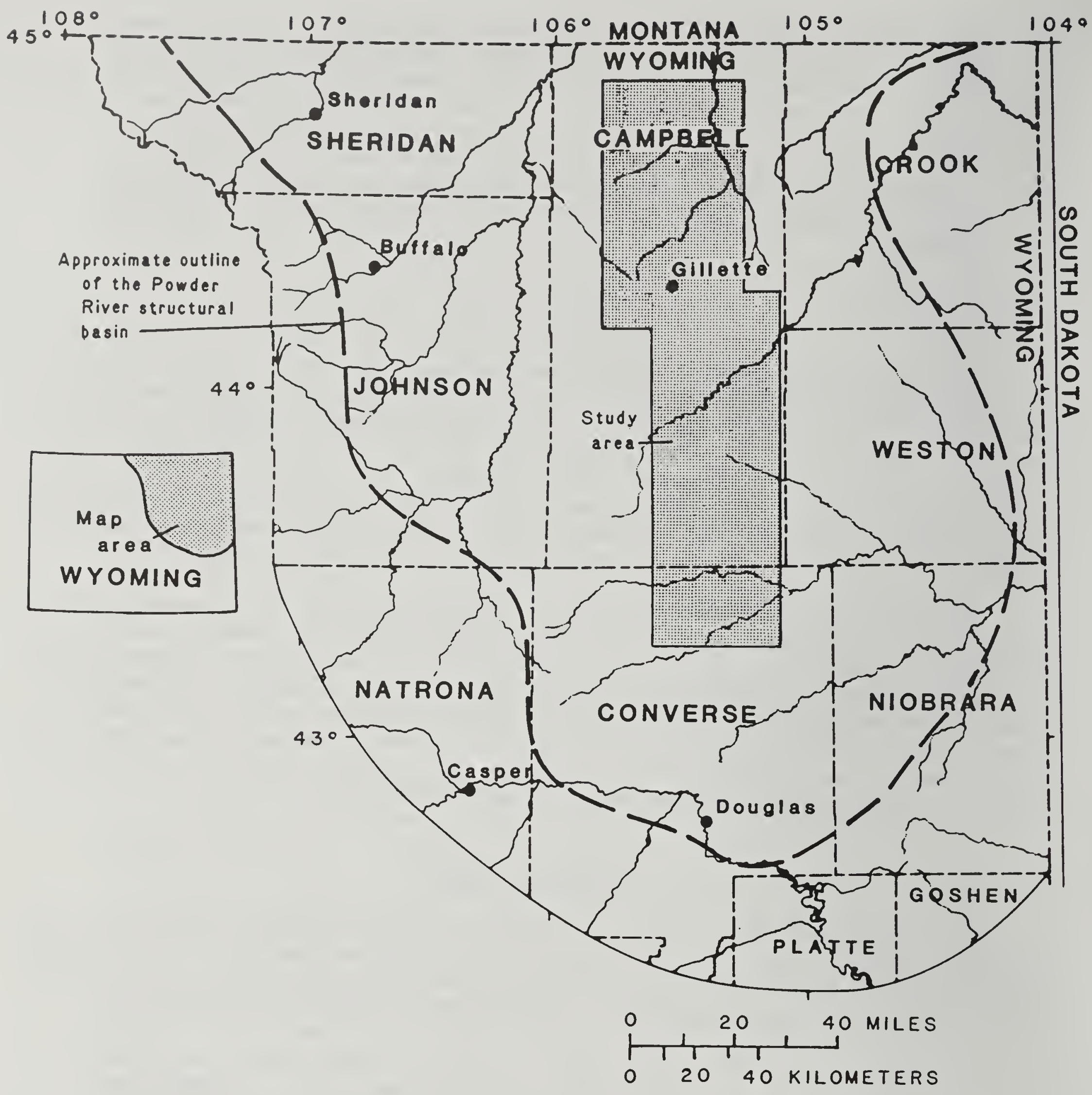

Figure 1.--Location of the study area and the Powder River structural basin in Wyoming. 
4. By use of existing data from batch-mixing and column-leaching experiments, evaluate their predictive capabilities for selected chemical constituents.

5. By use of detailed and site-specific geochemical data from two surface coal mines, define the possible geochemical reactions that control the postmining water quality in the coal and spoil aquifers, investigate possible future ground-waterquality changes in coal and spoil aquifers, and identify reclamation methods that could minimize future postmining water-quality degradation in the spoil aquifer.

6. By use of geochemical-modeling techniques to determine hypothetical reaction paths, estimate possible water-quality changes that might occur in the coal aquifer as a result of offsite movement of postmining ground water from a spoil aquifer.

7. Determine if a significant change in runoff will occur in the Little Powder, Belle Fourche, and Cheyenne River drainage basins as a result of surface coal mining.

8. Determine whether surface coal mining will cause either an increase or decrease in sediment yield.

9. Determine if postmining drainage networks and stream channels will be stable by evaluating the stability of reclaimed drainages.

\section{$\underline{\text { Previous Investigations }}$}

A narration about the eastern Powder River basin is published in the Wyoming Geological Association 13th Annual Field Conference Guidebook (Wyoming Geological Association Guidebook Committee, 1958). The guidebook contains the geologic history of the area, the stratigraphy of the underlying rocks, the economic importance of the mineral resources, and a general bibliography.

A hydrologic study of the area by Hodson and others (1973) describes the general geology, availability of ground water, chemical quality of the ground water, and streamflow characteristics. Breckenridge and others (1974) provide a synoptic view of the geology, hydrology, land use, and mineral resources of the area.

Koch and others (1982) investigated the regional effects of surface mining on the ground-water system in the eastern Powder River basin. This investigation, funded by the U.S. Bureau of Mines, used computer-based models to simulate ground-water flow, surface-water flow, and water quality. 
A comprehensive report by Lowry, Wilson, and others (1986) summarizes the hydrology of the entire Powder River drainage basin and parts of adjacent drainage basins. It is one of a series of reports by the U.S. Geological survey that resulted from a nationwide program to summarize the hydrology of areas within the major coal provinces of the United States.

Bloyd and others (1986) investigated the effects of surface coal mining on the surface- and ground-water systems in the eastern Powder River basin. A computer model of surface-water flow in the Belle Fourche River drainage basin was developed and physical characteristics of 102 drainage subbasins in the area were determined. Premining and postmining ground-water quality data also were compiled from selected mines in the basin.

A map of the premining potentiometric surface for the Wyodak-Anderson coal bed in Campbell County was constructed by Daddow (1986). The potentiometric surface indicates ground-water movement is from the coal outcrops toward the north and northwest and that the coal bed is recharged along its outcrop.

Rankl and Lowry (in press) looked for evidence of regional ground-water discharge to streams in the area. They found little evidence of groundwater discharge from a regional flow system and concluded that local groundwater systems are much more likely to be affected by coal development than the regional flow system.

Fogg and others (in press) identified recharge and discharge areas, directions of ground-water movement, and possible effects of mining for 12 coal-lease areas in the Powder River structural basin. Their study concluded that surface coal mining would affect only local ground-water flow systems. Potential effects include alteration of ground-water flow systems and changes in water quality.

\section{Acknowledgments}

The authors express their gratitude to the hydrology staff of the Wyoming Department of Environmental Quality, Land Quality Division, for their assistance with data retrieval and knowledge of mining activities in the study area. Assistance from the Gillette Area Groundwater Monitoring Organization (GAGMO) and company hydrologists at the coal mines in the study area was invaluable and is much appreciated.

This study was funded by the U.S. Geological Survey, the Wyoming Department of Environmental Quality, and the U.S. Office of Surface Mining. This report does not necessarily reflect the views of the Wyoming Department of Environmental Quality, or the U.S. Office of Surface Mining. 


\section{Climate}

The climate of the study area is temperate and semiarid, with considerable variations in temperature and precipitation between winter and summer seasons. The growing season is short, averaging about 120 days between the last spring and first fall freezes.

During the winter, average daily minimum temperatures range between $5{ }^{\circ} \mathrm{F}$ and $40^{\circ} \mathrm{F}$. However, nighttime temperatures commonly may be less than $0{ }^{\circ} \mathrm{F}$ and daytime temperatures may be as much as $50{ }^{\circ} \mathrm{F}$. Summers generally are mild with short periods of temperatures exceeding $100{ }^{\circ} \mathrm{F}$. The mean maximum daily temperature for July is $90^{\circ} \mathrm{F}$. Nights usually are cool despite high daytime temperatures.

Average annual precipitation ranges from $11 \mathrm{in.}$ in the southern part of the study area to $18 \mathrm{in.}$ in the north. More than two-thirds of the annual precipitation occurs as rainfall between March and August of the average year. About one-third of the annual precipitation is snowfall. The average annual snowfall of 50 in. is well distributed through the winter but is greatest during December.

Prevailing winds in the study area are from the northwest. Maximum wind velocities commonly occur in the spring. Wind velocity averages about $14 \mathrm{mi} / \mathrm{h}$ annually, ranging from an average of $10 \mathrm{mi} / \mathrm{h}$ during July and August to an average of $16 \mathrm{mi} / \mathrm{h}$ during November through April.

\section{Topography and Drainage}

The eastern Powder River basin lies within the unglaciated part of the Missouri Plateau of the Northern Great Plains. The entire study area is within the drainage basin of the Missouri River. The Little Powder River flowing northward, and the Belle Fourche and Cheyenne Rivers flowing eastward are the main tributaries draining the study area. Elevations in the Little Powder drainage basin range from 3,600 ft above sea level along the Little Powder River to about 4,800 ft on the ridges, from 4,400 ft along the Belle Fourche River to $5,000 \mathrm{ft}$ on the prairie, and from 4,400 ft along the Cheyenne River to 4,800 $\mathrm{ft}$ on the uplands. The larger stream valleys are deeply eroded and have wide, flat floors and broad floodplains. The landscape is dominated by plains and low-lying hills and tablelands, interrupted by entrenched river valleys and isolated, flat-topped buttes and mesas, and long narrow divides and ridges that are from 100 to $500 \mathrm{ft}$ above valley floors. 
The streams draining the study area are described by Rankl (1986a):

The channel bottom of the Little Powder River consists of clay, silt, and some clinker gravel. The stream is perennial. The Belle Fourche and the Cheyenne Rivers originate in and drain an area underlain by continental deposits of shale, sandstone, and coal. The channel of the Belle Fourche River is relatively narrow, has a silt and clay bottom, and in places is grass covered. The ground-water table is intercepted by the channel in many reaches, thus forming pools, but very little ground water is contributed to streamflow. The channel of the Cheyenne River and its major tributaries have wide sand channels and flow is ephemeral.

Most of the tributaries to the Little Powder, Belle Fourche, and the Cheyenne Rivers are ephemeral, and streamflow results from rainstorms and melting snow.

\section{Soil Characteristics and Vegetation}

Soils in the study area have developed under the short-grass vegetative cover common to the semiarid Great Plains. Due to prevailing climatic and vegetative conditions, organic matter accumulates slowly, and soils have developed with light-colored surfaces. Subsoil colors are normally light brown or reddish brown, and substratum colors are commonly affected by white, powdery, limey carbonate accumulations caused by minimal precipitation and insufficient leaching. Soils are mostly residual (developed in place) and formed from weathered sedimentary bedrock, which is commonly sandstone and shale.

On gently rolling uplands, slightly altered bedrock usually is not more than 36 in. below the land surface. On more rolling lands, the depth to bedrock is about 20 to 30 in. On steep slopes, only a few inches of soil or soil material overlies the partly weathered bedrock. Rock outcrops are common on the steep slopes.

Developed soils have characteristics similar to the bedrock. Areas of sandy and medium-textured friable soils are underlain by sandstone and sandy shale. Dense clay soils are underlain by clay shale.

The natural vegetation in the study area is a mixture of grasses and shrubs. Common plants include prairie sandreed grass, needleandthread grass, western wheatgrass, blue gramma grass, little bluestem grass, big sagebrush, and greasewood (Peterson, 1986, p. 20). Cottonwood trees commonly grow along the streams. 


\section{$\underline{\text { Geology }}$}

The geologic units of interest in this study are the relatively shallow units stratigraphically above the Pierre Shale of Cretaceous age. These geologic units, in ascending order, are the Fox Hills Sandstone and Lance Formation of Late Cretaceous age, the Fort Union Formation of Paleocene age, the Wasatch Formation of Eocene age, and alluvium of Pleistocene and Holocene age. The outcrop areas of these units are shown in figure 2.

The Fox Hills Sandstone and Lance Formation consist of fine- to mediumgrained sandstone interbedded with sandy shale. The Fort Union Formation consists of the Tullock, Lebo, and Tongue River Members in ascending order. The Tullock Member consists principally of interbedded medium- to light-gray shale and light-gray, fine-grained sandstone and siltstone. Thin coal beds in the Tullock Member grade upward into light-gray sandy or silty shale and locally resistant sandstone. The Lebo Member is predominantly dark shale and concretionary sandstone with siltstone, and locally thin coal beds. The Tongue River Member consists of light-yellow to light-gray, fine- to mediumgrained, thick-bedded to locally massive cross-bedded and lenticular sandstone and siltstone interbedded with gray and black shale. South of the Belle Fourche River, the Lebo Member is equivalent to the Lebo and Tongue River Members of the Fort Union Formation in the northern part of the eastern Powder River basin (Denson and others, 1978).

Many thick and laterally persistent coal beds are present in the Tongue River Member. However, the only major coal bed that is presently (1987) mined is the Wyodak coal bed. The Wyodak coal bed has been correlated in many parts of the eastern Powder River basin and has different names in different parts of the basin. The coal bed has been called the WyodakAnderson and the Anderson-Canyon coal bed. Because of correlation problems, the Wyodak coal bed was erroneously called the Roland-Smith coal bed in some reports. North of Gillette, the Wyodak coal bed separates into an upper Wyodak and lower Wyodak (Glass, 1986a, p. 26). In places, the upper Wyodak separates into the Smith, Swartz, and Anderson coal beds, and the lower Wyodak separates into the Canyon and Cook coal beds (Kent and others, 1980, sheet 1). The Wyodak also separates into the Anderson and Canyon coal beds south and west of Gillette (Glass, 1986a, p. 26-27). Clinker, which consists of fractured shale, siltstone, and sandstone that have been baked by the burning of underlying coal beds, is present near the coal outcrops (Lewis and Hotchkiss, 1981; Love and Christiansen, 1985).

The Wasatch Formation consists of brownish-gray, fine- to coarsegrained lenticular sandstone interbedded with shale and coal. Coal beds occur in the lower part of the Wasatch Formation. Clinker also occurs near the coal outcrops (Lewis and Hotchkiss, 1981; Love and Christiansen, 1985). 


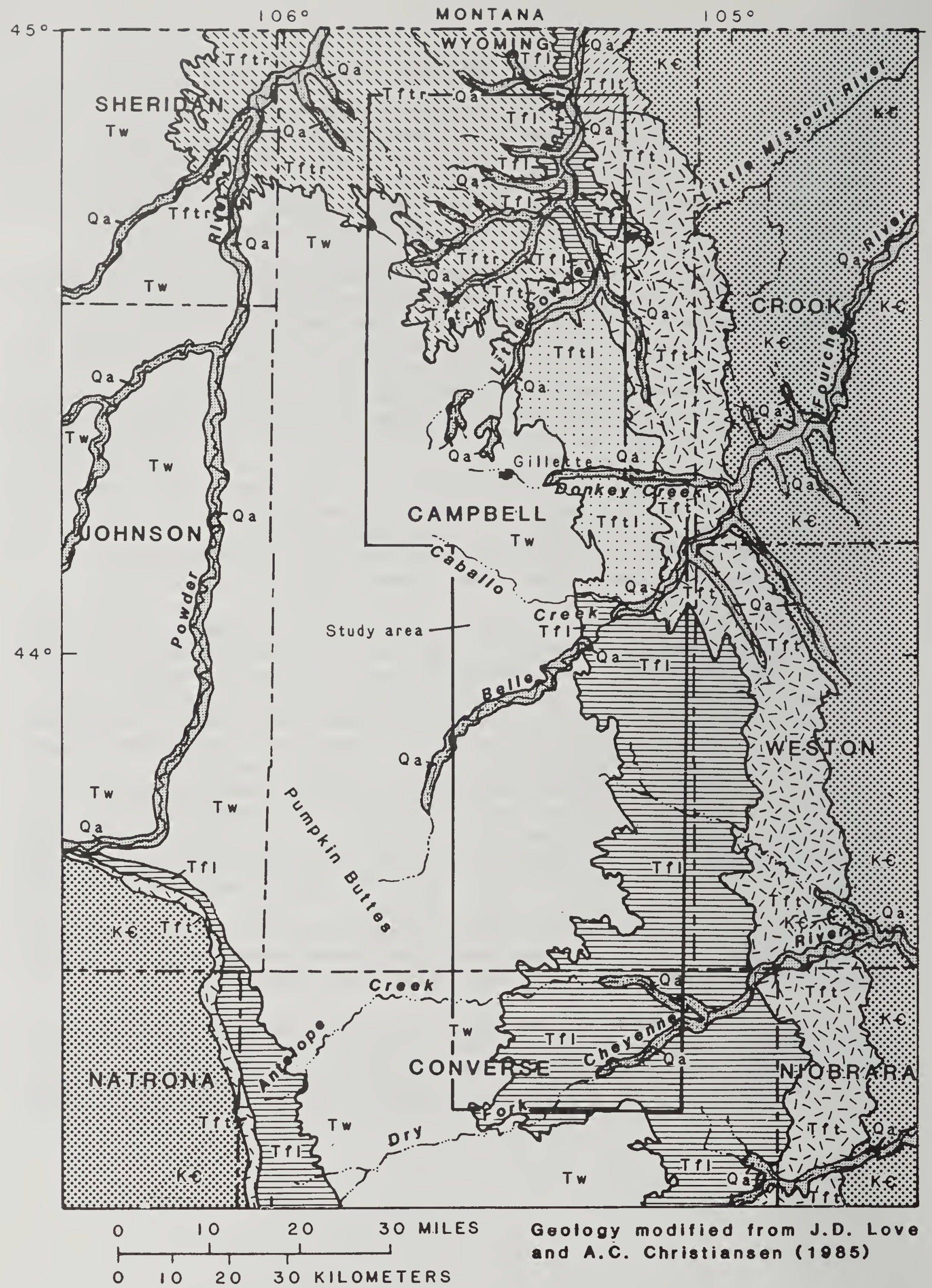

Figure 2.--Surficial geology within and adjacent to the study area. 
The Fort Union and Wasatch Formations consist of continental-type sediments deposited in fluvial, lacustrine, and swampy environments. Consequently, the strata of these formations are alternating sandstone, siltstone, and mudstone, with occasional coal. The strata are lenticular and seldom correlate for more than short distances in any direction. The Fort Union Formation is less variable lithologically than the Wasatch Formation; lenses and channels of sandstone are common in the Wasatch. Coal beds are thicker and more numerous in the Fort Union than in the Wasatch. Local custom among the coal-mining companies has been to consider the top of the thick Wyodak coal bed as being equivalent to the top of the Fort Union Formation. For this report, the top of the Wyodak coal bed is assumed to be the contact between the Fort Union and Wasatch Formations.

The alluvium consists of unconsolidated deposits of silt, sand, and gravel. Generally fine to medium grained, the alluvial deposits may be coarser grained in the valleys of the Belle Fourche and Little Powder Rivers (Hodson and others, 1973).

\section{EXPLANATION}

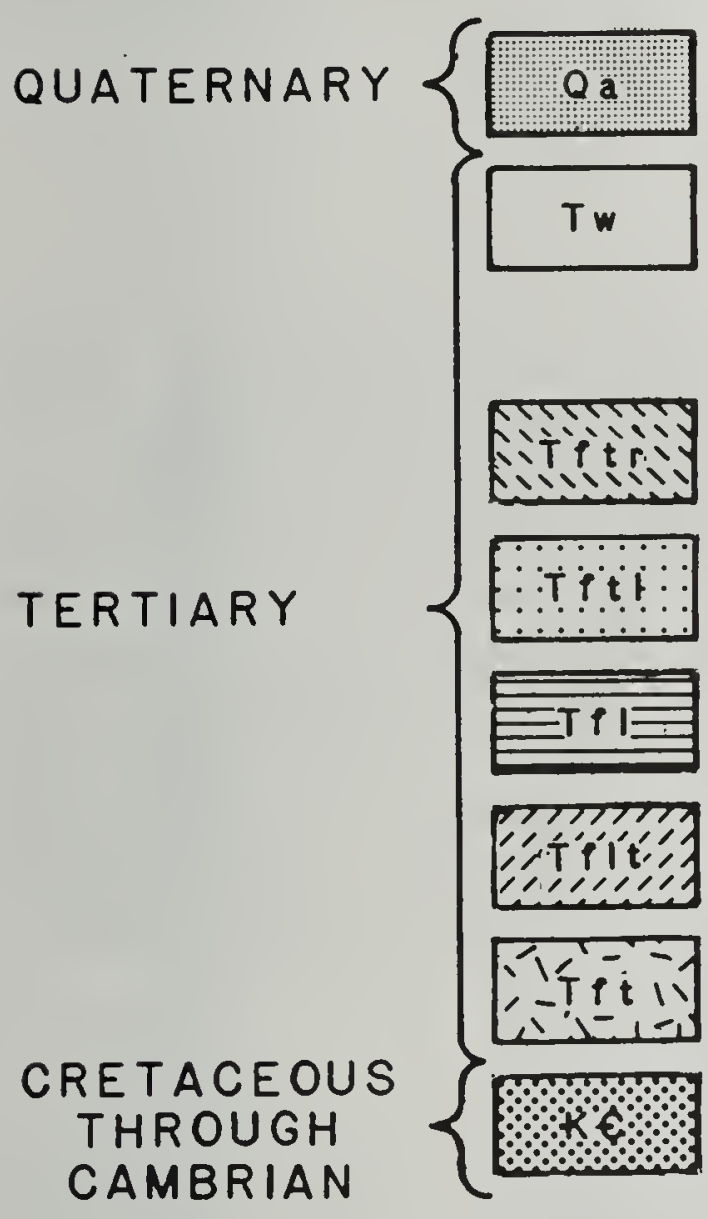

ALLUVIUM (HOLOCENE AND PLEISTOCENE)

WASATCH FORMATION (EOCENE)

FORT UNION FORMATION (PALEOCENE)

Tongue River Member

Tongue River and Lebo Members

Lebo Member

Lebo and Tullock Members

Tullock Member

ROCKS OF CRETACEOUS THROUGH CAMBRIAN AGE - Includes Lance Formation, Fox Hills Sandstone, and Pierre Shale of Cretaceous age

CONTACT--APproximately located

Figure 2.--Continued. 
Coal in the eastern Powder River basin is extracted by surface-mining methods. Topsoil is removed from areas in advance of overburden removal and stockpiled for later use in reclamation. After removal of the topsoil, overburden is excavated down to the coal. After being excavated, the overburden is referred to as spoil. Thickness of the overburden at existing and proposed mines generally ranges from as little as several feet to as much as $300 \mathrm{ft}$. During the initial stages of pit excavation, the overburden is placed in spoil piles near the perimeter of the mine. After the overburden has been removed, the coal is blasted and hauled by truck or conveyors to railroad-loading facilities. After completion of mining, the overburden spoil piles are used to fill in the final pit. As mining progresses, reclamation takes place where mining has been completed. Mined areas are backfilled with overburden material from areas being mined and are then re-contoured and re-vegetated. A typical mining and reclamation process is illustrated in figure 3.

Even though the volume of the overburden increases as it is broken and disturbed during mining, the increase in volume of the overburden used as backfill generally is not sufficient to compensate for the removal of the thick coal beds. The final result generally is a lowering and flattening of the land surface after mining and reclamation are completed.

\section{$\underline{\text { Existing Mines }}$}

Currently (1987), 16 surface coal mines are operating in the eastern Powder River basin (table 1). The mines are aligned along a northerly trend approximately coincident with the coal outcrop. The lease areas for the existing mines are shown on plate 1. Mining at the Wyodak Mine began in 1922. The remainder of the mines started operations during the $1970^{\prime} \mathrm{s}$ and 1980 's. The projected completion dates of existing surface mines range from 1996 (Buckskin Mine) to 2026 (Caballo Mine). Projected completion dates may change due to fluctuations in market conditions and the demand for lowsulfur, subbituminous coal. The projected maximum areas to be disturbed by existing surface coal mines range from 959 to 13,217 acres. The projected completion dates and maximum areas to be disturbed are from mine-permit applications on file with the Wyoming Department of Environmental Quality.

\section{$\underline{\text { Proposed Mines }}$}

Six additional surface coal mines in the eastern Powder River basin are proposed (table 2). Permits have been issued by the Wyoming Department of Environmental Quality for five of these mines. The other proposed mine has a mine-permit application pending with the Wyoming Department of Environmental Quality. The lease areas for these proposed mines are shown on plate 1. There is one other lease area (Peabody) listed in table 2 and shown on plate 1 for which a mine-permit application for surface coal mining has not been made. 

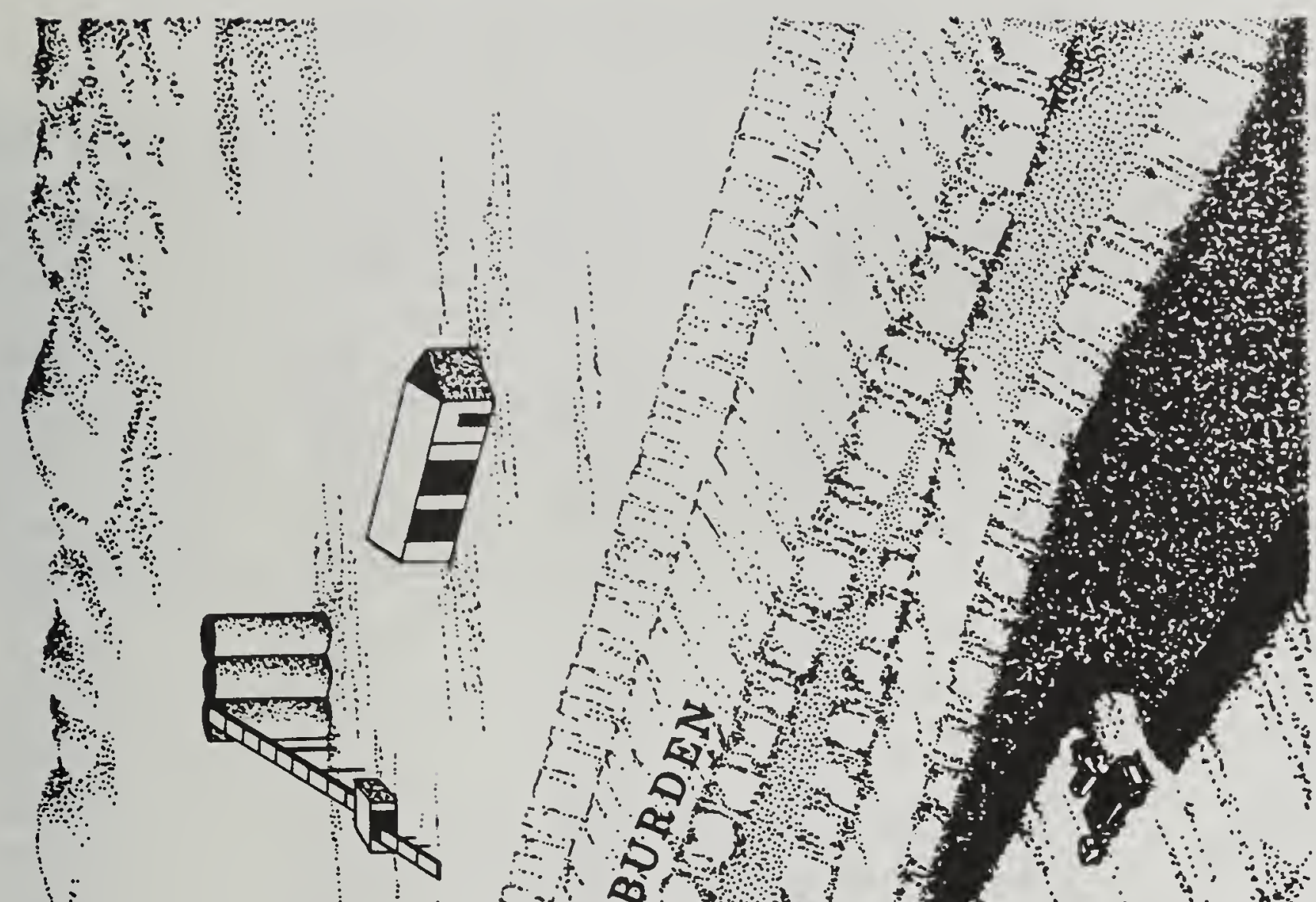

10 a

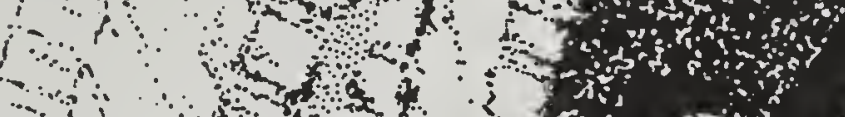

$\frac{1}{2}$

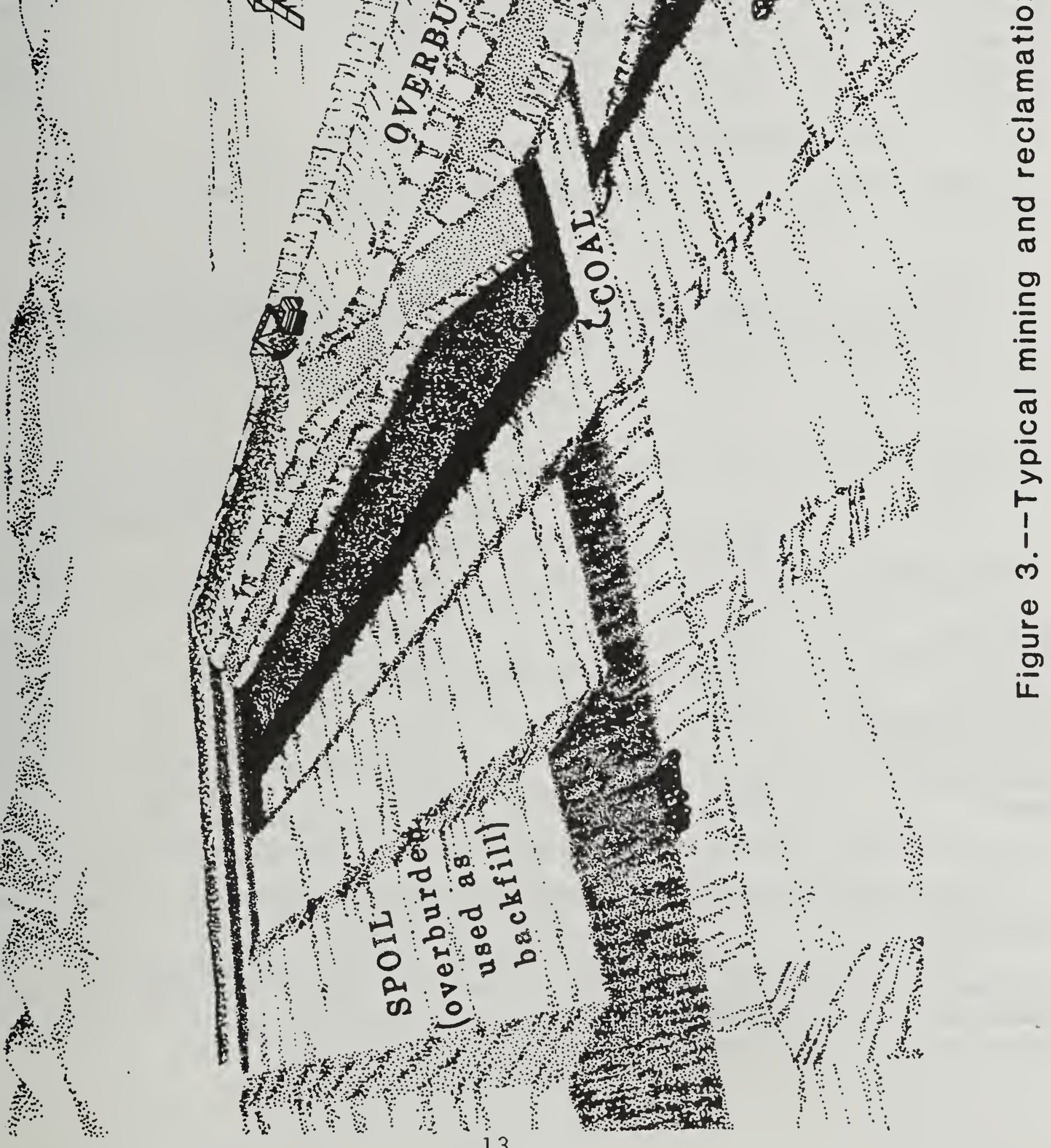


Table 1.--Existing surface coal mines ${ }^{1}$

\begin{tabular}{|c|c|c|c|c|c|}
\hline \multirow[b]{2}{*}{ Mine name } & \multirow[b]{2}{*}{$\begin{array}{l}\text { Permit } \\
\text { number }\end{array}$} & \multirow[b]{2}{*}{$\begin{array}{c}\text { Start-up } \\
\text { date }\end{array}$} & \multirow{2}{*}{$\begin{array}{l}\text { Projected } \\
\text { completion } \\
\text { date }\end{array}$} & \multicolumn{2}{|c|}{$\begin{array}{c}\text { Area disturbed by mining } \\
\text { (acres) }\end{array}$} \\
\hline & & & & $\begin{array}{c}\text { End of } \\
1986\end{array}$ & $\begin{array}{c}\text { Projected } \\
\text { maximum }\end{array}$ \\
\hline Antelope & 525 & 1982 & 2011 & 338 & 4,896 \\
\hline Belle Ayr & 214 & 1973 & 2016 & 2,495 & 4,250 \\
\hline Black Thunder & 233 & 1974 & 2018 & 2,817 & 13,217 \\
\hline Buckskin & 500 & 1980 & 1996 & 760 & 959 \\
\hline Caballo & 433 & 1977 & 2026 & 1,199 & 9,104 \\
\hline Caballo Rojo & 511 & 1981 & 2007 & 815 & 4,922 \\
\hline Clovis Point & 447 & 1977 & 2000 & 672 & 1,067 \\
\hline Coal Creek & 483 & 1979 & 2011 & 1,047 & 8,310 \\
\hline Cordero & 237 & 1974 & 2006 & 1,631 & 7,102 \\
\hline Eagle Butte & 428 & 1976 & 2019 & 1,337 & 4,759 \\
\hline Fort Union & 486 & 1979 & 2019 & 217 & 2,454 \\
\hline Jacobs Ranch & 271 & 1975 & 2005 & 2,253 & 4,687 \\
\hline North Antelope & 532 & 1982 & 2019 & 667 & 2,792 \\
\hline Rawhide & 240 & 1974 & 2004 & 1,296 & 4,921 \\
\hline Rochelle & 569 & 1984 & 2017 & 196 & 5,285 \\
\hline Wyodak & 232 & 1922 & 2014 & 572 & 1,720 \\
\hline
\end{tabular}
Quality.

Data from mine-permit applications, Wyoming Department of Environmental

Table 2.--Proposed surface coal mines including mines that have been granted permits, but that have not been constructed'

$$
\text { [--, not applicable] }
$$

\begin{tabular}{|c|c|c|c|c|c|}
\hline \multirow[b]{2}{*}{ Mine name } & \multirow[b]{2}{*}{$\begin{array}{l}\text { Permit } \\
\text { number }\end{array}$} & \multirow[b]{2}{*}{$\begin{array}{l}\text { Start-up } \\
\text { date }\end{array}$} & \multirow{2}{*}{$\begin{array}{l}\text { Projected } \\
\text { completion } \\
\text { date }\end{array}$} & \multicolumn{2}{|c|}{$\begin{array}{c}\text { Area disturbed by mining } \\
\text { (acres) }\end{array}$} \\
\hline & & & & $\begin{array}{c}\text { End of } \\
1986 \\
\end{array}$ & $\begin{array}{l}\text { Projected } \\
\text { maximum }\end{array}$ \\
\hline Dry Fork & 599 & -- & 2020 & -- & 2,905 \\
\hline East Gillette & 581 & -- & 2011 & -- & 2,603 \\
\hline Keeline & 602 & -- & 2009 & -- & 4,692 \\
\hline North Rochelle & 550 & 1985 & 2011 & 4 & 3,271 \\
\hline Peabody Lease 2 & -- & -- & -- & -- & 4,000 \\
\hline Rocky Butte & -- & -- & 2002 & -- & 1,054 \\
\hline Wymo & 540 & -- & 1995 & -- & 750 \\
\hline
\end{tabular}
Quality.

2 The Peabody Lease is an area that has been leased for coal mining; however, a mine-permit application has not been filed with the Wyoming Department of Environmental Quality. Therefore, it is not counted as a proposed mine in the text of this report. 


\section{Other Areas Considered for Mining}

Additional areas being considered for surface coal mines in the eastern Powder River basin can be grouped in two categories: Selected coal Tracts and areas with Preference Right Lease Applications (table 3). A Selected Coal Tract is an area that has been evaluated by the U.S. Bureau of Land Management for inclusion in future competitive leasing. Generally, each Selected Coal Tract would constitute an individual mine. Areas with Preference Right Lease Applications were claimed by specific companies prior to the beginning of the competitive-leasing system now used. Generally, Preference Right Lease Applications are small areas that would be appended to existing mines. Locations of Selected Coal Tracts and Preference Right Lease Applications are shown on plate 1.

Table 3.--Selected Coal Tracts and Preference Right Lease Applications

\begin{tabular}{cc}
\hline Name & $\begin{array}{c}\text { Area }^{1} \\
\text { (acres) }\end{array}$ \\
\hline Selected Coal Tracts &
\end{tabular}

Calf Creek Donkey Creek

Hay Creek Kintz Creek Mount Logan Porcupine Ridgerunner Rochelle Hills Rockpile Roundup Thundercloud Timber Creek Wildcat
7,050

3,270

5,370

4,200

6,805

720

5,396

6,625

5,585

5,890

4,525

3,750

4,085

Preference Right Lease Applications

Caballo

East Black Thunder

Rochelle

2,250

South Antelope

820

Wildcat Creek

10,450

1 Data from U.S. Bureau of Land

Management, Casper office. 
In addition to the areas already being mined or being considered for development, large tracts remain that have thick deposits of coal suitable for extraction by surface-mining methods. These large tracts probably will not be developed in the near future unless there is a substantial increase in the demand for coal. It should be recognized, however, that these tracts do exist and may be developed as the existing mines are mined to completion. Additional tracts may be added to existing lease areas by noncompetitive lease modifications. Because the size, location, and time of acquisition can not be predicted, these tracts are generically referred to in this report as areas of possible future mining.

\section{Definition of "All Anticipated Mining"}

One of the requirements of the Surface Mining Control and Reclamation Act of 1977 (SMCRA) is that the regulatory agency assess the probable cumulative impacts of "all anticipated mining" in the region to assure that proposed mining operations have been designed to prevent material damage to the hydrologic balance outside the permit area of the proposed mine.

In its broadest context, "all anticipated mining" could include all surface mining in a north-trending strip bounded on the east by the coal outcrop and on the west by an arbitrary economic limit (for example, $300 \mathrm{ft}$ of overburden). Analysis of impacts from mining such a large area would require many assumptions and generalizations by the investigators. The result would be a nebulous report of limited use to the regulatory agencies.

For the purposes of this study, "all anticipated mining" is defined as the existing (1987) and potential surface coal mining in the lease areas, Selected Coal Tracts, and areas with Preference Right Lease Applications. The quantity of detailed hydrologic data varies considerably for each of the types of areas. Lease areas have large amounts of data readily available in mine-permit applications submitted to the Wyoming Department of Environmental Quality. Site-specific data for Selected Coal Tracts are almost never available. Limited data are available for areas with Preference Right Lease Applications.

In order to maintain the level of detail needed in this report, the study was conducted using data primarily from existing lease areas and mine plans. Hydrologic conditions for Selected Coal Tracts and areas with Preference Right Lease Applications, by default, are addressed with less certainty. Because they are in the same general area as lease areas, hydrologic conditions are assumed to be the same as in lease areas. The level of analysis in each area varies with the availability of hydrologic data. Estimations and assumptions need to be made for areas where sitespecific hydrologic data are not available. 


\section{HYDROGEOLOGY}

The ground-water system occurs predominantly in a matrix of lenticular sandstone and siltstone beds interbedded with shale and coal, which results in discontinuous aquifers of limited areal extent. For this report, the hydrogeologic units of interest are the aquifers in stratigraphic units overlying the Pierre Shale. In descending order, these aquifers are the Wasatch aquifer, Wyodak coal aquifer, Tongue River-Lebo aquifer, Tullock aquifer, and the Lance-Fox Hills aquifer. The relation between stratigraphic units and hydrogeologic units is shown in figure 4.

The Wasatch aquifer consists primarily of discontinuous lenticular sandstone beds and sand channels surrounded by siltstone and shale. The siltstone and shale may be saturated and static water levels may be at the same elevation as in the adjacent sand deposits. However, wells completed in the siltstone and shale generally will not yield sufficient quantities of water to consider the material as an aquifer. Transmissivity of the Wasatch aquifer is typically less than $13 \mathrm{ft}^{2} / \mathrm{d}$ and commonly is less than $1.3 \mathrm{ft}^{2} / \mathrm{d}$. Wells completed in the sandstone beds and sand channels may yield from 10 to $50 \mathrm{gal} / \mathrm{min}$ in the northern part of the basin and as much as $500 \mathrm{gal} / \mathrm{min}$ in the southern part of the basin (Hodson and others, 1973, pl. 3). Quaternary alluvium is present in most stream valleys in the study area. In this study, the aquifers in alluvial deposits are defined as being part of the Wasatch aquifer.

The Wyodak coal bed is the most continuous hydrogeologic unit in the study area. Water in the Wyodak coal bed is confined between a shale forming the basal sequence of the overlying Wasatch Formation and a thick shale sequence directly underlying the coal. The Wyodak coal aquifer consists of the Wyodak coal bed and associated coal beds where the Wyodak splits and separates into multiple beds, interbedded sandstone beds, and clinker beds along the coal outcrop. Flow of water in the coal is affected in places where the coal bed separates to form two or more coal beds with interbedded claystone, shale, or sandstone. Flow in the coal also may be affected by differences in aquifer properties caused by differences in the distribution and density of fractures in the coal. Solid coal is virtually impermeable. Permeability is imparted to the coal as a result of fracturing and is dependent on the degree of fracturing. The Wyodak coal bed is an anisotropic aquifer with flow occurring through fractures in the coal bed. Transmissivity of the Wyodak coal aquifer is typically less than $134 \mathrm{ft}^{2} / \mathrm{d}$. Wells completed in the Wyodak coal aquifer generally yield from 10 to $50 \mathrm{gal} / \mathrm{min}$ (Hadley and Keefer, 1975, sheet 1).

The Tongue River-Lebo aquifer consists of sandstone lenses in a predominantly shale and siltstone matrix. Transmissivity of sandstone lenses comprising the Tongue River-Lebo aquifer generally ranges from 10 to $75 \mathrm{ft}^{2} / \mathrm{d}$. Wells completed in the Tongue River-Lebo aquifer will yield adequate quantities of water for domestic and livestock use if a sufficient thickness of saturated sandstone lenses is penetrated. The thick shale sequence underlying the Wyodak coal hydrologically isolates the Tongue River-Lebo aquifer from impacts due to dewatering of mine pits in the Wyodak coal aquifers. 


\begin{tabular}{|c|c|c|c|c|c|}
\hline $\begin{array}{l}\text { ERA- } \\
\text { THEM }\end{array}$ & $5^{+5^{x^{2}}}$ & $5^{8^{5}}$ & \multicolumn{2}{|c|}{ Stratigraphic Unit } & Hydrogeologic Unit \\
\hline \multirow{9}{*}{$\begin{array}{l}. \frac{0}{0} \\
N \\
0 \\
\frac{1}{0} \\
0 \\
0\end{array}$} & $\begin{array}{c}\text { Quater- } \\
\text { nary }\end{array}$ & $\begin{array}{l}\text { Holo- } \\
\text { cene } \\
\text { and } \\
\text { Pleisto- }\end{array}$ & \multicolumn{2}{|c|}{ Alluvium } & \multirow{3}{*}{ Wasatch aquifer } \\
\hline & \multirow{8}{*}{ 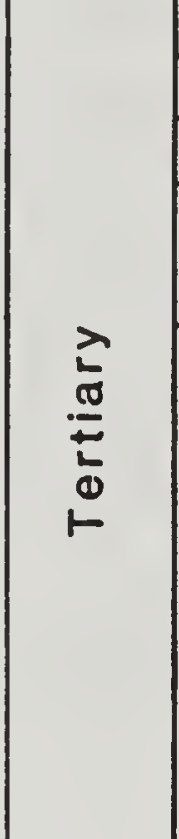 } & \begin{tabular}{|c|} 
cene \\
Mio- \\
cene \\
Oligo- \\
cene \\
\end{tabular} & & & \\
\hline & & \multirow{2}{*}{$\begin{array}{l}\text { Eo- } \\
\text { cene }\end{array}$} & \multirow{2}{*}{\multicolumn{2}{|c|}{ Wasatch Formation }} & \\
\hline & & & & & Confining unit \\
\hline & & \multirow{5}{*}{\begin{tabular}{l}
0 \\
\multicolumn{1}{c}{} \\
0 \\
0 \\
0 \\
0 \\
$\frac{0}{\sigma}$ \\
0
\end{tabular}} & \multirow{5}{*}{ 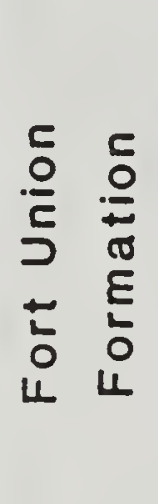 } & $\begin{array}{l}\text { Wyodak } \\
\text { coal bed }\end{array}$ & $\begin{array}{c}\text { Wyodak coal } \\
\text { aquifer }\end{array}$ \\
\hline & & & & Tongue River & Confining unit \\
\hline & & & & Member & \multirow{2}{*}{$\begin{array}{l}\text { Tongue River- } \\
\text { Lebo aquifer }\end{array}$} \\
\hline & & & & Lebo Member & \\
\hline & & & & Tullock Member & Tullock aquifer \\
\hline \multirow{3}{*}{$\begin{array}{l}.0 \\
0 \\
N \\
0 \\
0 \\
0 \\
\Sigma\end{array}$} & \multirow{3}{*}{ 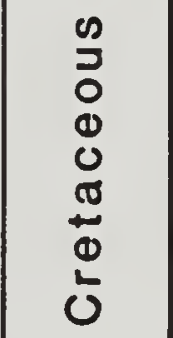 } & \multirow{3}{*}{$\begin{array}{l}\frac{1}{0} \\
\frac{0}{2} \\
\frac{2}{2}\end{array}$} & \multicolumn{2}{|c|}{ Lance Formation } & \multirow{2}{*}{$\begin{array}{l}\text { Lance-Fox } \\
\text { Hills aquifer }\end{array}$} \\
\hline & & & \multicolumn{2}{|c|}{ Fox Hills Sandstone } & \\
\hline & & & \multicolumn{2}{|c|}{ Pierre Shale } & Confining unit \\
\hline
\end{tabular}

Figure 4.--Relation of stratigraphic units to hydrogeologic units. 
The Tullock aquifer consists of fine-to-medium grained sandstone beds and thin coal beds interbedded with siltstone, shale, and carbonaceous shale. Sandstone beds in the Tullock tend to be coarser and more massive than those in the overlying Tongue River-Lebo aquifer. Transmissivity of the Tullock aquifer generally ranges from 200 to $400 \mathrm{ft}^{2} / \mathrm{d}$. Yields of 200 to $300 \mathrm{gal} / \mathrm{min}$ are available from wells completed in the Tullock. Most of the wells for facilities at coal mines are completed in the Tullock.

The Lance-Fox Hills aquifer consists of numerous lenticular beds of massive sandstone isolated by interbedded shale and siltstone. Transmissivity generally ranges from about 10 to $250 \mathrm{ft}^{2} / \mathrm{d}$. Wells completed in the Lance-Fox Hills aquifer generally yield several hundred gallons per minute. However, few wells in the study area are completed in the Lance-Fox Hills because it lies 2,500 to $3,000 \mathrm{ft}$ below the land surface. This aquifer is utilized for water supplies in waterflood operations at oil fields in Campbell County and for municipal supplies at Gillette.

\section{Hydraulic Conductivity}

Site-specific determinations of hydraulic conductivity have been made by coal-mining companies. These data have been reported to the wyoming Department of Environmental Quality as part of the mine-permit applications. Data for hydraulic conductivity of the Wasatch aquifer and the Wyodak coal aquifer were obtained from these applications. Results of aquifer tests were available for 203 tests using wells completed in the Wasatch aquifer and 357 tests using wells completed in the Wyodak coal aquifer. Values of hydraulic conductivity were determined by several aquifer-test methods including multiple- and single-well drawdown and recovery tests, and slug tests.

In order to check the validity of aquifer-test results reported in the mine-permit applications, a representative sample of aquifer tests was selected for re-analysis. Data from 39 aquifer tests of the Wyodak coal aquifer involving 63 wells were re-analyzed to ascertain the reliability of the reported aquifer-test results. Results of the re-analysis of aquifertest data were not substantially different from those originally reported by the coal-mining companies.

The logs of hydraulic-conductivity values from aquifer tests using wells completed in the Wasatch aquifer and Wyodak coal aquifer are plotted as histograms in figures 5 and 6 . The $\log$ values of hydraulic conductivity were used to normalize the hydraulic-conductivity data from markedly skewed arithmetic distributions. The hydraulic conductivity of the Wasatch aquifer has a log normal distribution with a geometric mean of $-0.685(0.2 \mathrm{ft} / \mathrm{d})$. The frequency distribution of hydraulic conductivity in the Wyodak coal aquifer approximates a log normal distribution with a geometric mean of $-0.09(0.8 \mathrm{ft} / \mathrm{d})$. Rehm and others (1980, p. 554) report a geometric mean from 70 aquifer tests using wells completed in sandstone (overburden) as $0.35 \mathrm{ft} / \mathrm{d}$ and from 63 aquifer tests using wells completed in siltstone and claystone (also in overburden) as $0.007 \mathrm{ft} / \mathrm{d}$. They also report a geometric mean of hydraulic conductivity from 193 coal-aquifer tests conducted in Wyoming, North Dakota, and Montana as $0.9 \mathrm{ft} / \mathrm{d}$. 


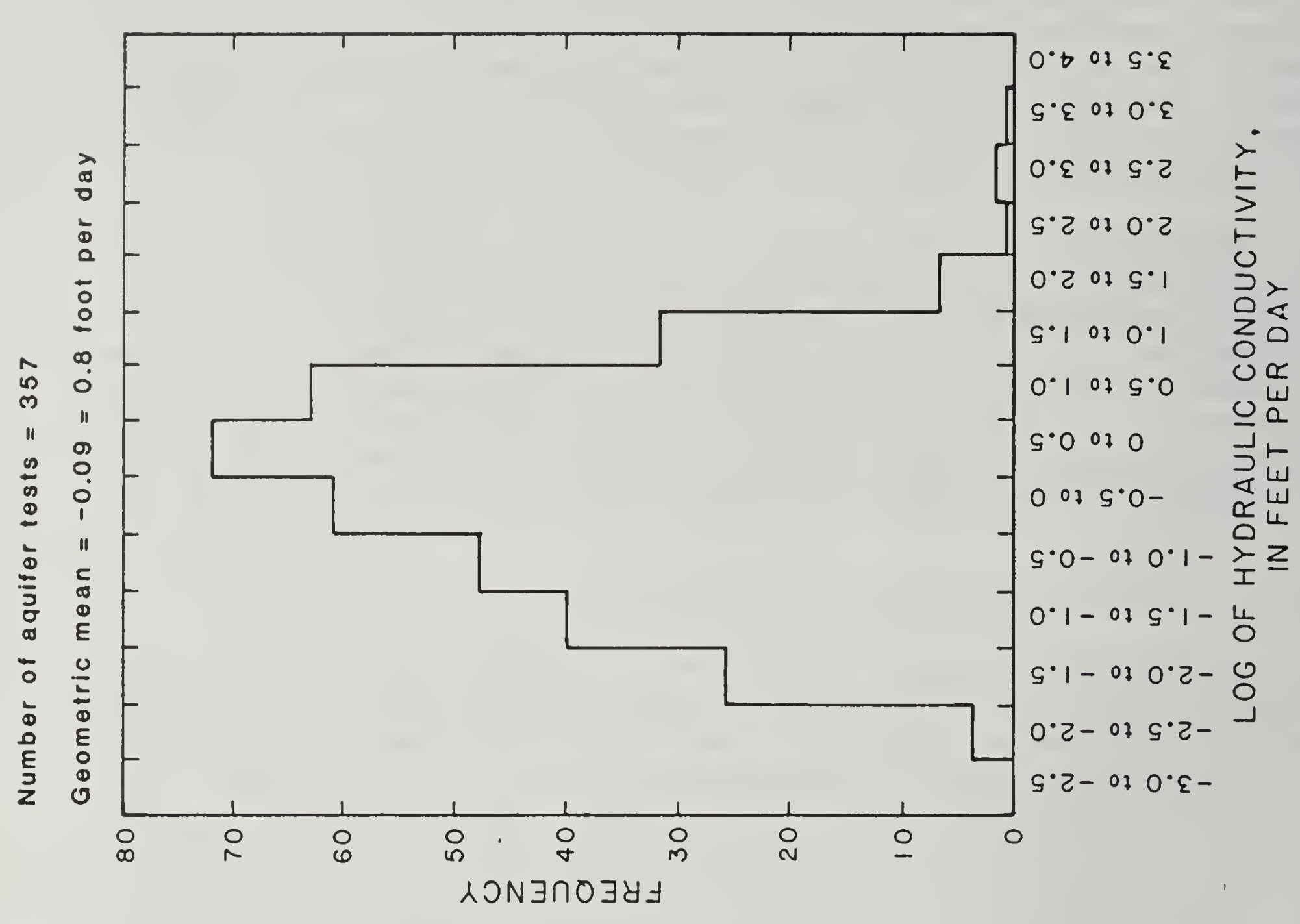

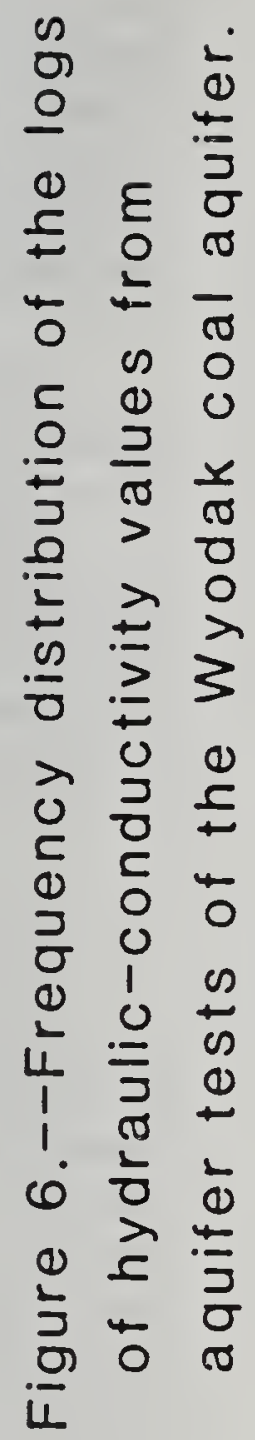

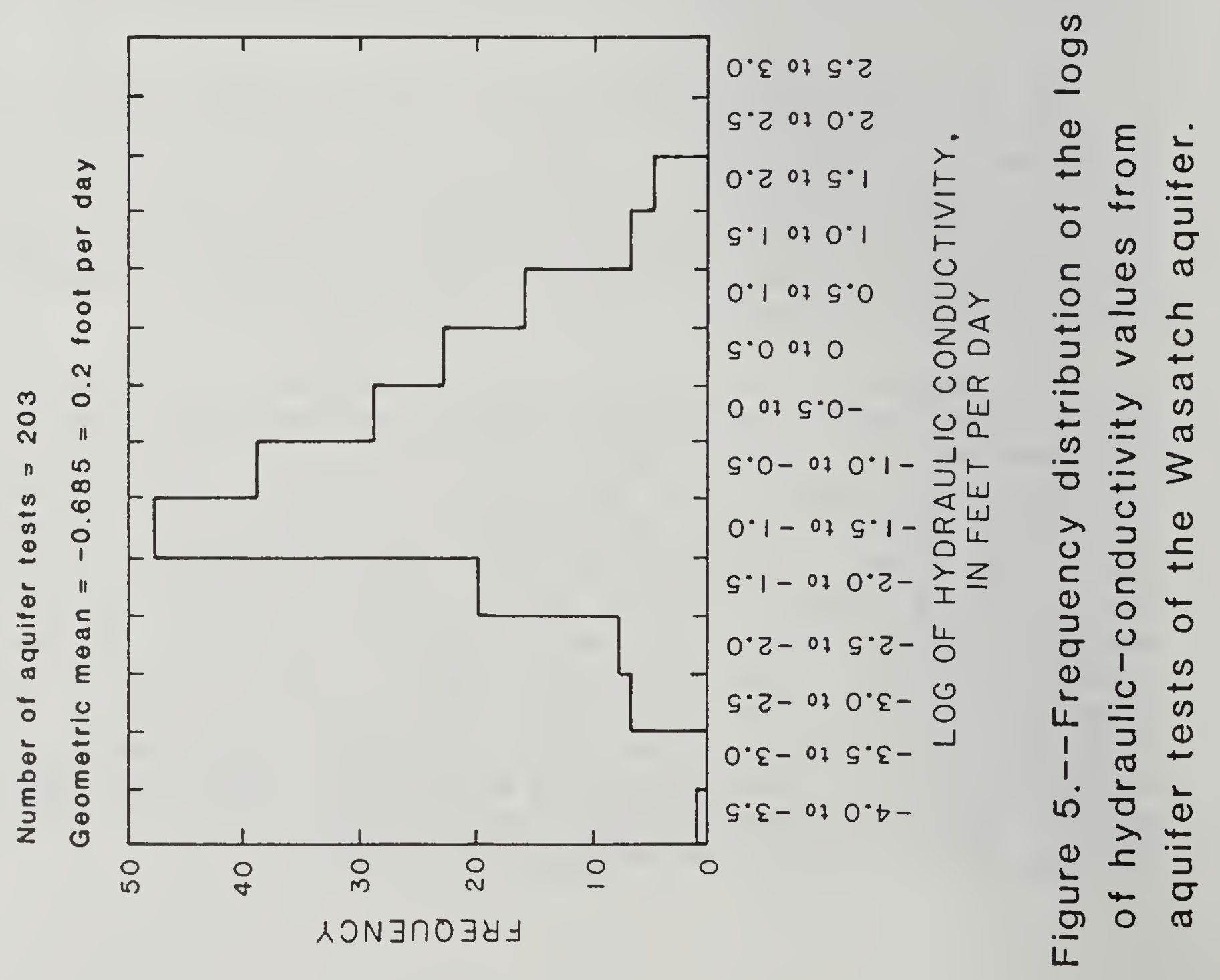


Areal variation of hydraulic conductivity in the Wyodak coal aquifer was investigated by dividing the study area into three subareas: north, central, and south. Comparison was made of the probability distribution of the hydraulic conductivity between each of the three subareas. The north subarea included all mines north of and including the Wyodak Mine (T. 50-52 N.). The central subarea included all mines from Rocky Butte on the north to Keeline on the south ( $\mathrm{T} .45-49 \mathrm{~N}$.$) . The south subarea included$ all mines from Jacobs Ranch on the north to Antelope on the south (T. 40-43 N.). These three subareas were chosen because mines are close together in each subarea and because subareas are separated by gaps of several miles. The probability distribution of the logs of hydraulicconductivity values for each of the three subareas and for the total study area is shown on figure 7. There is no significant difference in the distribution of hydraulic conductivity for the three subareas.

\section{Recharge, Movement, and Discharge}

Recharge to the Wasatch aquifer is from infiltration of precipitation and lateral movement of water from adjacent clinker. Water is discharged by small springs and seeps along stream drainages, by evaporation and transpiration, and by pumping of wells. Local flow systems are predominant, with discharge occurring along creeks and minor tributaries adjacent to recharge areas. Regional ground-water movement is toward the north, however, the quantity of water is small and the rate of movement is slow because the fine-grained rocks in the Wasatch Formation impede the flow of water.

Recharge to the Wyodak coal aquifer occurs primarily along the outcrop areas of associated clinker. Regional flow is toward the northwest as indicated by the configuration of the potentiometric surface prepared by Daddow (1986). Local flow may differ from regional flow. Coal-aquifer recharge and discharge occurs locally where the coal subcrops under the floor of alluvium-filled valleys. In the southern part of the study area, water in the coal is not moving north, but is moving toward local discharge areas where Antelope and Porcupine Creeks cross the coal subcrop.

Recharge to aquifers underlying the Wyodak coal bed is primarily from the infiltration of precipitation on outcrop areas. General movement of water in the aquifers is northward toward the Powder River and Little Powder River. However, discharge to these streams is too small to measure (Rankl and Lowry, in press). Other possible discharge mechanisms include evapotranspiration along stream drainages and pumping by wells. Some water leaks downward through the Fort Union Formation into the underlying strata.

Maps showing areas of ground-water recharge and discharge at each mine are included in the mine-permit applications. Many of these maps depict local flow systems rather than regional flow systems. 


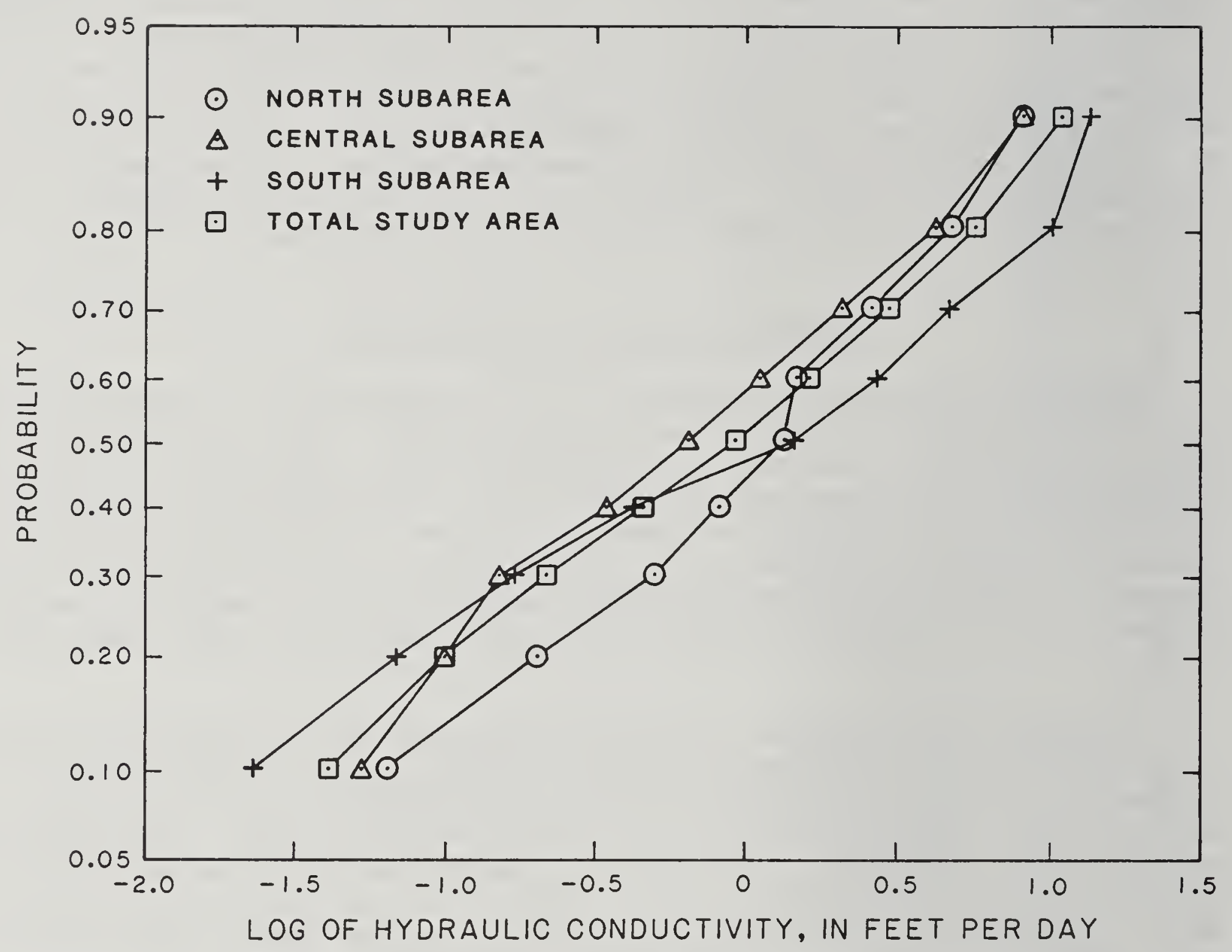

Figure 7.--Comparison of probability distribution of the logs of hydraulic-conductivity values for the Wyodak coal aquifer for three subareas and the total study area. 


\section{Impacts of Mining on Hydrogeology}

\section{Hydraulic Conductivity}

Mining and reclamation will result in the replacement of the wasatch aquifer in the overburden and the Wyodak coal aquifer with unconsolidated backfilled overburden materials referred to as spoil. The spoil aquifer is developed as the spoil materials become saturated. Although the lithologic materials in the spoil aquifer will be the same as previously described for the overburden, the bedding and arrangement of materials will be different.

The spoil aquifer will be created by physically moving overburden to areas being backfilled, either by dragline or shovel-and-truck methods. Most of the spoil will consist of unconsolidated clay, silt, and sand mixed with fragments of consolidated claystone, shale, and sandstone. It is anticipated that the zone closest to the base of the pit, or the base of each layer in areas backfilled by multiple layers, will be the most permeable horizon within the reclaimed spoil (Rahn, 1976; Van Voast and others, 1976; Groenewold, 1979). The more permeable zone is formed by the tendency for the coarser overburden material to roll to the bottom of the pit floor or to the base of the layer as the material is dumped.

Research in other coal-mining areas in the northern Great Plains indicates that hydraulic conductivity in the reclaimed spoil will be large enough to consider the material an aquifer. Rehm and others (1980) reported hydraulic-conductivity values of spoil aquifers, ranging from 0.02 to $2.9 \mathrm{ft} / \mathrm{d}$ with a geometric mean of $0.23 \mathrm{ft} / \mathrm{d}$. Van Voast and others (1976) reported hydraulic-conductivity values of spoil aquifers ranging from 0.004 to $9.8 \mathrm{ft} / \mathrm{d}$ with an average from 0.2 to $1.0 \mathrm{ft} / \mathrm{d}$. Thompson and Van Voast (1983) reported an average hydraulic conductivity for spoil aquifers of $0.5 \mathrm{ft} / \mathrm{d}$.

Values of hydraulic conductivity determined from aquifer tests using wells completed in spoil aquifers within the study area generally ranged from 0.07 to $2.0 \mathrm{ft} / \mathrm{d}$ with the arithmetic average skewed to the low end of the range. Some settling and compaction of the spoil material is anticipated, causing the hydraulic conductivity to decrease. However, the final hydraulic conductivity of the spoil aquifer probably will approximate the geometric mean values of hydraulic conductivity for the undisturbed Wasatch aquifer $(0.2 \mathrm{ft} / \mathrm{d})$ and the Wyodak coal aquifer $(0.8 \mathrm{ft} / \mathrm{d})$.

Mining and reclamation will result in the replacement of the Wasatch aquifer and Wyodak coal aquifer with unconsolidated backfilled spoil materials. The resulting spoil aquifer is predicted to have approximately the same hydraulic conductivity as did the Wasatch aquifer and Wyodak coal aquifer. 


\section{Recharge, Movement, and Discharge}

The potential for recharge to the backfilled spoil will be greater than in areas not disturbed by mining. The natural bedding will be destroyed, creating a more isotropic condition in the spoil, resulting in generally greater vertical permeability than exists in undisturbed areas. The infiltration capacity of the backfilled and reclaimed spoil will be greater than that of the undisturbed Wasatch aquifer and Wyodak coal aquifer. However, the infiltration rate for reclaimed soils is less than that for natural soils due to the lack of root structure and other paths for vertical movement of water. After several years, infiltration rates for reclaimed soils will increase to approximately the same rates as for undisturbed soils. As infiltration rates increase to approximate premining conditions, ground-water recharge rates also will increase to approximate premining conditions.

Although the recharge potential of the reclaimed mine areas will increase, the actual recharge rate after reclamation probably will approximate or be somewhat greater than premining recharge. Actual recharge will depend on how well vegetation is re-established and maintained, and how well the surface contours are restored. A flatter average slope of the reclaimed land would increase the potential recharge by decreasing the rate of runoff from reclaimed areas. Recharge will increase locally where water is allowed to pond in surface impoundments. Also, some increase in recharge along re-constructed channels probably will occur during the infrequent periods of surface runoff.

Postmining recharge rates and mechanisms will not change in areas where lateral movement of ground water from adjacent clinker is a major source of recharge. This is because, in general, the clinker will not be disturbed by mining operations. After mining and reclamation have been completed, water will move laterally from clinker to the spoil aquifer.

Recharge to the spoil aquifer will be from infiltration of precipitation, lateral flow from the undisturbed clinker and the Wasatch aquifer and Wyodak coal aquifer, and leakage from surface-water impoundments and stream channels. Estimates of the time required for the ground-water system to re-establish equilibrium varies from a few tens of years to hundreds of years. The anticipated potentiometric surface of the spoil aquifer will resemble a composite of the premining potentiometric surfaces in the Wasatch aquifer and Wyodak coal aquifer. After equilibrium is re-established, ground-water flow patterns will approximate premining conditions. Discharge from the spoil aquifer will flow into the undisturbed Wasatch aquifer and Wyodak coal aquifer to the west (regional flow) or to reclaimed stream channels (local flow). The quantity and quality of ground water that may be discharged from the spoil aquifer is not known, and so impacts of surface coal mining cannot be fully addressed in this area. 
Postmining recharge, movement, and discharge of ground water in the Wasatch aquifer and Wyodak coal aquifer will probably not be substantially different from premining conditions. Recharge rates and mechanisms will not change substantially. Hydraulic conductivity of the spoil aquifer will be approximately the same as in the Wasatch aquifer and Wyodak coal aquifer allowing ground water to move from recharge areas where clinker is present east of mine areas through the spoil aquifer to the undisturbed Wasatch aquifer and Wyodak coal aquifer to the west.

\section{Ground-Water Levels}

Measured Declines

Water levels in the Wasatch aquifer and Wyodak coal aquifer are measured annually, on or about October 1, by members of the Gillette Area Groundwater Monitoring Organization (GAGMO). Water levels in about 1,200 monitoring wells at 20 mine sites were measured in 1986. Well location, aquifers in which wells are completed, and water levels are tabulated and published annually by GAGMO. Also included in the annual reports are potentiometric-surface maps and water-level-change maps for both the Wasatch aquifer and Wyodak coal aquifer.

The water-level-change maps for the wasatch aquifer indicate that water-level declines from 1980 through 1986 resulting from mining activities are limited to areas near mine pits (Gillette Area Groundwater Monitoring Organization, 1987). Measured water-level declines are generally less than $5 \mathrm{ft}$ at distances greater than $0.5 \mathrm{mi}$ from mine pits. Water-level measurements in wells more than $0.5 \mathrm{mi}$ from mine pits indicate approximately an equal number of occurrences of water-level $r$ ises and water leveldeclines. Water-level fluctuations in these wells probably are due to naturally occurring events, such as climatic variations, rather than mining operations. Water-level declines in the Wasatch aquifer near the Wyodak Mine have been limited to an area within 1,500 to 2,000 ft of the pit (Everett, 1979, p. 157) even though the mine has been in operation for 65 years.

The water-level-change maps for the Wyodak coal aquifer indicate that water-level declines from 1980 through 1986 resulting from mining activities generally are less than $10 \mathrm{ft}$ at distances greater than $1 \mathrm{mi}$ from the mine pits (Gillette Area Groundwater Monitoring Organization, 1987). Water levels in wells completed in the Wyodak coal aquifer and located near mine pits have declined as much as $80 \mathrm{ft}$ during 1980-86. Water levels in wells more than 2 to $3 \mathrm{mi}$ from mine pits have not been affected by mining operations. In the vicinity of active mine pits, the water-level-change maps indicate cones of depression. 
Predicted Areal Extent of Declines Resulting from Individual Existing and Proposed Mines

Each coal-mining company has predicted the areal extent of 5-ft or more water-level declines in the Wasatch aquifer and Wyodak coal aquifer resulting from mining operations at their existing and proposed mines. Predictions are based on the results of numerical-flow models and analytical methods. Site-specific data used in the models and analytical methods were obtained from aquifer tests and test drilling at the mine sites.

The small hydraulic conductivity of the interbedded claystone, shale, and siltstone, and the discontinuous, lenticular nature of the sandstone beds comprising the wasatch aquifer in the overburden will restrict the effects of mining on water levels in the wasatch aquifer to areas near active mine pits. Coal-mining companies predict water-level declines of $5 \mathrm{ft}$ or more in the Wasatch aquifer to extend from about 1,000 to about 2,000 ft beyond individual mine pits.

The predicted 5-ft or more water-level decline in the Wyodak coal aquifer resulting from an individual existing or proposed mine generally extends 4 to $8 \mathrm{mi}$ beyond the lease areas (pl. 2). Variations in the predicted areal extent of the 5-ft or more water-level decline are dependent on local hydraulic properties, length of time a pit will be mined, and professional judgement of hydrologists making the predictions.

The most notable exception is the Eagle Butte lease area north of Gillette where the areal extent of the predicted 5-ft or more water-level decline is shown to be farther than $12 \mathrm{mi}$ from the lease area. Use of large values of transmissivity to estimate the extent of water-level declines may be the reason that a larger area is predicted for this lease area than for other lease areas in the study area. Because there is no evidence to support the use of large values of transmissivity for the Wyodak coal aquifer outside the Eagle Butte lease area, it was assumed, in order to be consistent with predictions for other lease areas, that the areal extent of predicted 5 -ft or more water-level decline will be about $8 \mathrm{mi}$.

The areal extent of water-level declines depicted on plate 2 generally is the result of worst-case analyses using the projected maximum duration of mining operations at each lease area, which were required by the Wyoming Department of Environmental Quality, and, therefore usually does not reflect actual drawdowns. Water-level data available from Gillette Area Groundwater Monitoring Organization (1987) indicate that actual effects will be less than the worst-case predictions. The worst-case analyses were necessary in the early days of mine permitting, before most mines had been constructed. Predicted water-level changes will become more accurate with time as measurements of water levels become available for calibrating the numericalflow models.

The extent of the predicted 5-ft or more water-level decline resulting from anticipated mining in areas with Selected Coal Tracts and Preference Right Lease Applications is not shown on plate 2 because site-specific data necessary to make reasonable predictions are not available. The extent and configuration of water-level decline associated with Selected Coal Tracts will be approximately the same as for lease areas, assuming that mine plans 
and hydrologic conditions are similar to those at existing lease areas. The addition of Preference Right Lease Applications areas to existing coal leases will not have a significant effect on the areal extent of predicted water-level declines in the coal aquifer because of the small size of the Preference Right Lease Application areas and their location adjacent to large lease areas.

\section{Predicted Areal Extent of Cumulative Declines Resulting from All Existing and Proposed Mines}

Cumulative water-level declines are not expected to be substantial in the Wasatch aquifer because water-level declines due to individual mining operations generally will not extend more than 2,000 ft beyond the mine pits. The areal extent of water-level declines in the wasatch aquifer will be restricted because the ground-water system consists of discontinuous sandstone beds that have limited hydraulic connection. Therefore, there will be few areas where water-level declines from individual mines will overlap to create cumulative impacts. In areas where a cumulative impact may occur, the impacts will be localized because of the discontinuous, lenticular nature of the sandstone beds comprising the Wasatch aquifer.

Water-level declines in the Wyodak coal aquifer are predicted to extend beyond the area affected by individual existing and proposed mines because of the cumulative effect of adjacent mining operations. The probable areal extent of the cumulative impacts was determined for each mine as part of the mine-permit applications submitted to the wyoming Department of Environmental Quality. The areal extent of cumulative water-level declines generally is determined by superposition of predicted water-level declines resulting from individual existing and proposed mines. In its most sophisticated form, the determination is made by including several adjacent mining operations in a numerical model of ground-water flow. The area of cumulative impacts for existing and proposed mines was determined by compositing information from mine-permit applications for the entire study area.

The predicted areal extent of cumulative water-level declines of $5 \mathrm{ft}$ or more shown on plate 2 is considered a worst-case prediction because it is based on worst-case predictions of water-level declines resulting from individual mining operations at existing and proposed mines. Within the area of cumulative water-level declines, water-level declines are predicted to range from 5 to $80 \mathrm{ft}$ depending on the proximity to mining operations. Hydrologic conditions, such as permeable fracture zones or zones of small permeability, may affect the predicted effects locally.

North and west of Gillette, the areal extent of cumulative water-level declines is shown to be as much as $15 \mathrm{mi}$ from the lease areas. This large extent is due primarily to the large areal extent of water-level decline from the Eagle Butte lease area. In this study, it was assumed that the areal extent of 5-ft water-level decline in the Wyodak coal aquifer would be about $8 \mathrm{mi}$ from the Eagle Butte lease area. This assumption also will decrease the areal extent of predicted cumulative water-level decline to less than that shown on plate 2 . 


\section{Predicted Areal Extent of Cumulative Declines Resulting from All Anticipated Mining}

In order to determine which water-supply wells may be affected by water-level declines resulting from all anticipated mining, the area of the potential cumulative 5-ft or more water-level decline in the Wyodak coal aquifer resulting from all anticipated mining was approximated and is shown on plate 2. The extent of this area was approximated on the basis of the predicted cumulative 5-ft water-level decline ( $\mathrm{pl}$. 2) resulting from the existing and proposed mining, the location and potential effects of the Selected Coal Tracts and areas with Preference Right Lease Applications, and the extent of the Wyodak coal bed. In general, predicted cumulative waterlevel declines resulting from existing and proposed mining extend about $8 \mathrm{mi}$ from lease areas. Therefore, the area of potential cumulative water-level declines from all anticipated mining is defined, in this report, as extending from the outcrop of the Wyociar coal bed to about $\delta \mathrm{mi}$ from areas of all anticipated mining.

Addition of areas for possible future mining to existing lease areas may or may not affect the predicted extent of water-level declines from all anticipated mining shown on plate 2. The areal extent of water-level declines may be substantially changed if large areas are leased for mining where there are now (1987) no leases, Selected Coal Tracts, or Preference Right Lease Applications. The impacts of future mining in areas not included in the definition of all anticipated mining will depend on the size, location, timing of mining with respect to adjacent mines, and local hydrogeologic conditions. Generally, the probable maximum extent of 5-ft or more water-level decline in the Wyodak coal aquifer will be about $8 \mathrm{mi}$ from mined areas. If additional areas are leased for surface coal mining in the future, the 8-mi criterium can be applied to determine if the areal extent of water-level decline in the Wyodak coal aquifer will be substantially different from that shown on plate 2 .

\section{GROUND-WATER USE}

About 4,800 wells with valid ground-water rights are in the study area. The number of wells is estimated on the basis of a computer retrieval of water-well completion data for the entire study area by the Wyoming State Engineer's Office. Wells not registered with the State Engineer do not have valid water rights and are not included in the retrieval of well-completion data.

of the 4,800 wells in the study area, about 2,700 wells are used as sources of water supply: about 2,000 wells are used for domestic or livestock supplies, and about 700 wells are used for municipal, industrial, irrigation, or miscellaneous supplies. Miscellaneous uses include domestic supply for subdivisions, trailer parks, and potable supplies at coal mines and commercial establishments. The remaining 2,100 wells in the study area are used by coal-mining companies for monitoring or dewatering purposes. 
About 3,000 wells are in the area of potential cumulative water-level declines resulting from all anticipated mining. Of these 3,000 wells, about 1,200 are outside the areas of anticipated mining: about 1,000 wells supply water for domestic or livestock uses, and about 200 wells supply water for municipal, industrial, irrigation, and miscellaneous uses. The remaining 1,800 wells are used by coal-mining companies: about 1,700 wells are used for monitoring ground-water levels and quality, and about 100 wells are used for water supply and dewatering at mine sites.

\section{Impacts of Water-Level Declines on Ground-Water Use}

The impacts of water-level declines are of primary concern for the 1,200 wells outside the areas of anticipated mining and not for the 1,800 wells used by the coal-mining companies. Water-level declines in monitoring wells are not detrimental in that they do not affect the use of the well for its intended purpose. Water-level declines in water-supply wells and dewatering wells owned by coal-mining companies were not investigated because water-level declines in these wells will be caused primarily by mining operations of the companies owning the wells rather than by cumulative impacts of all anticipated mining operations.

In order to determine the impacts of water-level declines on the 1,200 water-supply wells outside the areas of anticipated mining, the aquifer in which the well is completed had to be determined. According to well logs and completion reports for these wells, about 580 wells are completed in the Wasatch aquifer, about 100 in the Wyodak coal aquifer, and about 280 in aquifers stratigraphically below the Wyodak coal bed. Stratigraphic location of the completion interval could not be determined for about 260 wells because of lack of information on the well-completion report. Wellcompletion data for the 1,200 water-supply wells outside the areas of anticipated mining are given in table 32 (Supplemental Data section at back of report).

The impacts of water-level declines on wells outside mining areas will depend on the magnitude of decline that occurs in the individual wells, which in turn, is related to the proximity of a well to mining operations. Other factors important in determining the impacts on individual wells include the depth of the well, the depth and number of perforated intervals, depth to water, and the yield required from the well to maintain it as a useable source of water.

The most important factor in determining if the water level in a well will be affected by mining operations is the stratigraphic location of the perforated interval of the well and, consequently, the aquifer in which the well is completed. In wells completed in the Wasatch aquifer in the area of anticipated water-level declines, water levels will decline only if the wells are about 2,000 ft or less from a mine pit. Water-supply wells completed in the Wasatch aquifer are shown on plate 3 . However, wells completed in the Wyodak coal aquifer may be affected as far away as $8 \mathrm{mi}$ from mine pits. Wells completed in the underlying aquifers will not be affected by dewatering of the mine pits, but may be affected by withdrawals from wells supplying facilities at mines. 
Wells completed in the Wyodak coal aquifer also are shown on plate 3 . Water-level declines in these wells are predicted to range from less than $5 \mathrm{ft}$ in wells far away from mining operations to more than $80 \mathrm{ft}$ in wells near mining operations. Most wells completed in the coal aquifer are smallyield (less than $25 \mathrm{gal} / \mathrm{min}$ ) domestic and livestock water-supply wells. If the water level in any of the wells declines such that the yield is markedly decreased, the well can be deepened or replaced with a well completed in the underlying aquifers.

Most mines in the Gillette area have wells completed in the lower part of the Fort Union Formation (Tongue River-Lebo aquifer and Tullock aquifer). Water from these wells is used for potable supply, dust control, equipment washing, and so forth. In addition to the wells at the mines, many of the subdivisions and trailer parks near Gillette obtain their water supply from wells completed in the lower part of the Fort Union Formation. The city of Gillette has 12 public-supply wells completed in this same stratigraphic interval.

Water-level declines in the lower part of the Fort Union Formation have been documented in the Gillette area. However, these declines are most likely attributable to withdrawals at subdivisions and trailer parks in and near Gillette (M.A. Crist, U.S. Geological Survey, written commun., 1987). Wells supplying facilities at mines are scattered throughout a large area. Because there is no major center of pumping, most of the water-level decline due to withdrawal from these wells occurs within $1 \mathrm{mi}$ of the pumped well. Static water levels measured in wells completed in the lower part of the Fort Union Formation generally are $500 \mathrm{ft}$ or more above the top of the perforated interval. Water-level declines of 100 to $200 \mathrm{ft}$ in the vicinity of a pumped well will not dewater the aquifer. However, the yields of wells located near wells supplying facilities at mines may be affected by waterlevel declines in the vicinity of the pumped wells.

\section{Alternative Sources of Supply}

Although surface-water supplies are limited in the study area, alternative sources of ground-water supplies are available to replace existing supplies that may be interrupted or depleted by water-level declines resulting from mining operations. Shallow ground water is the principal source of domestic and livestock supplies. Affected wells completed in the Wasatch aquifer or Wyodak coal aquifer could be replaced by wells completed in either the Tongue River-Lebo aquifer or Tullock aquifer. Wells completed in the Tongue River-Lebo aquifer or Tullock aquifer probably will not be affected by water-level declines; if they are affected, replacement wells could be completed in the underlying Lance-Fox Hills aquifer. Relocation of existing water-supply wells, deepening of wells, and construction of new wells require analysis and approval by the Wyoming State Engineer.

The Tongue River-Lebo aquifer consists of 800 to 1,000 ft of lenticular beds of fine-grained claystone, shale, and sandstone. Well yields generally are sufficient for domestic and livestock supplies. The Tullock aquifer is composed of numerous lenticular sandstone beds isolated by interbedded shale and siltstone. Yields of 200 to $300 \mathrm{gal} / \mathrm{min}$ are available from wells 
completed in the Tullock aquifer. The Lance-Fox Hills aquifer consists of lenticular beds of massive sandstone isolated by interbedded shale and siltstone. Well yields as much as $380 \mathrm{gal} / \mathrm{min}$ are available from wells perforated through the entire stratigraphic interval of the Lance-Fox Hills aquifer.

The main alternative sources of water supplies for wells significantly impacted by mining operations will be the Tongue River-Lebo aquifer for domestic and livestock supplies and the Tullock aquifer or Lance-Fox Hills aquifer for uses requiring a larger yield. Withdrawals from large-capacity wells completed in the Tullock aquifer or Lance-Fox Hills aquifer should not affect water supplies of wells completed in the Tongue River-Lebo aquifer because they are hydrologically separated by a thick shale zone.

\section{Quality of Alternative Supplies}

Water quality in aquifers in the Fort Union Formation is variable and appears to correlate with the permeability of the water-yielding sands and proximity to the recharge area. Dissolved-solids concentrations range from about 200 to about $3,000 \mathrm{mg} / \mathrm{L}$ (milligrams per liter), but commonly range between 500 and $1,500 \mathrm{mg} / \mathrm{L}$ (Hodson and others, 1973). Larson (1984) summarized dissolved-solids concentration data for 60 water samples from aquifers in the Fort Union Formation in Campbell County; the median concentration was $1,230 \mathrm{mg} / \mathrm{L}$, and the average concentration was $1,480 \mathrm{mg} / \mathrm{L}$.

Selected water-quality data for samples from wells completed in aquifers in Upper Cretaceous formations, stratigraphically below the Fort Union Formation, were compiled for areas within and adjacent to the study area ( $\mathrm{fig} .8$ ). Sources of data for this compilation include the Water Data Storage and Retrieval System (WATSTORE) water-quality file of the U.S. Geological Survey and geochemical studies done by Chatham and others (1981) and Henderson (1984). It was assumed that the data compiled from those sources were representative of water quality in the Lance-Fox Hills aquifer. Additional summaries of water-quality data that pertain to the study area have been done by Larson (1984) and Larson and Daddow (1984).

In order to provide a brief overview of the water quality from aquifers of Late Cretaceous age, the concentration ranges of dissolved solids, fluoride, and selenium in these ground waters are illustrated in figure 9. Dissolved-solids concentrations in 130 ground-water samples ranged from 240 to $2,800 \mathrm{mg} / \mathrm{L}$ ( $\mathrm{fig} .9$ ). About 13 percent of the samples had dissolvedsolids concentrations less than the $500-\mathrm{mg} / \mathrm{L}$ standard for domestic use (Wyoming Department of Environmental Quality, 1980a).

Dissolved fluoride concentrations in 124 ground-water samples ranged from less than 0.1 to $6.0 \mathrm{mg} / \mathrm{L}$ ( $f i g$. 9). Assuming a maximum daily air temperature of 54 to $58{ }^{\circ} \mathrm{F}$, the maximum acceptable fluoride concentration in a public water supply is $2.2 \mathrm{mg} / \mathrm{L}$ (Wyoming Department of Environmental Quality, 1980a). About 10 percent of the ground-water samples had fluoride concentrations that exceeded this maximum concentration. 


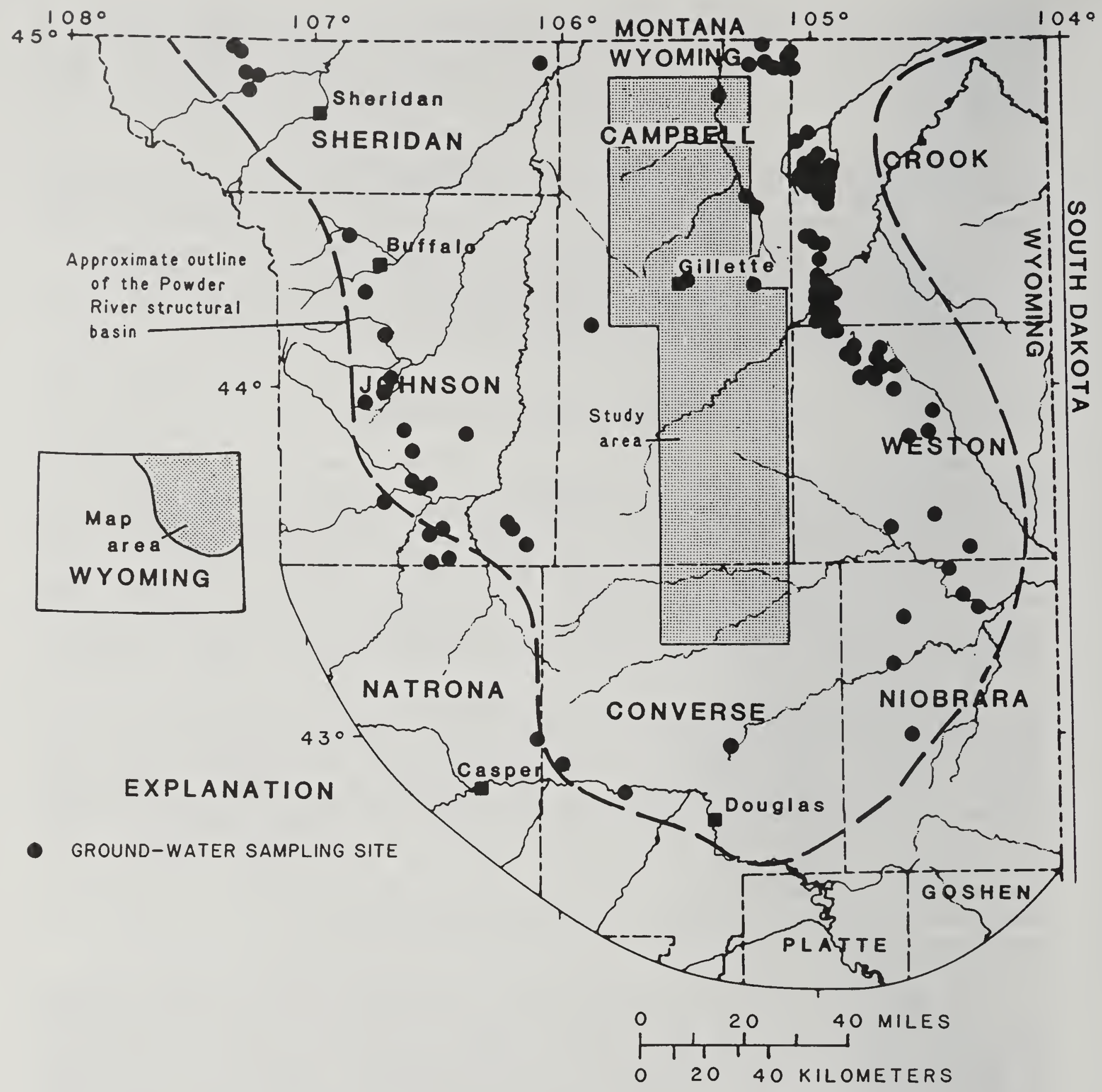

Figure 8.--Location of sampling sites for which water-quality data is available for water samples from aquifers in Upper Cretaceous formations. 


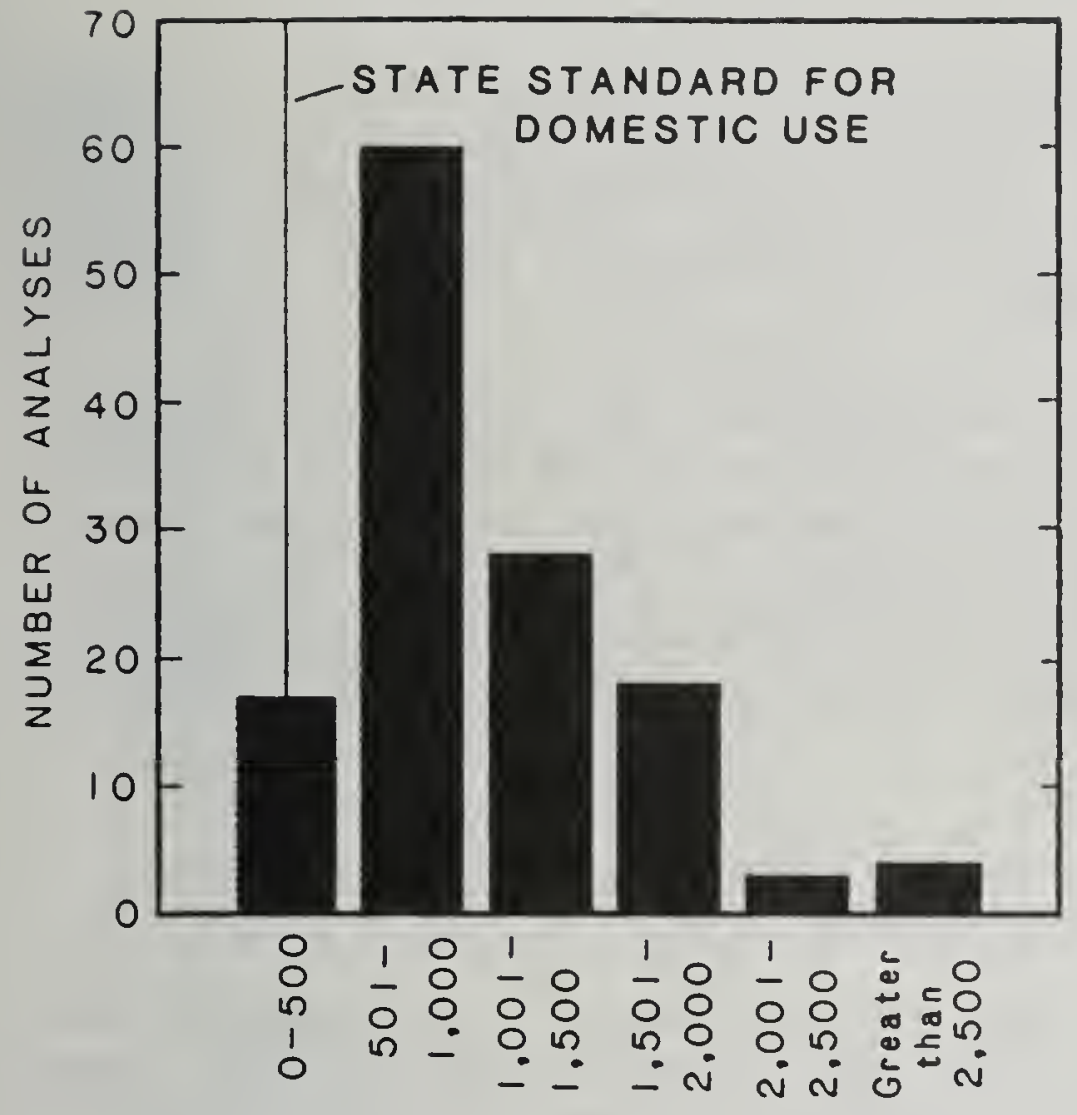

DISSOLVED-SOLIOS CONCENTRATION, IN MILLIGRAMS PER LITER

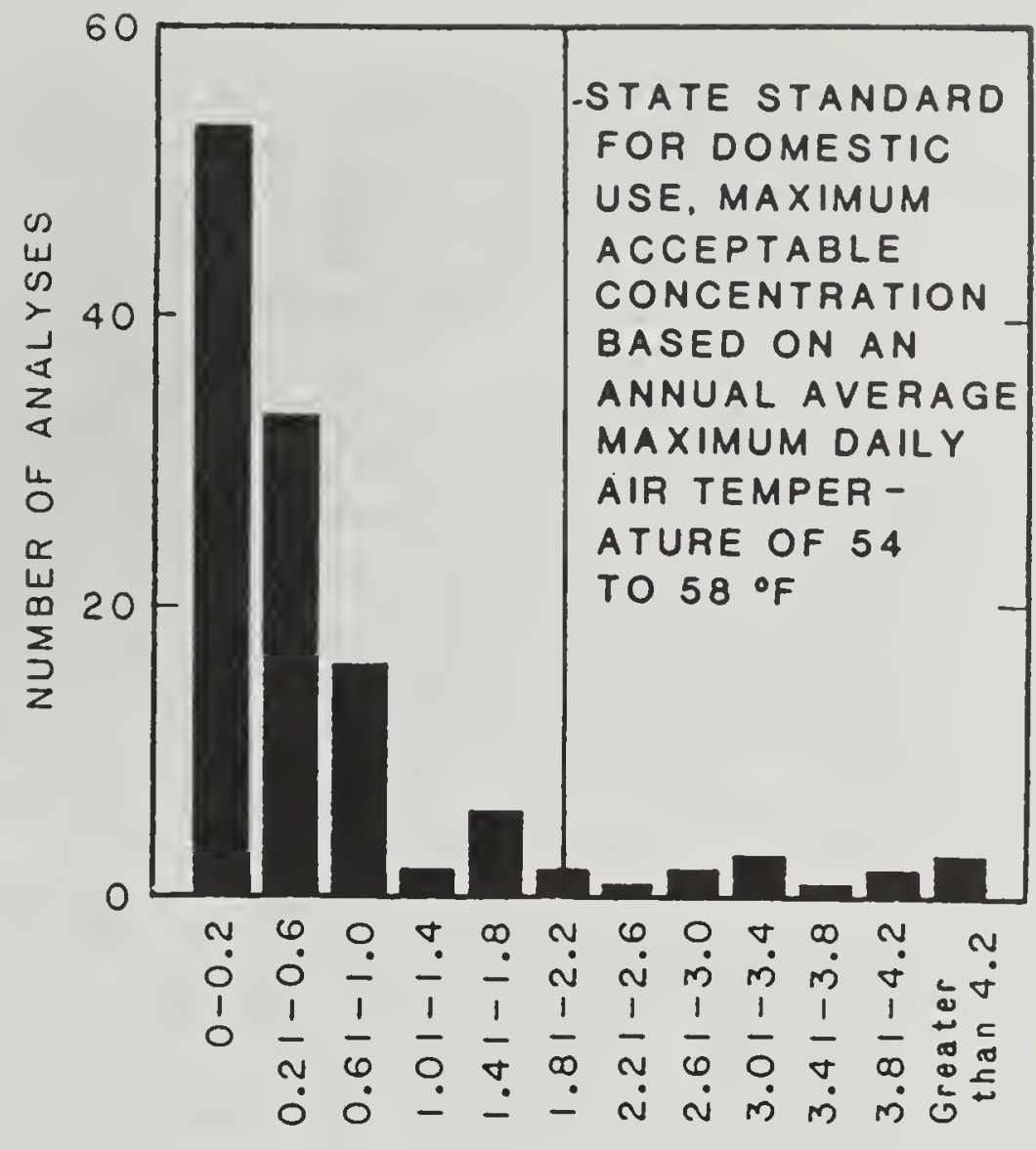

DISSOLVED-FLUORIDE CONCENTRATION, IN MILLIGRAMS PER LITER

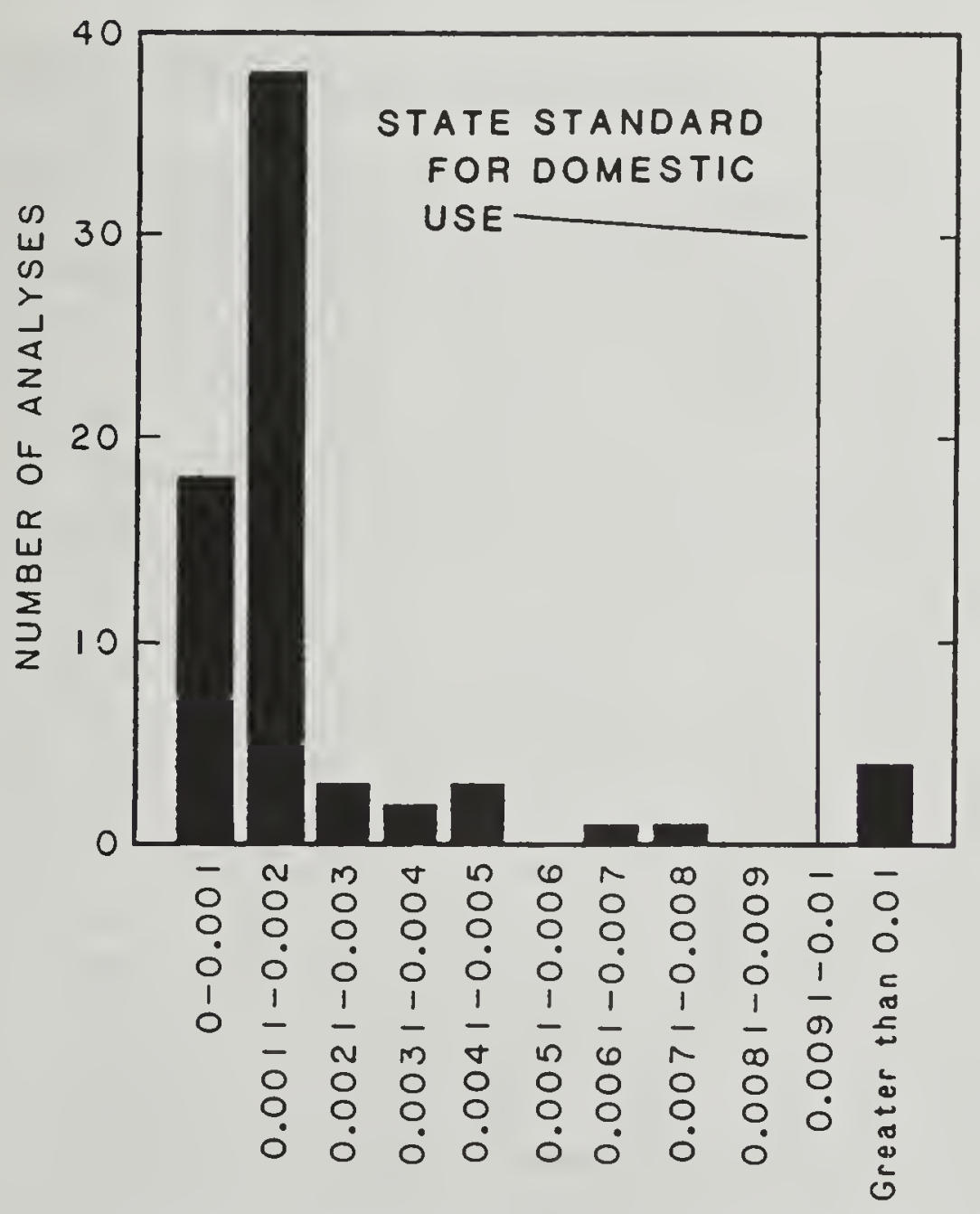

DISSOLVED-SELENIUM CONCENTRATION, IN MILLIGRAMS PER LITER

Figure 9.--Histograms of selected water-quality constituents in water samples from aquifers in Upper Cretaceous formations. 
Dissolved-selenium concentrations in 70 ground-water samples ranged from less than 0.001 to greater than $0.01 \mathrm{mg} / \mathrm{L}$ (fig. 9). About 6 percent of the ground-water samples had dissolved-selenium concentrations exceeding the standard of $0.01 \mathrm{mg} / \mathrm{L}$ for domestic use as prescribed by the Wyoming Department of Environmental Quality (1980a).

Alternative sources of ground-water supplies are available to replace existing supplies that are interrupted or depleted by water-level declines resulting from mining operations. Alternative sources are the Tongue RiverLebo aquifer and the Lance-Fox Hills aquifer. Although, the quality of water from these alternative sources does not always meet the State domestic standard, it is approximately the same as the quality of water currently being used.

\section{GROUND-WATER QUALITY}

Surface coal mining in the study area has the potential to affect the ground-water quality in near-surface aquifers. The removal of coal from mines in the study area modifies near-surface aquifers by replacing the Wasatch aquifer and Wyodak coal aquifer with rubblized overburden material which becomes saturated as the postmining water table equilibrates after mining. In general, the wasatch aquifer and spoil aquifers are of limited regional extent, whereas the Wyodak coal aquifer is more regional.

\section{Existing Water-Quality Data}

Chemical data from premining (Wasatch aquifer in the overburden and Wyodak coal aquifer) and postmining (spoil aquifers) ground-water samples were compiled from existing information collected from selected coal mines in the study area (fig. 10). Water samples were collected by the coalmining companies and the chemical analyses were compiled from files of the Wyoming Department of Environmental Quality. Premining water-quality data were compiled from 174 chemical analyses of samples collected from 50 wells completed in the Wasatch aquifer and from 379 chemical analyses of samples collected from 88 wells completed in the Wyodak coal aquifer at 7 existing mines. Postmining water-quality data were compiled from 336 chemical analyses of samples collected from 45 wells completed in spoil aquifers at 10 existing mines. The premining water-quality data were compiled for samples collected from 1977 through 1986; the postmining water-quality data were compiled for samples collected from 1981 through 1986. Because all existing chemical analyses were utilized in this data compilation, the postmining (spoil aquifer) data set is biased toward large concentrations of constituents. Because at present (1987), spoil aquifers are not fully saturated, relatively few areas of backfilled spoil are saturated, and more mining and resulting spoil areas are anticipated, the biased water-quality data represents a worst-case statistical summary of the existing water quality. For example, a spoil aquifer with water containing constituents that exceeded a particular water-quality standard commonly has more waterquality sampling wells and chemical analyses than does a spoil aquifer with water containing constituents that do not exceed any water-quality standards. 


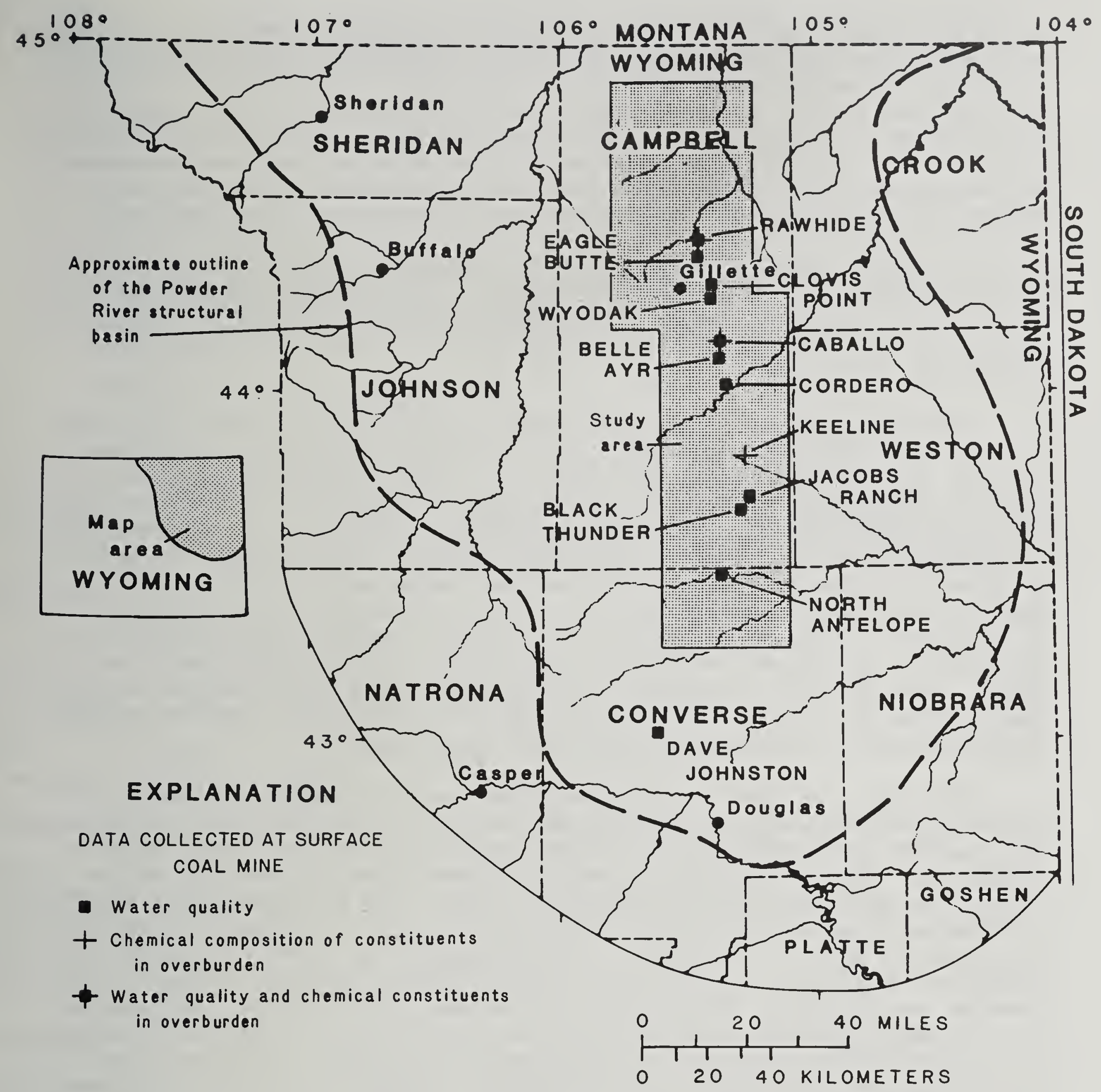

Figure 10.--Location of surface coal mines where data for determining the water quality in aquifers and the chemical composition of constituents in overburden were collected. 
Water-quality samples were analyzed by numerous laboratories and, therefore, are not subject to consistent quality-control checks. Analyses with a cation-anion charge balance differing by greater than 7 percent were eliminated from the data set. The sample-preservation and analytical methods used may not be consistent within the compiled data set, especially with respect to the minor- and trace-element analyses. However, within the limits of these qualifications, the compiled water-quality data are useful for summarizing premining water quality in the Wasatch aquifer and the Wyodak coal aquifer, and postmining water quality in spoil aquifers.

The compiled water-quality data were compared to the Quality Standards for Wyoming Groundwaters published by the Wyoming Department of Environmental Quality (1980a). Hereafter in the report, these water-quality standards will be referred to as the state standard for each chemical constituent of interest.

The median concentrations of dissolved solids and sulfate were larger in water from spoil aquifers compared to water from either the Wasatch aquifer or Wyodak coal aquifer (table 4). The median dissolved-solids and sulfate concentrations in water samples from the spoil aquifers were less than the State standard for livestock (see table 4). Dissolved-solids concentrations in 27 percent of the water samples from the spoil aquifers exceeded the State standard for livestock, compared to 0 percent for water samples from the Wyodak coal aquifer. Dissolved-sulfate concentrations in 16 percent of the water samples from the spoil aquifers exceeded the State standard for livestock, compared to 0 percent for water samples from the Wyodak coal aquifer. The maximum dissolved-solids concentration in water samples from the spoil aquifers was about $25,000 \mathrm{mg} / \mathrm{L}$, and the maximum dissolved-sulfate concentration was about $17,000 \mathrm{mg} / \mathrm{L}$.

Data from 7 of the 10 individual mines listed in table 5 indicate that median dissolved-solids concentrations were smaller in water from the Wyodak coal aquifer compared to water from the Wasatch aquifer and spoil aquifers (table 5). The increase in the median concentration of dissolved solids in water from the spoil aquifers compared to water from the Wyodak coal aquifer is because of material redistribution during mining. As noted by Groenewold and others (1983, p. 138-139), redistribution of overburden materials (Wasatch Formation) creates the potential for substantial changes in the chemical reactivity of the spoil-pile landscape. For example, emplacement of sediments from the unsaturated zone (premining) to depths below the postmining water table could cause increases in the dissolved-solids concentration resulting from dissolution of gypsum and other efflorescent salts accumulated in these spoil materials.

The median concentration of fluoride in water from the spoil aquifers $(0.34 \mathrm{mg} / \mathrm{L})$ was smaller than in water from the Wyodak coal aquifer $(0.52 \mathrm{mg} / \mathrm{L})$ (table 4$)$. A possible reason for the smaller median fluoride concentration in water from the spoil aquifers could be the increased calcium concentrations in water from the spoil aquifers resulting in precipitation of fluorite. The median concentration of calcium in water from the Wyodak coal aquifer was $105 \mathrm{mg} / \mathrm{L}$; the median concentration of calcium in water from the spoil aquifers was $478 \mathrm{mg} / \mathrm{L}$. 
Table 4.--Percentage of samples with concentrations exceeding State standards and statistical summary of selected constituents in water samples from the Wasatch aquifer, Wyodak coal aquifer, and spoil aquifers from selected coal mines

[Constituents are dissolved; concentrations and standards are in milligrams per liter. Samples collected by coal-mining companies; analyses from the files of the Wyoming Department of Environmental Quality. Total number of samples equals total number of samples that were chemically analyzed. Percentage of samples with concentrations less than detection limit(s) was computed from the total number of samples with concentrations less than the detection limit(s) divided by the total number of samples for each constituent; there may be more than one detection limit due to the various laboratories and methods used to produce the data. State standard refers to ground-water quality standards of Wyoming Department of Environmental Quality (1980a). (--), no State standard; l.d., less than analytical detection limit(s); -., no data]

\begin{tabular}{|c|c|c|c|c|c|c|}
\hline $\begin{array}{l}\text { Chemical } \\
\text { constituent } \\
\text { and aquifer }\end{array}$ & $\begin{array}{c}\text { Total } \\
\text { number } \\
\text { of } \\
\text { samples' }\end{array}$ & $\begin{array}{l}\text { Percentage } \\
\text { of samples } \\
\text { with con- } \\
\text { centrations } \\
\text { less than } \\
\text { detection } \\
\text { limit(s) }\end{array}$ & $\begin{array}{c}\text { Median } \\
\text { concentration }\end{array}$ & $\begin{array}{r}\text { Percenta } \\
\text { with cc } \\
\text { exceeding } \\
\text { (standards } \\
\text { Domestic }\end{array}$ & $\begin{array}{l}\text { samples } \\
\text { ations } \\
\text { standards } \\
\text { rentheses) } \\
\text { Livestock }\end{array}$ & $\begin{array}{c}\text { Maximum } \\
\text { concentration }\end{array}$ \\
\hline$\frac{\text { Dissolved }}{\text { solids }}$ & & & & $(500)$ & $(5,000)$ & \\
\hline $\begin{array}{l}\text { Wasatch } \\
\text { aquifer }\end{array}$ & 174 & 0 & 2,215 & 98 & 5 & 9,470 \\
\hline $\begin{array}{l}\text { Wyodak coal } \\
\text { aquifer }\end{array}$ & 379 & 0 & 1,310 & 100 & 0 & 5,180 \\
\hline $\begin{array}{l}\text { Spoil } \\
\text { aquifers }\end{array}$ & 336 & 0 & 3,680 & 100 & 27 & 25,320 \\
\hline Sulfate & & & & (250) & $(3,000)$ & \\
\hline $\begin{array}{l}\text { Wasatch } \\
\text { aquifer }\end{array}$ & 174 & 0 & 1,215 & 83 & 7 & 5,800 \\
\hline $\begin{array}{l}\text { Wyodak coal } \\
\text { aquifer }\end{array}$ & 379 & 2 & 565 & 100 & 0 & 3,030 \\
\hline $\begin{array}{l}\text { Spoil } \\
\text { aquifers }\end{array}$ & 336 & 0 & 2,080 & 87 & 16 & 17,170 \\
\hline Fluoride & & & & $=(1.4-2.4)$ & $(--)$ & \\
\hline $\begin{array}{l}\text { Wasatch } \\
\text { aquifer }\end{array}$ & 173 & 4 & 0.430 & 0 & -- & 1.8 \\
\hline $\begin{array}{l}\text { Wyodak coal } \\
\text { aquifer }\end{array}$ & 374 & 0 & .515 & 0 & -- & 2.92 \\
\hline $\begin{array}{l}\text { Spoil } \\
\text { aquifers }\end{array}$ & 336 & 0 & .34 & 0 & -- & 2.15 \\
\hline
\end{tabular}


Table 4.--Percentage of samples with concentrations exceeding State standards and statistical summary of selected constituents in water samples from the Wasatch aquifer, Wyodak coal aquifer, and spoll aquifers from selected coal mines--Continued

\begin{tabular}{|c|c|c|c|c|c|c|}
\hline $\begin{array}{l}\text { Chemical } \\
\text { constituent } \\
\text { and aquifer }\end{array}$ & $\begin{array}{l}\text { Total } \\
\text { number } \\
\text { of } \\
\text { samples' }\end{array}$ & $\begin{array}{l}\text { Percentage } \\
\text { of samples } \\
\text { with con- } \\
\text { centrations } \\
\text { less than } \\
\text { detection } \\
\text { limit }(s)\end{array}$ & $\begin{array}{c}\text { Median } \\
\text { concentration }\end{array}$ & $\begin{array}{r}\text { Percent } \\
\text { with } \\
\text { exceeding } \\
\text { (standard } \\
\text { Domestic }\end{array}$ & $\begin{array}{l}\text { samples } \\
\text { ations } \\
\text { standards } \\
\text { rentheses) } \\
\text { Livestock }\end{array}$ & $\begin{array}{c}\text { Maximum } \\
\text { concentration }\end{array}$ \\
\hline$\frac{\text { Ammonia }}{\text { (as nitrogen) }}$ & & & & $(0.50)$ & $(--)$ & \\
\hline $\begin{array}{l}\text { Wasatch } \\
\text { aquifer }\end{array}$ & 138 & 3 & 1.52 & 88 & -- & 5.36 \\
\hline $\begin{array}{c}\text { Wyodak coal } \\
\text { aquifer }\end{array}$ & 337 & 2 & 1.81 & 89 & -- & 20.2 \\
\hline $\begin{array}{l}\text { Spoil } \\
\text { aquifers }\end{array}$ & 335 & 1 & 1.53 & 85 & -- & 29 \\
\hline$\frac{\text { Nitrate }}{\text { (asnitrogen) }}$ & & & & $(10.0)$ & ${ }^{3}(--)$ & \\
\hline $\begin{array}{l}\text { Wasatch } \\
\text { aquifer }\end{array}$ & 139 & 23 & .120 & 4 & -- & 36.4 \\
\hline $\begin{array}{l}\text { Wyodak coal } \\
\text { aquifer }\end{array}$ & 324 & 30 & .09 & 1 & -- & 21.3 \\
\hline $\begin{array}{l}\text { Spoil } \\
\quad \text { aquifers }\end{array}$ & 323 & 25 & .130 & 19 & -- & 305 \\
\hline Aluminum & & & & $(--)$ & $(5.0)$ & \\
\hline $\begin{array}{l}\text { Wasatch } \\
\text { aquifer }\end{array}$ & 167 & 72 & l.d. & -- & 0 & .9 \\
\hline $\begin{array}{l}\text { Wyodak coal } \\
\text { aquifer }\end{array}$ & 366 & 80 & l.d. & -- & 0 & 1.5 \\
\hline $\begin{array}{l}\text { Spoil } \\
\text { aquifers }\end{array}$ & 336 & 61 & l.d. & -- & 0 & 8.4 \\
\hline Arsenic & & & & $(0.050)$ & $(0.020)$ & \\
\hline $\begin{array}{l}\text { Wasatch } \\
\text { aquifer }\end{array}$ & 170 & 92 & 1.d. & 0 & 0 & .021 \\
\hline $\begin{array}{l}\text { Wyodak coal } \\
\text { aquifer }\end{array}$ & 369 & 100 & l.d. & 0 & 0 & .006 \\
\hline $\begin{array}{l}\text { Spoil } \\
\text { aquifers }\end{array}$ & 336 & 66 & l.d. & 0 & 0 & .049 \\
\hline Barium & & & & $(1.0)$ & $(--)$ & \\
\hline $\begin{array}{l}\text { Wasatch } \\
\text { aquifer }\end{array}$ & 156 & 81 & 1.d. & 0 & -- & .59 \\
\hline $\begin{array}{l}\text { Wyodak coal } \\
\text { aquifer }\end{array}$ & 348 & 77 & 1.d. & 1 & -- & 2.4 \\
\hline $\begin{array}{l}\text { Spoil } \\
\text { aquifers }\end{array}$ & 320 & 81 & $1 . d$. & 1 & -- & 2.2 \\
\hline
\end{tabular}


Table 4.--Percentage of samples with concentrations exceeding State standards and statistical summary of selected constituents in water samples from the Wasatch aquifer, Wyodak coal aquifer, and spoil aquifers from selected coal mines--Continued

\begin{tabular}{|c|c|c|c|c|c|c|}
\hline $\begin{array}{l}\text { Chemical } \\
\text { constituent } \\
\text { and aquifer }\end{array}$ & $\begin{array}{l}\text { Total } \\
\text { number } \\
\text { of } \\
\text { samples }\end{array}$ & $\begin{array}{l}\text { Percentage } \\
\text { of samples } \\
\text { with con- } \\
\text { centrations } \\
\text { less than } \\
\text { detection } \\
\text { limit(s) }\end{array}$ & $\begin{array}{c}\text { Median } \\
\text { concentration }\end{array}$ & $\begin{array}{c}\text { Percent } \\
\text { with } \\
\text { exceeding } \\
\text { (standar } \\
\text { Domestic }\end{array}$ & $\begin{array}{l}\text { samples } \\
\text { ations } \\
\text { standards } \\
\text { rentheses) } \\
\text { Livestock }\end{array}$ & $\begin{array}{c}\text { Maximum } \\
\text { concentration }\end{array}$ \\
\hline Boron" & & & & $(0.75)$ & $(5.00)$ & \\
\hline $\begin{array}{l}\text { Wasatch } \\
\text { aquifer }\end{array}$ & 163 & 31 & 0.07 & 0 & 0 & 0.71 \\
\hline $\begin{array}{l}\text { Wyodak coal } \\
\text { aquifer }\end{array}$ & 356 & 18 & .10 & 2 & 0 & 2.9 \\
\hline $\begin{array}{l}\text { Spoil } \\
\text { aquifers }\end{array}$ & 336 & 5 & .15 & 5 & 0 & 1.5 \\
\hline Cadmium" & & & & $(0.01)$ & $(0.05)$ & \\
\hline $\begin{array}{l}\text { Wasatch } \\
\text { aquifer }\end{array}$ & 172 & 84 & $1 . d$. & 1 & 0 & .02 \\
\hline $\begin{array}{c}\text { Wyodak coal } \\
\text { aquifer }\end{array}$ & 373 & 96 & l.d. & 0 & 0 & .03 \\
\hline $\begin{array}{l}\text { Spoil } \\
\quad \text { aquifers }\end{array}$ & 336 & 57 & l.d. & 3 & 0 & .029 \\
\hline Chromium & & & & $(0.05)$ & $(0.05)$ & \\
\hline $\begin{array}{l}\text { Wasatch } \\
\text { aquifer }\end{array}$ & 173 & 82 & l.d. & 1 & 1 & .06 \\
\hline $\begin{array}{l}\text { Wyodak coal } \\
\text { aquifer }\end{array}$ & 324 & 91 & l.d. & 1 & 1 & .09 \\
\hline $\begin{array}{l}\text { Spoil } \\
\quad \text { aquifers }\end{array}$ & 336 & 78 & 1.d. & 7 & 7 & .75 \\
\hline Copper ${ }^{4}$ & & & & $(1.0)$ & $(0.05)$ & \\
\hline $\begin{array}{l}\text { Wasatch } \\
\text { aquifer }\end{array}$ & 170 & 64 & 1.d. & 1 & 0 & 1.61 \\
\hline $\begin{array}{l}\text { Wyodak coal } \\
\text { aquifer }\end{array}$ & 368 & 72 & 1.d. & 0 & 0 & 1.21 \\
\hline $\begin{array}{l}\text { Spoil } \\
\text { aquifers }\end{array}$ & 336 & 64 & l.d. & 0 & 0 & .2 \\
\hline Iron" & & & & $(0.30)$ & $(--)$ & \\
\hline $\begin{array}{l}\text { Wasatch } \\
\text { aquifer }\end{array}$ & 139 & 43 & .06 & 28 & -- & 98.1 \\
\hline $\begin{array}{l}\text { Wyodak coal } \\
\text { aquifer }\end{array}$ & 305 & 34 & .08 & 24 & -- & 7.53 \\
\hline $\begin{array}{l}\text { Spoil } \\
\text { aquifers }\end{array}$ & 334 & 13 & .18 & 42 & -- & 114 \\
\hline
\end{tabular}


Table 4.--Percentage of samples with concentrations exceeding State standards and statistical summary of selected constituents in water samples from the Wasatch aquifer, wyodak coal aquifer, and spoil aquifers from selected coal mines--Continued

\begin{tabular}{|c|c|c|c|c|c|c|}
\hline $\begin{array}{l}\text { Chemical } \\
\text { constituent } \\
\text { and aquifer }\end{array}$ & $\begin{array}{l}\text { Total } \\
\text { number } \\
\text { of } \\
\text { samples } \\
\end{array}$ & $\begin{array}{l}\text { Percentage } \\
\text { of samples } \\
\text { with con- } \\
\text { centrations } \\
\text { less than } \\
\text { detection } \\
\text { limit(s) }\end{array}$ & $\begin{array}{c}\text { Median } \\
\text { concentration }\end{array}$ & $\begin{array}{r}\text { Percenta } \\
\text { with co } \\
\text { exceeding } \\
\text { (standards } \\
\text { Domestic } \\
\end{array}$ & $\begin{array}{l}\text { samples } \\
\text { rations } \\
\text { standards } \\
\text { arentheses) } \\
\text { Livestock }\end{array}$ & $\begin{array}{c}\text { Maximum } \\
\text { concentration }\end{array}$ \\
\hline Lead" & & & & $(0.05)$ & $(0.10)$ & \\
\hline $\begin{array}{l}\text { Wasatch } \\
\text { aquifer }\end{array}$ & 169 & 89 & 1.d. & 5 & 4 & .83 \\
\hline $\begin{array}{l}\text { Wyodak coal } \\
\text { aquifer }\end{array}$ & 368 & 95 & 1.d. & 1 & 0 & .13 \\
\hline $\begin{array}{l}\text { Spoil } \\
\quad \text { aquifers }\end{array}$ & 334 & 73 & 1.d. & 2 & 0 & 1.36 \\
\hline Manganese" & & & & $(0.05)$ & $(--)$ & \\
\hline $\begin{array}{l}\text { Wasatch } \\
\text { aquifer }\end{array}$ & 172 & 7 & .25 & 86 & -- & 9.80 \\
\hline $\begin{array}{l}\text { Wyodak coal } \\
\text { aquifer }\end{array}$ & 373 & 18 & .06 & 52 & -- & 2.90 \\
\hline $\begin{array}{l}\text { Spoil } \\
\quad \text { aquifers }\end{array}$ & 335 & 2 & .58 & 93 & -- & 8.52 \\
\hline Mercury" & & & & $(0.0002)$ & ${ }^{5}(0.00005)$ & \\
\hline $\begin{array}{l}\text { Wasatch } \\
\text { aquifer }\end{array}$ & 164 & 98 & 1.d. & 2 & 2 & 0.3 \\
\hline $\begin{array}{c}\text { Wyodak coal } \\
\text { aquifer }\end{array}$ & 355 & 96 & l.d. & 2 & 4 & .016 \\
\hline $\begin{array}{l}\text { Spoil } \\
\text { aquifers }\end{array}$ & 335 & 97 & l.d. & 1 & 3 & .004 \\
\hline Molybdenum & & & & $(--)$ & $(--)$ & \\
\hline $\begin{array}{l}\text { Wasatch } \\
\text { aquifer }\end{array}$ & 112 & 97 & l.d. & -- & -- & .02 \\
\hline $\begin{array}{l}\text { Wyodak coal } \\
\text { aquifer }\end{array}$ & 245 & 99 & l.d. & -- & -- & .03 \\
\hline $\begin{array}{l}\text { Spoil } \\
\quad \text { aquifers }\end{array}$ & 334 & 94 & l.d. & -- & -- & .12 \\
\hline Nickel $^{4}$ & & & & $(--)$ & $(--)$ & \\
\hline $\begin{array}{l}\text { Wasatch } \\
\text { aquifer }\end{array}$ & 173 & 66 & l.d. & -- & - & .13 \\
\hline $\begin{array}{l}\text { Wyodak coal } \\
\text { aquifer }\end{array}$ & 372 & 71 & l.d. & -- & -- & 1.1 \\
\hline $\begin{array}{l}\text { Spoil } \\
\text { aquifers }\end{array}$ & 291 & 55 & l.d. & -- & -- & .650 \\
\hline
\end{tabular}


Table 4.--Percentage of samples with concentrations exceeding State standards and statistical summary of selected constituents in water samples from the Wasatch aquifer, Wyodak coal aquifer, and spoil aquifers from selected coal mines--Continued

\begin{tabular}{|c|c|c|c|c|c|c|}
\hline $\begin{array}{l}\text { Chemical } \\
\text { constituent } \\
\text { and aquifer }\end{array}$ & $\begin{array}{l}\text { Total } \\
\text { number } \\
\text { of } \\
\text { samples }\end{array}$ & $\begin{array}{l}\text { Percentage } \\
\text { of samples } \\
\text { with con- } \\
\text { centrations } \\
\text { less than } \\
\text { detection } \\
\text { limit(s) }\end{array}$ & $\begin{array}{c}\text { Median } \\
\text { concentration }\end{array}$ & $\begin{array}{r}\text { Percent } \\
\text { with } \\
\text { exceeding } \\
\text { (standard } \\
\text { Domestic } \\
\end{array}$ & $\begin{array}{l}\text { samples } \\
\text { ations } \\
\text { standards } \\
\text { rentheses) } \\
\text { Livestock }\end{array}$ & $\begin{array}{c}\text { Maximum } \\
\text { concentration }\end{array}$ \\
\hline Selenium $^{4}$ & & & & $(0.01)$ & $(0.05)$ & \\
\hline $\begin{array}{l}\text { Wasatch } \\
\text { aquifer }\end{array}$ & 164 & 96 & 1.d. & 0 & 0 & .007 \\
\hline $\begin{array}{c}\text { Wyodak coal } \\
\text { aquifer }\end{array}$ & 355 & 100 & 1.d. & 0 & 0 & .005 \\
\hline $\begin{array}{l}\text { Spoil } \\
\text { aquifers }\end{array}$ & 335 & 60 & l.d. & 26 & 18 & 3.388 \\
\hline Zinc & & & & $(5.0)$ & $(25.0)$ & \\
\hline $\begin{array}{l}\text { Wasatch } \\
\text { aquifer }\end{array}$ & 173 & 29 & 0.02 & 0 & 0 & 2.83 \\
\hline $\begin{array}{l}\text { Wyodak coal } \\
\text { aquifer }\end{array}$ & 372 & 29 & 0.02 & 0 & 0 & 3.22 \\
\hline $\begin{array}{l}\text { Spoil } \\
\text { aquifers }\end{array}$ & 336 & 17 & .05 & 0 & 0 & 5.09 \\
\hline
\end{tabular}

- For Wasatch aquifer and the Wyodak coal aquifer, number refers to water samples collected at seven existing mines, and for the spoil aquifers, number refers to water samples collected at the Eagle Butte, North Antelope, and Rawhide Mines in addition to the same seven existing mines.

2 Depends on the annual average of the maximum daily air temperature. The limit of 2.4 milligrams per liter corresponds to a temperature of $12.0{ }^{\circ} \mathrm{Celsius}$ and less.

3 State nitrite plus nitrate standard for livestock is 100 milligrams per liter as nitrogen.

- Concentrations are reported in milligrams per liter rather than micrograms per liter to conform with units used in State standards by Wyoming Department of Environmental Quality.

S State mercury standard for livestock ( 0.00005 milligram per liter) is less than the analytical detection limit of procedures used by the laboratories doing the analyses. Therefore, all water samples with a detectable mercury concentration exceed the livestock standard. 


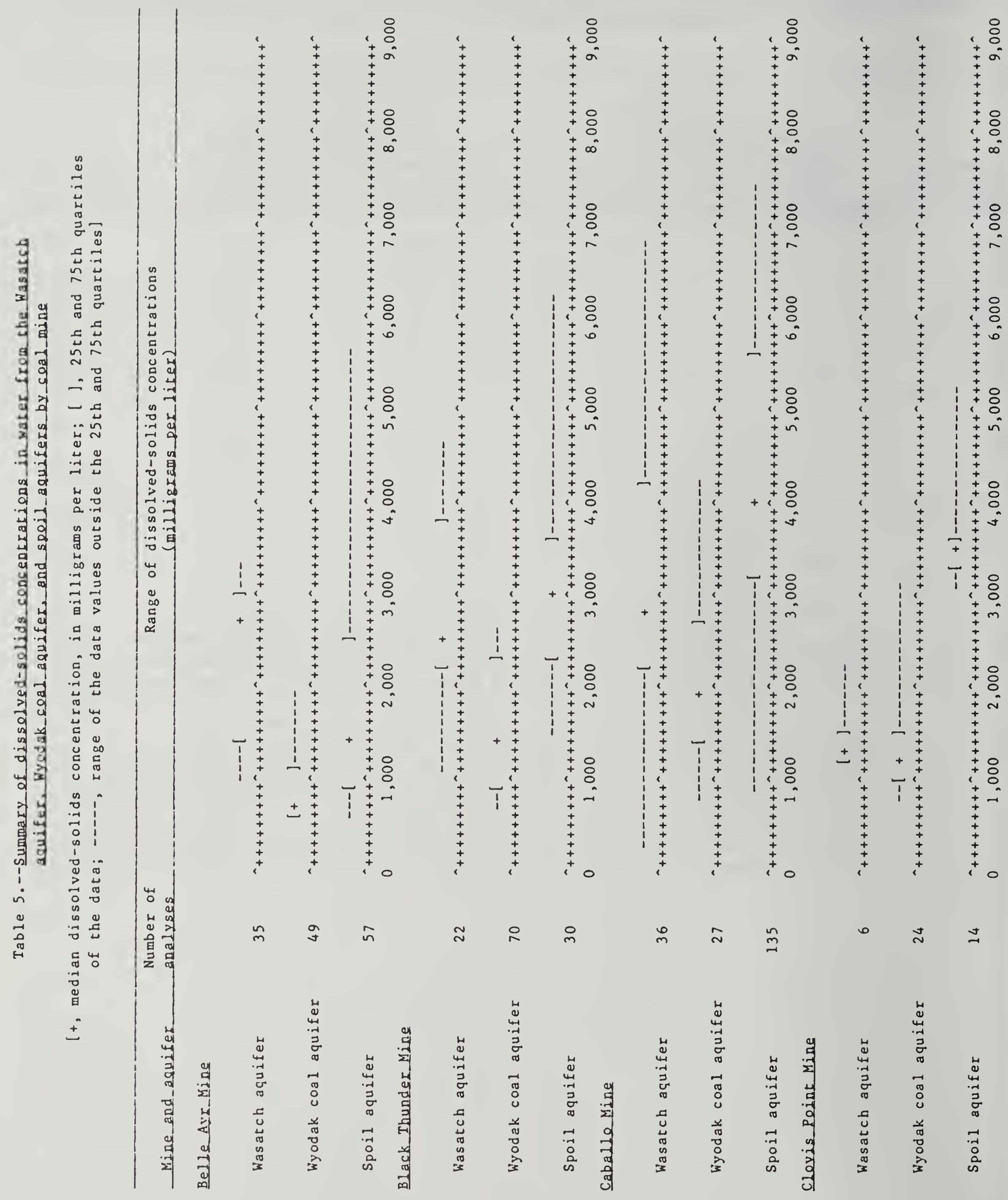




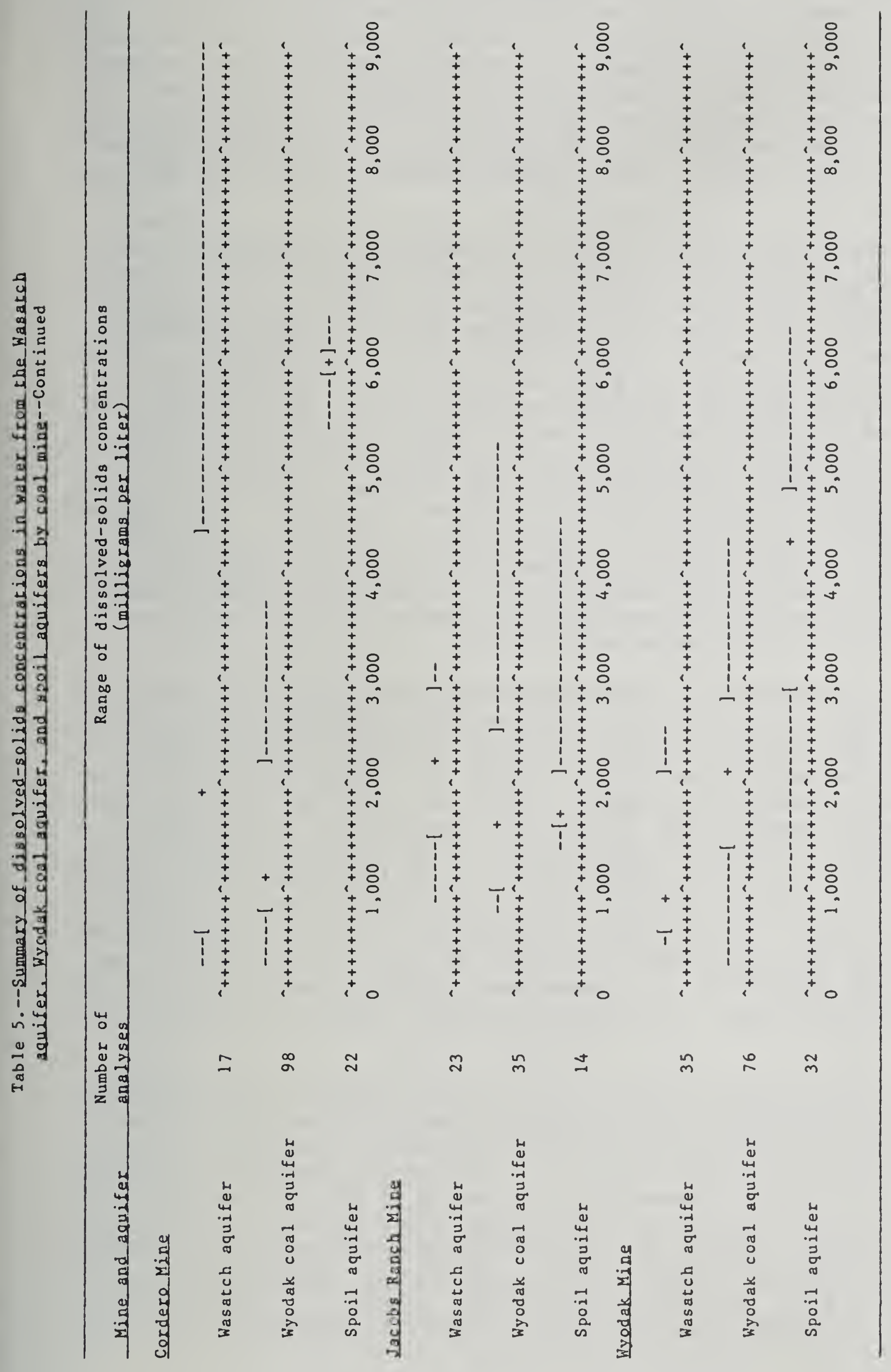


The median concentration of nitrate (as nitrogen) was slightly larger in water from the spoil aquifers compared to the median concentration in water from the Wasatch aquifer and the Wyodak coal aquifer (table 4 ). Nitrite plus nitrate in 10 percent of the water samples from the spoil aquifers exceeded the State standard for livestock compared to zero percent of the water samples from the Wasatch aquifer and Wyodak coal aquifer. All of the water samples exceeding the State standard for livestock were from five closely spaced wells at the Caballo Mine. (The maximum nitrate concentration in water samples from the spoil aquifers exceeded $300 \mathrm{mg} / \mathrm{L}$ as nitrogen.)

Although the median concentrations of chromium and selenium in water samples from the spoil aquifers were less than the analytical detection limits, 7 percent of the water samples analyzed for chromium and 18 percent of the water samples analyzed for selenium exceeded the State standard for livestock (table 4). Based on the water samples from the Wasatch aquifer and the Wyodak coal aquifer, 1 percent analyzed for chromium and zero percent analyzed for selenium exceeded the State standard for livestock. Of the 10 mines where water samples from the spoil aquifers were collected, five mines had at least one sample in which chromium exceeded the State standard for livestock and three mines had at least one sample in which selenium exceeded the State standard for livestock. Except for four samples from the North Antelope Mine and one sample from the Belle Ayr Mine, all the selenium analyses exceeding the State standard for livestock were from six closely spaced wells at the Caballo Mine. In the water samples from the spoil aquifers, the maximum concentration of chromium was $0.750 \mathrm{mg} / \mathrm{L}$ and the maximum concentration of selenium was $3.388 \mathrm{mg} / \mathrm{L}$.

Changes with time in dissolved-solids, sulfate, nitrate, chromium, and selenium concentrations, in water samples from selected wells illustrate that water quality in spoil aquifers may change with time in the same well and may differ between mines (figs. 11 and 12). Part of this variation possibly is due to sources and magnitude of recharge to the spoil aquifers and the chemical composition of the spoil materials. For example, a distinct increase in dissolved-solids and sulfate concentrations during nearly 4 years of record is indicated in well EG16-1R (Clovis Point Mine) (fig. 11). A distinct decrease in dissolved-solids and sulfate concentrations from 1983 to 1985, followed by a distinct increase in the concentrations of both constituents from 1985 to 1987 is documented for well MB26-1P (Cordero Mine) ( $\mathrm{fig}$. 11). Dissolved nitrate concentrations for all three wells shown in figure 11 indicate decreasing trends in concentration with time.

Chromium and selenium concentrations in water samples from different wells indicate varying trends with time. For example, a marked increase in chromium concentration during the 1 year of record is documented for well SP4NA (North Antelope Mine) ( $\mathrm{fig}$. 12). An overall decrease in chromium concentration from a large concentration exceeding $0.35 \mathrm{mg} / \mathrm{L}$ to less than the detection limit of $0.02 \mathrm{mg} / \mathrm{L}$ during the 3-year period is recorded for well RW2801 (Belle Ayr Mine) ( $\mathrm{fig} .12$ ). Selenium concentrations in wells CA723 and CA724 (Caballo Mine), and in well SP4NA (North Antelope Mine) (fig. 12) generally decreased with time. None of the selenium concentrations in samples from these three wells in figure 12 were less than the State standard for livestock of $0.05 \mathrm{mg} / \mathrm{L}$. 

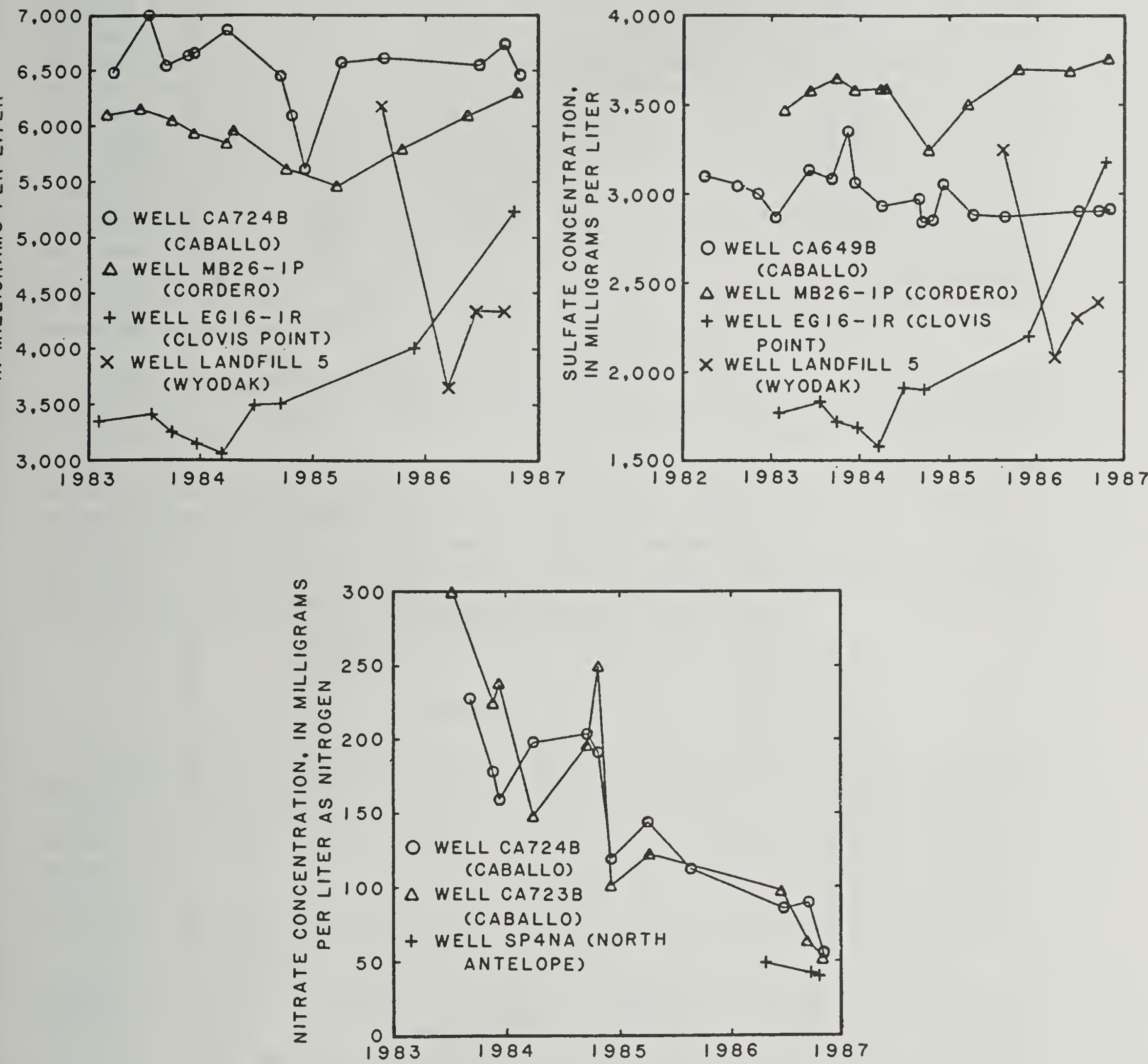

Figure 11.--Changes in the dissolved-solids, sulfate, and nitrate concentrations, as a function of time, in water samples from wells completed in the spoil aquifers at selected mines. 

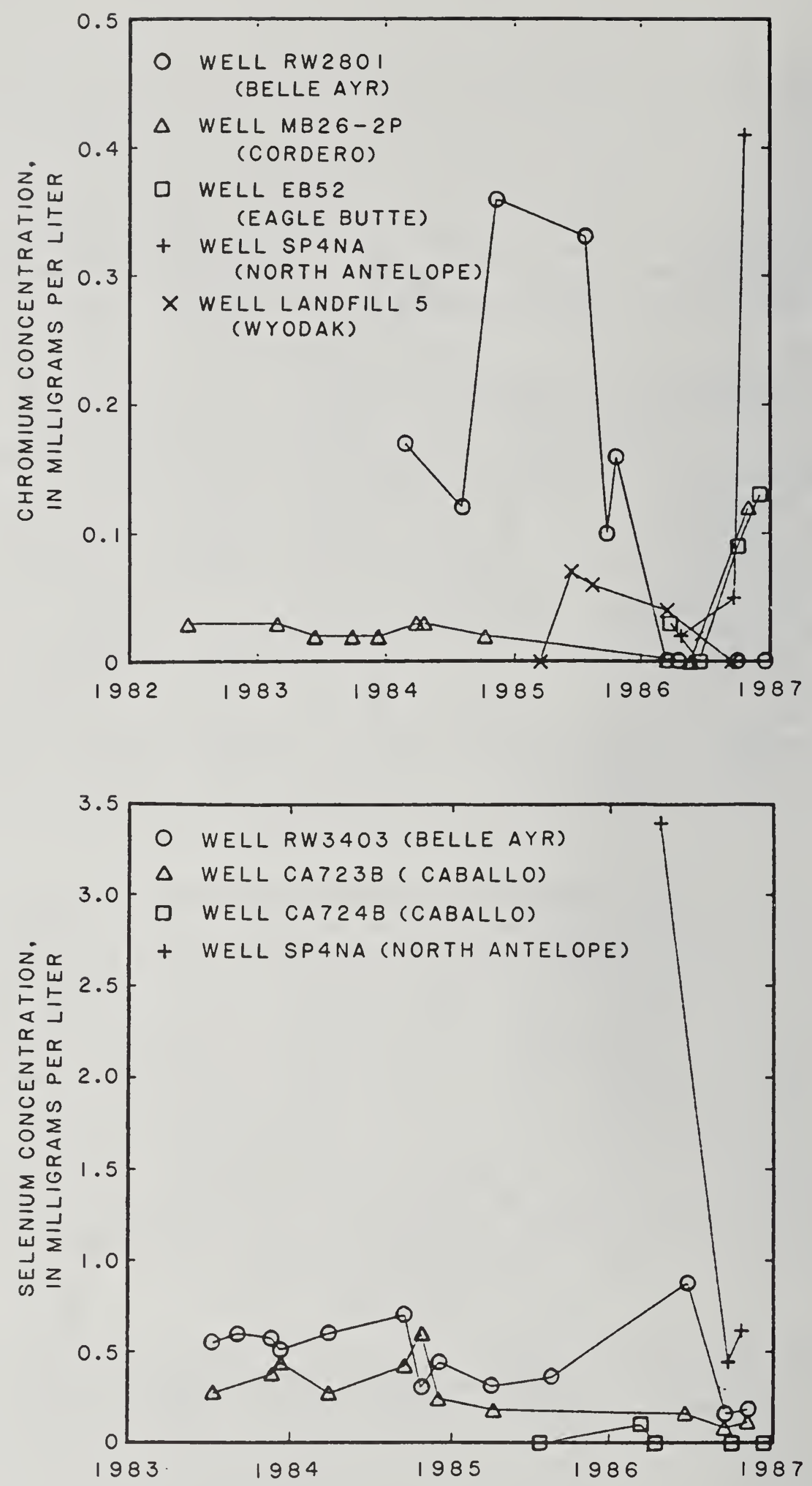

Figure 12.--Changes in the chromium and selenium concentrations, as a function of time, in water samples from wells completed in the spoil aquifers at selected mines. 
On the basis of the comparison between the existing water-quality data compiled for the Wasatch aquifer and the data compiled for the Wyodak coal aquifer and the spoil aquifers, surface coal mining will initially degrade ground-water quality in the areas of mining. Because dissolved-solids and sulfate concentrations in water from the Wasatch aquifer and the Wyodak coal aquifer already exceed the State standard for domestic use (table 4), the primary concern is water-quality degradation that might make the water unsuitable for livestock. In general, the quality of current (1987) and future water from the majority of spoil aquifers will meet the state standard for livestock. Based on the existing water-quality data from the spoil aquifers, the primary chemical constituents in selected wells that exceed the State standard for livestock are dissolved solids, sulfate, nitrate, chromium, and selenium. Except for the consistently detected decrease in nitrate and selenium concentrations (figs. 11 and 12), data for the other constituents of concern (dissolved solids, sulfate, and chromium) do not indicate consistent decreases in concentration with time. Additional monitoring data is needed to determine if the concentrations of all constituents of concern (dissolved solids, sulfate, nitrate, chromium, and selenium) will decrease and become less than the State standard for livestock.

Additional surface coal mining in the study area probably will produce postmining ground water of similar quality as that previously identified in table 4. Because only 10 of the 16 coal mines in the study area currently (1987) have spoil aquifers, additional mining at these 16 active mines and the 6 proposed mines probably will increase the number of spoil aquifers. Assuming that the water quality in future spoil aquifers will be similar to the quality indicated by the water-quality data for the existing spoil aquifers, the increase in the number and extent of spoil aquifers resulting from future mining will expand the areal extent of the recent (through 1986) effects of surface coal mining on water quality.

\section{Analysis of Variance}

The number of samples needed to define representative concentrations of chemical constituents in ground water from a particular aquifer is directly related to the natural variation of concentrations in time and space. If the chemical composition of ground water from a particular aquifer does not change with time and is spatially homogenous, then one sample anywhere in the aquifer will describe the concentration of the chemical constituent of interest, assuming sampling and analytical errors do not exist. However, in a realistic situation, many different factors affect the concentration of a dissolved chemical constituent in an aquifer. For example, the concentration of a particular chemical constituent can be affected by different components of the total variance (geologic, geographic, temporal, analytical, and so forth). By assessing the individual variance components in the existing premining (Wyodak coal aquifer) and postmining (spoil aquifers) data, insights into required sampling density and frequency during current (1987) and future programs for ground-water quality monitoring can be gained. The insights gained from analyzing the variance components at existing mines will be useful in designing future monitoring programs at future mines planned in the study area. Assessing these components of variance can aid in the interpretation and application of present and future monitoring data. 
In order to analyze the variance components described above, a hierarchial or nested analysis of variance (NANOVA) was applied to waterquality data sets for the Wyodak coal and spoil aquifers that were compiled from the existing water-quality information. A three-level, nested design is used ( $f i g .13$ ) and is unbalanced after the first level. The first two levels are associated with geographic scales; the third level measures temporal variation within each well. The top-level of this resign (among mines) consists of mines in the eastern Powder River basin ( $\mathrm{fig}$. 13). Data were available from 7 mines for the premining analysis and 10 mines for the postmining analysis. The second level (among wells) consists of numerous monitoring wells within each mine, and the third level (within a well) consists of different sampling times at each well. This type of sampling design and interpretation has been applied to premining ground-water-quality data in the eastern Powder River basin (U.S. Geological Survey, 1975, p. 58-61; 1977, p. 173-178). For a detailed description of the application of NANOVA calculations to sampling design, the reader is referred to Klusman and others (1980).

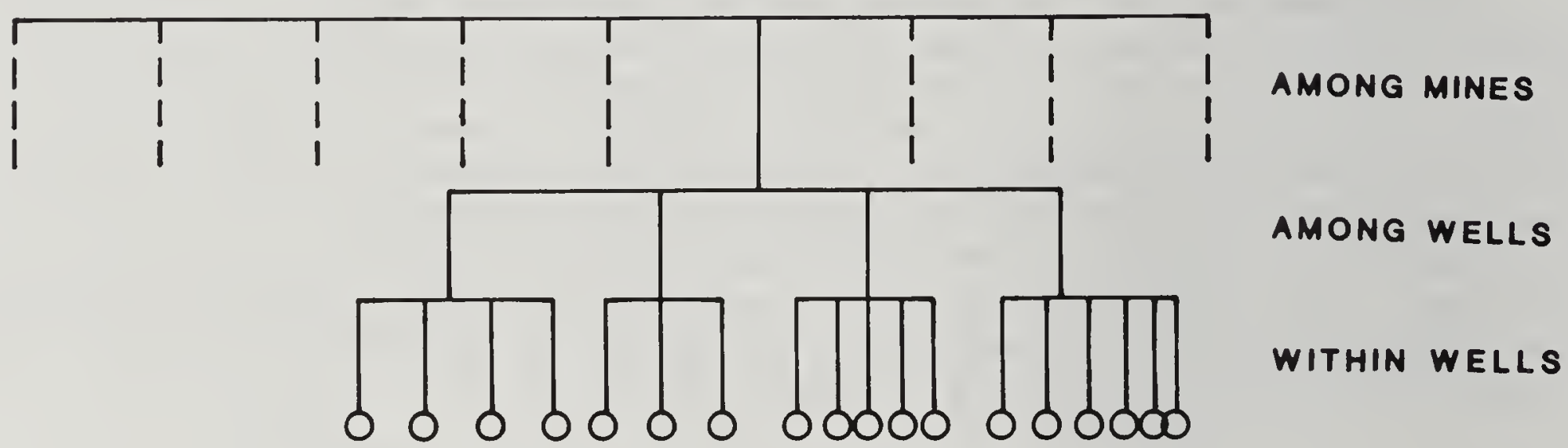

Figure 13.--Design of unbalanced analysis of variance used for water-quality data sets for the Wyodak coal aquifer
and spoil aquifers.

Because the data bases consist of existing water-quality data, a completely randomized sample selection is not possible. By imposing the three-level, nested design on the existing water-quality data bases for the Wyodak coal and spoil aquifers, a qualitative indication of variance distributions is derived.

Only selected chemical constituents were chosen for analysis of variance. If more than 20 percent of the concentrations for a particular constituent were less than the detection limit, the constituent was not chosen for analysis of variance. For samples with fewer than 20 percent of the concentrations less than the detection limit, a concentration equal to 0.7 of the detection limit was substituted for the concentrations less than the detection limit (Miesch, 1976, p. A26). 
The sample variance $\left(s^{2}\right)$ for ground water from both the Wyodak coal (premining) aquifer and spoil (postmining) aquifers is partitioned into three components according to the following:

$$
s_{\text {total }}^{2}=s^{2} \text { among mines }+s^{2} \text { among wells }+s^{2} \text { within wells. }
$$

Due to the lack of analytical and sampling duplicates in the existing data sets, the analytical and sampling variance components could not be evaluated for their contribution to the total variance.

In order to evaluate the importance of the among-mines variance component, the variance ratio $\left(v_{r}\right)$ as referenced by Klusman and others (1980) is calculated. The variance ratio for the among-mines level is calculated by the following:

$$
v_{r}=\frac{N_{v}}{D_{v}}=\frac{s^{2} \text { among mines }}{s^{2} \text { among wells }+s^{2} \text { within wells }}
$$

where $\mathrm{N}_{\mathrm{v}}$ = the estimated variance among mines, and

$D_{v}=$ the estimated variance within mines.

The larger the variance ratio, the more likely the among-mines variance is significant. For example, a chemical constituent with a large variance ratio has a large degree of variance in concentration at the among-mines level, which indicates that a minewide average of this constituent can be estimated using a small number of samples and still be distinguishable among mines. In contrast, a chemical constituent with a small variance ratio indicates a large part of the total variance is associated with small scale, or within-mine variance. A large proportion of small-scale variance for a particular constituent indicates that a large number of water-quality samples collected from the Wyodak coal aquifer or spoil aquifers need to be analyzed.

Calculation of the variance ratios for selected chemical constituents can provide important information on the sampling adequacy in monitoring programs of the Wyodak coal (premining) aquifer and spoil (postmining) aquifers. Klusman and others (1980) have used the variance ratio to quantify the number of random samples that are required within a unit cell so the averages of the two unit cells can be distinguished. This same technique can be used to quantify the number of samples needed within a mine area so that the chemical quality of water at two mines can be distinguished. The variance ratio $\left(v_{r}\right)$ can be used to determine the number of random samples needed per unit cell (mine, for example) at both the 80and 95-percent confidence limits (fig. 14). For example, according to figure 14 , a variance ratio of 0.9 would require five water samples per mine to differentiate average concentrations of chemical constituents among mines at the 95-percent confidence limit. 
Estimates of the logarithmic variance components $\mathrm{s}^{2}$ (among mines)' $\mathrm{s}^{2}$ (among wells), and $\mathrm{s}^{2}$ (within wells), and their corresponding percentage of the total variance $\mathrm{s}^{2}$ (total) for selected dissolved chemical constituents are given in table 6 . Variance estimates for selected chemical constituents from the Wyodak coal aquifer and spoil aquifers were derived using the UANOVA (unvariate analysis of variance) computer code (Garrett and Goss, 1980) for nested analysis of variance with unequal subclasses.

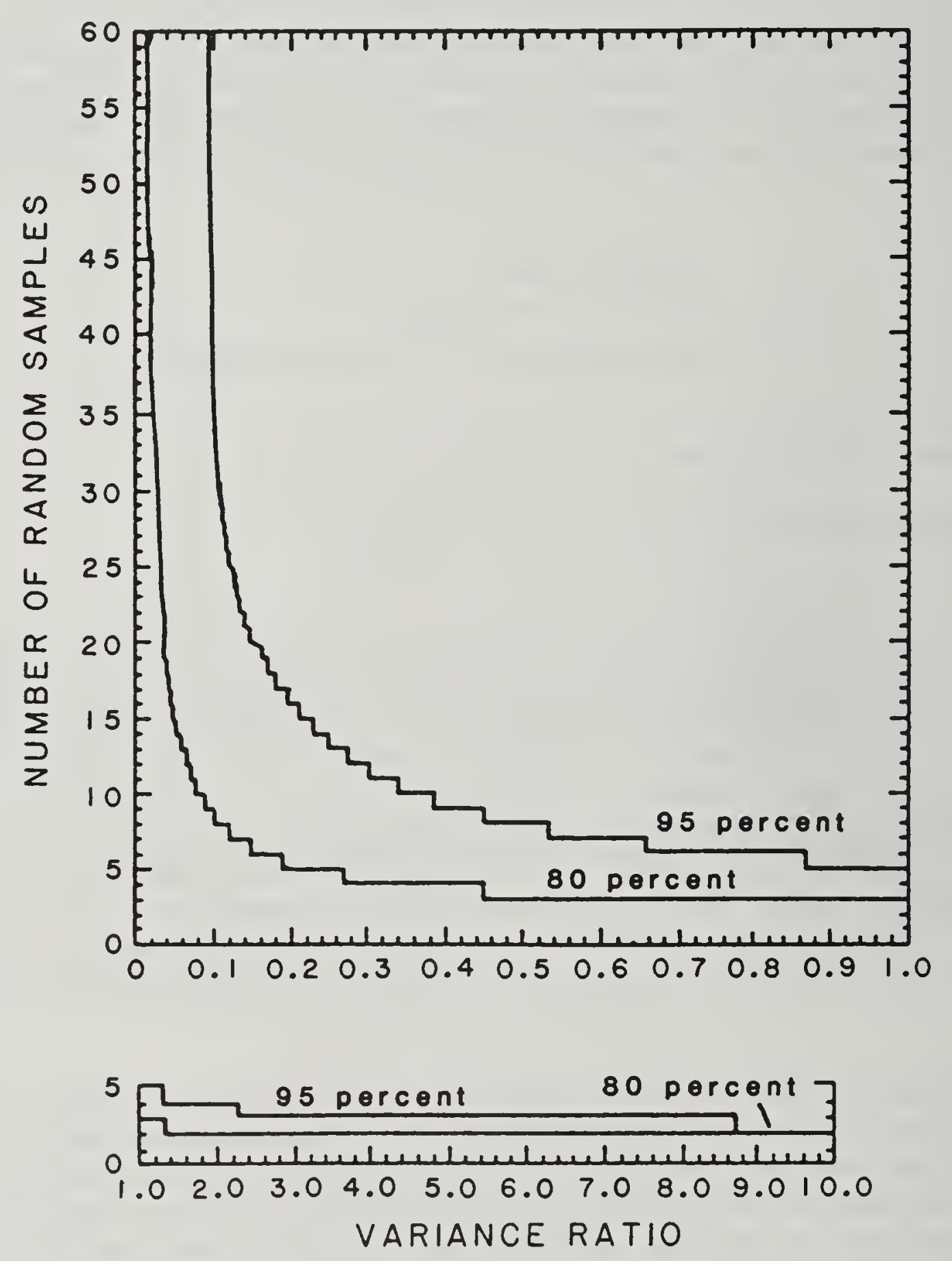

Figure 14.--The variance ratio that can be used to approximate the number of random water samples needed from each unit area in order to describe the gross differences among a number of units (from Dean and others, 1979). 
Table 6.--Comparison of estimated logarithmic variance components for selected chemical properties and constituents in samples of water from the Wyodak coal aquifer and spoil aquifers

[Concentrations in milligrams per liter unless noted otherwise; variance components are expressed as percentages of the total logarithmic variance for each chemical constituent. Symbols: $v_{r}$, variance ratio for mines; $n_{n}$, minimum number of random samples per mine needed to estimate the average concentration of the selected chemical constituent at the 95-percent confidence level; n.d., not determined because $n_{r}$ is infinitely large]

\begin{tabular}{|c|c|c|c|c|c|c|}
\hline $\begin{array}{l}\text { Chemical } \\
\text { property or } \\
\text { constituent } \\
\text { and aquifer }\end{array}$ & $\begin{array}{l}\text { Total } \\
\text { logio } \\
\text { variance }\end{array}$ & $\begin{array}{l}\text { Perce } \\
\text { Among } \\
\text { mines }\end{array}$ & $\begin{array}{l}\frac{\text { of tota }}{\text { Among }} \\
\text { wells }\end{array}$ & $\begin{array}{l}\frac{\text { riance }}{\text { Within }} \\
\text { wells }\end{array}$ & $v_{r}$ & $n_{r}$ \\
\hline \multicolumn{7}{|l|}{$\mathrm{pH}\left(\right.$ units) ${ }^{\prime}$} \\
\hline $\begin{array}{l}\text { Wyodak coal aquifer } \\
\text { Spoil aquifer } \\
\text { Alkalinity (as } \mathrm{HCO}_{3}^{-} \text {) }\end{array}$ & $\begin{array}{r}0.143 \\
.331\end{array}$ & $\begin{array}{l}26.33 \\
45.48\end{array}$ & $\begin{array}{l}16.89 \\
26.09\end{array}$ & $\begin{array}{l}56.78 \\
28.43\end{array}$ & $\begin{array}{r}0.357 \\
.834\end{array}$ & \\
\hline $\begin{array}{l}\text { Wyodak coal aquifer } \\
\text { Spoil aquifer }\end{array}$ & $\begin{array}{l}.043 \\
.057\end{array}$ & $\begin{array}{l}.79 \\
.00\end{array}$ & $\begin{array}{l}76.11 \\
82.20\end{array}$ & $\begin{array}{l}23.10 \\
17.80\end{array}$ & $\begin{array}{l}.008 \\
.059\end{array}$ & $\begin{array}{l}\text { n.d. } \\
\text { n.d. }\end{array}$ \\
\hline
\end{tabular}

Dissolved solids

$\begin{array}{llllrrr}\text { Wyodak coal aquifer } & .059 & 23.97 & 64.81 & 11.21 & .315 & 11 \\ \text { Spoil aquifer } & .080 & 20.22 & 71.74 & 8.04 & .253 & 13\end{array}$

\section{Calcium}

$\begin{array}{llllllr}\text { Wyodak coal aquifer } & .170 & 22.37 & 65.09 & 12.54 & .288 & 12 \\ \text { Spoil aquifer } & .258 & 39.81 & 46.78 & 13.40 & .662 & 6\end{array}$

\section{Magnesium}

$\begin{array}{lllllll}\text { Wyodak coal aquifer } & .206 & 24.75 & 56.85 & 18.40 & .329 & 11 \\ \text { Spoil aquifer } & .178 & 24.21 & 61.45 & 14.34 & .319 & 11\end{array}$

Sodium

\begin{tabular}{|c|c|}
\hline $\begin{array}{l}\text { Nyodak coal aquifer } \\
\text { Spoil aquifer }\end{array}$ & $\begin{array}{l}.052 \\
.060\end{array}$ \\
\hline
\end{tabular}

\section{Potassium}

$\begin{array}{lllllll}\text { Wyodak coal aquifer } & .053 & 31.60 & 43.44 & 24.96 & .462 & 8 \\ \text { Spoil aquifer } & .050 & 40.32 & 31.99 & 27.69 & .676 & 6\end{array}$


Table 6.--Comparison of estimated logarithmic variance components for selected chemical properties and constituents in samples of water from the Wyodak coal aquifer and spoil aquifers--Continued

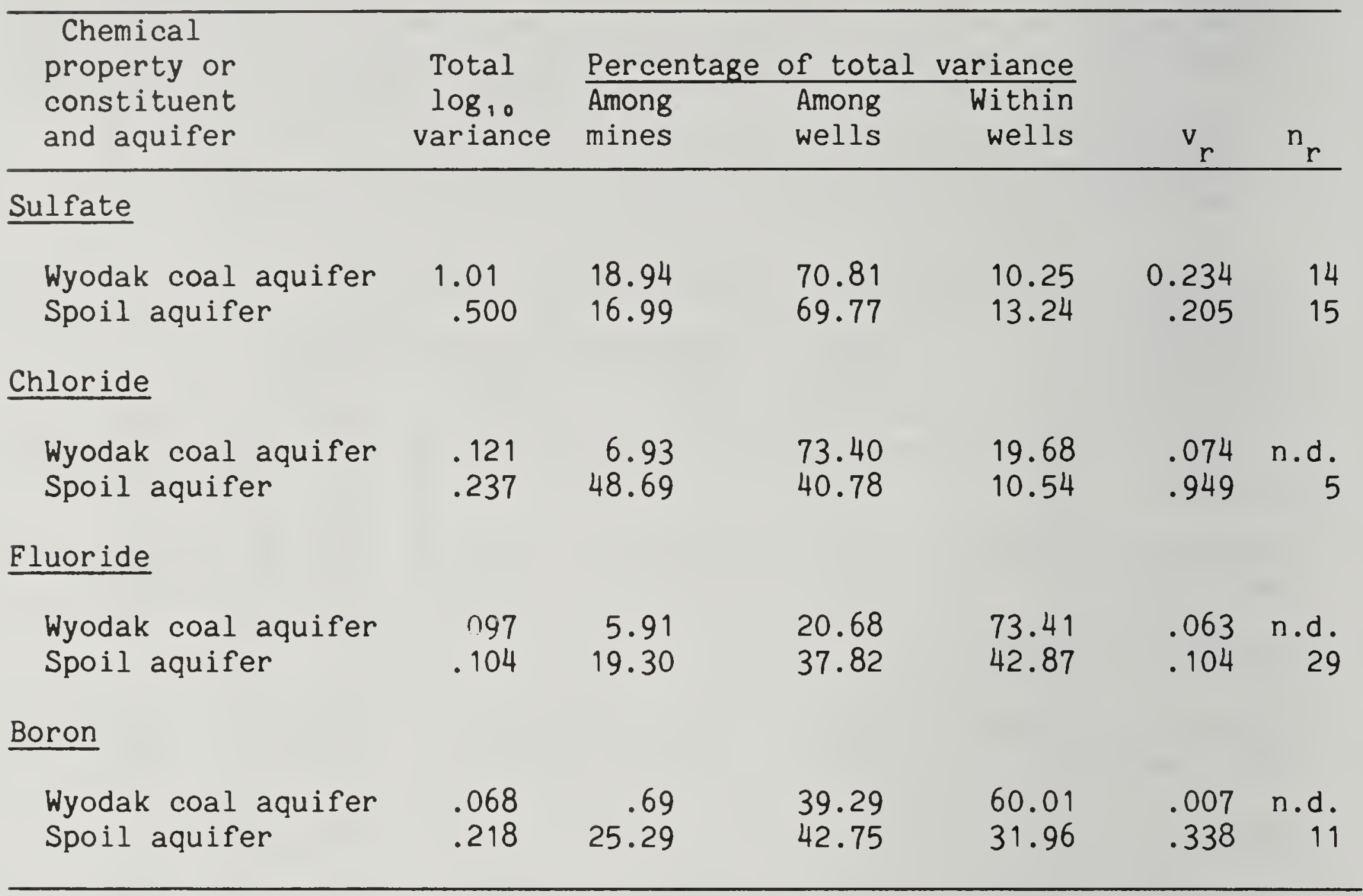

pH, by definition, is a logarithmic value and was not transformed for this analysis.

The results of the analysis of variance calculations indicate a large component of the total variance at the within-mines level ( $s^{2}$ among wells plus $s^{2}$ within wells). In general, most of the within-mines ( $s^{2}$ among-wells plus $s^{2}$ within wells) variance is associated with the among-wells component rather than the within-wells component (table 6). This variance analysis indicates that temporal variation of concentration within a well was relatively small compared to the among-wells variation. Therefore, a large number of water samples are needed to characterize the chemistry of the ground water from the Wyodak coal aquifer and spoil aquifers within a mine site. Because most of the water-quality monitoring data for the Wyodak coal aquifer and spoil aquifers generally were from periods of less than 5 years, the relative proportion of temporal variance could change as more data become available in the future. 
The calculated variance ratios $\left(v_{r}\right)$ are presented in table 6 for selected chemical properties and constituents in samples of water from the Wyodak coal aquifer and spoil aquifers. Based on analysis-of-variance results and calculated variance ratios for the selected chemical properties and constituents, considerations for current (1987) and future ground-waterquality monitoring of the Wyodak coal aquifer and spoil aquifers include the following:

1. Sampling efforts need to focus on completing numerous wells in spoil aquifers rather than collecting a large number of water samples, numerous times, from a only a few wells. The current (1986) number of monitoring wells completed in spoil aquifers at each mine in the study area ranges from 1 well at the Rawhide Mine to 11 wells at the Caballo Mine.

2. For maximum sampling effectiveness with the minimum possible cost and the maximum usefulness of present and future monitoring data, different sampling densities need to be investigated for different chemical properties and constituents. The exact number of sampled wells or number of times to collect samples cannot be determined with the information in this report; however, some generalized conclusions can be made. Chemical properties and constituents with large proportions (greater than 40 percent) of the total variance at the among-mines level ( $\mathrm{pH}$, potassium, and chloride) only need a small number of samples at each mine site to calculate a representative minewide average; whereas, chemical constituents with small proportions (less than 40 percent) of the total variance at the among-mines level (alkalinity, dissolved solids, calcium, magnesium, sodium, sulfate, fluoride and boron) need a larger number of samples at each mine site to calculate a representative average for the mine.

\section{Laboratory Simulations}

Batch-mixing and column-leaching tests are common laboratory procedures used to simulate the postmining water quality that might occur in the spoil aquifer at the mine. Results from batch-mixing and column-leaching tests were compiled to evaluate the predictive capabilities of these procedures by comparing the laboratory results to the actual postmining water quality in the spoil aquifers in the study area.

Batch-mixing experiments can be conducted by mixing water from the Wyodak coal aquifer and spoil material in a specified ratio of water to spoil material, then allowing the water and spoil material to react for a specified time. During the interaction of the water and spoil material, the batch-mixing vessel is usually shaken or rotated. Davis (1984, p. 9) describes the procedure used in this study, which is one of the many batchmixing procedures. 
Naftz (in press) compared the major-ion chemistry of water derived from batch-mixing experiments (batch-extract water) with the actual postmining quality of water samples collected during July 1984 from a well completed in the spoil aquifer at the Cordero Mine; selected results are presented in figure 15. In the batch-mixing experiments, using a ratio of water to spoil material of $2: 1$ (by weight), the batch-extract water had smaller concentrations of major ions, except for alkalinity, than did water samples representing the water quality of the spoil aquifer in July 1984. If a smaller ratio of water to spoil material had been used in this particular set of batch-mixing experiments, then the quality of the batch-extract water would have more closely simulated the postmining water quality of the spoil aquifer at the Cordero Mine (Naftz, in press).

Column-leaching tests are done by packing a cylindrical column with spoil material and then injecting water into the column. Effluent water from the column is then analyzed at different time intervals to obtain an indication of how the postmining water quality will change with time. Column-leaching tests vary in the flow rate, degree of saturation, column length, type and packing of spoil material, and source of water.

Data from column-leaching tests were compiled from mining permits obtained from the Wyoming Department of Environmental Quality in an attempt to evaluate whether the tests could simulate postmining water quality. Data from column-leaching tests at Caballo, Keeline, and Rawhide Mines were used in this compilation. The general procedure used for all three of the column-leaching tests is described by McWhorter and Landers (1985). Deionized water was used in the column-leaching tests at the Caballo and Rawhide Mines to simulate recharge; whereas, water from the Wyodak coal aquifer was used in the tests at the Keeline Mine to simulate recharge.

Changes in the concentrations of dissolved solids and dissolved nitrate (as nitrogen) during the three sets of column-leaching tests were compared with median concentrations of dissolved solids and nitrate in existing spoil aquifers at 10 surface coal mines in the eastern Powder River basin (figs. 16 and 17). In general, median concentrations of dissolved solids and nitrate in the spoil aquifers are exceeded until at least 1 pore volume of water has passed through the columns (figs. 16 and 17). A distinct flattening of the slope of the line for dissolved-solids and nitrate concentrations occurs after about 1 pore volume of water has passed through the columns (figs. 16 and 17). The flattening of slope after 1 pore volume possibly is indicative of future improvements in postmining water quality after the initial dissolution and desorption reactions have occurred in the newly created spoil aquifer.

The column-leaching tests using water from the Wyodak coal aquifer at the Keeline Mine indicate larger concentrations of dissolved solids after 1 pore volume has passed through the column compared to the column-leaching tests using deionized water (fig. 16). This was due to the larger initial concentration of dissolved solids in water from the Wyodak coal aquifer $(2,200 \mathrm{mg} / \mathrm{L})$ compared to the deionized water. If the major source of recharge to a spoil aquifer is water from the coal aquifer, the use of water from a coal aquifer in column-leaching tests possibly represents the longterm postmining water quality more accurately than does the use of deionized water. 

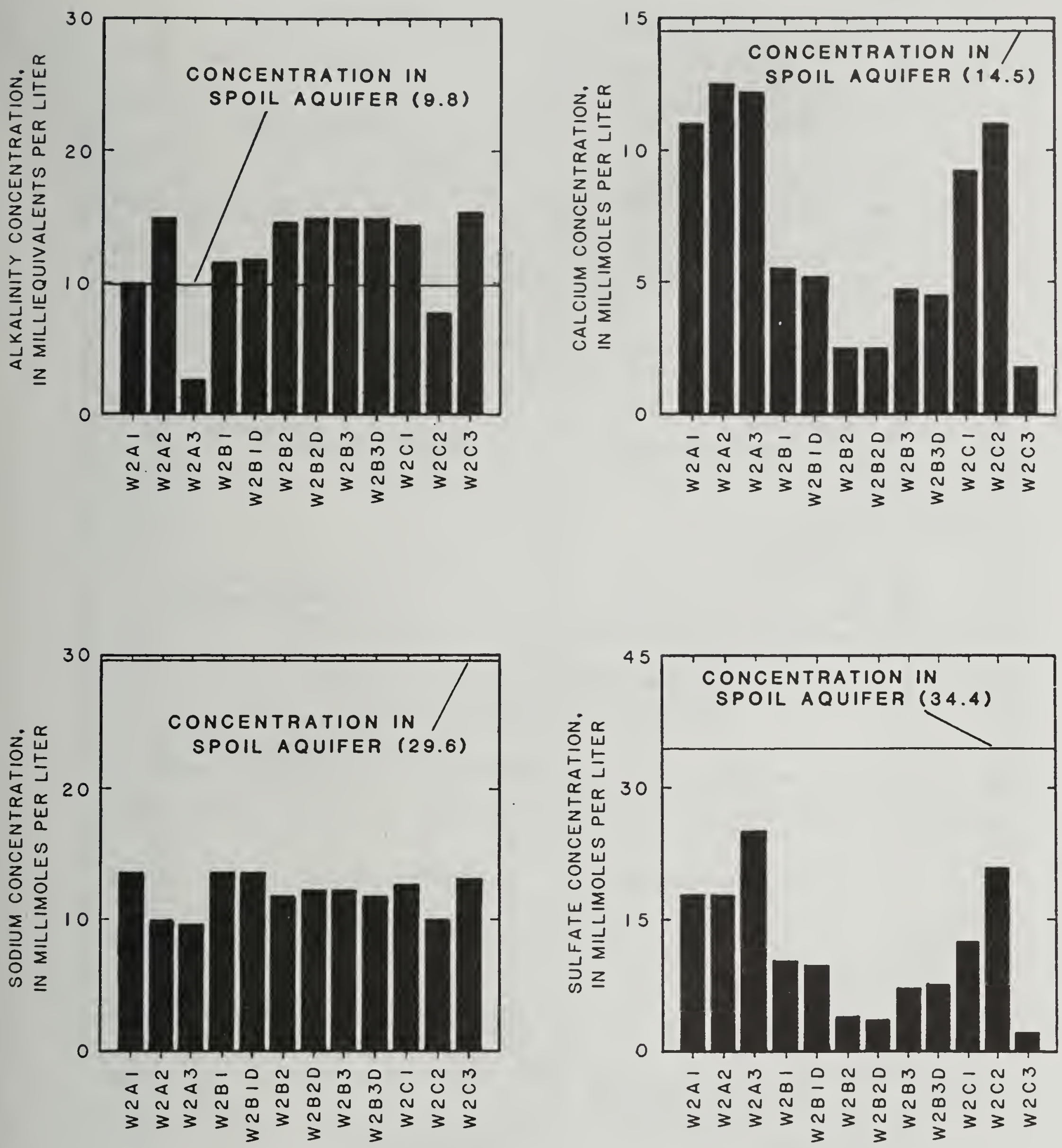

BATCH-EXTRACT WATER SAMPLE

Figure 15.--Comparison of concentrations in batch-extract water to actual concentrations of alkalinity, calcium, sodium, and sulfate in water from the spoil aquifer sampled during July 1984 at the Cordero Mine (from Naftz, in press). 


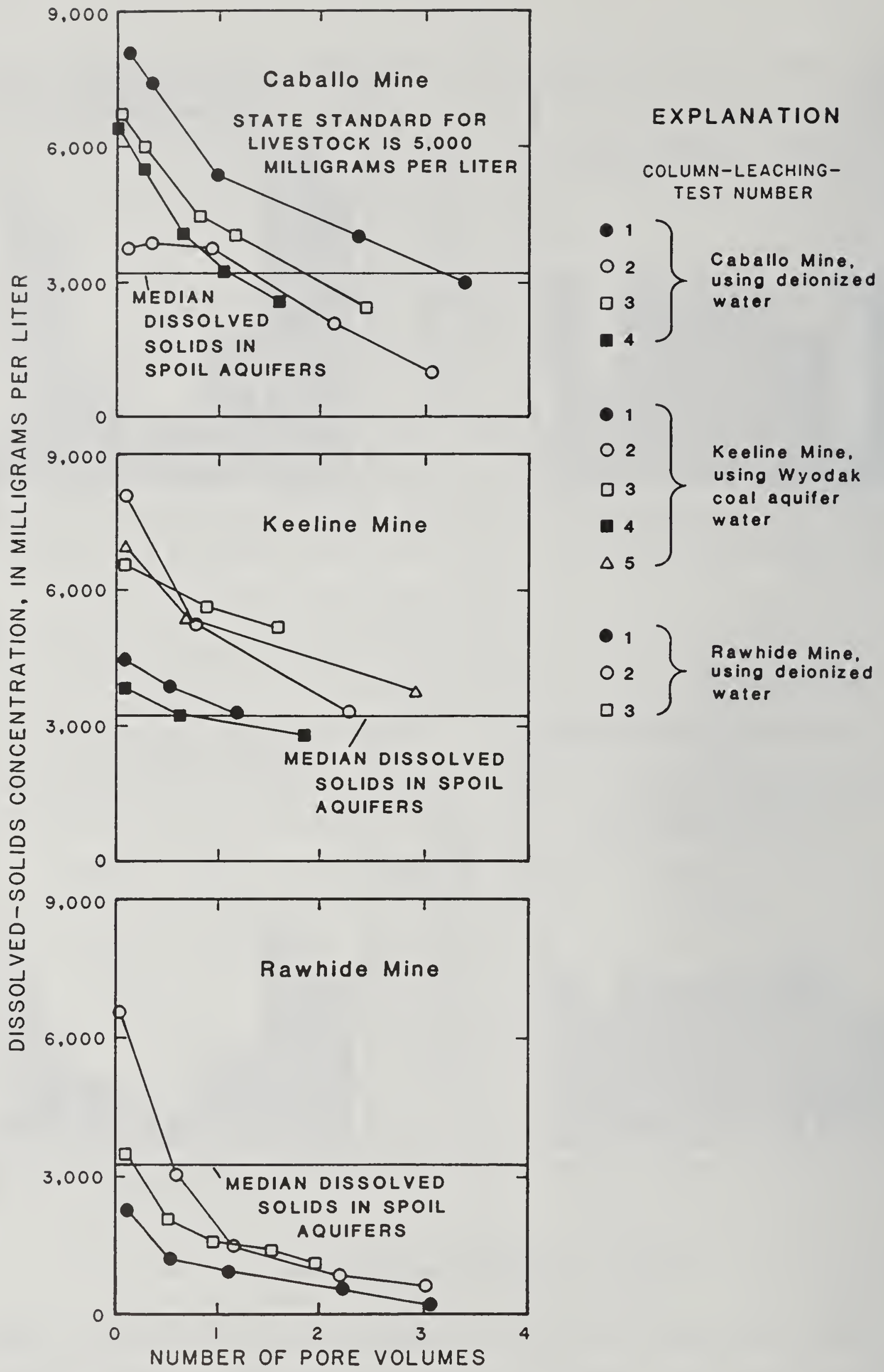

Figure 16.--Comparison of dissolved-solids concentration in water derived from selected column-leaching tests to the number of pore volumes of water leached through the overburden. 

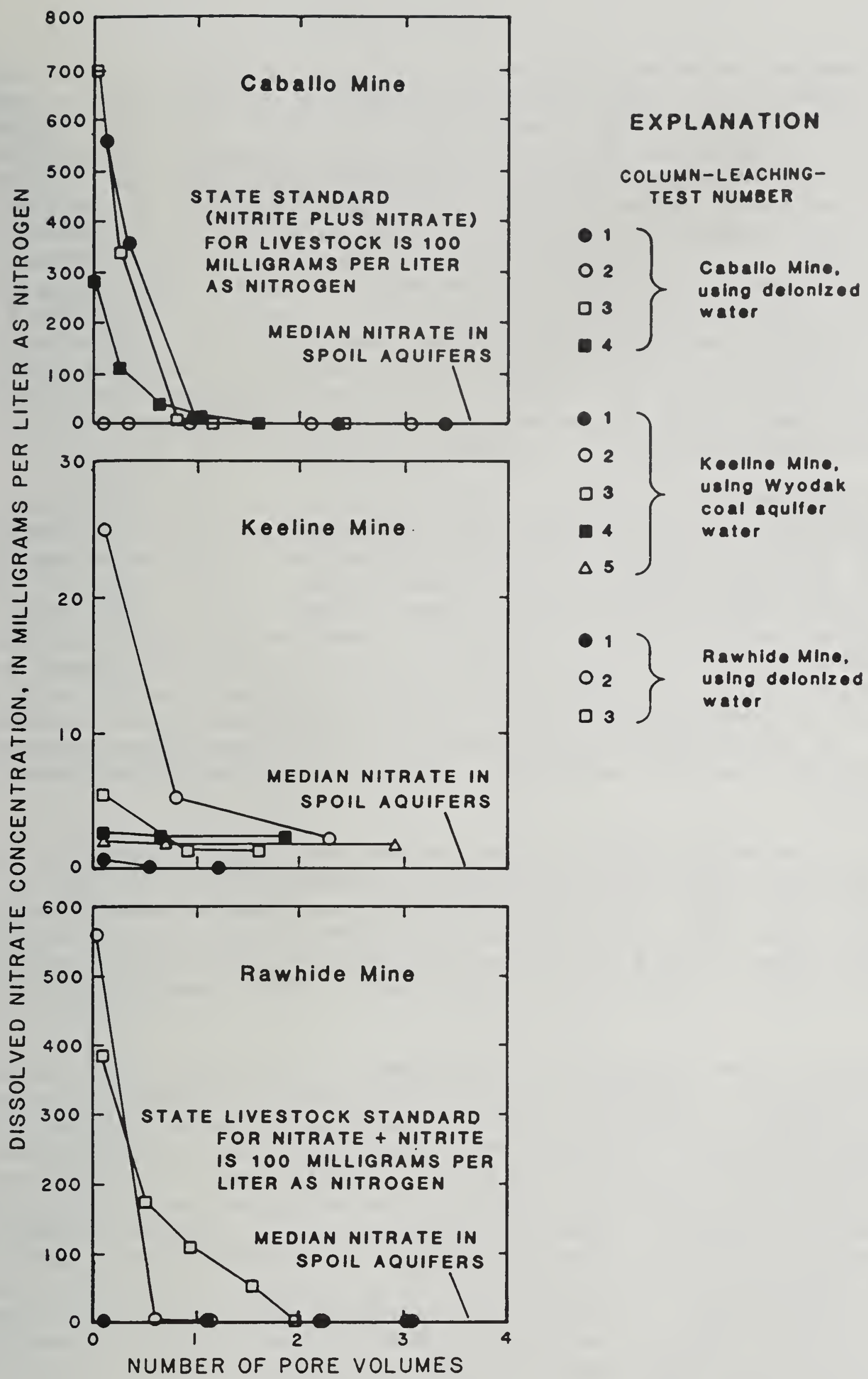

Figure 17.--Comparison of dissolved-nitrate concentration in water derived from selected column-leaching tests to the number of pore volumes of water leached through the overburden. 
The dissolved-selenium concentrations in water derived from columnleaching tests at the three mines became smaller as the number of pore volumes leaching through the columns increased (fig. 18). The largest concentration of dissolved selenium measured in the initial column effluent exceeded $1.5 \mathrm{mg} / \mathrm{L}$ using spoil material from Rawhide Mine ( $\mathrm{fig}$. 18). Ground water with selenium concentrations larger than $0.05 \mathrm{mg} / \mathrm{L}$ is considered unsuitable for consumption by livestock (Wyoming Department of Environmental Quality, 1980a, p. 9). Dissolved-selenium concentrations in the spoil aquifer at the Caballo Mine initially exceeded $0.5 \mathrm{mg} / \mathrm{L}$. Similar to the dissolved-solids and nitrate concentrations in the effluent waters, the graphs for dissolved selenium concentrations show a distinct flattening of the slope that occurred after about 1 pore volume of water was leached through the columns (fig. 18). Effluent waters derived after about 1 pore volume had passed through the columns generally had selenium concentrations exceeding the State standard for livestock of $0.05 \mathrm{mg} / \mathrm{L}$ ( $\mathrm{fig} .18$ ).

Determination of overburden suitability for aquifer restoration may be another important use of column-leaching tests. The specific conductance of overburden and the content of nitrate in overburden in relation to concentrations of dissolved solids and dissolved nitrate (as nitrogen) in the first effluent water (less than 0.11 pore volume) in the three sets of column-leaching tests are shown in figure 19. When the specific conductance of the overburden material was greater than 2,900 $\mathrm{\mu S} / \mathrm{cm}$ (microsiemens per centimeter at $25^{\circ} \mathrm{C}$ ), it produced an initial effluent water with a dissolved-solids concentration greater than the State standard for livestock (fig. 19). No standard for specific conductance of the overburden material is recommended for aquifer restoration (Wyoming Department of Environmental Quality, 1984).

Contents of extractable nitrate greater than $30 \mathrm{\mu g} / \mathrm{g}$ (micrograms per gram) as nitrogen in the overburden material produced an initial effluent water with a dissolved-nitrate concentration exceeding the State standard for livestock (fig. 19). Overburden material with contents of extractable nitrate less than $50 \mathrm{\mu g} / \mathrm{g}$ as nitrogen are considered suitable for aquifer restoration after mining (Wyoming Department of Environmental Quality, 1984 ).

In general, water-soluble selenium contents of overburden material do not indicate the total quantity of selenium that could be released to ground water after mining. Although selenium concentrations in water derived from column-leaching tests were usually much larger than $0.005 \mathrm{mg} / \mathrm{L}$, the watersoluble selenium contents in the overburden material used in the columnleaching tests were generally less than the detection limit of $20 \mathrm{\mu g} / \mathrm{kg}$ (micrograms per kilogram). Total-selenium contents in overburden samples from the Keeline and Caballo Mines (not the same overburden material used in the column-leaching tests) were determined (fig. 20), and ranged from less than 100 to $3,800 \mu \mathrm{g} / \mathrm{kg}$. In general, the sandstone samples from these mines had total-selenium contents less than $500 \mu \mathrm{g} / \mathrm{kg}$; whereas, the shale samples had total-selenium contents ranging from $800 \mu \mathrm{g} / \mathrm{kg}$ to $3,800 \mu \mathrm{g} / \mathrm{kg}$ ( $\mathrm{fig}$. 20). Ebens and Shacklette (1982, p. 121) reported the average selenium content as $190 \mathrm{\mu g} / \mathrm{kg}$ in sandstone from the Fort Union Formation. Spoil-material samples from the Dave Johnston Mine had an average selenium content of $280 \mathrm{\mu g} / \mathrm{kg}$ (Ebens and Shacklette, 1982, p. 120). 


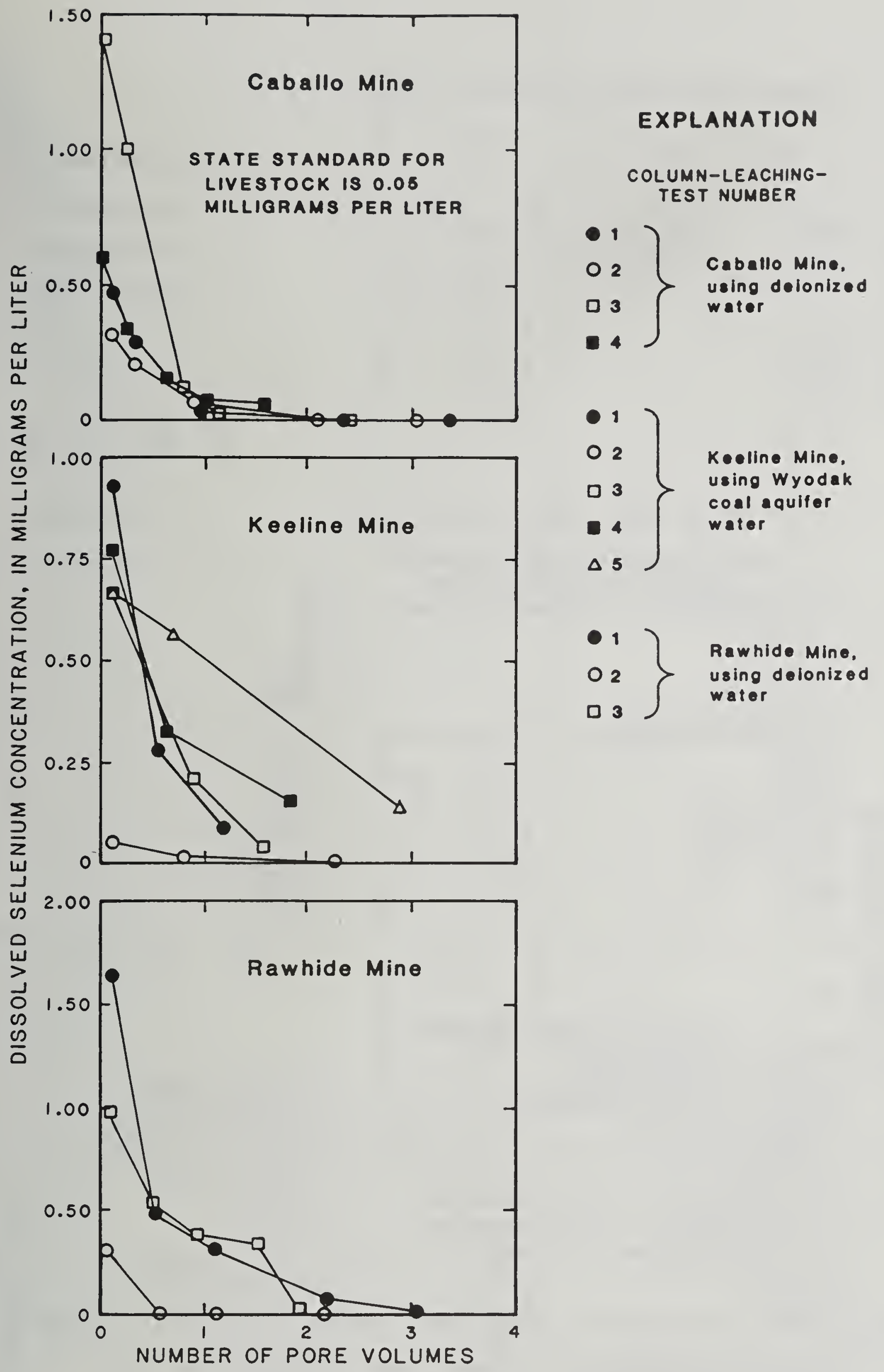

Figure 18.--Comparison of dissolved-selenium concentration in water derived from selected column-leaching tests to the number of pore volumes of water leached through the overburden. 

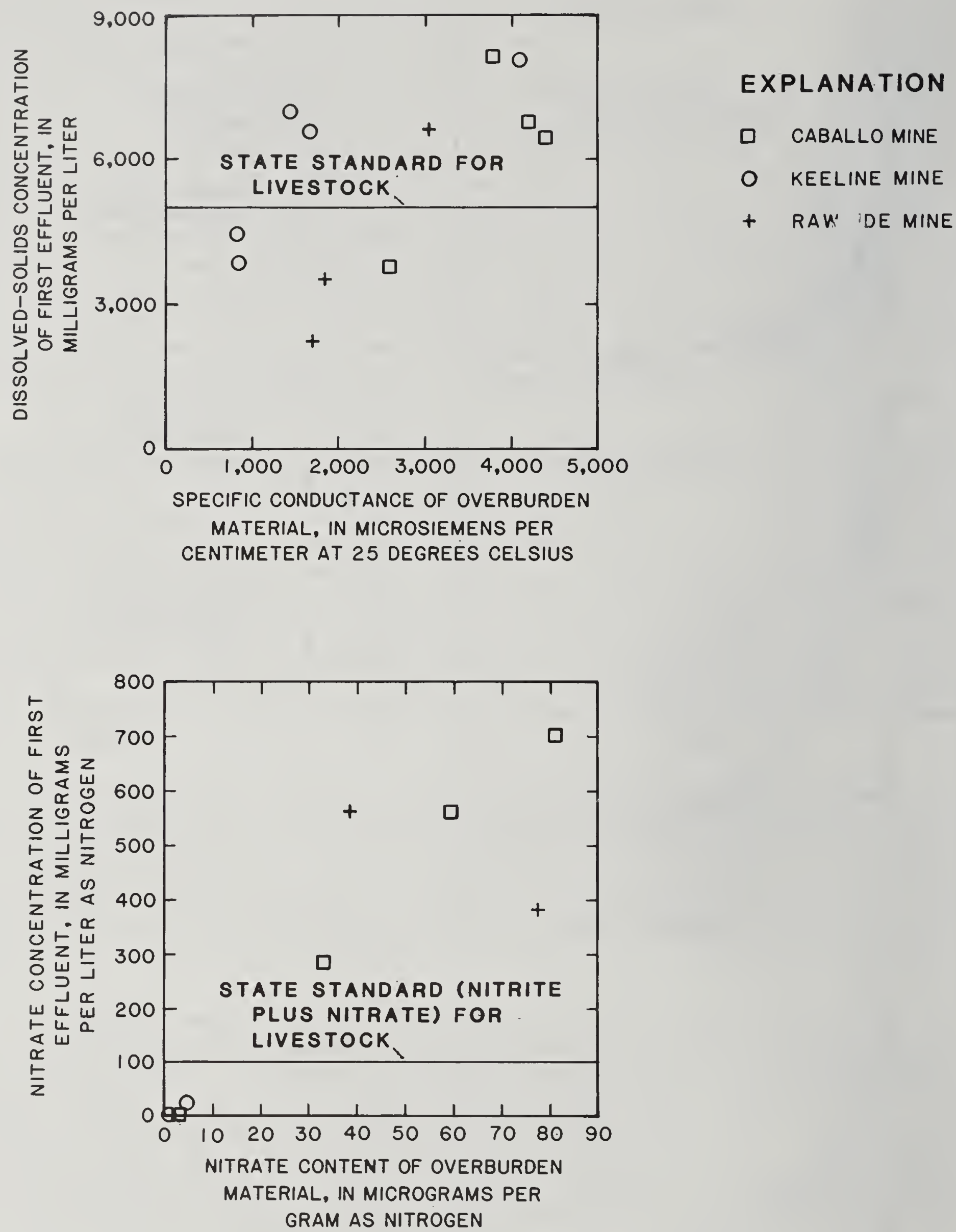

Figure 19.--Dissolved-solids and nitrate concentrations in the first effluent from selected column-leaching tests in relation to the specific conductance and extractable-nitrate content in the overburden material used in the tests. 

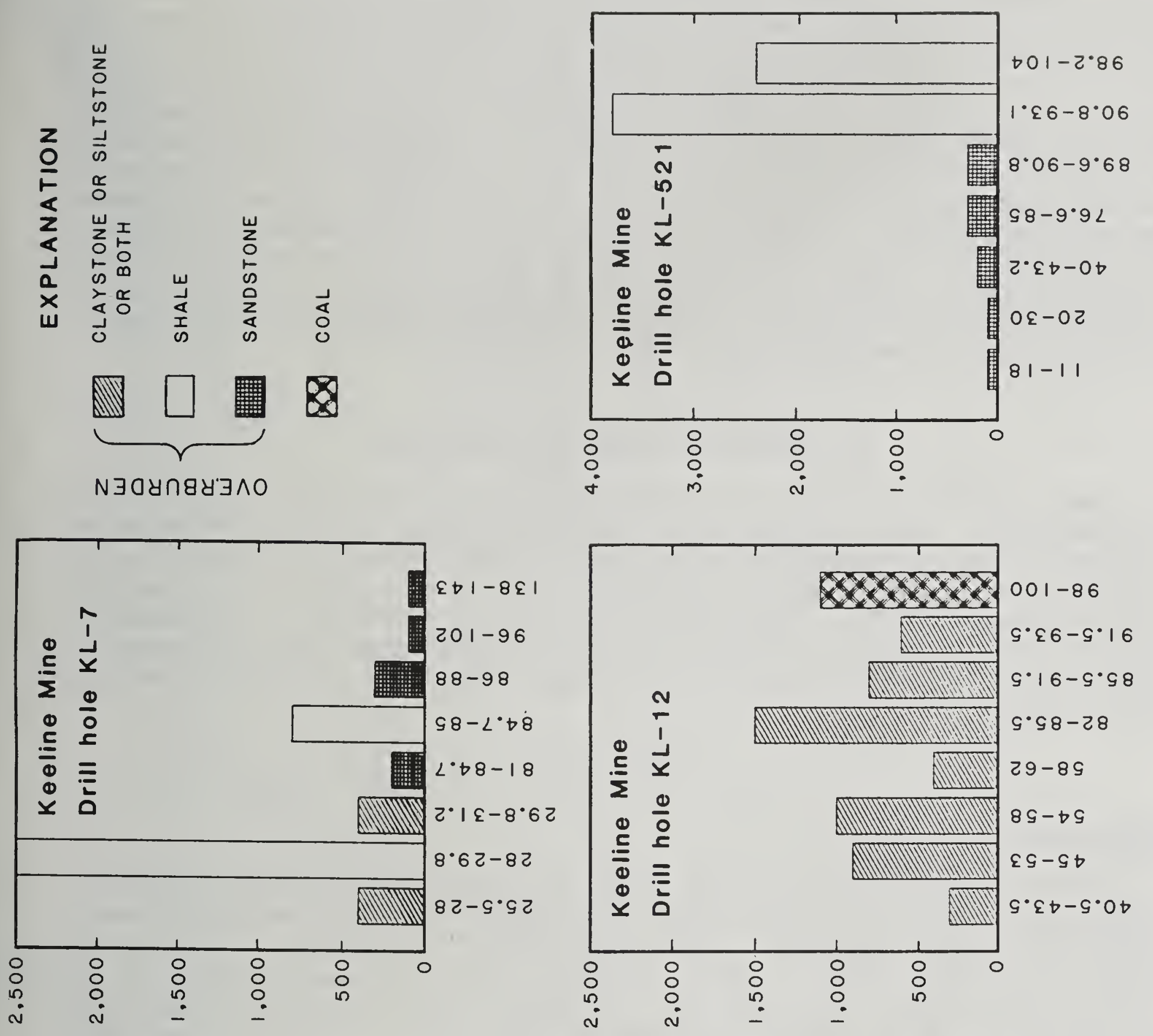

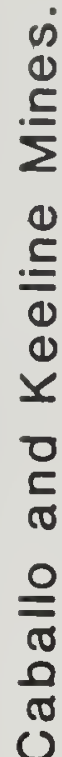

$\stackrel{0}{\mp}$
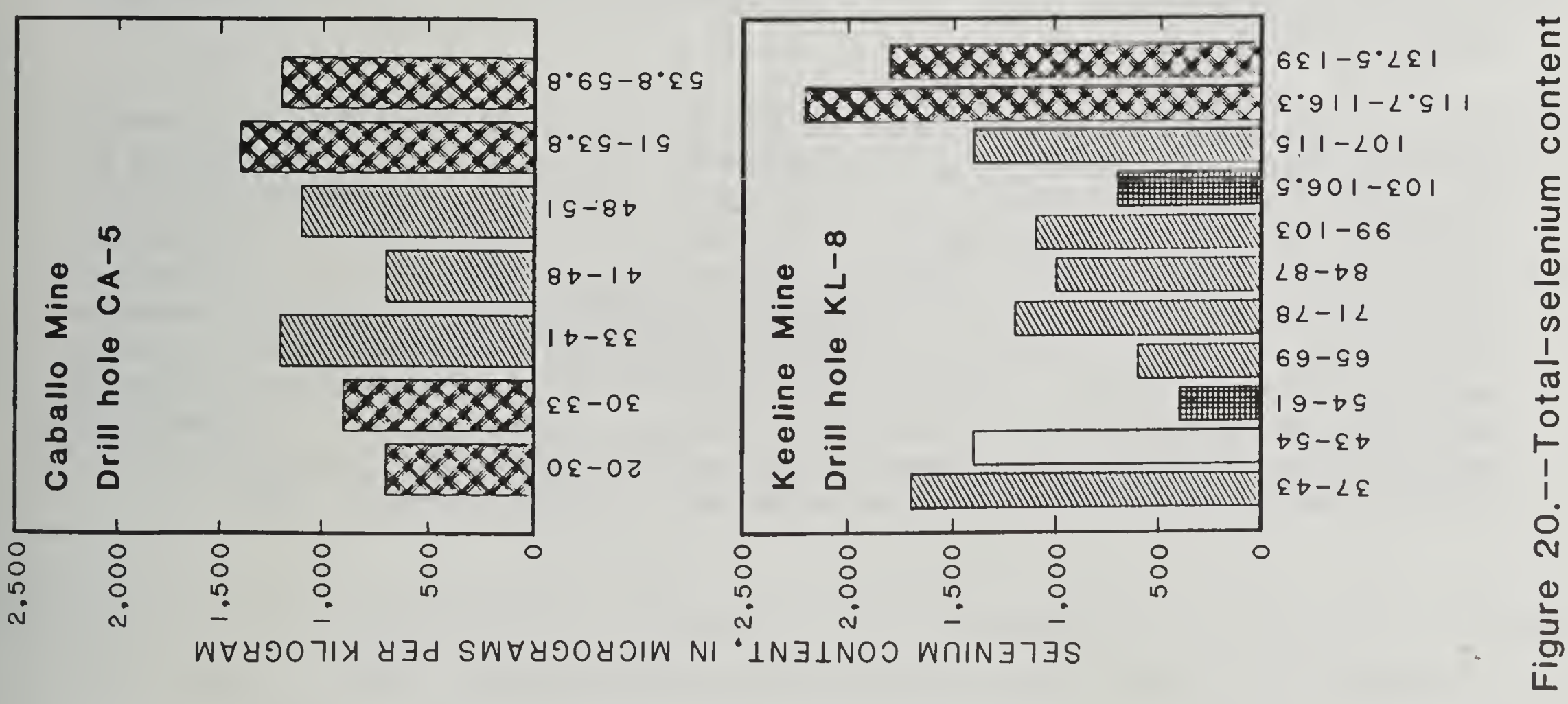
In summary, batch-mixing experiments using a water-to-spoil material ratio of $2: 1$ (by weight), had smaller major-ion concentrations compared to a July 1984 sample of the water quality in the spoil aquifer at the Cordero Mine. Column-leaching test results were highly variable depending on the type of water used in the columns (deionized or water from a coal aquifer) and the chemical composition of the overburden. The median dissolved-solids and nitrate concentrations using all postmining water analyses in the study area were generally exceeded until at least one pore volume had passed through the columns. Smaller concentrations of dissolved solids, nitrate, and selenium in future postmining water were predicted by the columnleaching test results. Actual postmining nitrate and selenium concentrations are currently (1986) indicating decreases with time at selected wells in the study area (figs. 11 and 12).

\section{Site-Specific Geochemical Studies}

The Cordero and Dave Johnston Mines (fig. 10) were selected for detailed study. Detailed geochemical data were collected from these mines and used to interpret the hydrogeology of the spoil-aquifer systems and the possible geochemical reactions controlling the evolution of postmining ground-water quality. Conclusions drawn from the following site-specific studies may not apply to all mine sites in the study area because of differences in overburden quality, hydrologic conditions, methods of mining, and so forth.

\section{Cordero Mine}

\section{Hydrogeology}

Ground water at the Cordero Mine is present in the Wasatch aquifer, Wyodak coal aquifer, and spoil aquifers. Except for a few isolated areas, yields from wells completed in the Wasatch aquifer are small (Cordero Mine personnel, written commun., 1983). Clinker along the eastern edge of the Cordero Mine ( $\mathrm{fig} .21$ ) is partially saturated except where mine dewatering operations have taken place. The spoil aquifer studied at the Cordero Mine (fig. 22), which was created during pit backfilling, currently (1987) is partially saturated.

The potentiometric surface of the Wyodak coal aquifer is based on ground-water levels measured during December 1981 ( $\mathrm{fig} .21$ ). Discharge to the spoil aquifer from the wyodak coal aquifer is indicated by the configuration of the potentiometric surface (fig. 21). The proximity of clinker along the eastern extent of the mine (fig. 21) creates a potential source of recharge to the spoil aquifer. One additional source of recharge to the spoil aquifer is water from a pond created to store water for dust suppression (site CSW-1). One possible source of recharge to the Wyodak coal aquifer was from the clinker-coal outcrop. Recharge to the Wyodak coal aquifer from the clinker has been estimated to be about $4.5(\mathrm{gal} / \mathrm{d}) / \mathrm{ft}^{2}$ of clinker-coal contact (Cordero Mine personnel, written commun., 1983). 


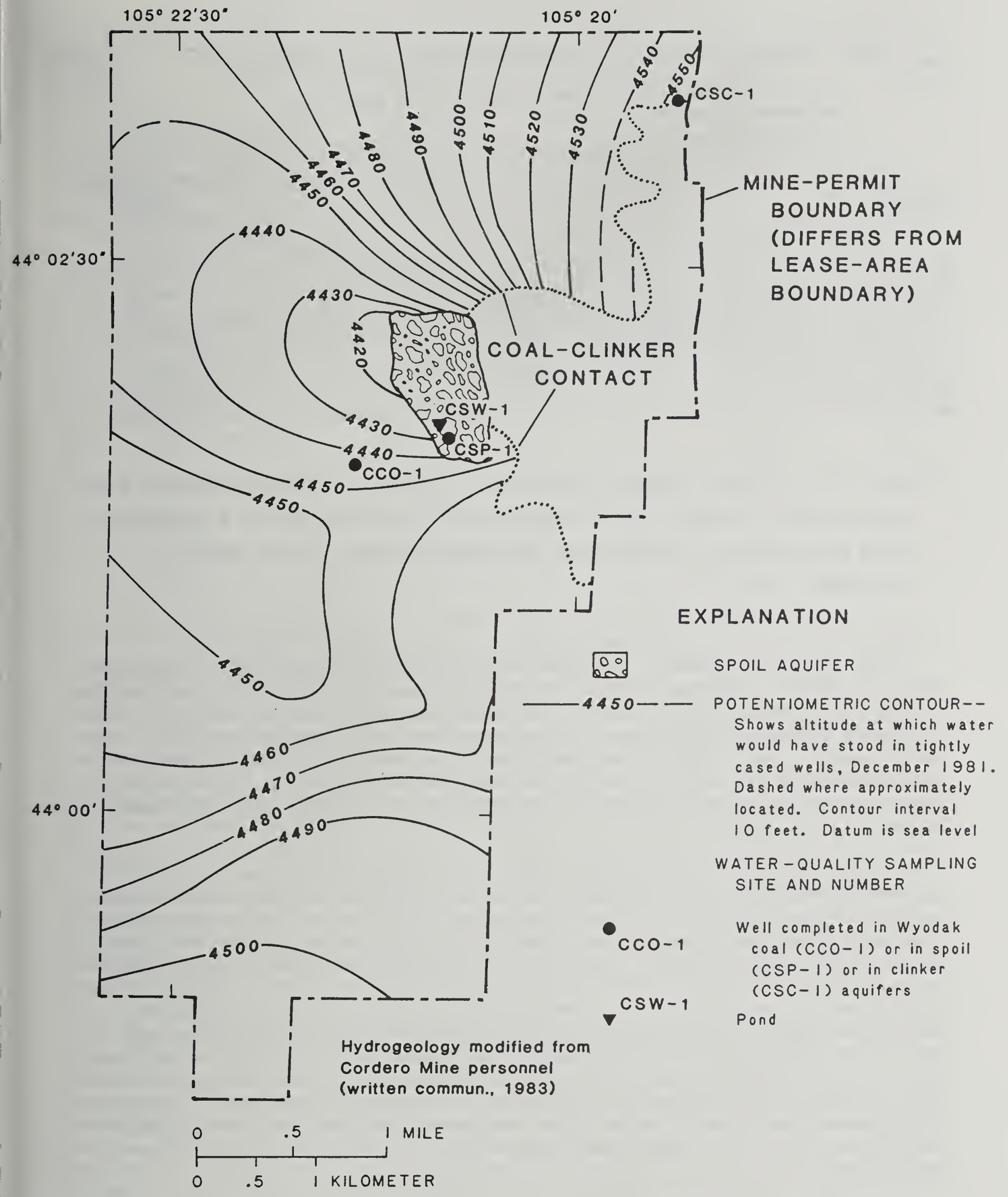

Figure 21.--Potentiometric surface of the Wyodak coal aquifer during December 1981 and location of water-quality sampling sites, Cordero Mine. 


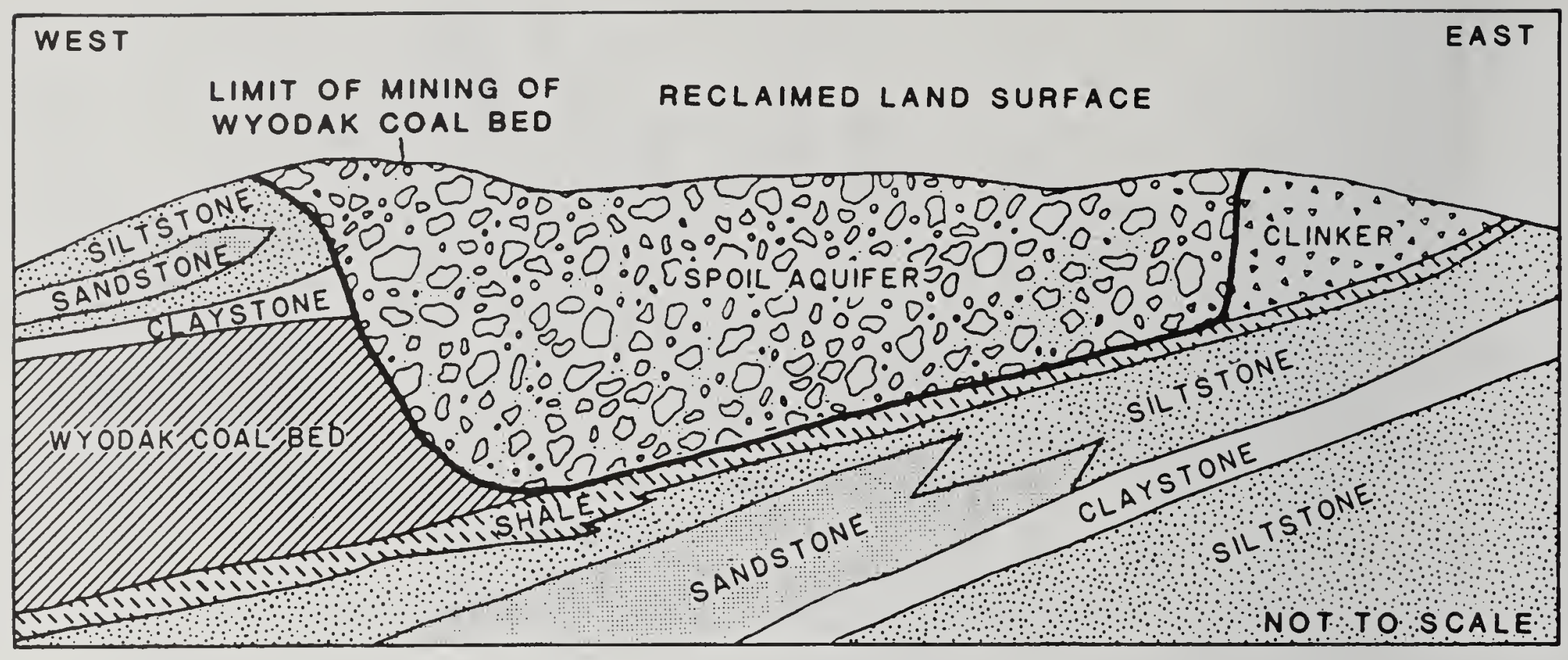

Figure 22.--Diagrammatic geologic section of the Wyodak coal bed of the Tongue River Member of the Fort Union Formation and associated strata, and the spoil aquifer after mining, Cordero Mine.

The concentrations of stable and radioactive isotopes in ground and surface water from the Cordero Mine were used to confirm previously identified recharge sources to the spoil aquifer. Water samples were collected from wells completed in the Wyodak coal aquifer (well $\mathrm{CCO}-1$ ), the spoil aquifer (well CSP-1), and the clinker aquifer (well CSC-1), and from a pond overlying the spoil aquifer (site CSW-1) (fig. 21). The isotopic compositions of ground and surface water from the Cordero Mine are shown in table 7 .

The $\delta^{18} 0$ (oxygen-18/oxygen-16 isotopic ratio) and $\delta D$ (deuterium/hydrogen isotopic ratio) values for ground-and surface-water samples collected from the Cordero Mine were compared to the composition of the North American continental precipitation as reported by Gat (1980) $\left(\delta D=\left(7.95 \delta^{18} 0\right)+6.03\right)$. The $\delta^{18} 0$ and $\delta D$ values from all four samples represented in figure 23 approximately correspond to the composition of North American continental precipitation, indicating the presence of present-day meteoric water in the aquifers. The $\delta^{18} 0$ and $\delta D$ composition of the water samples from wells CSP-1 (spoil aquifer) and CCO-1 (Wyodak coal aquifer) were similar (fig. 23), which indicates water from the coal aquifer may be a principal source of recharge to the spoil aquifer. However, significant quantities of water from the Wyodak coal aquifer recharging the spoil aquifer is not supported by the tritium content of water from the spoil aquifer. 
Table 7.--Isotopic ratios or activities of isotopes in ground-and surface-water samples collected at Cordero Mine

[SO- ${ }^{2}$, sulfate; $\delta^{10} 0$, oxygen-18/oxygen- 16 isotopic ratio; $\delta D$, deuterium/hydrogen isotopic ratio; $\delta^{13} \mathrm{C}$, carbon-13/carbon-12 isotopic ratio; $\delta^{34} \mathrm{~S}$, sulfur $-34 /$ sulfur -32 isotopic ratio; $\mathrm{pCi} / \mathrm{L}$, picocuries per liter]

\begin{tabular}{lcccccc}
\hline $\begin{array}{l}\text { Well or } \\
\text { site }\end{array}$ & Source & $\begin{array}{c}\text { Oxygen } \\
\left(\delta^{18} \mathrm{O}\right)\end{array}$ & $\begin{array}{c}\text { Hydrogen } \\
(\delta \mathrm{D})\end{array}$ & $\begin{array}{c}\text { Carbon } \\
\left(\delta^{13} \mathrm{C}\right)\end{array}$ & $\begin{array}{c}\text { Sulfur, } \mathrm{SO}_{4}^{-2} \\
\left(\delta^{3}{ }^{4} \mathrm{~S}\right)\end{array}$ & $\begin{array}{c}\text { Tritium } \\
(\mathrm{pCi} / \mathrm{L})\end{array}$ \\
$\begin{array}{c}\text { CCO-1 } \\
\begin{array}{c}\text { Wyodak coal } \\
\text { aquifer }\end{array}\end{array}$ & -16.5 & -127 & -8.2 & -9.8 & 4 \\
$\mathrm{CSP}-1$ & Spoil aquifer & -16.1 & -127 & -12.3 & -8.1 & 130 \\
$\mathrm{CSC}-1$ & Clinker aquifer & -18.9 & -146 & -15.2 & -7.8 & 180 \\
$\mathrm{CSW}-1$ & Pond & -16.6 & -113 & -7.5 & -7.8 & 71 \\
\hline
\end{tabular}

Tritium concentrations in water samples from the Cordero Mine ranged from 71 to $180 \mathrm{pCi} / \mathrm{L}$ (picocuries per liter) except for water from well CCO- 1 (completed in Wyodak coal aquifer), which had a concentration of $4 \mathrm{pCi} / \mathrm{L}$ (table 7). The small tritium concentration in the water sample from the Wyodak coal aquifer indicates the lack of substantial quantities of recent (post-1952) recharge. The large tritium concentration in water from the spoil aquifer indicates a substantial proportion of the total recharge is recent recharge. Because water from well CCO-1 (completed in Wyodak coal aquifer) had a small tritium concentration, water from the Wyodak coal aquifer was not considered to be a principal source of recharge to the spoil aquifer. The large tritium concentrations in water from well CSC-1 (completed in clinker aquifer) and $\mathrm{CSW}-1$ (pond) indicates these are the possible major recharge sources to the spoil aquifer. Direct infiltration of precipitation also could be a recharge source to the spoil aquifer. Although the tritium concentration in precipitation was not measured, recent precipitation probably has a tritium concentration similar to that in water from site CSW-1 (pond).

The approximate temperature of recharge water was derived from $\delta^{18} 0$ values for samples of ground water collected at the Cordero Mine. The $\delta^{\prime}{ }^{8} 0$ values for continental precipitation have been correlated with average surface temperatures by Yurtsever (1975), allowing a determination of recharge-water temperature to be made. The $\delta^{18} \mathrm{O}$ values from ground-water samples collected at the Cordero Mine ranged from -18.9 to -16.1 per mil, indicating a recharge-water temperature of about $0{ }^{\circ} \mathrm{C}$ ( $\mathrm{fig} .24$ ). An average recharge-water temperature of about $0{ }^{\circ} \mathrm{C}$ indicates that most recharge to ground water at the mine is derived from spring snowmelt rather than late spring and early summer rainfall. 


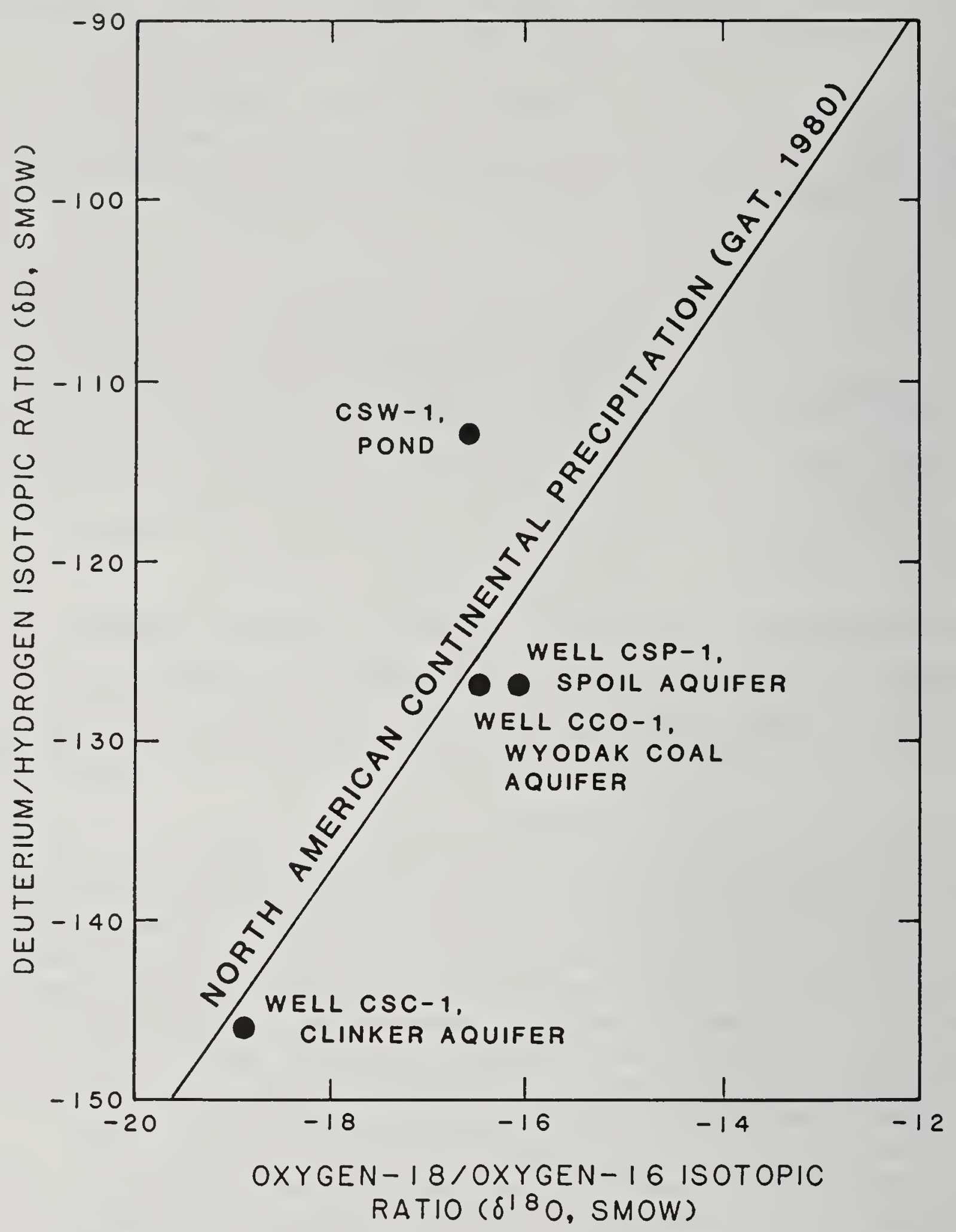

Figure 23.--Comparison of the isotopic composition of ground-water samples from the Cordero Mine to the isotopic composition of North American continental precipitation. SMOW, standard mean ocean water. 


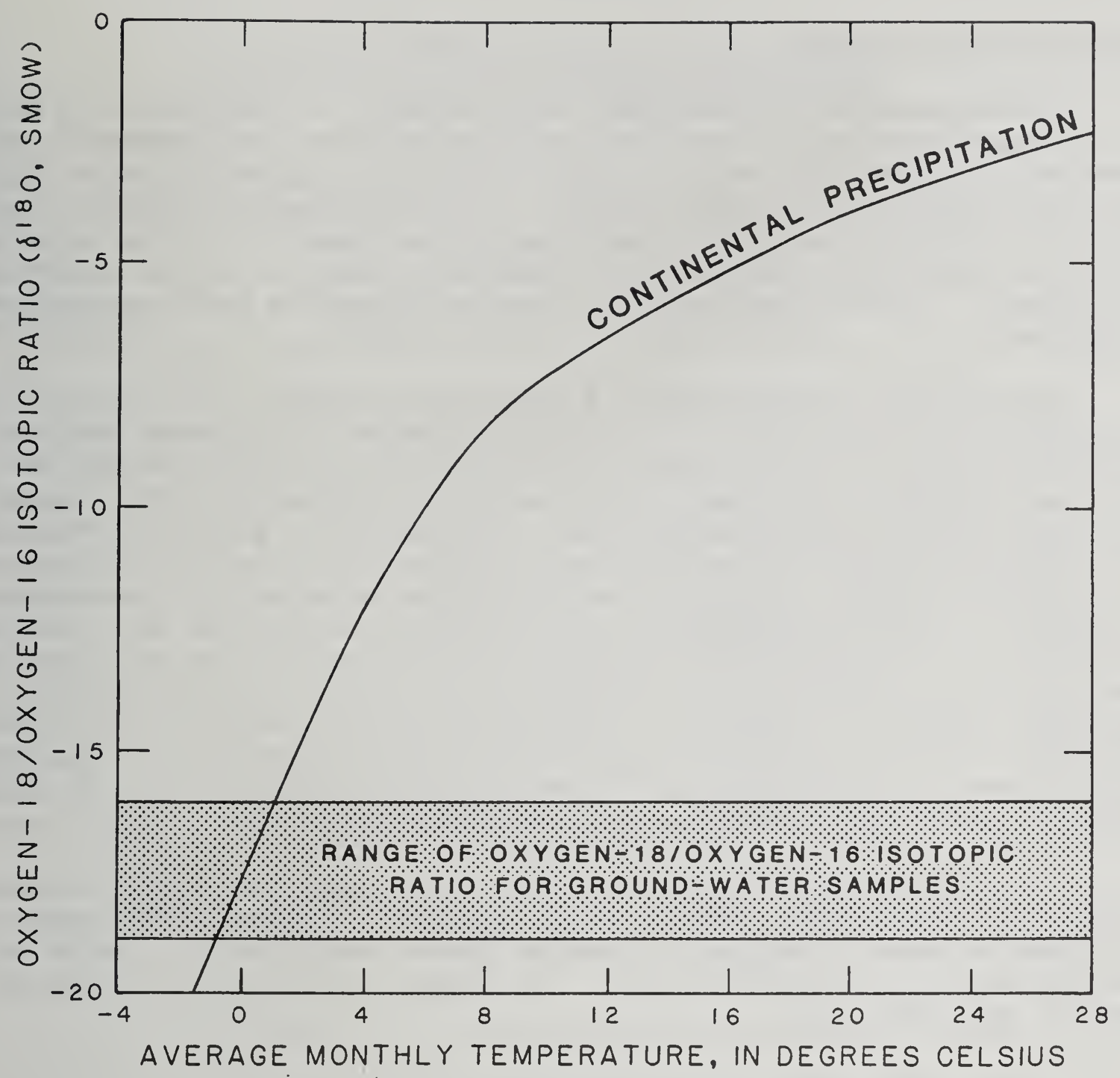

Figure 24.--Correlation of $\delta 180$ composition of continental precipitation compared to the average monthly temperature from continental stations (Yurtsever, 1975) superposed with the $\delta 180$ composition of ground-water samples from the Cordero Mine. SMOW, standard mean ocean water. 


\section{Mineral-water relations}

Mass-balance and thermodynamic calculations, in combination with the mineralogy of the spoil material, were used to establish a plausible set of chemical reactions that would simulate the actual changes in water quality during recharge of the spoil aquifer. By identifying the possible chemical reactions controlling the actual changes in water quality during recharge of the spoil aquifer, probable solid-phase sources of the solutes may be determined. In addition, further changes in postmining water quality can be evaluated.

The computer program WATEQF (Plummer and others, 1978) was used to calculate the activities of the aqueous species in the water samples that were collected. Based on the activities calculated by WATEQF for the various species of interest, the degree of saturation with respect to a particular mineral phase was determined for each water analysis. The degree of saturation with respect to a particular mineral phase is defined as the ion-activity product divided by the equilibrium constant for the mineral of interest. Log transformation of this ratio is referred to as a saturation index (SI). In general, a positive SI for a particular mineral phase denotes that the mineral, if present, will tend to precipitate from solution; whereas, a negative SI denotes that the mineral will tend to dissolve. An SI of about zero signifies that the solution is in equilibrium with respect to the mineral of interest. The results of the speciation calculations for calcite and gypsum are given in table 8 .

Mass-balance calculations, using the computer program BALANCE (Parkhurst and others, 1982a), were performed to determine the proportions of plausible phases that could enter or leave the water to result in the actual changes in water quality. The general chemical reaction is in the form of the following:

\section{initial solution composition + reactant phases $\longrightarrow$}

final solution composition + product phases,

where the terms "reactant phases" and "product phases" refer to constituents that enter or leave the aqueous phase during a reaction. The possible reactant and product phases were determined by the mineralogical analyses of the spoil material as well as from speciation calculations and geological inferences derived from the spoil material.

On the basis of the stable isotope data, possible sources of recharge to the spoil aquifer include water from the clinker aquifer and the pond. Mass-balance calculations were made for both possible sources. For the first calculation, the chemical composition of water from well CSC-1 (table 8, completed in clinker aquifer) was considered to be the chemical composition of all recharge water. For the second calculation, the chemical composition of water from site CSW-1 (table 8, pond) was considered to be the chemical composition of all recharge water. The chemical composition of water from well CSP-1, (table 8, completed in spoil aquifer) was considered to be the chemical composition of the final water in both mass-balance calculations. 
Table 8.--Water-quality data used in the

geochemical-reaction models, Cordero Mine

[Concentration, in millimoles per liter, except as indicated]

\begin{tabular}{|c|c|c|c|}
\hline $\begin{array}{l}\text { Chemical } \\
\text { property or } \\
\text { constituent }\end{array}$ & $\begin{array}{l}\text { Well completed } \\
\text { in clinker } \\
\text { aquifer } \\
\text { (well CSC-1) }\end{array}$ & $\begin{array}{c}\text { Well completed } \\
\text { in spoil } \\
\text { aquifer } \\
\text { (well CSP-1) }\end{array}$ & $\begin{array}{c}\text { Pond } \\
\text { (site CSW-1) }\end{array}$ \\
\hline $\mathrm{pH}$ (units) & 6.9 & 6.8 & 7.2 \\
\hline Dissolved oxygen & 1.156 & .025 & .156 \\
\hline Redox state & 109.747 & 258.584 & 13.892 \\
\hline Calcium & 10.728 & 14.471 & .649 \\
\hline Magnesium & 3.414 & 12.751 & .346 \\
\hline Sodium & 1.479 & 29.578 & 1.479 \\
\hline Potassium & .639 & .844 & .079 \\
\hline Sulfur & 12.492 & 34.354 & 1.562 \\
\hline Chloride & .178 & 3.667 & .118 \\
\hline Fluoride & .032 & .016 & .010 \\
\hline Silica & .632 & .216 & .020 \\
\hline Aluminum & 1.000 & 1.000 & 1.000 \\
\hline Iron & .005 & .004 & .000 \\
\hline Carbon, total & 8.389 & 13.087 & .974 \\
\hline Saturation index: & & & \\
\hline Calcite & .143 & .099 & -1.462 \\
\hline Gypsum & -.170 & .117 & -1.719 \\
\hline
\end{tabular}

1 Estimated concentration; analytical datum was either less than detection limit or was not available.

Plausible phases considered in the following geochemical-reaction models are based on the mineralogical and sulfur-form analyses of the spoil material at the Cordero Mine (L.R. Larson, U.S. Geological Survey, written commun., 1986). The following minerals were identified by X-ray diffraction: smectite, chlorite, illite, kaolinite, gypsum, quartz, potassium feldspar, plagioclase feldspar, dolomite, and calcite. Pyrite was inferred by the sulfur-form analyses. Seven reaction sets of plausible phases are considered for both sources of recharge to the spoil aquifer (table 9). In each of the seven sets of phases considered, magnesium is derived from chlorite or epsomite or both; sodium from cation exchange and halite dissolution; potassium from the dissolution of potassium feldspar; chloride from halite dissolution; and silica from potassium feldspar and chlorite. Precipitation of chalcedony and kaolinite was the sink for silica, and precipitation of kaolinite is the sink for aluminum. 
Table 9.--Selected reaction sets of plausible phases for mass-balance calculations, Cordero Mine

Reaction
set
1 Clausible phases
halite, kaolinite, oxygen, potassium feldspar, pyrite, silica
Carbon dioxide, cation exchange, chlorite, goethite, gypsum,
halite, kaolinite, oxygen, potassium feldspar, pyrite, silica
Calcite, cation exchange, chlorite, goethite, gypsum, halite,
kaolinite, oxygen, potassium feldspar, pyrite, silica
Calcite, cation exchange, chlorite, goethite, gypsum, halite,
kaolinite, organic carbon, oxygen, potassium feldspar, silica
Calcite, carbon dioxide, cation exchange, chlorite, goethite,
gypsum, halite, kaolinite, oxygen, potassium feldspar, silica
Calcite, carbon dioxide, cation exchange, chlorite, gypsum,
halite, kaolinite, potassium feldspar, silica
Calcite, cation exchange, chlorite, epsomite, gypsum, halite,
kaolinite, potassium feldspar, silica

Possible sources considered for the actual sulfate increases include pyrite, gypsum, and epsomite. In reaction set 1, pyrite oxidation is the only source of sulfate considered; whereas reaction sets 2 and 3 also considered gypsum. Gypsum dissolution is considered as the only source of sulfate in reaction sets 4, 5, and 6; whereas reaction set 7 also considered epsomite in combination with gypsum as sulfate sources.

Pyrite and chlorite are considered as possible sources of iron with goethite as the only iron sink considered. In reaction sets 1, 2, and 3 , pyrite is the primary iron source. Chlorite weathering is the source of iron in reaction sets 4 and 5 . As noted by Powell and Larson (1985, p. 7), ferrous iron can substitute for magnesium in the chlorite structure. Reaction sets 6 and 7 do not include iron sources or sinks because iron is not assumed to be in the chlorite mineral structure for these reaction sets.

Carbon sources and sinks considered in the reaction sets include calcite, carbon dioxide, and organic matter (for example, carbon with a valence of 0 ). Reaction sets 1,2, 5, and 6 are open to exchange with carbon dioxide; reaction sets 3,4 , and 7 are not. 
Oxidation-reduction reactions are considered as possible geochemical reactions in reaction sets $1,2,3,4$, and 5 ; whereas they are not considered in reaction sets 6 and 7 . Oxidation-reduction reactions considered include pyrite oxidation (table 10, reaction 1), oxidation of ferrous iron (table 10, reaction 3 ), and oxidation of organic matter (table 10 , reaction 4 ).

Table 10.--Pertinent chemical reactions

[Subscript $(\mathrm{g})$ denotes gaseous phase]

\begin{tabular}{|c|c|}
\hline $\begin{array}{l}\text { Reaction } \\
\text { number }\end{array}$ & Reaction \\
\hline & Oxidation-reduction \\
\hline 1 & $\underset{\text { (pyrite) }}{\mathrm{FeS}_{2}+3 \cdot 5_{2}(\mathrm{~g})}+\mathrm{H}_{2} \mathrm{O}=\mathrm{Fe}^{+2}+2 \mathrm{SO}_{4}^{-2}+2 \mathrm{H}^{+}$ \\
\hline 2 & 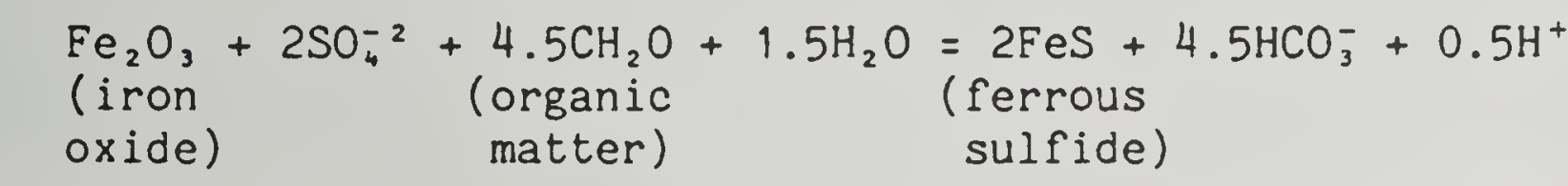 \\
\hline 3 & $\mathrm{Fe}^{+2}+0.25 \mathrm{O}_{2}+\mathrm{H}^{+}=\mathrm{Fe}^{+3}+0.5 \mathrm{H}_{2} \mathrm{O}$ \\
\hline 4 & $\begin{array}{l}\mathrm{CH}_{2} \mathrm{O}+\mathrm{O}_{2}=\mathrm{CO}_{2}(\mathrm{~g})+\mathrm{H}_{2} \mathrm{O} \\
\text { (organic } \\
\text { matter) }\end{array}$ \\
\hline & Mineral precipitation \\
\hline 5 & $\begin{aligned} \mathrm{Ca}^{+2}+2 \mathrm{HCO}_{3}^{-} & =\mathrm{CaCO}_{3}+\mathrm{CO}_{2}+\mathrm{H}_{2} \mathrm{O} \\
& (\text { calcite })\end{aligned}$ \\
\hline
\end{tabular}


The redox state (RS) shown in table 8 is a means of keeping track of electron transfer in the redox reactions considered. Redox state is defined as follows:

$$
\operatorname{RS}=\sum_{i=1}^{I} m_{i} v_{i}
$$

where $I$ = the number of species in solution,

$m_{i}=$ the molality of the $i^{\prime}$ th species in solution, and

$v_{i}=$ the operational valance of the species.

Plummer and others (1983, p. 4-6) address the definition of operational valance.

Mass-balance calculation results for the seven reaction sets of combined plausible phases (table 11 ) identify reaction models that can be used to explain water-quality changes that occurred during recharge of the spoil aquifer from both possible recharge sources. Each reaction set in table 11 represents the results of a particular combination of the plausible phases considered. The values in the columns indicate the concentration of each phase (in millimoles per kilogram of water) either entering or leaving the water. A positive value $(+)$ indicates dissolution of the phase; a negative value (-) indicates formation of the phase.

The feasibility of reaction model 1 may be tested by comparing the measured $\delta^{34} \mathrm{~S}$ in water from well CSP-1 (completed in spoil aquifer) with the calculated isotopic composition of dissolved sulfate in the sample indicated by the mass transfer of pyrite in reaction model 1 (table 11). This calculation can be done with both sources of recharge water. Because no sulfur minerals are forming in reaction model 1, the calculated $\delta^{34} S$ of dissolved sulfate in water from well CSP-1 can be approximated according to the linear isotope-balance equation (Plummer and others, 1983, p. 675):

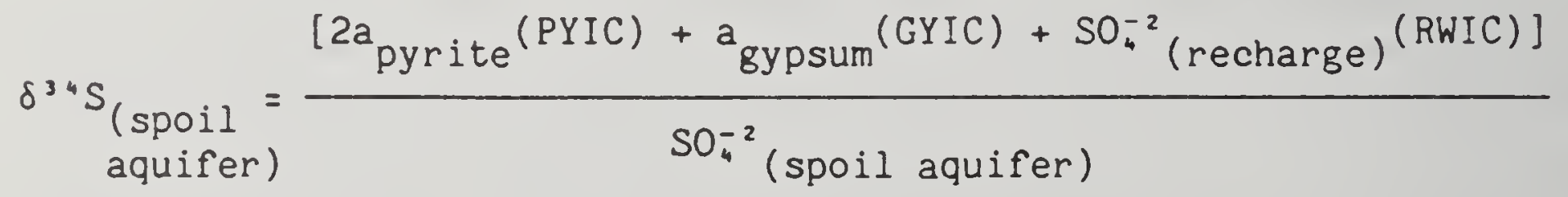

where

$$
\begin{aligned}
a_{\text {pyrite }}=\begin{array}{r}
\text { the stoichiometric coefficient of } \\
\text { pyrite from the reaction model } \\
\text { (table } 11),
\end{array} \\
\text { PYIC = the } \delta^{34} \text { composition of pyrite, } \\
a_{\text {gypsum }=} \begin{array}{c}
\text { the stoichiometric coefficient of } \\
\text { gypsum from the reaction model, }
\end{array}
\end{aligned}
$$


GYIC = the $\delta^{3}{ }^{4} S$ composition of gypsum,

RWIC = the $\delta^{34} \mathrm{~S}$ composition of the recharge water, and

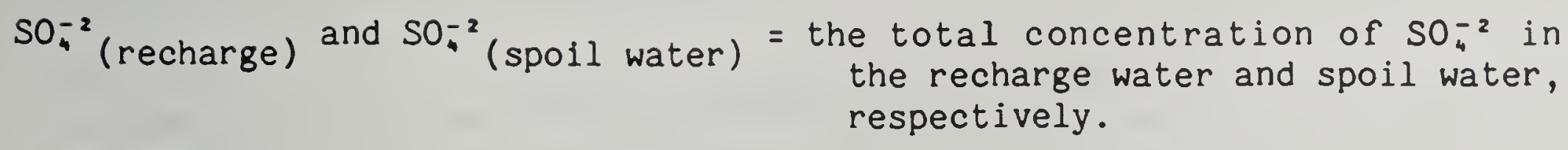

The value of -4.7 per mil, used for the $\delta^{3}{ }^{4} \mathrm{~S}$ composition of pyrite is derived from the average $\delta^{34} \mathrm{~S}$ composition of 10 samples containing disseminated pyrite collected from the Wyodak coal bed in the Powder River structural basin by Hackley and Anderson (1986, p. 1706).

Using equation 4 and the calculated mass transfer of pyrite from reaction model 1 (table 11 ), the values of $\delta^{3} 4 \mathrm{~S}$ in water from well CSP-1 (completed in spoil aquifer) are calculated for both possible recharge sources. The calculated values of $\delta^{34} S$ for water from well CSP-1 are -5.8 per mil using the clinker-aquifer recharge source and -4.8 per mil using the surface-pond recharge source. The actual $\delta^{34} \mathrm{~S}$ of water from well CSP-1 is -8.1 per mil (table 7). Lack of agreement between the calculated and actual $\delta^{34} \mathrm{~S}$ values indicates that reaction model 1 may not be representative of actual conditions. However, the site specific $\delta^{34} \mathrm{~S}$ composition of disseminated pyrite at the Cordero Mine needs to be determined for more precise isotope-balance calculations.

The water-quality changes occurring at the Cordero Mine probably are not represented by reaction models 1, 2, and 3. Reaction models 1, 2, and 3 all derive at least part of the actual increase in dissolved sulfate from pyrite dissolution (table 11). Because the $\mathrm{pH}$ of water from well CSP-1 (completed in spoil aquifer) is 6.8 (table 8 ), any pyrite dissolution that occurs must be buffered by calcite dissolution. Reaction model 2 does not consider calcite dissolution as a plausible phase to buffer the acidity produced by the pyrite oxidation and, therefore, is eliminated from further consideration.

Although reaction models 1 and 3 have substantial calcite dissolution and pyrite oxidation (table 11), the dissolution is not sufficient to buffer all of the acidity. For every $1 \mathrm{mmol}$ (millimole) of pyrite oxidized, at least $4 \mathrm{mmol}$ of acidity are produced (Drever, 1982, p. 62). The concentration of alkalinity available for the buffering of pyrite oxidation is a function of the partial pressure of carbon dioxide and the solubility of the calcite. The calcite-pyrite equilibrium line shown in figure 25 is derived from the addition of oxygen to each of the initial recharge waters, while maintaining equilibrium with calcite, pyrite, and goethite. The quantity of calcite and pyrite dissolution predicted by reaction models 1 and 3 also is plotted in figure 25. As shown in figure 25, the quantity of calcite dissolution accompanying the pyrite oxidation in reaction models 1 and 3 is insufficient for complete acid buffering. Because the $\mathrm{pH}$ measured in water from well CSP-1 (completed in spoil aquifer) is not acidic enough to indicate unbuffered pyrite dissolution, reaction models 1 and 3 are eliminated as representative models. 
Table 11.--Results of mass-balance calculations for water from the well

[Data for phases shown in millimoles per of the phase; -, indicates formation

\begin{tabular}{|c|c|c|c|c|c|c|}
\hline \multirow[b]{3}{*}{$\begin{array}{l}\text { Plausible } \\
\text { phases }\end{array}$} & \multicolumn{6}{|c|}{ Reaction model } \\
\hline & \multicolumn{2}{|c|}{1} & \multicolumn{2}{|c|}{2} & \multicolumn{2}{|c|}{3} \\
\hline & $\begin{array}{l}\text { Well com- } \\
\text { pleted in } \\
\text { clinker } \\
\text { aquifer }\end{array}$ & Pond & $\begin{array}{l}\text { Well com- } \\
\text { pleted in } \\
\text { clinker } \\
\text { aquifer }\end{array}$ & Pond & $\begin{array}{l}\text { Well com- } \\
\text { pleted in } \\
\text { clinker } \\
\text { aquifer }\end{array}$ & Pond \\
\hline Calcite & +16.0480 & +26.0970 & -- & - & +4.6980 & +12.1130 \\
\hline $\begin{array}{l}\text { Carbon } \\
\quad \text { dioxide }\end{array}$ & -11.3500 & -13.9840 & +4.6980 & +12.1130 & -- & -- \\
\hline $\begin{array}{l}\text { Cation } \\
\text { exchange }\end{array}$ & +12.3050 & +12.2750 & +12.3050 & +12.2750 & +12.3050 & +12.2750 \\
\hline Chlorite & +3.1123 & +4.1350 & +3.1123 & +4.1350 & +3.1123 & +4.1350 \\
\hline Epsomite & -- & -- & -- & -- & -- & -- \\
\hline Goethite & -17.1567 & -24.6620 & -9.1327 & -11.6135 & -11.4817 & -17.6700 \\
\hline Gypsum & -- & -- & +16.0480 & +26.0970 & +11.3500 & +13.9840 \\
\hline Halite & +3.4890 & +3.5490 & +3.4890 & +3.5490 & +3.4890 & +3.5490 \\
\hline Kaolinite & -3.2148 & -4.5175 & -3.2148 & -4.5175 & -3.2148 & -4.5175 \\
\hline $\begin{array}{l}\text { Organic } \\
\text { carbon }\end{array}$ & -- & -- & -- & -- & -- & -- \\
\hline Oxygen & +42.2664 & +63.4215 & +12.1764 & +14.4896 & +20.9852 & +37.2015 \\
\hline $\begin{array}{l}\text { Potassium } \\
\text { feldspar }\end{array}$ & +.2050 & +.7650 & +.2050 & +.7650 & +.2050 & +.7650 \\
\hline $\begin{array}{l}\text { Pyrite } \\
\text { Silica }\end{array}$ & $\begin{array}{r}+10.9310 \\
-3.9383\end{array}$ & $\begin{array}{r}+16.3960 \\
-5.4690\end{array}$ & $\begin{array}{l}+2.9070 \\
-3.9383\end{array}$ & $\begin{array}{l}+3.3475 \\
-5.4690\end{array}$ & $\begin{array}{l}+5.2560 \\
-3.9383\end{array}$ & $\begin{array}{l}+9.4040 \\
-5.4690\end{array}$ \\
\hline
\end{tabular}


completed in the clinker aquifer and from the pond at Cordero Mine

kilogram of water. +, indicates dissolution

of the phase; --, indicates no data]

\begin{tabular}{|c|c|c|c|c|c|c|c|}
\hline \multicolumn{8}{|c|}{ Reaction model } \\
\hline \multicolumn{2}{|r|}{4} & \multicolumn{2}{|r|}{5} & \multicolumn{2}{|r|}{6} & \multicolumn{2}{|r|}{7} \\
\hline $\begin{array}{l}\text { Well com- } \\
\text { pleted in } \\
\text { clinker } \\
\text { aquifer }\end{array}$ & Pond & $\begin{array}{l}\text { Well com- } \\
\text { pleted ir } \\
\text { clinker } \\
\text { aquifer }\end{array}$ & Pond & $\begin{array}{l}\text { Well com- } \\
\text { pleted ir } \\
\text { clinker } \\
\text { aquifer }\end{array}$ & Pond & $\begin{array}{l}\text { Well com } \\
\text { pleted ir } \\
\text { clinker } \\
\text { aquifer }\end{array}$ & Pond \\
\hline $\begin{array}{c}+5.8140 \\
--\end{array}$ & $\begin{array}{c}-6.6950 \\
--\end{array}$ & $\begin{array}{r}-5.8140 \\
+10.5120\end{array}$ & $\begin{array}{r}-6.6950 \\
+18.8080\end{array}$ & $\begin{array}{r}-5.8140 \\
+10.5120\end{array}$ & $\begin{array}{r}-6.6950 \\
+18.8080\end{array}$ & $\begin{array}{c}+4.6980 \\
--\end{array}$ & $\begin{array}{c}+12.1130 \\
--\end{array}$ \\
\hline+12.3050 & +12.2750 & +12.3050 & +12.2750 & +12.3050 & +12.2750 & +12.3050 & +12.2750 \\
\hline+3.1123 & +4.1350 & +3.1123 & +4.1350 & +1.8674 & +2.4810 & +2.4810 & -1.2806 \\
\hline-6.2257 & $-8 . \overline{2660}$ & -6.2257 & -8.2660 & -- & -- & $\begin{array}{l}.5120 \\
--\end{array}$ & $\begin{array}{c}+18.8080 \\
--\end{array}$ \\
\hline+21.8620 & +32.7920 & +21.8620 & +32.7920 & +21.8620 & +32.7920 & +11.3500 & +13.9840 \\
\hline+3.4890 & +3.5490 & +3.4890 & +3.5490 & +3.4890 & +3.5490 & +3.4890 & +3.5490 \\
\hline-3.2148 & -4.5175 & -3.2148 & -4.5175 & -1.9699 & -2.8635 & 1325 & .8981 \\
\hline+10.5120 & +18.8080 & -- & - & -- & -- & -- & -- \\
\hline $\begin{array}{r}+11.7872 \\
+.2050\end{array}$ & $\begin{array}{r}+20.7445 \\
+.7650\end{array}$ & $\begin{array}{r}+1.2752 \\
+.2050\end{array}$ & $\begin{array}{r}+1.9365 \\
+.7650\end{array}$ & $\begin{array}{c}-- \\
+.2050\end{array}$ & $\begin{array}{c}-- \\
+.7650\end{array}$ & $\begin{array}{c}-- \\
+.2050\end{array}$ & $\begin{array}{c}-- \\
+.7650\end{array}$ \\
\hline -- & $-\bar{c}$ & -- & $-\bar{c}$ & - & -- & -- & -- \\
\hline-3.9383 & -5.4690 & -3.9383 & -5.4690 & -2.6934 & -3.8150 & -0.5910 & -0.0534 \\
\hline
\end{tabular}


Both recharge sources in reaction model 4 derive the increase in carbon from oxidation of organic carbon (table 11). Organic matter in sedimentary rocks is generally refractory (Drever, 1932, p. 292) and probably is not easily oxidized by percolating waters. Therefore, reaction model 4 probably is not representative of actual conditions.

Reaction model 7 is inconsistent with the saturation indexes for calcite in table 8 for the clinker-aquifer recharge source. Reaction model 7 also indicates dissolution of large quantities of calcite (table 11), which is not possible because the clinker-aquifer recharge is initially oversaturated with respect to calcite; therefore, this model is not representative of actual conditions.

Reaction models 5 and 6 are the only models remaining that are consistent with the available data. Although the $\delta^{34} \mathrm{~S}$ of sulfate minerals was not determined for overburden samples from within the eastern Powder River basin, equation 4 was used to calculate the $\delta^{34} S$ of gypsum (relative to the Canyon Diablo meteorite) for each source of recharge water used in reaction models 5 and 6 . The calculated $\delta^{34} \mathrm{~S}$ for gypsum required for models 5 and 6 , with a recharge source from the clinker, is -8.3 per mil. The calculated
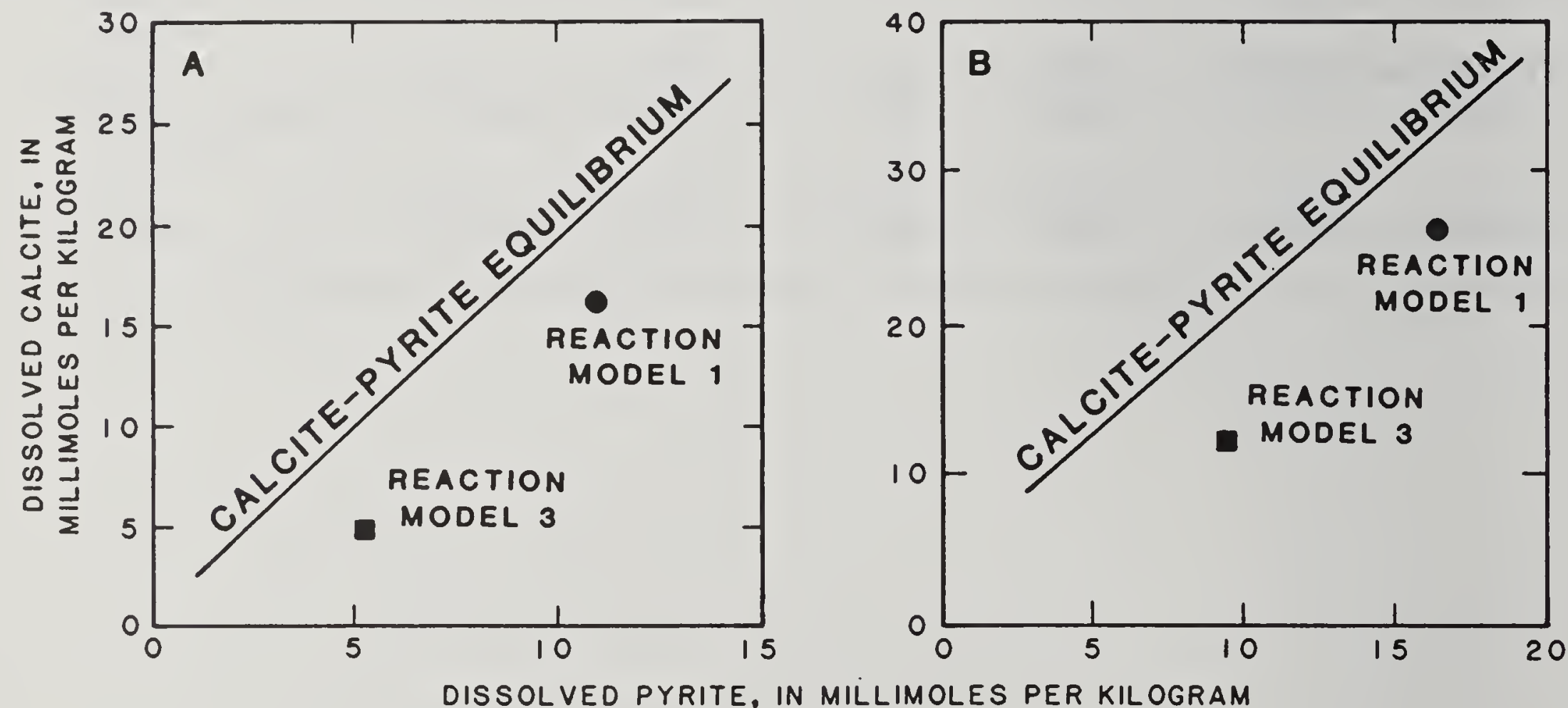

Figure 25.--Quantity of dissolved calcite in relation to quantity of dissolved pyrite predicted to dissolve in water under equilibrium conditions superposed with the quantities of dissolved calcite and pyrite predicted by reaction models 1 and 3 , Cordero Mine: A, recharge from clinker aquifer, $B$, recharge from pond. 
$\delta^{34} \mathrm{~S}$ for gypsum required for reaction models 5 and 6 using a recharge source from the pond is -8.1 per mil. These calculated values do not agree with the $\delta^{34} \mathrm{~S}$ of 14 oxidized-sulfur samples collected in North Dakota by Houghton and others $\left(1985\right.$, p. 26). The $\delta^{34} \mathrm{~S}$ values determined by Houghton and others (1985) were all positive, ranging from 5.4 to 26.2 per mil (relative to the Canyon Diablo meteorite). Site-specific $\delta^{34} S$ data are needed for sulfate containing minerals within the study area to further confirm reaction models 5 and 6 .

Based on the isotope data and mass-balance modeling results at the Cordero Mine, predictions concerning future ground-water quality changes and methods to minimize future postmining water-quality degradation are noted and summarized. Because the postmining water is in equilibrium with respect to gypsum, it is unlikely that the dissolved-solids concentrations will increase further. Naftz (in press) has determined that contact of postmining ground water from the Cordero Mine with recently backfilled spoil material resulted in minimal increases in dissolved constituents. Dissolved-solids concentrations have not decreased substantially during the almost 4 years of record ( $f i g .11$ ); however, Houghton and others (1987, p. 62) estimate at least 1 pore volume of water must leach the spoil before the dissolved-solids concentration in the water would be similar to the premining dissolved-solids concentration in studies done in North Dakota.

The time required to pass 1 pore volume of water through the spoil aquifer is greater than the time required for the postmining ground-water system to re-establish equilibrium. Current estimates of the time required for the ground-water system to re-establish equilibrium varies from a few tens of years to hundreds of years.

During future reclamation at the Cordero Mine and other mines with similar hydrogeologic and geochemical conditions, steps could be taken to minimize increases of dissolved-solids concentrations in postmining ground water. According to reaction models 5 and 6 , gypsum dissolution coupled with cation exchange is a major contributor to the actual increase in dissolved-solids concentration (table 11). Isolation of overburden material with large soluble-salt contents to areas above the postmining ground-water table in confunction with decreasing the rates of infiltration of precipitation and runoff in the spoil aquifer could minimize future increases in dissolved-solids concentrations. Finally, as noted by Houghton and others (1987, p. 65), isolation of spoil material with large soluble-salt contents from clay-rich and organic-rich strata during backfilling also will minimize increases in dissolved-solids concentrations in postmining ground water.

\section{Dave Johnston Mine}

The Dave Johnston Mine is located outside of the study area; it was chosen for additional study because data concerning postmining water-quality changes were available for the mine, and water-level data indicates movement of postmining ground water from the spoil aquifer into the adjacent coal aquifer. Understanding the processes affecting water-quality changes associated with movement of postmining water from the spoil aquifer into the adjacent coal aquifer is important for assessing the impacts of surface coal mining on offite users of ground water. 
Ground water at the Dave Johnston Mine is present primarily in the Badger and School coal beds and adjacent strata (Dave Johnston Mine personnel, written commun., 1983). The Badger and School coal beds occur in the lower part of the Wasatch Formation. The Badger coal bed is stratigraphically above the School coal bed ( $\mathrm{fig} .26$ ). The two coal beds are separated by a 110- to 180-ft zone consisting of claystone, siltstone, and fine-grained silty sandstone. Claystone layers associated with the two coal beds have hydraulically isolated the Badger and School coal beds from each other ( $\mathrm{fig}$. 26). Water also occurs locally in clinker along outcrops of the Badger and School coal beds. The clinker provides increased recharge to the adjacent coal beds. The School coal bed also is referred to as the School coal aquifer.

The potentiometric surface of the School coal aquifer, based on groundwater levels measured during April 1981, is shown in figure 27 . The direction of flow within the School coal aquifer is generally to the east and northeast, in the direction of the dip of the coal bed. Before mining, recharge to the School coal aquifer was from infiltration of precipitation in the vicinity of the outcrop. After mining and replacement of the coal with rubblized spoil, precipitation must first percolate through the spoil aquifer before recharging the unmined parts of the School coal aquifer (fig. 26).

Mining and reclamation has been and is being accomplished at the Dave Johnston Mine using a dragline compared to shovels and trucks used at most mines within the study area. Use of a dragline during mine reclamation can result in greater permeability of the spoil material compared to the permeability of spoil material associated with shovel-and-truck mining and reclamation operations. The greater permeability of the spoil material associated with dragline reclamation at the Dave Johnston Mine has probably increased the rate of recharge to the spoil aquifer compared to similar recharge rates at mines using shovel-and-truck reclamation methods.

The concentrations of stable and radioactive isotopes in ground-water samples from the Dave Johnston Mine (table 12) were used to confirm sources of recharge to the spoil aquifer and movement of water from the spoil aquifer into the School coal aquifer. As shown in figure 28 , the $\delta^{18} 0$ and $\delta D$ values of ground-water samples from the Dave Johnston Mine approximately correspond to the composition of the North American continental precipitation as reported by Gat $(1980)\left(\delta D=\left(7.95 \delta^{18} 0\right)+6.03\right)$, indicating the presence of mostly meteoric water in the aquifers.

The $\delta^{18} O$ and $\delta D$ isotopic composition of a water formed by combining two or more components with different isotopic compositions is additive. Water from well DSP-1 (completed in spoil aquifer) is isotopically heavy relative to water from wells DCO-37 and DCO-12 (completed in School coal aquifer), which are located about 0.4 and $0.7 \mathrm{mi}$ downgradient from the spoil aquifer ( $f i g .27$ ). On the basis of the linear plot of $\delta D$ versus $\delta^{18} O$ ( $f i g .28$ ), water from well DCO-30 (completed in the School coal aquifer), $0.1 \mathrm{mi}$ downgradient from the spoil aquifer (fig. 27), appears to be a mixture of 40 percent water from the spoil aquifer and 60 percent water from the School coal aquifer. 


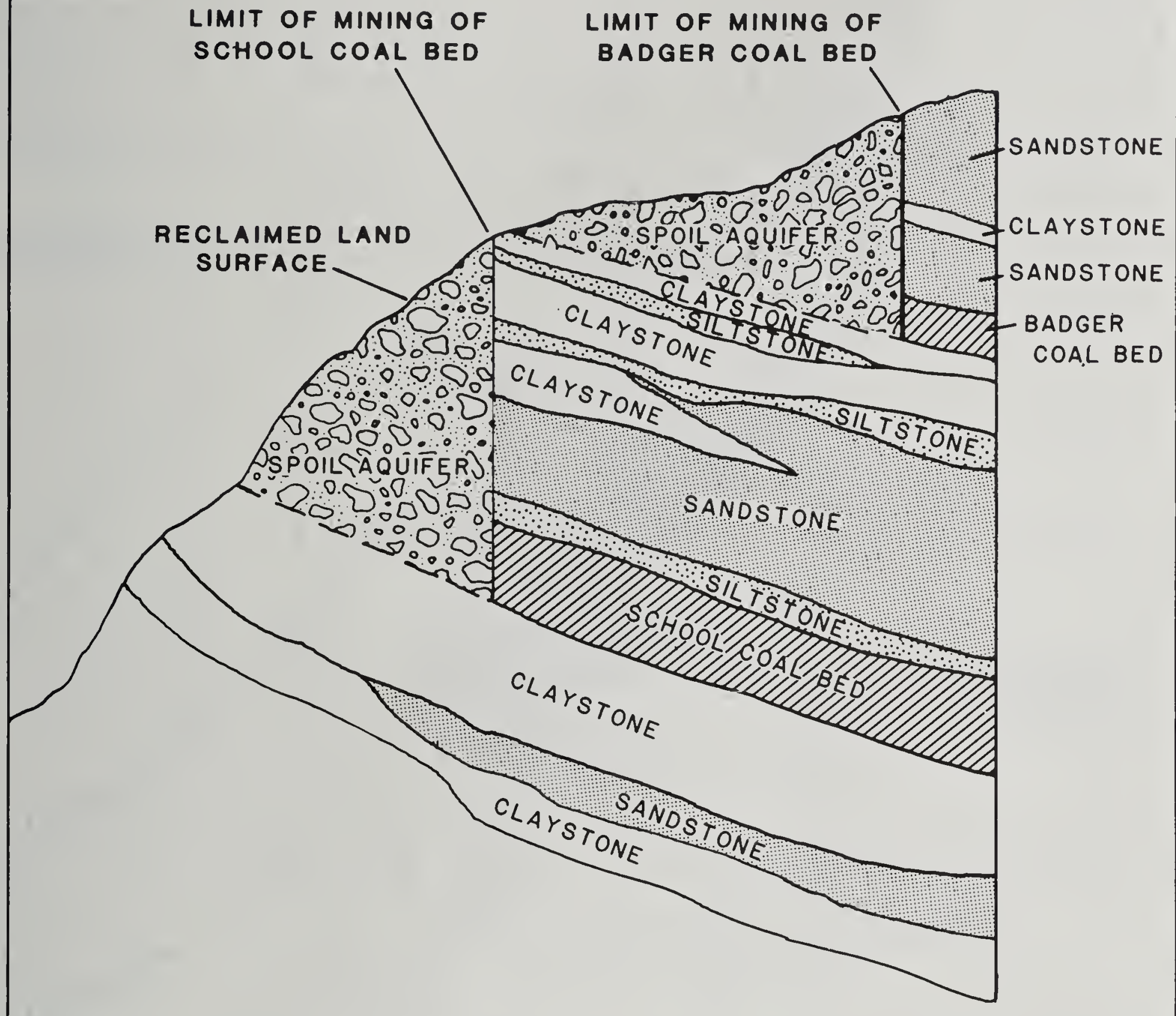

NOT TO SCALE

Modified from Dave Johnston Mine personnel (written commun., 1983)

Figure 26.--Diagrammatic geologic section showing the Badger and School coal beds of the Wasatch Formation, and associated strata after mining, Dave Johnston Mine. 

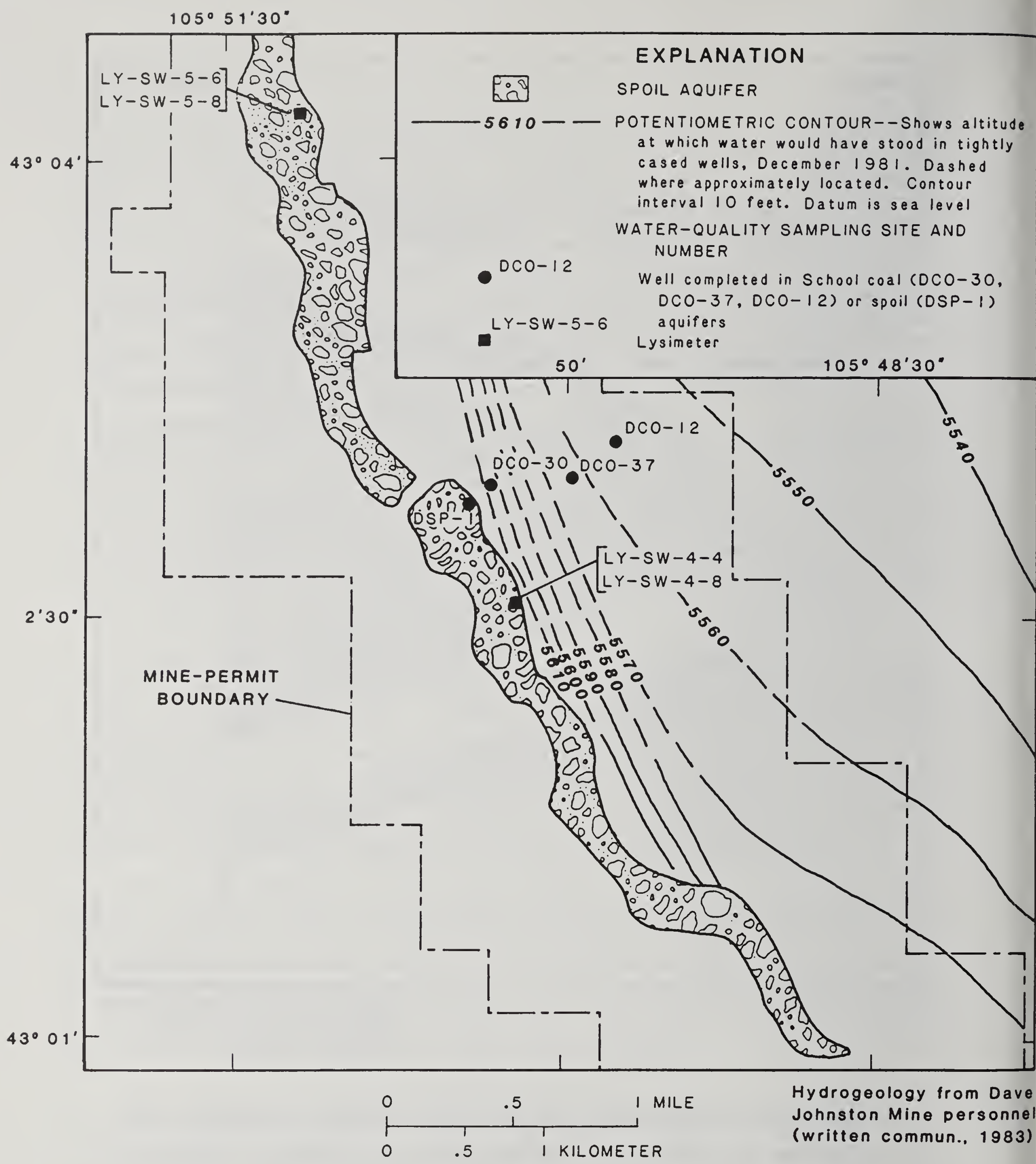

Hydrogeology from Dave Johnston Mine personnel (written commun.. 1983)

Figure 27.--Potentiometric surface of the School coal aquifer during December 1981 and location of water-quality sampling sites, Dave Johnston Mine. 


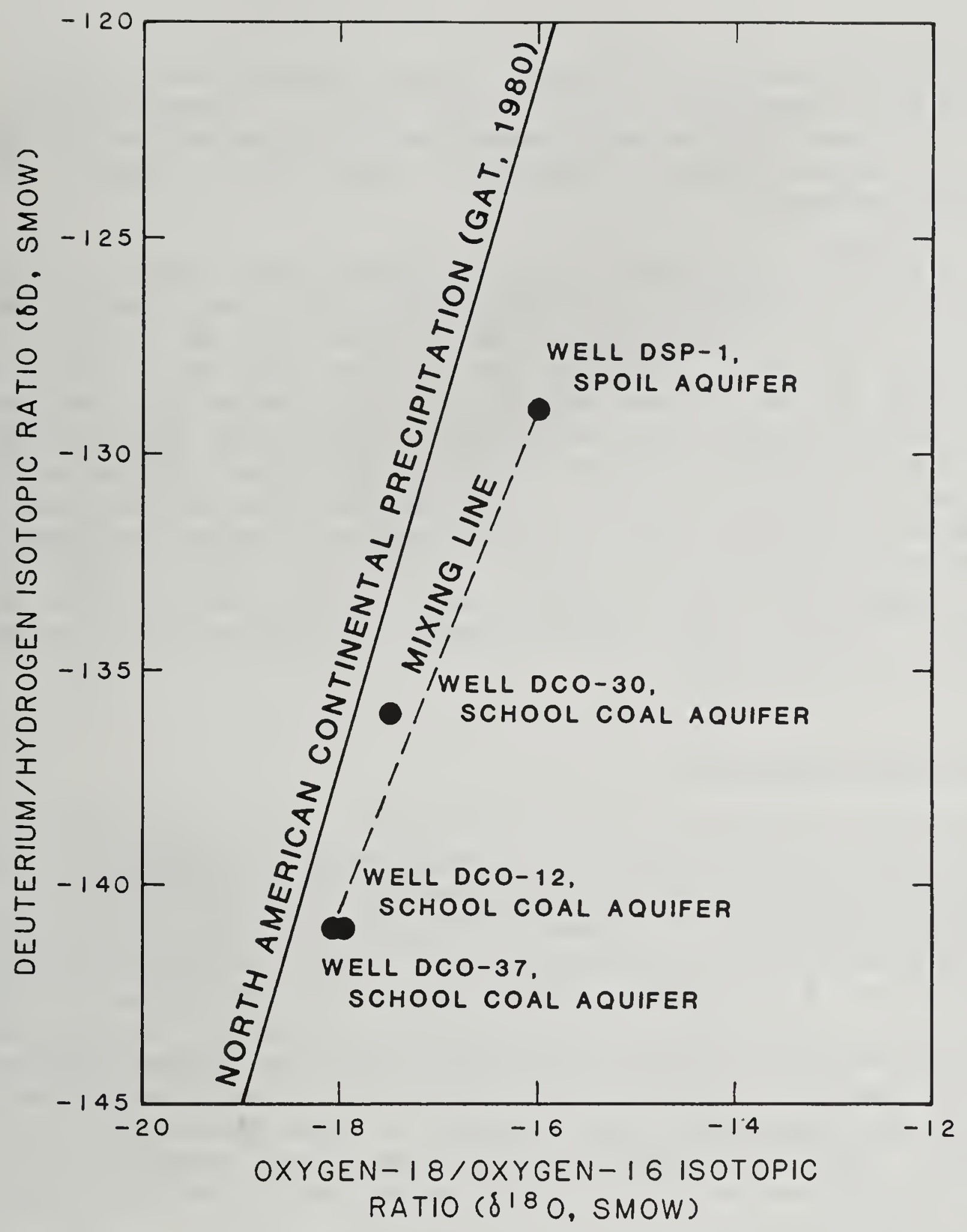

Figure 28.--Comparison of the isotopic composition of ground-water samples from the Dave Johnston Mine to the isotopic composition of North American continental precipitation. SMOW, standard mean ocean water. 
The $\delta^{18} 0$ values from ground-water samples coliected at the Dave Johnston Mine ranged from -18.1 to -16.0 per mil. Comparison of the range of $\delta^{18} 0$ values with the continental precipitation data of Yurtsever (1975) (fig. 29) indicates that recharge-water temperature was about $0{ }^{\circ} \mathrm{C}$, such as for spring snowmelt.

The tritium concentrations in ground-water samples from the Dave Johnston Mine decrease in a downgradient direction from the spoil aquifer (fig. 30). The tritium concentration in water from wells DSP-1 and DCO-30 was 92 and $21 \mathrm{pCi} / \mathrm{L}$, whereas the tritium concentration in water from wells DCO-37 and DCO-12 was less than $1 \mathrm{pCi} / \mathrm{L}$ (table 12). The tritium data coupled with the potentiometric surface of the School coal aquifer (fig. 27) indicate infiltration of recent precipitation as the dominant source of recharge to the spoil aquifer. Although the large tritium concentration in water from well DCO-30 indicates infiltration of recent recharge, the small tritium concentrations in water from wells DCO-37 and DCO-12, collected further downgradient in the School coal aquifer, indicate that substantial volumes of recent (post-1952) recharge water have not yet moved into this part of the coal aquifer.

\section{Mineral-water relations}

The water chemistry of the unsaturated zone was determined by personnel at the Dave Johnston Mine using pressure-vacuum lysimeters located in the unsaturated zone of the spoil aquifer at the mine (fig. 27). Specific conductance of the water collected from the lysimeters ranged from 3,400 to $3,900 \mu \mathrm{S} / \mathrm{cm}$ (table 13). The $\mathrm{pH}$ of water samples collected from lysimeter LY-SW-5-6 was 4.8 and that from lysimeter LY-SW-5-8 was 4.9 ( $\mathrm{fig} .27$ and table 13). Lysimeter-water samples with small pH values (lysimeters LY-SW-5-6 and LY-SW-5-8) also had large concentrations of aluminum, cadmium, copper, iron, manganese, nickel, selenium, and $z$ inc, compared to lysimeter-water samples with $\mathrm{pH}$ values of 8.1 and 7.7 (table 13). Water with small pH values and large concentrations of trace elements is characteristic of acid generation by pyrite oxidation (Drever, 1982, p. 62-63).

The quality of water from the saturated zone of the spoil aquifer effects (well DSP-1) also indicates the effects of pyrite oxidation in the unsaturated zone. The pH of water from well DSP-1 was 5.8; the concentration of dissolved iron was $2.0 \mathrm{mg} / \mathrm{L}$ and the concentration of dissolved manganese was $1.0 \mathrm{mg} / \mathrm{L}$.

The negative $\delta^{34} \mathrm{~S}$ compositinn of water from well DSP-1 ( -15.2 per mil) also indicates possible pyrite oxidation in the unsaturated zone. In general, the $\delta^{34} \mathrm{~S}$ of biogenic pyrite is depleted with respect to the standard and ranges from +4 to -35 per mil (Drever, 1982, p. 346); whereas the $\delta^{34} \mathrm{~S}$ of evaporite deposits (sulfate salts) is generally greater than 0 per mil. Therefore, if most of the sulfate contained in the water from well DSP-1 is derived from pyrite oxidation, a negative $\delta^{34} \mathrm{~S}$ value would be expected, assuming the effects of isotope fractionation by bacteria are negligible. 


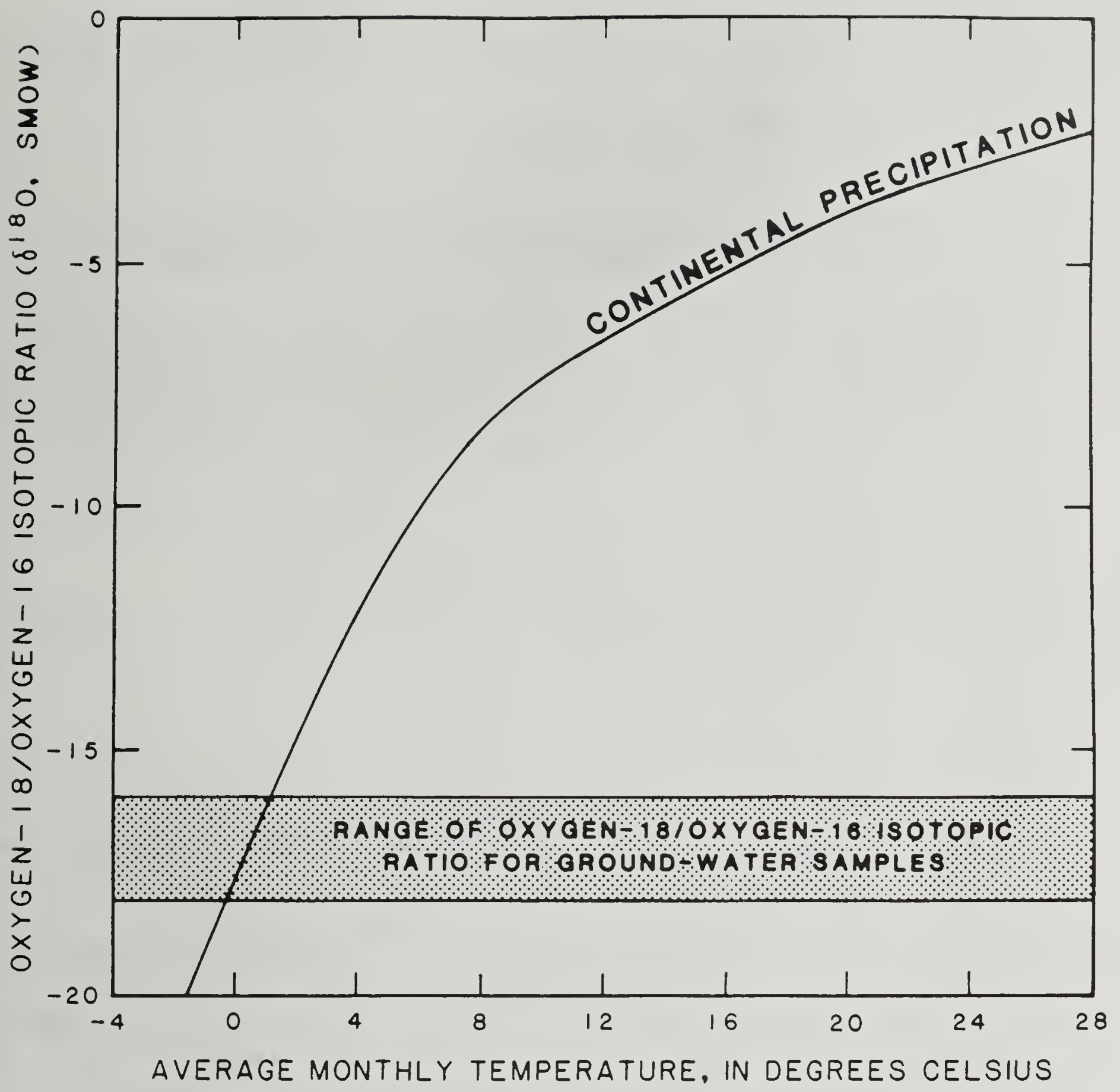

Figure 29.--Correlation of $\$ 180$ composition of continental precipitation compared to the average monthly temperature from continental stations (Yurtsever, 1975) superposed with the $\delta 180$ composition of ground-water samples from the Dave Johnston Mine. SMOW, standard mean ocean water. 


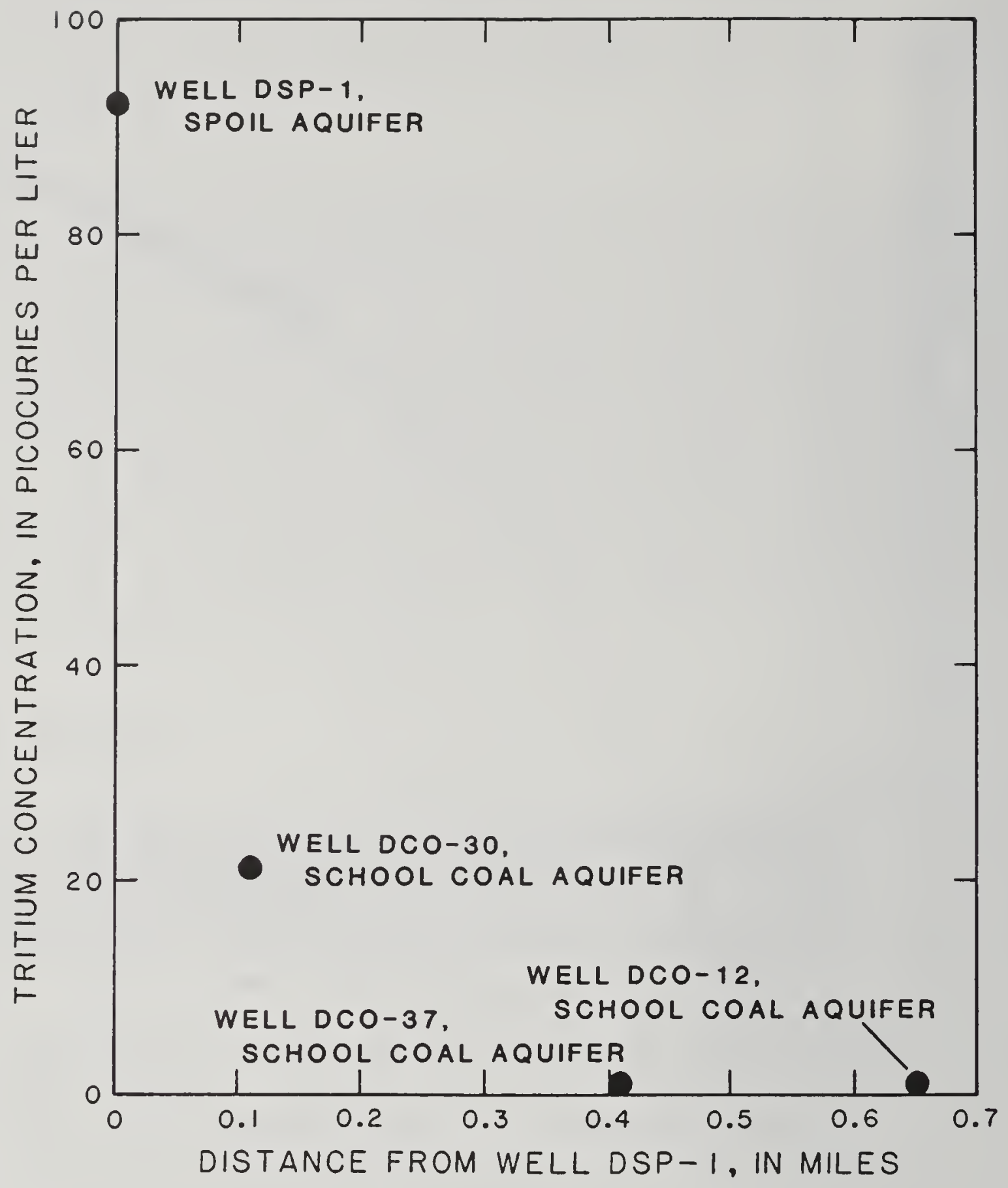

Figure 30.--Tritium concentration in ground-water samples in relation to the distance downgradient from well DSP-1 completed in the spoil aquifer, Dave Johnston Mine. 
Table 12.--Isotopic ratios or activities of isotopes in groundwater samples collected at Dave Johnston Mine

[ $\mathrm{SO}_{4^{2}}$, sulfate; $\delta^{10} 0$, oxygen-18/oxygen-16 isotopic ratio; $\delta D$, deuterium/hydrogen isotopic ratio; $\delta^{13} \mathrm{C}$, carbon-13/carbon-12 isotopic ratio; $\delta^{34} \mathrm{~S}$, sulfur-34/sulfur-32 isotopic ratio; $\mathrm{pCi} / \mathrm{L}$, picocuries per liter; <, indicates concentration less than detection limit for the analysis; --, data not available]

\begin{tabular}{lcccccc}
\hline Well & Source & $\begin{array}{c}\text { Oxygen } \\
\left(\delta^{18}\right)\end{array}$ & $\begin{array}{c}\text { Hydrogen } \\
(\delta \mathrm{D})\end{array}$ & $\begin{array}{c}\text { Carbon } \\
\left(\delta^{13} \mathrm{C}\right)\end{array}$ & $\begin{array}{c}\text { Sulfur, } \mathrm{SO}_{4}^{-2} \\
\left(\delta^{3} \mathrm{~S}\right)\end{array}$ & $\begin{array}{c}\text { Tritium } \\
(\mathrm{pC} / \mathrm{L})\end{array}$ \\
\hline DSP-1 & Spoil aquifer & -16.0 & -129 & -14.2 & -15.2 & 92 \\
DCO-30 & $\begin{array}{c}\text { School coal } \\
\text { aquifer }\end{array}$ & -17.5 & -136 & -15.4 & -2.8 & 21 \\
DC0-37 & $\begin{array}{c}\text { School coal } \\
\text { aquifer }\end{array}$ & -18.0 & -141 & 6.7 & 12.5 & $<1$ \\
DC0-12 & $\begin{array}{c}\text { School coal } \\
\text { aquifer }\end{array}$ & -18.1 & -141 & 9.1 & -- & $<1$ \\
\hline
\end{tabular}


Table 13.--Chemical analyses of water samples collected from pressurevacuum lysimeters at Dave Johnston Mine

[Concentrations in milligrams per liter unless noted otherwise; $\mu \mathrm{S} / \mathrm{cm}$, microsiemens per centimeter at 25 degrees Celsius; <, less than detection limit. Data from Dave Johnston Mine personnel, written commun., 1986]

\begin{tabular}{|c|c|c|c|c|}
\hline \multirow{2}{*}{$\begin{array}{l}\text { Chemical } \\
\text { property or } \\
\text { constituent }\end{array}$} & \multicolumn{4}{|c|}{ Lysimeter number } \\
\hline & $L Y-S W-4-4$ & $L Y-S W-4-8$ & $L Y-S W-5-6$ & LY-SW-5-8 \\
\hline \multicolumn{5}{|c|}{ Properties } \\
\hline $\begin{array}{l}\text { Specific } \\
\text { conductance } \\
(\mu S / \mathrm{cm})\end{array}$ & 3,400 & 3,400 & 3,810 & 3,900 \\
\hline $\mathrm{pH}$ (units) & 8.1 & 7.7 & 4.8 & 4.9 \\
\hline \multicolumn{5}{|c|}{ Major constituents } \\
\hline Calcium & 627 & 671 & 575 & 565 \\
\hline Magnesium & 203 & 204 & 276 & 296 \\
\hline Sodium & 90 & 63 & 77 & 85 \\
\hline Potassium & 12 & 7.4 & 44 & 41 \\
\hline Bicarbonate & 261 & 569 & 61 & 4 \\
\hline Sulfate & 2,230 & 2,040 & 2,170 & 2,230 \\
\hline Chloride & 75 & 61 & 65 & 75 \\
\hline Nitrite plus & .36 & 3.59 & 142 & 124 \\
\hline \multicolumn{5}{|c|}{ Trace constituents } \\
\hline Aluminum & 0.1 & $<0.1$ & 6.0 & 2.9 \\
\hline Arsenic & $<.005$ & .005 & $<.005$ & $<.005$ \\
\hline Barium & $<.5$ & $<.5$ & $<.5$ & $<.5$ \\
\hline Cadmium & $<.002$ & $<.002$ & .005 & .004 \\
\hline Chromium & .03 & .02 & $<.02$ & $<.02$ \\
\hline Copper & .03 & .02 & .05 & .04 \\
\hline Iron & $<.05$ & $<.05$ & .07 & .06 \\
\hline Lead & $<.02$ & $<.02$ & $<.02$ & $<.02$ \\
\hline Manganese & $<.02$ & .16 & 2.59 & 2.66 \\
\hline Mercury & .001 & $<.001$ & $<.001$ & $<.001$ \\
\hline Nickel & .07 & .08 & .52 & .32 \\
\hline Selenium & .01 & $<.005$ & .525 & .45 \\
\hline Zinc & .03 & $<.01$ & 2.17 & 3.15 \\
\hline
\end{tabular}


The dissolved-solids concentration in the spoil-aquifer water changes as it moves downgradient into the School coal aquifer (fig. 31). According to the $\delta^{18} 0$ and $\delta D$ isotope data for ground-water samples at the mine ( $\mathrm{fig} .28$ ), the water from well DCO-30 is possibly a mixture of 40 percent water from the spoil aquifer (well DSP-1) and 60 percent water from the School coal aquifer (wells DCO-37 and DCO-12). Mixing of the dissolvedsolids concentrations in water from the spoil aquifer (well DSP-1) and the School coal aquifer (well DCO-37) in the ratio of 40 to 60 approximates the dissolved-solids concentration in water from well DCO-30 ( $\mathrm{fig} .31$ ).

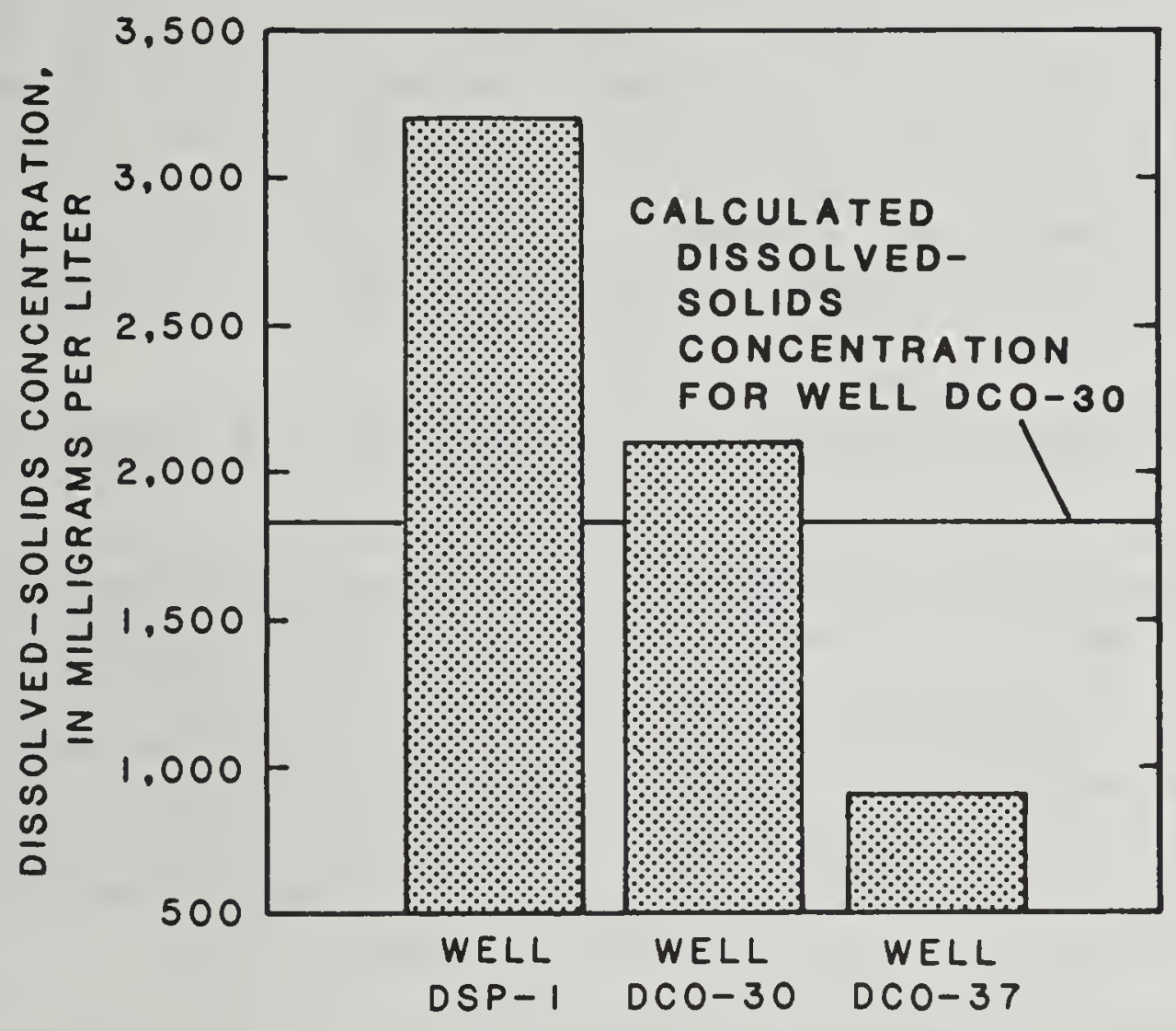

Figure 31.--Actual dissolved-solids concentrations in wells $D S P-1, D C O-30$, and $D C O-37$, and the calculated dissolved-solids concentration based on isotopic ratios for well DCO-30. 
On the basis of the geochemical information collected at the Dave Johnston Mine, insights into possible changes in offsite water quality can be gained for mines within the study area. Because of the mining method and hydrogeologic and geochemical conditions present at the Dave Johnston Mine, these insights may not apply to all the mines within the study area. Isotopic analyses of the water indicates movement of postmining ground water from the spoil aquifer into the adjacent School coal aquifer and $m i x i n g$ with water from the school coal aquifer resulting in a net increase in the dissolved-solids concentration in water from the School coal aquifer. Because only a finite quantity of soluble salt is available for leaching in the spoil material, this increase in dissolved-solids concentration in water within the School coal aquifer will probably be temporary. As the soluble salts continue to leach from the spoil material, future postmining water entering the School coal aquifer will decrease in dissolved-solids concentration until a postmining equilibrium condition is attained. Based on the lack of recent (post-1952) recharge in water from wells DCO-37 and DCO-12 (about 0.4 and $0.7 \mathrm{mi}$ downgradient from the spoil aquifer), movement of postmining water within the School coal aquifer will be slow, possibly minimizing the extent of water-quality degradation to offsite areas.

\section{Possible Offsite Water-Quality Changes in the Wyodak Coal Aquifer}

The larger concentrations of dissolved-solids in water from the spoil aquifers compared to concentrations in water from adjacent coal aquifers (table 4) indicates that deterioration of water quality may result from surface coal mining. A question that needs to be addressed is: "What are the possible water-quality changes that could occur as water from the spoil aquifer recharges a coal aquifer and begins to flow across the mine-permit boundary?" Davis and Dodge (1986) reported that water from a spoil aquifer that was mixed with coal during selected batch-mixing experiments had measurable decreases in dissolved-solids concentration.

The reaction-path geochemical model PHREEQE (Parkhurst and others, 1982b) was used to simulate possible water-quality changes that could occur under different sets of geochemical conditions as water with a large dissolved-solids concentration (spoil-aquifer water) recharges a coal aquifer with water having a chemical composition similar to water from well DCO-37 at the Dave Johnston Mine. Water from this well is a calcium bicarbonate type with a dissolved-solids concentration of $910 \mathrm{mg} / \mathrm{L}$.

In the reaction-path simulations, the composition of the spoil-aquifer water was simulated by: (1) Beginning with chemically pure water, (2) allowing unlimited quantities of oxygen to enter the system, (3) allowing unlimited time for reaction, (4) using a temperature of $20{ }^{\circ} \mathrm{C}$, and (5) allowing the weathering reactions to occur until the water was saturated with respect to gypsum, calcite, pyrite, goethite, and dolomite. The simulated spoil water had a dissolved-solids concentration of $3,540 \mathrm{mg} / \mathrm{L}$ and a dissolved-sulfate concentration of $2,160 \mathrm{mg} / \mathrm{L}$ ( $\mathrm{fig} .32$ ). The median dissolved-solids concentration in water analyses from spoil aquifers in the eastern Powder River basin was $3,680 \mathrm{mg} / \mathrm{L}$ (table 4 ). 
The reaction-path simulations did not include the effects of adsorption and cation exchange. Clay and organic matter within the spoil and coal aquifers could selectively remove specific chemical constituents. For example, if sodic clay is present within the spoil material, the calcium in the water derived from calcite dissolution will be partly removed from solution and exchanged for sodium on the clay. Removal of calcium from solution by ion exchange would increase the magnitude of calcite dissolution, which, in turn, would increase the sodium, bicarbonate, and dissolved-solids concentrations in the simulated spoil-aquifer water. This process can and does occur at coal mines within the study area.

The simulated chemical composition of the spoil-aquifer water was then subjected to four possible sets of chemical simulations that could occur during movement of spoil-aquifer water into a coal aquifer. Simulation 1 was based on the assumption that constant volume mixing of spoil-aquifer water with coal-aquifer water in a system where organic carbon within the coal aquifer is available for use by sulfate-reducing bacteria and that equilibrium is maintained between calcite, goethite, and amorphous ferrous sulfide. According to the stable-isotope data collected at the Dave Johnston Mine, water samples from the spoil and School coal aquifers indicate a large degree of mixing immediately downgradient from the interface between spoil and School coal aquifers ( $\mathrm{fig} .28$ ). Simulation 1 also was based on the assumption that the simulated composition of the spoil-aquifer water is mixed with water having the composition of water from well DCO-37, completed in the School coal aquifer, in a purely hypothetical ratio of 0.15 to 0.85 by volume. Four millimoles per liter of carbon with a valance of zero was added to the hypothetically mixed solution, while maintaining equilibrium with calcite, goethite, and amorphous ferrous sulfide. The composition of this ground water was saved and subjected to the same set of chemical reactions described previously. These reaction sets were repeated five times and are operationally defined as reaction increments.

The reaction constraints imposed on simulations 2,3 , and 4 were similar to those imposed on simulation 1. Simulation 2 had the same reaction constraints as simulation 1 except that dolomite equilibrium also was maintained. Simulation 3 had the same reaction constraints as simulation 1 except that goethite was not present for dissolution within the coal aquifer. Simulation 4 had the same reaction constraints as simulation 1 except the organic carbon within the coal aquifer was not available to sulfate-reducing bacteria and goethite was not available for dissolution. Drever (1982, p. 292) has noted that sulfate reduction in some coal aquifers is a slow process because the sulfate-reducing bacteria are incapable of utilizing the carbon compounds in the coal.

The simulated changes in water quality for the four different reaction simulations described previously are shown in figure 32. The decrease in calcium, sulfate, and dissolved-solids concentrations are largest for simulations 1 and 2. Simulations 1 and 2 had a carbon source that could be utilized by bacteria to reduce the sulfate to sulfide (table 10, reaction 2) and an iron source to provide iron for the formation of amorphous ferrous sulfide. 

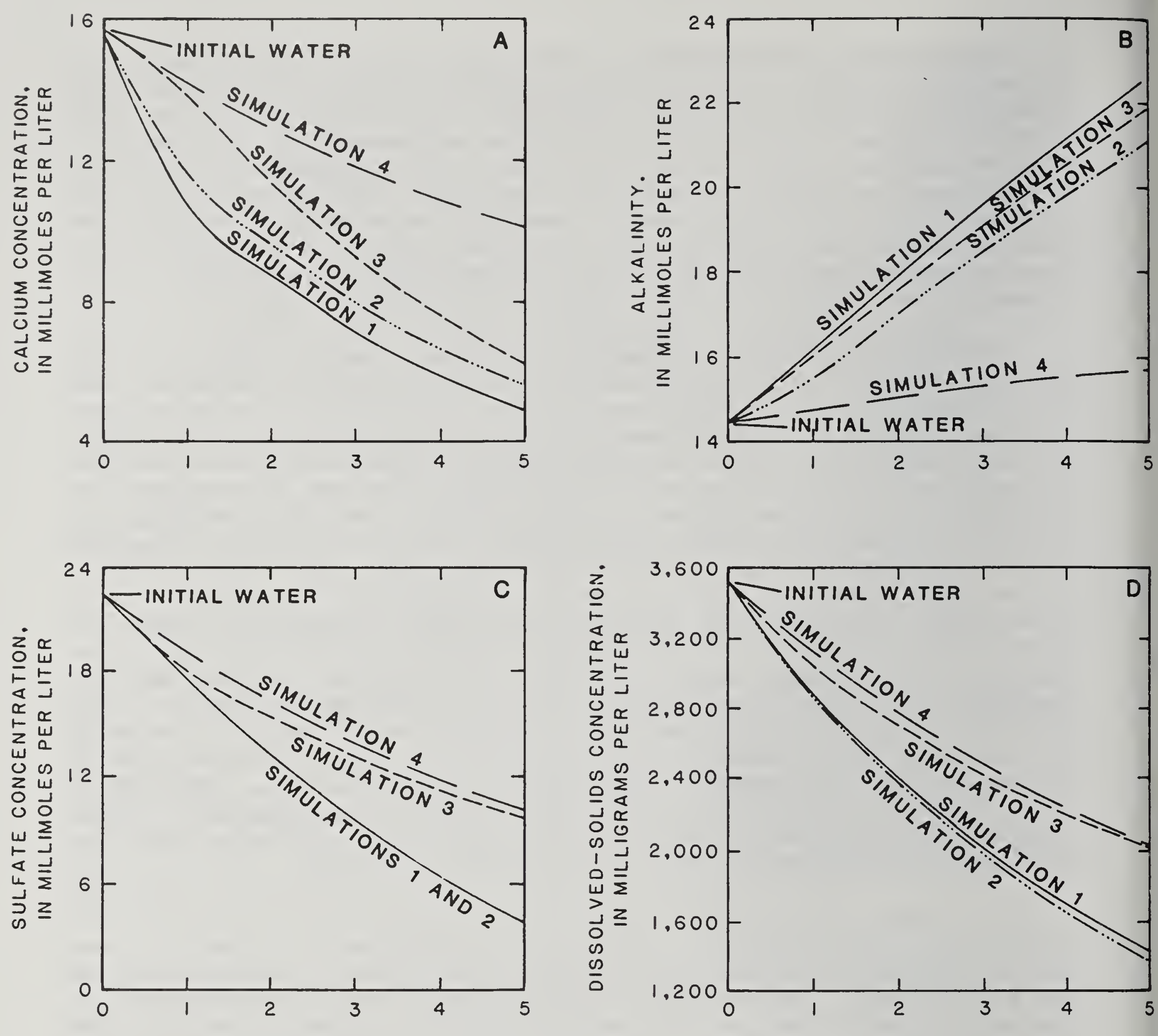

REACTION INCREMENT (DIMENSIONLESS)

Figure 32.--Changes in concentrations of calcium, alkalinity, sulfate, and dissolved-solids in relation to the reaction increments using the reaction-path geochemical model PHREEQE. 
Reaction simulations 3 and 4 do not indicate as large a decrease in calcium, sulfate, and dissolved-solids concentrations as reaction simulations 1 and 2 ( $\mathrm{fig}$. 32). Although a carbon source was provided in simulation 3, an iron source was not provided. The lack of an iron source for simulation 3 prevents the reduced sulfur generated from reaction 2 (table 10) to form as much amorphous ferrous sulfide as is formed in reaction simulations 1 and 2 , thereby preventing as much sulfate reduction as occurred in reaction simulations 1 and 2 . Less sulfate reduction in reaction simulation 3 results in a larger calcium concentration relative to reaction simulations 1 and 2 ( $\mathrm{fig} .32$ ) because smaller quantities of reduced carbon are being oxidized (table 10, reaction 2). Less carbon oxidation results in less carbonate precipitation (table 10, reaction 5). Because a reduced carbon source was not available in reaction simulation 4, sulfate reduction could not occur, resulting in only moderate decreases in dissolved-solids concentration as a function of reaction increment (fig. 32).

The results of the modeling exercise indicate the potential for improvements in postmining water quality as a postmining ground water with a large dissolved-solids concentration $(3,540 \mathrm{mg} / \mathrm{L})$ moves into a coal aquifer with relatively small dissolved-solids concentrations $(910 \mathrm{mg} / \mathrm{L})$. The modeling results are purely hypothetical; however, the results do indicate geochemical conditions that are most ideal for large decreases in dissolved-solids concentrations in coal aquifers receiving recharge from a spoil aquifer. According to the modeling results, a coal aquifer with the following geochemical conditions would be most ideal for large decreases in dissolved-solids concentrations:

1. Bacteria populations capable of reducing sulfate.

2. Organic-carbon sources that can be utilized by bacteria to facilitate sulfate reduction.

3. A source of iron that will facilitate the removal, by mineral precipitation, of the sulfide produced by sulfate reduction.

Geochemical condition 1, previously described, probably is operating within the study area. Based on indirect geochemical evidence, sulfatereducing bacteria probably are present in at least a few aquifers within the study area. Work done by Houghton and others (1985, p. 38) reported sulfate-reducing bacteria in lignite, sandstone, and spoil aquifers located in North Dakota. In the study by Houghton and others (1985), ground-water samples with detectable concentrations of sulfide and large concentrations of dissolved organic carbon (DOC) had the largest bacterial populations. Water samples from the coal aquifers at the Dave Johnston and Cordero Mines had detectable sulfide concentrations, and samples from the spoil aquifer at the Caballo Mine had DOC concentrations exceeding $250 \mathrm{mg} / \mathrm{L}$. As noted previously, the presence of these bacteria could decrease the dissolvedsolids concentrations in postmining ground water as it moves offsite. Additional study is needed to identify if geochemical conditions 2 and 3 are operating within the coal aquifers. 


\section{Impacts of Surface Coal Mining on Ground-Water Quality}

Surface coal mining will initially degrade ground-water quality in the areas of mining. In general, the chemical quality of current (1986) and future water from the spoil aquifers will meet the state standard for livestock. The primary chemical constituents that exceeded and might exceed the State standard for livestock in selected samples are dissolved solids, sulfate, nitrate, chromium, and selenium. Additional monitoring data are needed to determine if the concentrations of all constituents of concern (dissolved solids, sulfate, nitrate, chromium, and selenium) will decrease to and stabilize at concentrations 3 ess than the state standard for livestock. Assuming that the water quality in future spoil aquifers will be similar to the quality indicated by the water-quality data for the existing spoil aquifers, the increase in the number and extent of spoil aquifers resulting from future mining will expand the extent of the area where water quality currently (1986) is affected by surface coal mining. Smaller concentrations of dissolved solids, nitrate, and selenium in future postmining water were predicted by column-leaching-test results.

Dissolved-solids concentrations have not decreased substantially during the almost 4 years of record at the Cordero Mine ( $\mathrm{fig}$. 11); however, Houghton and others (1987, p. 62), on the basis of studies done in North Dakota, estimate that at lest 1 pore volume of water needs to leach the spoil material before the water would contain a dissolved-solids concentration similar to the premining dissolved-solids concentration. The time required to pass 1 pore volume of water through the spoil aquifer is greater than the time required for the postmining ground-water system to re-establish equilibrium. Current (1987) estimates of the time required for the postmining ground-water system to re-establish equilibrium varies from a few tens of years to hundreds of years.

During future reclamation at the Cordero Mine and at other mines with similar hydrogeologic and geochemical conditions, steps could be taken to minimize increases of dissolved-solids concentrations in postmining ground water. Isolation of overburden material with large soluble-salt contents to areas above the postmining ground-water table in conjunction with decreasing the rates of surface-water infiltration in the spoil aquifer could minimize future increases in dissolved-solids concentrations. In addition, isolation of spoil material with large soluble-salt contents from clay-rich and organic-rich strata during backfilling also could minimize increases in dissolved-solids concentrations in postmining ground water.

On the basis of the geochemical information collected at the Dave Johnston Mine, movement of postmining ground water from the spoil aquifer into the adjacent school coal aquifer initially resulted in a net increase in the dissolved-solids concentration in water from the School coal aquifer. Because only a finite quantity of soluble salt is available for leaching in the spoil material, this increase in dissolved-solids concentration in water within the School coal aquifer will probably be temporary. As the soluble salts continue to leach from the spoil material, future postmining water entering the school coal aquifer will decrease in dissolved-solids concentration until a postmining equilibrium condition is attained. 
According to geochemical modeling results, a coal aquifer with the following geochemical conditions would be most ideal for large decreases in dissolved-solids concentrations:

1. Bacteria populations capable of reducing sulfate.

2. Organic-carbon sources that can be utilized by bacteria to facilitate sulfate reduction.

3. A source of iron that will facilitate the removal, by mineral precipitation, of the sulfide produced by sulfate reduction.

Based on indirect geochemical evidence, sulfate-reducing bacteria probably are present in at least a few aquifers within the study area.

\section{SUREACE-WATER HYDROLOGY}

The purpose of the surface-water analysis is to determine the premining hydrologic characteristics and the cumulative impacts that surface coal mining will have on surface-water flow, quality, and sediment yield. Major streams draining the study area are described in the topography and drainage section of this report.

The location of streamflow-gaging stations operated by the U.S. Geological Survey and the coal-mining companies is shown on plate 4. Information, such as location and period of record, for stations operated by the Survey is listed in table 14; similar information for stations operated by the coal-mining companies is listed in table 33 in the Supplemental Data section. Records of streamflow and water quality collected in the study area by the Survey are published in a series of annual reports. They also may be retrieved through computerized data systems, WATSTORE, of the Survey. A summary of statistical analyses of streamflow data for Survey-operated stations has recently been prepared by Peterson (in press).

The streamflow and water-quality data collected by the coal-mining companies are submitted annually to the Wyoming Department of Environmental Quality, Land Quality Division. Several of the coal-mining companies have their own computerized file systems for storage and retrieval of their individual data; however, a centralized data system currently (1987) does not exist for compiling and analyzing the company data.

The list of company-operated stations in table 33 was compiled from mine-permit applications and annual reports on file with the Wyoming Department of Environmental Quality. In addition, each company was asked to provide a refined list of their surface-water data stations having highquality records. The intent of the compilation and refinement was to obtain an index of surface-water data stations operated by the coal-mining companies. Not all companies responded to the request; therefore, table 33 likely still contains some stations for which the records are of marginal value for assessing streamflow and water quality. 


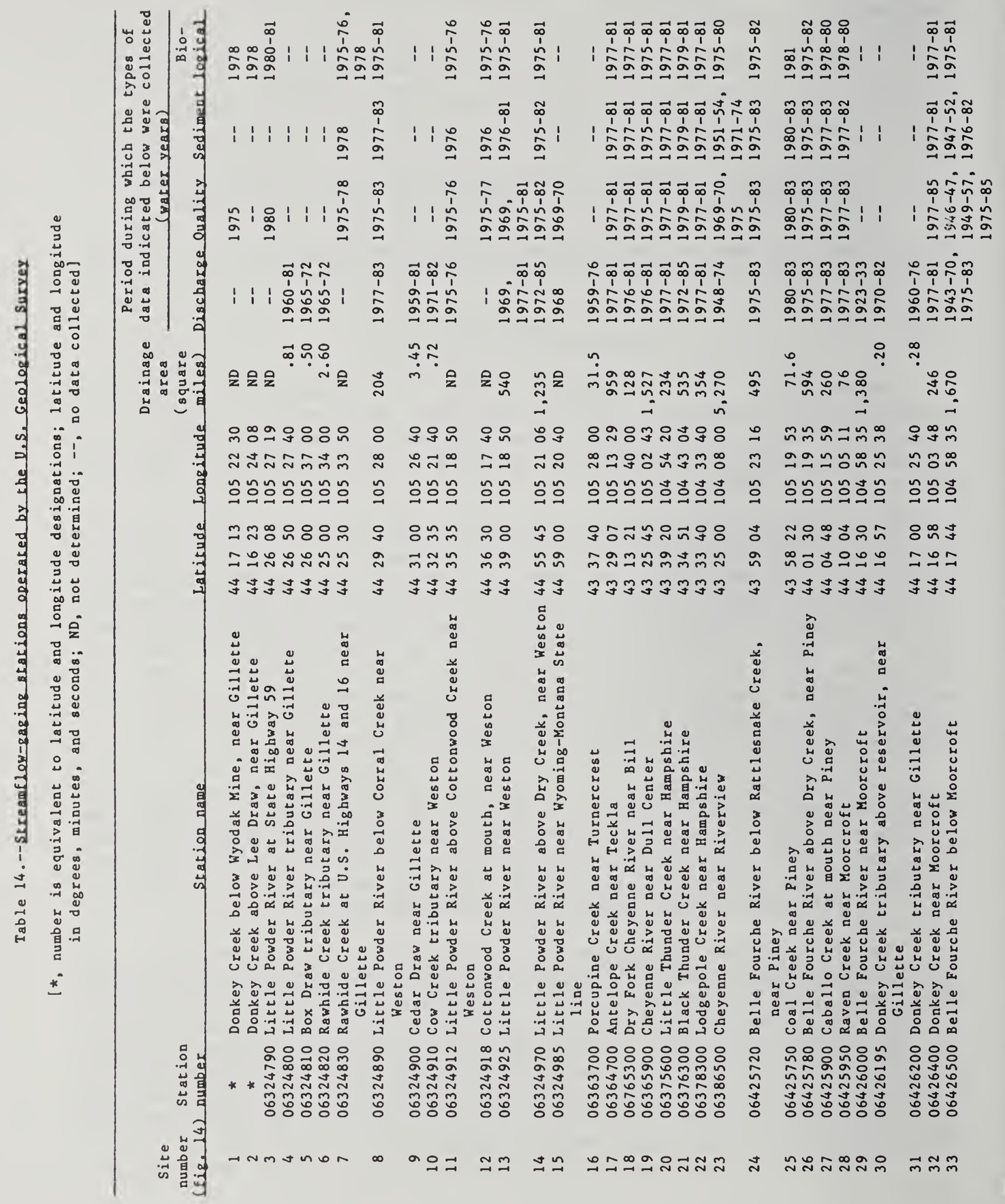


A large sample of the streamflow records for company-operated stations was reviewed for adequacy of data for hydrologic analysis. The streamflow records were both short and incomplete. Some streamflow-gaging stations were moved as mining and reclamation progressed. Periods of record during recorder malfunction were not estimated; therefore, an annual average-flow value could not be estimated and large discharges may not have been recorded. At most stations, streamflow measurements were not used to verify the stage-discharge ratings.

\section{Streamflow}

Three primary streamflow characteristics are considered in the analysis of cumulative hydrologic impacts: average runoff, peak flow, and low flow. These characteristics are a function of precipitation and infiltration of precipitation into the soil column. A change in infiltration will result in a direct or indirect change in all three streamflow characteristics.

Average runoff is the sum of annual average discharges for the period of the record divided by the number of years. At least 5 water years of record are preferred to estimate the average runoff. Seven streamflowgaging stations in the study area have sufficient length of record to compute average annual runoff. Streamflow-gaging stations, drainage area, period of record, average annual runoff in units of acre-feet and inches are listed in table 15. The location of these streamflow-gaging stations is shown in figure 33. Average annual precipitation for the study area is about $14 \mathrm{in.}$ The weighted mean annual runoff computed from the data in table 15 is 0.185 in.; 1.3 percent of the annual precipitation becomes runoff.

Floodflow of an undisturbed natural stream is a function of drainage area, basin slope, channel slope, maximum relief, infiltration, and precipitation. Relations for estimating peak flows for small natural streams in the study area were developed by Craig and Rankl (1978) as part of a report describing runoff from ephemeral streams. The relations are applicable for streams with drainage areas between 0.69 and $10.8 \mathrm{mi}^{2}$, basin slopes between 240 and $929 \mathrm{ft} / \mathrm{mi}$, channel slopes between 59 and $204 \mathrm{ft} / \mathrm{mi}$, and maximum basin relief between 173 and $752 \mathrm{ft}$. The following equations from Craig and Rankl (1978, p. 27) are used to estimate peak flow for selected recurrence intervals:

$$
\begin{aligned}
& Q_{2}=34.06 A^{1.134} S_{B}{ }^{1.216} R_{M}{ }^{-1.609} S_{10 / 85} 0.539 \\
& Q_{5}=30.77 A^{1.105} S_{B}{ }^{1.135} R_{M}{ }^{-1412} S_{10185} 0.580 \\
& Q_{10}=32.99 A^{1.094} S_{B}{ }^{1.000} R_{M}-1.300 S_{10105} 0.603
\end{aligned}
$$




$$
\begin{aligned}
& Q_{23}=37.73 A^{1.006} S_{B}{ }^{1.012} R_{M}{ }^{-1.192} S_{10105} 0.613 \\
& Q_{50}=43.88 A^{10004} S_{B}^{0.962} R_{M}{ }^{-1.118} S_{10105} 0.616 \\
& Q_{100}=50.25 A^{1.082} S_{B}^{0.914} R_{M}{ }^{-1.047} S_{10105^{0.615}}
\end{aligned}
$$

where $Q_{t}=$ annual peak flow, in cubic feet per second, with subscript $t$ designating the average recurrence interval, in years;

$A=$ contributing drainage area, in square miles;

$S_{B}=$ average basin slope, in feet per mile, obtained by measuring the lengths (in miles) of all contour lines within the drainage basin boundary, multiplying by the contour interval in feet, and dividing by the drainage area in square miles;

$R_{M}=$ maximum relief in the drainage basin, in feet, determined by taking the difference in elevation between the channel at the streamflow-gaging station and the highest point in the drainage basin; and

$S_{10 / 8 s}=$ main-channel slope in feet per mile, determined from the elevations at points 10 and 85 percent of the distance along the channel from the streamflow-gaging station to drainagebasin divide.

A typical basin and computations of basin characteristics and the 100-year peak flow are shown in figure. 34.

The estimating equations 5-10 were developed through an analys is of data collected for 8 years at 22 streamflow-gaging stations. The annual peak flow data were extended in time ( 73 years) using rainfall and runof modeling techniques.

In addition to the magnitude and frequency of floodflows, Craig and Rankl (1978) defined the magnitude and frequency of flood volumes in the plains and intermontane valleys of Wyoming. Flood volumes were related to drainage area, maximum relief, and basin slope. A dimensionless hydrograph was developed to provide a synthetic, single-peak hydrograph using peak and volume estimated from basin characteristics. Procedures for estimating the peak discharge and the associated runoff volume to compute the synthetic, single-peak hydrograph are described by Craig and Rankl (1978). 
Table 15.--Average annual runoff from drainage basins upstream from streamflow-gaging stations with more than 5 water years of record

[Site No., site number for streamflow-gaging station listed in table 14 and located on plate 4 and in figure 33]

\begin{tabular}{|c|c|c|c|c|c|}
\hline \multirow{2}{*}{$\begin{array}{l}\text { Site } \\
\text { No. }\end{array}$} & \multirow[b]{2}{*}{ Station name } & \multirow{2}{*}{$\begin{array}{l}\text { Drainage area } \\
\text { upstream from } \\
\text { gaging station } \\
\text { (square miles) }\end{array}$} & \multirow{2}{*}{$\begin{array}{l}\text { Period } \\
\text { of record } \\
\text { (water } \\
\text { years) }\end{array}$} & \multicolumn{2}{|c|}{ Annual runoff } \\
\hline & & & & (acre-feet) & (inches) \\
\hline 8 & $\begin{array}{l}\text { Little Powder River } \\
\text { below Corral Creek, } \\
\text { near Weston }\end{array}$ & 204 & $1977-83$ & 4,270 & 0.392 \\
\hline 14 & $\begin{array}{l}\text { Little Powder River } \\
\text { above Dry Creek, } \\
\text { near Weston }\end{array}$ & 1,235 & $1972-85$ & 16,520 & .251 \\
\hline 21 & $\begin{array}{c}\text { Black Thunder Creek } \\
\text { near Hampshire }\end{array}$ & 535 & $1972-85$ & 5,110 & .179 \\
\hline 24 & $\begin{array}{l}\text { Belle Fourche River } \\
\text { below Rattlesnake } \\
\text { Creek, near Piney }\end{array}$ & 495 & $1975-83$ & 1,820 & .069 \\
\hline 26 & $\begin{array}{l}\text { Belle Fourche River } \\
\text { above Dry Creek, } \\
\text { near Piney }\end{array}$ & 594 & $1975-83$ & 3,170 & .100 \\
\hline 27 & $\begin{array}{l}\text { Caballo Creek at } \\
\text { mouth, near Piney }\end{array}$ & 260 & $1977-83$ & 1,890 & .136 \\
\hline 33 & $\begin{array}{c}\text { Belle Fourche River } \\
\text { below Moorcroft }\end{array}$ & 1,670 & $\begin{array}{l}1943-70 \\
1975-83\end{array}$ & 16,590 & .186 \\
\hline
\end{tabular}




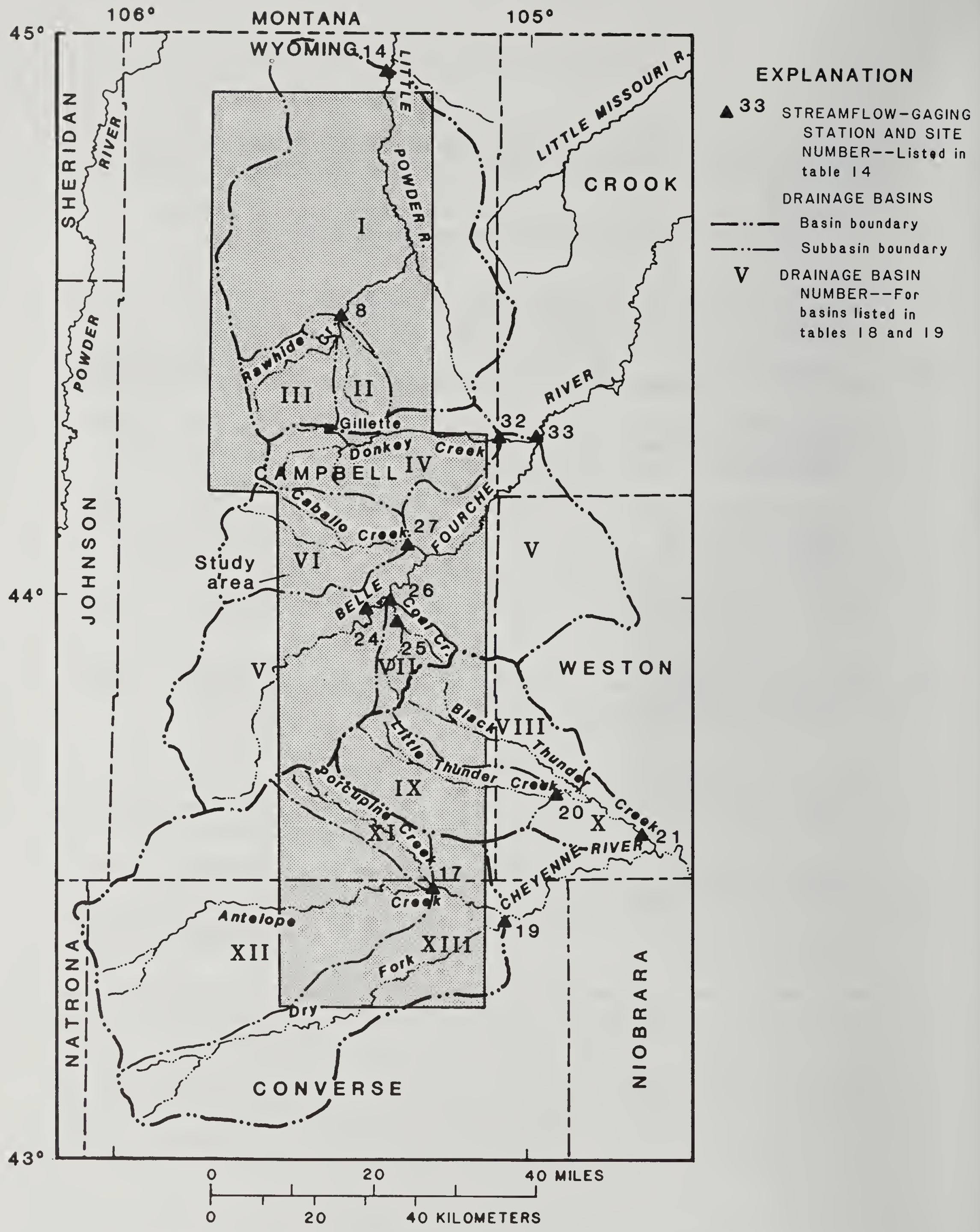

Figure 33.--Location of streamflow-gaging stations and drainage basins used in surface-water analyses. 


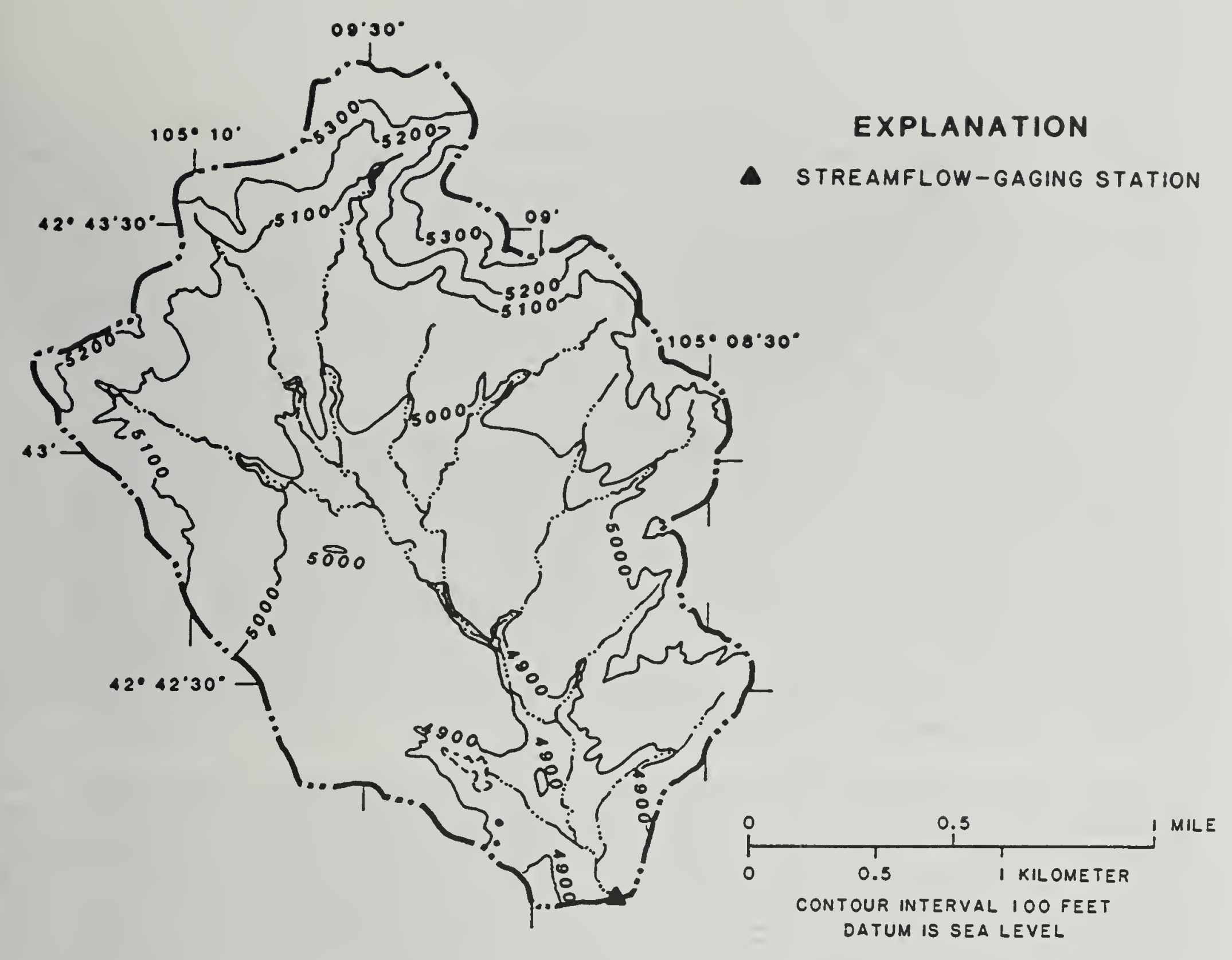

Area of drainage basin $(A)=2.12$ square miles

Total length of 100 -foot contour lines $(L)=14.9$ miles

Basin slope $\left(S_{B}\right)=\frac{L \times \text { Contour interval }}{A}=\frac{14.9 \times 100}{2.12}=703$ feet per mile

Maximum relief $\left(R_{M}\right)=$ Highest elevation in drainage basin - stream channel elevation at gage $=5,370-4,822=548$ feet

Stream channel slope $\left(S_{10 / 85}\right)=\frac{\text { Elevation }_{35}-\text { Elevation,o }_{10}}{\text { Distancess }_{3}-\text { Distance,。 }_{10}}$

$$
\left(S_{10,0 s}\right)=\frac{221}{2.05}=108 \text { feet per mile }
$$

Where the elevations are determined at points 10 and 85 percent of the distance along the stream channel from the streamflow-gaging station to the drainage-basin divide.

100-year peak flow $=Q_{100}=50.25 A^{1.082} S_{B}{ }^{0.914} R_{M}{ }^{-1.047} S_{10185^{0.615}}$

$$
Q_{100}=1,093 \text { cubic feet per second }
$$

Figure 34.--Typical drainage basin used for analysis of runoff and an example of runoff computation. 
Equations for estimating floodflows for basins between 10.8 and $5,270 \mathrm{mi}^{2}$ were developed by Lowham (1976). H.W. Lowham (U.S. Geological Survey, oral commun., 1987) currently (1987) is developing an updated set of equations using all peak flow data used in the earlier reports plus the data collected since 1976. Both the report by Craig and Rankl (1978) and the updated equations being developed by H.W. Lowham (oral commun., 1987) show drainage area and basin slope as the two most significant basin features affecting peak flows. Thus, the magnitude of peak flows in reclaimed basins will be affected to some extent by re-construction of these features.

Sustained low flows commonly are the result of discharge to stream channels from water stored in aquifers and natural surface reservoirs. Low flow of streams in the study area is the result of discharge from the alluvial and bedrock aquifers. Armentrout and Wilson (1987) analyzed streamflow-gaging-station records for streams in northeastern Wyoming, which includes the study area, and reported that the streams cease to flow for many days each year. Druse and others (1981), as part of a study of low flow and chemical quality of streams in the northern Great Plains area, measured low flows in 1978 to determine gain or loss in reaches of streams in this study area.

Only one station, Belle Fourche River below Moorcroft, had a record of sufficient length to compute probabilities of no flow (Armentrout and Wilson, 1987). During any 1 year, the probability of having 1 to 3 days of no flow is 90 percent. The probability of no flow is 87 percent for 7 days and 14 days. Flow in the Belle Fourche River is typical of the streams in the southern part of the study area. The Little Powder River, which has extensive alluvial deposits, has a small low flow of about $1 \mathrm{ft}^{3} / \mathrm{s}$ (cubic foot per second) and is dry only a few days each year (Rankl and Lowry, in press).

\section{Streamflow Quality}

Premining surface-water quality within and adjacent to the study area is described in detail by Lowry, Wilson, and others (1986, p. 56-87). Average dissolved-solids concentrations in most streams in the area exceed the national secondary standard for public water supplies of $500 \mathrm{mg} / \mathrm{L}$ established by the U.S. Environmental Protection Agency (1986b). Average alkalinity concentrations in streams at stations within the study area exceed $200 \mathrm{mg} / \mathrm{L}$. Based on data compiled by Larson (1986a, p. 62), all surface water in the study area had a $\mathrm{pH}$ greater than 6.0 .

Although selenium concentrations in excess of the national primary standard for public water supplies of $0.01 \mathrm{mg} / \mathrm{L}$ (U.S. Environmental Protection Agency, 1986a) have been reported in surface waters to the west of the study area (Larson, 1986c, p. 68), selenium and other trace-element concentrations in streams within the study area generally do not exceed national water-quality standards. Exceptions include selected surface-water samples within the study area that had iron and manganese concentrations exceeding the secondary standard for public water supplies (U.S. Environmental Protection Agency, 1986b). 


\section{Sediment Yield}

Daily records of sediment concentration and discharge have been collected by the U.S. Geological Survey at three streamflow-gaging stations in the study area; all are in the Belle Fourche River basin. Two of the stations are located about 7 river $\mathrm{mi}$ apart on the Belle Fourche River. These stations are located upstream and downstream from active mining, but the disturbed areas were small at the time data were collected. The third station is located on Coal Creek, a tributary flowing into the Belle Fourche River between the the two mainstem stations. Coal Creek accounts for almost three-fourths of the intervening drainage area between the two mainstem stations. The drainage area of the Belle Fourche River basin contributing to the flow at the upstream station is $495 \mathrm{mi}^{2}$ and at the downstream station it is $594 \mathrm{mi}^{2}$; the drainage area upstream from the station on Coal Creek is $71.8 \mathrm{mi}^{2}$. Data for the total sediment discharge (suspended and bedload) collected at the three streamflow-gaging stations are presented in table 16. The sediment samples were collected from the turbulent section of a weir by an automatic sampler. All sediment sampled was in suspension. Particlesize analyses of samples from all three stations indicate that all sediment is sand-size or smaller (less than 0.062 millimeter in diameter).

In 2 years, sufficient sediment samples were collected at Coal Creek near $P$ iney to define the total sediment load for 12 peak flows. A relation between peak discharge and total sediment load (Rankl, 1987) is being developed through a cooperative program between the Wyoming State Engineer and the U.S. Geological Survey. This relation is useful for estimating sediment loads for ephemeral streams where peak-flow-frequency data or methods of estimating peak-flow frequency are available. The peakdischarge/sediment-load relation for Coal Creek is applicable only for Coal Creek ( $\mathrm{fig}$. 35). Both peak discharge and sediment data are being collected at streamflow-gaging stations in and near the study area in order to define a regional relation.

Sediment data also have been collected by several of the coal-mining companies; for example, Antelope Coal Company has operated automatic sediment samplers at five sites. However, the records, especially for ephemeral streams, are limited to three or four peak flows, which provides insufficient data to determine the annual sediment yield or differences in sediment yield between natural and reclaimed drainages.

The sediment records collected for the Belle Fourche River basin are not of sufficient length for a statistical analysis, but general characteristics can be described. The median annual sediment discharge and sediment yield for the downstream streamflow-gaging station on the Belle Fourche River (site 26) is about eight times the sediment discharge and sediment yield at the upstream station (site 24), but the drainage area is only 20 percent larger. The increase in sediment yield appears to be attributable to Coal Creek (site 25), which flows into the Belle Fourche River about 1 river mi upstream from the downstream station (site 26). 
Table 16.--Sediment data for three sediment-sampling stations in the Belle Fourche River basin

$$
\text { [--, data not available] }
$$

\begin{tabular}{|c|c|c|c|}
\hline $\begin{array}{l}\text { Water } \\
\text { year }\end{array}$ & $\begin{array}{c}\text { Total sedimer } \\
\text { Belle Fourche River } \\
\text { below Rattlesnake } \\
\text { Creek, near Piney } \\
\text { (site 24) }\end{array}$ & $\begin{array}{l}\text { discharge ( } \\
\text { Coal Creek } \\
\text { near Piney } \\
\text { (site 25) }\end{array}$ & $\begin{array}{c}\text { ns per year) } \\
\text { Belle Fourche River } \\
\text { above Dry Creek, } \\
\text { near Piney } \\
\text { (site 26) }\end{array}$ \\
\hline 1977 & 80.4 & -- & 1,260 \\
\hline 1978 & 5,740 & -- & 58,500 \\
\hline 1979 & 522 & -- & 2,440 \\
\hline 1980 & 9.31 & -- & 36.6 \\
\hline 1981 & 49.4 & 5,030 & 3,850 \\
\hline 1982 & 409 & 1,820 & 3,460 \\
\hline 1983 & -- & -- & 228 \\
\hline $\begin{array}{l}\text { Median sediment } \\
\text { discharge (tons } \\
\text { per year) }\end{array}$ & 245 & 1 & 2,440 \\
\hline $\begin{array}{l}\text { Drainage area } \\
\text { (square miles) }\end{array}$ & 495 & 71.8 & 594 \\
\hline $\begin{array}{l}\text { Suspended sediment } \\
\text { yield (tons per } \\
\text { square mile } \\
\text { per year) }\end{array}$ & .5 & 1 & 4.1 \\
\hline
\end{tabular}
yield.

1 Insufficient record to calculate median sediment discharge and sediment 
A landsat image of the Belle Fourche River basin drainage shows that the Coal Creek drainage basin is dissected, steep-sloped, and subject to erosion. Large areas of Renohill clay loam and Renohill loam developed on land with slopes between 15 and 20 percent are present along the channels of East Fork Coal Creek and Middle Fork Coal Creek (Glassey and others, 1955, p. 40-41). Natural erosion of these soils provides a source for large sediment yields from the basin. The soils in the upstream part of the Belle Fourche River basin are primarily Ulm loam, which has developed on flatter terrain and contains a moderate quantity of well-decomposed humus (Glassey and others, 1955, p. 47). Soil erodibility and steep slopes in the Coal Creek drainage basin account for the large sediment yield from the basin.

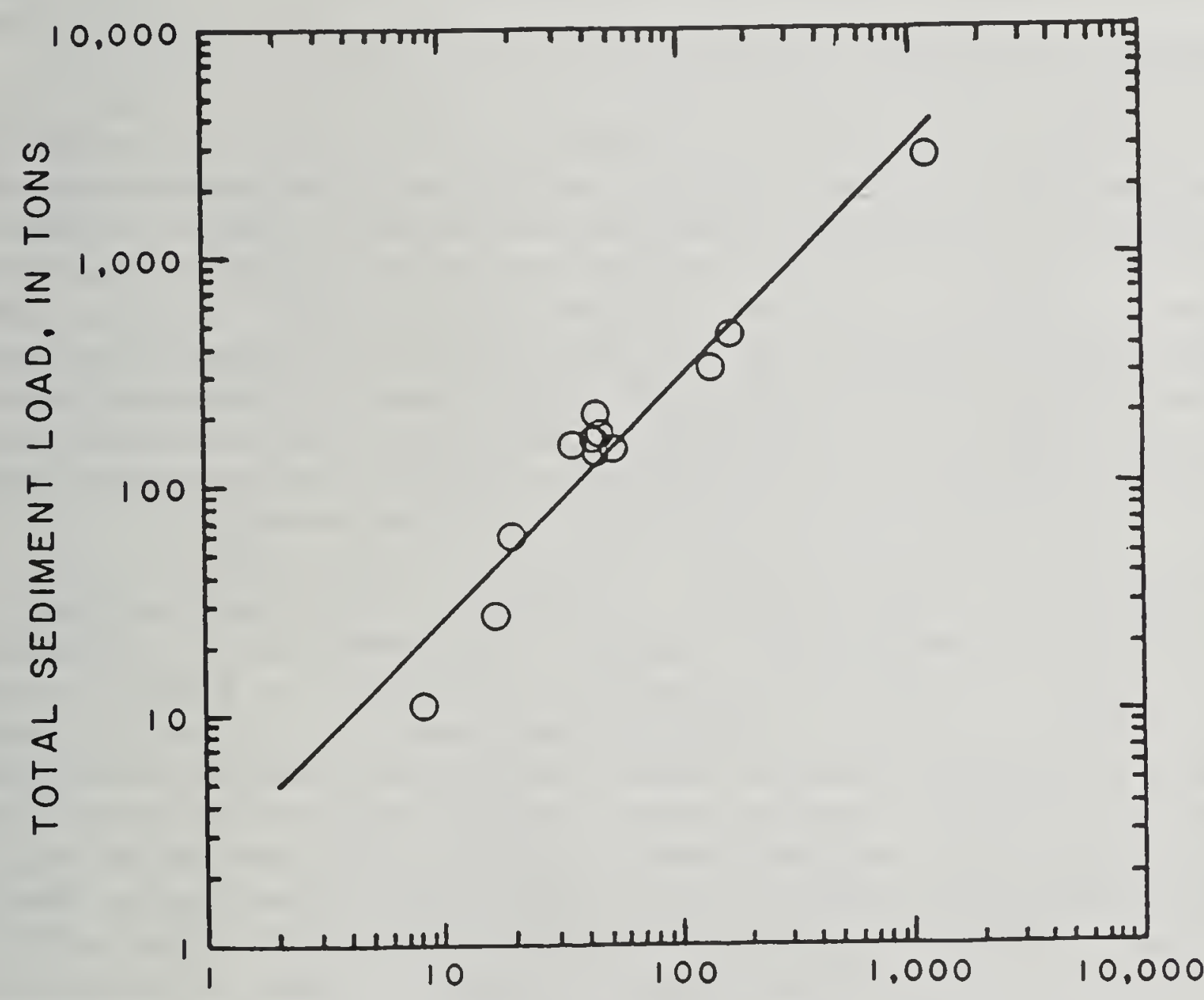

PEAK DISCHARGE, IN CUBIC FEET PER SECOND

Figure 35.--Relation of total sediment load to peak discharge for storm runoff, Coal Creek near Piney. 


\section{Water Rights}

The Wyoming Constitution declares that surface water within Wyoming is the property of the State (Wyoming Water Planning Program, 1972, p. 46). The Wyoming State Engineer's Office and the Wyoming Board of Control supervise the appropriation and distribution of surface water. Wyoming water laws establish the priority of adjudicated water rights on the basis of "first in time is first in right."

A listing of surface-water permits for an area including the lease areas and a 1-mi buffer from the lease boundaries was compiled in conjunction with the Wyoming State Engineer's Office. In 1987, there were permit records for 46 ditches, 2 enlargements, 292 reservoirs, and 158 stock reservoirs on file for the study area. Some unpermitted reservoirs may exist in the study area; these may decrease surface-water runoff. The location and identification of the permits are shown on plate 5 . A complete listing of the permit information is on file in the office of the U.S. Geological Survey in Cheyenne; this listing also may be obtained from the Wyoming State Engineer. A review of the permits indicates that many of the permits on the lease areas are for sediment-retention ponds constructed by the coal-mining companies.

\section{Impacts of Surface Coal Mining on Surface-Water Hydrology}

Evaluation of impacts of surface coal mining on streamflow and streamflow quality requires special sample collection and measurement techniques that can be used to detect or measure changes in quantity and quality of surface water. An evaluation can be made provided a change can be detected in the flow system. Using present (1987) technology, four general approaches are available: (1) Collection of streamflow quantity and quality data before, during, and after mining has been completed, (2) analysis of rainfall and runoff data, (3) analysis of rainfall-simulator tests, and, (4) analysis of the sensitivity of the flow system to changes in the system. Each approach has advantages and disadvantages.

Concurrent with the expansion of energy development, particularly surface coal mining during mid-1970's, a network of streamflow-gaging stations was established in the eastern Powder River basin by the U.S. Geological Survey to collect surface-water quantity and quality data. The stations were selected to collect data from natural streams with little or no impacts from surface coal mining, streams draining the coal mining and proposed mining areas, and streams draining the areas of oil-field development. Because of funding limitations, data collection at most of the stations ceased before a record of sufficient length for statistical analysis could be collected. However, several local changes of short duration, such as increased streamflow resulting from mine dewatering and increased nitrate concentrations, were noted (U.S. Geological Survey, 1980, p. 359-361). But the records were too short to establish cumulative, longterm trends. 
Three streamflow-gaging stations, Little Powder River above Dry Creek, near Weston (site 14), Black Thunder Creek near Hampshire (site 21), and Belle Fourche River below Moorcroft (site 33) have records before mining began until the present (1987). Although these stations are downstream from mines and should be useful for determining cumulative impacts, they were not established for that purpose and are too far downstream to detect even major changes in streamflow or streamflow quality.

Calibration of numerical models using rainfall and runoff data can be accomplished for small basins containing ephemeral streams (Craig and Rankl, 1978; Lowry and Rankl, 1987). Results from small-basin model studies provide information to evaluate site-specific hydrologic impacts, but cannot be used for cumulative impacts. Runoff in small ephemeral streams is periodic and cannot be summed to determine cumulative runoff; therefore, cumulative hydrologic impacts cannot be evaluated by numerical models using rainfall and runoff data from small basins. Large basins, the size required to evaluate cumulative hydrologic impacts by numerical models, seldom have a storm with precipitation that is widespread and areally uniform. The limited storm and runoff data do not provide the necessary information to accurately calibrate parameters used in a numerical model. The calibration of model parameters needs to be based on at least 3 years of record (Bloyd and others, 1986, p. 24).

Infiltration rates can be determined by two methods. First, infiltration rates can be computed from rainfall and runoff data; second, infiltration rates can be determined from the results of rainfall-simulator tests. However, the infiltration rates that are computed using these two methods do not provide comparable results.

Infiltration rates computed using rainfall and runoff data usually are slower than those computed using rainfall-simulator tests. The saturated hydraulic conductivity or the saturated infiltration rate determined from rainfall-runoff studies ranged from 0.02 in./h for clay soils to about $0.2 \mathrm{in./h}$ for sandy soils (Rankl, 1982). Saturated infiltration rates computed from rainfall and runoff model calibrations (Craig and Rankl, 1978, p. 15), ranged from 0.017 to $0.105 \mathrm{in.} / \mathrm{h}$. Equations used to compute infiltration for the rainfall and runoff studies account for the antecedant moisture conditions, in this case initially dry soil.

Rainfall-simulator tests performed on soils developed from the Cody Shale of Cretaceous age resulted in a computed infiltration rate of $0.61 \mathrm{in.} / \mathrm{h}$, which is about three times greater than that computed using rainfall and runoff data (J.G. Rankl, U.S. Geological Survey, oral commun., 1987). The tests were performed on dry soils in order to simulate soilmoisture conditions common in a semiarid climate.

Rainfall-simulator tests were performed on reclaimed mine soil at three mines in the eastern Powder River basin. The majority of the tests were performed in 1979, 1981, 1983, and 1984 at the Belle Ayr Mine, which is in the study area (Gifford, 1983; Hutten and Gifford, 1984). The soils were classified into three categories--heavy, medium, and light--except for the test in 1984. In order to determine that the results of infiltration studies at the Belle Ayr Mine were not totally due to the reclamation process used at that mine, infiltration studies conducted by Lusby and Toy 
(1976) at the Dave Johnston Mine in Converse County and at the Big Horn Mine near Sheridan in 1976 were included in this study. The rainfall-simulator tests were performed in pairs: natural soils and reclaimed soils. For all tests, the soil was prewetted in order to simulate a saturated soil-moisture content common to all tests. Information on the elapsed time between reclamation and the rainfall-simulator tests was not available. The tests for infiltration rates on reclaimed soils in 1979, 1981, and 1983 were conducted at the same 30 plots; therefore, the 1983 test was performed on reclaimed soils at least 4 years after reclamation. The elapsed time between reclamation and the 1984 rainfall-simulator tests was variable (Hutten and Gifford, 1984). A summary of the results is listed in table 17.

Differences between infiltration rates for natural soils and reclaimed soils may be masked by the variability of infiltration rates of soils and the variability of measuring infiltration rates. Statistical analysis of infiltration rates measured in 1984 at the Belle Ayr Mine indicates no significant differences between infiltration rates of natural and reclaimed soils (Hutten and Gifford, 1984). Although a significant difference in infiltration rates between natural and reclaimed soils cannot be established from the individual studies, a tendency of reclaimed soils to have infiltration rates that are slightly less than those for natural soils is indicated by the data in table 17. The weighted mean difference for all samples indicates that reclaimed soils have an infiltration rate of about 29 percent less than that for natural soils.

Infiltration rates for reclaimed soils probably will increase to or nearly to rates of infiltration for undisturbed soils. Little information is available on the time before infiltration rates increase to premining rates for soils in a semiarid climate, but some data are available for a study of grazing lands in Idaho (Gifford, 1982). That study, conducted during a 12-year period, indicated that a complete recovery of infiltration rates due to plowing would require at least 6 years. Grazing of the plowed lands would increase the time for recovery. Regardless that the infiltration rates increased on both the natural and reclaimed soils, the average percentage difference between infiltration rates for natural and reclaimed soils at the Belle Ayr Mine for 1979, 1981, and 1983 indicates a similar trend ( $f$ ig. 36).

\section{Streamflow}

For this study, the measured change in infiltration rates is the best measure of a change in average runoff. A change in infiltration rates does not have an inverse corresponding change in runoff, but on the average, the change in infiltration rates is a good index of the change in runoff. Runoff is a function of total storm precipitation, storm intensity, natural storage, land slope, evaporation, and infiltration. Runoff will be least changed by changes in infiltration for short-duration storms with intense precipitation and most changed by changes in infiltration for long-duration storms with less intense precipitation. For this study, the runoff from reclaimed mine areas was assumed to be 29 percent greater than that from unmined areas, due to the average 29-percent decrease in infiltration rate for reclaimed soils. 
Table 17.--Summary of rainfall-simulator tests comparing infiltration rates for natural and reclaimed soils

[DJ, Dave Johnson Mine; BH, Big Horn Mine; BA, Belle Ayr Mine]

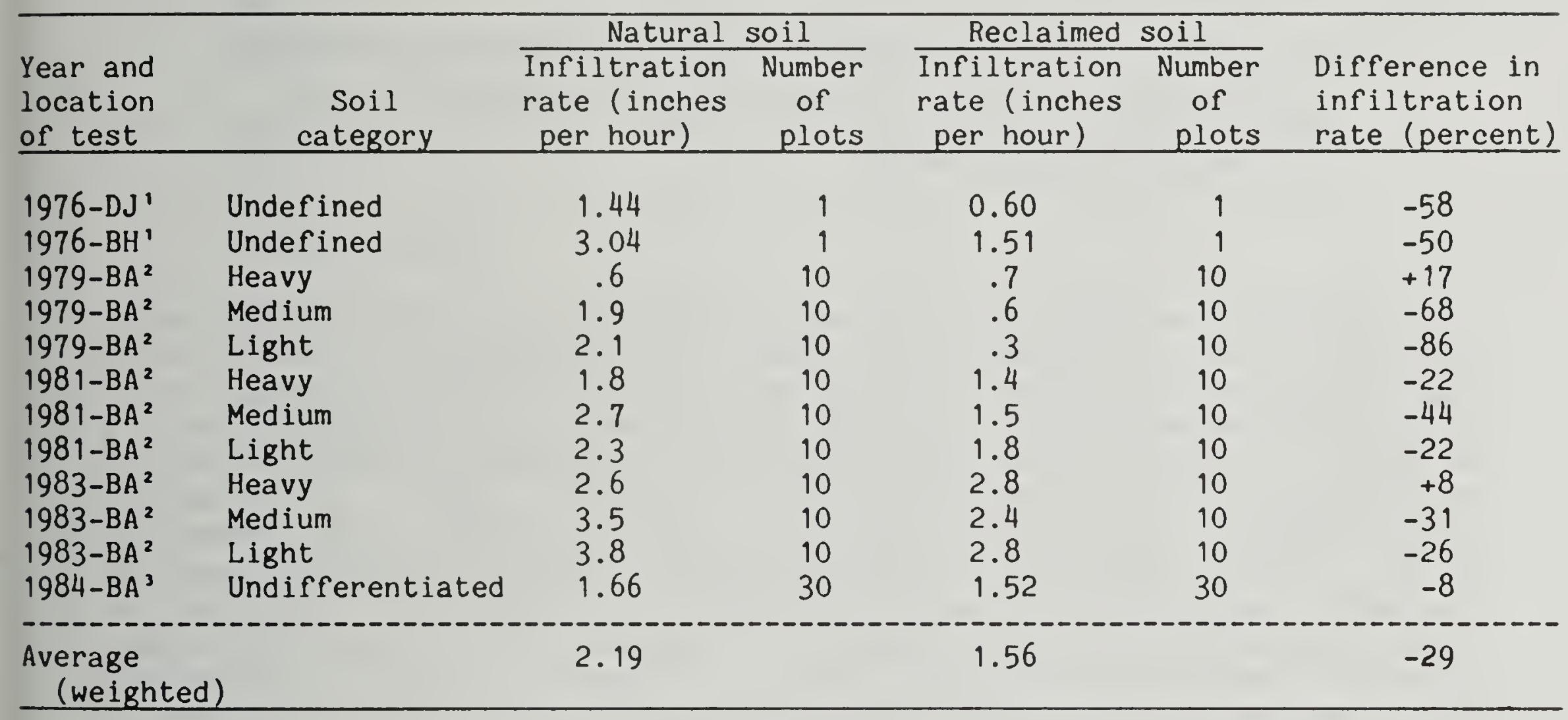

- From Lusby and Toy (1976, p. 381)

2 From Gifford (1983)

3 From Hutten and Gifford (1984, p. 24-25) 


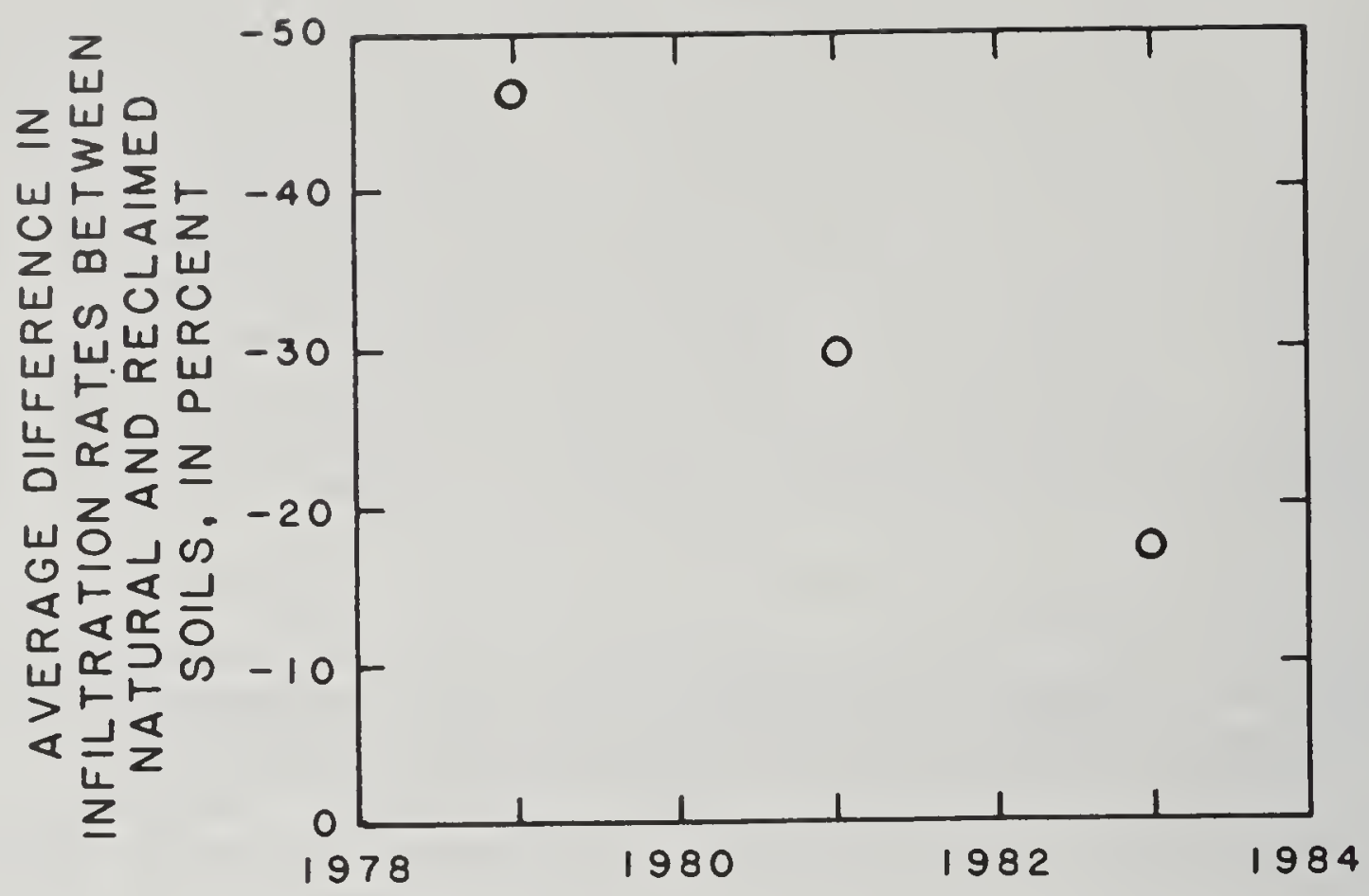

\section{Figure 36.--Average percentage difference between infiltration rates for natural and reclaimed soils at the Belle Ayr Mine.}

Projected maximum areas to be disturbed during mining, which were obtained from the Wyoming Department of Environmental Quality, were digitized; disturbed areas (mine pits and reclaimed areas) were computed for each major drainage basin. Drainage basins used in this study were jointly selected by hydrologists from the Wyoming Department of Environmental Quality and the U.S. Geological Survey. The criteria used for the selection of the basins was the proximity of mining and the availability of streamflow data. If the location of a streamflow-gaging station is near the mouth of the basin, the station is used for the point of reference; otherwise the point of reference is the mouth of the basin. The projected maximum disturbed areas are shown on plate 4. A summary of projected maximum disturbed areas in the major drainage basins (fig. 33) in the study area is listed in table 18.

A sensitivity analysis was made for theoretical changes in flow for Black Thunder Creek near Hampshire. An assumption was made that flow from the disturbed area of the basin $\left(32.2 \mathrm{mi}^{2}\right)$ both increased and decreased by 10,30 , and 50 percent. The cumulative change was computed in a downstream direction with an increasing drainage area to determine the effective change in flow in relation to the natural flow. If a statistical analysis were performed on the flow data before and after mining for a drainage area of $300 \mathrm{mi}^{2}$ with a 50-percent change in runoff from the mined areas, a significant difference could not be determined because the change in flow would be less than the measurement accuracy and the annual variability of flow. The sensitivity analysis is presented in graphical form in figure 37. 
Table 18.--Projected maximum areas of drainage basins to be disturbed during mining of selected existing and proposed mines, and increases in runoff in major drainage basins

\begin{tabular}{|c|c|c|c|c|c|c|}
\hline \multirow{2}{*}{$\begin{array}{c}\text { Drainage } \\
\text { basin } \\
\text { number } \\
\text { (rig. 33) } \\
\end{array}$} & \multirow[b]{2}{*}{ Drainage basin } & \multirow{2}{*}{$\begin{array}{l}\text { Drainage } \\
\text { area } \\
\text { (square } \\
\text { miles) } \\
\end{array}$} & \multirow[t]{2}{*}{$\begin{array}{l}\text { Projected } \\
\text { maximum area } \\
\text { of drainage } \\
\text { basin to be } \\
\text { disturbed } \\
\text { by mining } \\
\text { (square miles) }\end{array}$} & \multirow{2}{*}{$\begin{array}{l}\text { Percentage } \\
\text { of drainage } \\
\text { area to be } \\
\text { disturbed } \\
\text { by mining }\end{array}$} & \multicolumn{2}{|c|}{$\begin{array}{c}\text { Increase in runoff } \\
\text { resulting from } \\
\text { areas disturbed } \\
\text { by mining }\end{array}$} \\
\hline & & & & & Inches & Percent \\
\hline I & $\begin{array}{l}\text { Little Powder River } \\
\text { above Dry Creek, } \\
\text { near Weston' } 2\end{array}$ & 1,235 & 25.1 & 2.0 & 0.0011 & 0.6 \\
\hline II & $\begin{array}{l}\text { Little Powder River } \\
\text { below Corral Creek, } \\
\text { near Weston' } 2\end{array}$ & 204 & 25.1 & 12.3 & .0066 & 3.6 \\
\hline II I & $\begin{array}{l}\text { Rawhide Creek at } \\
\text { confluence with } \\
\text { Little Powder River }\end{array}$ & 120 & 13.6 & 11.3 & .0061 & 3.3 \\
\hline IV & $\begin{array}{l}\text { Donkey Creek near } \\
\text { Moorcroft }\end{array}$ & 246 & 6.02 & 2.4 & .0013 & .7 \\
\hline v & $\begin{array}{l}\text { Belle Fourche River } \\
\text { below Moorcroft }{ }^{3}\end{array}$ & 1,670 & 57.7 & 3.5 & .0018 & 1.0 \\
\hline VI & $\begin{array}{l}\text { Caballo Creek at } \\
\text { mouth, near Piney' }\end{array}$ & 260 & 29.3 & 11.3 & .0061 & 3.3 \\
\hline VII & $\begin{array}{l}\text { Coal Creek at } \\
\text { confluence with } \\
\text { Belle Fourche River }\end{array}$ & 74.7 & 11.1 & 14.9 & .0080 & 4.3 \\
\hline VIII & $\begin{array}{l}\text { Black Thunder Creek at } \\
\text { confluence with } \\
\text { Little Thunder Creek }\end{array}$ & 217 & 9.19 & 4.2 & .0023 & 1.2 \\
\hline IX & $\begin{array}{c}\text { Little Thunder Creek } \\
\text { near Hampshire' }\end{array}$ & 234 & 23.0 & 9.8 & .0053 & 2.9 \\
\hline$x$ & $\begin{array}{c}\text { Black Thunder Creek } \\
\text { near Hampshire' }\end{array}$ & 535 & 32.2 & 6.0 & .0032 & 1.7 \\
\hline$X I$ & $\begin{array}{l}\text { Porcupine Creek } \\
\text { at confluence with } \\
\text { Antelope Creek }\end{array}$ & 139 & 9.75 & 7.0 & .0038 & 2.0 \\
\hline$X I I$ & $\begin{array}{c}\text { Antelope Creek } \\
\text { near Teckla' }\end{array}$ & 959 & 18.2 & 1.9 & .0010 & .6 \\
\hline$X I I I$ & $\begin{array}{l}\text { Cheyenne River near } \\
\text { Dull Center' }\end{array}$ & 1,527 & 20.0 & 1.3 & .001 & .4 \\
\hline
\end{tabular}

- Drainage area upstream from streamflow-gaging station

2 Includes the drainage and disturbed areas of Rawhide Creek

- Includes the drainage and disturbed areas of Donkey Creek, Coal Creek and Caballo Creek

- Includes the drainage and disturbed areas of Little Thunder Creek

- Includes the drainage and disturbed areas of Porcupine Creek

- Includes the drainage and disturbed areas of Porcupine and Antelope Creek 


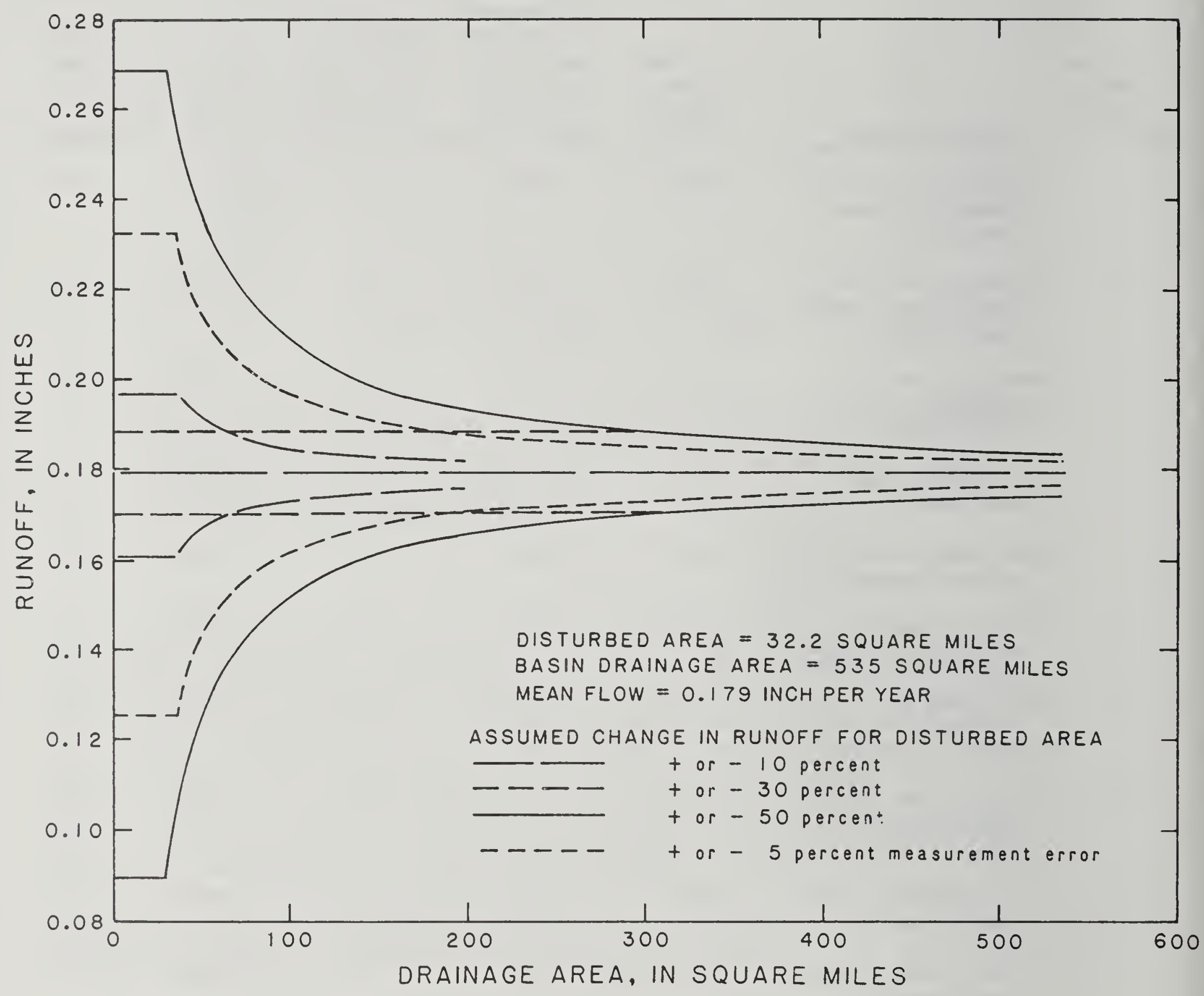

Figure 37.--Sensitivity analysis for hypothetical changes in runoff in Black Thunder Creek. 
Black Thunder Creek (site 21) was used in the analysis because the streamflow-gaging station (site 21) on Black Thunder Creek has 13 years of streamflow record, the basin has a large projected maximum disturbed area, and the disturbed areas are located at the headwaters of the drainage basin. From the analysis, changes in quantity and quality could not be detected at the streamflow-gaging station located at the mouth of the basin (site 21).

An analysis of increase in runoff was made for each drainage basin listed in table 18. A 29-percent increase in runoff was assumed for all projected maximum disturbed areas. A weighted mean runoff value of $0.185 \mathrm{in}$. was computed using the runoff data listed in table 15. The runoff data were weighted using drainage area. The mean runoff value was used to compute increases in runoff and percentage changes in runoff for each of the drainage basins. The following equations were used to compute the increase in runoff:

$$
I R=\left|\frac{(D I S A * 0.185 * 1.29)+((D A-D I S A) * 0.185)}{D A}\right|-0.185
$$

and

$$
P C R=(C I R / 0.185) * 100
$$

where $I R=$ increase in runoff, in inches;

$$
\begin{aligned}
\text { DISA } & =\text { disturbed area, in square miles; } \\
D A & =\text { drainage area, in square miles; and } \\
P C R & =\text { change in runoff, in percent. }
\end{aligned}
$$

For each drainage basin, the computed increase in runof $f$ and the percentage change in runoff is listed in table 18. The percentage change in runoff for all of the basins would be less than 5 percent, which is less than the accuracy of most streamflow records (Druse and others, 1987, p. 15).

Runoff from Coal Creek, which occurred on May 27 and 28, 1981, was used to demonstrate the effect that the projected maximum disturbed area in the Coal Creek basin would have on runoff from an individual storm. The data used in the analysis were collected at the streamflow-gaging station, Coal Creek near Piney (site 25), which has a drainage area of $71.6 \mathrm{mi}^{2}$. The peak discharge was 1,170 $\mathrm{ft}^{3} / \mathrm{s}$, and the volume was 512 acre-ft. The increase in flow due to the disturbed area was computed as 4.5 percent. Because flow data are not available at the mouth of Coal Creek, the analysis was done on data collected at the streamflow-gaging station. 
The analysis was accomplished in two steps. First, a mean dimensionless hydrograph (Craig and Rankl, 1978, p. 44-55) was used to produce a synthetic hydrograph. The synthetic hydrograph was nearly identical to the hydrograph of flow in Coal Creek except that the synthetic hydrograph was offset by 1 hour (fig. 38-A). Second, the volume of runoff was increased by 4.5 percent, from 512 acre-ft to 535 acre-ft. The increased value of runoff was used to compute a new synthetic hydrograph. The two synthetic hydrographs are compared in figure 38-B. The peak discharge of $1,170 \mathrm{ft}^{3} / \mathrm{s}$ was used to compute both synthetic hydrographs.

The Coal Creek drainage basin has the largest percentage of projected maximum areas to be disturbed by existing and proposed mining in the study area; therefore, changes in flow for individual storms for other basins in the study area would not be discernable.

Selected Coal Tracts and areas with Preference Right Lease Applications (pl. 1) were digitized and added to the projected maximum disturbed areas (pl. 4) for each of the drainage basins listed in table 18. Because mine plans were not available for the Selected Coal Tracts and the Preference Right Lease Applications areas shown on plate 1, the areas were considered disturbed. All of the disturbed areas were summed to determine a worst-case condition for the computation of runoff. A 29-percent increase in runoff was assumed for disturbed areas for all anticipated mining without the increased runoff decreasing to premining rates. The equations used to compute increases in runoff for the projected maximum areas disturbed by existing and proposed mines were used for the worst-case study. The results of the worst-case surface-water analyses for disturbed areas for all anticipated mining are presented in table 19.

Runoff in two drainage basins, Coal Creek and Little Thunder Creek, would increase by more than 5 percent for the worst-case analysis. If data were available to compute a 6-year recovery of infiltration rates for the entire disturbed area, all increases in runoff would be less than 5 percent.

\section{Streamflow Quality}

The possible impacts of mining on the streamflow quality in the eastern Powder River basin was assessed by Bloyd and others (1986, p. 33-41) using a computer model of the Belle Fourche River basin. Impacts of surface mining on streamflow quality in other basins will depend on climate, geologic and soil characteristics, vegetation, and streamflow, and those impacts may, therefore, be different in other basins than in Belle Fourche. After calibration and verification, the model was used to calculate the changes in dissolved-solids and sulfate concentrations that might result from mining. Two sets of measured and estimated rainfall and evaporation data were used for the modeling. The first set of data was for May and June 1980, a period of slightly less than average rainfall (rainfall A), and second set of data was for May and June 1982, a period of greater than average rainfall ( $r a i n f a l l B)$. Increases in average dissolved-solids and sulfate concentrations using rainfall A ranged from 1 to 7 percent from premining to postmining conditions. The simulated dissolved-solids and sulfate concentrations for flows exceeding $1.0 \mathrm{ft}^{3} / \mathrm{s}$ decreased by as much as 49 percent from premining to postmining conditions using rainfall $\mathrm{B}$. 

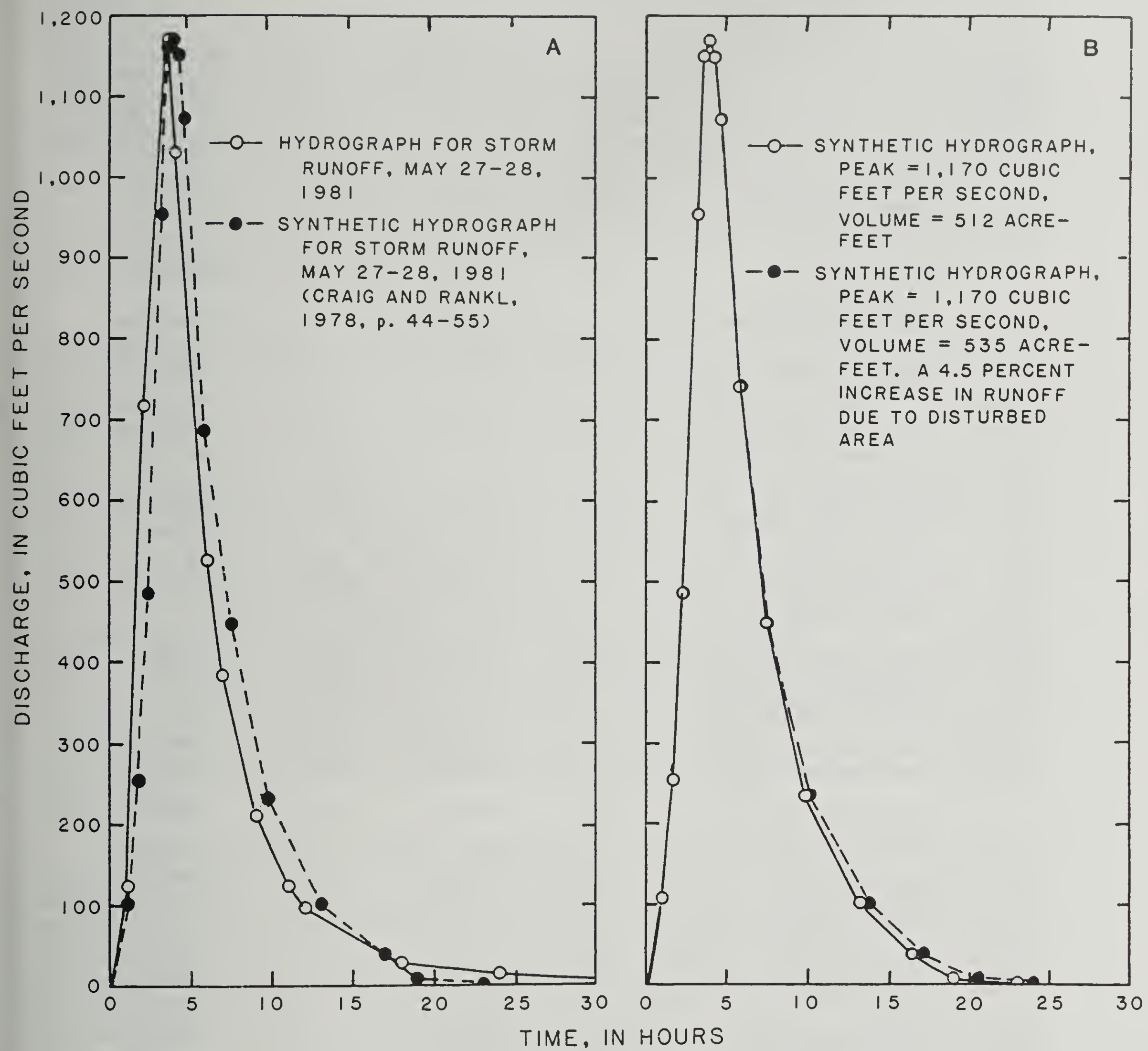

Figure 38.--Analysis of runoff and change in runoff for storm of May 27-28, 1981, Coal Creek near Piney. 
Table 19.--projected maximum areas of drainage basins to be disturbed during all anticlpated mining and increases in runoff in major drainage basins

\begin{tabular}{|c|c|c|c|c|c|c|}
\hline \multirow{2}{*}{$\begin{array}{c}\text { Dra Inage } \\
\text { basin } \\
\text { number } \\
(\text { fig. } 33) \\
\end{array}$} & \multirow[b]{2}{*}{ Drainag? bas in } & \multirow{2}{*}{$\begin{array}{c}\text { Dralnage } \\
\text { area } \\
\text { (square } \\
\text { miles) } \\
\end{array}$} & \multirow{2}{*}{$\begin{array}{l}\text { Projected max- } \\
\text { imum area of } \\
\text { drainage basin } \\
\text { to be disturbed } \\
\text { by mining } \\
\text { (square miles) }\end{array}$} & \multirow{2}{*}{$\begin{array}{l}\text { Percentage } \\
\text { of drainage } \\
\text { area to be } \\
\text { disturbed } \\
\text { by mining } \\
\end{array}$} & \multicolumn{2}{|c|}{$\begin{array}{l}\text { Increase in runoff } \\
\text { resulting from } \\
\text { areas disturbed } \\
\text { by mining }\end{array}$} \\
\hline & & & & & Inches & Percent \\
\hline I & $\begin{array}{l}\text { Little Powder River } \\
\text { above Dry Creek, } \\
\text { near Weston' } 2\end{array}$ & 1,235 & 72.4 & 6.3 & 0.0032 & 1.8 \\
\hline I I I & $\begin{array}{l}\text { Rawhide Creek at } \\
\text { confluence with } \\
\text { Little Powder River }\end{array}$ & 120 & 14.3 & 11.9 & .0064 & 3.5 \\
\hline IV & $\begin{array}{l}\text { Donkey Creek near } \\
\text { Moorcroft }\end{array}$ & 246 & 12.4 & 5.0 & .0027 & 1.5 \\
\hline v & $\begin{array}{l}\text { Belle Fourche River } \\
\text { below Moorcroft }\end{array}$ & 1,670 & 82.9 & 5.0 & .0027 & 1.4 \\
\hline VI & $\begin{array}{l}\text { Caballo Creek at } \\
\text { Mouth, near Piney' }\end{array}$ & 260 & 31.9 & 12.3 & .0066 & 3.6 \\
\hline VI I & $\begin{array}{l}\text { Coal Creek at } \\
\text { confluence with } \\
\text { Belle Fourche River }\end{array}$ & 74.7 & 19.6 & 26.2 & .0141 & 7.6 \\
\hline VIII & $\begin{array}{l}\text { Black Thunder Creek at } \\
\text { confluence with } \\
\text { Little Thunder Creek }\end{array}$ & 217 & 13.1 & 6.0 & .0032 & 1.8 \\
\hline IX & $\begin{array}{c}\text { Little Thunder Creek } \\
\text { near Hampshire }\end{array}$ & 234 & 42.6 & 18.2 & .0098 & 5.3 \\
\hline$x$ & $\begin{array}{c}\text { Black Thunder Creek } \\
\text { near Hampshire }\end{array}$ & 535 & 55.7 & 10.4 & .0056 & 3.0 \\
\hline$X I$ & $\begin{array}{l}\text { Porcupine Creek } \\
\text { at confluence with } \\
\text { Antelope Creek }\end{array}$ & 139 & 15.9 & 11.4 & .0061 & 3.3 \\
\hline XI I & $\begin{array}{l}\text { Antelope Creek } \\
\text { near Teckla' }\end{array}$ & 959 & 39.4 & 4.1 & .0022 & 1.2 \\
\hline XIII & $\begin{array}{l}\text { Cheyenne River near } \\
\text { Dull Center' }\end{array}$ & 1,527 & 41.7 & 2.7 & .0015 & .8 \\
\hline
\end{tabular}

' Drainage area upstream from streamflow-gaging station

2 Includes the drainage and disturbed areas of Rawhide Creek

- Includes the drainage and disturbed areas of Donkey Creek, Coal Creek and Caballo Creek

- Includes the drainage and disturbed areas of Little Thunder Creek

- Includes the drainage and disturbed areas of Porcupine Creek

- Includes the drainage and disturbed areas of Porcupine and Antelope Creek 


\section{Sediment Yield}

Erosion studies at small soil plots were conducted in confunction with the rainfall-simulator tests. Sediment detached by raindrop impact and washed from soil surfaces was collected at the downstream end of each soil plot. The sediment was dried and weighed to determine the yield from each plot. The data were converted to standard units, tons per square mile, in order to compare the results with different studies. The sediment-yield data are listed in table 20. A trend in the percentage difference in sediment yield for natural soil plots and reclaimed soil plots was not identified. The data indicate a six-fold decrease in sediment yield for reclaimed-soil plots between 1979 and 1983, but the natural-soil plots also had a five-fold decrease during the same period. Because of the variability of the data, a conclusion on the decrease in sediment yield for reclaimedsoil plots cannot be made.

Sediment yield from plots located on reclaimed soil was, on the average, 436 percent larger than sediment yield from plots on comparative natural soil. The sediment yields from the plots located on reclaimed soil were greater because of: (1) Steeper land slopes at the plots with reclaimed soil than at the plots with natural soil, (2) increased runoff from the reclaimed-soil plots due to slower infiltration rates, (3) lesser density of root development in the reclaimed-soil plots, and (4) lack of a well-developed soil profile in the reclaimed-soil plots, resulting in a loss of soil cohesiveness. Detailed data on slopes and vegetation cover of the soil plots were not available for the 1979, 1981, 1983 studies, but information was available for the studies conducted in 1984. The slope and vegetation data for 1984 was considered a representative sample for the studies at the Belle Ayr Mine. The average slope for the reclaimed-soil plots was 12.9 percent and for the natural-soil plots it was 9.4 percent. The reclaimed-soil plots had a 68-percent cover of litter, grass, forbs, and shrubs, and the natural-soil plots had a 95-percent cover. Particle-size analyses were not made for samples collected from the soil plots; therefore, the information needed to determine the type and source of sediment is not available.

Larger sediment yields probably will not be conveyed to the mouth of drainage basins listed in table 18 because of: (1) Sediment deposition occurring before runoff reaches the stream channel in areas where landsurface slopes decrease from hillside to stream channel, and (2) sediment deposition in settling ponds. A study of sediment sources and drainagebasin characteristics in eastern Wyoming determined that "Upland sediment yields cannot be used directly to determine sediment yield of larger basins, because with increased size of drainage basins, runoff and sediment rates decrease" (Hadley and Schumm, 1961, p. 137). They used 99 measurements to develop a relation between sediment accumulation in reservoirs and drainage area (fig. 39). The sediment yield for a $0.034-\mathrm{mi}^{2}$ drainage area was 10 times greater than the sediment yield for a 1.6-mi² drainage area; therefore, very little of the sediment measured at the soil plots will be conveyed to the major drainages. The small percentage of disturbed area in relation to undisturbed area in the drainage basins and the decrease in sediment conveyed to the main stream channels will result in a minor impact by sediment on the major drainage basins in the study area. 
Table 20.--Erosion rates for natural and reclaimed soils

[DJ, Dave Johnson Mine; BH, Big Horn Mine; BA, Belle Ayr Mine]

\begin{tabular}{|c|c|c|c|c|c|c|}
\hline \multirow[b]{2}{*}{$\begin{array}{l}\text { Year and } \\
\text { location } \\
\text { of test }\end{array}$} & \multirow[b]{2}{*}{$\begin{array}{c}\begin{array}{c}\text { Soil } \\
\text { category }\end{array} \\
\end{array}$} & \multicolumn{2}{|c|}{ Natural soil } & \multicolumn{2}{|c|}{ Reclaimed soil } & \multirow[b]{2}{*}{$\begin{array}{c}\text { Increase in } \\
\text { sediment } \\
\text { yield } \\
\text { (percent) } \\
\end{array}$} \\
\hline & & $\begin{array}{l}\text { Sediment } \\
\text { yield (toris } \\
\text { per square } \\
\text { mile) } \\
\end{array}$ & $\begin{array}{l}\text { Number } \\
\text { of } \\
\text { plots }\end{array}$ & $\begin{array}{l}\text { Sediment } \\
\text { yield (tons } \\
\text { per square } \\
\text { mile) }\end{array}$ & $\begin{array}{l}\text { Number } \\
\text { of } \\
\text { plots }\end{array}$ & \\
\hline 1976-DJ' & Undef ined & 283 & 1 & 1,200 & 1 & 324 \\
\hline $1976-\mathrm{BH}^{\prime}$ & Undefined & 39.7 & 1 & 2,437 & 1 & 6,039 \\
\hline $1979-B A^{2}$ & Heavy & 133 & 10 & 497 & 10 & 274 \\
\hline $1979-B A^{2}$ & Medium & 20.9 & 10 & 400 & 10 & 1,814 \\
\hline $1979-B A^{2}$ & Light & 31.3 & 10 & 359 & 10 & 1,047 \\
\hline $1981-B A^{2}$ & Heavy & 61.5 & 10 & 132 & 10 & 115 \\
\hline $1981-B A^{2}$ & Medium & 16.6 & 10 & 98.4 & 10 & 493 \\
\hline $1981-B A^{2}$ & Light & 24.6 & 10 & 84.8 & 10 & 245 \\
\hline $1983-\mathrm{BA}^{2}$ & Heavy & 30.1 & 10 & 100 & 10 & 232 \\
\hline $1983-B A^{2}$ & Medium & 6.1 & 10 & 77.5 & 10 & 1,170 \\
\hline $1983-\mathrm{BA}^{2}$ & Light & 3.7 & 10 & 21.5 & 10 & 481 \\
\hline $1984-B A^{3}$ & Und ifferentiated & 76.8 & 30 & 344 & 30 & 348 \\
\hline $\begin{array}{l}\text { Average } \\
\text { (weight }\end{array}$ & & 48.4 & & 260 & & 436 \\
\hline
\end{tabular}

' From Lusby and Toy (1976, p. 381)

2 From Gifford (1983)

3 From Hutten and Gifford (1984, p. 26-27) 
At the root of Wyoming water law is the protection of prior appropriators. Applications for stream-related developments such as sedimentation reservoirs or diversions are required by law to be filed with the Wyoming State Engineer, who reviews how such developments may affect downstream water users (Frank Trelease, III, Assistant Wyoming State Engineer, written commun., 1987). As shown on plate 5, most water rights in the lease areas have been permitted for coal-mining companies to construct sediment ponds. Several stock reservoirs and ditches are permitted on the lease areas; however, if they are physically destroyed, the appropriators are protected by law and proper restitution or compensation must be made, within legal constraints, to the owner's satisfaction. Likewise, water rights downstream from the mined areas are protected from a decrease in runoff due to mining activities.

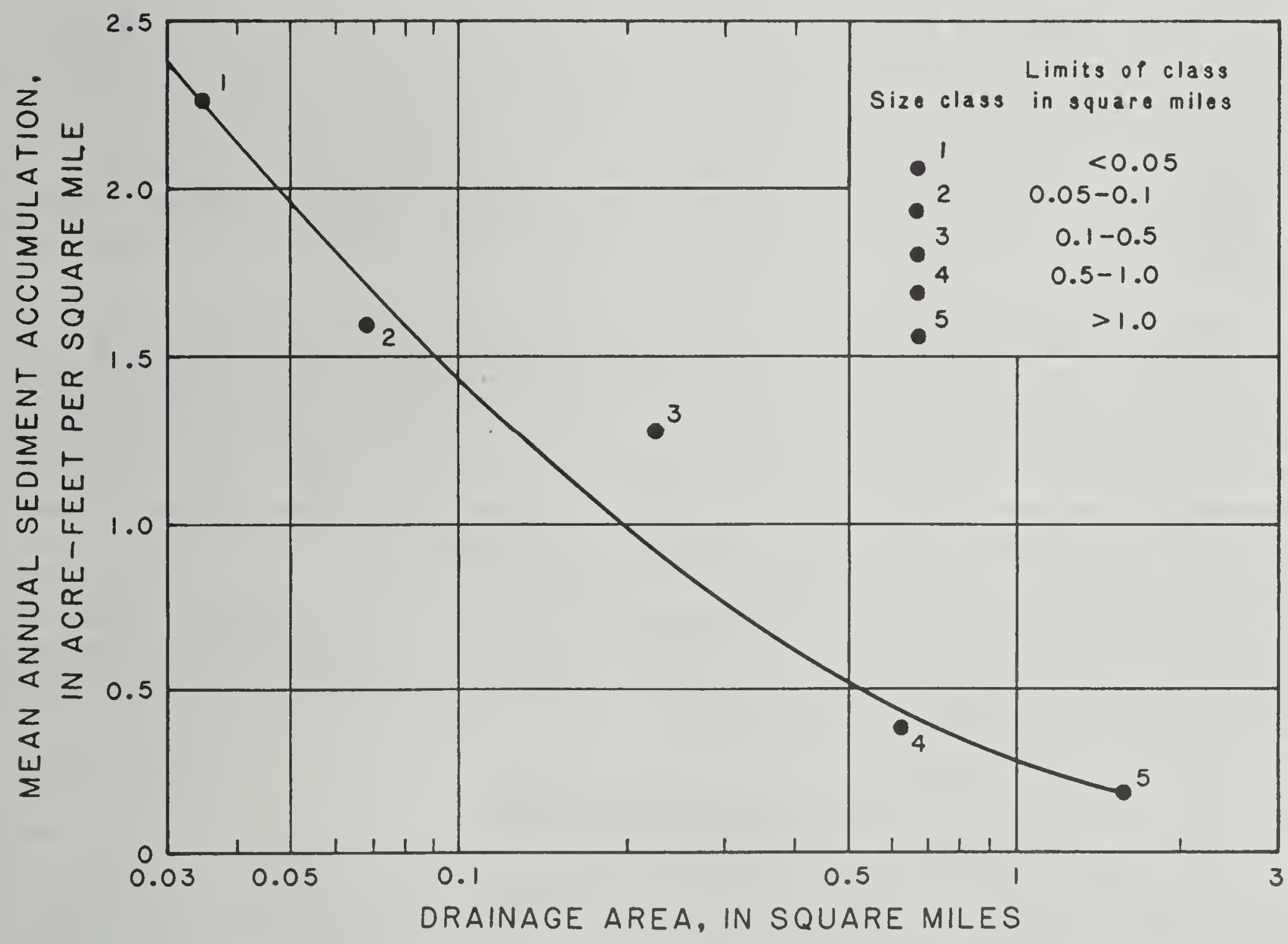

Figure 39.--Relation between sediment accumulation in reservoirs and drainage area, upper Cheyenne River basin (from Hadley and Schumm, 1961, p. 163). 
If affected by mining developments, such as reservoir storage or diversion of flow, downstream appropriators having prior water rights can request release of water from the coal-mining facilities. All permits granted to coal-mining companies for stream-related developments, such as sedimentation ponds, include the State Engineer's conditions requiring a means of releasing water for downstream appropriators, after the water-quality standards are met by the settling of suspended sediment in the ponds.

Because prior water appropriators are protected by law, no significant cumulative impacts are expected to occur due to mining of either existing permitted areas or of areas of all anticipated mining.

\section{STABILITY OF RECLAIMED DRAINAGES}

Surface coal mining disturbs large areas of the land surface. About $135 \mathrm{mi}^{2}$ of the land surface currently (1987) are projected to be disturbed and subsequently reclaimed by existing and proposed mines in the study area; as much as $253 \mathrm{mi}^{2}$ potentially could be disturbed by all anticipated mining in the study area.

Flowing water is the major natural force affecting reclaimed areas. Because streams are prone to erode and transport sediment, the disturbance of large land areas has the potential to impact natural channel stability some distance upstream or downstream from mining as well as locally. Undesirable modifications of drainage networks may result in increases in erosion and sedimentation. Increased rates of erosion and sedimentation can be detrimental to reclaimed areas, adjacent areas, and downstream water quality.

The design of stable drainage basins for postmining areas is critical to the type and degree of use the land may support after reclamation. According to Bishop (1980, p. 249), the more closely postmining topography can be restored to surrounding natural conditions and approximate original contours, the greater the likelihood of stable drainage networks and successful reclamation. Natural drainage networks and stream channels have evolved during long periods, and, thus, are considered to be in equilibrium with the climatic and physical conditions of their basins. In referring to natural landscapes and stream channels, the term "stability" means "dynamic stability." Basin surfaces and channels are in a continuous state of evolution as they are subjected to forces such as tectonism, climate, and runoff, and use by humans and animals.

\section{Regulatory Considerations}

The restoration of mined land to its approximate original contour is a requirement of the Surface Mining Control and Reclamation Act of 1977 . However, the relatively thick coal beds and small overburden-to-coal ratio in the study area prevent restoring the landscape to its former elevation (Keefer and Hadley, 1976, p. 15-20). As discussed by Toy and Hadley (1987, p. 276), it generally is agreed that "approximate original contour," as required by law, means that the shape of the land after mining should be about the same as it was before, but not necessarily at the same elevation. 
In addition to the requirement that coal-mining companies restore the approximate original contour of the land after mining, the Surface Mining Control and Reclamation Act of 1977 also requires that spoil materials "...be shaped and graded in such a way as to prevent slides, erosion, and water pollution..." and that "adequate drainage" be provided. The Act basically requires that procedures during mining and reclamation minimize the contribution of suspended materials to areas outside the lease boundaries, control rilling and gullying, and minimize disturbance to the prevailing hydrologic balance. Surface coal mines currently (1987) in operation in the study area are exempt from the strict requirement of restoring the land to the "approximate original contour" because they are classified as having "thin overburden." This classification is applied when the thickness of the coal is large relative to the overburden. Adequate drainage is still required, but the reclaimed landscape can be more subdued than it was before mining.

The Wyoming Environmental Quality Act (Wyoming State Legislature, 1973) requires that operators of surface coal mines provide a plan to minimize disturbances to the prevailing hydrologic balance at the mine site and in adjacent areas, and to protect the quantity and quality of water in groundand surface-water systems during and after mining. Guidelines prepared by the Wyoming Department of Environmental Quality (1980b) recommend that coalmining companies measure various basin and channel characteristics to aid in the reclamation of surface-drainage systems. Mine plans on file with the Wyoming Department of Environmental Quality contain these data and also document the procedures used or planned for re-construction of stream channels and drainage networks. In addition, numerous studies and guidelines for design criteria have been made by hydrologists working with the coal-mining companies and State and Federal agencies. (See for example: articles by Bergstrom (1985), Harvey and others (1985), and Kearney (1985), published in proceedings of the "Second Hydrology Symposium on Surface Coal Mining in the Northern Great Plains;" Knutson (1982), Lidstone (1982), and Tarquin and Baeder (1982), published in proceedings of the "Hydrology Symposium on Surface Coal Mines in the Powder River Basin;" and Divis and Tarquin (1981)).

\section{Method of Impact Analysis}

The evaluation of whether a re-constructed landscape will be stable in relation to the prevailing hydrologic balance is a difficult task, especially for semiarid and arid regions. As noted by Lidstone (1982, p. 44), "The long-term stability of a landscape is difficult to quantify on a site-specific basis and virtually impossible to quantify on a regional basis." Runoff, which is the major natural force affecting the landscape in the semiarid study area, may be infrequent, especially within small basins. For basins of only several square miles or less, it is common to have periods of 1 year or more between substantial runoff. The adjustment of a re-constructed drainage basin that is incipiently unstable may not be noticeable until several large flows have occurred, which could take several tens of years. Although readily visible responses such as rilling and gullying may occur rapidly where all or part of the basin is unstable, it also is possible that only a gradual response would take place during several or more years until substantial runoff occurs. It is practically 
impossible even for an expert to look at a stream channel and tell whether the channel is presently in a period of gradual aggradation or gradual degradation (Leopold, 1962, p. 3-4).

Quantifying the degree of stability and subsequent impact of re-constructed basins on the regional landscape and sediment yield is a difficult task; however, investigators have used geomorphic analyses successfully to assess changes and assist with design of stream-related developments. For example, Patton and Schumm (1975) quantified a relation between valley-floor slope and drainage area for small drainage basins in the Piceance Creek area of Colorado, whereby a threshold slope was identified above which trenching or valley instability would occur. Dunne and Leopold (1978, p. 22-28) described the use of geomorphology and hydrology for land-use planning of the valley associated with the mobile channel of the Yakima River near Yakima, Washington. Lowham and others (1982, p. 40-45) examined severe gullying in the Salt Creek basin near Rock Springs, Wyo., and determined the causes and approximate period of occurrence.

The drainage basin is the unit most basic to reclamation of the relatively large areas being mined. The assessment of impacts of fluvial processes on landscape stability, therefore, was made by comparing fundamental geomorphic relations for natural or premining basins in the area to characteristics described for the planned postmining basins. In addition, final reclamation plans for active mines were reviewed and reclaimed areas were inspected. Steps in the procedure to analyze the stability of reclaimed drainages and to determine cumulative impacts of the mining and reclamation on regional stability and sedimentation are describer: below:

1. Characteristics important to the stability of drainage basins and stream channels were measured for a representative sample of natural drainage networks in or near the study area. These data were then analyzed to determine the range and average for each characteristic, and fundamental relations between the characteristics were examined and developed.

2. Characteristics of the drainage basins and stream channels for a representative sample of areas planned for reclamation were measured from maps of postmining topography prepared by the coal-mining companies as part of their final reclamation plans. Those characteristics most important to basin and channel stability were compared with those for the natural basins.

3. A review was made of the methods used in the design of re-constructed drainage networks and stream channels.

4. The stability of currently (1987) reclaimed hillslopes and stream channels was examined during visits to several mines having areas that have been mined and reclaimed. 
The use of geomorphic relations derived from natural basins to determine the expected impact of re-constructed basins is based on the assumption that the natural basins currently are stable. A measure of basic geomorphic processes in relation to the prevailing hydrologic balance in drainage basins in the semiarid and arid regions of the western United States for a long period was implemented in 1962 through the Vigil Network (Leopold, 1962), whereby representative ephemeral draws, gullies, and stream channels were selected and instrumented to measure channel changes with time. Instrumentation of small tributaries was done with the intent of measuring changes resulting from climatic variation as well as those resulting from human activities.

From measurements made at eight Vigil Network sites in the semiarid and arid western United States, including several sites in the vicinity of the study area, Emmett (1974, p. 53-54) concludes that the valley trenching that began in about 1880 has now decreased, and that stream channels are stable or aggrading. Observations of stream channels in the study area since the $1960^{\prime}$ 's by one of the authors of this report, H.W. Lowham, support the conclusion that the fluvial system currently (1987) is stable. Although some gullying and headcutting is occurring, the processes appear to be related to natural rejuvenation of the basins and generally are of a local nature. For example, a discontinuous gully west of Gillette, which is typical of drainages in the area, with local changes such as small, slowly advancing headcuts developing as part of a naturally changing landscape is shown in figure 40.

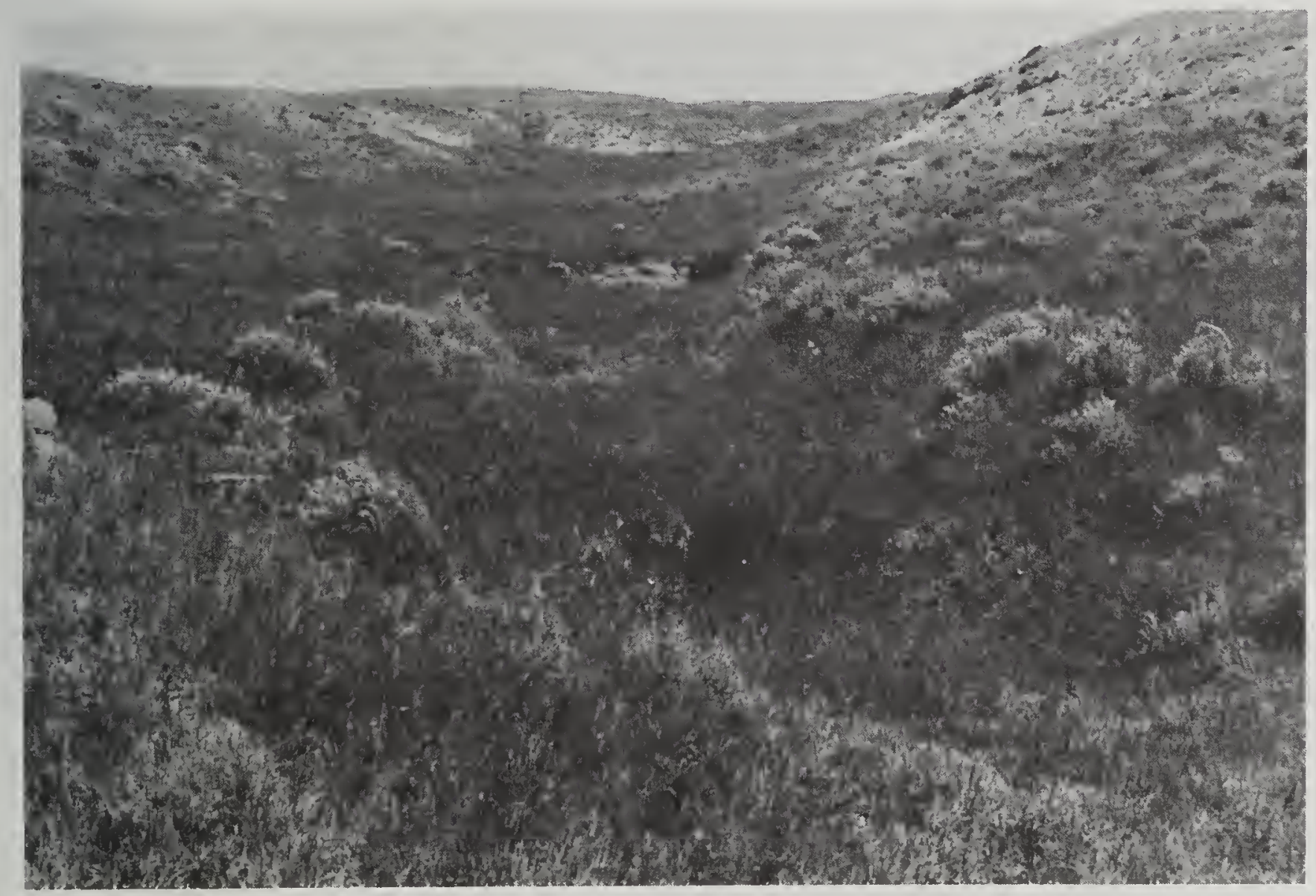

Figure 40.--Example of discontinuous gully with slowly advancing headcuts as part of a naturally changing landscape. 
A drainage basin is composed of two basic features: (1) A drainage network, and (2) hillslope and valley areas between stream channels. Stream channels and hillslopes are interrelated because what happens on the interfluve areas between streams has a dominant effect on the character of streams and on the hydrology of the basin (Chorley and others, 1984 , p. 258). The stream-channel network of a drainage basin is defined as the number and form of all streams in the basin. When surface geology is fairly uniform, the network of stream channels develops in a dendritic pattern, as is shown by the example drainage basin in figure 41. Drainage networks of the study area generally are dendritic, although erosion-resistant outcrops, different lithologies, and geologic structures such as joints or faults occasionally may affect the orientation of the streams.

A quantitative description of drainage networks in the study area was made using a method commonly referred to as the Horton analysis (Horton, 1945). The fundamental aspect of the Horton analysis is the relation of certain physical characteristics, such as drainage area, stream number, and stream length, to stream order. Stream order is defined as the position of a stream within a drainage network (fig. 41). The ordering system described by Strahler (1957, p. 914) was used in this analysis. The smallest stream channels of the network are unbranched tributaries, which are designated as first-order streams. When two first-order streams join, the resulting stream channel is a second-order stream. Third-order streams receive two or more tributaries of the second order, but also may receive first-order streams, and so on. In this system, the main stream has the highest order. The order of the main stream describes the order of the drainage basin.

Stream order generally is determined by examining the drainage network of a basin on topographic maps. The map scale limits the size of the smallest stream that may be recognized. To include the smallest rills evident in the drainage basin in stream ordering, several orders of streams may have to be added to the smallest streams shown on 1:24,000-scale topographic maps (Leopold and Miller, 1956, p. 16). However, the inclusion of small rills in a drainage-net analysis is useful for only special studies. For most purposes, one may restrict consideration only to the drainage network appearing on 1:24,000-scale topographic maps (Leopold and others, 1964, p. 141).

A visit of drainage basins and stream channels in the study area was made by H.W. Lowham, who compared features observed in the field with those depicted on the topographic maps. The comparison indicated that rills, some swales, and some small stream channels are not shown on the maps; however, the drainage network and physical features shown by 1:24,000-scale topographic maps are considered adequate to define the fundamental aspects of basin stability. 


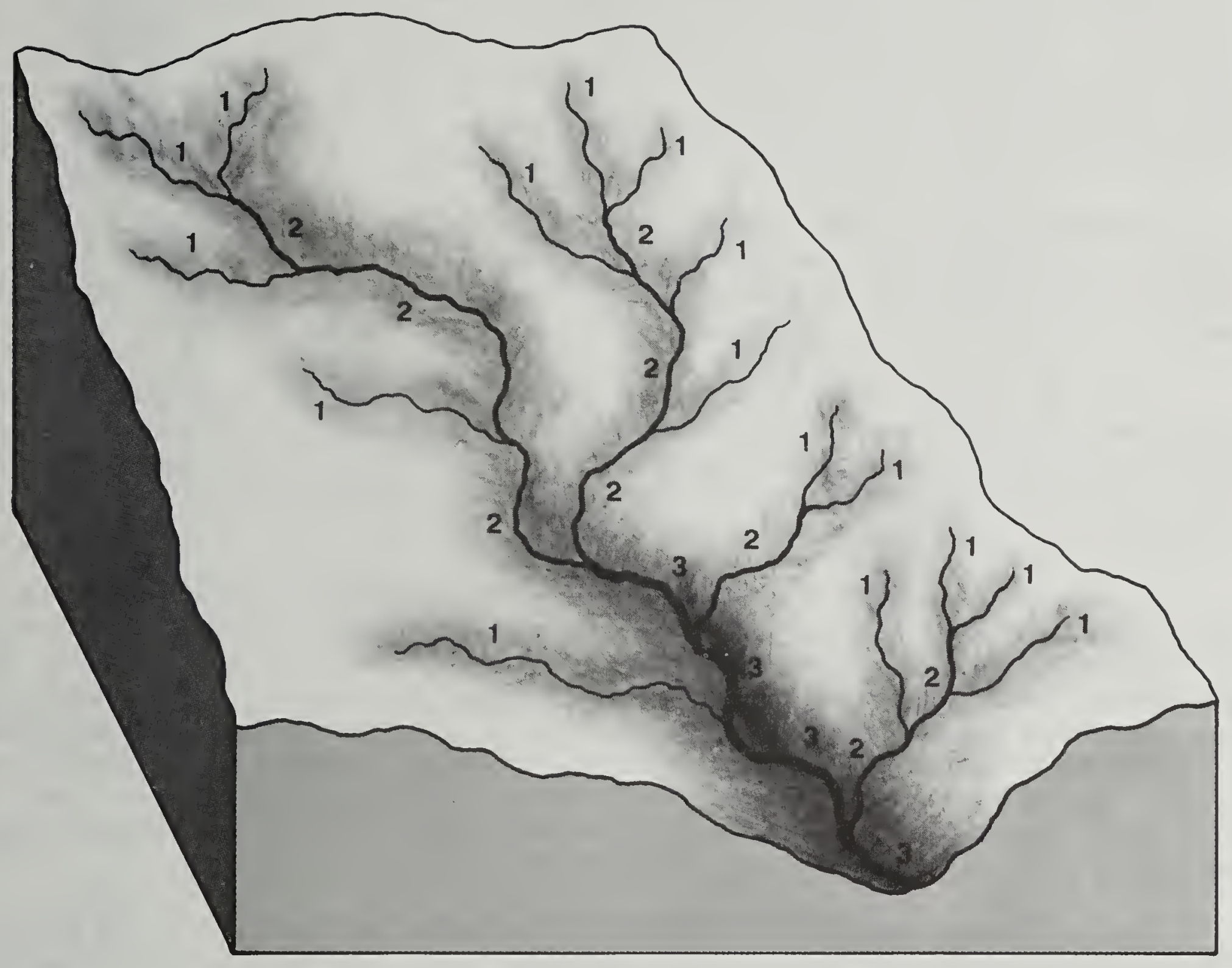

Figure 41.--Sketch of a drainage network with a dendritic pattern in a third-order drainage basin showing first-, second-, and third-order streams. 
A sample of 102 first- or higher-order drainage basins was selected for determining the physical characteristics of drainage networks in the study area. The selected drainage basins are natural with insignificant controls or impacts from human activities. All of the drainage basins are located within the study area. The drainage basins were randomly selected using a mathematical procedure in conjunction with a grid overlay for topographic maps of the study area. The drainage basins were selected using the following procedure. The coal-permit areas were plotted on twenty-five $1: 24,000$-scale topographic maps. An overlay grid, exactly the size of one map, was divided into 150 rectangles of equal area. A mathematical procedure was used to generate a random grid number, and 51 drainage basins (fig. 42) located in the randomly selected grids were delineated for analysis. Due to the size of the grid, only second-or higher-order basins were selected using this process. A subset of 51 first-order basins was then selected from the larger basins, using a random process to select 1 first-order basin from each of the larger basins.

Twenty-one physical characteristics were measured for each of the 51 second- or higher-order drainage basins using a computerized digitizer. A description of each of the characteristics is given in table 21; the values measured for each of the 51 drainage basins are given in table 22 .

Due to limitations of the map scale, some of the characteristics measured for the second-or higher-order drainage basins could not be accurately measured for the smaller first-order drainage basins. The characteristics measured for the first-order drainage basins are identified in table 21; the values are listed in table 23.

A statistical summary of the values of the physical characteristics is given in tables 24-27 for each of the drainage basin orders. The tables list the minimum and maximum values measured, the arithmetic mean, the geometric mean, and the standard deviation of the sample. The arithmetic and geometric means for each of the characteristics indicate the expected average magnitudes. The geometric mean, which is computed using logarithms of the values, generally is considered a more representative descriptor of the first moment of distributions in hydrology than the arithmetic mean, because the distributions usually are asymmetrical.

Measurements for a large sample of drainage basins within the eastern Powder River basin were used in the analysis. Similar data concerning the physical characteristics have been collected by the coal-mining companies for local areas. The data and relations determined by the coal-mining companies may vary from those of this study, depending on the scale of maps or aerial photographs used, the number of drainage basins sampled, and the local relief.

The physical characteristics of drainage networks commonly are interrelated. For example, as drainage area increases, the number of stream channels and the order of the main stream channel also increase. To determine those variables for which significant interrelations might exist, a correlation analysis was made. Results of this analysis are given in table 28. 


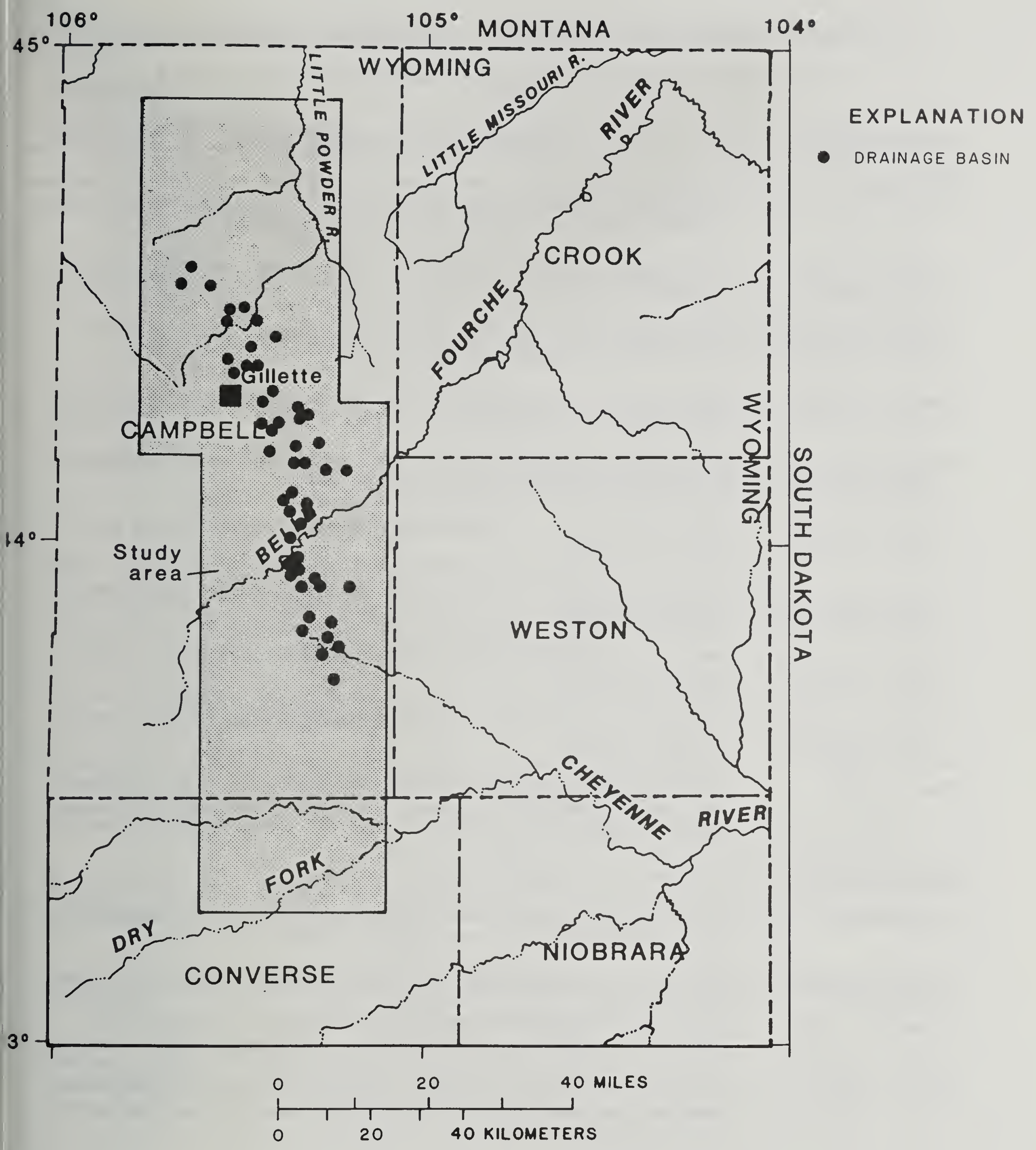

Figure 42.--Location of drainage basins used to determine physical characteristics. 
Table 21.--Characteristics measured in drainage-basin-stability analysis

[*, indicates characteristics measured for first-order basins]

Characteristic

*Drainage area

Number of firstorder channels

Number of secondorder channels

Number of thirdorder channels

Number of fourthorder channels

Length of firstorder channels

Length of secondorder channels

Length of thirdorder channels

Length of fourthorder channels

*Basin length

*Basin perimeter Basin width

*Valley length

*Channel length

*Basin relief

\section{Explanation of characteristic}

The area, measured in a horizontal plane, from which direct surface runoff from precipitation normally drains into the stream channel upstream from the specified point, in square miles.

Total number of stream channels in the drainage basin that are classified as first order.

Total number of stream channels in the drainage basin that are classified as second order.

Total number of stream channels in the drainage basin that are classified as third order.

Total number of stream channels in the drainage basin that are classified as fourth order.

Summation of lengths of all stream channels classified as first order, in miles.

Summation of lengths of all stream channels classified as second order, in miles.

Summation of lengths of all stream channels classified as third order, in miles.

Summation of lengths of all stream channels classified as fourth order, in miles.

Straight-line distance across the drainage basin from the point on the drainage divide nearest the head of the dominant channel to the basin mouth, in miles.

Perimeter of the drainage basin, in miles.

Representative width of the drainage basin, generally measured at about the midpoint of the basin, in miles.

Length of the valley along the dominant stream channel, in miles.

Length of the dominant stream channel measured using the blue streamline shown on a 1:24,000-scale topographic map, in miles.

Difference in elevation between the point on the drainage divide nearest the head of the dominant stream channel and the basin mouth, in feet. 
Table 21.--Characteristics measured in drainage-basin-stability analysis--Continued

*used relief

* Channel slope

Basin order

*Sinuosity

* Relief ratio

* Total channel length

*Drainage density

* Circularity ratio

Stream frequency

Maximum sideslope relief

Sideslope
distance

* Maximum value sideslope
Difference in elevation between two points on the stream channel, channel, in feet. For the first-order basins, the points were selected at each end of the blue streamline shown on a 1:24,000scale topographic map. For the second-and higher-order basins, the points were selected at 15 and 85 percent of the dominant stream channel length.

Used relief divided by the length of stream channel between the points identified in used relief, in foot per foot. This depicts an average stream-channel slope, which should not be confused or compared with values that are measured at particular locations along stream-channels.

Order of the stream channel at the drainage-basin mouth.

Stream-channel length divided by valley length. This depicts an average sinuosity for the stream channel, which should not be confused with values that are measured at particular locations along stream channels.

Basin relief divided by basin length.

Summation of lengths of all stream channels of all orders in the drainage basin, in miles. For first-order streams, this is the same as stream-channel length.

Total stream-channel length divided by the drainage area, in miles per square mile.

Area of the drainage basin divided by the area of a circle having the same perimeter as the drainage basin.

Total number of stream channels of all orders divided by the drainage area, in number of stream channels per square mile.

Difference in elevation between the hilltop and the stream channel on the valley sideslope at the point of maximum difference, in feet.

Straight-line distance measured in a horizontal plane between the hilltop and the stream channel at the same point as the maximum sideslope relief was measured, in miles.

Maximum value of sideslope relief divided by the sideslope distance, in foot per foot. 


\begin{tabular}{|c|c|c|c|c|c|c|c|c|c|c|c|c|c|c|}
\hline $\begin{array}{c}\text { Map } \\
\text { name }\end{array}$ & $\begin{array}{l}\text { Drainage- } \\
\text { basin } \\
\text { sequence } \\
\text { number }\end{array}$ & $\begin{array}{c}\text { Drainage } \\
\text { area } \\
\text { (square } \\
\text { miles) }\end{array}$ & Num & ex e & chan & $\frac{n e 1 s}{4 t h}$ & $\begin{array}{l}\text { ler num } \\
\text { Tot } \\
\text { chan } \\
\text { lst }\end{array}$ & $\begin{array}{l}\text { ber of } \\
\text { al len } \\
\text { nels, } \\
2 \text { ad }\end{array}$ & $\begin{array}{l}\text { chann } \\
\text { gth of } \\
\text { in mil } \\
3 \mathrm{rd}\end{array}$ & $\sqrt{4+b}$ & $\begin{array}{l}\text { Bas in } \\
\text { length } \\
\text { (miles) }\end{array}$ & $\begin{array}{l}\text { Basin } \\
\text { perim- } \\
\text { eter } \\
\text { (miles) }\end{array}$ & $\begin{array}{l}\text { Basin } \\
\text { widtb } \\
\text { (miles) }\end{array}$ & $\begin{array}{l}\text { Valles } \\
\text { lengtb } \\
\text { Soiles }\end{array}$ \\
\hline Calf Creek & D59 & 0.74 & 5 & 2 & 1 & 0 & 1.42 & 1.28 & 0.62 & 0.00 & 1.66 & 4.28 & 0.47 & 1.50 \\
\hline Calf Creek & D58 & 7.73 & 34 & 11 & 2 & 1 & 12.01 & 7.60 & 3.31 & 4.14 & 5.29 & 13.03 & 1.97 & 4.97 \\
\hline Calf Creek & D57 & .91 & 3 & 1 & 0 & 0 & 2.51 & .48 & .00 & .00 & 1.42 & 3.88 & .84 & 1.25 \\
\hline Calf Creek & D56 & .71 & 5 & 1 & 0 & 0 & 1.06 & 1.64 & .00 & .00 & 1.67 & 4.05 & .52 & 1.50 \\
\hline Fort in Draw & D5S & .51 & 3 & 1 & 0 & 0 & 1.55 & .95 & .00 & .00 & 1.57 & 3.64 & .42 & 1.38 \\
\hline Rawhide School & D54 & 3.22 & 16 & 6 & 2 & 1 & 5.79 & 2.98 & .70 & 1.35 & 2.95 & 7.68 & 1.55 & 2.92 \\
\hline Moyer Springs & D53 & 2.12 & 11 & 5 & 1 & 0 & 5.95 & 2.03 & 1.86 & .00 & 2.37 & 6.94 & .98 & 1.99 \\
\hline Rawhide School & D52 & .88 & 4 & 1 & 0 & 0 & 1.36 & 1.69 & .00 & .00 & 1.85 & 5.09 & .47 & 1.85 \\
\hline Rawhide School & DS1 & 3.24 & 10 & 3 & 1 & 0 & 4.81 & 3.93 & .96 & .00 & 2.78 & 9.02 & 1.10 & 2.42 \\
\hline Rawhide School & D50 & 1.88 & 6 & 2 & 1 & 0 & 3.34 & 2.23 & .36 & .00 & 2.21 & 5.89 & 1.09 & 1.89 \\
\hline Gillette West & D49 & 3.41 & 8 & 2 & 1 & 0 & 5.20 & 1.57 & 2.30 & .00 & 3.16 & 8.35 & 1.35 & 3.03 \\
\hline Gillette East & $D 48$ & .93 & 4 & 1 & 0 & 0 & 2.69 & 1.32 & .00 & .00 & 2.37 & 5.10 & .51 & 2.29 \\
\hline Gillette West & $D 47$ & 1.38 & 5 & 1 & 0 & 0 & 2.34 & .36 & .00 & .00 & 1.71 & 5.10 & 1.02 & 1.68 \\
\hline Gillette East & $D 46 B$ & 8.18 & 13 & 4 & 2 & 1 & 7.51 & 5.02 & 6.87 & .80 & 6.32 & 14.69 & 1.91 & 6.00 \\
\hline Gillette East & D46 & 2.78 & 6 & 2 & 1 & 0 & 4.71 & 2.03 & 2.40 & .00 & 3.32 & 8.32 & 1.06 & 3.20 \\
\hline Gillette East & $D 45$ & 1.55 & 5 & 2 & 0 & 0 & 2.98 & 1.51 & .00 & .00 & 1.26 & 5.92 & .81 & 1.20 \\
\hline Gillette East & $D 44$ & .40 & 2 & 1 & 0 & 0 & .98 & .55 & .00 & .00 & 1.10 & 2.80 & .41 & 1.05 \\
\hline Gillette East & D43 & 3.33 & 16 & 4 & 1 & 0 & 7.32 & 4.62 & 2.18 & .00 & 3.89 & 9.52 & 1.20 & 3.76 \\
\hline Gillette East & $D 42$ & 2.13 & 5 & 2 & 1 & 0 & 1.89 & 1.61 & .67 & .00 & 2.48 & 8.01 & .70 & 2.16 \\
\hline Coyote Draw & $D 41$ & 2.15 & 8 & 2 & 1 & 0 & 4.31 & 2.83 & .90 & .00 & 2.86 & 6.97 & .87 & 2.58 \\
\hline The Gap & D40 & 4.16 & 10 & 3 & 1 & 0 & 6.55 & 3.25 & 2.28 & .00 & 3.80 & 10.13 & 1.61 & 3.77 \\
\hline Coyote Draw & D39 & 4.45 & 15 & 4 & 2 & 1 & 8.88 & 2.94 & 1.40 & 1.14 & 4.43 & 12.58 & 1.31 & 3.64 \\
\hline The Gap & D38 & 1.04 & 3 & 1 & 0 & 0 & 1.52 & 1.96 & .00 & .00 & 2.12 & 4.96 & .74 & 2.12 \\
\hline Coyote Draw & D37 & 1.24 & 8 & 3 & 1 & 0 & 3.56 & 1.04 & 1.38 & .00 & 2.21 & 6.28 & .56 & 2.17 \\
\hline Coyote Draw & D36 & 2.62 & 15 & 4 & 1 & 0 & 6.91 & 1.75 & 3.21 & .00 & 3.58 & 8.72 & .87 & 3.58 \\
\hline Coyote Draw & D35 & 1.36 & 3 & 1 & 0 & 0 & 1.81 & 1.59 & .00 & .00 & 2.27 & 5.36 & .77 & 1.55 \\
\hline The Gap & D34 & .96 & 2 & 1 & 0 & 0 & 1.26 & .95 & .00 & .00 & 1.63 & 4.28 & .67 & 1.63 \\
\hline The Gap & D33 & 1.08 & 4 & 1 & 0 & 0 & 2.29 & 1.25 & .00 & .00 & 2.19 & 5.19 & .58 & 2.07 \\
\hline Coyote Draw & D32 & 1.24 & 3 & 1. & 0 & 0 & 2.50 & .80 & .00 & .00 & 2.04 & 5.00 & .72 & 1.74 \\
\hline Coyote Draw & D31 & 2.50 & 11 & 2 & 1 & 0 & 6.15 & 1.93 & 2.08 & .00 & 3.34 & 7.77 & .82 & 3.27 \\
\hline Saddle Borse Butte & e D30 & .70 & 5 & 2 & 1 & 0 & 1.64 & 1.04 & .55 & .00 & 1.50 & 3.82 & .67 & 1.34 \\
\hline Saddle Borse Butte & D D29 & .40 & 3 & 1 & 0 & 0 & 1.25 & .60 & .00 & .00 & 1.37 & 3.13 & .44 & $\begin{array}{l}1.03 \\
2.59\end{array}$ \\
\hline $\begin{array}{l}\text { Saddle Borse Butte } \\
\text { Neil Butte }\end{array}$ & $\begin{array}{l}\text { D28 } \\
\text { D27 }\end{array}$ & $\begin{array}{l}1.37 \\
3.52\end{array}$ & $\begin{array}{l}4 \\
3\end{array}$ & $\begin{array}{l}1 \\
1\end{array}$ & $\begin{array}{l}0 \\
0\end{array}$ & $\begin{array}{l}0 \\
0\end{array}$ & $\begin{array}{l}2.42 \\
1.64\end{array}$ & $\begin{array}{l}2.41 \\
1.12\end{array}$ & $\begin{array}{l}.00 \\
.00\end{array}$ & $\begin{array}{l}.00 \\
.00\end{array}$ & $\begin{array}{l}2.83 \\
1.54\end{array}$ & $\begin{array}{l}6.35 \\
9.44\end{array}$ & $\begin{array}{r}.70 \\
1.51\end{array}$ & $\begin{array}{l}. .59 \\
.96\end{array}$ \\
\hline $\begin{array}{l}\text { Neil Butte } \\
\text { Eagle Rock }\end{array}$ & $\begin{array}{l}\text { D26 } \\
\text { D25 }\end{array}$ & $\begin{array}{l}3.70 \\
2.26\end{array}$ & $\begin{array}{l}8 \\
8\end{array}$ & $\begin{array}{l}1 \\
2\end{array}$ & $\begin{array}{l}0 \\
1\end{array}$ & $\begin{array}{l}0 \\
0\end{array}$ & $\begin{array}{l}5.86 \\
3.25\end{array}$ & $\begin{array}{l}2.35 \\
3.99\end{array}$ & $\begin{array}{l}.00 \\
.92\end{array}$ & $\begin{array}{l}.00 \\
.00\end{array}$ & $\begin{array}{l}2.72 \\
3.29\end{array}$ & $\begin{array}{r}10.06 \\
7.94\end{array}$ & $\begin{array}{r}1.70 \\
.81\end{array}$ & $\begin{array}{l}2.46 \\
3.01\end{array}$ \\
\hline Neil Butte & D24 & 2.14 & 10 & 2 & 1 & 0 & 3.22 & 1.48 & 2.61 & .00 & 3.56 & 8.31 & $\begin{array}{l}.81 \\
.83\end{array}$ & $\begin{array}{l}3.01 \\
3.25\end{array}$ \\
\hline Neil Butte & D23 & .80 & 7 & 1 & 0 & 0 & 1.53 & 1.05 & .00 & .00 & 1.37 & 4.28 & .58 & 1.18 \\
\hline Neil Butte & D22 & .80 & 3 & 1 & 0 & 0 & .71 & 1.80 & .00 & .00 & 2.02 & 4.66 & .54 & 2.02 \\
\hline Neil Butte & D21 & 1.78 & 9 & 2 & 1 & 0 & 3.54 & 1.98 & .75 & .00 & 2.32 & 6.05 & 1.32 & 2.10 \\
\hline Neil Butte & D20 & .82 & 4 & 1 & 0 & 0 & .84 & 1.92 & .00 & .00 & 1.97 & 4.31 & .52 & 1.84 \\
\hline Reno Reservoir & D19 & 8.84 & 41 & 10 & 3 & 1 & 15.70 & 6.56 & 6.50 & 5.17 & 6.84 & 14.57 & 1.78 & 6.40 \\
\hline Hiligbt & D1 8 & 1.98 & 6 & 2 & 1 & 0 & 2.27 & 2.43 & .50 & .00 & 2.29 & 6.66 & 1.27 & 2.21 \\
\hline Hilight & D1 7 & 3.72 & 8 & 2 & 1 & 0 & 3.37 & .66 & 4.14 & .00 & 4.20 & 9.97 & 1.39 & 3.87 \\
\hline Hiligbt & D1 6 & 1.14 & 6 & 1 & 0 & 0 & 1.92 & 2.28 & .00 & .00 & 2.15 & 5.08 & .72 & 2.05 \\
\hline Bilight & D15 & 1.14 & 6 & 2 & 1 & 0 & 2.31 & .72 & 1.70 & .00 & 2.18 & 5.97 & .65 & 2.05 \\
\hline Hilight & D14 & 3.26 & 14 & 3 & 1 & 0 & 5.21 & 3.24 & 1.74 & .00 & 3.30 & 9.84 & 1.10 & 2.86 \\
\hline Open A Ranch & D1 3 & 1.60 & 6 & 2 & 1 & 0 & 3.04 & 1.78 & .68 & .00 & 2.51 & 6.75 & .76 & 2.46 \\
\hline The Gap SW & D11 & 1.65 & 6 & 2 & 1 & 0 & 2.63 & 1.83 & 1.12 & .00 & 2.58 & 6.49 & .99 & 2.58 \\
\hline $\begin{array}{l}\text { Saddle Horse Butte } \\
\text { The Gap SW }\end{array}$ & $\begin{array}{l}\mathrm{DOS} \\
\mathrm{DO3}\end{array}$ & $\begin{array}{l}2.86 \\
3.56\end{array}$ & 11 & 3 & 1 & 0 & 5.03 & 2.15 & 2.65 & .00 & $\begin{array}{l}4.19 \\
4.40\end{array}$ & 8.27 & 1.09 & $\begin{array}{l}3.11 \\
2.85\end{array}$ \\
\hline & & 3.30 & 3 & 1 & 0 & 0 & 2.05 & 3.08 & .00 & .00 & 4.40 & 10.17 & 1.13 & 2.85 \\
\hline
\end{tabular}

Name of U.S. Geological Survey $1: 24,000$-scale topographic map. 


\begin{tabular}{|c|c|c|c|c|c|c|c|c|c|c|c|c|c|}
\hline $\begin{array}{l}\text { Channel } \\
\text { lengtb } \\
\text { (miles) }\end{array}$ & $\begin{array}{l}\text { Bas in } \\
\text { relief } \\
\text { (feet) }\end{array}$ & $\begin{array}{l}\text { Used } \\
\text { relief } \\
\text { (feet) }\end{array}$ & $\begin{array}{l}\text { Cbannel } \\
\text { slope } \\
\text { (foot } \\
\text { per } \\
\text { feet) }\end{array}$ & $\begin{array}{l}\text { Bas in } \\
\text { erder. }\end{array}$ & Siauesity & $\begin{array}{l}\text { Relief } \\
\text { ratie }\end{array}$ & $\begin{array}{l}\text { Total } \\
\text { channel } \\
\text { lengtb } \\
\text { (miles) }\end{array}$ & $\begin{array}{c}\text { Drainage } \\
\text { density } \\
\text { (miles } \\
\text { per } \\
\text { square } \\
\text { mile) }\end{array}$ & $\begin{array}{l}\text { Circu- } \\
\text { larity } \\
\text { ratie }\end{array}$ & $\begin{array}{l}\text { Stream } \\
\text { fre- } \\
\text { quency } \\
\text { (streams } \\
\text { per } \\
\text { square } \\
\text { mile) }\end{array}$ & $\begin{array}{l}\text { Maxi- } \\
\text { mum } \\
\text { side- } \\
\text { s lope } \\
\text { relief } \\
\text { (feet) }\end{array}$ & $\begin{array}{c}\text { side- } \\
\text { slope } \\
\text { dis- } \\
\text { stance } \\
\text { (miles) }\end{array}$ & $\begin{array}{l}\text { Maximum } \\
\text { value } \\
\text { side- } \\
\text { slope } \\
\text { (foot } \\
\text { per } \\
\text { foot) }\end{array}$ \\
\hline 1.66 & 314 & 180 & 0.030 & 3 & 1.10 & 189 & 3.32 & 4.49 & 0.506 & 10.8 & 180 & 0.120 & 0.284 \\
\hline $\begin{array}{l}7.09 \\
1.42 \\
1.72\end{array}$ & $\begin{array}{l}331 \\
184 \\
410\end{array}$ & $\begin{array}{r}132 \\
92 \\
122\end{array}$ & $\begin{array}{r}.012 \\
017 \\
.019\end{array}$ & $\begin{array}{l}4 \\
2 \\
2\end{array}$ & $\begin{array}{l}1.42 \\
1.13 \\
1.14\end{array}$ & $\begin{array}{l}62.6 \\
130 \\
246\end{array}$ & $\begin{array}{r}27.06 \\
2.99 \\
2.70\end{array}$ & $\begin{array}{l}3.50 \\
3.29 \\
3.81\end{array}$ & $\begin{array}{r}.571 \\
.757 \\
.541\end{array}$ & $\begin{array}{l}6.2 \\
4.4 \\
8.4\end{array}$ & $\begin{array}{r}120 \\
60 \\
180\end{array}$ & $\begin{array}{r}.092 \\
.187 \\
.137\end{array}$ & $\begin{array}{l}.247 \\
.060 \\
.248\end{array}$ \\
\hline $\begin{array}{l}1.66 \\
3.20 \\
2.68\end{array}$ & $\begin{array}{l}375 \\
403 \\
433\end{array}$ & $\begin{array}{l}221 \\
220 \\
119\end{array}$ & $\begin{array}{l}.036 \\
.018 \\
.012\end{array}$ & $\begin{array}{l}2 \\
4 \\
3\end{array}$ & $\begin{array}{l}1.20 \\
1.09 \\
1.34\end{array}$ & $\begin{array}{l}239 \\
137 \\
183\end{array}$ & $\begin{array}{r}2.50 \\
10.82 \\
9.84\end{array}$ & $\begin{array}{l}4.92 \\
3.36 \\
4.65\end{array}$ & $\begin{array}{l}.481 \\
.685 \\
.551\end{array}$ & $\begin{array}{l}7.8 \\
7.7 \\
8.0\end{array}$ & $\begin{array}{r}120 \\
120 \\
90\end{array}$ & $\begin{array}{l}.054 \\
.120 \\
.096\end{array}$ & $\begin{array}{l}.420 \\
.189 \\
.177\end{array}$ \\
\hline $\begin{array}{l}2.01 \\
2.60 \\
2.21\end{array}$ & $\begin{array}{l}284 \\
276 \\
461\end{array}$ & $\begin{array}{l}135 \\
120 \\
139\end{array}$ & $\begin{array}{l}.018 \\
.013 \\
.017\end{array}$ & $\begin{array}{l}2 \\
3 \\
3\end{array}$ & $\begin{array}{l}1.08 \\
1.07 \\
1.16\end{array}$ & $\begin{array}{l}154 \\
99.3 \\
209\end{array}$ & $\begin{array}{l}3.05 \\
9.70 \\
5.93\end{array}$ & $\begin{array}{l}3.48 \\
2.99 \\
3.15\end{array}$ & $\begin{array}{l}.424 \\
.500 \\
.680\end{array}$ & $\begin{array}{l}5.7 \\
4.3 \\
4.7\end{array}$ & $\begin{array}{l}130 \\
140 \\
300\end{array}$ & $\begin{array}{l}.486 \\
.403 \\
.520\end{array}$ & $\begin{array}{l}.050 \\
.065 \\
.109\end{array}$ \\
\hline $\begin{array}{l}3.87 \\
2.58 \\
1.98\end{array}$ & $\begin{array}{l}441 \\
232 \\
194\end{array}$ & $\begin{array}{l}130 \\
120 \\
124\end{array}$ & $\begin{array}{l}.009 \\
.012 \\
.016\end{array}$ & $\begin{array}{l}3 \\
2 \\
2\end{array}$ & $\begin{array}{l}1.27 \\
1.12 \\
1.17\end{array}$ & $\begin{array}{c}140 \\
97.9 \\
113\end{array}$ & $\begin{array}{l}9.07 \\
4.01 \\
2.70\end{array}$ & $\begin{array}{l}2.65 \\
4.33 \\
1.95\end{array}$ & $\begin{array}{l}.614 \\
.447 \\
.666\end{array}$ & $\begin{array}{l}3.2 \\
5.3 \\
4.3\end{array}$ & $\begin{array}{l}140 \\
180 \\
100\end{array}$ & $\begin{array}{l}.300 \\
.428 \\
.454\end{array}$ & $\begin{array}{l}.088 \\
.079 \\
.041\end{array}$ \\
\hline 8.44 & 405 & 148 & .004 & 4 & 1.40 & 64.1 & 20.20 & 2.46 & .476 & 2.4 & 300 & 1.07 & .063 \\
\hline $\begin{array}{l}4.42 \\
1.28\end{array}$ & $\begin{array}{l}205 \\
205\end{array}$ & $\begin{array}{r}85 \\
152\end{array}$ & $\begin{array}{l}.005 \\
.032\end{array}$ & $\begin{array}{l}3 \\
2\end{array}$ & $\begin{array}{l}1.38 \\
1.06\end{array}$ & $\begin{array}{l}61.7 \\
163\end{array}$ & $\begin{array}{l}9.14 \\
4.49\end{array}$ & $\begin{array}{l}3.28 \\
2.89\end{array}$ & $\begin{array}{l}.504 \\
.555\end{array}$ & $\begin{array}{l}3.2 \\
4.5\end{array}$ & $\begin{array}{l}100 \\
120\end{array}$ & $\begin{array}{r}2.31 \\
.320\end{array}$ & $\begin{array}{l}.008 \\
.071\end{array}$ \\
\hline $\begin{array}{l}1.12 \\
4.69 \\
2.35\end{array}$ & $\begin{array}{l}211 \\
312 \\
190\end{array}$ & $\begin{array}{r}140 \\
197 \\
93\end{array}$ & $\begin{array}{l}.033 \\
.011 \\
.010\end{array}$ & $\begin{array}{l}2 \\
3 \\
3\end{array}$ & $\begin{array}{l}1.06 \\
1.24 \\
1.08\end{array}$ & $\begin{array}{r}192 \\
80.2 \\
76.6\end{array}$ & $\begin{array}{r}1.53 \\
14.12 \\
4.17\end{array}$ & $\begin{array}{l}3.80 \\
4.24 \\
1.95\end{array}$ & $\begin{array}{l}.644 \\
.461 \\
.416\end{array}$ & $\begin{array}{l}7.4 \\
6.3 \\
3.7\end{array}$ & $\begin{array}{l}120 \\
141 \\
170\end{array}$ & $\begin{array}{l}.295 \\
.340 \\
.430\end{array}$ & $\begin{array}{l}.077 \\
.078 \\
.074\end{array}$ \\
\hline $\begin{array}{l}3.18 \\
4.14 \\
4.41\end{array}$ & $\begin{array}{l}241 \\
443 \\
379\end{array}$ & $\begin{array}{l}135 \\
155 \\
152\end{array}$ & $\begin{array}{l}.011 \\
.010 \\
.009\end{array}$ & $\begin{array}{l}3 \\
3 \\
4\end{array}$ & $\begin{array}{l}1.23 \\
1.09 \\
1.21\end{array}$ & $\begin{array}{l}84.3 \\
117 \\
85.6\end{array}$ & $\begin{array}{r}8.04 \\
12.08 \\
14.36\end{array}$ & $\begin{array}{l}3.73 \\
2.90 \\
3.22\end{array}$ & $\begin{array}{l}.555 \\
.509 \\
.353\end{array}$ & $\begin{array}{l}5.1 \\
3.3 \\
4.9\end{array}$ & $\begin{array}{l}100 \\
100 \\
125\end{array}$ & $\begin{array}{l}.248 \\
.237 \\
.353\end{array}$ & $\begin{array}{l}.076 \\
.079 \\
.067\end{array}$ \\
\hline $\begin{array}{l}2.38 \\
2.45 \\
4.70\end{array}$ & $\begin{array}{l}289 \\
283 \\
241\end{array}$ & $\begin{array}{r}98 \\
136 \\
106\end{array}$ & $\begin{array}{l}.011 \\
.015 \\
.006\end{array}$ & $\begin{array}{l}2 \\
3 \\
3\end{array}$ & $\begin{array}{l}1.12 \\
1.12 \\
1.31\end{array}$ & $\begin{array}{r}136 \\
128 \\
67\end{array}$ & $\begin{array}{r}3.48 \\
5.98 \\
11.87\end{array}$ & $\begin{array}{l}3.34 \\
4.82 \\
4.53\end{array}$ & $\begin{array}{l}.530 \\
.394 \\
.432\end{array}$ & $\begin{array}{l}3.8 \\
9.6 \\
7.6\end{array}$ & $\begin{array}{r}160 \\
80 \\
202\end{array}$ & $\begin{array}{l}.542 \\
.302 \\
.697\end{array}$ & $\begin{array}{l}.059 \\
.050 \\
.054\end{array}$ \\
\hline $\begin{array}{l}2.33 \\
1.79 \\
2.18\end{array}$ & $\begin{array}{l}176 \\
231 \\
252\end{array}$ & $\begin{array}{l}58 \\
85 \\
78\end{array}$ & $\begin{array}{l}.006 \\
.012 \\
.009\end{array}$ & $\begin{array}{l}2 \\
2 \\
2\end{array}$ & $\begin{array}{l}1.50 \\
1.09 \\
1.05\end{array}$ & $\begin{array}{l}77.5 \\
142 \\
115\end{array}$ & $\begin{array}{l}3.40 \\
2.21 \\
3.54\end{array}$ & $\begin{array}{l}2.50 \\
2.30 \\
3.27\end{array}$ & $\begin{array}{l}.594 \\
.657 \\
.503\end{array}$ & $\begin{array}{l}2.9 \\
3.1 \\
4.6\end{array}$ & $\begin{array}{r}80 \\
140 \\
192\end{array}$ & $\begin{array}{l}.349 \\
.358 \\
.406\end{array}$ & $\begin{array}{l}.043 \\
.074 \\
.089\end{array}$ \\
\hline $\begin{array}{l}2.03 \\
4.01 \\
1.40\end{array}$ & $\begin{array}{l}329 \\
320 \\
222\end{array}$ & $\begin{array}{l}113 \\
164 \\
116\end{array}$ & $\begin{array}{l}.015 \\
.011 \\
.022\end{array}$ & $\begin{array}{l}2 \\
3 \\
3\end{array}$ & $\begin{array}{l}1.16 \\
1.22 \\
1.04\end{array}$ & $\begin{array}{r}162 \\
95.8 \\
148\end{array}$ & $\begin{array}{r}3.30 \\
10.16 \\
3.23\end{array}$ & $\begin{array}{l}2.66 \\
4.06 \\
4.61\end{array}$ & $\begin{array}{l}.622 \\
.520 \\
.602\end{array}$ & $\begin{array}{r}3.2 \\
5.6 \\
11.4\end{array}$ & $\begin{array}{r}100 \\
160 \\
80\end{array}$ & $\begin{array}{l}.423 \\
.484 \\
.178\end{array}$ & $\begin{array}{l}.044 \\
.062 \\
.085\end{array}$ \\
\hline $\begin{array}{l}1.10 \\
3.10 \\
1.38\end{array}$ & $\begin{array}{l}200 \\
240 \\
379\end{array}$ & $\begin{array}{r}74 \\
135 \\
95\end{array}$ & $\begin{array}{l}.018 \\
.011 \\
.018\end{array}$ & $\begin{array}{l}2 \\
2 \\
2\end{array}$ & $\begin{array}{l}1.06 \\
1.19 \\
1.43\end{array}$ & $\begin{array}{c}146 \\
84.8 \\
246\end{array}$ & $\begin{array}{l}1.85 \\
4.83 \\
2.76\end{array}$ & $\begin{array}{r}4.56 \\
3.52 \\
.78\end{array}$ & $\begin{array}{l}.519 \\
.426 \\
.496\end{array}$ & $\begin{array}{l}9.8 \\
3.6 \\
1.1\end{array}$ & $\begin{array}{r}100 \\
60 \\
207\end{array}$ & $\begin{array}{l}.196 \\
.199 \\
.396\end{array}$ & $\begin{array}{l}.099 \\
.057 \\
.099\end{array}$ \\
\hline $\begin{array}{l}2.92 \\
3.70 \\
4.01\end{array}$ & $\begin{array}{l}432 \\
429 \\
393\end{array}$ & $\begin{array}{r}67 \\
176 \\
130\end{array}$ & $\begin{array}{l}.006 \\
.012 \\
.008\end{array}$ & $\begin{array}{l}2 \\
3 \\
3\end{array}$ & $\begin{array}{l}1.18 \\
1.22 \\
1.23\end{array}$ & $\begin{array}{l}159 \\
130 \\
110\end{array}$ & $\begin{array}{l}8.21 \\
8.16 \\
7.31\end{array}$ & $\begin{array}{l}2.21 \\
3.61 \\
3.41\end{array}$ & $\begin{array}{l}.459 \\
.450 \\
.389\end{array}$ & $\begin{array}{l}2.4 \\
1.8 \\
6.0\end{array}$ & $\begin{array}{l}145 \\
252 \\
283\end{array}$ & $\begin{array}{l}.393 \\
.353 \\
.540\end{array}$ & $\begin{array}{l}.069 \\
.135 \\
.199\end{array}$ \\
\hline $\begin{array}{l}1.31 \\
2.04 \\
3.03\end{array}$ & $\begin{array}{l}223 \\
134 \\
254\end{array}$ & $\begin{array}{l}92 \\
50 \\
70\end{array}$ & $\begin{array}{l}.019 \\
.006 \\
.006\end{array}$ & $\begin{array}{l}2 \\
2 \\
3\end{array}$ & $\begin{array}{l}1.11 \\
1.00 \\
1.44\end{array}$ & $\begin{array}{l}163 \\
66.3 \\
109\end{array}$ & $\begin{array}{l}2.58 \\
2.51 \\
6.27\end{array}$ & $\begin{array}{l}3.21 \\
3.15 \\
3.52\end{array}$ & $\begin{array}{l}.550 \\
.459 \\
.610\end{array}$ & $\begin{array}{l}9.9 \\
5.0 \\
6.7\end{array}$ & $\begin{array}{l}80 \\
80 \\
80\end{array}$ & $\begin{array}{l}.190 \\
.230 \\
.232\end{array}$ & $\begin{array}{l}.079 \\
.065 \\
.065\end{array}$ \\
\hline $\begin{array}{l}2.13 \\
9.67 \\
2.60\end{array}$ & $\begin{array}{l}204 \\
274 \\
191\end{array}$ & $\begin{array}{r}92 \\
100 \\
107\end{array}$ & $\begin{array}{l}.009 \\
.002 \\
.011\end{array}$ & $\begin{array}{l}2 \\
4 \\
3\end{array}$ & $\begin{array}{l}1.15 \\
1.51 \\
1.17\end{array}$ & $\begin{array}{r}104 \\
40.1 \\
83.4\end{array}$ & $\begin{array}{r}2.76 \\
33.93 \\
5.20\end{array}$ & $\begin{array}{l}3.36 \\
3.83 \\
2.62\end{array}$ & $\begin{array}{l}.555 \\
.523 \\
.560\end{array}$ & $\begin{array}{l}6.0 \\
6.2 \\
4.5\end{array}$ & $\begin{array}{r}90 \\
120 \\
100\end{array}$ & $\begin{array}{l}.310 \\
.530 \\
.234\end{array}$ & $\begin{array}{l}.054 \\
.042 \\
.080\end{array}$ \\
\hline $\begin{array}{l}5.00 \\
2.43 \\
2.53\end{array}$ & $\begin{array}{l}390 \\
276 \\
165\end{array}$ & $\begin{array}{r}210 \\
172 \\
89\end{array}$ & $\begin{array}{l}.011 \\
.019 \\
.009\end{array}$ & $\begin{array}{l}3 \\
2 \\
3\end{array}$ & $\begin{array}{l}1.29 \\
1.18 \\
1.23\end{array}$ & $\begin{array}{l}92.9 \\
128 \\
75.7\end{array}$ & $\begin{array}{l}8.17 \\
4.20 \\
4.73\end{array}$ & $\begin{array}{l}2.19 \\
3.68 \\
4.14\end{array}$ & $\begin{array}{l}.470 \\
.554 \\
.401\end{array}$ & $\begin{array}{l}2.9 \\
6.1 \\
7.8\end{array}$ & $\begin{array}{l}217 \\
110 \\
190\end{array}$ & $\begin{array}{l}.619 \\
.509 \\
.267\end{array}$ & $\begin{array}{l}.066 \\
.040 \\
.134\end{array}$ \\
\hline $\begin{array}{l}3.65 \\
2.76 \\
2.96\end{array}$ & $\begin{array}{l}232 \\
259 \\
296\end{array}$ & $\begin{array}{l}156 \\
125 \\
160\end{array}$ & $\begin{array}{l}.011 \\
.012 \\
.014\end{array}$ & $\begin{array}{l}3 \\
3 \\
3\end{array}$ & $\begin{array}{l}1.27 \\
1.12 \\
1.14\end{array}$ & $\begin{array}{l}70.3 \\
103 \\
115\end{array}$ & $\begin{array}{r}10.19 \\
5.50 \\
5.58\end{array}$ & $\begin{array}{l}3.12 \\
3.43 \\
3.38\end{array}$ & $\begin{array}{l}.422 \\
.441 \\
.492\end{array}$ & $\begin{array}{l}5.5 \\
5.6 \\
5.45\end{array}$ & $\begin{array}{l}110 \\
200 \\
150\end{array}$ & $\begin{array}{l}.425 \\
.283 \\
.280\end{array}$ & $\begin{array}{l}.049 \\
.133 \\
.101\end{array}$ \\
\hline $\begin{array}{l}4.19 \\
3.17\end{array}$ & $\begin{array}{l}342 \\
402\end{array}$ & $\begin{array}{l}132 \\
112\end{array}$ & $\begin{array}{l}.008 \\
.009\end{array}$ & $\begin{array}{l}3 \\
2\end{array}$ & $\begin{array}{l}1.34 \\
1.11\end{array}$ & $\begin{array}{l}81.6 \\
91.4\end{array}$ & $\begin{array}{l}9.88 \\
5.13\end{array}$ & $\begin{array}{l}3.45 \\
1.44\end{array}$ & $\begin{array}{l}.525 \\
.432\end{array}$ & $\begin{array}{l}5.24 \\
1.12\end{array}$ & $\begin{array}{l}110 \\
230\end{array}$ & $\begin{array}{l}.065 \\
.820\end{array}$ & $\begin{array}{l}.320 \\
.053\end{array}$ \\
\hline
\end{tabular}




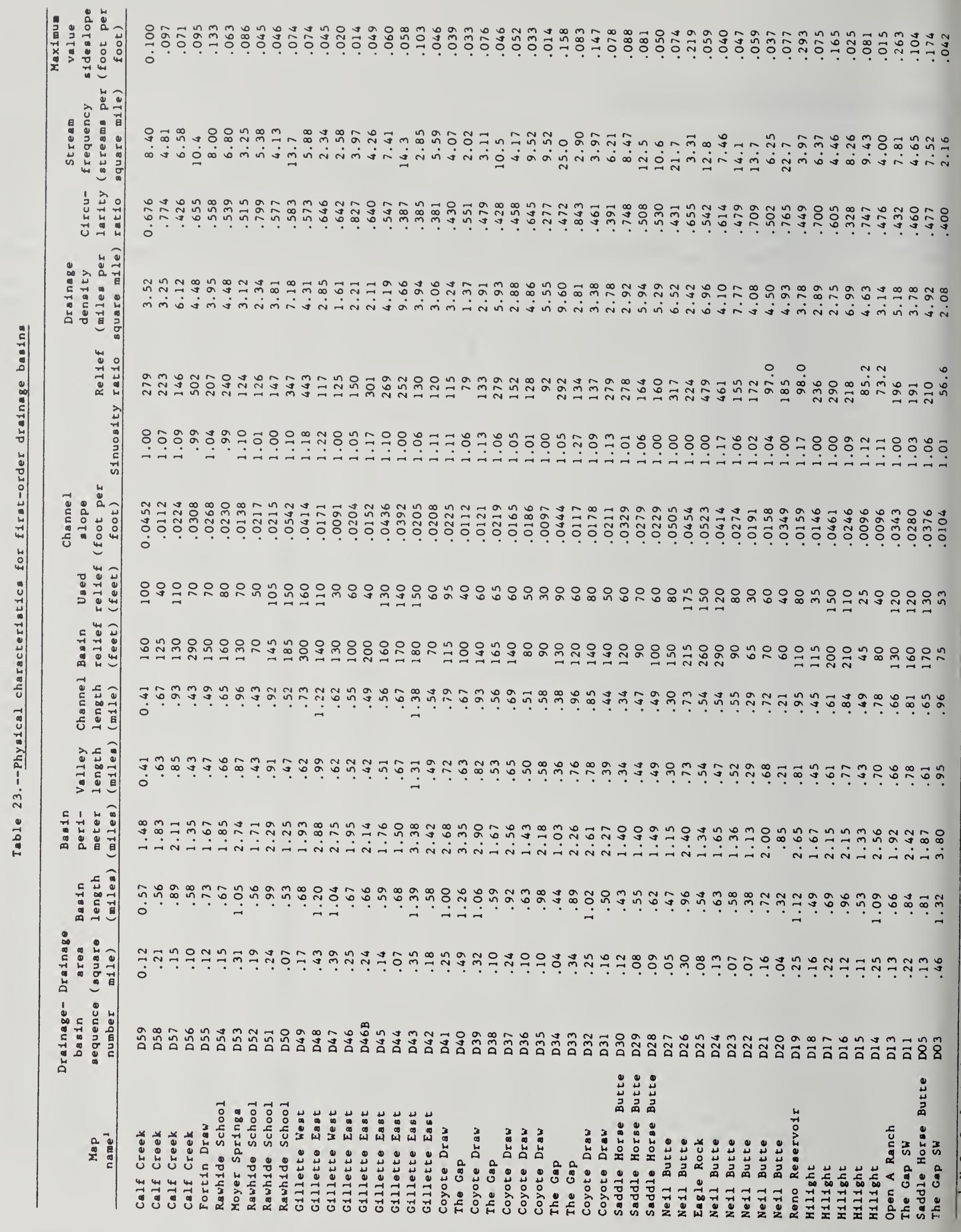


Table 24.--Statistical properties for first-order drainage basins

[Number of basins in sample $=51$ ]

\begin{tabular}{|c|c|c|c|c|c|c|}
\hline \multirow[b]{2}{*}{ Characteristic } & \multirow[b]{2}{*}{ Minimum } & \multirow[b]{2}{*}{ Maximum } & \multirow{2}{*}{$\begin{array}{l}\text { Arith- } \\
\text { metic } \\
\text { mean }\end{array}$} & \multirow{2}{*}{$\begin{array}{c}\text { Geo- } \\
\text { metric } \\
\text { mean }\end{array}$} & \multicolumn{2}{|c|}{$\begin{array}{c}\text { Standard } \\
\text { deviation of } \\
\text { geometric mean, } \\
\text { in percent } \\
\end{array}$} \\
\hline & & & & & Minus & Plus \\
\hline $\begin{array}{l}\text { Drainage area } \\
\text { (square miles) }\end{array}$ & 0.04 & 0.49 & 0.19 & 0.16 & 46.7 & 87.7 \\
\hline Basin length (miles) & .32 & 1.39 & .76 & .72 & 28.8 & 40.5 \\
\hline Basin perimeter (miles) & .85 & 3.81 & 2.02 & 1.92 & 27.8 & 38.6 \\
\hline Valley length (miles) & .22 & 1.31 & .61 & .58 & 29.1 & 41.1 \\
\hline Channel length (miles) & .22 & 1.38 & .65 & .61 & 30.6 & 44.0 \\
\hline Basin relief (feet) & 45.0 & 300 & 140 & 129 & 34.3 & 51.9 \\
\hline Used relief (feet) & 25.0 & 175 & 82.2 & 72.8 & 39.8 & 66.2 \\
\hline $\begin{array}{l}\text { Channel slope (foot } \\
\text { per foot) }\end{array}$ & .009 & .054 & .026 & .023 & 50.6 & 102 \\
\hline Sinuosity & 1.00 & 1.28 & 1.06 & 1.06 & 5.9 & 6.26 \\
\hline Relief ratio & 56.6 & 502 & 204 & 180 & 39.6 & 66.0 \\
\hline $\begin{array}{l}\text { Total channel length } \\
\text { (miles) }\end{array}$ & .22 & 1.38 & .65 & .61 & 30.6 & 44.0 \\
\hline $\begin{array}{l}\text { Drainage density } \\
\text { (miles per square mile) }\end{array}$ & 1.37 & 9.66 & 4.26 & 3.90 & 34.7 & 52.9 \\
\hline Circularity ratio & .277 & .843 & .551 & .535 & 21.2 & 28.5 \\
\hline $\begin{array}{l}\text { Maximum value sideslope } \\
\text { (foot per foot) }\end{array}$ & .014 & .293 & .081 & .065 & 49.1 & 96.6 \\
\hline
\end{tabular}


Table 25.--Statistical properties for second-order drainage basins

[Number of basins in sample $=22$ ]

\begin{tabular}{|c|c|c|c|c|c|c|}
\hline \multirow[b]{2}{*}{ Characteristic } & \multirow[b]{2}{*}{ Minimum } & \multirow[b]{2}{*}{ Maximum } & \multirow{2}{*}{$\begin{array}{l}\text { Arith- } \\
\text { metic } \\
\text { mean } \\
\end{array}$} & \multirow{2}{*}{$\begin{array}{c}\text { Geo- } \\
\text { metric } \\
\text { mean }\end{array}$} & \multicolumn{2}{|c|}{$\begin{array}{c}\text { Standard } \\
\text { deviation of } \\
\text { geometric mean, } \\
\text { in percent } \\
\end{array}$} \\
\hline & & & & & Minus & Plus \\
\hline $\begin{array}{l}\text { Drainage area } \\
\text { (square miles) }\end{array}$ & 0.04 & 3.70 & 1.32 & 1.09 & 45.5 & 83.3 \\
\hline Basin length (miles) & $1 . .10$ & 4.40 & 1.98 & 1.89 & 26.7 & 36.4 \\
\hline Basin perimeter (miles) & 2.80 & 10.2 & 5.36 & 5.06 & 28.3 & 39.5 \\
\hline Basin width (miles) & .41 & 1.70 & .74 & .69 & 32.1 & 47.3 \\
\hline Valley length (miles) & .96 & 2.85 & 1.74 & 1.66 & 26.9 & 36.7 \\
\hline Channel length (miles) & 1.10 & 3.17 & 2.00 & 1.91 & 26.9 & 36.9 \\
\hline Basin relief (feet) & 134 & 432 & 266 & 254 & 27.0 & 37.0 \\
\hline Used relief (feet) & 50.0 & 124 & 116 & 107 & 33.1 & 49.4 \\
\hline $\begin{array}{l}\text { Channel slope (foot } \\
\text { per foot) }\end{array}$ & .006 & .037 & .016 & .015 & 39.3 & 64.7 \\
\hline Sinuosity & 1.01 & 1.50 & 1.16 & 1.15 & 8.81 & 9.65 \\
\hline Relief ratio & 66.3 & 246 & 143 & 135 & 30.3 & 43.5 \\
\hline $\begin{array}{l}\text { Total channel length } \\
\text { (miles) }\end{array}$ & 1.53 & 8.21 & 3.40 & 3.17 & 30.6 & 44.2 \\
\hline $\begin{array}{l}\text { Drainage density } \\
\text { (miles per square mile) }\end{array}$ & .784 & 4.92 & 3.12 & 2.92 & 33.5 & 50.6 \\
\hline Circularity ratio & .424 & .757 & .540 & .533 & 14.8 & $17 \cdot 3$ \\
\hline $\begin{array}{l}\text { Stream frequency } \\
\text { (streams per } \\
\text { square mile) }\end{array}$ & 1.12 & 9.96 & 5.06 & 4.41 & 44.3 & 79.6 \\
\hline $\begin{array}{l}\text { Maximum sideslope relief } \\
\text { (feet) }\end{array}$ & 60.0 & 230 & 127 & 118 & 31.7 & 46.5 \\
\hline Sideslope distance (miles) & .054 & .820 & .349 & .306 & 43.8 & 78.0 \\
\hline $\begin{array}{l}\text { Maximum value sideslope } \\
\text { (foot per foot) }\end{array}$ & .041 & .421 & .090 & .073 & 42.5 & 74.0 \\
\hline $\begin{array}{l}\text { Average channel length for } \\
\text { first-order basins } \\
\text { (miles) }\end{array}$ & .210 & .84 & .511 & .471 & 35.6 & 55.4 \\
\hline $\begin{array}{l}\text { Average channel length for } \\
\text { second-order basins } \\
\text { (miles) }\end{array}$ & .360 & 3.08 & 1.40 & 1.21 & 44.0 & 78.5 \\
\hline
\end{tabular}


Table 26.--Statistical properties for third-order drainage basins

[Number of basins in sample $=24$ ]

\begin{tabular}{|c|c|c|c|c|c|c|}
\hline \multirow[b]{2}{*}{ Characteristic } & \multirow[b]{2}{*}{ Minimum } & \multirow[b]{2}{*}{ Maximum } & \multirow{2}{*}{$\begin{array}{l}\text { Arith- } \\
\text { metic } \\
\text { mean }\end{array}$} & \multirow{2}{*}{$\begin{array}{l}\text { Geo- } \\
\text { metric } \\
\text { mean }\end{array}$} & \multicolumn{2}{|c|}{$\begin{array}{c}\text { Standard } \\
\text { deviation of } \\
\text { geometric mean, } \\
\text { in percent } \\
\end{array}$} \\
\hline & & & & & Minus & Plus \\
\hline $\begin{array}{l}\text { Drainage area } \\
\text { (square miles) }\end{array}$ & 0.70 & 4.16 & 2.31 & 2.11 & 37.3 & 59.4 \\
\hline Basin length (miles) & 1.50 & 4.20 & 2.90 & 2.80 & 24.1 & 31.8 \\
\hline Basin perimeter (miles) & 3.82 & 10.1 & 7.51 & 7.31 & 21.9 & 28.1 \\
\hline Basin width (miles) & .47 & 1.61 & .98 & .94 & 26.3 & 35.8 \\
\hline Valley length (miles) & 1.34 & 3.87 & 2.67 & 2.58 & 24.9 & 33.1 \\
\hline Channel length (miles) & 1.40 & 5.00 & 3.28 & 3.13 & 28.2 & 39.2 \\
\hline Basin relief (feet) & 165 & 461 & 306 & 292 & 26.2 & 35.5 \\
\hline Used relief (feet) & 70.0 & 210 & 135 & 130 & 23.8 & 31.2 \\
\hline $\begin{array}{l}\text { Channel slope (foot } \\
\text { per foot) }\end{array}$ & .005 & .303 & .012 & .011 & 31.8 & 46.6 \\
\hline Sinuosity & 1.04 & 1.44 & 1.22 & 1.21 & 8.24 & 8.98 \\
\hline Relief ratio & 61.7 & 209 & 110 & 104 & 28.3 & 39.4 \\
\hline $\begin{array}{l}\text { Total channel length } \\
\text { (miles) }\end{array}$ & 3.23 & 14.1 & 7.82 & 7.27 & 33.0 & 49.4 \\
\hline $\begin{array}{l}\text { Drainage density } \\
\quad \text { (miles per square mile) }\end{array}$ & 1.96 & 4.82 & 3.54 & 3.45 & 21.0 & 26.6 \\
\hline Circularity ratio & .389 & .681 & .501 & .495 & 13.1 & 16.5 \\
\hline $\begin{array}{l}\text { Stream frequency } \\
\text { (streams per } \\
\text { square mile) }\end{array}$ & 2.96 & 11.4 & 5.93 & 5.53 & 31.3 & 45.4 \\
\hline $\begin{array}{l}\text { Maximum sideslope relief } \\
\text { (feet) }\end{array}$ & 80.0 & 300 & 153 & 141 & 33.4 & 50.1 \\
\hline Sideslope distance (miles) & .065 & 2.31 & .415 & .316 & 50.8 & 103 \\
\hline $\begin{array}{l}\text { Maximum value sideslope } \\
\text { (foot per foot) }\end{array}$ & .008 & .320 & .108 & .087 & 51.1 & 104 \\
\hline $\begin{array}{l}\text { Average channel length for } \\
\text { first-order basins } \\
\text { (miles) }\end{array}$ & .284 & .785 & .467 & .453 & 21.5 & 27.3 \\
\hline $\begin{array}{l}\text { Average channel length for } \\
\text { second-order basins } \\
\text { (miles) }\end{array}$ & .330 & 2.00 & .884 & .797 & 38.3 & 62.1 \\
\hline $\begin{array}{l}\text { Average channel length for } \\
\text { third-order basins } \\
\text { (miles) }\end{array}$ & .360 & 4.14 & 1.61 & 1.32 & 48.8 & 95.4 \\
\hline
\end{tabular}


Table 27.--Statistical properties for fourth-order drainage basins

[Number of basins in sample $=5$ ]

\begin{tabular}{|c|c|c|c|c|c|c|}
\hline \multirow[b]{2}{*}{ Characteristic } & \multirow[b]{2}{*}{ Minimum } & \multirow[b]{2}{*}{ Maximum } & \multirow{2}{*}{$\begin{array}{l}\text { Arith- } \\
\text { metic } \\
\text { mean }\end{array}$} & \multirow{2}{*}{$\begin{array}{l}\text { Geo- } \\
\text { metric } \\
\text { mean }\end{array}$} & \multicolumn{2}{|c|}{$\begin{array}{c}\text { Standard } \\
\text { deviation of } \\
\text { geometric mean, } \\
\text { in percent }\end{array}$} \\
\hline & & & & & Minus & Plus \\
\hline $\begin{array}{l}\text { Drainage area } \\
\text { (square miles) }\end{array}$ & 3.22 & 8.84 & 6.48 & 6.04 & 35.8 & 55.8 \\
\hline Basin length (miles) & 2.95 & 6.84 & 5.17 & 4.96 & 28.5 & 39.8 \\
\hline Basin perimeter (miles) & 7.68 & 14.7 & 12.51 & 12.21 & 23.4 & 30.6 \\
\hline Basin width (miles) & 1.31 & 1.97 & 1.70 & 1.68 & 15.5 & 18.3 \\
\hline Valley length (miles) & 2.92 & 6.40 & 4.79 & 4.59 & 28.4 & 39.7 \\
\hline Channel length (miles) & 3.20 & 9.67 & 6.56 & 6.06 & 37.1 & 59.1 \\
\hline Basin relief (feet) & 274 & 405 & 358 & 355 & 15.3 & 18.0 \\
\hline Used relief (feet) & 100 & 220 & 150 & 146 & 24.7 & 32.9 \\
\hline $\begin{array}{l}\text { Channel slope (foot } \\
\text { per foot) }\end{array}$ & .003 & .019 & .010 & .008 & 53.3 & 114 \\
\hline Sinuosity & 1.10 & 1.51 & 1.33 & 1.32 & 12.4 & 14.2 \\
\hline Relief ratio & 40.0 & 137 & 77.8 & 71.6 & 36.4 & 57.1 \\
\hline $\begin{array}{l}\text { Total channel length } \\
\text { (miles) }\end{array}$ & 10.8 & 33.9 & 21.3 & 19.6 & 36.9 & 58.5 \\
\hline $\begin{array}{l}\text { Drainage density } \\
\text { (miles per square mile) }\end{array}$ & 2.47 & 3.83 & 3.28 & 3.24 & 15.3 & 18.0 \\
\hline Circularity ratio & .353 & .680 & .522 & .510 & 21.8 & 27.8 \\
\hline $\begin{array}{l}\text { Stream frequency } \\
\text { (streams per } \\
\text { square mile) }\end{array}$ & 2.44 & 7.76 & 5.52 & 5.15 & 36.0 & 56.2 \\
\hline $\begin{array}{l}\text { Maximum sideslope relief } \\
\text { (feet) }\end{array}$ & 120 & 300 & 157 & 145 & 33.3 & 50.0 \\
\hline Sideslope distance (miles) & .092 & 1.07 & .433 & .294 & 64.1 & 179 \\
\hline $\begin{array}{l}\text { Maximum value sideslope } \\
\text { (foot per foot) }\end{array}$ & .043 & .247 & .121 & .097 & 53.2 & 113 \\
\hline $\begin{array}{l}\text { Average channel length for } \\
\text { first-order basins } \\
\text { (miles) }\end{array}$ & .353 & .592 & .454 & .441 & 22.8 & 29.5 \\
\hline $\begin{array}{l}\text { Average channel length for } \\
\text { second-order basins } \\
\text { (miles) }\end{array}$ & .497 & 1.26 & .77 & .730 & 28.7 & 40.2 \\
\hline $\begin{array}{l}\text { Average channel length for } \\
\text { third-order basins } \\
\text { (miles) }\end{array}$ & .350 & 3.44 & 1.66 & 1.25 & 60.0 & 150 \\
\hline $\begin{array}{l}\text { Average channel length for } \\
\text { fourth-order basins } \\
\text { (miles) }\end{array}$ & .800 & 5.17 & 2.52 & 1.92 & 56.3 & 128 \\
\hline
\end{tabular}




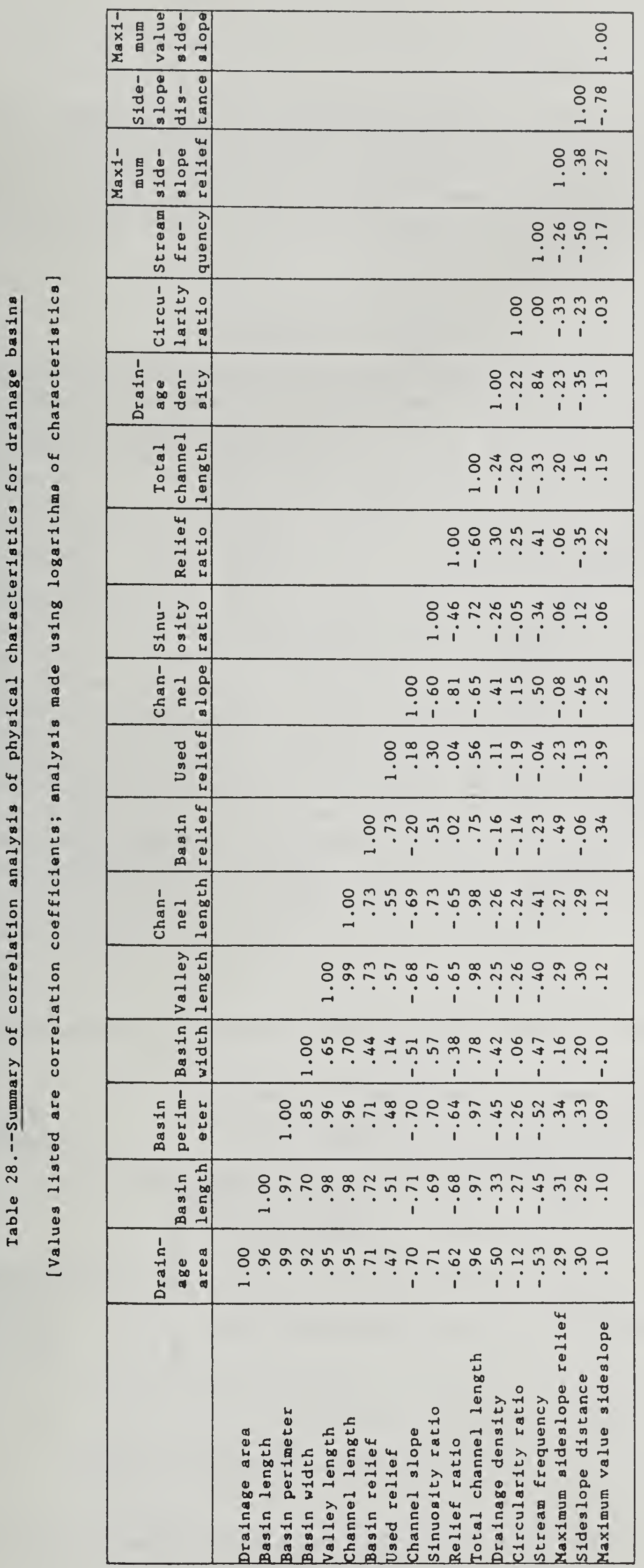


These correlations were used as a guide to develop graphs (figs. 43-45) and regression relations (table 29) for the physical characteristics that are significantly related and that are considered important in assessing drainage-basin stability. These relations were then used to compare the physical characteristics from postmining plans to those existing for natural drainage basins of the area.

\section{Illustrative Example}

An example of how the previously described graphs and relations quantify physical characteristics of natural drainage basins follows, using a headwater drainage basin of $1.9 \mathrm{mi}^{2}$. The data and relation of drainagebasin order to drainage area in figure 43 indicate that, on the average for the data base in this study, a drainage-basin order of 2.8 is necessary to drain an area of $1.9 \mathrm{mi}^{2}$. The figure 2.8 rounds to the whole number 3 , indicating the main stream channel at the mouth of the drainage basin needs to be a third-order stream channel. On the basis of the relative numbers of stream channels in various orders for the study sample, the relations in figure 44 indicate that for a drainage area of $1.9 \mathrm{mi}^{2}, 12$ first-order, 3 second-order, and 1 third-order stream channels also are necessary to complete the drainage network. The average slope of first- to fourth-order stream channels is shown by the relation in figure 45, which illustrates that lower-order stream channels and valleys have relatively steeper gradients than do higher-order stream channels and valleys. Valley slope, which has not previously been defined in the report, is computed by either: (1) Multiplying stream-channel slope by sinuosity, or (2) dividing used relief by the length of valley between the points identified in used relief. As shown in the example ( $\mathrm{fig}$. 45), a second-order stream channel will have a slope of $0.016 \mathrm{ft} / \mathrm{ft}$, on the average. The physical characteristics of the example drainage basin are summarized in table 30.

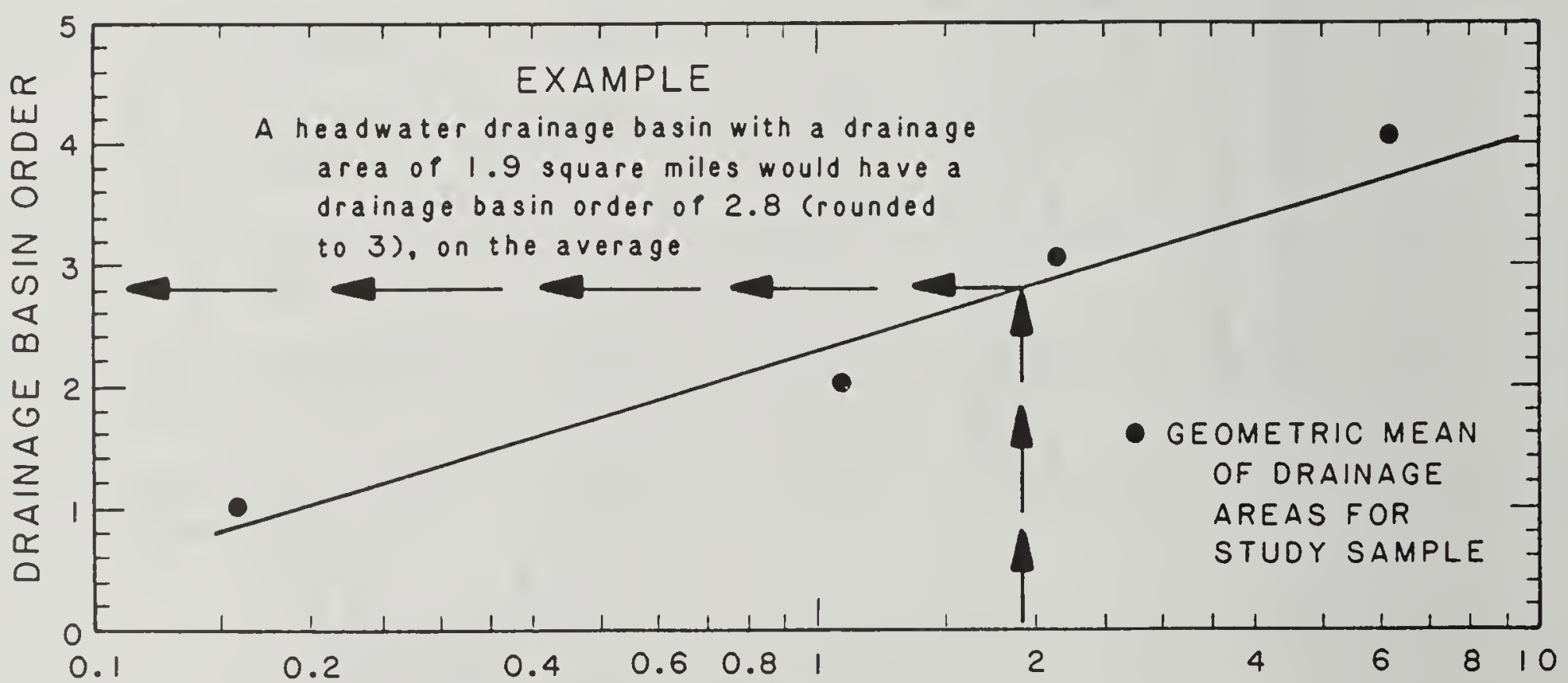

DRAINAGE AREA, IN SQUARE MILES

Figure 43.--Relation of drainage-basin order to drainage area. 


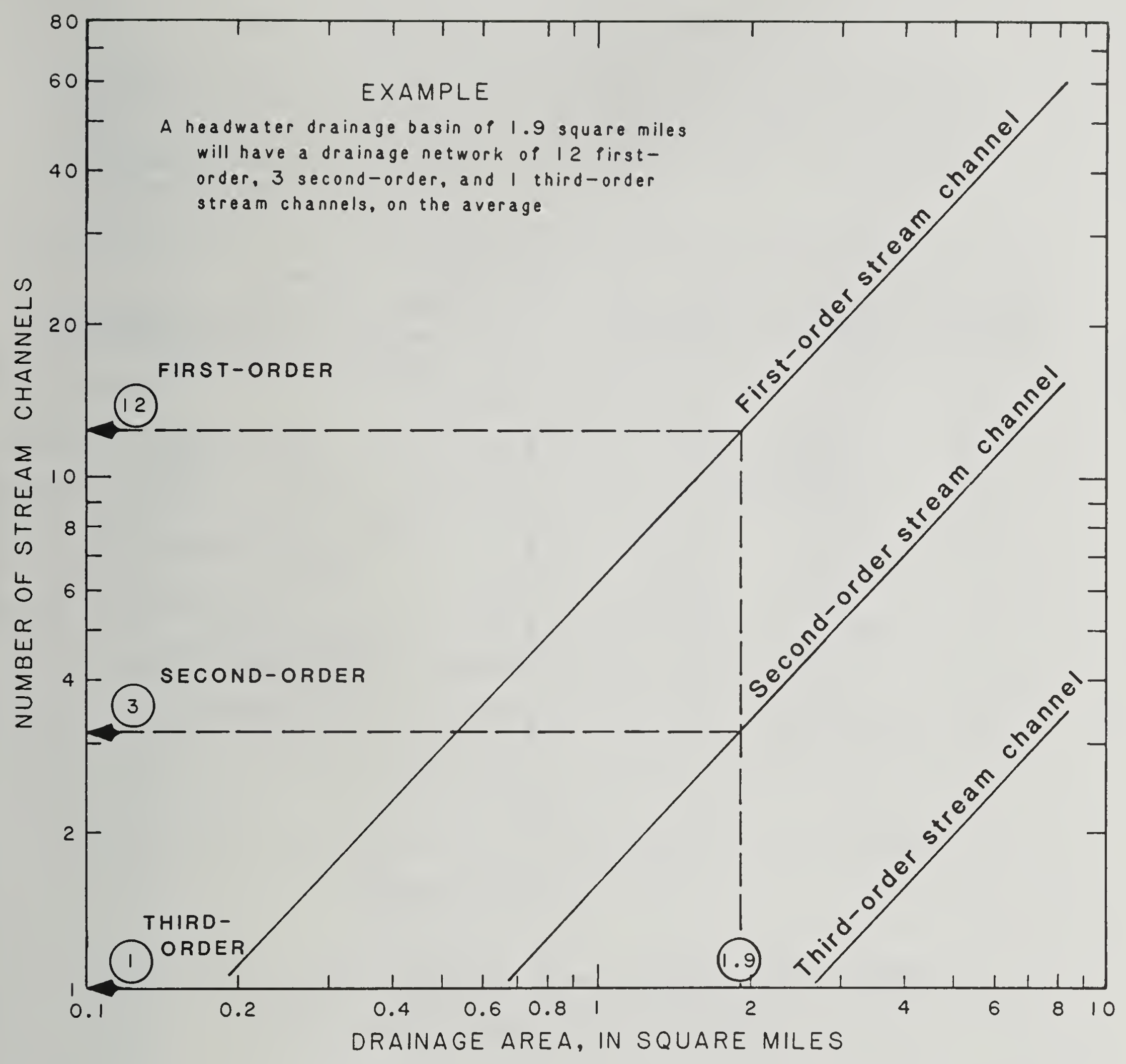

Figure 44.--Relation of number of stream channels to drainage area. 


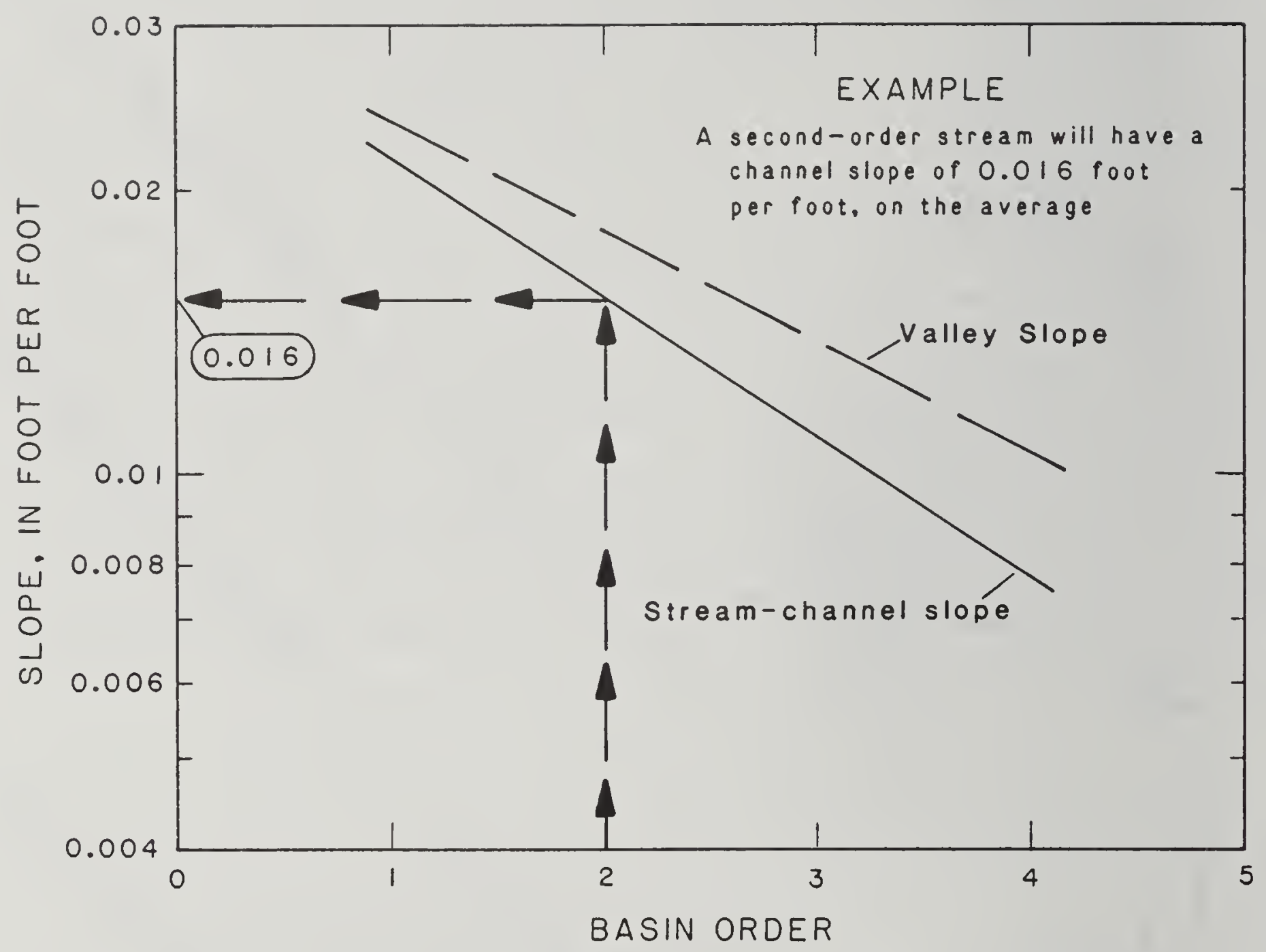

Figure 45.--Relations of stream-channel and valley slopes to drainage-basin order. 
Table 29.--Summary of regression analysis

[BL, basin length, in miles; AREA, drainage area, in square miles; RELIEF, basin relief, in feet; UR, used relief, in feet; CHAN-L, length of main stream channel, in miles; CHAN-S, average slope of main stream channel, in foot per foot; and CL-TOTAL, total length of stream channels, in miles]

\begin{tabular}{|c|c|c|c|c|}
\hline \multirow[b]{2}{*}{ Regression equation } & \multirow{2}{*}{$\begin{array}{c}\text { Correlation } \\
\text { coefficient } \\
\text { (R) }\end{array}$} & \multicolumn{3}{|c|}{ Standard error of estimate (SE) } \\
\hline & & Log units & Average & Percent \\
\hline$B L=1.85$ AREA 0.51 & 0.96 & 0.091 & -18.9 & +23.3 \\
\hline RELIEF $=227$ AREA 0.28 & .71 & .164 & -31.5 & +23.3 \\
\hline RELIEF $=163 \mathrm{BL} 0.52$ & .72 & .163 & -31.3 & -45.5 \\
\hline$U R=2.56$ RELIEF 0.69 & .73 & .144 & -28.2 & +39.3 \\
\hline CHAN-L $=0.92 \mathrm{BL}^{1.16}$ & .98 & .066 & -14.1 & +16.4 \\
\hline CHAN-S $=0.00036 \mathrm{BL}^{-0.89} \mathrm{UR}^{0.90}$ & .96 & .072 & -15.3 & +18.0 \\
\hline CL-TOTAL $=3.22$ AREA 0.86 & .96 & .147 & -28.7 & +40.3 \\
\hline
\end{tabular}


Table 30.-- Physical characteristics for example drainage basin

[BL, basin length, in miles; AREA, drainage area, in square miles; RELIEF, basin relief, in feet; UR, used relief, in feet; CHAN-L, length of main stream channel, in miles; CHAN-S, average slope of main stream channel, in foot per foot; and CL-TOTAL, total length of stream channels, in miles]

Basin area $=1.9 \mathrm{mi}^{2}$

Characteristics from relations of figures 43 to 45

Average slope of first-order stream channels $=0.022$ foot per foot

Average slope of second-order stream channels $=0.016$ foot per foot

Average slope of the third-order stream channels $=0.011$ foot per foot

Characteristics from regression relations in table 29

Basin length $=B L=1.85$ AREA $^{0.51}=1.85(1.9)^{0.51}=2.6$ miles

Basin relief $=$ RELIEF $=227$ AREA $^{0.20}=227(1.9)^{0.20}=270$ feet

Used relief $=$ UR $=2.56$ RELIEF $^{0.69}=2.56(270)^{0.69}=120$ feet

Length of main stream channel $=$ CHAN $-\mathrm{L}=0.92 \mathrm{BL}^{1.16}=0.92(2.6)^{1.16}$

$=2.8$ miles

Average slope of main stream channel $=$ CHAN-S $=0.00036 \mathrm{BL}^{-0.89} \mathrm{UR}^{0.90}$

$$
=0.00036(2.6)^{-0.09}(120)^{0.090}
$$

$=0.0114$ foot per foot

Total length of stream channels $=$ CL-TOTAL $=3.22$ AREA 0.86

$$
\begin{aligned}
& =3.22(1.9)^{0.86} \\
& =5.6 \text { miles }
\end{aligned}
$$


The results of a hypsometric analysis evaluating the stability of natural drainage basins can be used to determine how well re-constructed drainage basins compare with natural drainage basins. Hypsometric analysis provides a quantitative description of the distribution of material within a drainage basin from the base, or low point of the basin, to the top, or high point of the basin (Strahler, 1952, 1964). A hypsometric analysis was made for second-and higher-order drainage basins in the data base of the study sample. The average hypsometric curve for the respective drainage-basin order is shown in figures 46-48. The curves indicate the relative area that exists at various heights within the drainage basin from measurements of the area between successive land-surface contours on a topographic map. The square in which each of the curves are plotted may be visualized as a vertical section through the mass of material that will be removed as the drainage basin evolves (Schumm, 1977, p. 68-69).

The shape of a hypsometric curve provides a representation of the erosional development of a drainage basin in time. During erosion of a drainage basin, the shape of the hypsometric curve will change from convex upward to virtually straight and then to concave upward (Schumm, 1977, p. 70). Such changes indicate that the zone of maximum erosion migrates with time toward the head of the drainage basin. The concave shape of the hypsometric curves for all three drainage-basin orders indicates the basins have reached a state in their geomorphic development where further development will be slow.

A review of the means and standard deviations of the hypsometric sample data indicates that the variability of material distribution decreases with increasing stream order. That is, the standard deviation of the data for fourth-order drainage basins is less than that for third-order drainage basins, and so forth. This is because: (1) The larger drainage basins are older and have had more time to develop than many of the smaller headwater basins, and (2) the larger drainage basins have the magnitude of streamflow and associated energy necessary to attain a base level of equilibrium despite erosion-resistant outcrops and inequalities in surface structure.

\section{Impacts of Surface Coal Mining on Drainage-Basin Stability}

As discussed in detail earlier, the method used for determining the cumulative impact of surface coal mining and reclamation on drainage-basin stability involved: (1) Comparison of characteristics for premining and postmining drainage basins, (2) review of the methods used for design of the re-constructed drainage networks and stream channels, and (3) visits of areas that have already been reclaimed. 


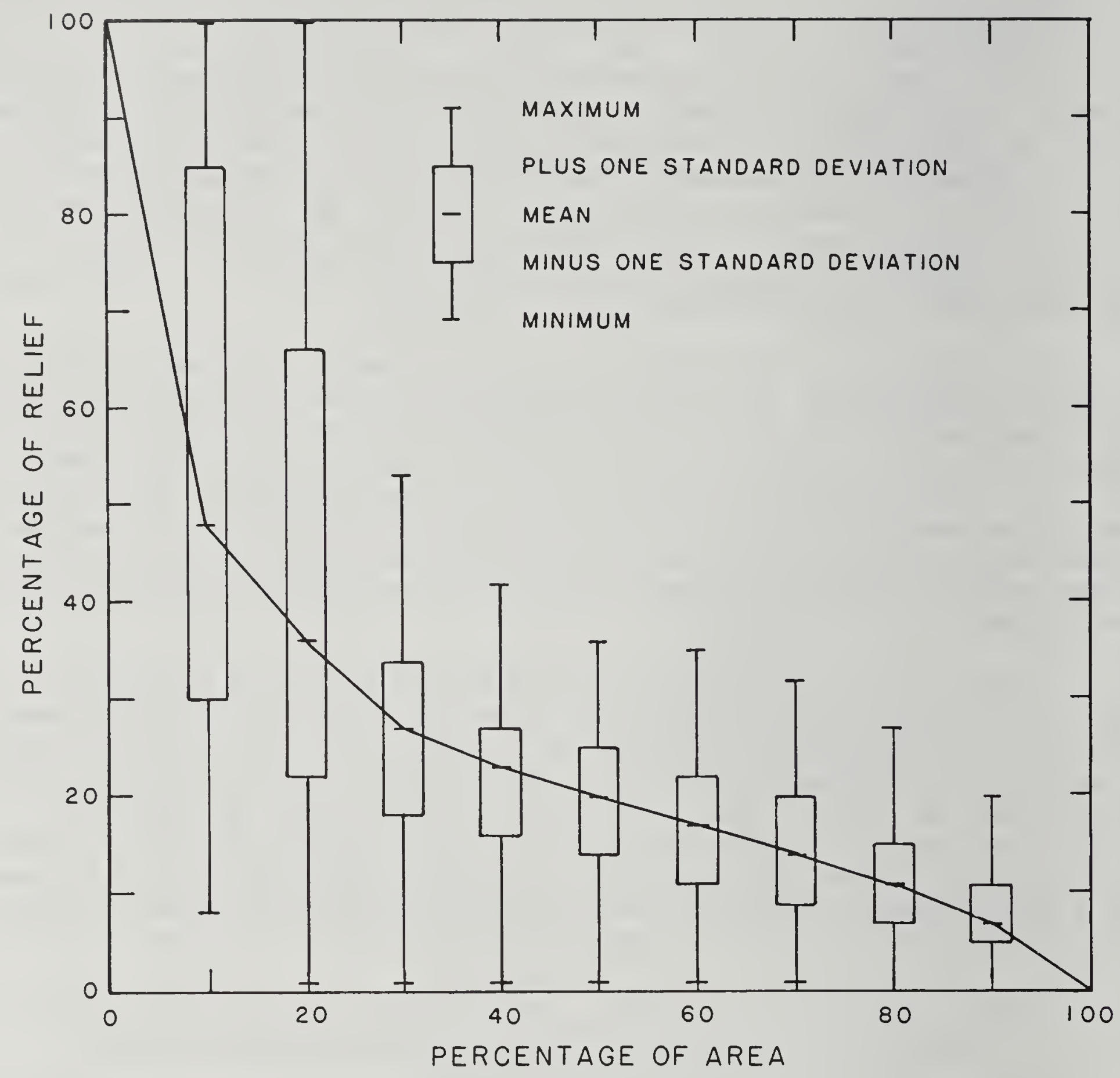

Figure 46.--Average hypsometric curve for second-order drainage basins (represents 22 basins). 


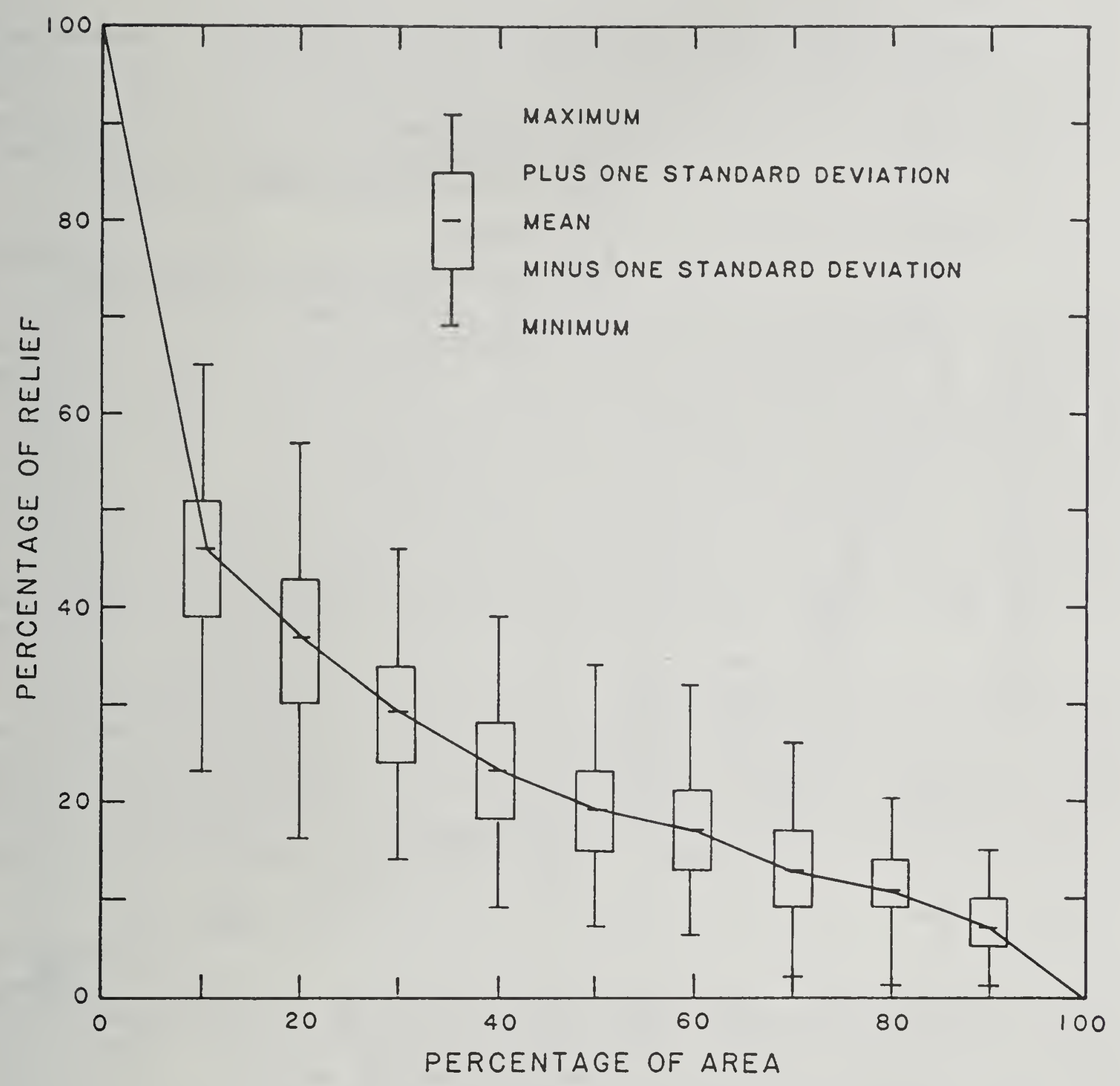

Figure 47.--Average hypsometric curve for third-order drainage basins (represents 24 basins). 


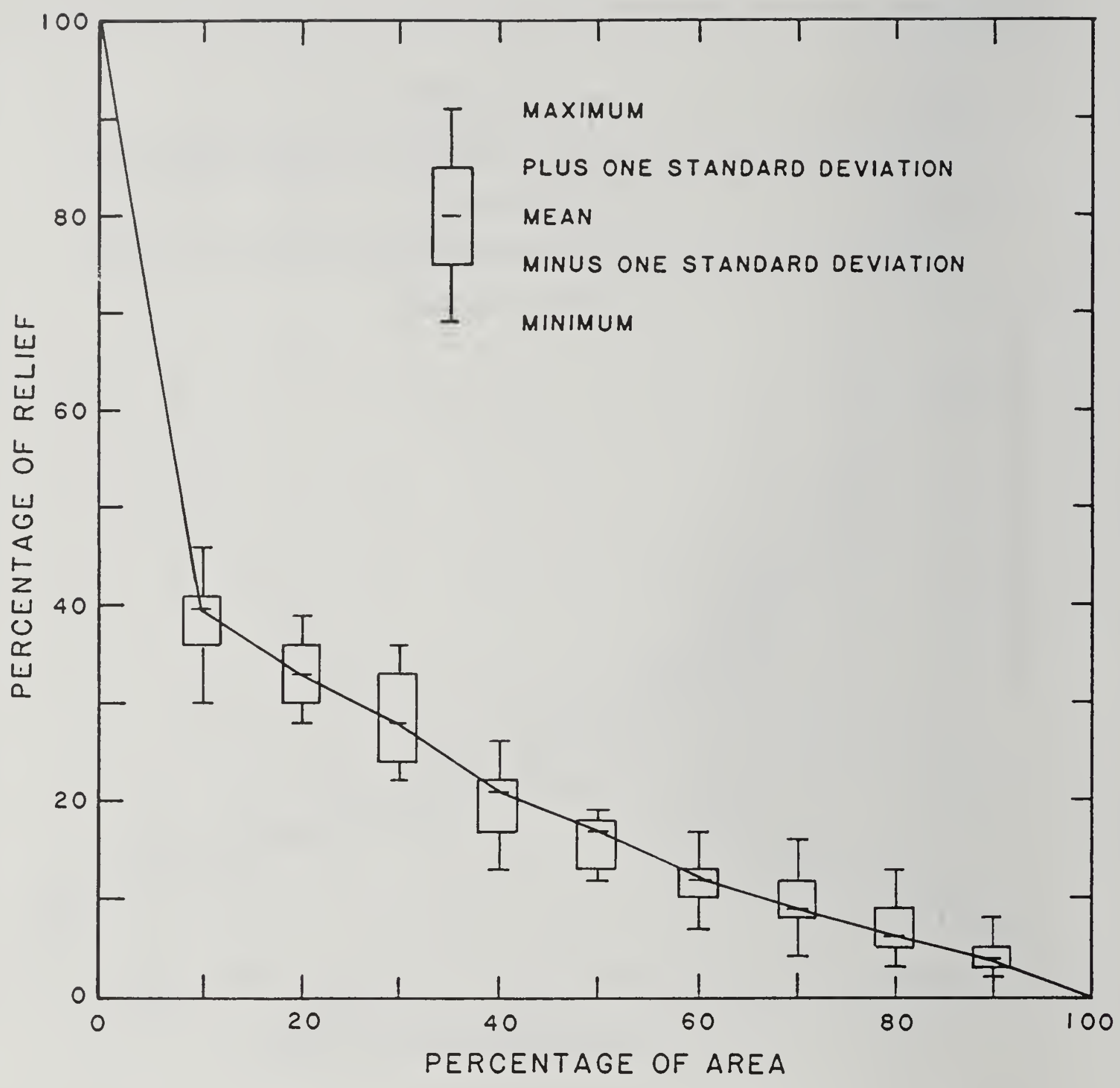

Figure 48.--Average hypsometric curve for fourth-order drainage basins (represents five basins). 
The plans for postmining topography and drainage were reviewed for each of the existing mines. A sample of 33 drainage basins planned for re-construction was randomly selected, using at least one drainage basin for each mine. Drainage area, drainage-basin order, channel length, used relief, and stream-channel and valley slopes were determined for each drainage basin from maps of the postmining topography and drainage (table 31). Assuming re-vegetation of interfluve areas is successful, stream-channel slope, valley slope, and drainage density are among the most important characteristics to drainage-basin stability.

\section{$\underline{\text { Stream-channel slope }}$}

The slope of a stream stream channel affects stability. Unstable stream channels resulting from rapid velocities and erosion of streambeds and banks are most likely to occur in reaches with steep gradients. A plot of stream-channel slopes for the sample of postmining drainage basins in comparison to the average relation determined for natural drainage basins is shown in figure 49. The slopes measured for the sample of postmining stream channels are consistent with the range of slopes for the sample of natural drainage basins. Data for only one postmining stream channel plots above the line depicting the maximum slopes measured for the sample of natural stream channels. Slopes for most postmining stream channels plot close to the average relation for the natural drainage basins.

The drainage-basin orders used for plotting the postmining streamchannel slopes in figure 49 were calculated using figure 43 , rather than using the actual drainage-basin order shown on the postmining maps. This was done to afford comparability between the 1:24,000-scale topographic maps used for determining the natural characteristics and the topographic maps of $1: 4,800$ to $1: 12,000$ scale used for postmining plans.

\section{Valley slope}

The sinuosity and slope of a stream channel are affected by valley slope (Schumm, 1977, p. 137-149). In addition to the control imposed by surface geology, variation of valley slope can be caused by changes in rates of colluvium deposition from hillslopes and increases in sediment loads from tributaries. Sinuosity of a re-constructed stream channel could be shown on a postmining plan to dictate appropriate stream-channel distance and slope to achieve nonerosive velocity. However, re-constructed stream channels can be modified by subsequent high flows; valley slope is a more suitable indicator than stream-channel slope of drainage-basin stability.

A comparison of valley slopes for the natural and postmining drainage basins is shown in figure 50. With the exception of one valley with a relatively steep slope, the valley slopes for the sample of postmining drainage basins plot near or below the average relation of valley slope for the sample of natural drainage basins. 
Table 31.--Physical characteristics for sample of postmining drainage basins

$$
[-- \text {, not determined }]
$$

\begin{tabular}{|c|c|c|c|c|c|c|c|c|}
\hline $\begin{array}{c}\text { Drainage } \\
\text { area } \\
\text { (square } \\
\text { miles) }\end{array}$ & $\begin{array}{l}\text { Basin } \\
\text { order }\end{array}$ & $\begin{array}{c}\text { Basin } \\
\text { order } \\
\text { computed } \\
\text { from } \\
\text { figure } 42\end{array}$ & $\begin{array}{l}\text { Total } \\
\text { channel } \\
\text { length } \\
\text { (miles) }\end{array}$ & $\begin{array}{l}\text { Used } \\
\text { relief } \\
\text { (feet) }\end{array}$ & $\begin{array}{l}\text { Channel } \\
\text { length } \\
\text { (miles) }\end{array}$ & $\begin{array}{l}\text { Channel } \\
\text { slope } \\
\text { (foot } \\
\text { per } \\
\text { foot) }\end{array}$ & $\begin{array}{l}\text { Valley } \\
\text { length } \\
\text { (miles) }\end{array}$ & $\begin{array}{l}\text { Valley } \\
\text { slope } \\
\text { (foot } \\
\text { per } \\
\text { foot) }\end{array}$ \\
\hline 0.08 & 1 & 1 & 0.41 & 55 & 0.41 & 0.026 & 0.39 & 0.027 \\
\hline .09 & 1 & 1 & .68 & 41 & .68 & .016 & .62 & .018 \\
\hline .11 & 1 & 1 & .41 & 75 & .41 & .035 & .40 & .036 \\
\hline .11 & 2 & 1 & 1.13 & 60 & .53 & .031 & .50 & .032 \\
\hline .13 & 1 & 1 & .50 & 46 & .50 & .025 & .48 & .031 \\
\hline .15 & 1 & 1 & .61 & 80 & .61 & .025 & .59 & .026 \\
\hline .15 & 1 & 1 & .54 & 60 & .54 & .021 & .51 & .022 \\
\hline .16 & 1 & 1 & .46 & 40 & .46 & .017 & .43 & .018 \\
\hline .18 & 1 & 1 & .49 & 42 & .49 & .016 & .47 & .017 \\
\hline .18 & 1 & 1 & .68 & 37 & .68 & .015 & .63 & .016 \\
\hline .21 & 1 & 1 & .51 & 51 & .51 & .027 & .44 & .031 \\
\hline .24 & 1 & 1 & .46 & 60 & .46 & .025 & .44 & .026 \\
\hline .25 & 2 & 1 & 1.53 & 65 & .89 & .020 & .87 & .020 \\
\hline .29 & 1 & 1 & .72 & 65 & .72 & .024 & .69 & .025 \\
\hline .35 & 1 & 1 & .72 & 154 & .72 & .058 & .68 & .061 \\
\hline .37 & 1 & 1 & .73 & 40 & .73 & .010 & .70 & .010 \\
\hline .38 & 1 & 1 & 1.30 & 95 & 1.30 & .020 & 1.22 & .021 \\
\hline .38 & 2 & 1 & 1.20 & 77 & .83 & .026 & .80 & .027 \\
\hline .40 & 1 & 2 & .70 & 34 & .70 & .013 & .69 & .013 \\
\hline .42 & 1 & 2 & .87 & 31 & .87 & .010 & .79 & .010 \\
\hline .46 & 1 & 2 & .92 & 70 & .92 & .021 & -- & -- \\
\hline .48 & 1 & 2 & 1.62 & 85 & 1.62 & .014 & 1.50 & .015 \\
\hline .53 & 1 & 2 & 1.41 & 55 & 1.41 & .011 & 1.18 & .013 \\
\hline .57 & 1 & 2 & 1.40 & 42 & 1.40 & .008 & 1.25 & .009 \\
\hline .78 & 1 & 2 & 1.85 & 152 & 1.85 & .022 & 1.21 & .024 \\
\hline .83 & 3 & 2 & 3.98 & 64 & 1.47 & .012 & 1.40 & .013 \\
\hline .88 & -- & 2 & -- & 85 & 1.15 & .019 & 1.13 & .019 \\
\hline 1.08 & 1 & 2 & 1.40 & 51 & 1.40 & .010 & 1.36 & .010 \\
\hline 1.12 & 3 & 2 & 6.54 & 133 & 2.58 & .014 & 2.39 & .015 \\
\hline 2.48 & 3 & 3 & 10.1 & 170 & 3.75 & .012 & 3.40 & .013 \\
\hline 4.39 & 2 & 3 & 4.58 & 125 & 3.35 & .007 & 2.59 & .009 \\
\hline 5.80 & 2 & 4 & 6.50 & 69 & 2.91 & .006 & 2.77 & .007 \\
\hline 18.1 & 4 & 4 & 77.3 & 220 & 10.3 & .006 & 8.07 & .008 \\
\hline
\end{tabular}




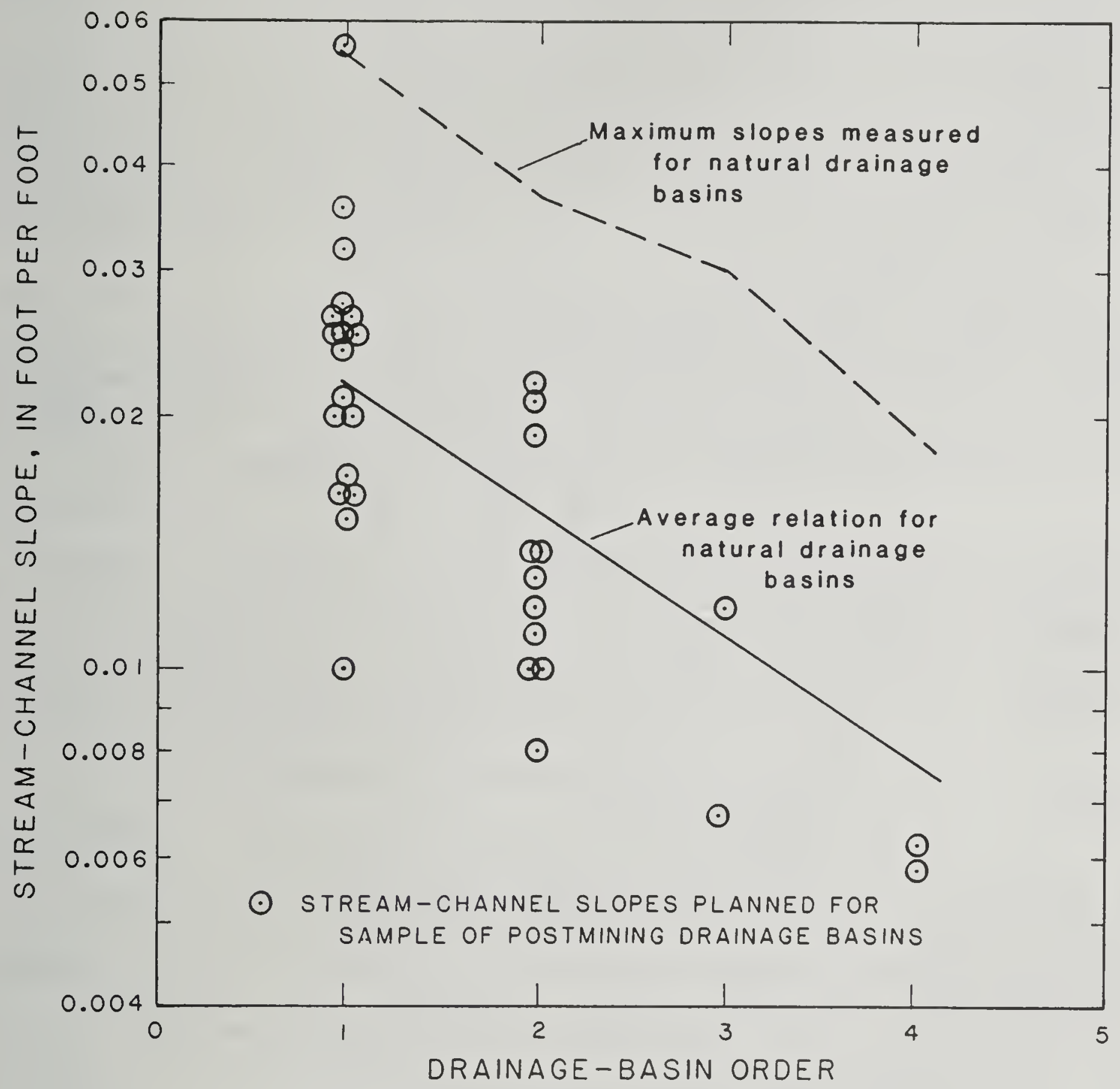

Figure 49.--Comparison of stream-channel slopes for natural and postmining drainage basins. 


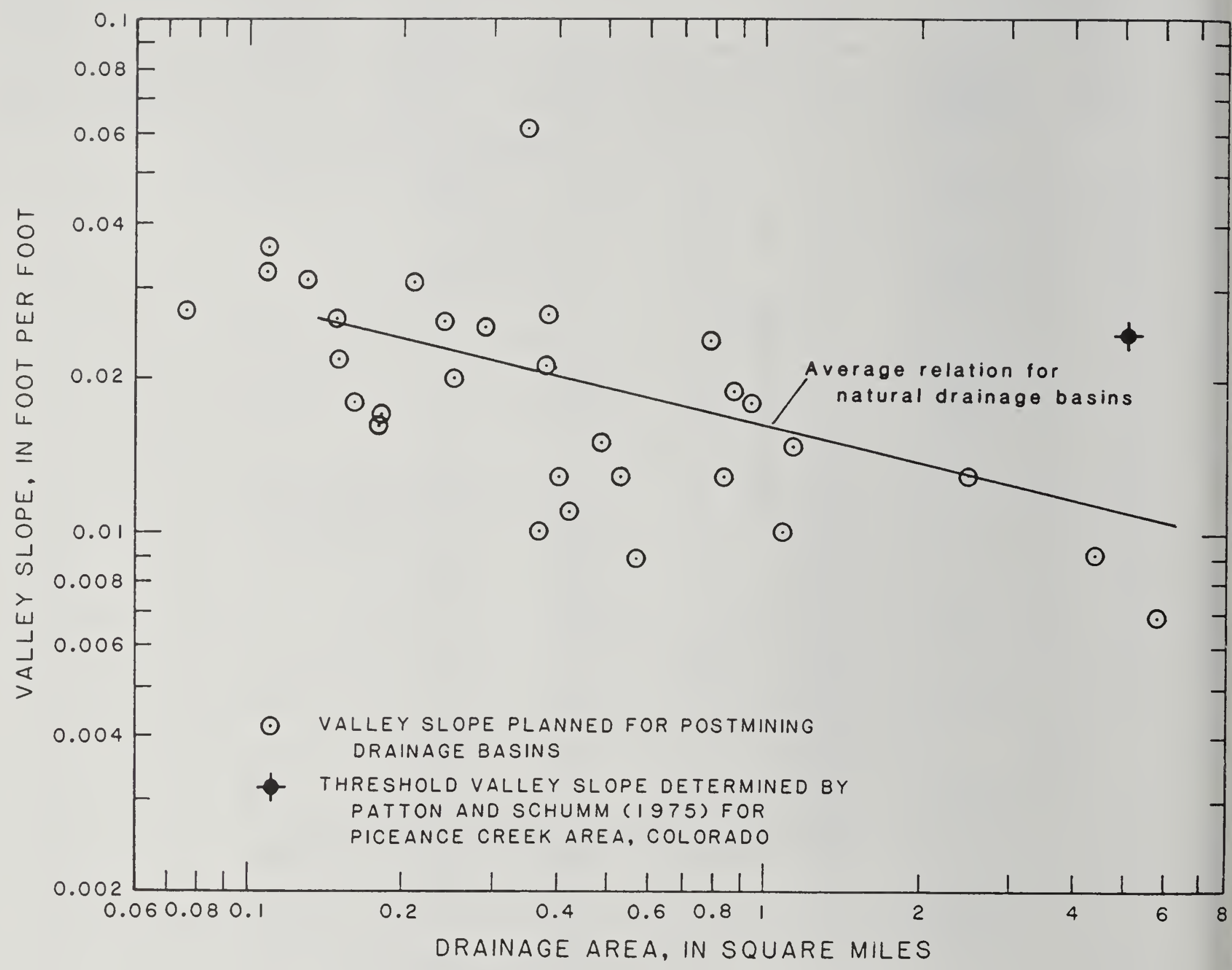

Figure 50.--Comparison of valley slopes for natural and postmining drainage basins. 
A threshold value of valley slope, above which instability of the stream occurs, has been examined for arid and semiarid regions by several investigators. For example, studies by Schumm and Hadley (1957) in semiarid valleys of Arizona, Colorado, New Mexico, and Wyoming indicated that discontinuous gullies can be related to slope of the valley. Patton and Schumm (1975) examined measurements of valley slope for drainage basins in the Piceance Creek area of Colorado, and defined a relation of threshold slope with drainage area, above which trenching or valley instability will occur. The relation was considered not to pertain to drainage basins smaller than about $5 \mathrm{mi}^{2}$, perhaps because vegetative cover becomes more dominant in small drainage basins and because local differences in vegetation prevent clear recognition of a critical threshold slope. The threshold slope at $5 \mathrm{mi}^{2}$ was determined to be about $0.024 \mathrm{ft} / \mathrm{ft}$ for the Piceance Creek area. This value is shown on figure 50 as a comparison to the data summarized in this study.

An investigation of areas containing reclaimed surface coal mines in Colorado currently (1987) is being conducted by the U.S. Geological Survey. According to John Elliot (U.S. Geological Survey, written commun., 1987), surveys of $10 \mathrm{first-and} \mathrm{second-order} \mathrm{drainage} \mathrm{basins} \mathrm{that} \mathrm{were} \mathrm{reclaimed}$ 3 years ago indicate that a threshold valley slope does appear to be in effect. However, additional surveys are being conducted, and the threshold relation has not been quantified yet (1987).

In summary, relations for defining specific threshold slopes of stream channels and valleys in the study area are not available; however, the slopes for the sample of postmining drainage basins are similar to those of the natural drainage basins. Assuming the valleys and stream channels are constructed as planned, no substantial impacts either on or offsite are expected in relation to the postmining slopes.

\section{Drainage density}

A review of the drainage-basin orders listed in table 31 indicates that for many of the stream channels designated as second order by the relation in figure 43, only a first-order stream channel was shown on the postmining maps. In addition, even though the 1:4,800- to $1: 12,000$-scale postmining topographic maps are larger and more detailed than the 1:24,000-scale topographic maps used for measuring the natural characteristics, fewer stream channels per unit area are shown for postmining drainage basins than occur for natural drainage basins. In general, the coal-mining companies are designing postmining topography with a lesser drainage density than occurs naturally in the area.

A comprehensive study of the determination of drainage density for surface-mine reclamation in the western United States has been made by Gregory and others (1985). Their study included the measurement of drainage density for 69 natural drainage basins near the Dave Johnston and Jim Bridger Coal Mines in Wyoming, and the McKinley Coal Mine in New Mexico. They note that drainage density is a geomorphic variable that integrates effects of other basin characteristics and they suggest that if the optimum density is restored, the initial adjustment of a reclaimed area should be minimal. Gregory and others (1985, p. 1) conclude "There is a 
characteristic drainage density for each location, and when this is identified, it should be used in reclamation design." However, they also note that surface coal mining and reclamation will change properties of the natural drainage basin that will affect drainage density, that characteristic drainage densities will require adjustment as a result of such changes, and that additional research is needed in order to refine estimates of drainage density.

Schaefer and others (1979) suggested that postmining drainage density could be estimated using measurements of premining drainage basins and aerial photographs, and then the drainage density could be increased to account for the effects of disruption. Conversely, Stiller and others (1980) note that reclaiming a drainage basin with a greater drainage density than the natural drainage density could create additional impacts such as increased magnitude of flood peaks. They suggest reclaiming with a drainage density at least equal to the premining drainage density.

A well-developed drainage density promotes efficient drainage, resulting in shorter runoff time with correspondingly higher peak flows. Due to the interrelations of various drainage-basin features on drainage density, the design of the optimum density that will result in the most stable landscape is complex. For example, because the dendritic drainage pattern is efficient, it also may be the most erosive. Zimpfer and others (1982, p. 3) describe studies conducted at the Rainfall-Erosion Facility (REF) that was built at Colorado State University to examine the erosional development of drainage patterns and other phenomena of drainage-basin evolution. On the basis of results of studies using the REF, Zimpfer and others (1982, p. 11) concluded that it may not be necessary to re-establish first-order stream channels on a reclaimed surface. They determined that first-order stream channels would eventually form, but that sediment yields from a drainage basin with only the larger-order stream channels would be less than yields from a fully re-constructed drainage basin with first-order stream channels.

As discussed by Chorley and others (1984, p. 257-258), drainage density is interrelated with the angle and length of hillslopes. As shown in figure 51, the greater the drainage density, the more closely streams are spaced and the steeper the hillslopes will be. Steep hillslopes usually contribute a large quantity of sediment to stream channels; stream channels also must be steep to transport the sediment.

Although headcuts and gullys characterize stream channels where erosion is occurring, surface erosion on unrilled slopes yielded 98 percent of the total sediment in a semiarid area of New Mexico (Leopold and others, 1966, p. 239). Likewise, Rankl (1987, p. 15) made detailed measurements of a tributary of Dugout Creek, a semiarid basin in Wyoming with active headcuts. He determined that sediment contribution of the headcuts was a relatively minor part of the total sediment yield from the drainage basin. Because steep hillslopes have overland flows with rapid velocities, which contribute to sediment yield, then re-constructed drainage basins with lesser drainage densities and correspondingly flatter hillslopes may yield smaller sediment yields. 


\section{LOW RELIEF}
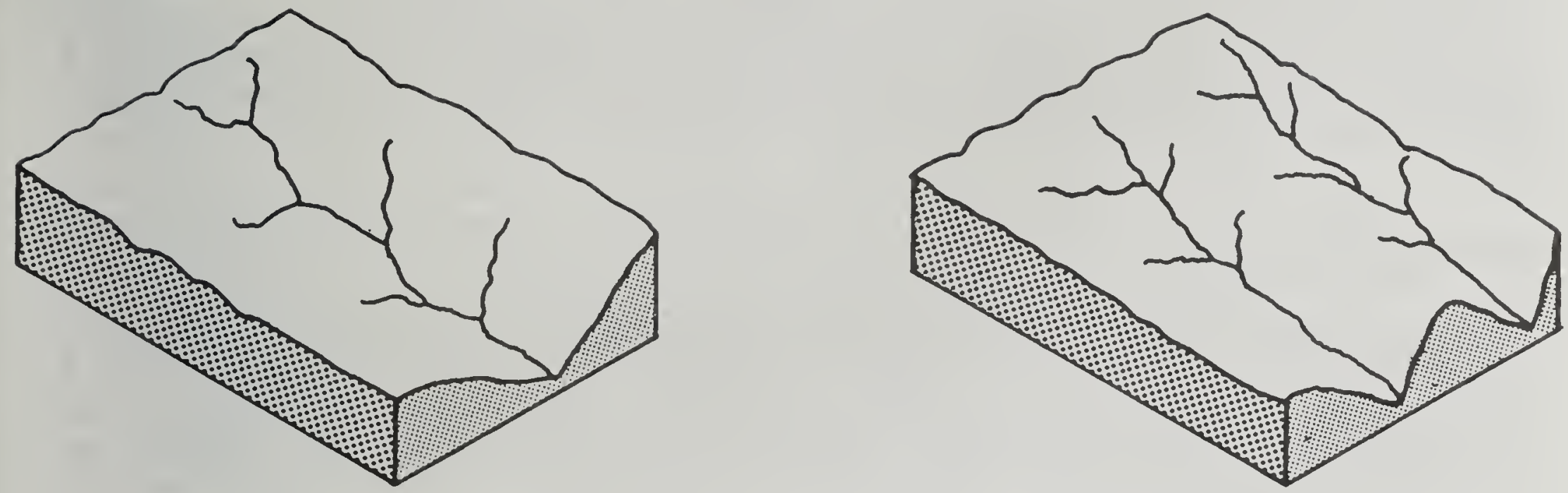

HIGH RELIEF

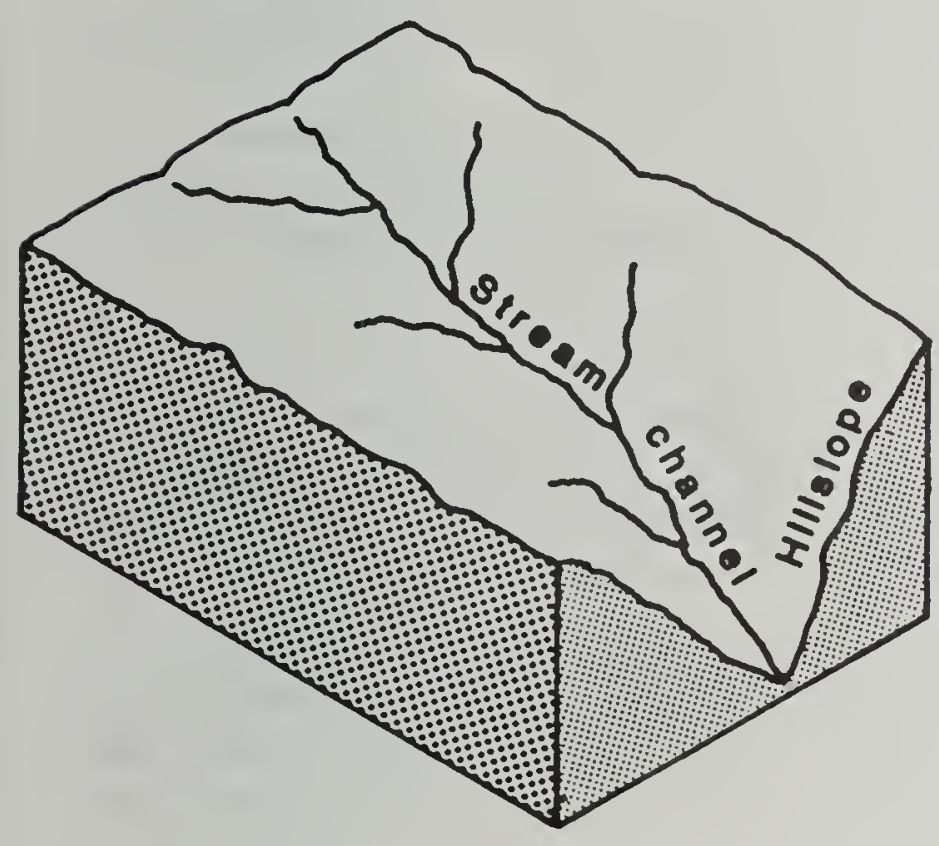

Minimal drainage density

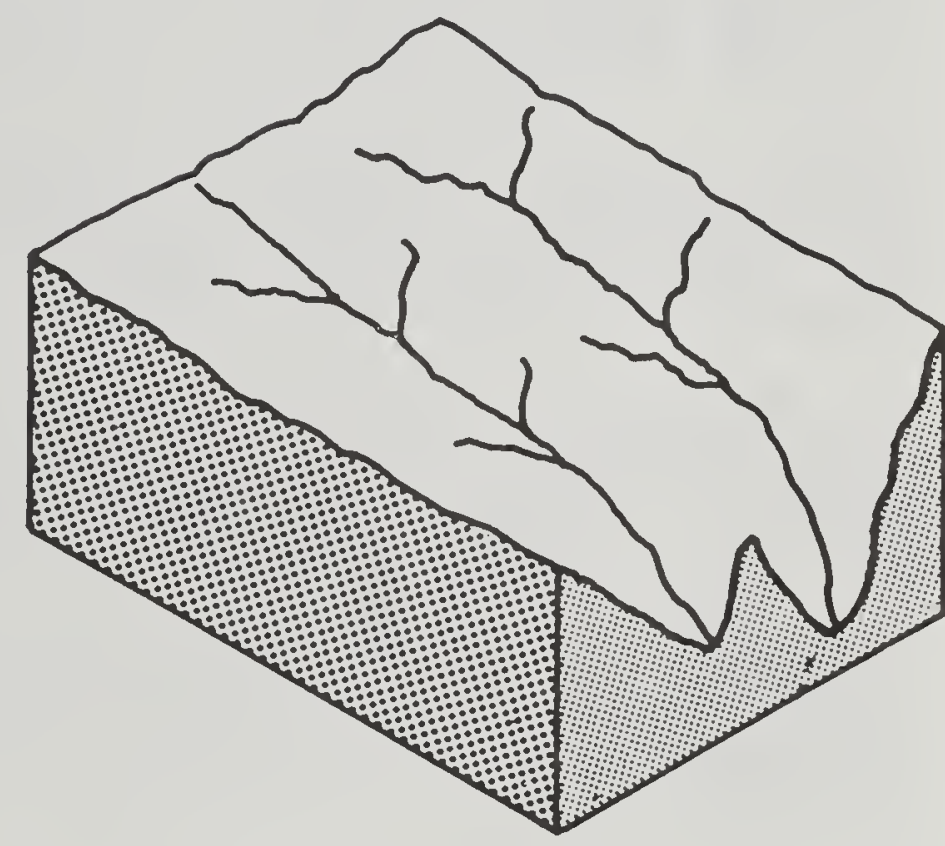

Substantial drainage density

Figure 51.--Effects of drainage density and relief on hillslope inclination and length. 
In summary, reclamation procedures using somewhat lesser drainage densities than occur naturally may improve re-vegetation success and decrease sedimentation problems. However, this conclusion is based on limited laboratory data and on onsite studies of natural drainage basins; additional laboratory studies of re-constructed drainage basins and onsite studies of reclaimed drainage basins are needed to verify optimum drainage patterns and densities.

Hypsometric analysis

Mine plans indicate that many of the coal-mining companies analyzed hypsometric curves for the premining drainage basins and also developed curves for the postmining drainage basins. Most of the postmining hypsometric curves have less concavity (indicating an early state of erosional development) than depicted for the sample of natural drainage basins in figures 46-48. Hypsometric curves with lines that are convex upward or straight do not necessarily mean faster rates of erosion and greater sediment load will occur in drainage basins than in basins with hypsometric curves that are concave upward. Parker (1977) reported that drainage density of a basin increases toward the headwater areas as a drainage basin evolves. If drainage basins are reclaimed with only the second-and higher-order stream channels re-constructed, they will be similar to natural drainage basins in an early stage of development, and further stream-channel development is likely to occur. However, this does not necessarily indicate faster rates of erosion in or greater sediment load from the drainage basin will occur.

As was noted earlier, in the discussion of drainage density, streamchannel reaches where erosion and deposition occur are readily visible. Erosion of topsoil, increased sediment loads, and destruction of vegetation will occur locally as first-order stream channels are established and as the drainage network evolves. However, reclamation of drainage basins to simulate an early state of erosional development may improve overall re-vegetation success and result in lesser annual sediment yield from the drainage basin.

\section{Review of Design Methods}

Two basic approaches, geomorphic and engineering, exist for the design of drainage networks and steam channels. As discussed by Toy and Hadley (1987), numerous problems are encountered with each approach. The geomorphic approach advocates re-construction of drainage basins to premining conditions; however, few onsite studies document the successful use of geomorphic principles for large mined areas in the arid and semiarid western United States. The engineering approach uses estimates of water and sediment discharges that the drainage network and stream channels must transport; however, these values generally need to be estimated and, consequently, are approximate. 
The application of geomorphic relations derived from natural or premining drainage basins to the design of postmining drainage basins is based on the assumption that postmining drainage basins will have runoff, lithology, soil, and vegetative cover similar to premining drainage basins. As described in the section concerning impacts on surface water, infiltration and runoff are expected to return to normal after about 6 years. Reclamation is directed toward the re-establishment of soil and vegetative cover. However, lithology cannot be re-established. Many of the first-and second-order stream channels for natural drainage basins have steep slopes that are supported by outcrops of erosion-resistant rocks. If such outcrops are not present in the postmining drainage basins, then slopes indicated by the geomorphic relations may be steeper than the reclaimed areas of spoil material can actually support. As surface coal mining progresses, documentation of successes and failures in the re-establishment of drainage basins will be necessary to the refinement of design methods.

The engineering approach to design of fluvial systems generally relies on estimates of streamflow and sediment loads; engineering design of stable stream channels also requires estimates of roughness factors. Many estimates are being made in such designs, and it is likely that some stream channels will be misdesigned. Local sedimentation and erosion will occur as misdesigned stream channels adjust to the actual surrounding conditions.

The ideal procedure for reclaiming mined areas is to construct a drainage network that would optimize overall stability and immediately minimize erosion and sediment transport. However, the realities of the state-of-the-art regarding drainage-basin and stream-channel design, as well as construction techniques, make this impossible. For example, even if the perfect drainage-basin and stream-channel design were implemented, unpredictable differential settling of the spoil material is likely to occur that would affect the hydrologic function of the drainage basin.

The design for at least one reclaimed area (Wyodak Mine) contains plans for a large depression to be left as a permanent feature, with a major stream routed around the depression. The bank and terrace between the stream and depression are to be stabilized against erosion, and the streamchannel capacity is designed to convey maximum expected floodflows. During a long period, this stream or others might possibly meander and intercept the depression. This would cause some erosion and sedimentation as the stream channel adjusted to the steep slope entering the depression; however, the depression would eventually fill with water and sediment. An occurrence such as this could have substantial local impact on the stream channel as it would result in a change in downstream hydrologic conditions, including: (1) Loss of water available to downstream water users, (2) degraded water quality due to less flow available for dilution of dissolved solids, and (3) possible lowered ground-water levels near the stream channel due to less water available for recharge. For such problems in reclamation, provisions for a long-term maintenance program may be needed. 
In June 1987, H.W. Lowham visited several mines that have been operating since the 1970's. Reclaimed areas were toured, and re-construction methods were discussed with company representatives for the Eagle Butte, Belle Ayr, Black Thunder, Cordero, and Antelope Mines. The following observations were noted:

1. Stream channels of third and higher order have been given a great deal of attention in design, because it is realized that flow in these stream channels can be large and such flow can occur frequently enough to be of immediate concern. A combination of engineering- and geomorphic-design methods generally has been used in the re-construction of these streams.

2. When stabilizing temporary storage piles or finishing off the highwall at the mined-area boundary, the general practice is to construct steep-sloped areas to maximize runoff as sheet flow and to avoid forming stream channels until absolutely necessary. Much effort is given to achieving re-vegetation with dense stands of grasses and shrubs in order to retard runoff and erosion.

3. The areas reclaimed to date (1987) generally appear to be stable. However, it is difficult to assess long-term stability from observations of the existing reclaimed areas because erosion damage, such as rilling and gullying, generally is immediately repaired.

4. Company representatives are concerned about the procedures that will be used for reclamation of the end-of-mine highwalls. Small drainage basins located just outside the highwall perimeter, but draining into the mined area, have potential to cause some of the greatest problems. For example, two small drainage basins that need to be re-constructed are shown in figure 52. If the stream channels are constructed without artificial structures or other innovative features, such as construction of storage and recharge areas to capture flow from the small drainage basins, then a great quantity of material will have to be moved to achieve stable streamchannel slopes in the vicinity of the highwall. Because thick coal beds are being removed, at most surface coal mines there will be an insufficient volume of overburden to accomplish the re-construction, and material may have to be borrowed from unmined areas. In addition to being extremely expensive, the disturbance of an unmined area for the purposes of borrowing soil material may be environmentally questionable.

In summary, the reclaimed areas appear to be stable, but they have been in existence for only a short time relative to the semiarid climate and infrequent nature of runoff in the study area. Rills that might develop on reclaimed areas are immediately repaired. Therefore, information obtained from the inspection was inconclusive in determining long-term stability of the reclaimed basins. 


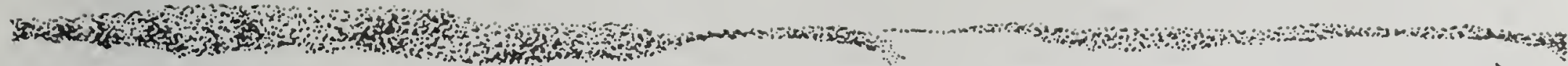

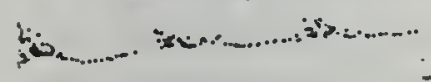

ras

1.

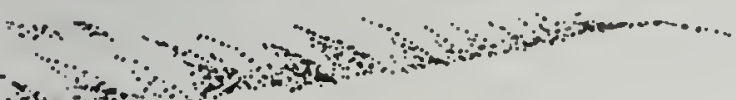

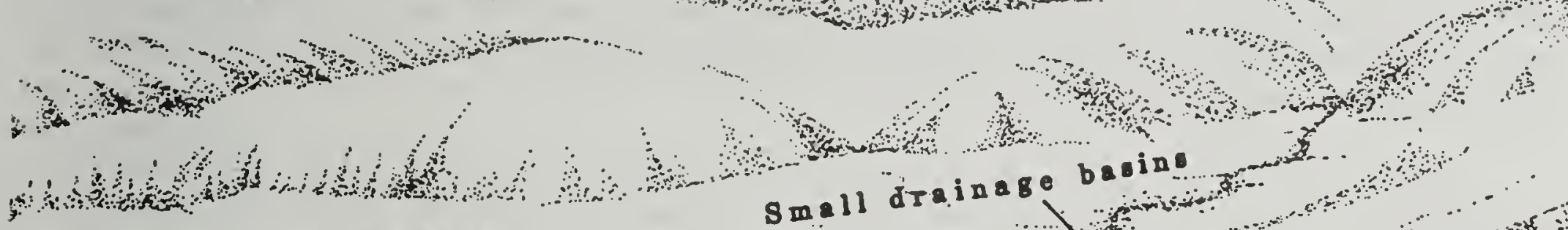
Unmined area Small dratage bagne

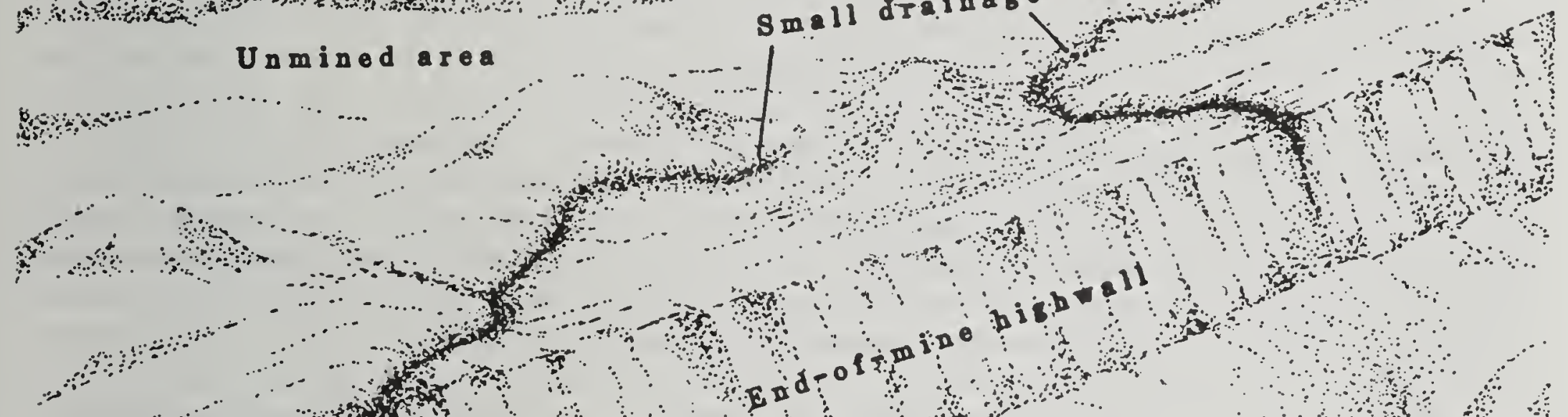

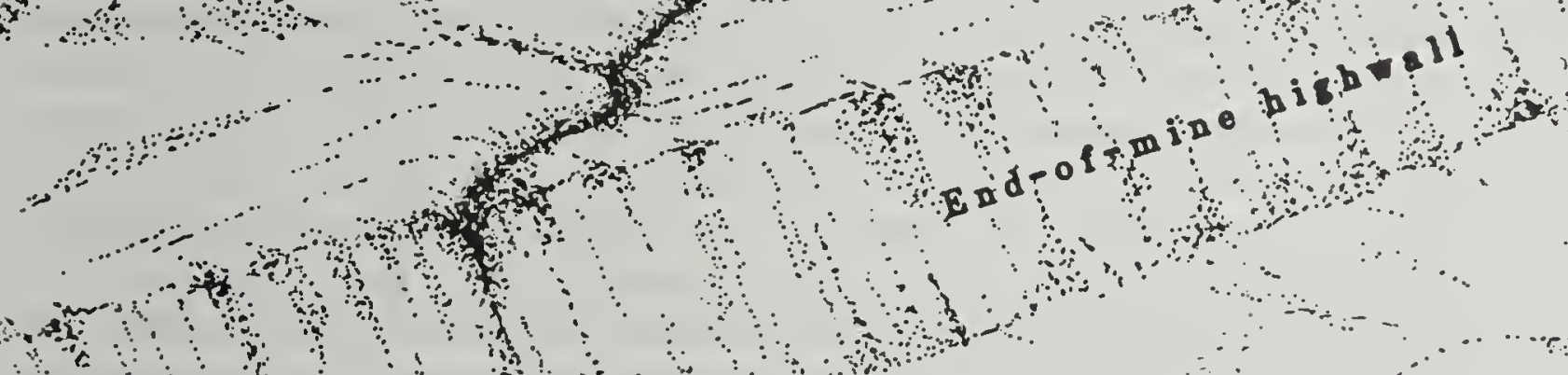

s:

a

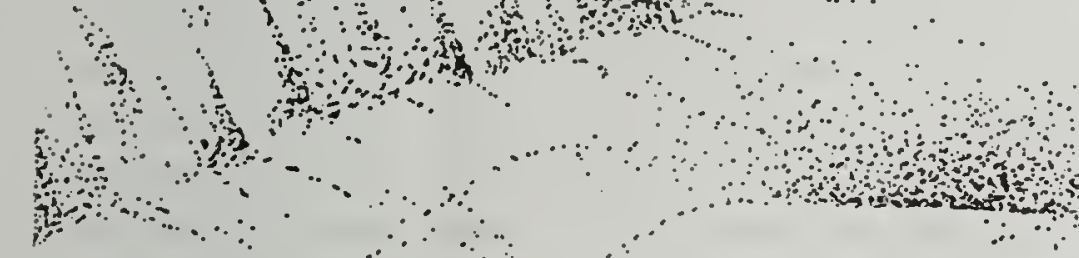

s.

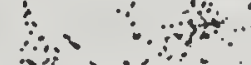




\section{Ground Water}

Evaluation of recent ground-water-level data indicates that the predictions of water-level declines likely have overestimated the magnitude and areal extent of water-level declines in the Wyodak coal aquifer. In addition, some backfilled spoils are being re-saturated more rapidly than was predicted by the models. If these conditions are accurate indicators of future trends, the effects of surface coal mining on water levels and ground-water use would be greatly decreased. Coal-mining companies will contribute toward more realistic predictions of water-level declines as ground-water models are recalibrated using the results of continued monitoring of water levels in the Wyodak coal aquifer. A more realistic assessment of the duration of water-level declines is needed to determine whether additional mining in the eastern Powder River basin would affect future water availability.

Monitoring wells need to be established in the Wyodak coal aquifer downgradient from the mining operations to document long-term water-level changes. These wells need to be located sufficiently distant from active mining operations to detect the maximum cumulative extent of water-level declines resulting from mining. There are several monitoring wells located on land owned by the State (school sections) that would suit this purpose. The wells, drilled in 1976 and 1977, are completed in the Wyodak coal aquifer and are located in sections 16 and 36 of several townships extending from north of Gillette to northwest of the North Antelope Mine. Water levels in these wells have not been monitored since 1985.

The recharge rate and source of recharge water for the spoil aquifers need to be investigated. Determination of the recharge rate is needed to evaluate the duration of impacts on the ground-water system. The source of recharge water is important in determining appropriate placement of acidforming material in the spoil.

\section{Geochemistry}

Additional study is needed to determine overburden suitability for aquifer restoration, water-quality changes associated with selective placement of overburden material, and long-term changes in postmining water quality. On the basis of column-leaching data presented, additional information is needed about the geochemistry of selected chemical constituents in the overburden to adequately predict concentrations of these constituents in the postmining ground water. For example, overburden with extractable-selenium concentrations less than the detection limit has produced water from column-leaching tests with selenium concentrations exceeding the State standard for livestock. 
Without additional information on the source or sources of recharge to the spoil aquifers, appropriate disposal of toxic and acid-forming spoil material cannot be guaranteed. For example, if a substantial part of recharge to the spoil aquifer is from infiltration of precipitation and leakage from ephemeral streams, perhaps acid-forming material would be better placed at depths below the postmining water table, where seasonal wet-dry cycles would not continue to oxidize the acid-forming material.

At some time in the future, the postmining potentiometric surface in the spoil aquifer will begin re-equilibrate such that water from the spoil aquifer will begin to move offsite into the adjacent wasatch aquifer and Wyodak coal aquifer. Although changes in offsite postmining water quality resulting from this offsite ground-water movement have been simulated and examined during this study, additional information is needed. Additional study is needed to determine the sulfate-reducing potential of aquifers and to determine site-specific, water-quality changes that occur as water from the spoil aquifer moves offsite into the Wasatch aquifer and Wyodak coal aquifer.

\section{Surface Water}

Infiltration values need to be more accurately defined. The study would involve collecting rainfall and runoff data on small, paired basins (less than $3 \mathrm{mi}^{2}$ ) consisting of natural basins and reclaimed basins. The data collected would be used to simulate the infiltration rates, which in turn can be used to predict long-term cumulative impacts for larger basins. Continuous sediment-concentration data need to be collected in conjunction with the rainfall and runoff data for additional evaluation of the erosion and sedimentation process in relation to reclaimed soil materials.

The analysis of cumulative impacts on surface-water flow is based on the analysis of available infiltrometer data from rainfall-simulation tests and on the assumption that the change in infiltration will result in an inverse change in runoff. A network of streamflow-gaging stations needs to be re-established on streams draining the mine areas in order to verify the relation between infiltration and runoff. These gaging stations need to be established downstream from the mine areas where large areas have been disturbed by surface mining and need to be operated for the duration of mining, but they do not need to include large undisturbed areas or areas disturbed by other activities. The network of gaging stations operated by coal-mining companies and methods of record collection need to be evaluated so that:

(1) A coordinated and efficient effort of data collection is maintained, (2) data are collected with proper quality assurance and control, (3) a centralized computer file is developed and maintained to facilitate retrievals and statistical summaries, and (4) future cumulative-impact evaluations will have data suitable to analyze hydrologic properties such as peak-flow yields, average runoff, and surface-water/ground-water relations.

Stream channels in the major drainage basins in the study area need to be monumented and documented to study erosion and sedimentation in mine areas. The information can be used for future reference in understanding the erosion and sedimentation processes in a semiarid climate with large areas disturbed by mining. 


\section{Stability of Reclaimed Drainage Basins}

Reclamation of large land areas in the arid and semiarid West has oniy been done for a few years; much needs to be learned concerning long-term processes affecting re-constructed drainage basins. Although much literature exists regarding fluvial processes in natural drainage basins, there is a paucity of literature reporting case histories of fluvial processes in reclaimed basins. There is a need to establish a network of reclaimed basins similar to the Vigil Network (Leopold, 1962) that exists for natural basins. Instrumentation for the network needs to include streamflow-gaging stations and monumented stream channel cross sections as discussed earlier; it also needs to include precipitation gages and erosion grids for hillslopes.

Due to the nature of the semiarid climate and resulting infrequent runoff in the study area, it may take as much as 10 years of data collection before results are achieved from the network described above. In the meantime, additional onsite and laboratory studies are needed whereby actual data are accurately and systematically collected to define geomorphic thresholds, such as basin and channel slopes, and to define optimum drainage patterrs and densities for re-constructed basins.

\section{CONCLUSIONS}

1. Mining and reclamation will result in the replacement of the Wasatch aquifer and Wyodak coal aquifer with unconsolidated backfilled spoil materials. The resulting spoil aquifer is estimated to have approximately the same hydraulic conductivity as did the Wasatch aquifer and Wyodak coal aquifer.

On the basis of data currently (1987) available, it appears that postmining recharge, movement, and discharge of water in the Wasatch aquifer and Wyodak coal aquifer will not be substantially different from premining conditions. Recharge rates and mechanisms will not change substantially. Because hydraulic conductivity of the spoil aquifer will be approximately the same as in the Wasatch aquifer and the Wyodak coal aquifer, water will move from recharge areas where clinker is present east of mine areas through the spoil aquifer to the undisturbed Wasatch aquifer and the Wyodak coal aquifer to the west.

Coal-mining companies predict water-level declines of $5 \mathrm{ft}$ or more in the Wasatch aquifer to extend from about 1,000 to about 2,000 ft beyond the mine pits. The predicted 5-ft water-level decline in the Wyodak coal aquifer generally extends 4 to $8 \mathrm{mi}$ westward beyond the lease areas.

Cumulative water-level declines are not expected to be substantial in the Wasatch aquifer because water-level declines due to individual coal-mining operations generally will not extend more than 2,000 ft beyond the mine pits. The extent of water-level declines in the Wasatch aquifer will be restricted because the ground-water system consists of discontinuous sandstone lenses that 
have limited hydraulic connection. Therefore, there will be few areas where water-level declines from individual mines will overlap to create cumulative impacts. In areas where a cumulative impact may occur, the impacts will be localized because of the discontinuous, lenticular nature of the sandstone lenses comprising the Wasatch aquifer.

Water-level declines in the Wyodak coal aquifer are predicted to extend beyond the area affected by individual coal mines because of the cumulative effect of adjacent coal-mining operations. The extent of cumulative water-level declines generally was determined by superposition of predicted water-level declines for individual coal mines. The area of cumulative impacts for existing and proposed coal-lease areas was determined by compositing information from mine-permit applications for the entire study area. Within the area of cumulative water-level declines that result from existing and proposed surface coal mining, water-level declines are predicted to range from 5 to $80 \mathrm{ft}$, depending on the proximity to coal-mining operations. Differences in transmissivity resulting from the variable degree and density of fracturing, variable thickness, and division of coal beds may affect the predicted declines locally.

In order to determine which water-supply wells may be affected by water-level declines resulting from all anticipated coal mining, the area of the potential cumulative 5 -ft or more water-level decline in the Wyodak coal aquifer resulting from all anticipated coal mining was approximated. The area of potential cumulative water-level declines from all anticipated coal mining is defined, in this report, as extending from the outcrop of the Wyodak coal bed to about $8 \mathrm{mi}$ from areas of all anticipated mining.

About 3,000 wells are in the area of potential cumulative waterlevel declines resulting from all anticipated coal mining. Of these 3,000 wells, about 1,200 are outside the areas of anticipated coal mining: about 1,000 wells supply water for domestic or livestock uses; and about 200 wells supply water for municipal, industrial, irrigation, and miscellaneous uses. The approximately 1,800 remaining wells are used by coal-mining companies.

In order to determine the effects of water-level declines on the 1,200 water-supply wells outside the areas of all anticipated coal mining, the aquifer in which the well is completed had to be determined. According to well logs and completion reports for these wells, about 580 wells are completed in the Wasatch aquifer, about 100 in the Wyodak coal aquifer, and about 280 in aquifers below the Wyodak coal bed. Stratigraphic location of the completion interval could not be determined for about 260 wells because of lack of information on the well-completion report.

The effect of water-level declines on wells outside coal-mining areas will depend on the magnitude of decline that occurs in the individual wells, which in turn is related to the proximity of a well to coal-mining operations. Other factors important in determining the effect on individual wells include the depth of the 
well, the depth and number of perforated intervals, deptl: to water, and the yield required from the well to maintain it as a useable source of water. If the water level in any of the wells is lowered such that production is seriously decreased, the well can be deepened or replaced with a well completed in the underlying aquifers.

The most important factor in determining if the water level in a well will be affected by coal-mining operations is the stratigraphic location of the perforated interval of the well and, consequently, the aquifer in which the well is completed. In the approximately 580 wells completed in the wasatch aquifer in the area of anticipated water-level declines, water levels will decline only if the wells are about 2,000 ft or less from a coal-mine pit.

However, wells completed in the Wyodak coal aquifer may be affected as far away as $8 \mathrm{mi}$ from coal-mine pits. Water-level declines in those wells are predicted to range from less than $5 \mathrm{ft}$ in wells far away from coal-mining operations to more than $80 \mathrm{ft}$ in wells near coal-mining operations. Wells completed in the underlying aquifers will not be affected by dewatering of the coal-mine pits; however, the yields of wells located near wells supplying facilities at the coal mines may be affected by water-level declines near the pumped wells.

2. Alternative sources of water supplies for wells markedly impacted by coal-mining operations are the Tongue River-Lebo aquifer (Paleocene Fort Union Formation) for domestic and livestock supplies, and the Tullock (Paleocene Fort Union Formation) aquifer or Lance-Fox Hills (Upper Cretaceous) aquifer for uses requiring a larger yield. Water quality in aquifers in the Fort Union Formation is variable and appears to correlate with the permeability of the water-yielding sandstone and proximity to the recharge area. Dissolved-solids concentrations range from about 200 to more than $3,000 \mathrm{mg} / \mathrm{L}$ but commonly range between 500 and $1,500 \mathrm{mg} / \mathrm{L}$.

In order to provide a brief overview of the water quality from aquifers in Upper Cretaceous formations, the concentration ranges of dissolved solids, fluoride, and selenium in water from these aquifers were summarized. Because of a lack of water-quality data for the Lance-Fox Hills aquifer in the study area, water-quality data from wells completed in aquifers in Upper Cretaceous formations in the entire Powder River structural basin were assumed to approximate the water quality in the Lance-Fox Hills aquifer. Dissolved-solids concentrations in 130 ground-water samples ranged from 240 to $2,800 \mathrm{mg} / \mathrm{L}$. Dissolved-fluoride concentrations in 124 ground-water samples ranged from less than 0.1 to $6.0 \mathrm{mg} / \mathrm{L}$.

Dissolved-selenium concentrations in 70 ground-water samples ranged from less than 0.001 to $0.1 \mathrm{mg} / \mathrm{L}$. Although the quality of water from these alternative sources does not always meet the state standard for domestic supplies, it is approximately the same as the quality of water currently (1987) being used for such supplies. 
3. On the basis of the compiled premining (Wasatch aquifer and Wyodak coal aquifer) and postmining (spoil aquifers) water-quality data, current (1986) and future postmining water quality generally will meet the state standard for livestock. The primary chemical constituents that exceed the State standard for livestock in selected wells include dissolved solids, sulfate, nitrate, chromium, and selenium. Except for the consistent decrease in nitrate and selenium concentrations with time, data for the other constituents of concern (dissolved solids, sulfate, and chromium) do not indicate consistent decreases in concentration with time. Future surface coal mining in the study area is expected to produce postmining ground water of similar quality to that currently (1987) present. Because only 10 of the 16 active coal mines in the study area currently (1987) have saturated spoil, additional mining at these 16 active and 6 proposed mines will expand the areal extent of the most recent (through 1986) detected effects of surface coal mining on water quality.

On the basis of analysis-of-variance results, current and future ground-water-quality-monitoring needs for spoil aquifers are listed. Future sampling efforts need to focus on collecting a few samples from numerous wells completed in spoil aquifers rather than collecting a large number of samples from only a few wells. For maximum sampling effectiveness and usefulness of existing and future monitoring data, different sampling densities need to be investigated for different chemical constituents depending on the distribution of variance for each constituent.

4. Batch-mixing experiments that use water and spoil material from the Cordero Mine in a water-to-spoil material ratio of $2: 1$ (by weight), resulted in smaller major-ion concentrations compared to the water quality in the spoil aquifer at the mine. Column-leaching-test results compiled from three mines in the study area were variable depending on the type of water used in the columns (deionized as opposed to actual ground water) and the chemical composition of the overburden materials. The median dissolved-solids and nitrate concentrations based on all postmining water analyses in the study area generally were exceeded until at least 1 pore volume of water leached through the columns. Decreases in the concentrations of dissolved solids, nitrate, and selenium in future postmining water are predicted by the column-leaching-test results. Water samples from selected wells in the study area indicate that actual postmining nitrate and selenium concentrations are currently (1987) decreasing.

5. Geochemical data collected at the Cordero and Dave Johnston Mines were used to predict future ground-water-quality changes and to identify reclamation methods that could minimize future postmining water-quality degradation. Because of differences in the method of mining and hydrologic and geochemical conditions present at the Cordero and Dave Johnston Mines, these predictions may not apply to all the mines within the study area. On the basis of the geochemical conditions in the postmining spoil aquifer at the Cordero Mine, it is unlikely that the dissolved-solids concentrations will 
increase further. Substantial decreases in dissolved-solids concentration in postmining water in the spoil aquifer at the Cordero Mine should not occur until at least 1 pore volume of water has leached the spoil. Leaching of 1 pore volume through the spoil could take from tens to hundreds of years. Isolation of overburden material with large soluble-salt contents to areas above the postmining ground-water table in conjunction with decreasing the rates of infiltration of precipitation and runoff in the spoil aquifer could minimize increases in dissolved-solids concentrations in future reclaimed areas. Furthermore, isolation of spoil material with large soluble-salt contents from clay-rich and organic-rich strata during backfilling also could minimize increases in dissolved-solids concentrations in postmining ground water.

Movement of postmining ground water from the spoil aquifer into the adjacent School coal aquifer at the Dave Johnston Mine indicated substantial mixing resulting in a net increase in the dissolvedsolids concentration in water from the School coal aquifer. This increase in dissolved-solids concentration in water within the School coal aquifer probably will be temporary. As the soluble salts continue to leach from the spoil material, future postmining water that enters the coal aquifer will decrease in dissolved-solids concentration until a postmining equilibrium condition is attained. On the basis of small tritium concentrations in the School coal aquifer downgradient from the coal outcrop at the Dave Johnston Mine, movement of postmining water within the School coal aquifer will be slow, possibly minimizing the extent of water-quality degradation to offsite areas.

6. Results of geochemical modeling of hypothetical reaction paths indicated the potential for marked improvements in postmining water quality as a postmining ground water with a large dissolved-solids concentration $(3,540 \mathrm{mg} / \mathrm{L})$ moves into a coal aquifer containing water with a relatively small dissolved-solids concentration $(910 \mathrm{mg} / \mathrm{L})$. Results of the geochemical modeling indicate geochemical conditions that are most ideal for large decreases in dissolved-solids concentrations in coal aquifers receiving recharge from a spoil aquifer. These conditions include: (1) The presence of sulfate-reducing bacteria populations, (2) organic-carbon sources that can be utilized by the sulfate-reducing bacteria, and (3) a source of iron within the coal aquifer that will facilitate the removal, by mineral precipitation, of the sulfide produced by sulfate reduction. On the basis of indirect geochemical evidence, sulfate-reducing bacteria and organic-carbon sources probably are present in at least a few spoil aquifers within the study area.

7. Simulated-rainfall studies indicated that reclaimed soils have, on the average, a 29-percent slower infiltration rate than do undisturbed soils. Statistical analysis of the infiltrometer data indicates that the decrease in infiltration rates is not significant for individual studies, but average values of all the studies would be useful for evaluating cumulative hydrologic impacts. In addition, the data indicated a trend for the infiltration rates to increase to premining 1 ates. For the purpose of computing the 
effective change in infiltration, it was assumed that runoff had an inverse corresponding value. The projected maximum areas to be disturbed during surface coal mining were computed for the major basins draining the study area. A computation of increase in runoff indicated that the increase in runoff at the mouth of the basins will be less than 5 percent. The disturbed areas for all anticipated coal mining (projected maximum disturbed areas of existing and proposed coal mines, and Selected Coal Tracts and areas with Preference Right Lease Applications) were compiled for all the major drainage basins. The computation of runoff using disturbed areas for all anticipated coal mining is a worst-case condition and indicated a maximum increase in runoff of 7.6 percent for Coal Creek and 5.3 percent for Little Thunder Creek. The remainder of the drainage basins analyzed for the worst-case condition would have increases in runoff of less than 5 percent.

A graphical analysis of storm runoff from the Coal Creek drainage basin indicated an insignificant change on the recession of the flow hydrograph. Coal Creek has the largest percentage of projected maximum disturbed area of all basins studied; therefore, the change in flow due to surface coal mining will be less for the remaining basins.

8. Analysis of changes in sediment yield are limited due to a lack of data; therefore, predictions of cumulative changes in sediment yield are subjective. Sediment yield from reclaimed-soil plots was 436 percent greater than sediment yield from natural-soil plots. The reclaimed-soil plots had less vegetation cover and slightly steeper slopes than the natural-soil plots. The larger sediment yield from reclaimed soils are not expected to be conveyed to the mouth of the basins due to sediment deposition as a result of slope decrease from hillsides to stream channels, and sediment deposition in settling ponds. The larger sediment yield indicated by the reclaimed-soil plots will have a minor impact on the major drainages because: (1) Sediment yield decreases as drainage area increases and, (2) the dilution effect caused by the small percentage of disturbed area in relation to total drainage area. Soil erodibility and steep land slopes, such as those in the Coal Creek drainage basin, account for sediment yields that are 8 times greater than those in the upland areas of the Belle Fourche River basin. The variability in natural sediment yields mask any increases in sediment yield resulting from surface coal mining.

9. The design and re-construction of stable drainage basins is critical to successful land use after reclamation. In addition, stable drainage networks and stream channels are needed to avoid adverse impacts in offsite streams due to increases in erosion and sedimentation. Postmining drainage networks and stream channels have been and are being designed with attention to existing geomorphic conditions and accepted engineering principles. In general, stream-channel and valley slopes are consistent with natural conditions for the area; however, re-constructed drainage basins have lesser drainage densities than exist for natural drainage basins. Although additional first-order stream channels 
likely will form in the reclaimed drainage basins, the practice of re-constructing only higher-order major stream channels is believed to have advantages of: (1) Smaller hillside slopes with resulting greater re-vegetation success, and (2) providing smaller sediment yields than if drainage networks were fully re-constructed to premining densities.

On the basis of the limited data and literature available for the study area and similar semiarid regions, no adverse cumulative impacts are expected due to instability of postmining drainage networks and stream channels. Some visible changes likely will occur on a local scale as the postmining drainage networks adjust to a new state of dynamic equilibrium. A maintenance program would be warranted for occasional severe adjustments and failures.

\section{SELECTED REFERENCES}

Armentrout, G.W., and Wilson, J.F., Jr., 1987, An assessment of low flows in streams in northeastern Wyoming: U.S. Geological Survey WaterResources Investigations Report 85-4246, $21 \mathrm{p}$.

Bergstrom, F.W., 1985, Determination of longitudinal profile for stream channel reclamation, in Second Hydrology Symposium on Surface Coal Mines in the Northern Great Plains, Gillette, Wyoming, Proceedings: Gillette Area Groundwater Monitoring Organization, Colorado GroundWater Association, and Wyoming Water Research Center, p. 29-60.

Bishop, M.B., 1980, Geomorphic concepts and their application to ephemeral stream channel reclamation, in Second Wyoming Mining Hydrology Symposium, Laramie, Wyoming, Proceedings: University of Wyoming, p. $249-261$.

Bloyd, R.M., Daddow, P.B., Jordan, P.R., and Lowham, H.W., 1986 , Investigation of possible effects of surface coal mining on hydrology and landscape stability in part of the Powder River structural basin, northeastern Wyoming: U.S. Geological Survey Water-Resources Investigations Report 86-4329, $101 \mathrm{p}$.

Breckenridge, R.M., Glass, G.B., Root, F.K., and Wendell, W.G., 1974, Campbell County Wyoming; Geologic Map Atlas and Summary of Land, Water and Mineral Resources: Laramie, Wyo., The Geological Survey of'Wyoming County Resource Series No. 3, 9 sheets.

Chatham, J.R., Wanty, R.B., and Langmuir, Donald, 1981, Groundwater prospecting for sandstone-type uranium deposits--The merits of mineralsolution equilibria versus single element tracer methods: U.S. Department of Energy National Uranium Resource Evaluation Report GJO 79-360-E, $197 \mathrm{p}$.

Chorley, R.J., Schumm, S.A., and Sugden, D.E., 1984, Geomorphology: New York, Methuen and Co., 607 p. 
Craig, G.S., Jr., and Rankl, J.G., 1978, Analysis of runoff from small drainage basins in Wyoming: U.S. Geological Survey Water-Supply Paper 2056, 70 p.

Daddow, P.B., 1986, Potentiometric-surface map of the Wyodak-Anderson coal bed, Powder River structural basin, Wyoming, 1973-84: U.S. Geological Survey Water-Resources Investigations Report 85-4305, scale 1:250,000.

Davis, R.E., 1984, Geochemistry and geohydrology of the West Decker and Big Sky coal-mining areas, southeastern Montana: U.S. Geological Survey Water-Resources Investigations Report 83-4225, $109 \mathrm{p}$.

Davis, R.E., and Dodge, K.A., 1986, Results of experiments related to contact of mine-spoils water with coal, West Decker and Big Sky Mines, southeastern Montana: U.S. Geological Survey Water-Resources Investigations Report 86-4002, $16 \mathrm{p}$.

Dean, W.E., Ringrose, C.D., and Klusman, R.W., 1979, Geochemical variation in soils in the Piceance Creek Basin, western Colorado: U.S. Geological Survey Bulletin 1479, $47 \mathrm{p}$.

Denson, N.M., Dover, J.H., and Osmonson, L.M., 1978, Lower Tertiary coal bed distribution and coal resources of the Reno Junction-Antelope Creek Area, in Campbell, Converse, Niobrara, and Weston Counties, Wyoming: U.S. Geological Survey Miscellaneous Field Studies Map MF-960, scale $1: 250,000$.

Divis, S.A., and Tarquin, P.A., 1981, The geohydrologic regime of the Powder River Basin: Wheat Ridge, Colo., Environmental Science Associates, January 1981 (revised), $109 \mathrm{p}$.

Drever, J.I., 1982, The geochemistry of natural waters: Englewood Cliffs, New Jersey, Prentice-Hall, Inc., 388 p.

Druse, S.A., Dodge, K.A., and Hotchkiss, W.R., 1981, Base flow and chemical quality of streams in the Northern Great Plains area, Montana and Wyoming: U.S. Geological Survey Water-Resources Investigations OpenFile Report 81-692, 60 p.

Druse S.A., Glass, W.R., McCollam, P.B., and Kennedy, H.I., 1987, Water resources data Wyoming, water year 1986: U.S. Geological Survey WaterData Report WY-86-1, 474 p.

Dunne, Thomas, and Leopold, L.B., 1978, Water in environmental planning: San Francisco, W.H. Freeman and Co., 818 p.

Ebens, R.J., and Shacklette, H.T., 1982, Geochemistry of some rocks, mine spoils, stream sediments, soils, plants, and waters in the western energy region of the conterminous United States: U.S. Geological Survey Professional Paper 1237, 173 p.

Emmett, W.W., 1974, Channel aggradation in western United States as indicated by observations at Vigil Network sites: Zeitschrift Für Geomorphologic Suppl., v. 21, December 1974, p. 52-62. 
Everett, L.G., ed., 1979, Ground-water quality monitoring of western coal strip mining: U.S. Environmental Protection Agency report, 239 p.

Feathers, K.R., Libra, Robert, and Stephenson, T.R., 1981, 0ncurrence and characteristics of ground water in the Powder River Basin, Wyoming: Laramie, University of Wyoming, Water Resources Research Institute Report, $171 \mathrm{p}$.

Fogg, J.L., Martin, M.W., Daddow, P.B., in press, Geohydrology and potential effects of coal mining in 12 coal-lease areas, Powder River structural basin, northeastern Wyoming: U.S. Geological Survey Water-Resources Investigations Report 87-4102.

Garrett, R.G., and Goss, T.I., 1980, UANOVA; A FORTRAN IV program for unbalanced nested analysis of variance: Computers and Geosciences, v. 6, p. 35-60.

Gat, J.R., 1980, The isotopes of oxygen and hydrogen in precipitation, in Fritz, Peter, and Fontes, J.C., eds., Handbook of environmental isotope geochemistry, part A--The terrestrial environment: New York, American Elsevier Publishing Co., p. 21-47.

Gifford, G.F., 1982, A long-term infiltrometer study in Southern Idaho, U.S.A.: Journal of Hydrology, v. 58, p. 367-374.

----- 1983, Rainfall simulator studies--1983: Gillette, Wyo., Amax Coal Co. report, no pagination.

Gillette Area Groundwater Monitoring Organization, 1987, GAGMO annual report: Gillette, Wyo., no pagination.

Glass, G.B., 1986a [1987], Coal [Geology], in Hydrology of area 50, Northern Great Plains and Rocky Mountain coal provinces, Wyoming and Montana: U.S. Geological Survey Water-Resources Investigations Open-File Report $83-545$, p. $26-27$.

-..- 1986b [1987], Coal [Economic development], in Hydrology of area 50, Northern Great Plains and Rocky Mountain coal provinces, Wyoming and Montana: U.S. Geological Survey Water-Resources Investigations OpenFile Report 83-545, p. 34-35.

Glassey, T.W., Dunnewald, T.J., Brock, John, Irving, H.H., Tippetts, Neff, and Rohrer, Conrad, 1955, Soil survey (reconnaissance) of Campbell County, Wyoming: U.S. Department of Agriculture, Soil Conservation Service, Series 1939, No. 22, 67 p.

Gregory, D.I., Schumm, S.A., Watson, C.C., 1985, Determination of drainage density for surface mine reclamation in the western U.S.: Fort Collins, Colo., Water Engineering and Technology, Inc., Final report to U.S. Office of Surface Mining, $59 \mathrm{p}$.

Groenewold, G.H., 1979, Hydrologic and hydrogeochemical characteristics of selected strip mine spoils in western North Dakota, in Wali, M.D., ed., Ecology and Coal Resource Development Symposium, Proceedings: New York, Pergamon Press, p. 685-692. 
Groenewold, G.H., Koob, R.D., McCarthy, G.J., Rehm, B.W., and Peterson, W.M., 1983, Geologic and geochemical controls on the chemical evolution of subsurface water in undisturbed and surface-mined landscapes in western North Dakota: North Dakota Geological Survey Report of Investigation No. 79, 151 p.

Hackley, K.C., and Anderson, T.F., 1986, Sulfur isotopic variations in lowsulfur coals from the Rocky Mountain region: Geochemica et Cosmochimica Acta, v. 50, p. 1703-1713.

Hadley, R.F., and Keefer, W.R., 1975, Map showing some potential effects of surface mining of the Wyodak-Anderson coal, Gillette area, Campbell County, Wyoming: U.S. Geological Survey Miscellaneous Investigations Map I-848-F, scale 1:125,000.

Hadley, R.F., and Schumm, S.A., 1961, Sediment sources and drainage-basin characteristics in upper Cheyenne River basin: U.S. Geological Survey Water-Supply Paper 1531-B, p. 137-198.

Harvey, M.D., Watson, C.C., and Schumm, S.A., 1985, Stream channel restoration criteria, in Second Hydrology Symposium on Surface Coal Mines in the Northern Great Plains, Gillette, Wyoming, Proceedings: Gillette Area Groundwater Monitoring Organization, Colorado GroundWater Association, and Wyoming Water Research Center, p. 61-73.

Hem, J.D., 1985, Study and interpretation of the chemical characteristics of natural water (3rd ed.): U.S. Geological Survey Water-Supply Paper $2254,263 \mathrm{p}$.

Henderson, Thomas, 1984, Geochemistry of ground-water in two sandstone aquifer systems in the Northern Great Plains in parts of Montana and Wyoming: U.S. Geological Survey Professional Paper 1402-C, 84 p.

Hodson, W.G., Pearl, R.H., and Druse, S.A., 1973 [1974], Water 1 esources of the Powder River Basin and adjacent areas, northeastern Wyoming: U.S. Geological Survey Hydrologic Investigations Atlas HA-465, 4 sheets.

Horton, R.E., 1945, Erosional development of streams and their drainage basins; hydrophysical approach to quantitative morphology: Geological Society of America Bulletin, v. 56, p. 275-370.

Houghton, R.L., Koob, R.D., and Groenewold, G.H., 1985, Progress report on the geochemistry of the sulfur cycle in Northern Great Plains Coal mines: U.S. Geological Survey Water-Resources Investigations Report $85-4016,70 \mathrm{p}$.

Houghton, R.L., Thorstenson, D.L., Fisher, D.W., and Groenewold, G.H., 1987 , Hydrogeochemistry of the upper part of the Fort Union Group in the Gascoyne Iignite strip-mining area, North Dakota: U.S. Geological Survey Professional Paper 1340, 104 p.

Hounslow, Arthur, Fitzpatrick, Joan, Cerrillo, Lawrence, and Freeland, Michael, 1978, Overburden mineralogy as related to ground-water chemical changes in coal strip mining: U.S. Environmental Protection Agency Report EPA-600/7-78-156, 156 p. 
Hutten, N.G., and Gifford, G.F., 1984, Survey of interrill erosion and infiltration rates on natural and reclaimed lands: Gillette, Wyo., Amax Coal Company report, $33 \mathrm{p}$.

Kearney, W.F., 1985, Channel reconstruction efforts to date in Wyoming, in Second Hydrology Symposium on Surface Coal Mines in the Northern Great Plains, Gillette, Wyoming, Proceedings: Gillette Area Groundwater Monitoring Organization, Colorado Ground-Water Association, and Wyoming Water Research Center, p. 74-75.

Keefer, W.R., and Hadley, R.F., 1976, Land and natural resource information and some potential environmental effects of surface mining of coal in the Gillette area, Wyoming: U.S. Geological Survey Circular 743, 27 p.

Kent, B.H., Berlage, L.J., Boucher, E.M., 1980, Stratigraphic framework of coal beds underlying the western part of the Recluse $1^{\circ} \mathrm{x} 1 / 2^{\circ}$ quadrangle, Campbell County, Wyoming: U.S. Geological Survey Coal Investigations Map C-81-C, scale 1:100,000, 2 sheets.

Klusman, R.W., Ringrose, C.D., Candito, R.J., Zuccaro, Bruce, Rutherford, D.W., and Dean, W.E., 1980, Sampling designs for geochemical baseline studies in the Colorado Oil Shale region: U.S. Department of Energy Report DOE/EV/10298-2, $180 \mathrm{p}$.

Knutson, Kent, 1982, Regional comparison of drainage basin morphometry-Eastern Powder River Basin, Wyoming, in Hydrology Symposium on Surface Coal Mines in the Powder River Basin of Wyoming, Gillette, Wyoming, Proceedure: Gillette Area Groundwater Monitoring Organization and American Institute of Mining Engineers, p. 157-172.

Koch, Donald, Ringrose, C.D., Moore, R.C., and Brooks, D.L., 1982, Monitoring and modeling the shallow ground-water systems in the Powder River Basin: Englewood, Colo., Hittman Associates, Inc., Report to U.S. Bureau of Mines, 359 p. (appendicies A through U, separate volume).

Larson, L.R., 1984, Ground-water quality in Wyoming: U.S. Geological Survey Water-Resources Investigations Report 84-4034, $71 \mathrm{p}$.

1986a [1987], pH [Surface water], in Hydrology of area 50, Northern Great Plains and Rocky Mountain coal provinces, Wyoming and Montana: U.S. Geological Survey Water-Resources Investigations Open-File Report 83-545, p. 62-63.

1986b [1987], Total phosphorous [Surface water], in Hydrology of area 50, Northern Great Plains and Rocky Mountain coal provinces, Wyoming and Montana: U.S. Geological Survey Water-Resources Investigations Open-File Report 83-545, p. 66-67.

1986c [1987], Trace metals [Ground water], in Hydrology of area 50, Northern Great Plains and Rocky Mountain coal provinces, Wyoming and Montana: U.S. Geological Survey Water-Resources Investigations OpenFile Report 83-545, p. 96-97. 
Larson, L.R., and Daddow, R.L., 1984, Ground-water quality data from the Powder River structural basin and adjacent areas, northeastern Wyoming: U.S. Geological Survey Open-File Report 83-939, 56 p.

Leopold, L.B., 1962, The man and the hill: U.S. Geological Survey Circular $460-A, 5 \mathrm{p}$.

Leopold, L.B., Emmett, W.W., and Myrick, R.M., 1966, Channel and hillslope processes in a semiarid area, New Mexico: U.S. Geological Survey Professional Paper 352, p. 193-253.

Leopold, L.B., and Miller, J.P., 1956, Ephemeral streams--Hydraulic factors and their relation to the drainage net: U.S. Geological Survey Professional Paper 282-A, p. 1-37.

Leopold, L.B., Wolman, M.G., and Miller, J.P., 1964, Fluvial processes in geomorphology: San Francisco, W.H. Freeman and Co., 522 p.

Lewis, B.D., and Hotchkiss, W.R., 1981, Thickness, percent sand, and configuration of shallow hydrogeologic units in the Powder River Basin, Montana and Wyoming: U.S. Geological Survey Miscellaneous Investigations Map I-1317, scale $1: 1,000,000,6$ sheets.

Lidstone, C.D., 1982, Stream channel reconstruction and drainage basin stability, in Hydrology symposium on surface coal mines in the Powder River Basin of Wyoming, Gillette, Wyoming, Proceedings: Gillette Area Groundwater Monitoring Organization and American Institute of Mining Engineers, p. 43-58.

Love, J.D., and Christiansen, A.C., 1985, Geologic map of Wyoming: Laramie, Geological Survey of Wyoming, scale 1:500,000.

Lowham, H.W., 1976, Techniques for estimating flow characteristics of Wyoming streams: U.S. Geological Survey Water-Resources Investigations Report $76-112,83 \mathrm{p}$.

-... 1986 [1987], Climate, in Hydrology of area 50, Northern Great Plains and Rocky Mountain coal provinces, Wyoming and Montana: U.S. Geological Survey Water-Resources Investigations Open-File Report 83-545, p. 12-13.

Lowham, H.W., DeLong, L.L., Collier, K.R., and Zimmerman, E.A., 1982, Hydrology of Salt Wells Creek--A plains stream in southwestern Wyoming: U.S. Geological Survey Water-Resources Investigations Report 81-62, $52 \mathrm{p}$.

Lowry, M.E., 1986 [1987], Availability [Ground water], in Hydrology of area 50, Northern Great Plains and Rocky Mountain coal provinces, Wyoming and Montana: U.S. Geological Survey Water-Resources Investigations Open-File Report 83-545, p. 90-91.

Lowry, M.E., and Rankl, J.G., 1987, Hydrology of the White Tail Butte area, northern Campbell County, Wyoming: U.S. Geological Survey WaterResources Investigations Report 82-4117, $47 \mathrm{p}$. 
Lowry, M.E., Wilson, J.F., Jr., and others, 1986 [1987], Hydrology of Area 50, Northern Great Plains and Rocky Mountain coal provinces, Wyoming and Montana: U.S. Geological Survey Water-Resources Investigations Open-File Report 83-545, $137 \mathrm{p}$.

Lusby, G.C., and Toy, T.J., 1976, An evaluation of surface-mine spoils area restoration in Wyoming using rainfall simulation: Earth Surface Processes, v. 1, p. 375-386.

McWhorter, D.B., and Landers, R.A., 1985, Prediction of post-mining water quality with column tests and overburden chemistry: Proceedings of the 1985 American Society for Surface Mining and Reclamation National Meeting, October 8-10, 1985, p. 1-28.

Miesch, A.T., 1967, Methods of computation for estimating geochemical abundance: U.S. Geological Survey Professional Paper 574-B, 15 p.

----- 1976, Geochemical survey of Missouri--Methods of sampling, laboratory analysis, and statistical reduction of data, with sections on Laboratory methods, by P.R. Barnett and others: U.S. Geological Survey Professional Paper 954-A, 39 p.

Naftz, D.L., in press, Geochemistry of batch-extract waters derived from spoil material collected at the Cordero coal mine, Powder River Basin, Wyoming: U.S. Geological Survey Water-Resources Investigations Report 87-4200.

Parker, R.S., 1977, Experimental study of basin evolution and its hydrologic implications: Fort Collins, Colo., Colorado State University, unpublished dissertation.

Parkhurst, D.L., Plummer, L.N., and Thorstenson, D.C., 1982a, BALANCE--A computer program for calculating mass transfer for geochemical reactions in ground water: U.S. Geological Survey Water-Resources Investigations Report $82-14,29 \mathrm{p}$.

Parkhurst, D.L., Thorstenson, D.C., and Plummer, L.N., 1982b, PHREEQE--A computer program for geochemical calculations: U.S. Geological Survey Water-Resources Investigations Report 80-96, $210 \mathrm{p}$.

Patton, P.C., and Schumm, S.A., 1975, Gully erosion, northern Colorado, a threshold phenomena: Geology, v. 3, p. 88-90.

Peterson, D.A., 1986 [1987], Vegetation, in Hydrology of area 50, Northern Great Plains and Rocky Mountain coal provinces, Wyoming and Montana: U.S. Geological Survey Water-Resources Investigations Open-File Report 83-545, p. 20-21.

in press, Streamflow characteristics of the Missouri River basin, Wyoming, through 1984: U.S. Geological Survey Water-Resources Investigations Report 87-4018. 
Plummer, L.N., Jones, B.F., and Truesdell, A.H., 1978, WATEQF--A FORTRAN IV version of WATEQ, a computer program for calculating chemical equilibrium of natural waters: U.S. Geological Survey Water-Resources Investigations Report 76-13, 63 p.

Plummer, L.N., Parkhurst, D.L., and Thorstenson, D.C., 1983, Development of reaction models for ground-water systems: Geochimica Cosmochimica Acta, v. 47, p. 665-686.

Powell, J.D., and Larson, J.D., 1985, Relation between ground-water quality and mineralogy in the coal-producing Norton Formation of Buchanan County, Virginia: U.S. Geological Survey Water-Supply Paper 2274 , $30 \mathrm{p}$.

Rahn, P.H., 1976, Potential of coal strip-mine spoils as aquifers in the Powder River Basin: Rapid City, South Dakota School of Mines and Technology, Project completion report prepared for Old West Regional Committee, Project No. 10470025, 108 p.

Rankl, J.G., 1982, An empirical method for determining average soil infiltration rates and runoff, Powder River structural basin, Wyoming: U.S. Geological Survey Water-Resources Investigations Report 81-76, $38 \mathrm{p}$.

1986a, Drainage, in Hydrology of area 50, Northern Great Plains and Rocky Mountain coal provinces, Wyoming and Montana: U.S. Geological Survey Water-Resources Investigations Open-File Report 83-545, p. 16-17.

1986b, Soils, in Hydrology of area 50, Northern Great Plains and Rocky Mountain coal provinces, Wyoming and Montana: U.S. Geological Survey Water-Resources Investigations Open-File Report 83-545, p. 18-19.

---- 1987, Analysis of sediment production from two small semiarid basins in Wyoming: U.S. Geological Survey Water-Resources Investigations Report $85-4314,27 \mathrm{p}$.

Rankl, J.G. and Lowry, M.E., in press, Regional ground-water flow in the Powder River structural basin, Wyoming and Montana: U.S. Geological Survey Water-Resources Investigations Report 85-4229.

Rehm, B.W., Groenewold, G.H., and Morin, K.A., 1980, Hydraulic properties of coal and related materials, Northern Great Plains: Ground Water, v. 18 , no. 6 , p. 551-561.

Schaefer, Melvin, Elifrits, Dale, and Barr, D.J., 1979, Sculpturing reclaimed land to decrease erosion: Lexington, University of Kentucky, Symposium on Surface Mining Hydrology, Sedimentology and Reclamation, December 4-7, p. 99-109.

Schumm, S.A., 1977, The fluvial system: New York, John Wiley and Sons, $338 \mathrm{p}$.

Schumm, S.A., and Hadley, R.F., 1957, Arroyos and the semiarid cycle of erosion: American Journal of Science, v. 255, p. 161-174. 
Stiller, D.M., Zimpfer, G.L., and Bishop, M.B., 1980, Application of geomorphic principles to surface mine reclamation: Journal of Soil and Water Conservation, v. 35, p. 274-277.

Strahler, A.N., 1952, Hypsometric (area-altitude) analysis of erosional topography: Geological Society of America Bulletin, $v .63$, p. $1117-1142$.

-.--- 1957, Quantitative analysis of watershed geomorphology: American Geophysical Union Transactions, v. 38, p. 913-920.

----- 1964, Quantitative geomorphology of drainage basins and channel networks, in Chow, V.T., ed., Handbc.: of applied hydrology: New York, McGraw-Hili, p. 4-39 to 4-76.

Surface Mining Control and Reclamation Act of 1977--Public Law 95-87: 95 th Congress of the United States, August 3, 1977, U.S. Statutes at Large, p. 445-532.

Tarquin, P.A., and Baeder, L.D., 1982, Stream channel reconstruction--The problem of designing lower order streams, in Hydrology Symposium on Surface Coal Mines in the Powder River Bas in of Wyoming, Gillette, Wyoming, Proceedings: Gillette Area Groundwater Monitoring Organization and American Institute of Mining Engineers, p. 257-270.

Thompson, K.A., and Van Voast, W.A., 1983, Update on mined land ground water research in southeastern Montana: Casper, Wyo., Symposium on Soils and Overburden in Arid/Semiarid Mined Land Reclamation.

Thorstenson, D.C., Fisher, D.W., and Croft, M.G., 1979, The geochemistry of the Fox Hills-basal Hell Creek aquifer in southwestern North Dakota and northwestern South Dakota: Water Resources Research, v. 15, no. 6, p. $1479-1498$.

Toy, T.J., and Hadley, R.F., 1987, Geomorphology and reclamation of disturbed lands: Orlando, Fla., Academic Press, Inc., $480 \mathrm{p}$.

U.S. Department of the Interior, U.S. Department of Agriculture, and U.S. Interstate Commerce Commission, 1974, Proposed development of coal resources in the eastern Powder River coal basin of Wyoming: Cheyenne, Wyo., U.S. Department of the Interior, Bureau of Land Management ( 1 ead agency), Final Environmental Impact Statement, 6 volumes.

U.S. Environmental Protection Agency, 1986a, Maximum contaminant levels (subpart B of part 141, National interim primary drinking-water regulations): U.S. Code of Federal Regulations, Title 40, Parts 100 to 149 , revised as of July 1, 1986, p. 524-528.

---- 1986b, Secondary maximum contaminant levels (section 143.3 of part 143, National secondary drinking-water regulations): U.S. Code of Federal Regulations, Title 40, Parts 100 to 149, revised as of July 1 , 1986 , p. 587-590. 
U.S. Geological Survey, 1975, Geochemical survey of the western coal regions, 2nd Annual Progress Report: U.S. Geological Survey Open-File Report 75-436, $132 \mathrm{p}$.

-.-- 1977, Geochemical survey of the western coal regions, 4 th Annual Progress Report: U.S. Geological Survey Open-File Report 77-872, 207 p.

---- 1980, Water resources data for Wyoming, water year 1979, volume 1, Missouri River Basin: U.S. Geological Survey Water-Data Report WY-79-1, $647 \mathrm{p}$.

Van Voast, W.A., Hedges, B., and McDermott, J.J., 1976, Strip coal mining and mined land reclamation in hydrologic systems, southeastern Montana, Appendix D in Williams, T.T., Koob, R.L., and Rechard, P.A., Surface and groundwater problems associated with potential strip mine sites: Draft final report for EPA Grant R-303727, 122 p.

Wyoming Department of Environmental Quality, 1980a, Quality standards for Wyoming groundwaters: Cheyenne, Wyo., Water Quality Rules and Regulations, Chapter VIII, $13 \mathrm{p}$.

-.-. 1980b, Hydrology: Cheyenne Wyo., Land Quality Division Guideline No. $8,25 \mathrm{p}$.

1984, Topsoil and overburden: Cheyenne, Wyo., Land Quality Division Guideline No. 1, $34 \mathrm{p}$.

-.--1986, Rules and regulations: Cheyenne, Wyo., Land Quality Division, $230 \mathrm{p}$.

Wyoming Geological Association, 1958, Guidebook--13th Annual Field Conference, Powder River Basin: Casper, Wyo., Wyoming Geological Association, $341 \mathrm{p}$.

Wyoming State Legislature, 1973, Wyoming Environmental Quality Act: Cheyenne, Wyoming Department of Environmental Quality, statutes $35-502.1$ to $35-502.56,32 \mathrm{p}$.

Wyoming Water Planning Program, 1972, Water and related land resources of northeastern Wyoming: Cheyenne, Office of the State Engineer, Wyoming Water Planning Program Report No. 10, 209 p.

Yurtsever, Y., 1975, Worldwide survey of stable isotopes in precipitation, in Environmental isotope data no. 5--World survey of isotope concentration in precipitation (1970-1971): Vienna, International Atomic Energy Agency, Technical Report Series No. 165, 40 p.

Zimpfer, G.L., O'Brien, Michael, and Schumm, S.A., 1982, Design of stable drainage networks for mined land reclamation: Final report to Colorado Commission on Higher Education, December 1982, 26 p. 
SUPPLEMENTAL DATA 


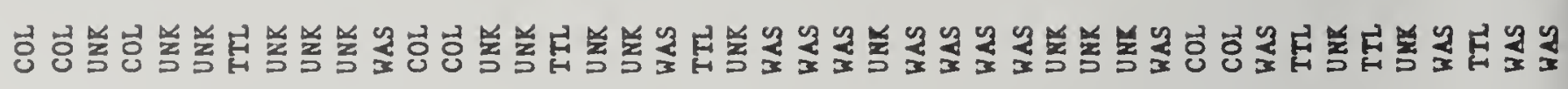

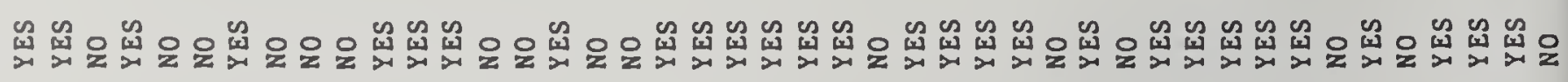

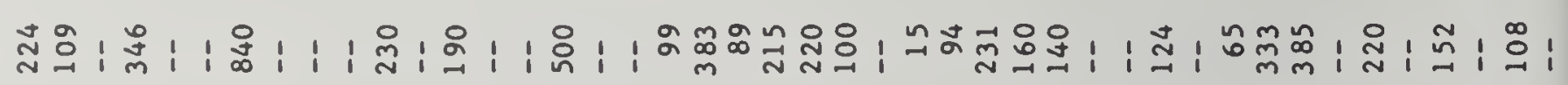

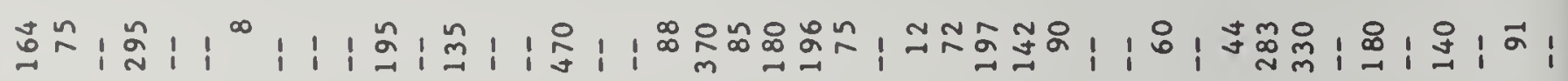

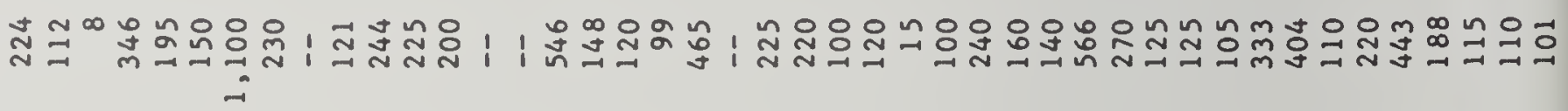

oง

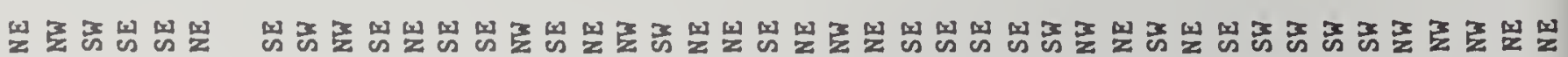

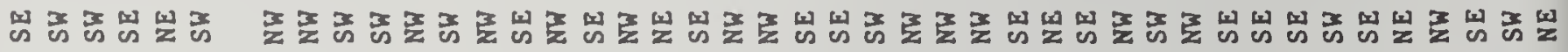

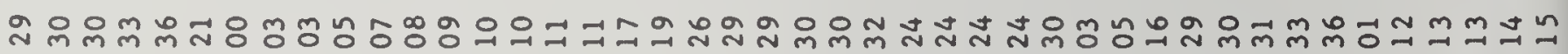

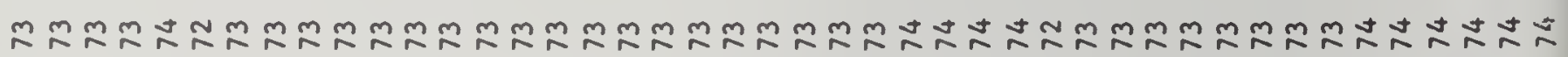

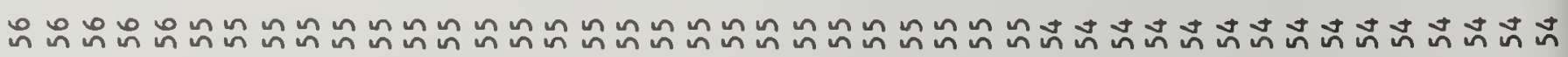

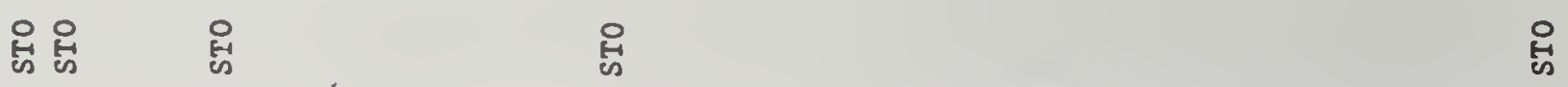

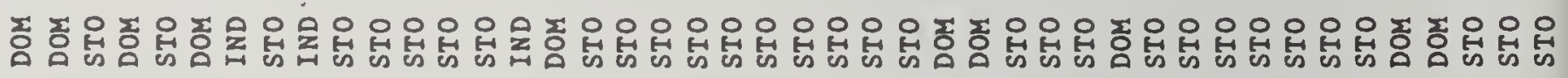

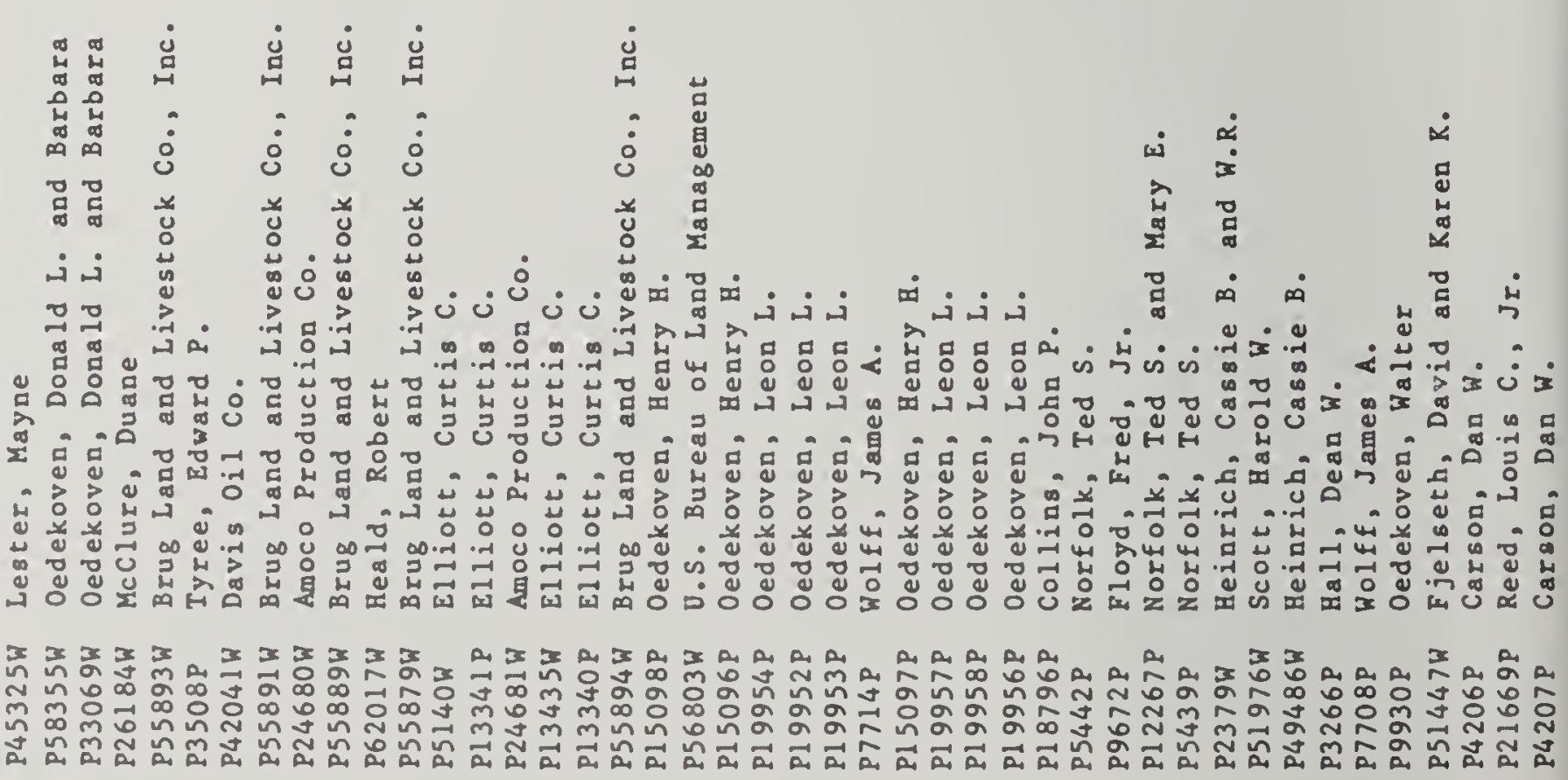




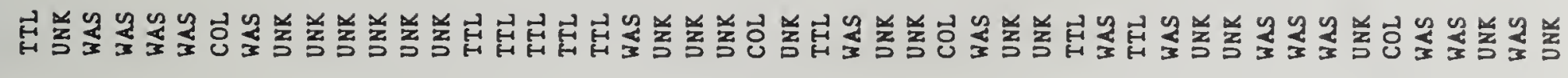

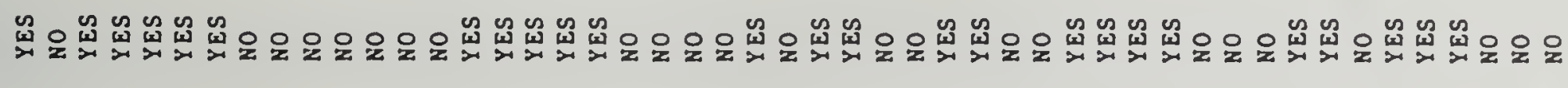

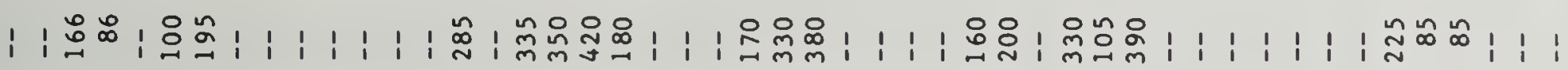

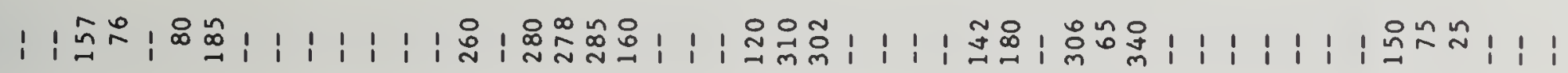

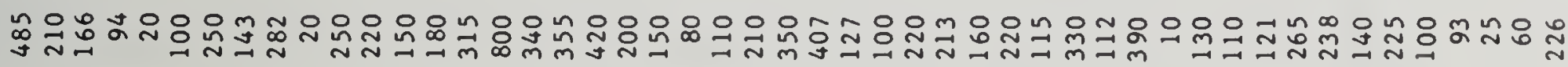

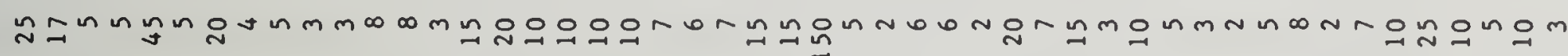

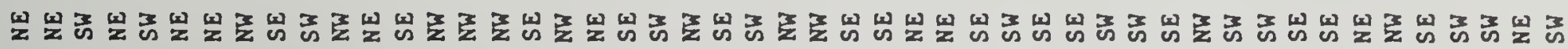

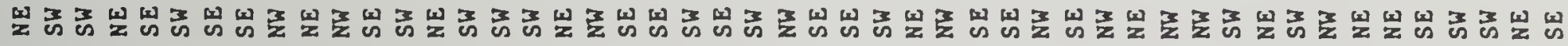

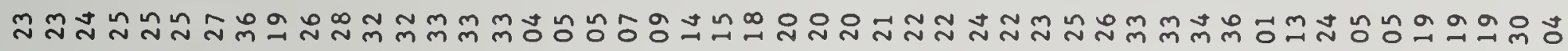

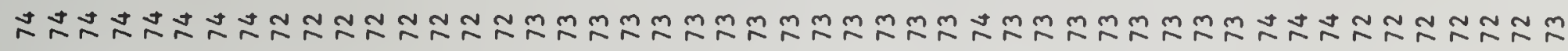

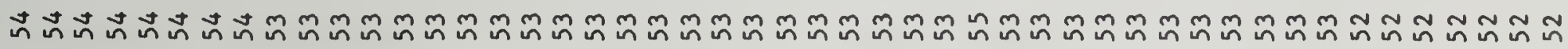

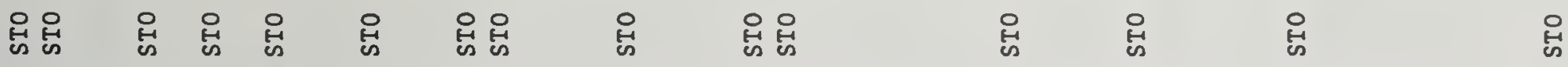

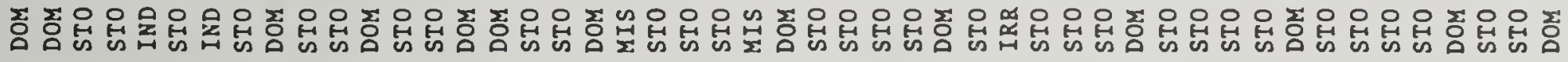

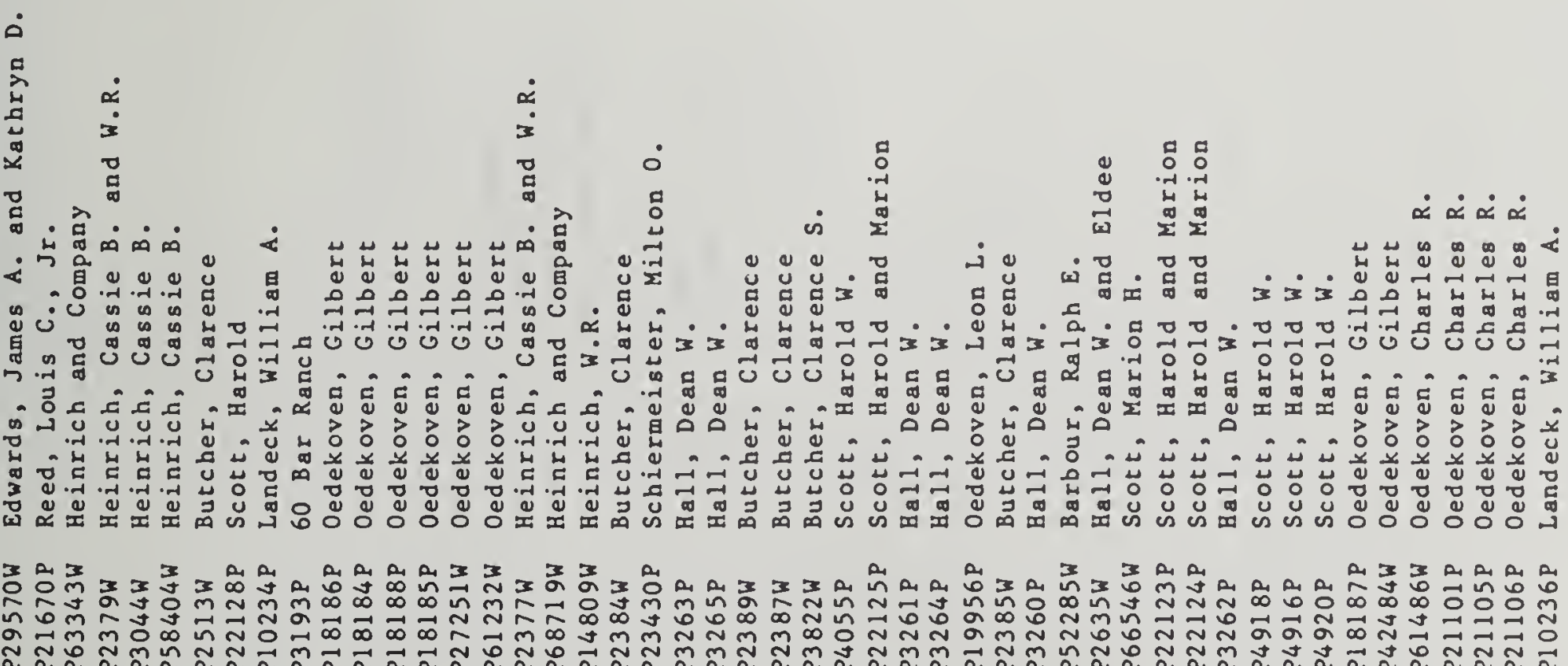

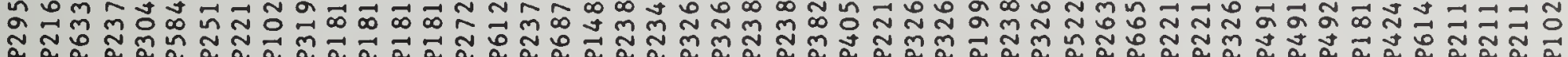




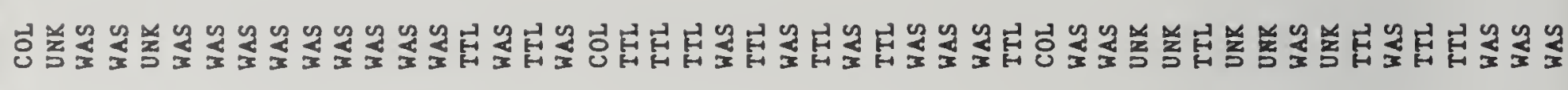

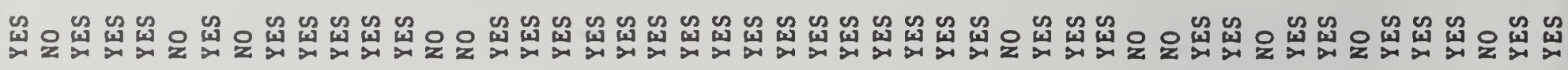

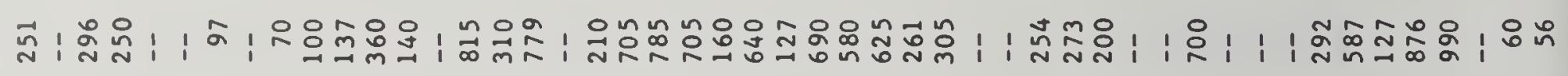

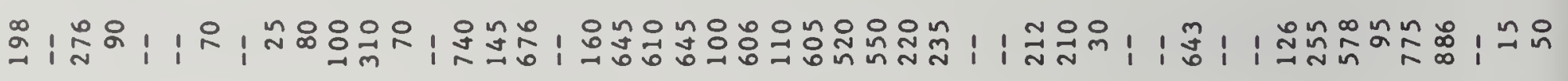

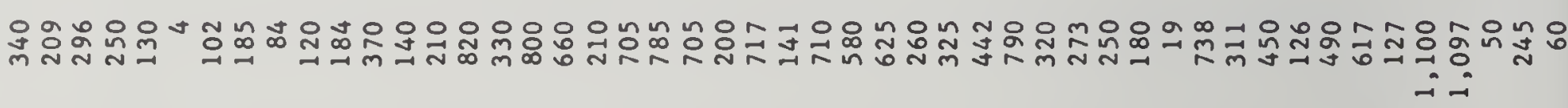

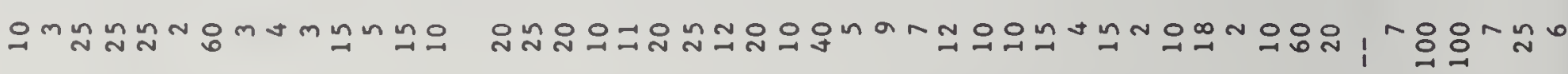

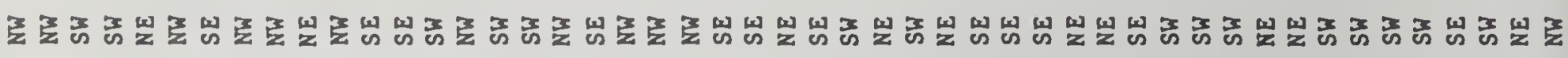

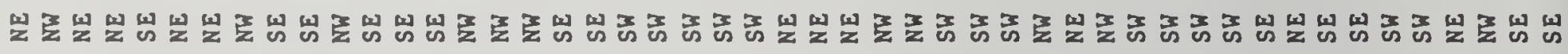

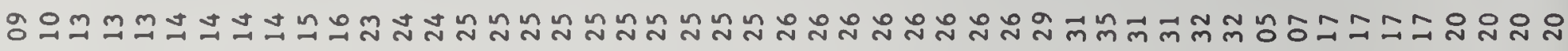

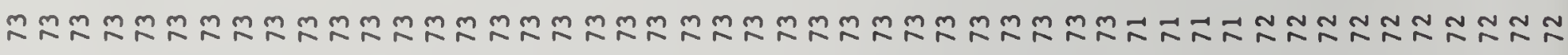

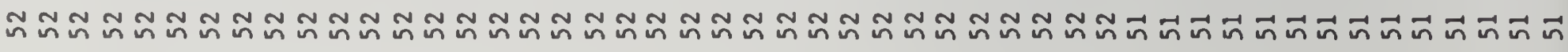

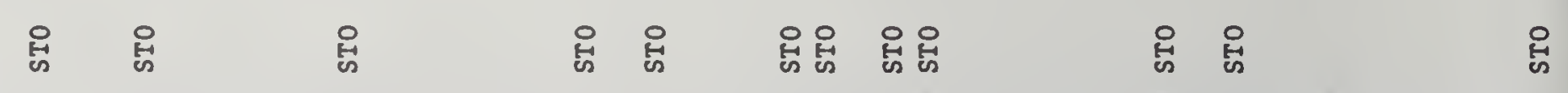

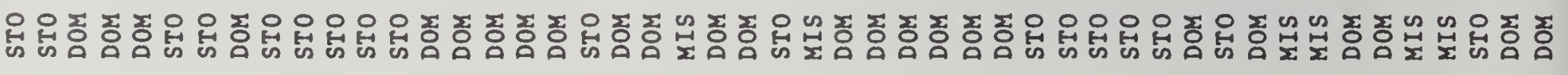

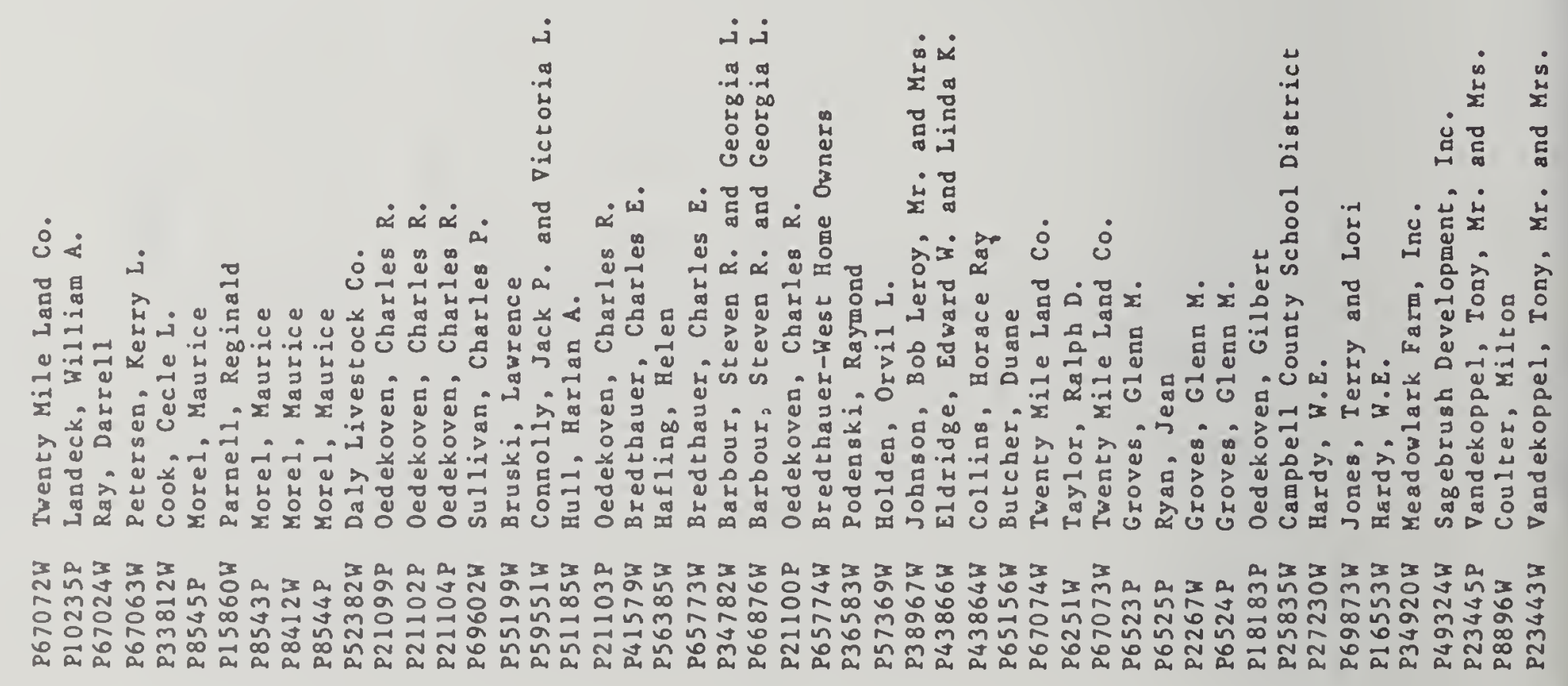




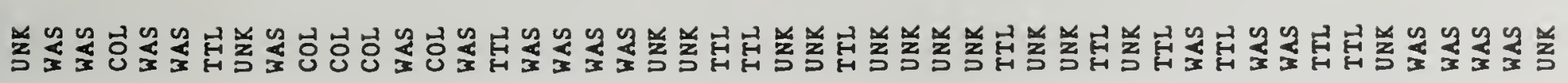

g

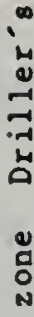

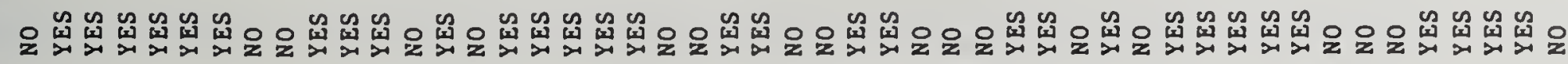

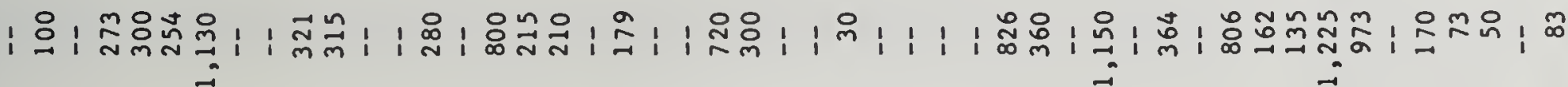

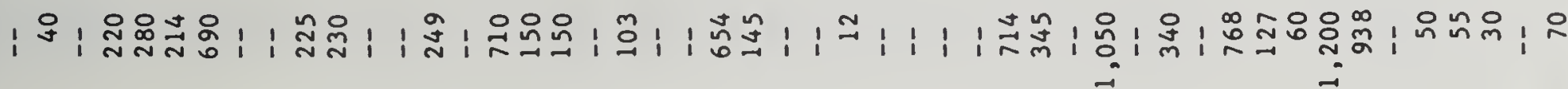

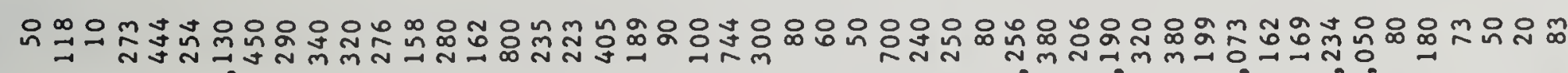

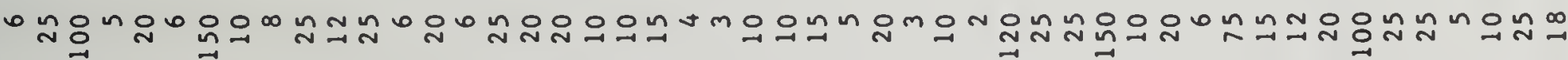

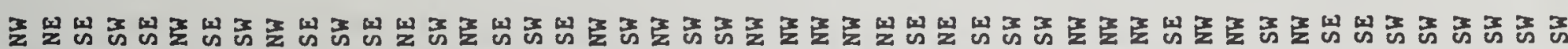

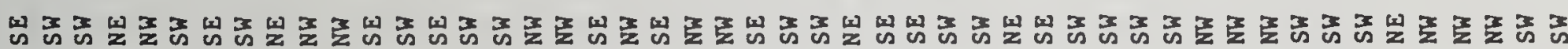

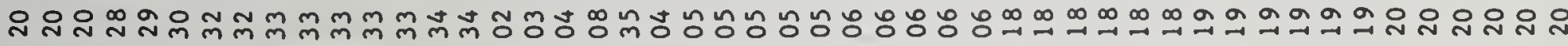

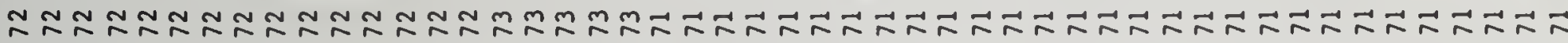
ที

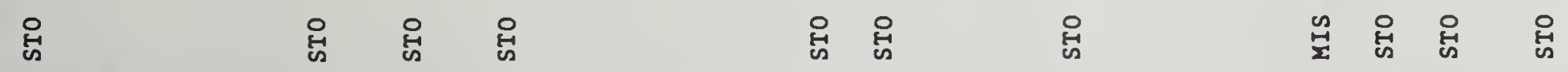

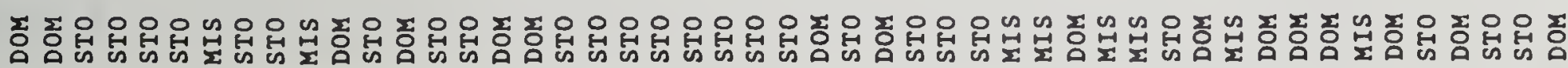

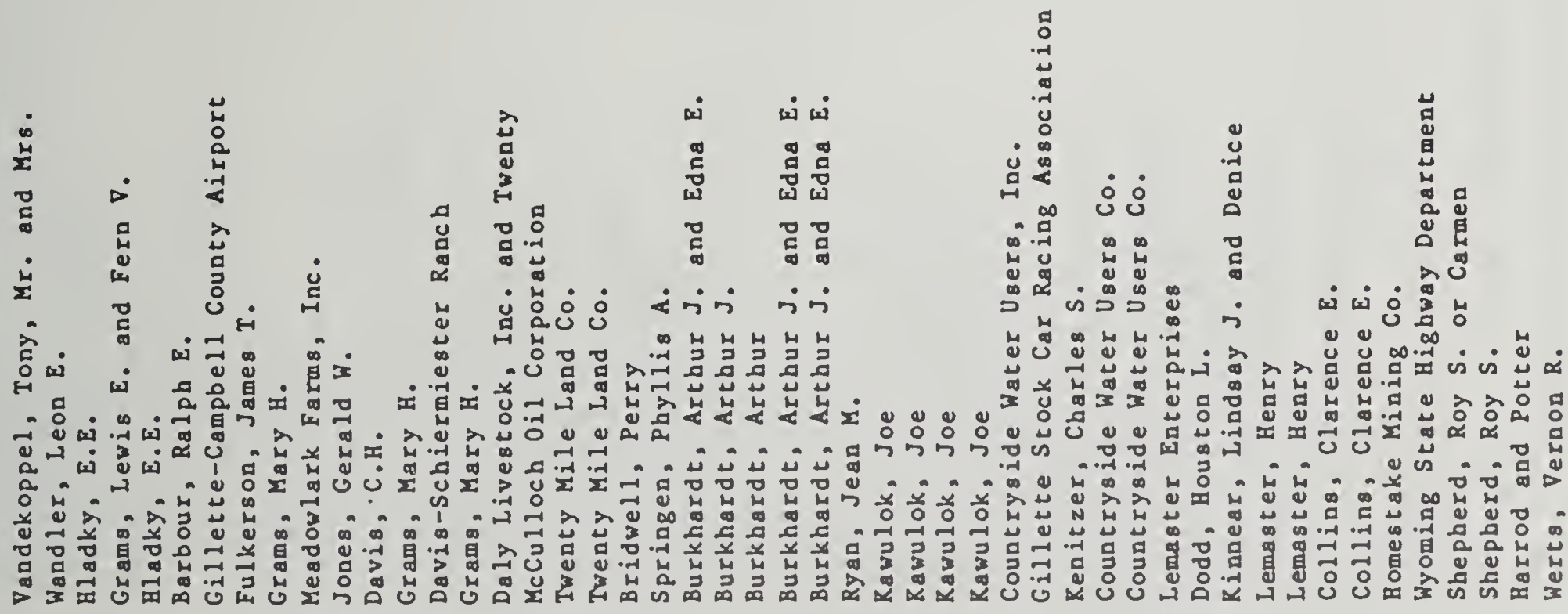

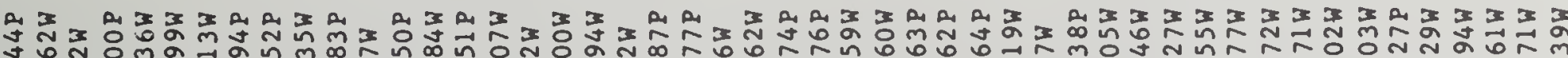

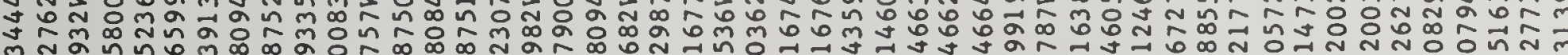

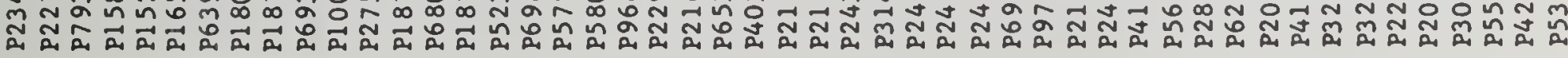




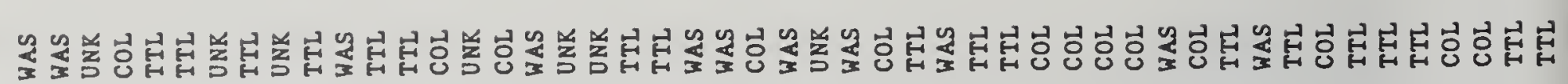

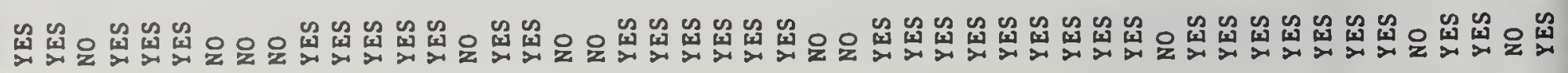

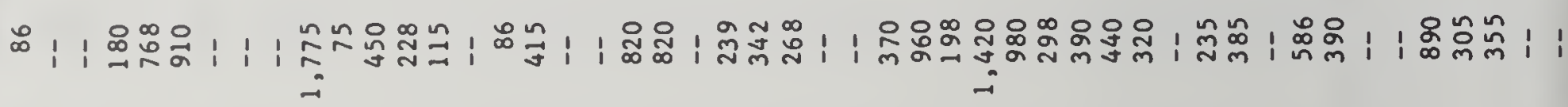

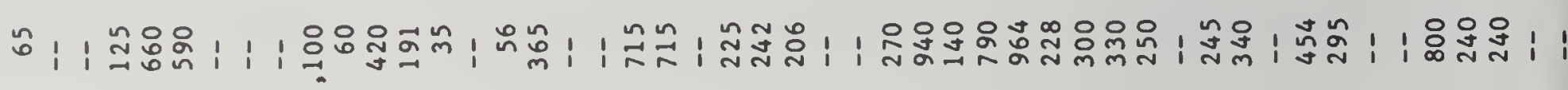

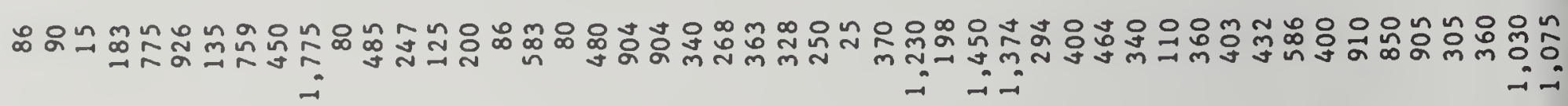

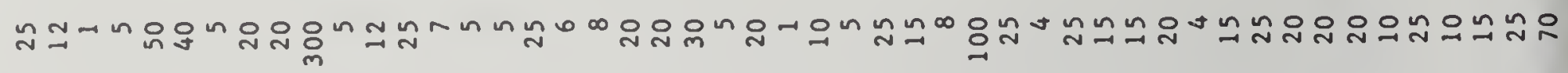

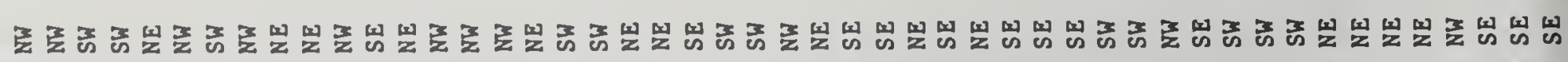

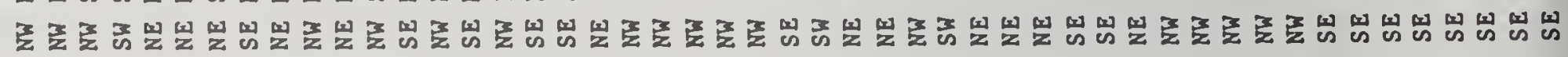

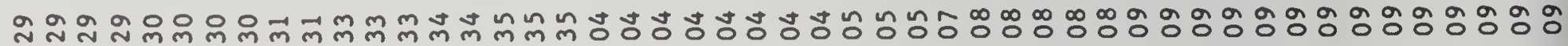

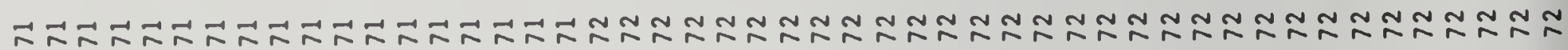

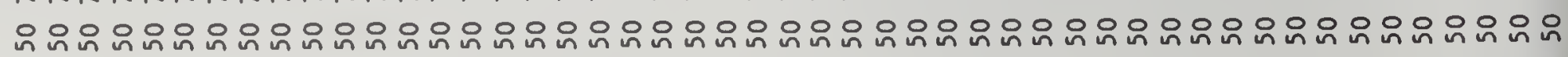

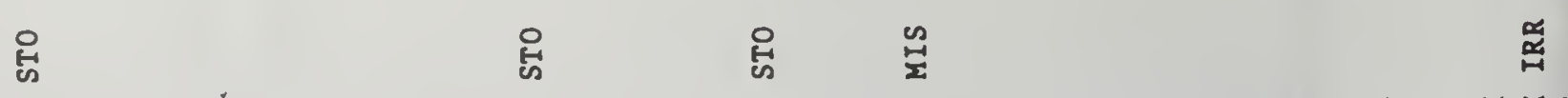

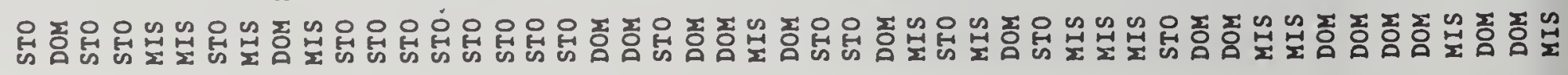

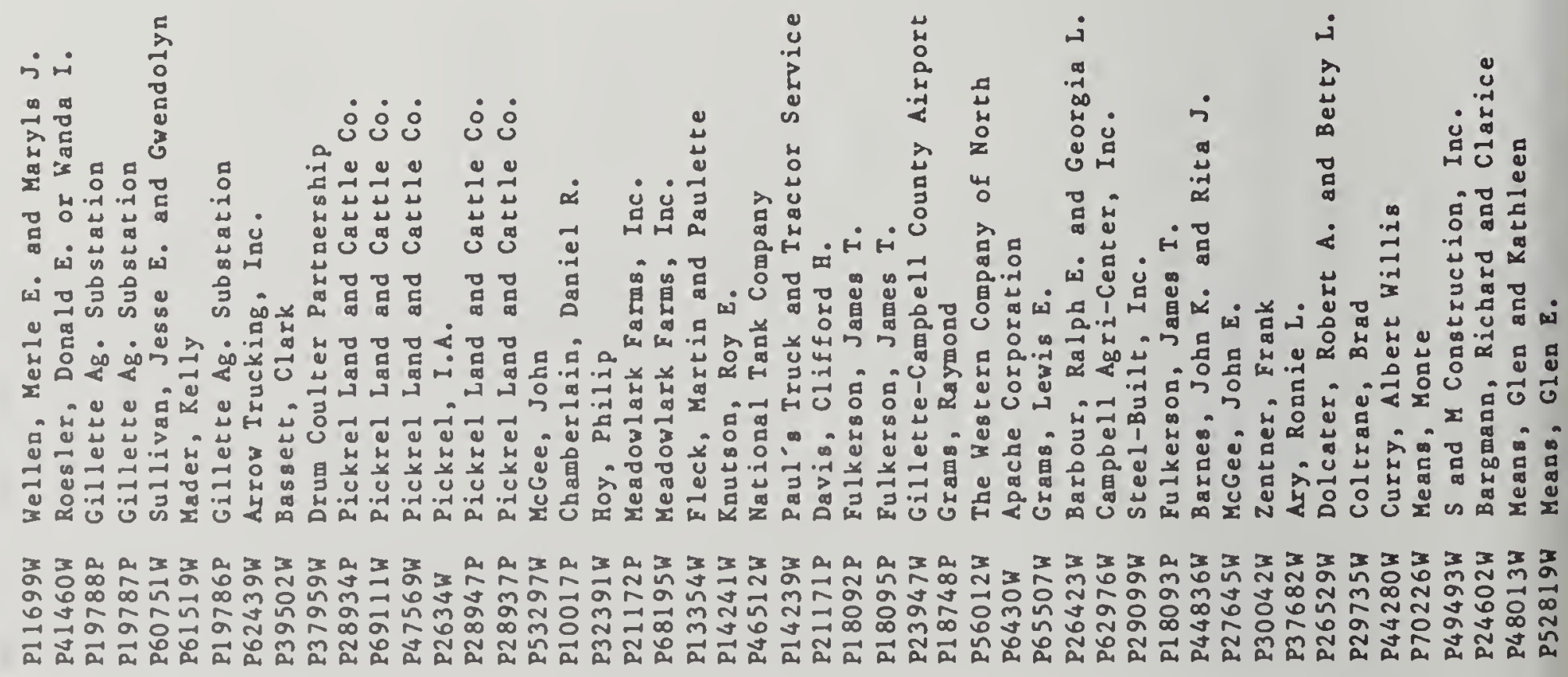




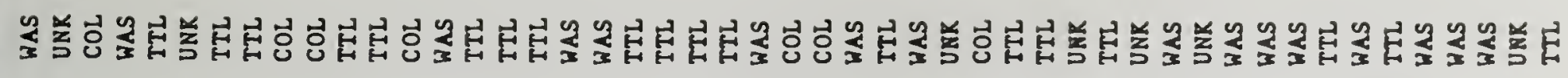

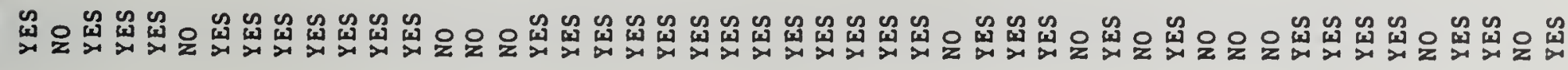

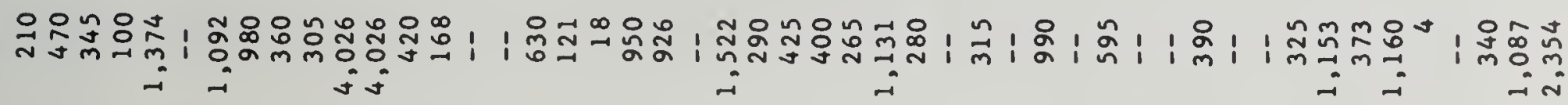

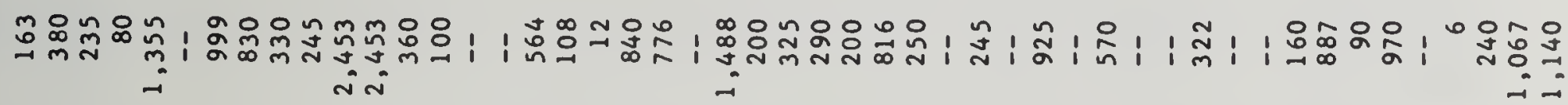

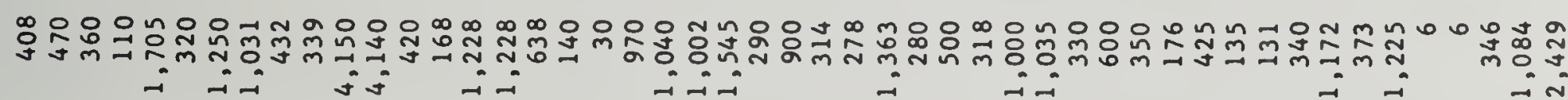

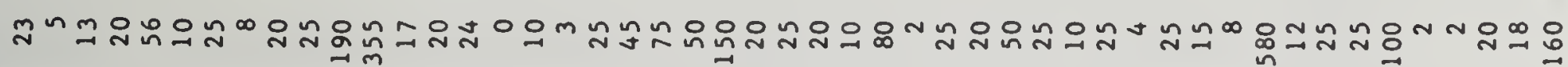

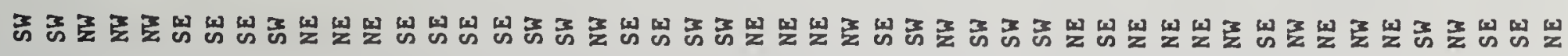

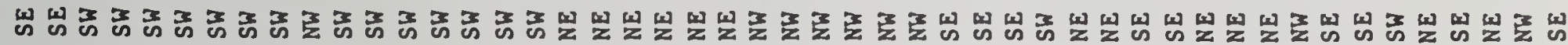

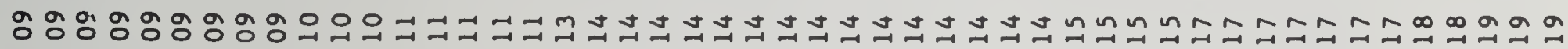
N.⿻

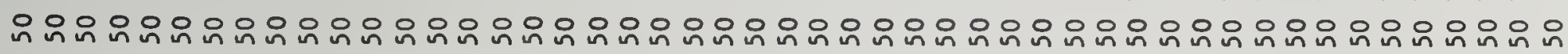

安

品

웄

웄 웄웄 웄

㝑

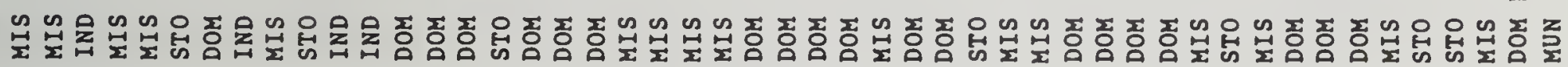

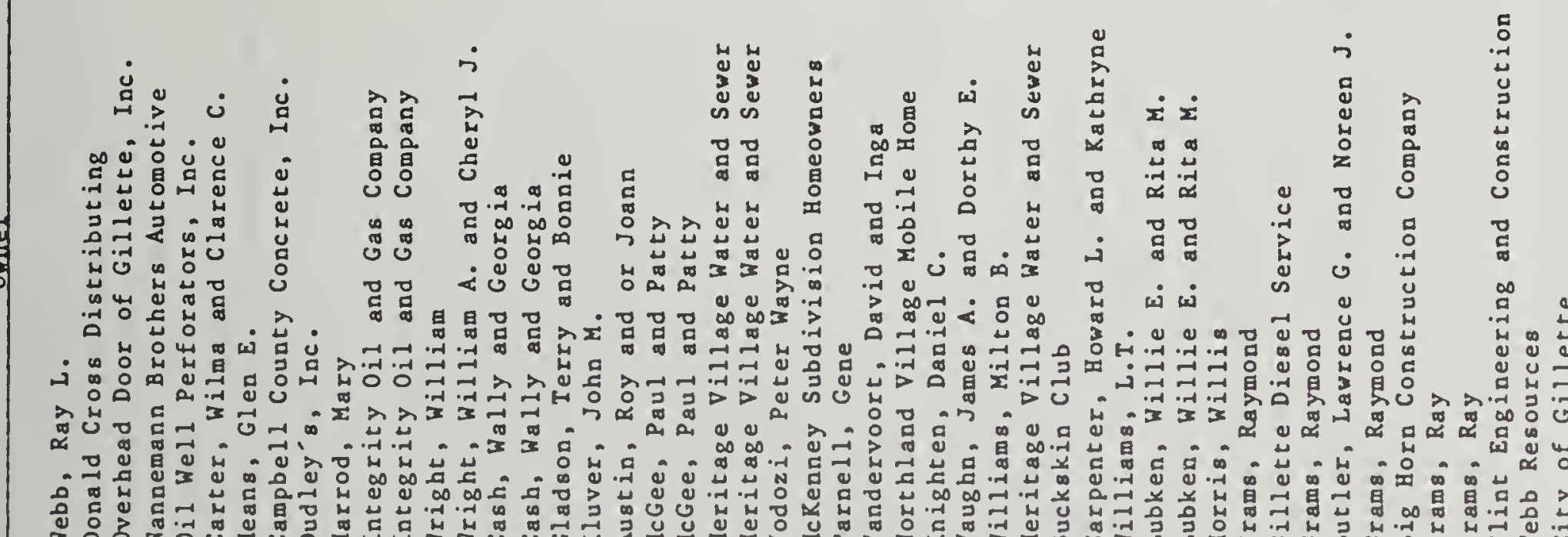

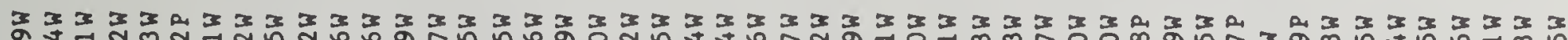

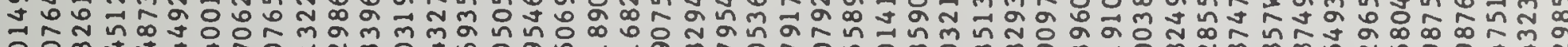

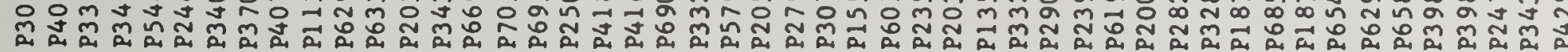




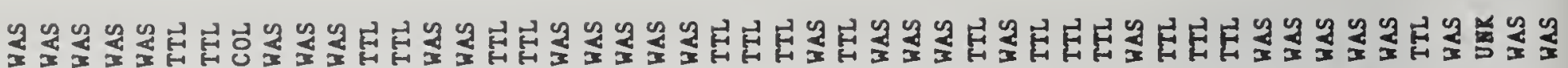

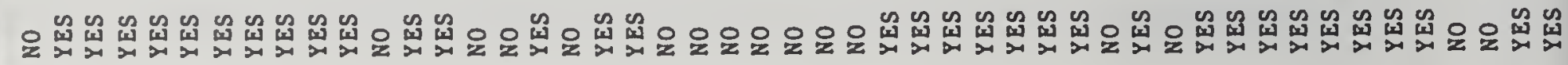

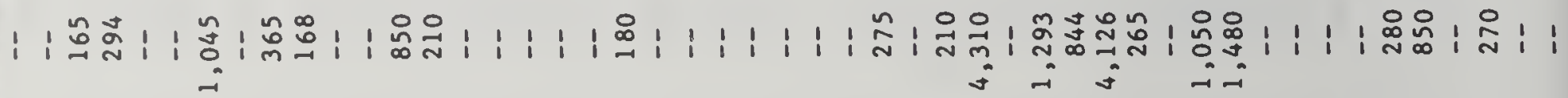

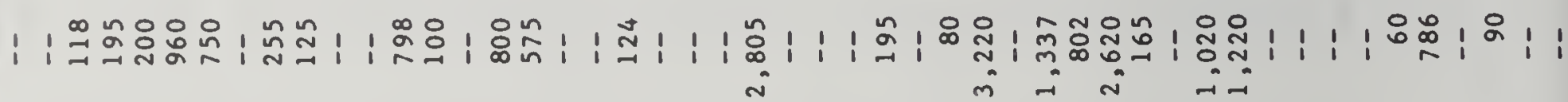

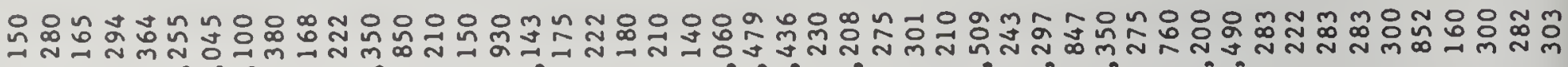
邹

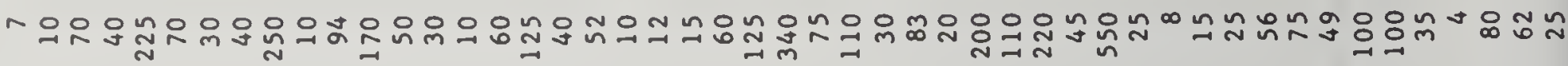

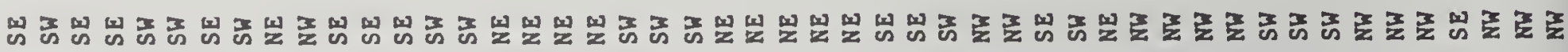

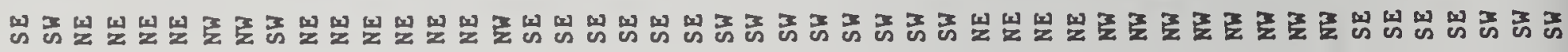

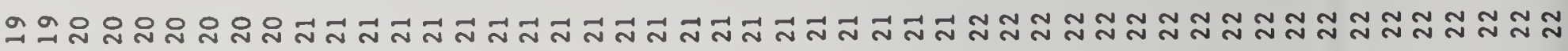
TNN

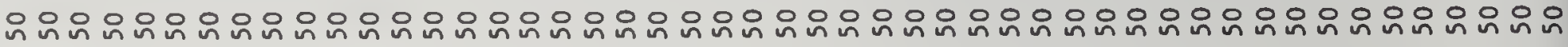

영

兽

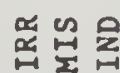
茫 登管 옹

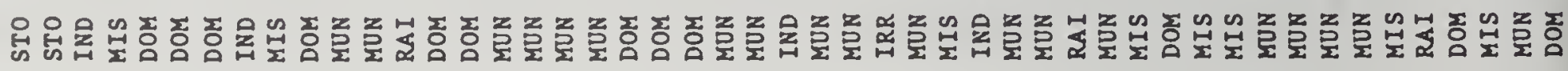




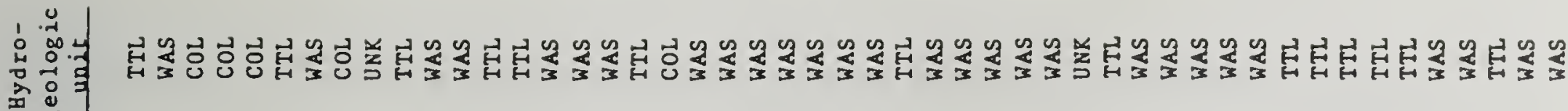

(1)

is $\infty$ aे

並

\section{芯}

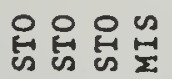

品

空

它 它

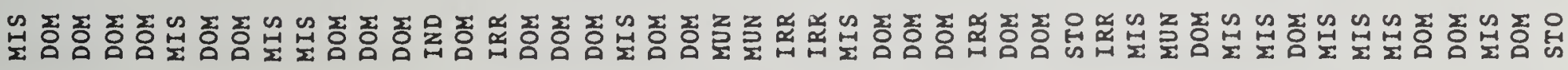

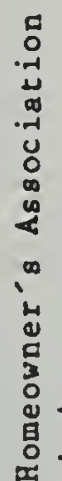

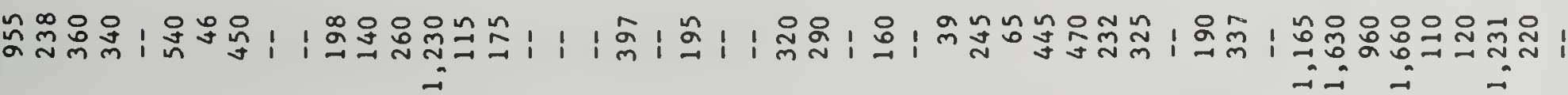

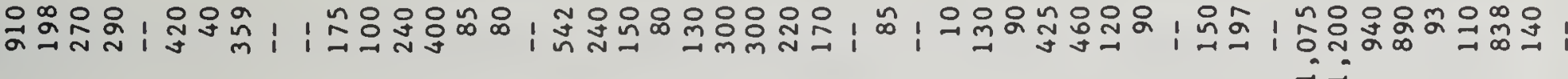

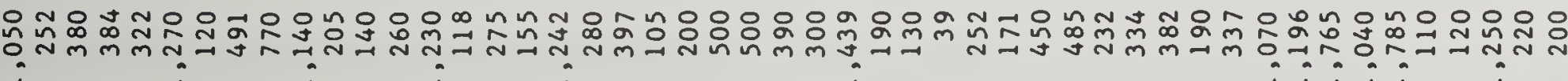

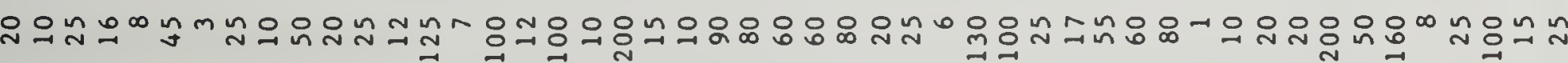

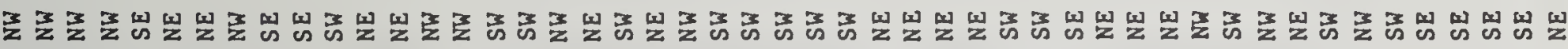

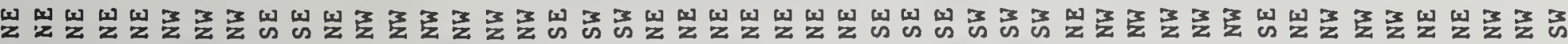

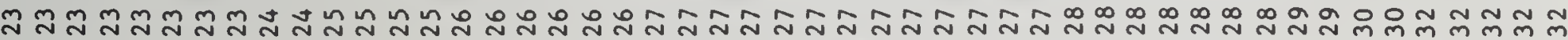

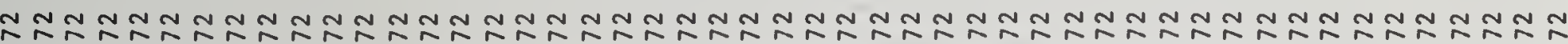

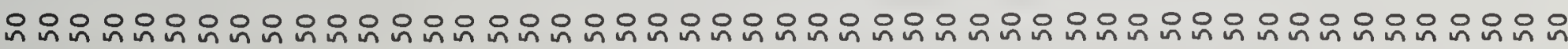




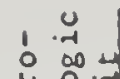

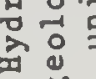

$\infty$

s

$\exists-7$

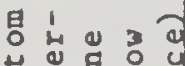

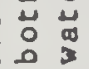

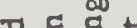

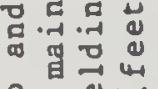

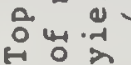

몬

品

곤

-

$$
\text { aे }
$$

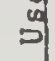

\section{혼}

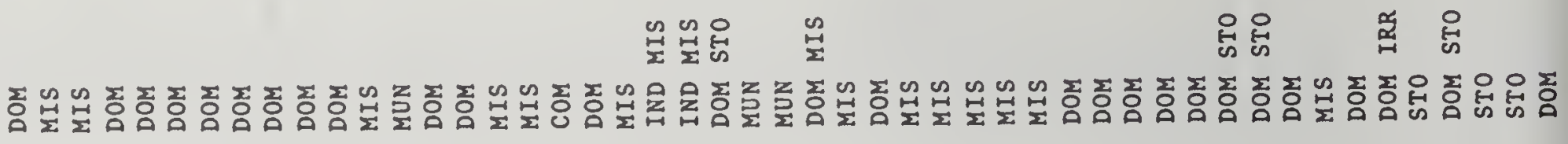

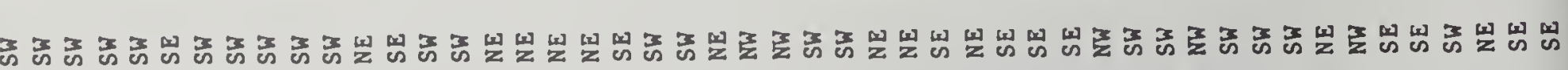

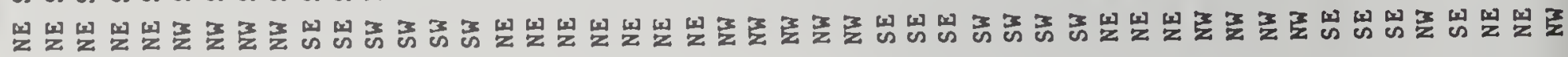

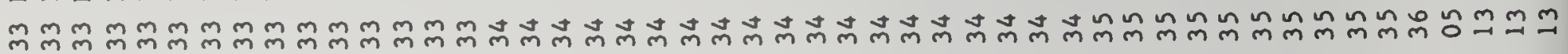

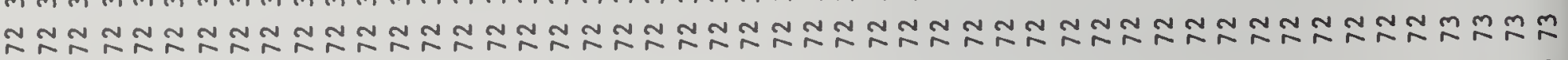

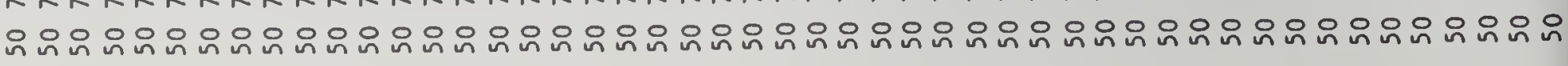

동

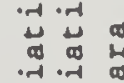

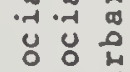

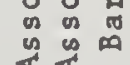

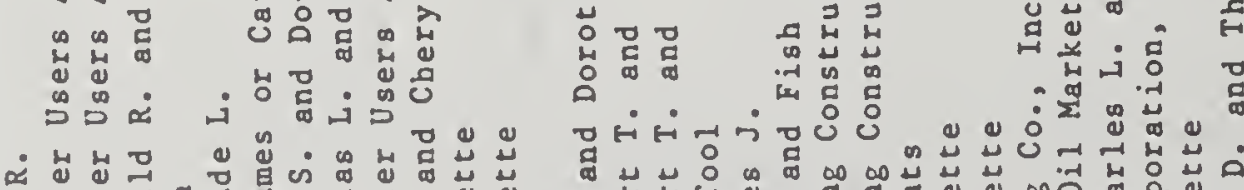

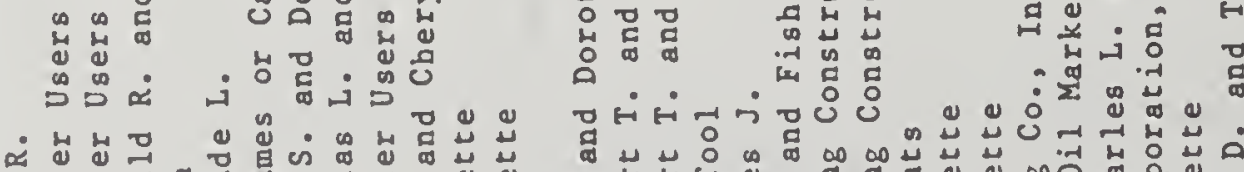

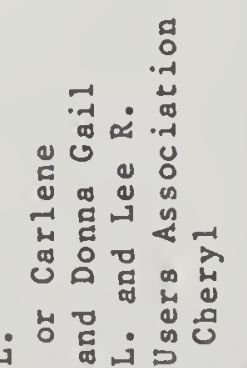

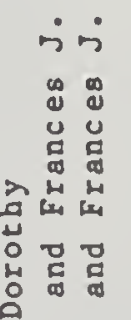

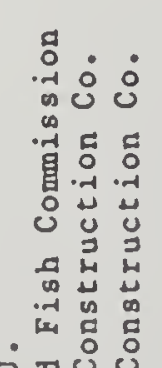

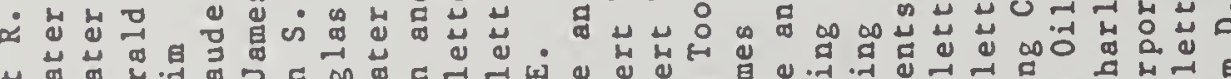

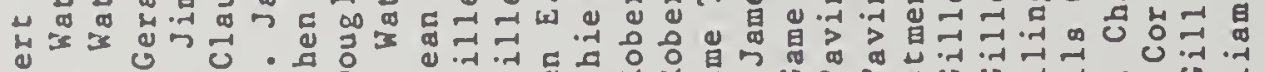

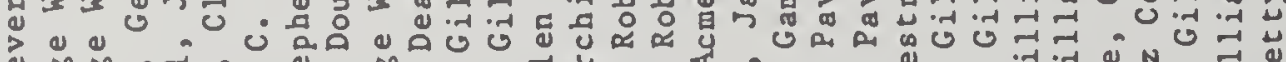

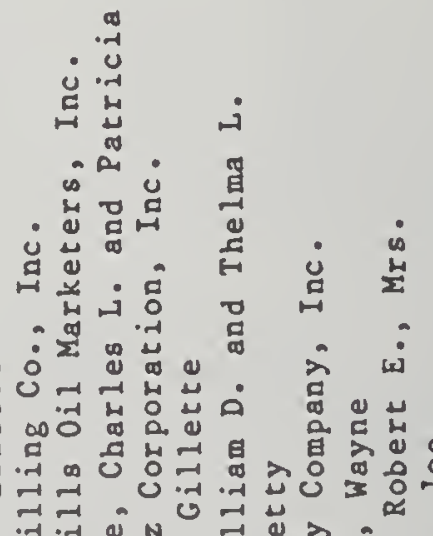

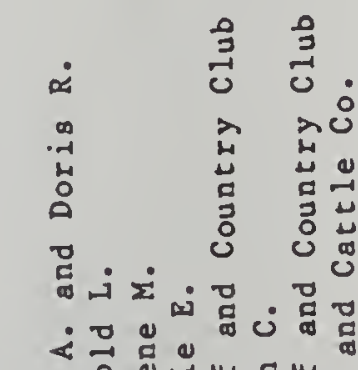

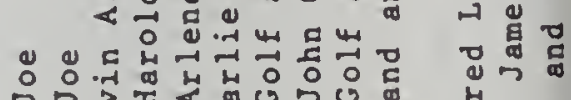

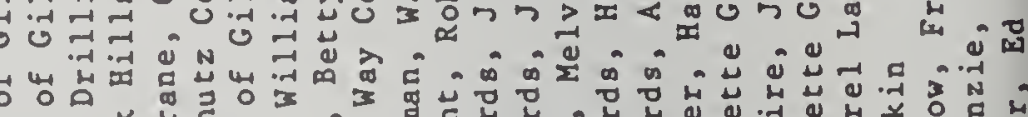

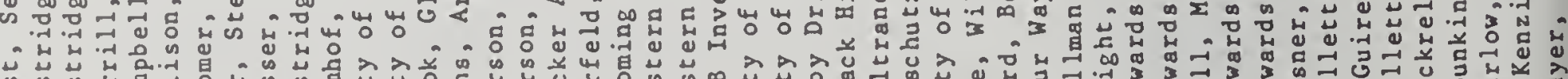

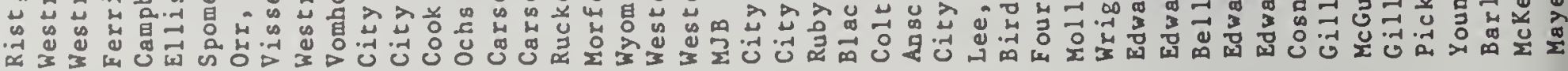

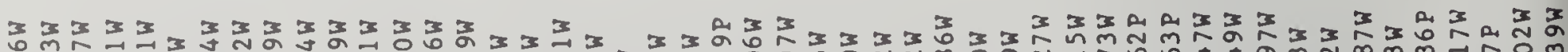

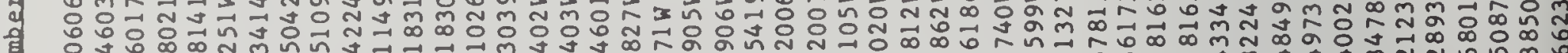

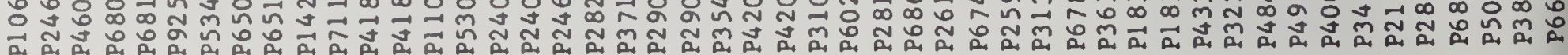


: 空落

is $\infty$ o

$\exists \rightarrow=$

青:

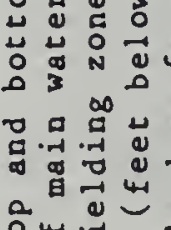

今.

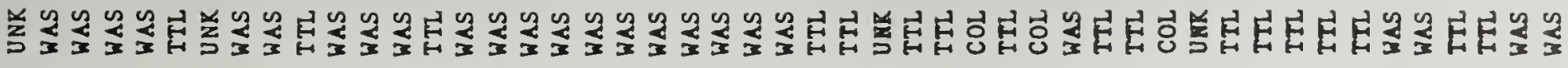

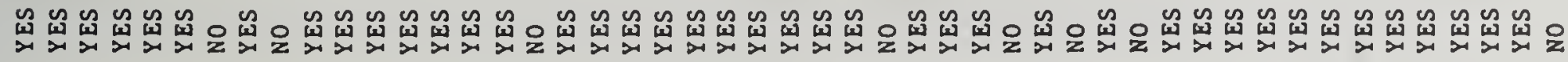

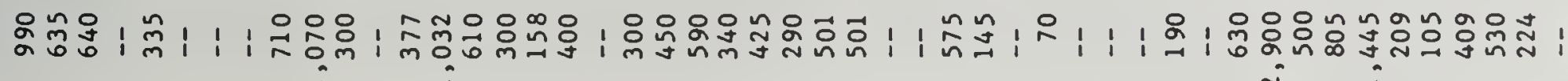

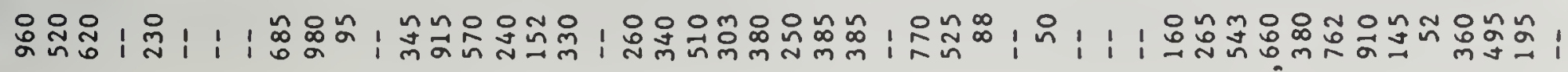

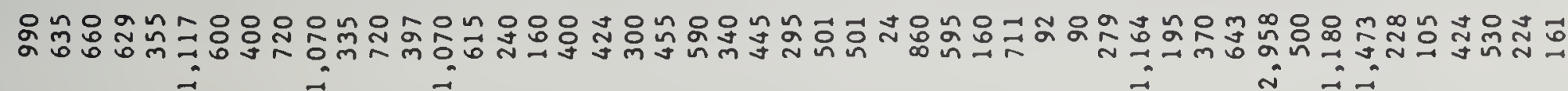

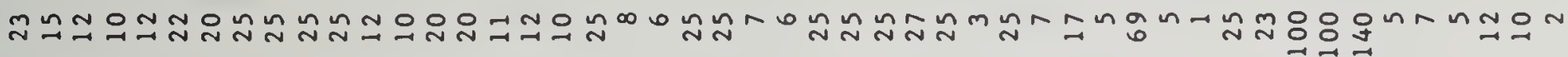

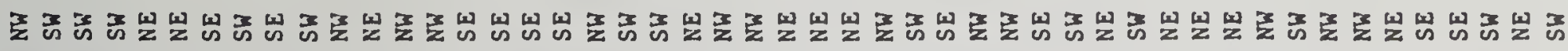

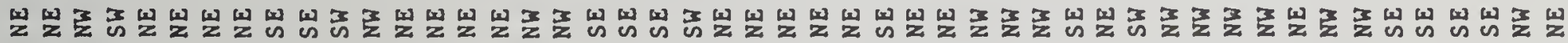

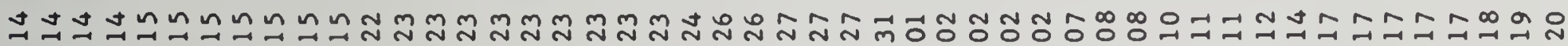

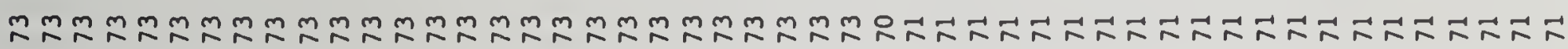

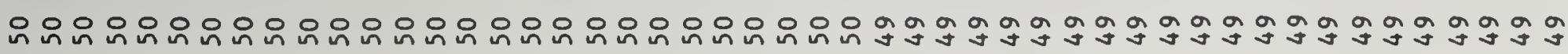
总总品品品
웄
옳 용 总
离

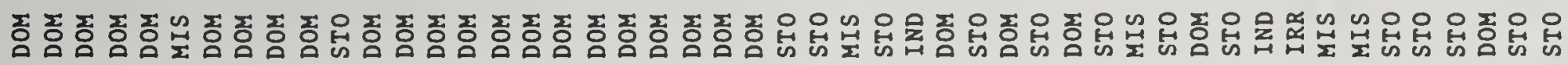
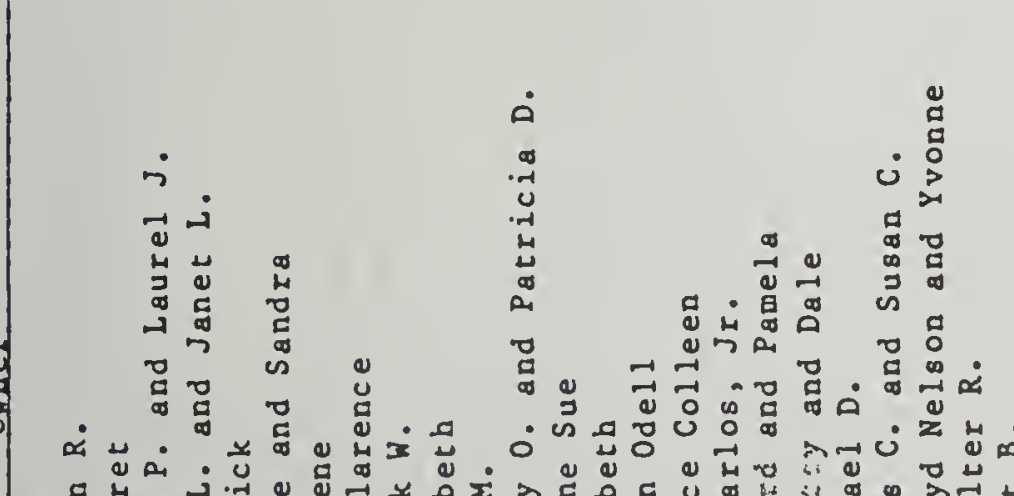

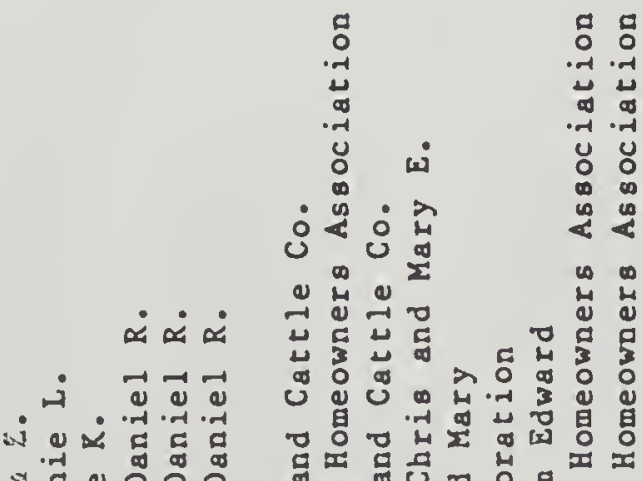

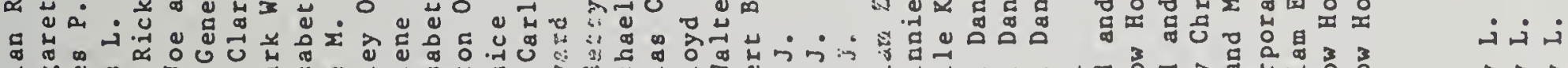

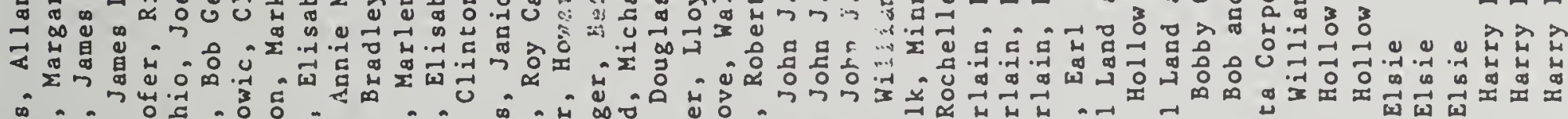

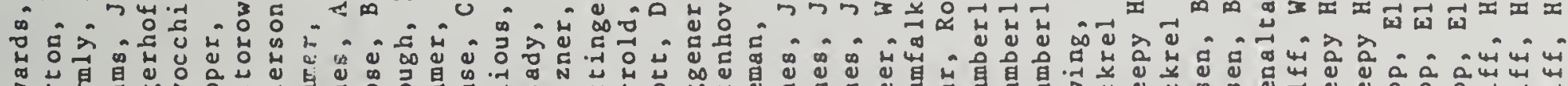

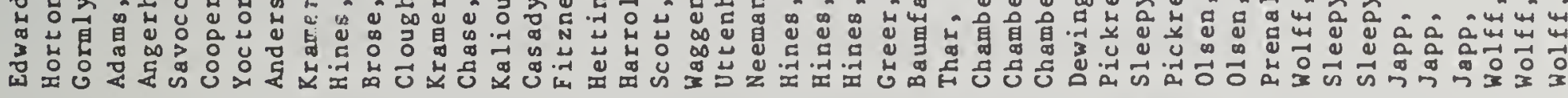

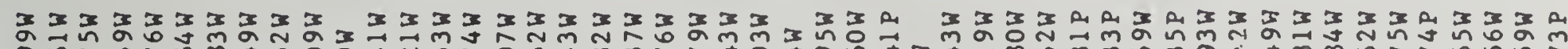

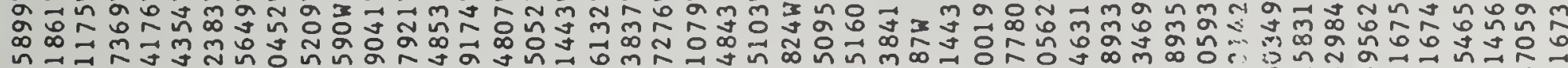

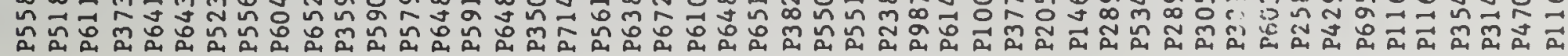




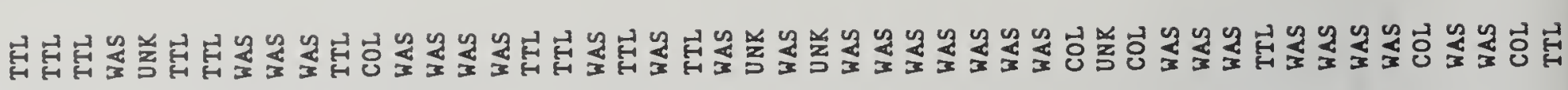

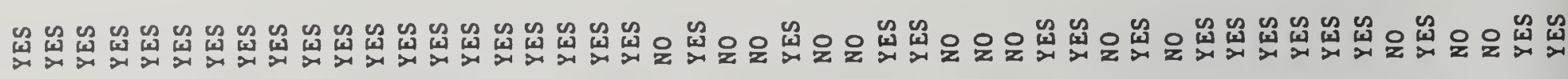

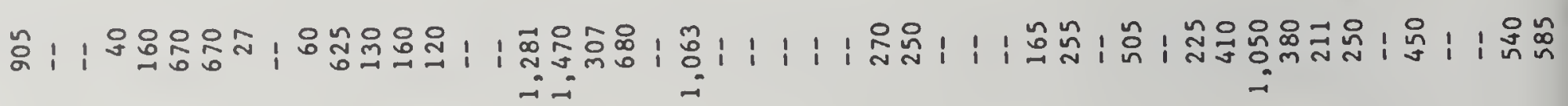

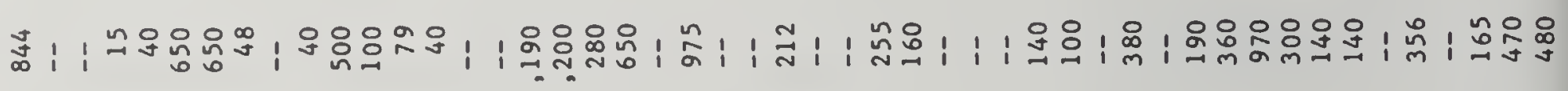

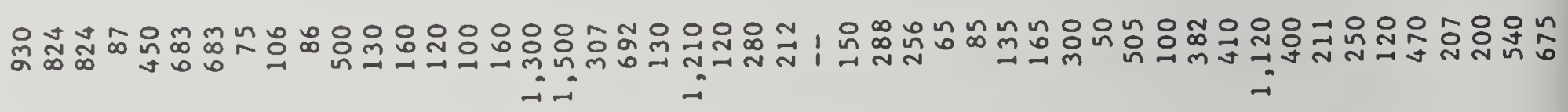

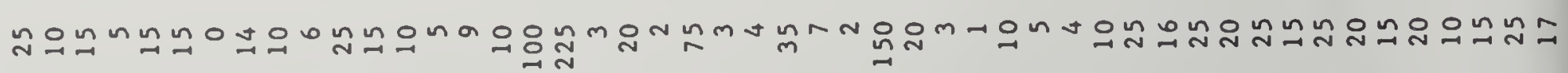

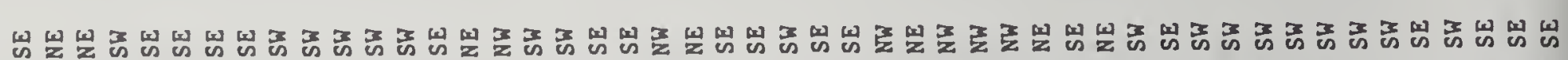

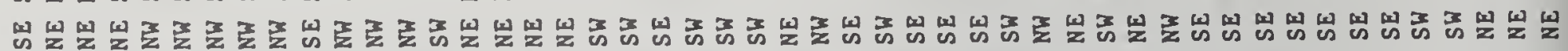

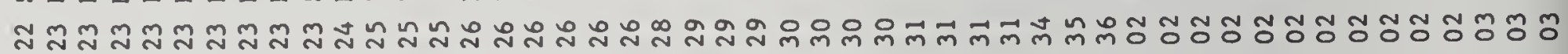

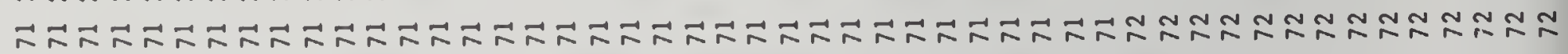

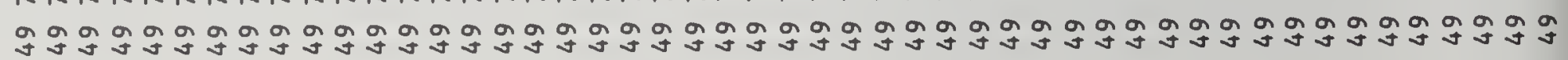

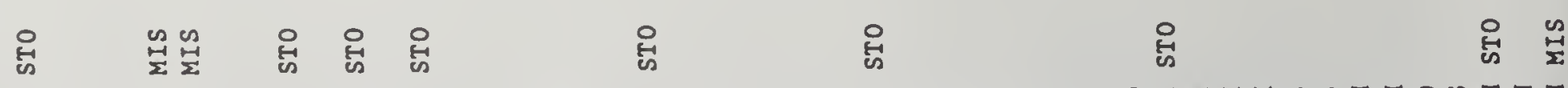

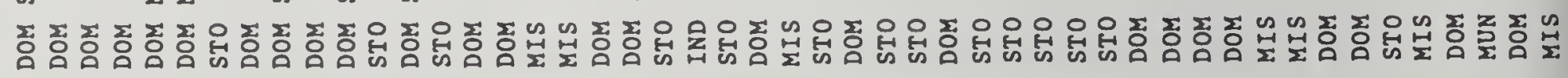

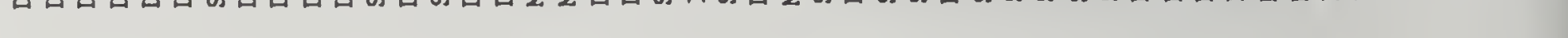

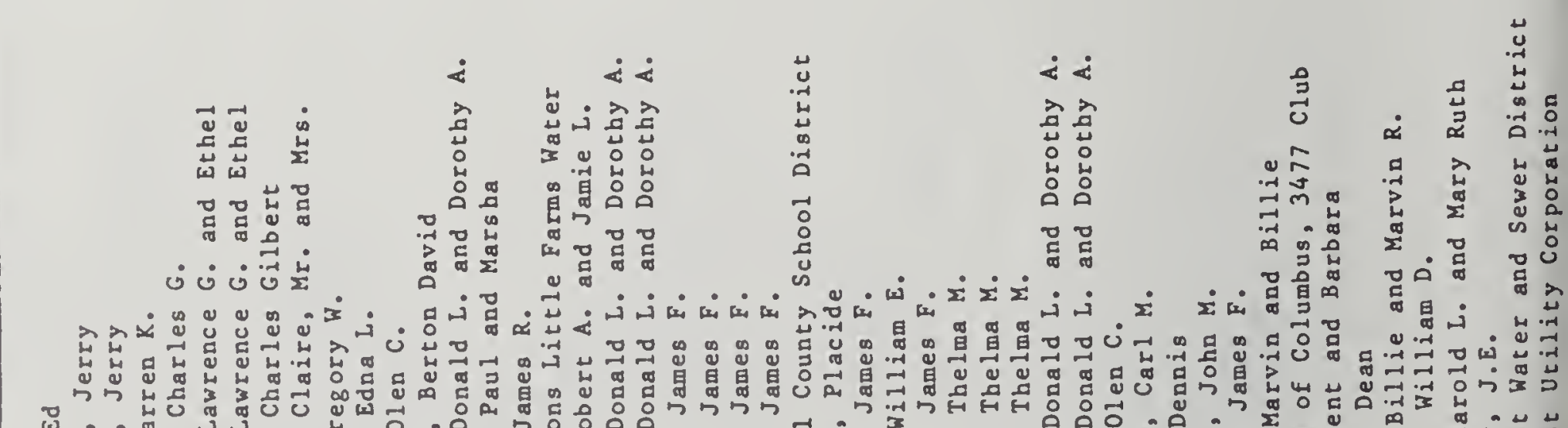

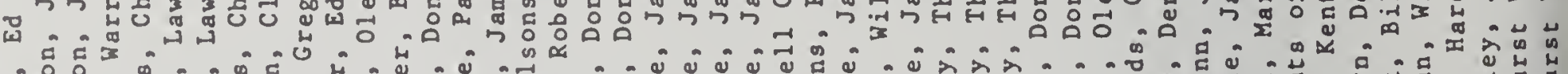

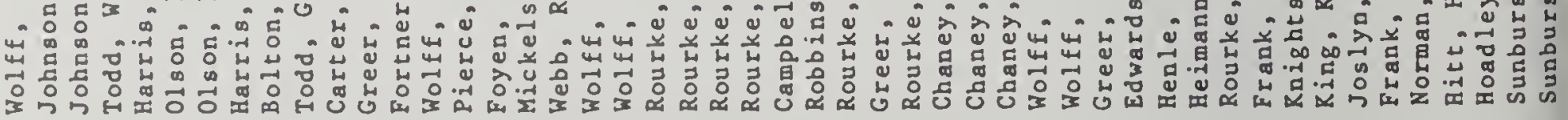

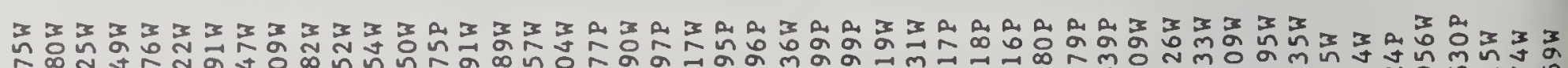

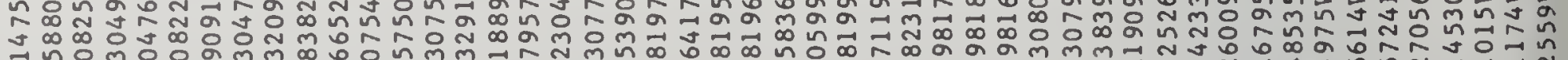

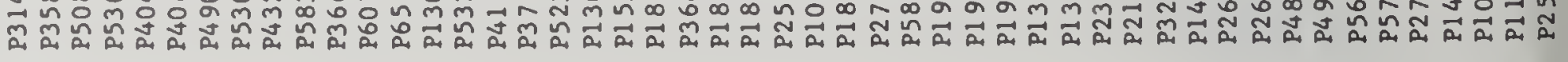




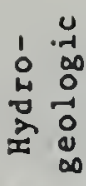

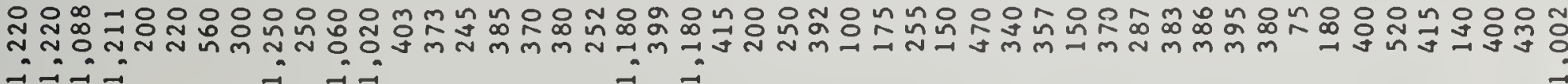

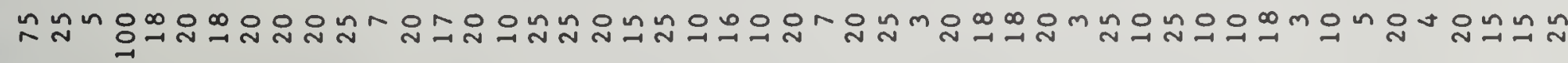

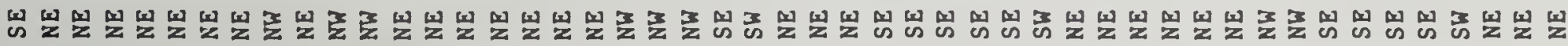

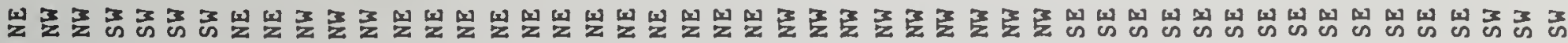

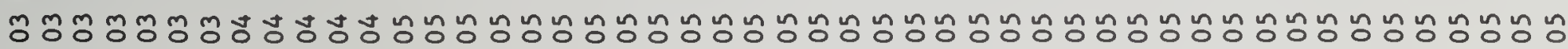

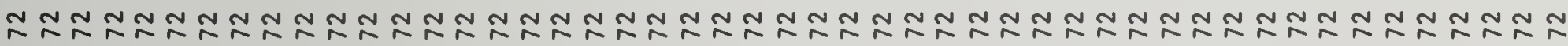

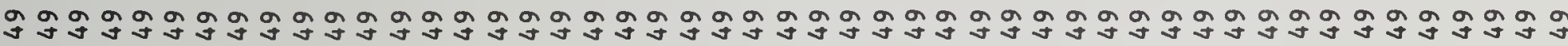
용
운
윴융
웄욨
웄융 융

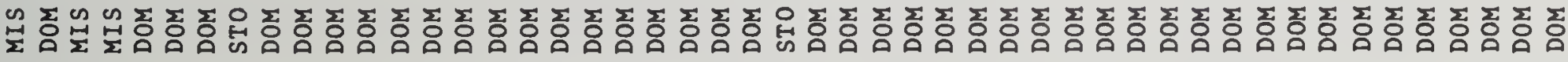

\section{政}

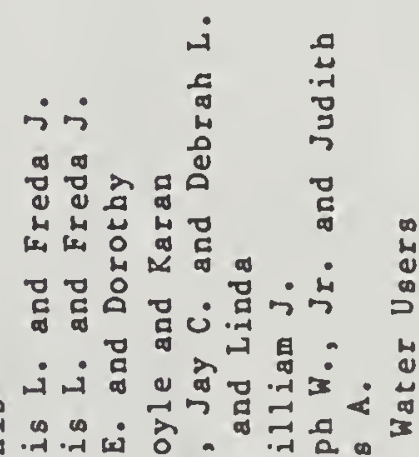

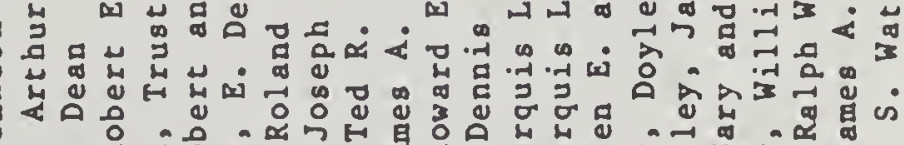

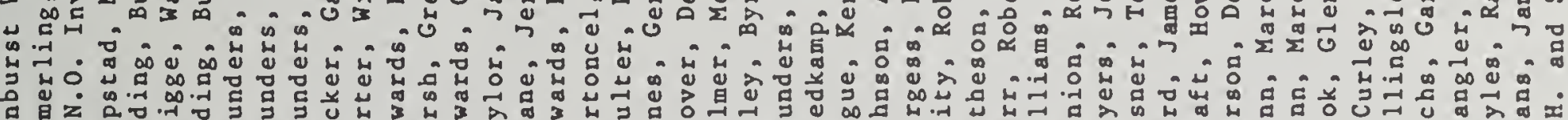

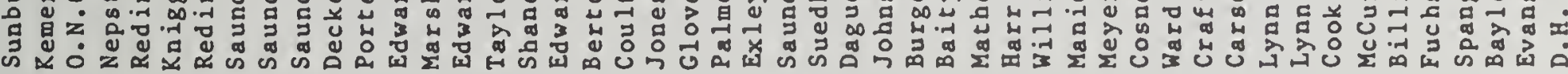

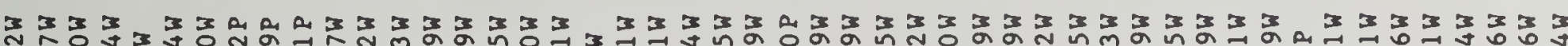
$7 m$ న 


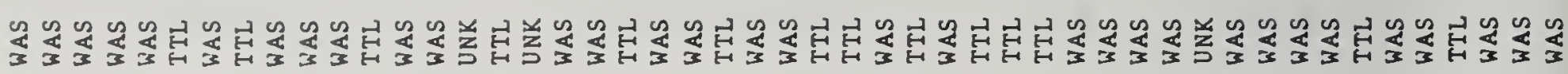

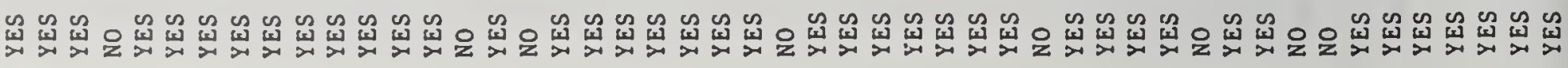

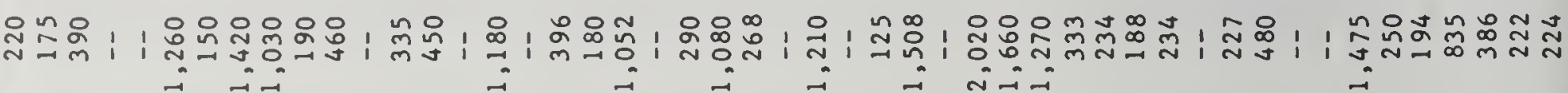

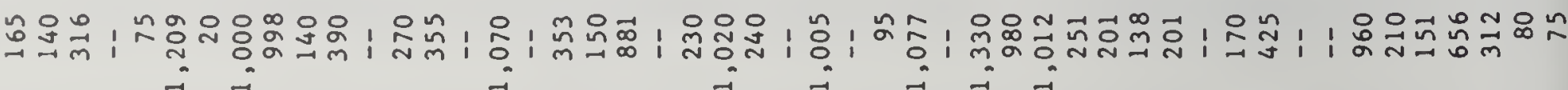

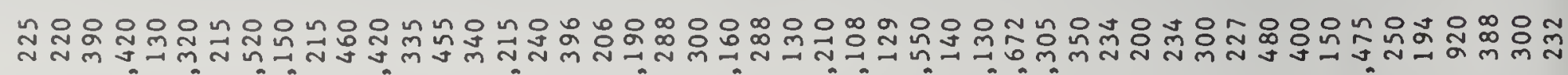

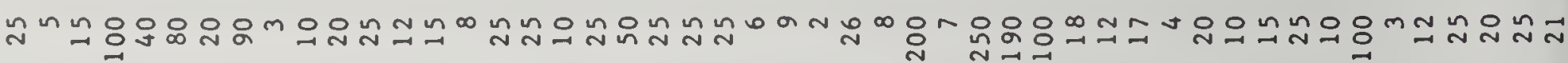

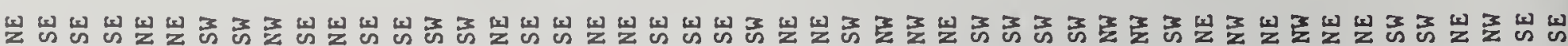

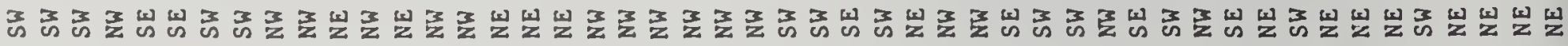

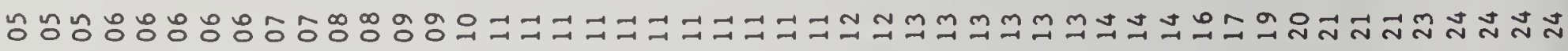
הNลNהN

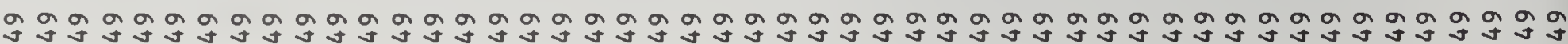

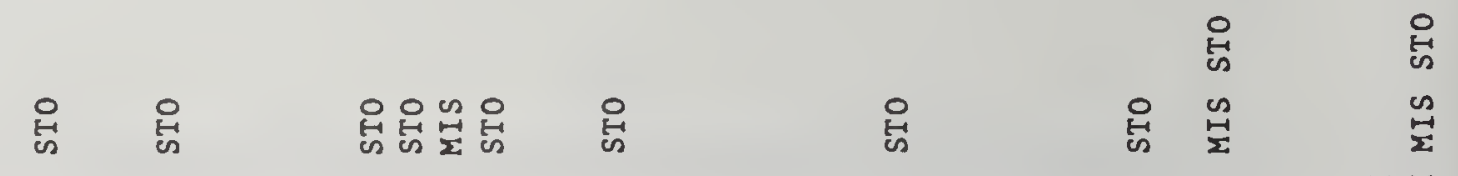

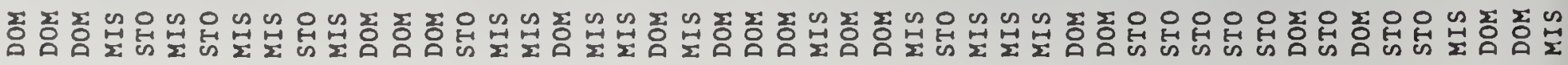

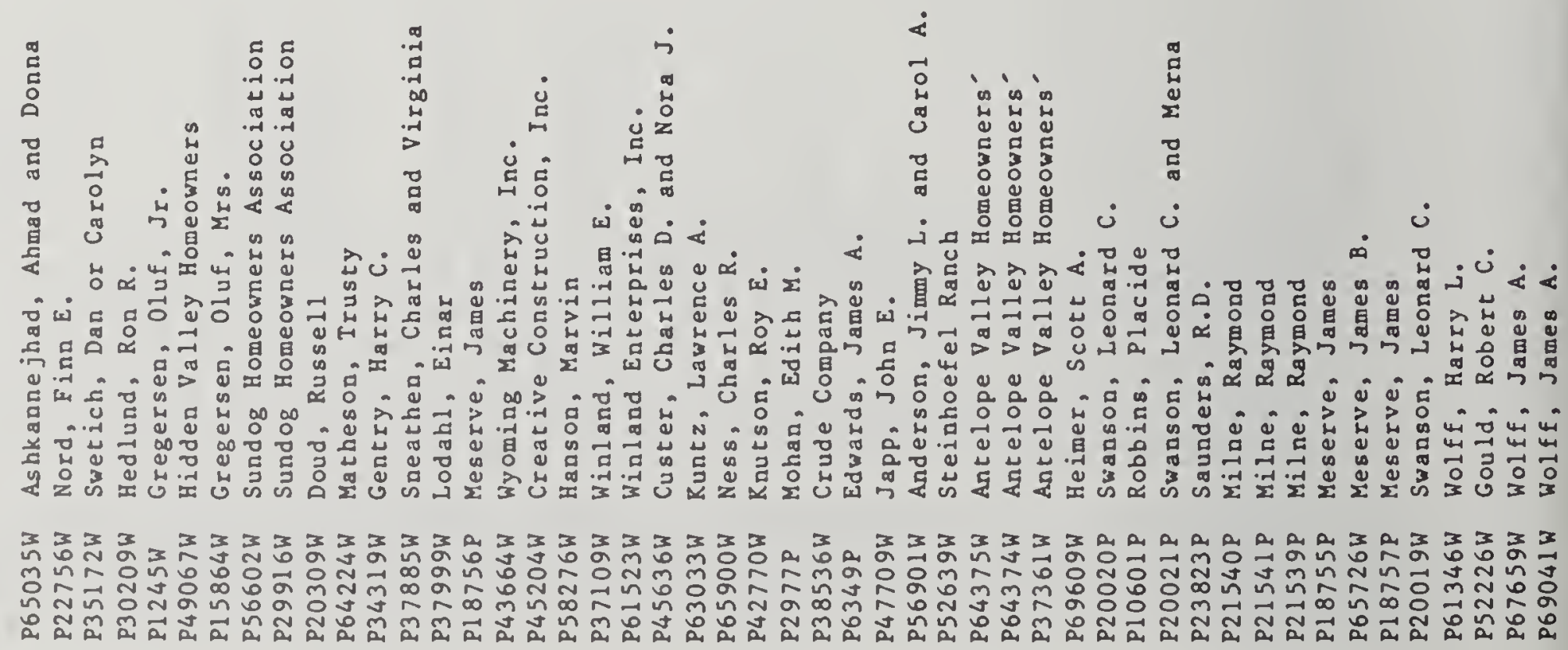




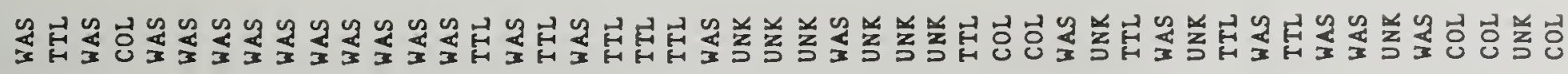

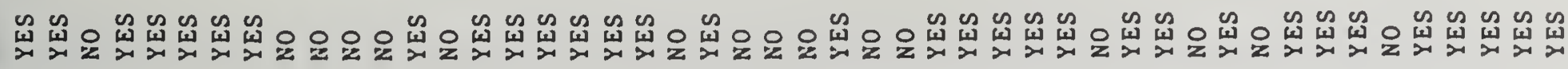

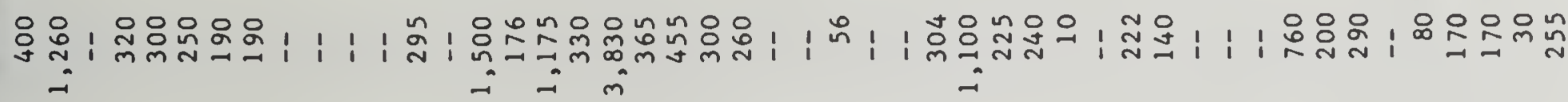

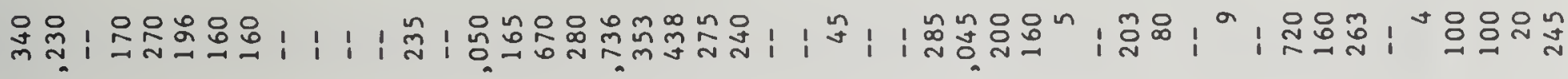

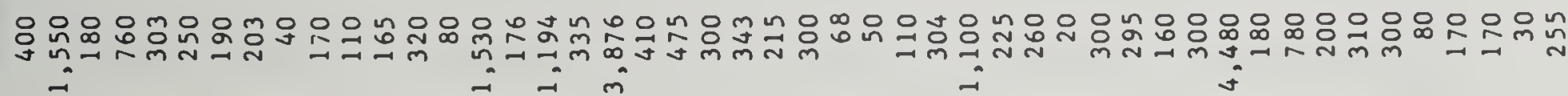
읏ำำ

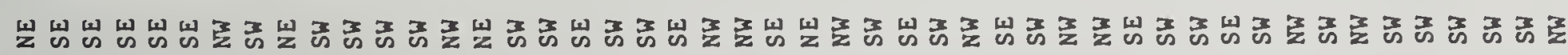

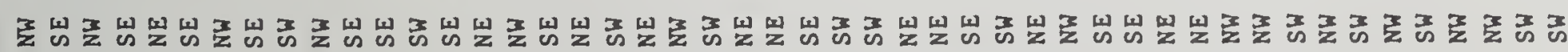
ㄱำกำกำm

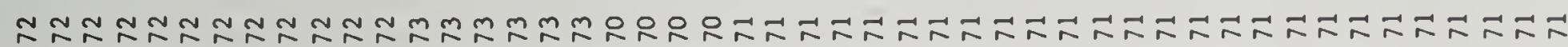

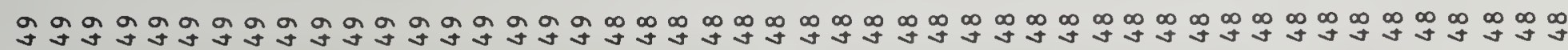
롤 온
운 웁운 운
웄앖옳
옳

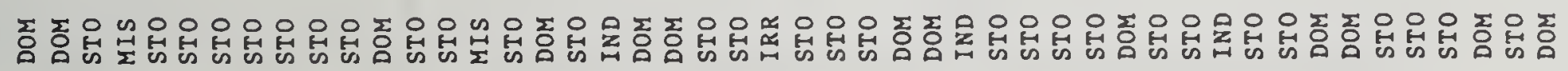

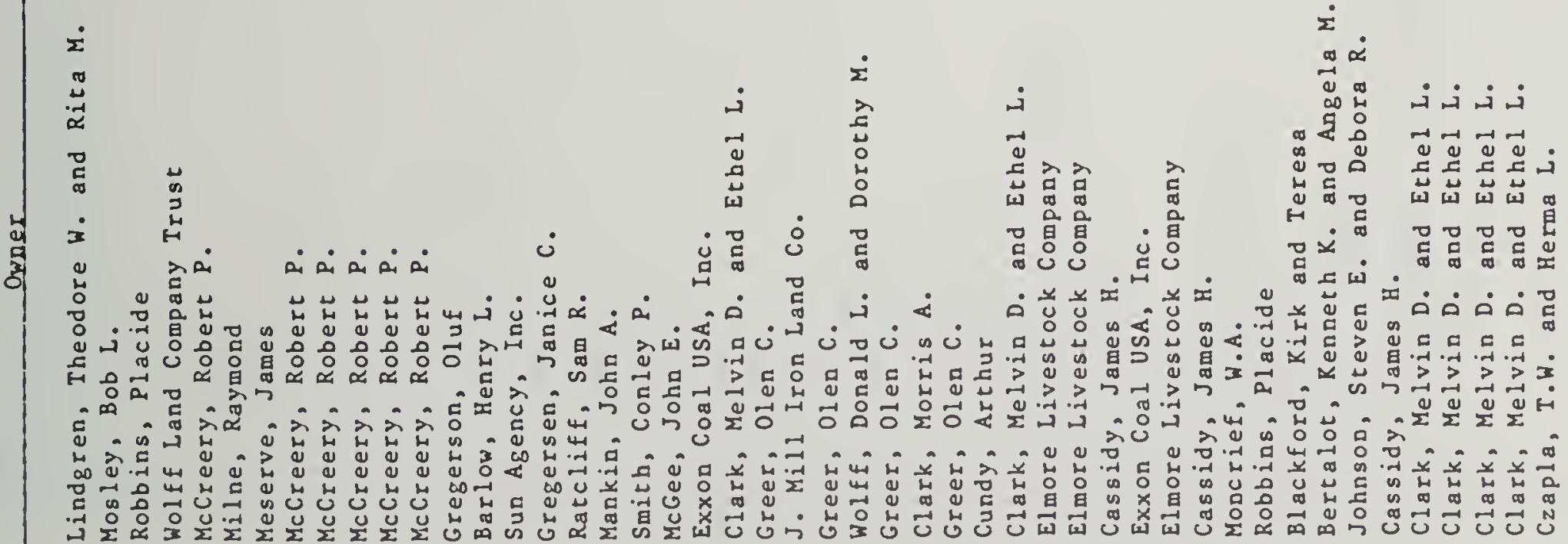

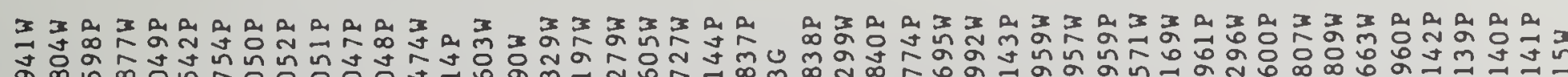
大o

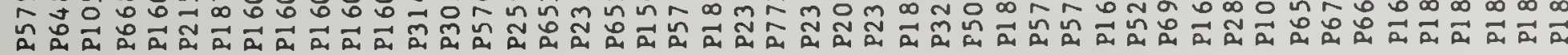


:

空䓪

$\infty$

$\stackrel{5}{\circ}$

㟧

星 :

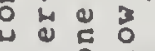

13

돈.

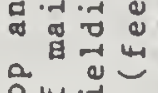

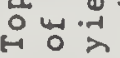

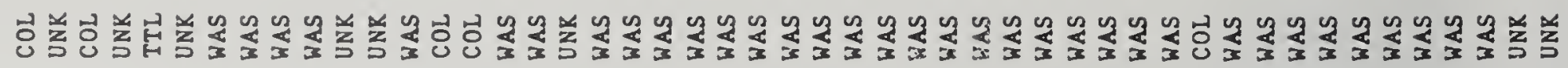

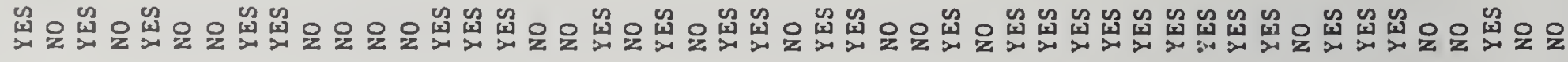

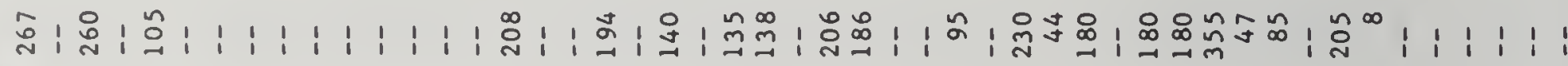

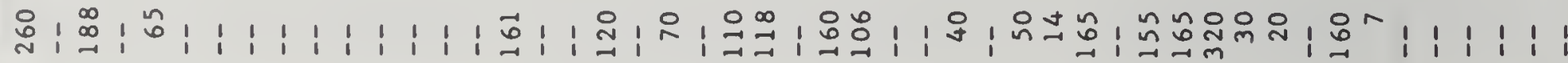

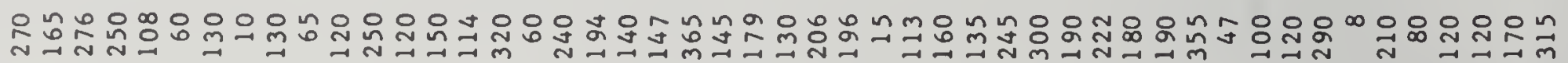

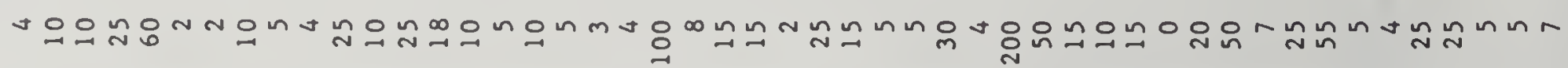

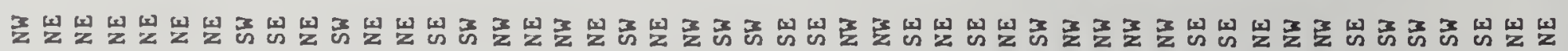

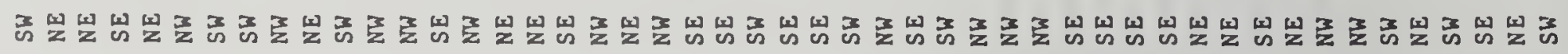

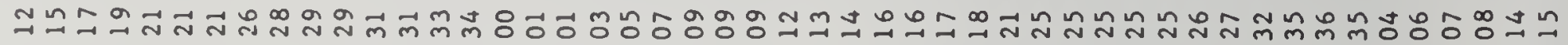

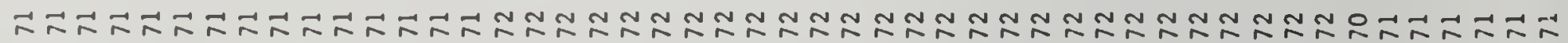

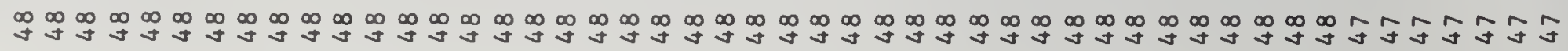

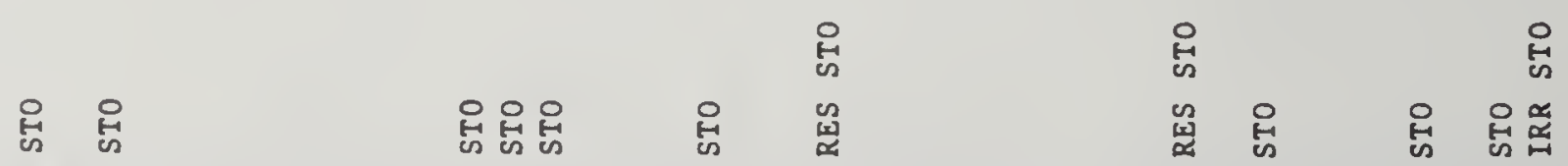

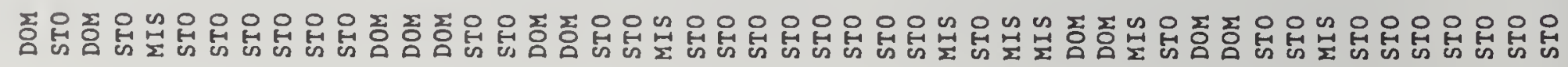

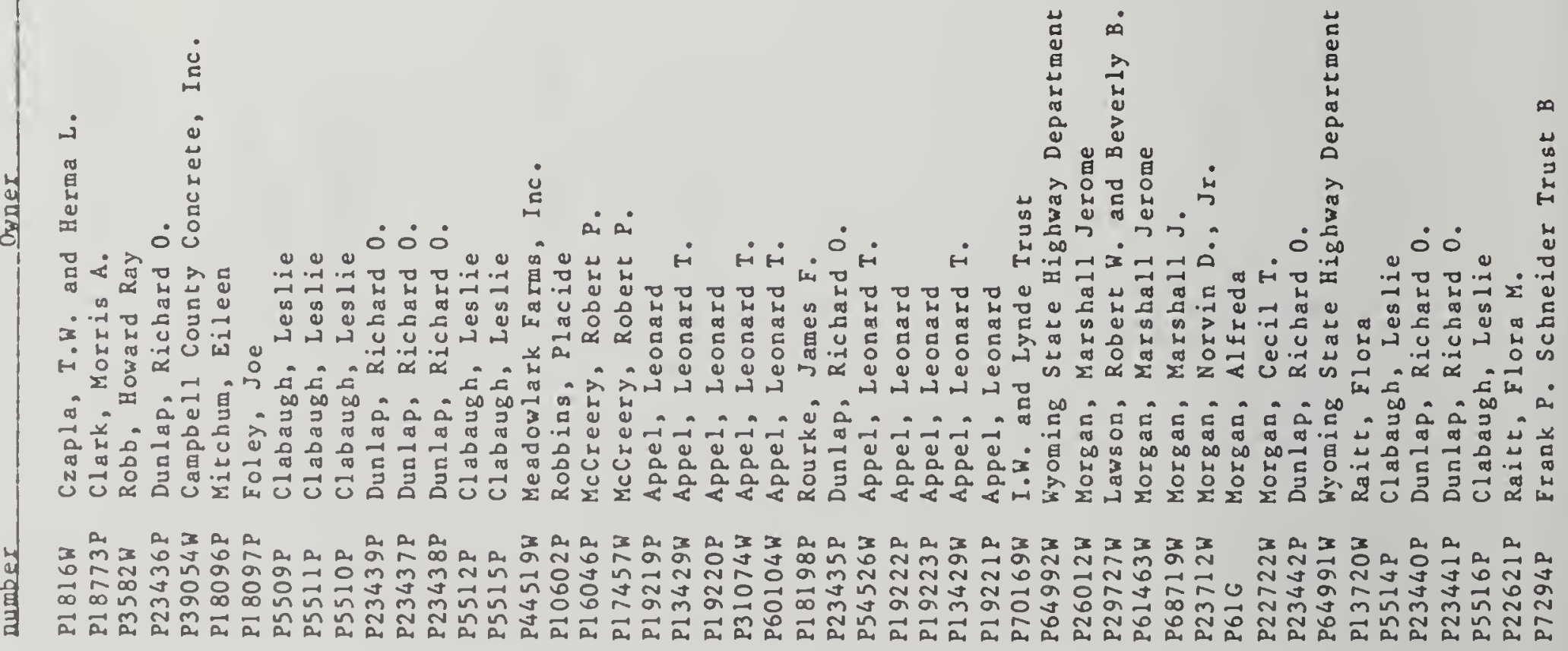


$\begin{array}{rl}1 & 0 \\ 1 & 0 \\ 0 & 0 \\ 0 & 0 \\ 2 & -1 \\ 2 & 0 \\ 0 & 0\end{array}$

(

出 $\infty \frac{0}{0}$

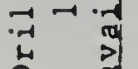

男出 3

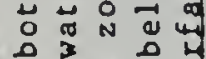

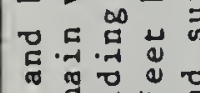

要出

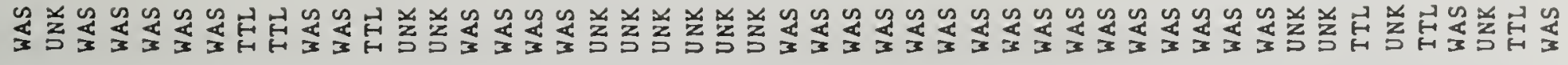

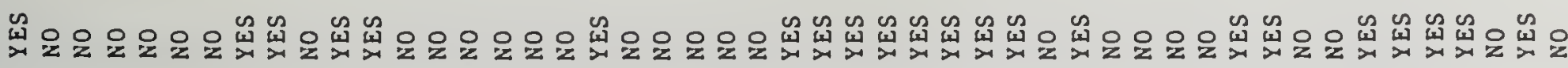

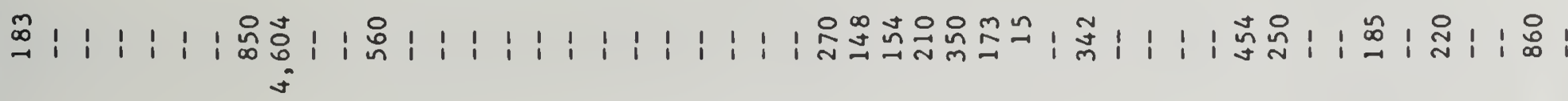

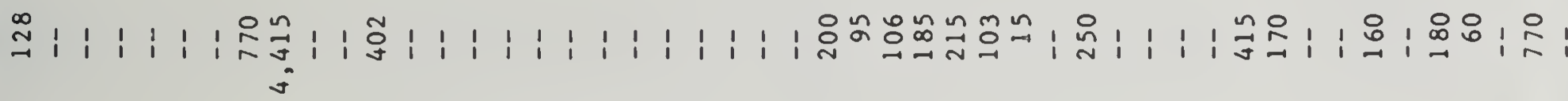

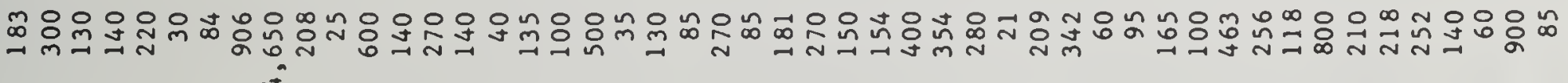

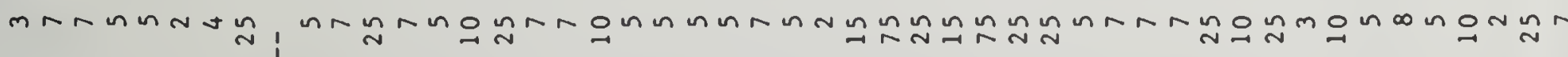

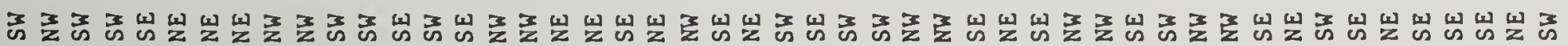

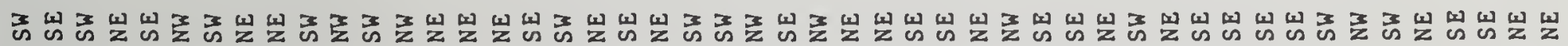

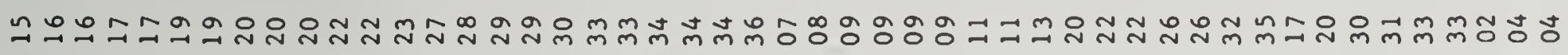

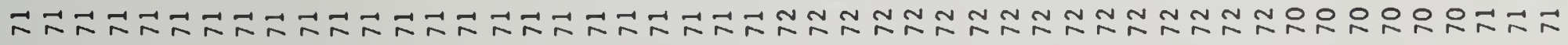

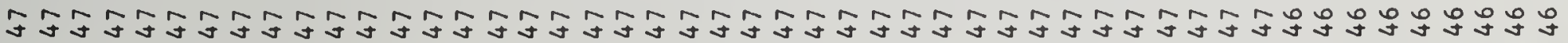

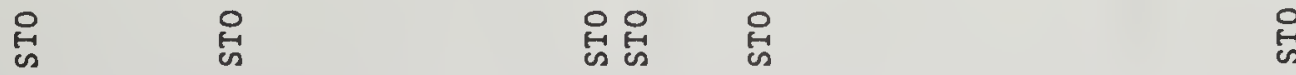

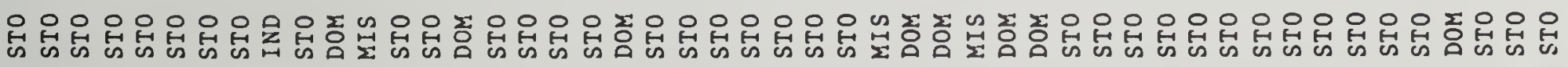

은

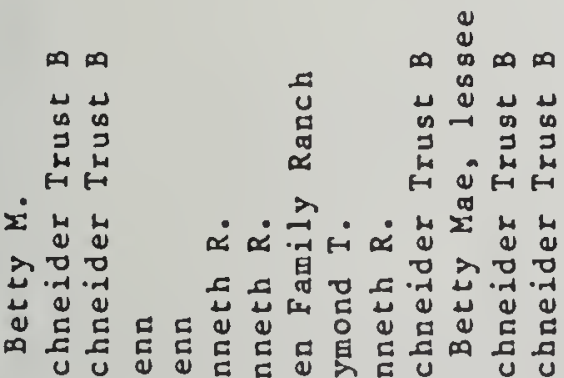

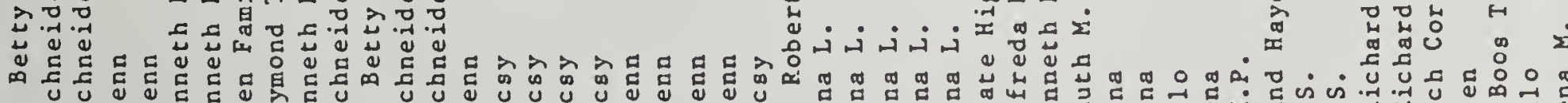

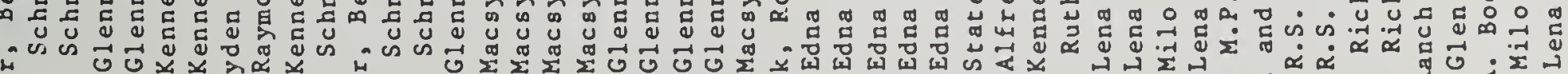

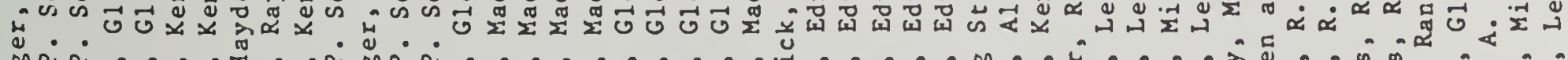

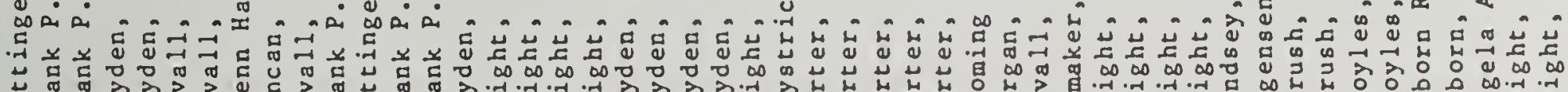

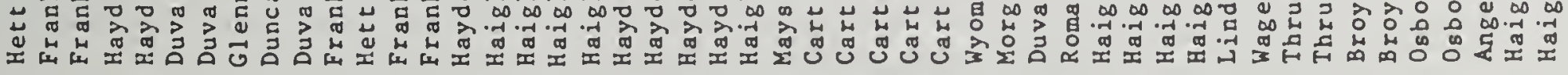

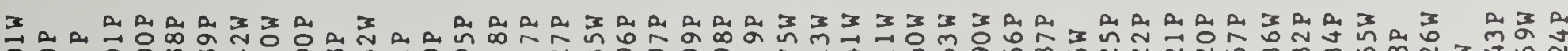

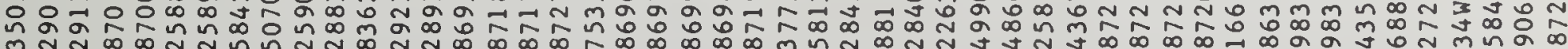

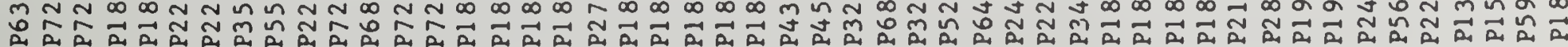




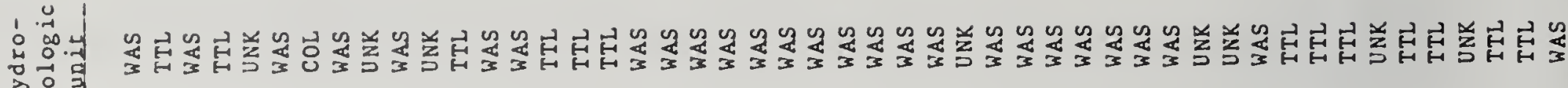

$\sum_{\substack{0 \\ 0}} \stackrel{1}{0}$

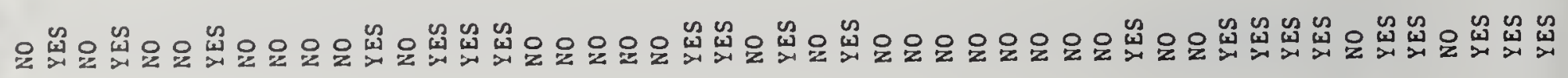

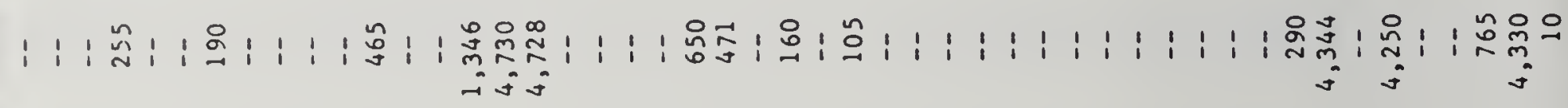

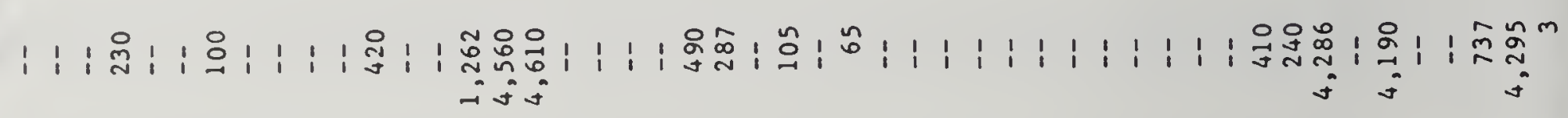

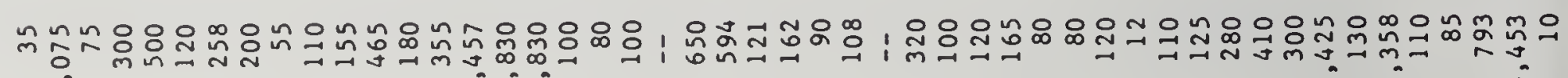

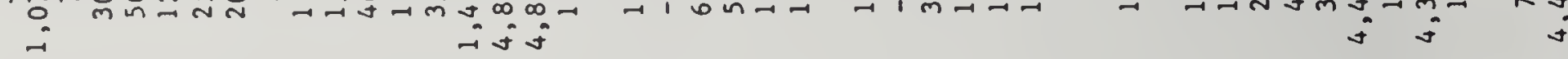

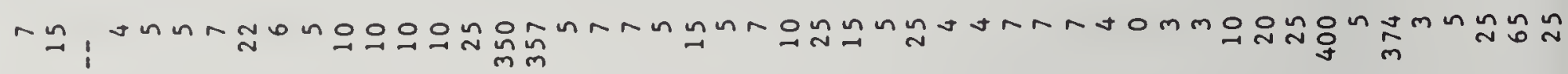

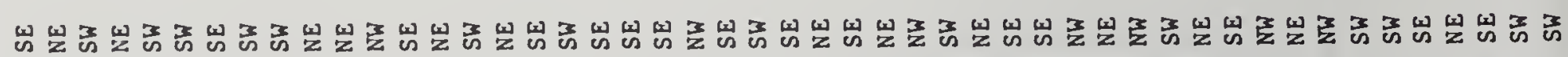

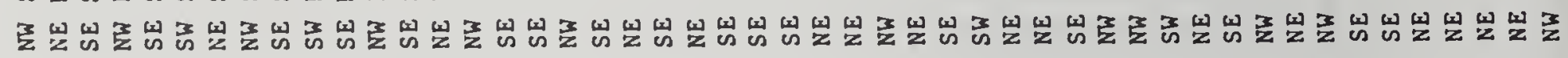

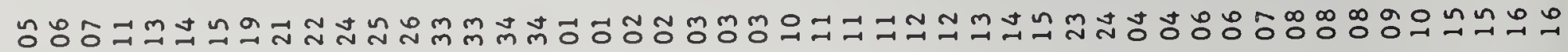

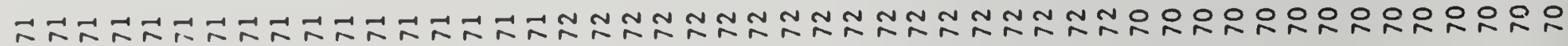

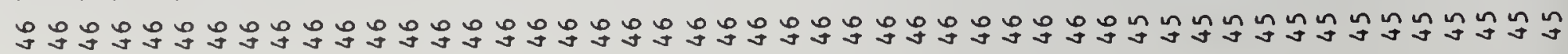

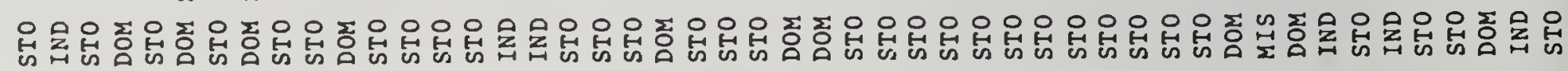

$\dot{\dot{g}}$

$:$

$\dot{0}$

$\dot{\delta} \dot{0} \dot{0} \dot{0}$

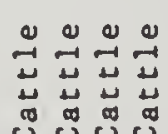

至

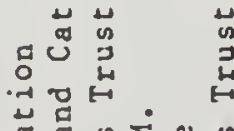

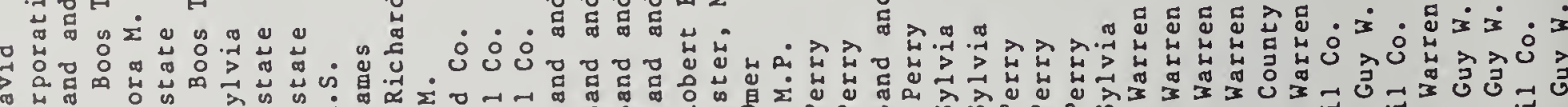

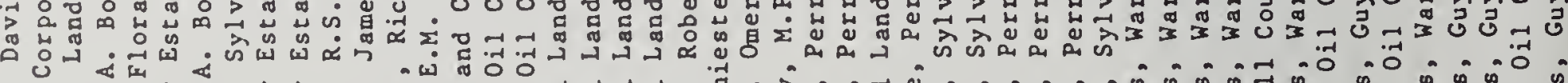

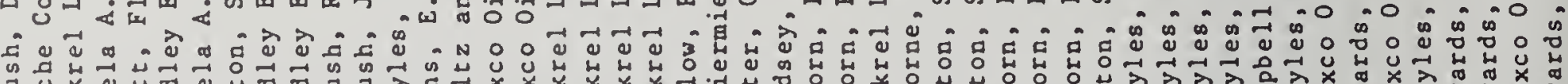

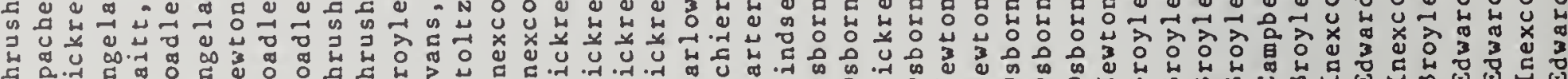

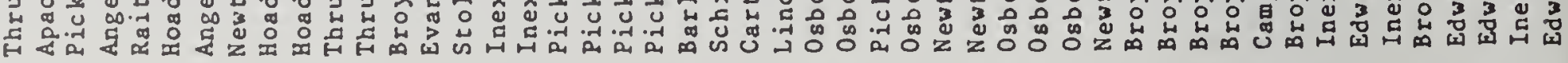

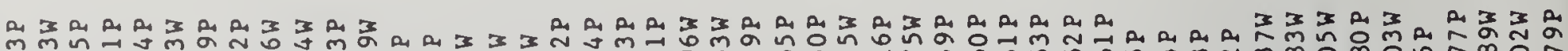

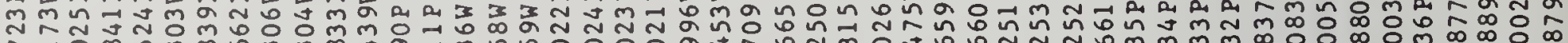

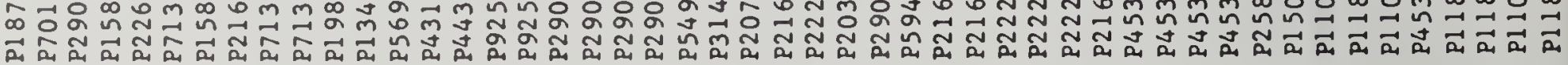




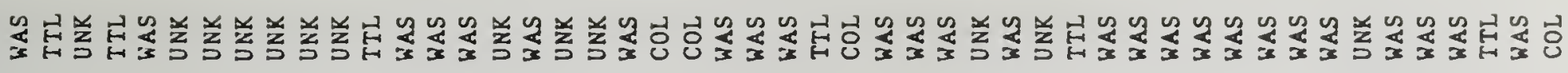

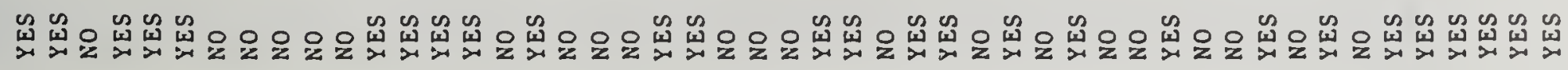

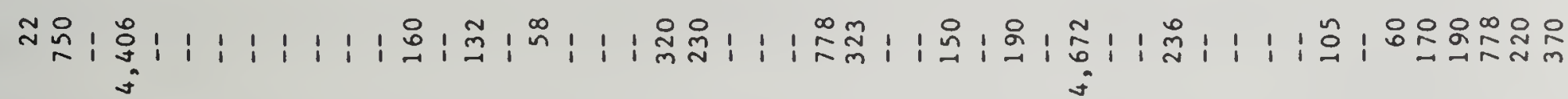

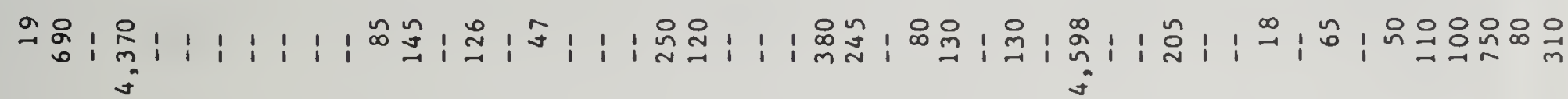

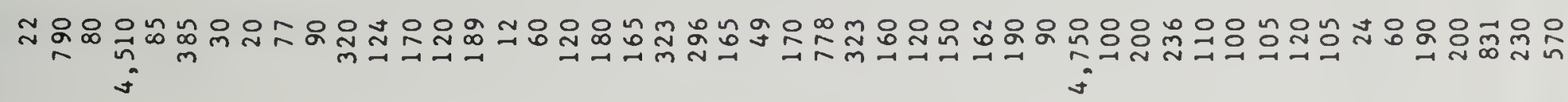

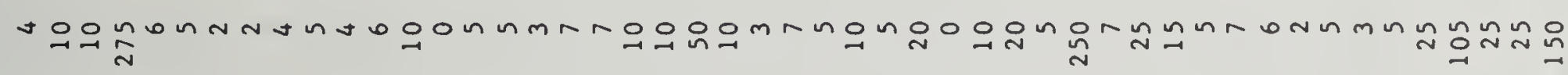

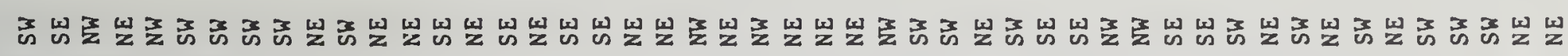

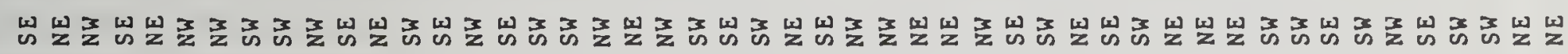

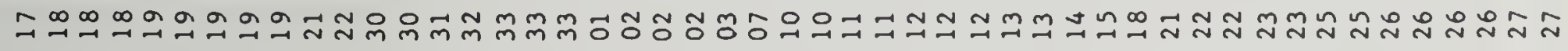

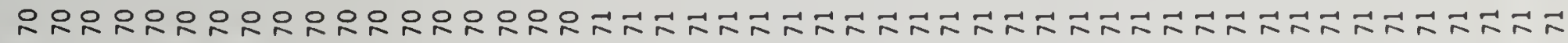

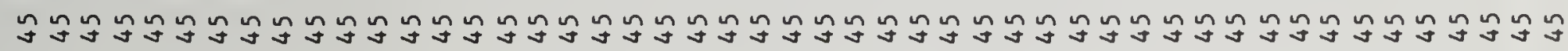

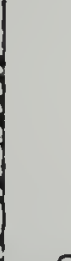

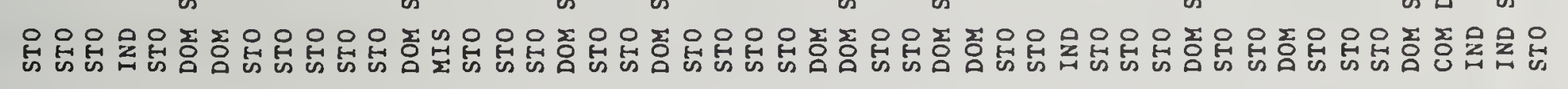
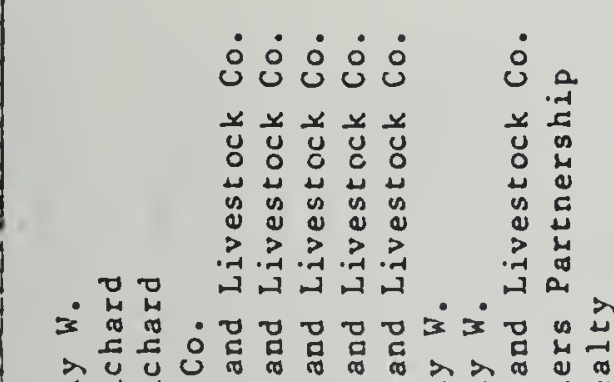

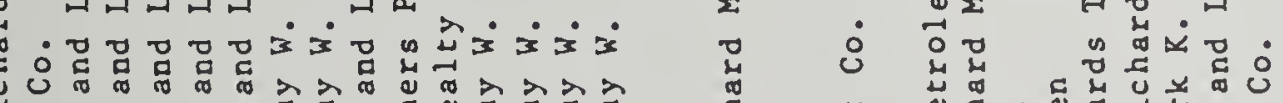

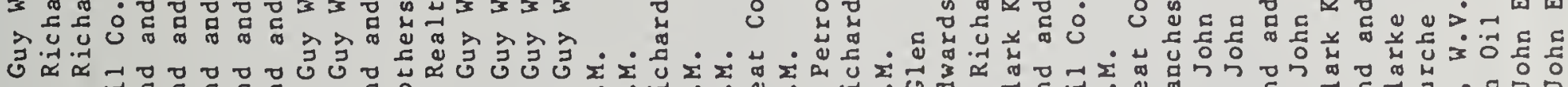

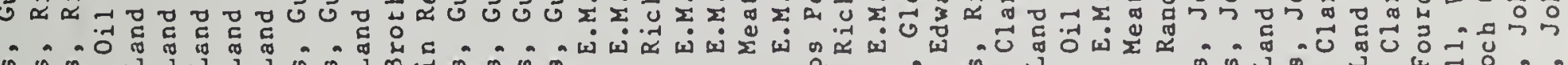
is

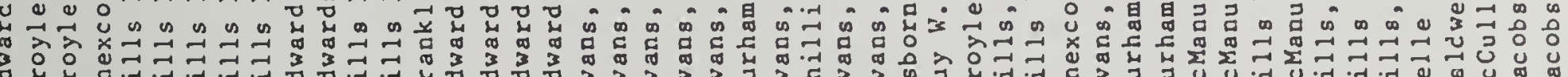

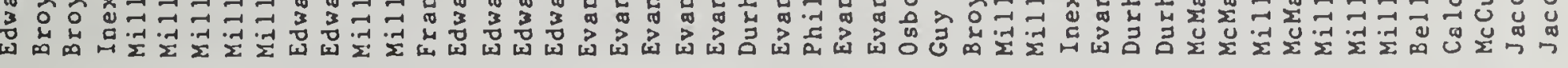

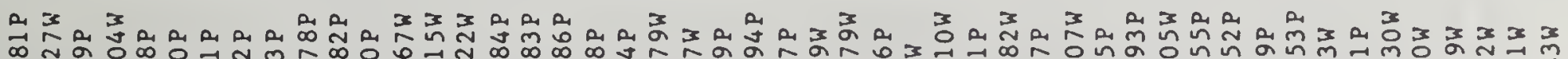

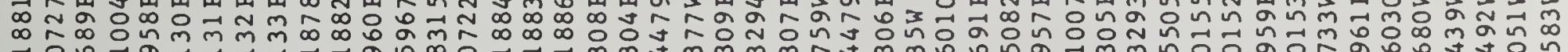

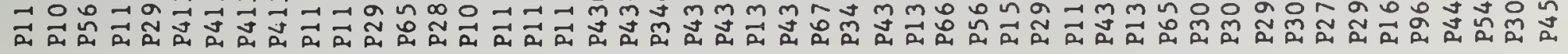




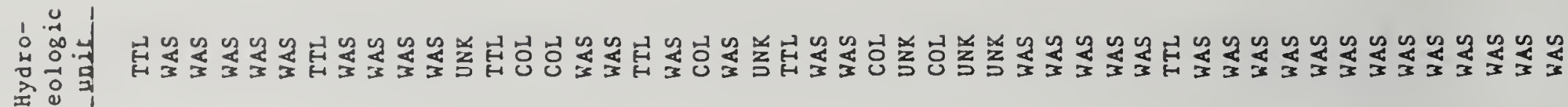

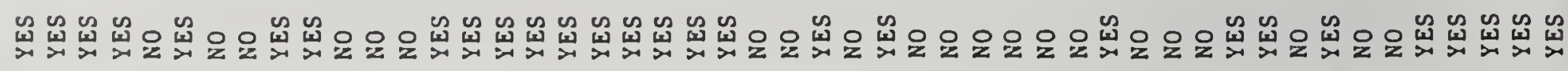

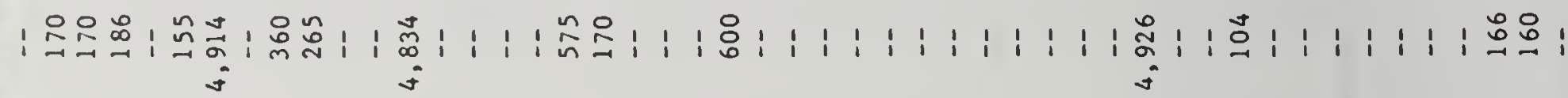

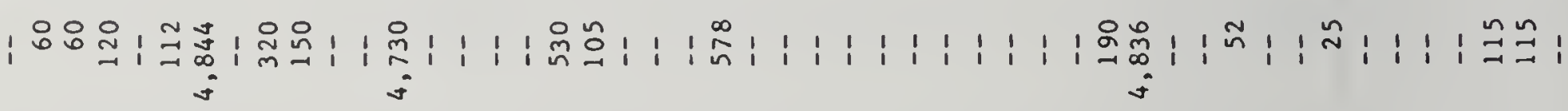

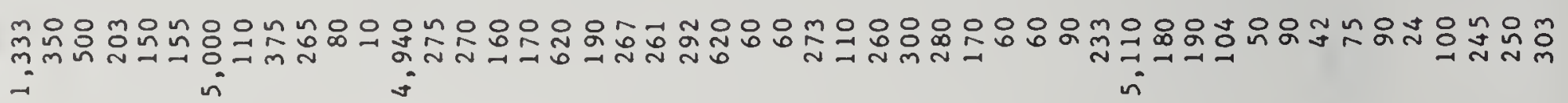
멱

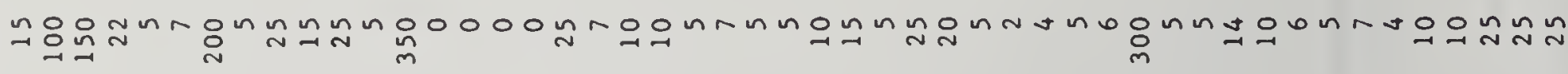

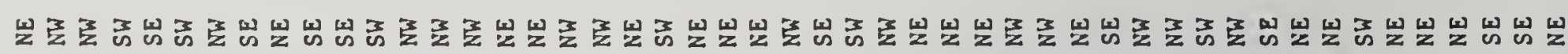

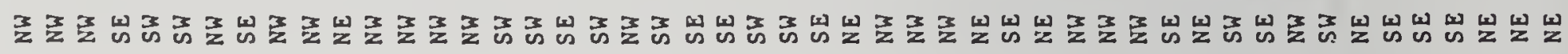

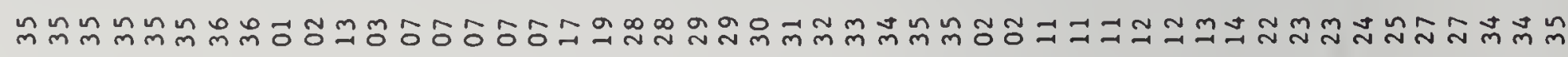

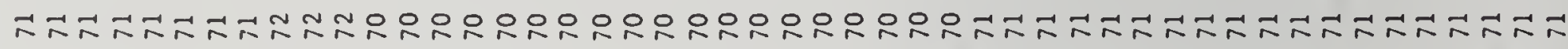

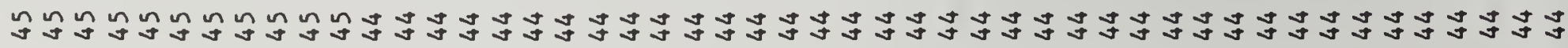

옹

웅

웄웄

品

唨

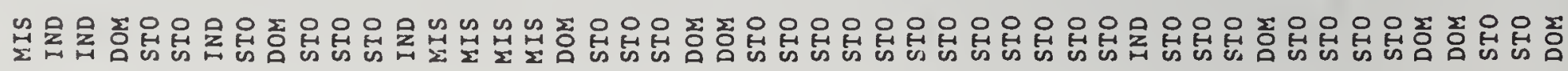

$\dot{0} \dot{0} \dot{0} \dot{0} \dot{0} \dot{0} \dot{0} \dot{0} \dot{0} \dot{0} \dot{0} \dot{0} \dot{0} \dot{0} \dot{0} \dot{0} \dot{0} \quad \dot{0} \dot{0} \dot{0}$

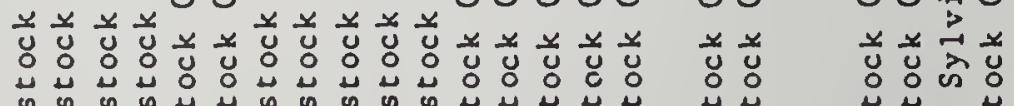

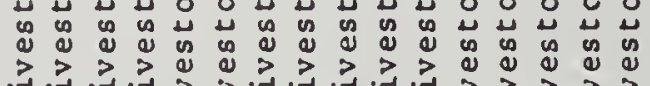

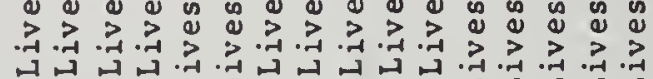

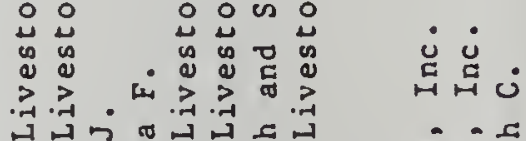

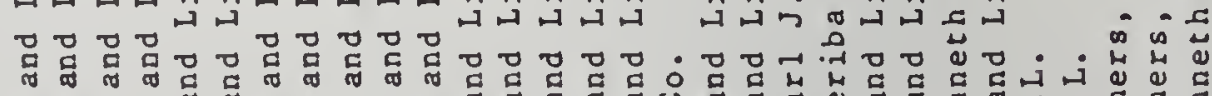

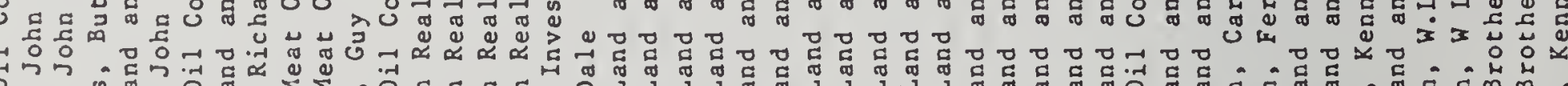

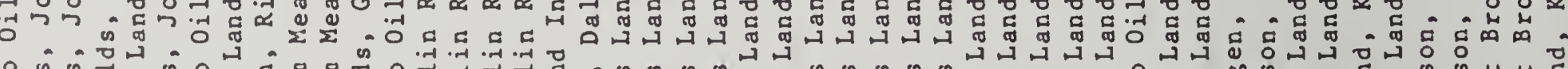

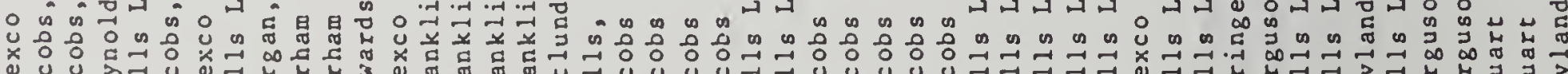

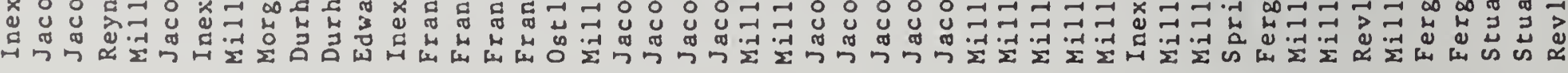

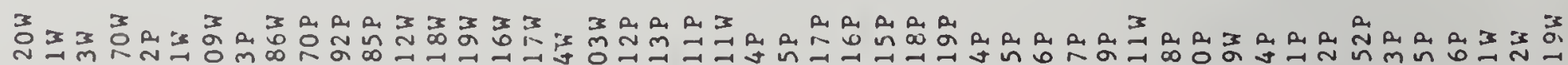




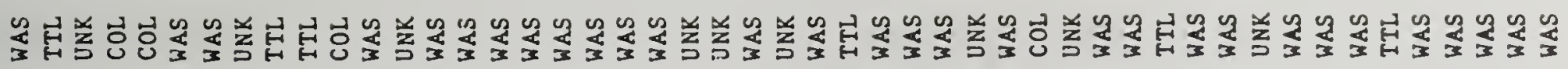

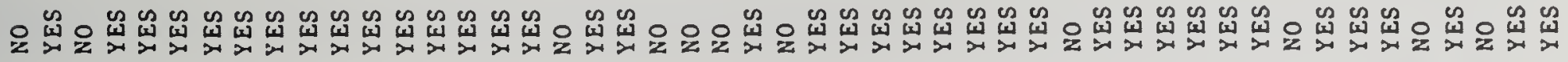

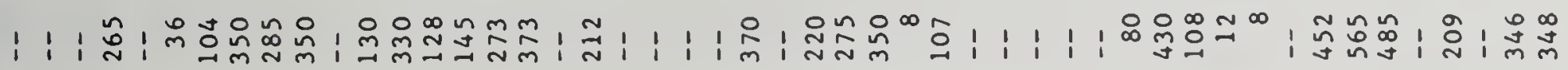

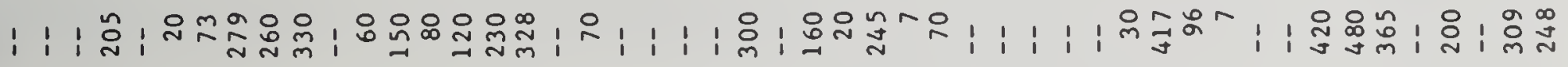

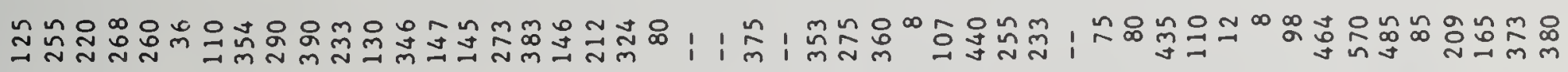

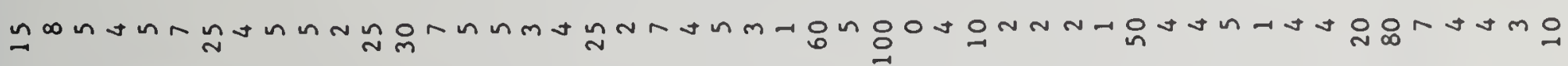

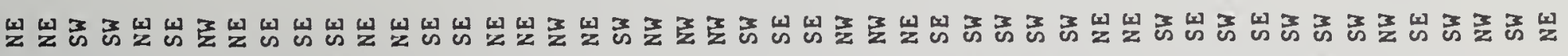

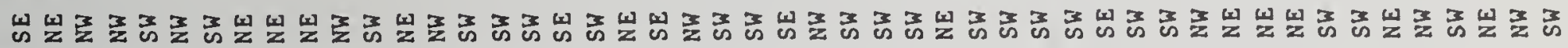

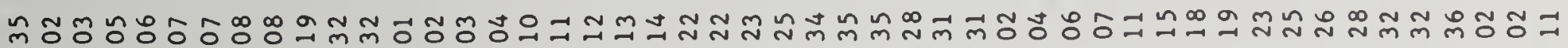

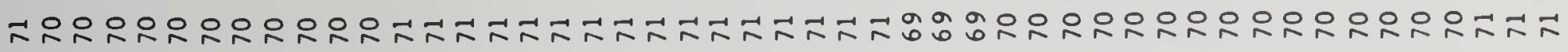

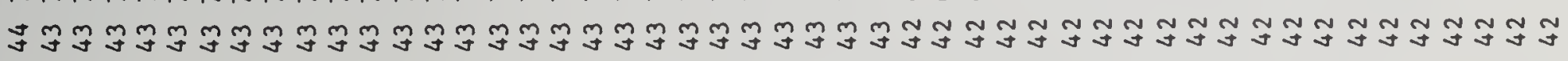

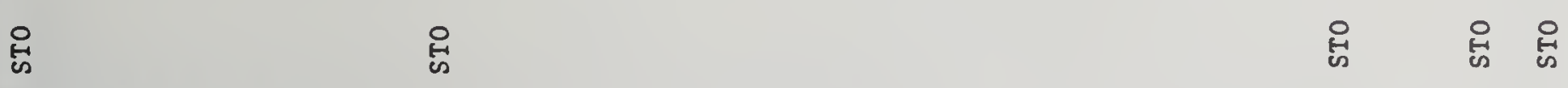

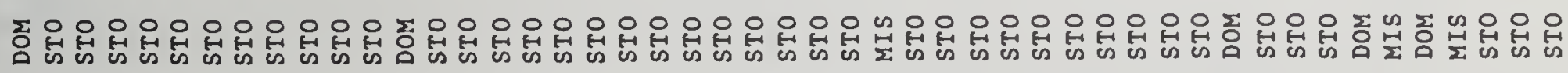

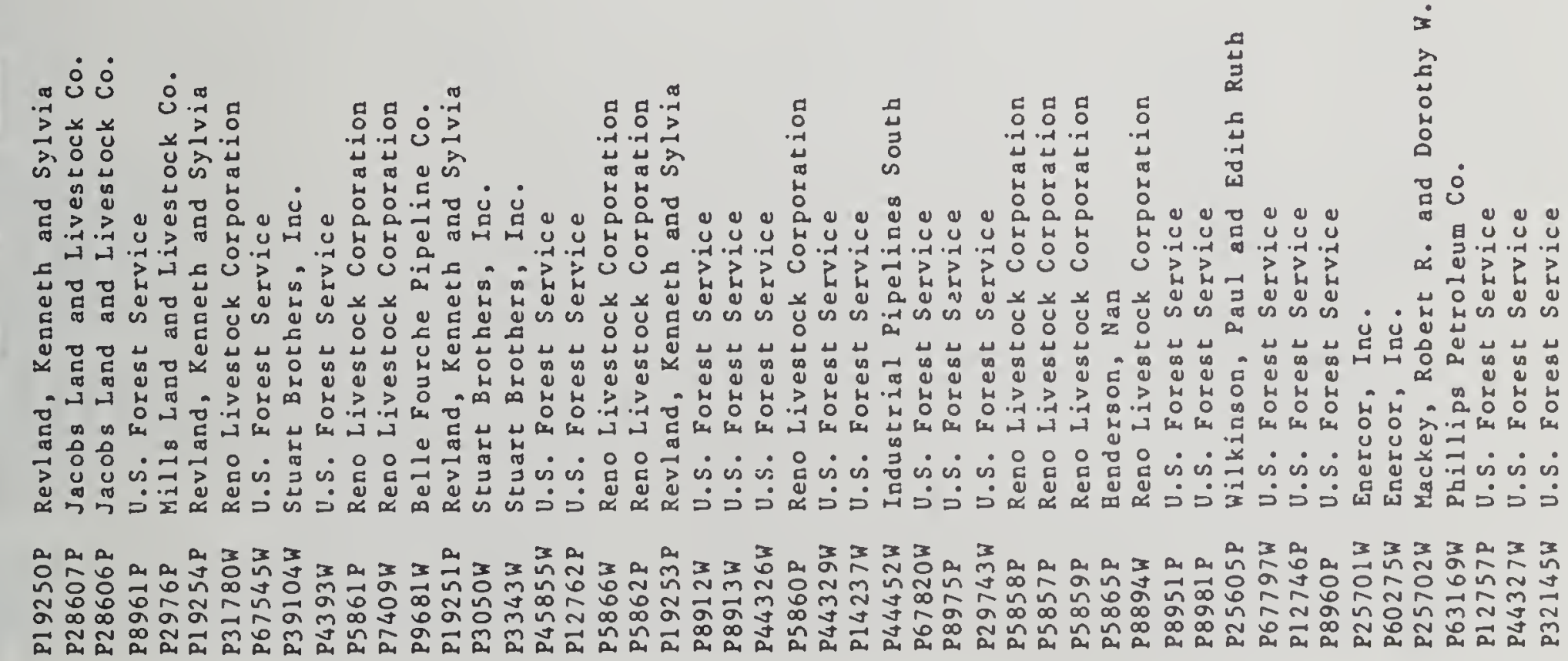




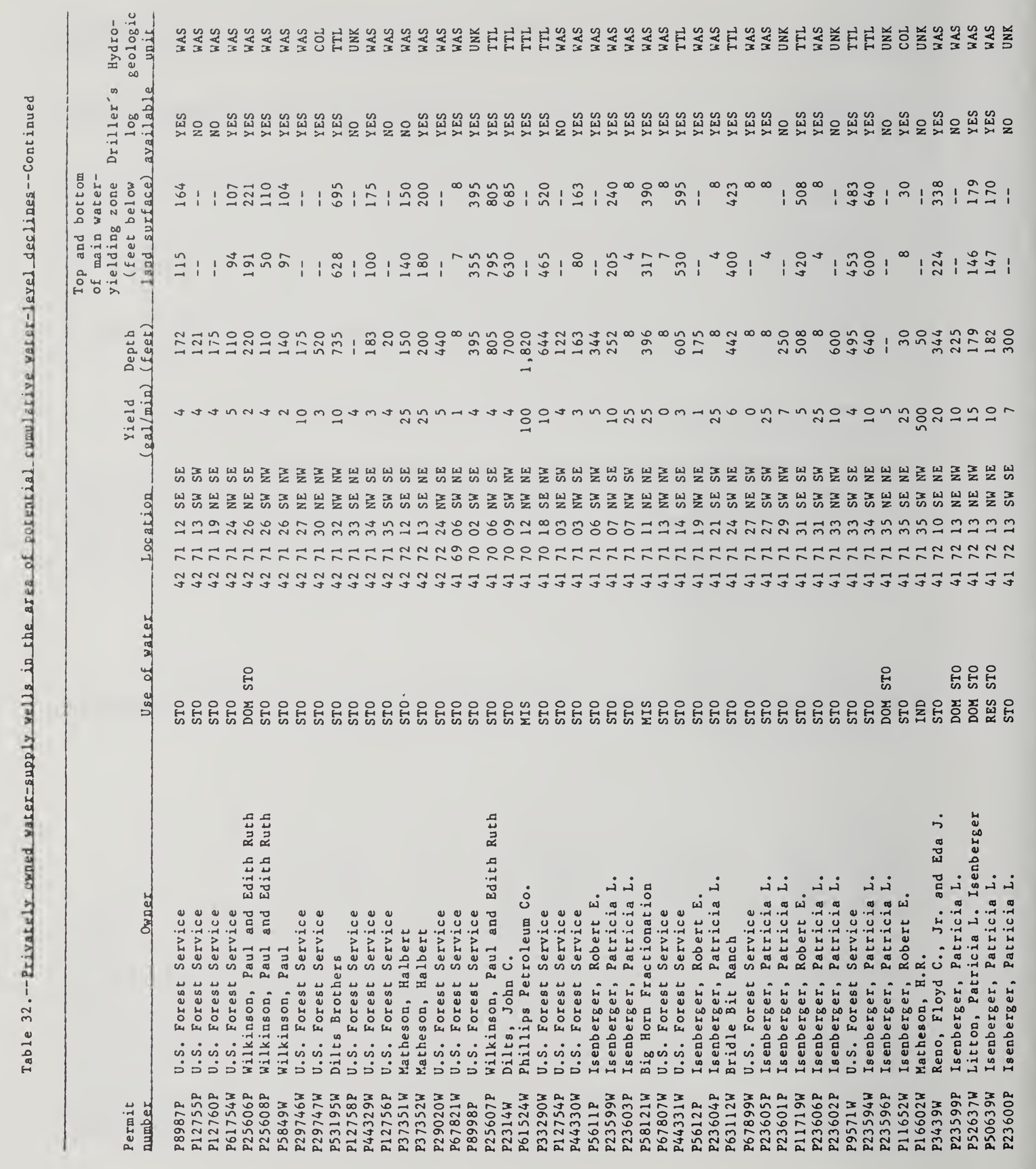




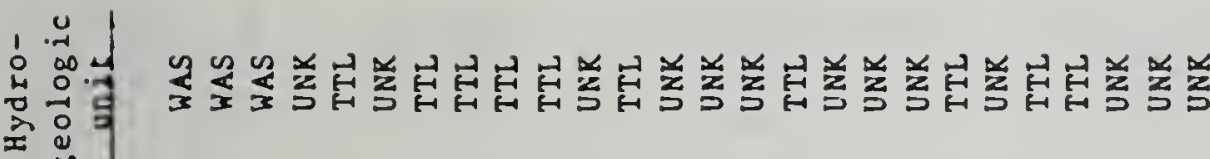

$\stackrel{\infty}{2}$

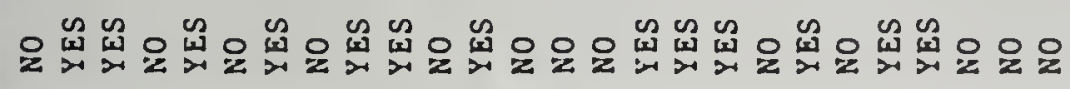

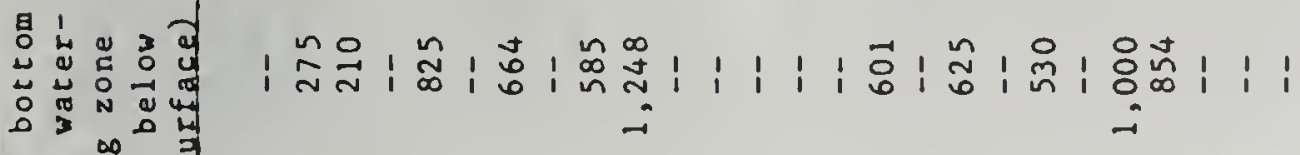

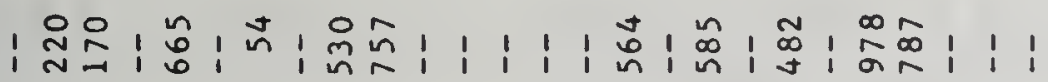

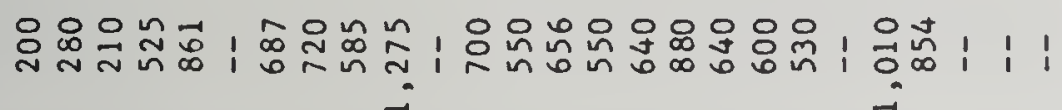

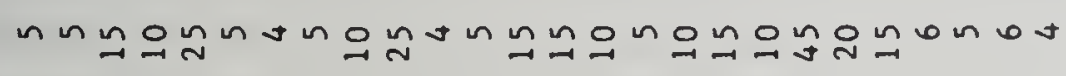

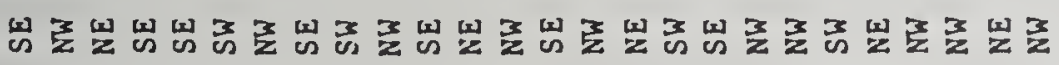

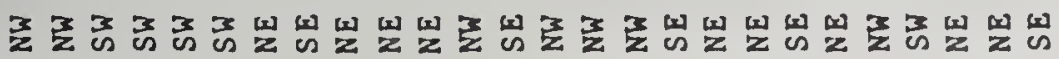

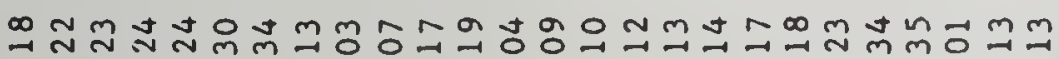

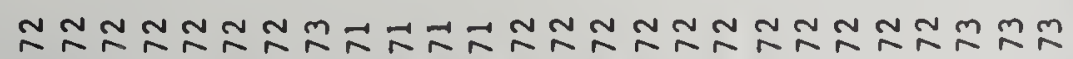

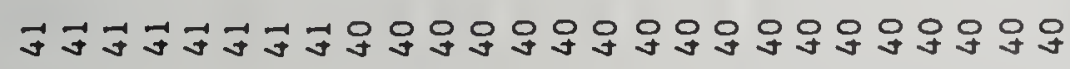

웅

윴요

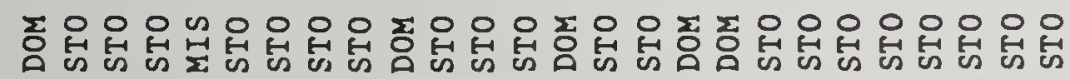

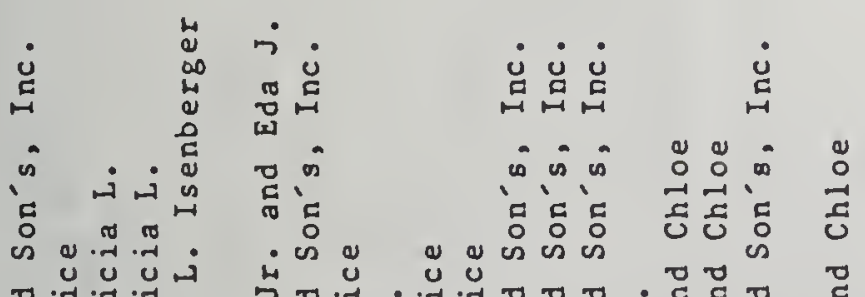

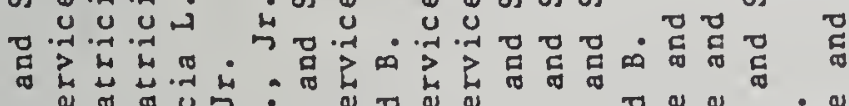

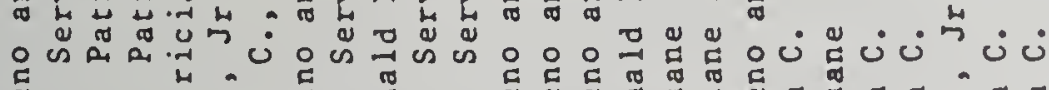

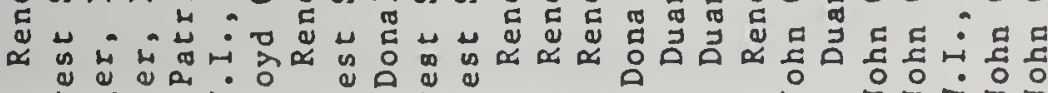

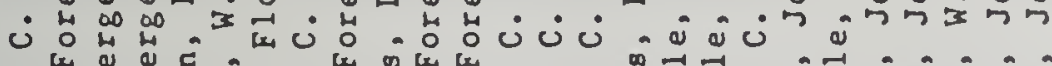
ए.

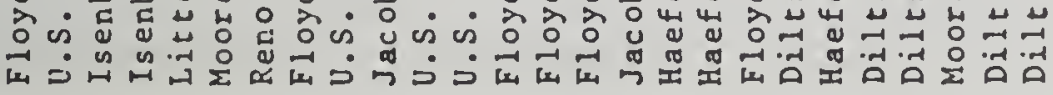

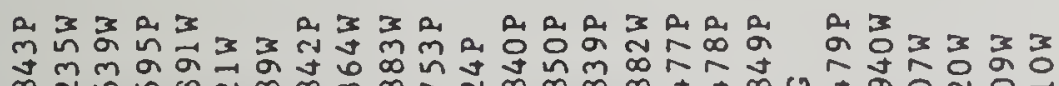




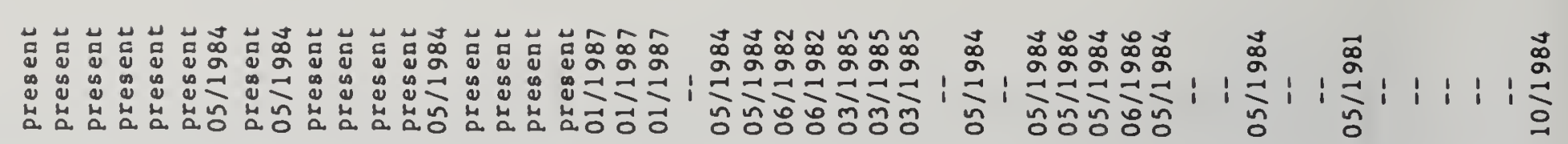

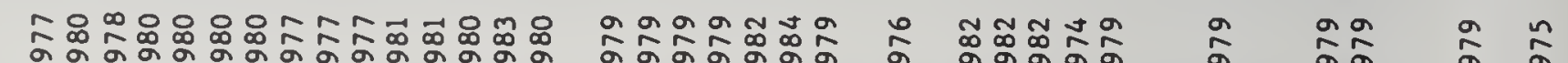

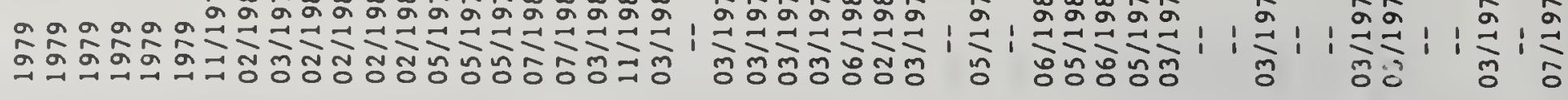

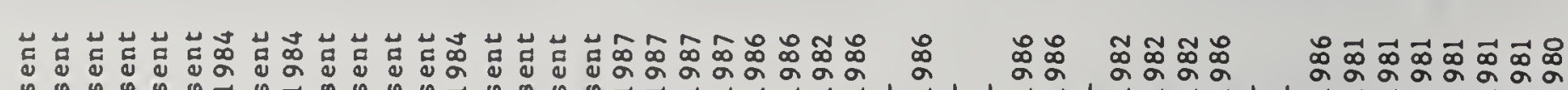

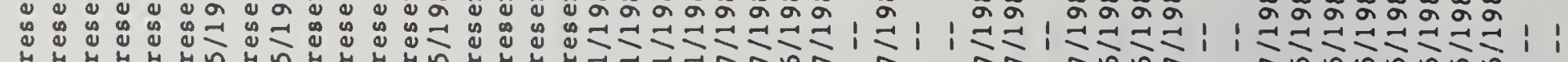

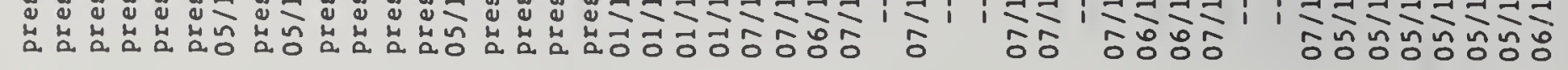

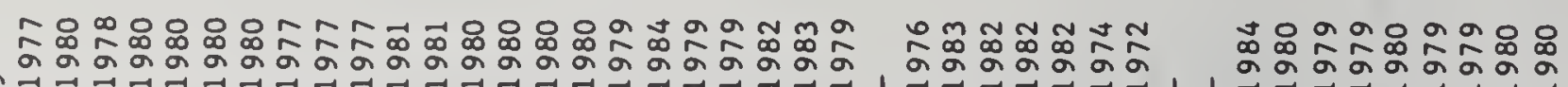

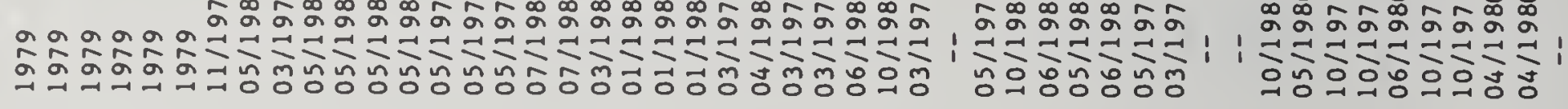
$\infty$

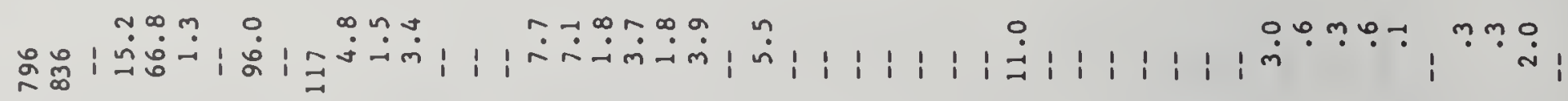

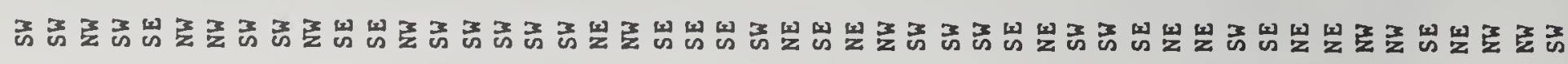

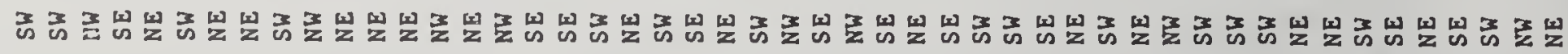

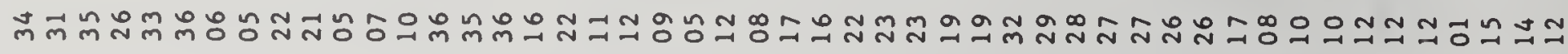

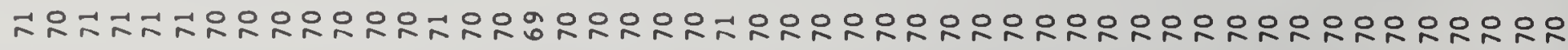

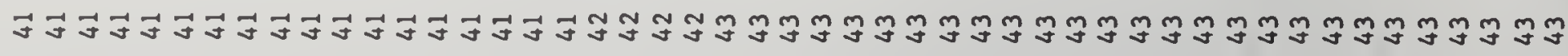

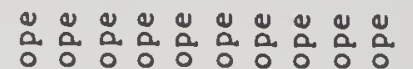

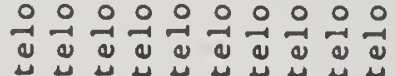

\section{$\stackrel{2}{\Rightarrow} \stackrel{0}{=}$}

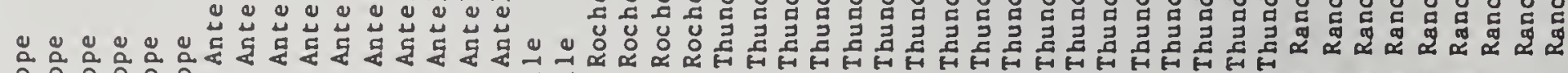

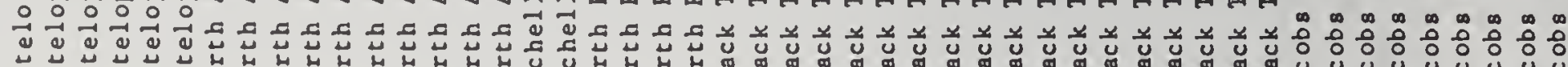

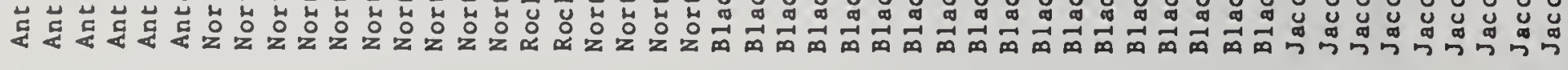

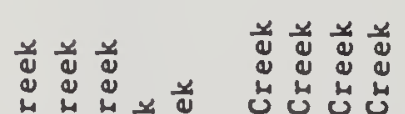

\section{$\forall \forall x$ 这}

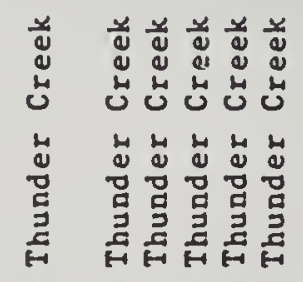

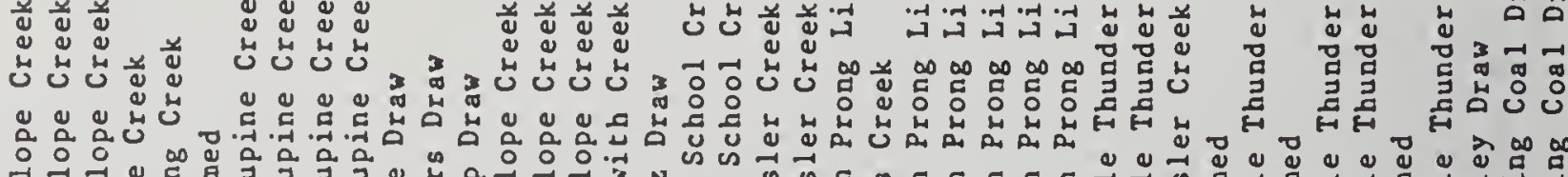

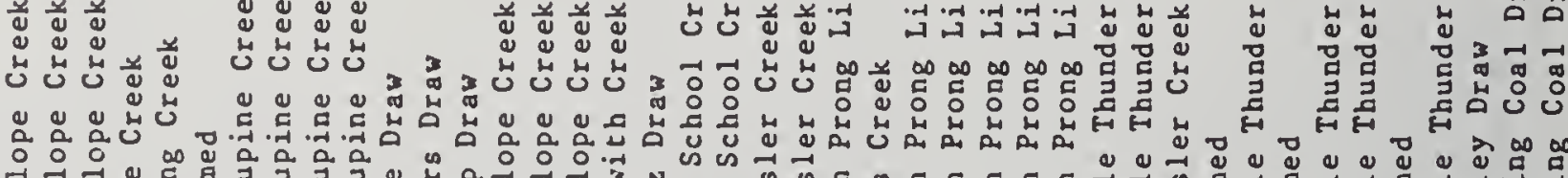

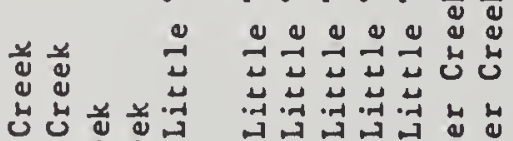

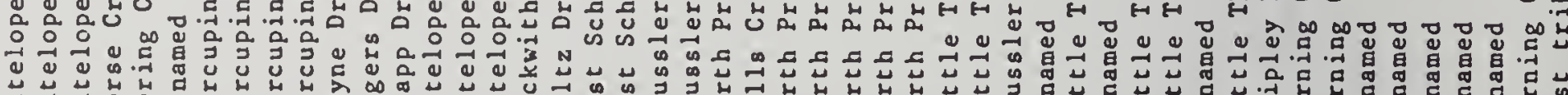

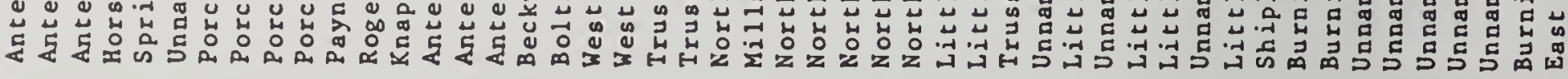

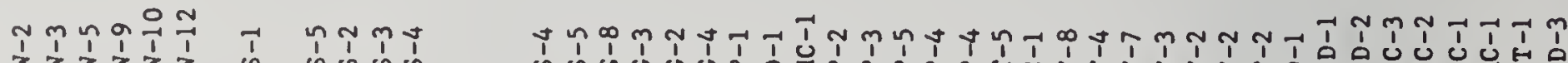

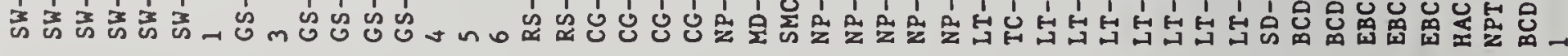

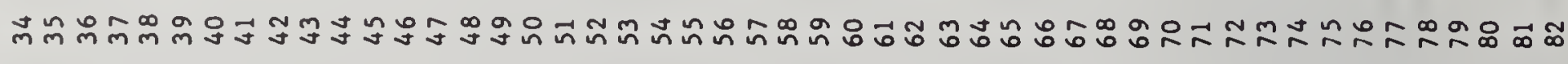




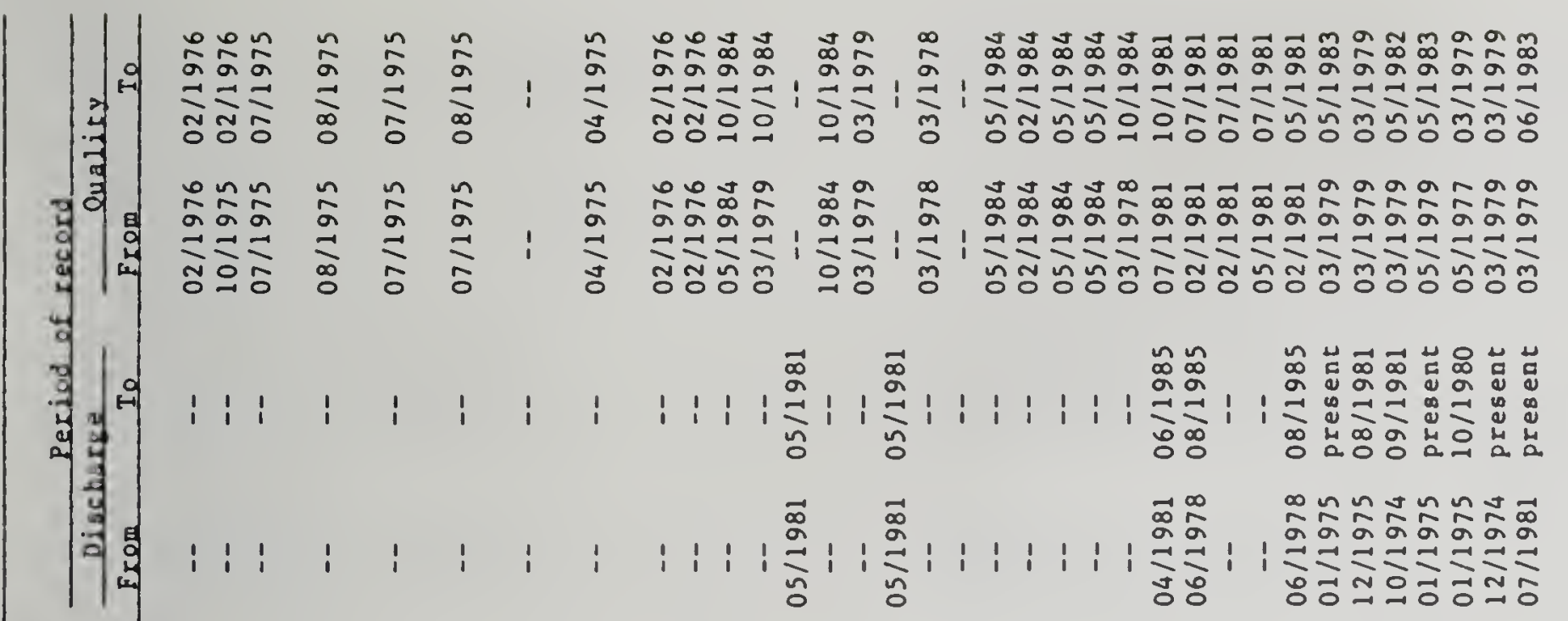

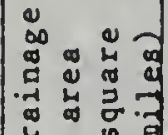

虫

a

בै

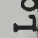

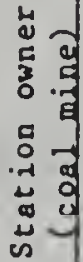

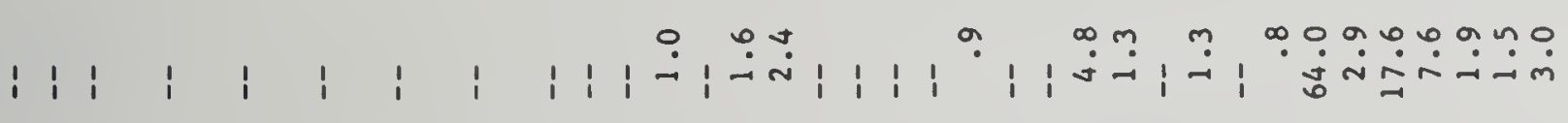

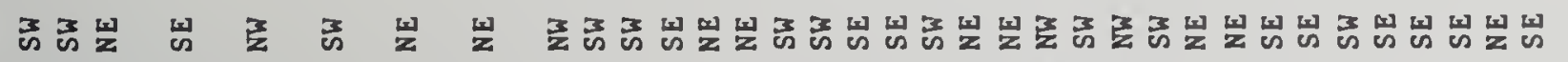

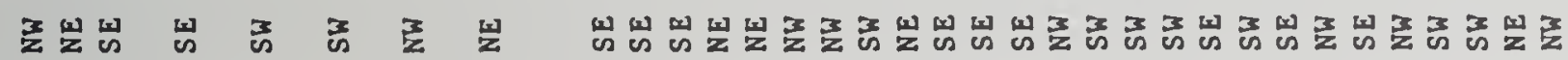
चปส

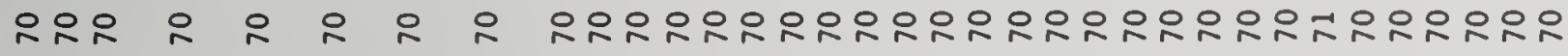

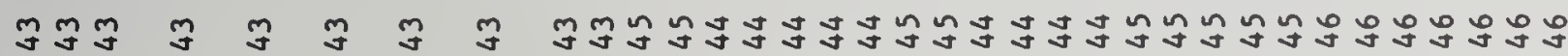

$\vec{\infty} \underset{2}{2} \hat{a}$

方

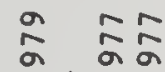

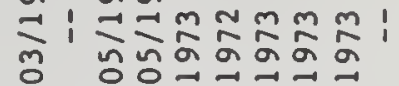

臨

㟔台

कूळ

로윤

$\because-\infty m \infty$

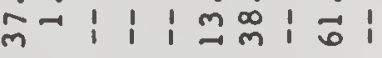

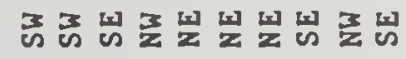

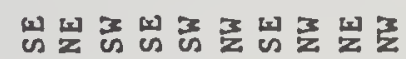

ㄱำ

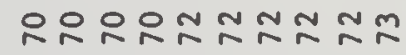

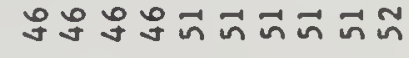

号苟

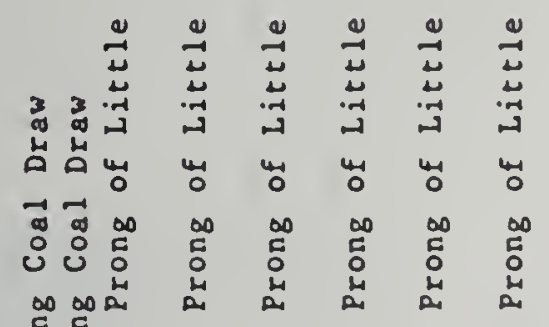

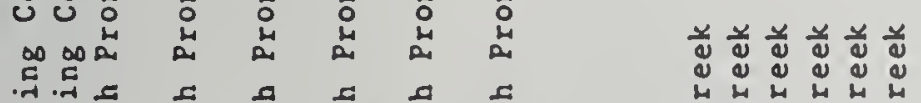

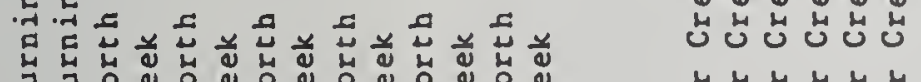

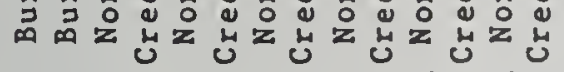

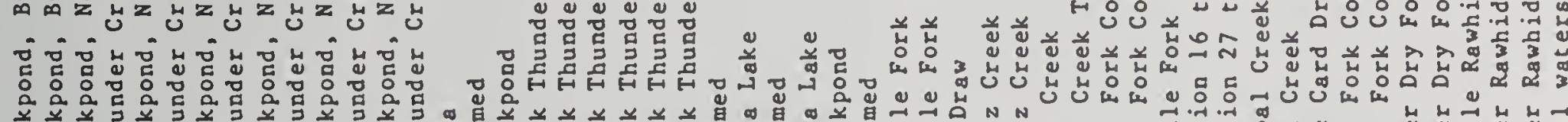

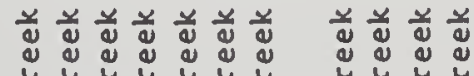

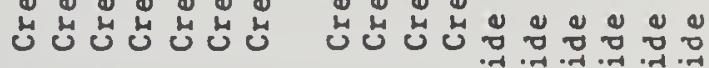

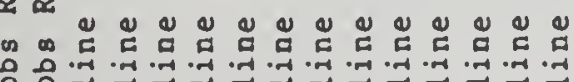

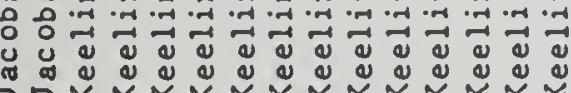

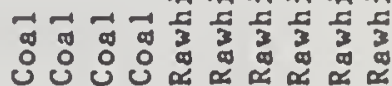

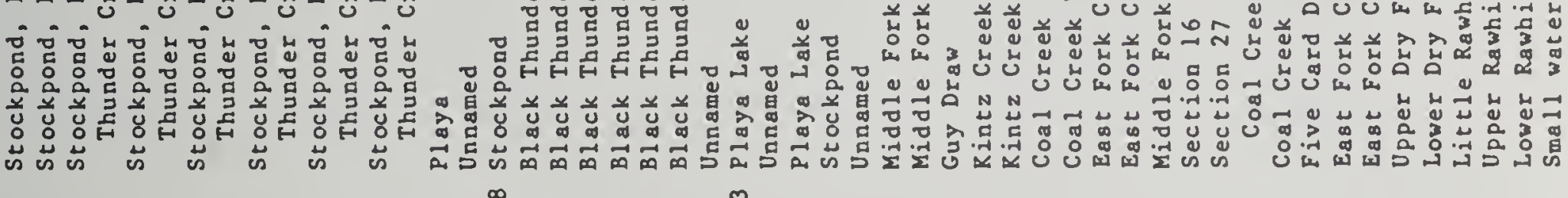

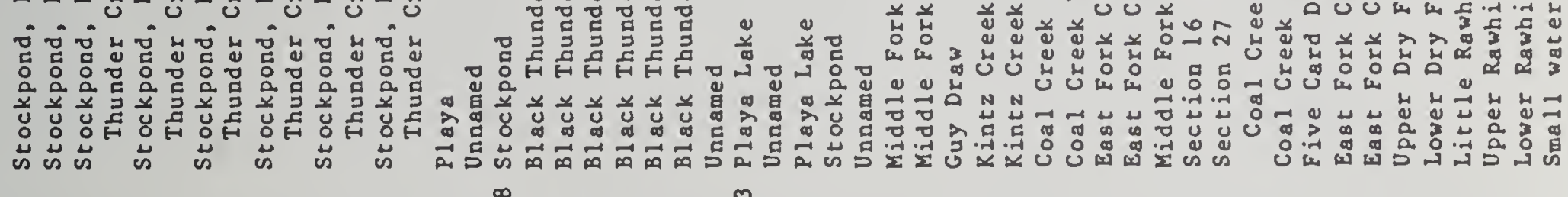

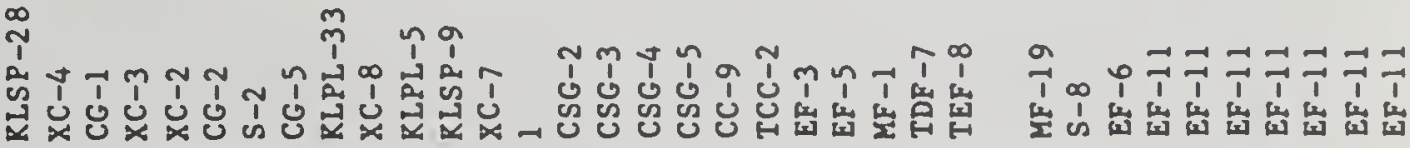

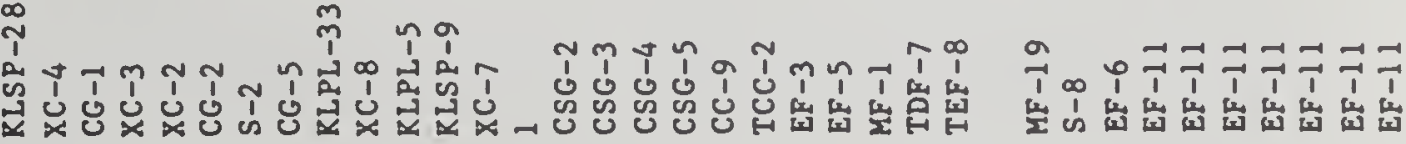

总

竞落

$\sum_{\infty}^{\Delta} \sum_{\alpha}^{\infty}$

苨产

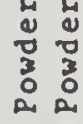

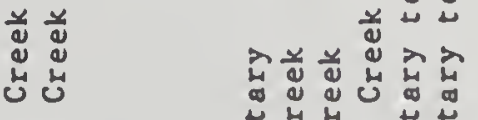

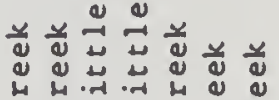

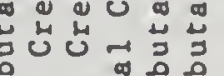

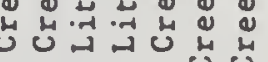

边边

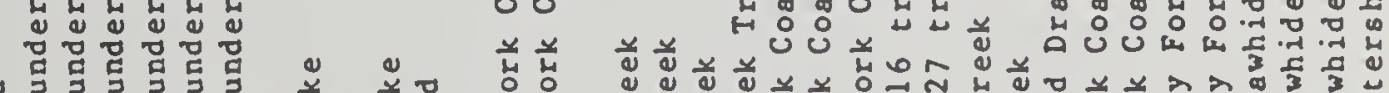
- 4

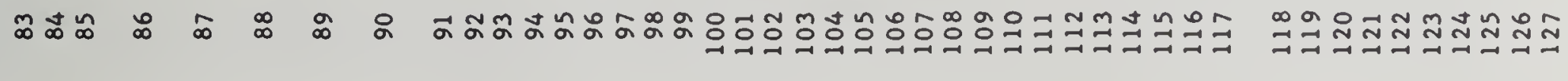




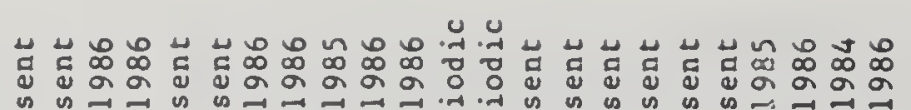

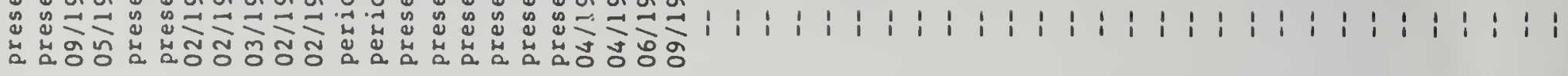

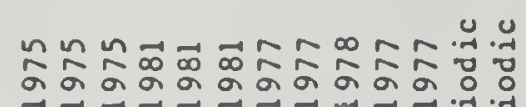
กำ

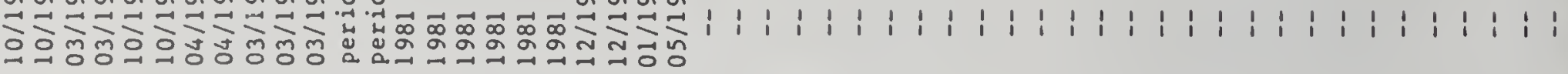

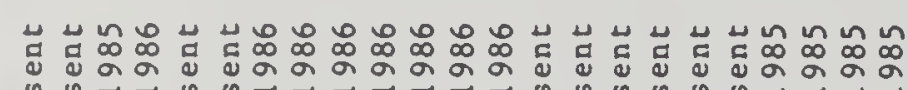

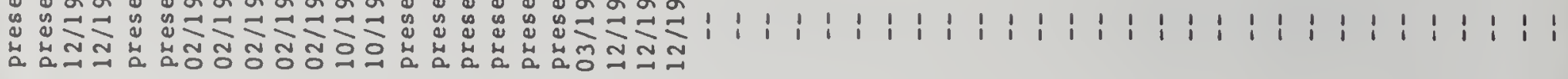

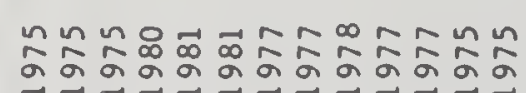

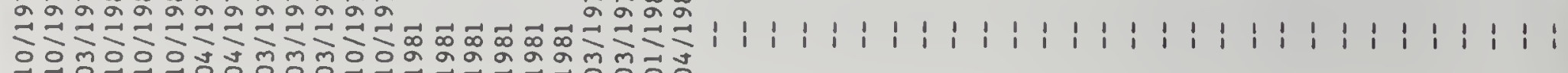

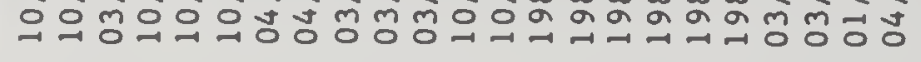

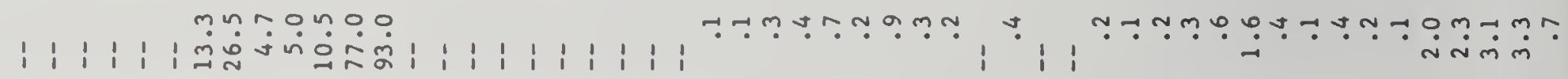

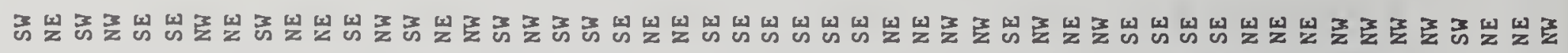

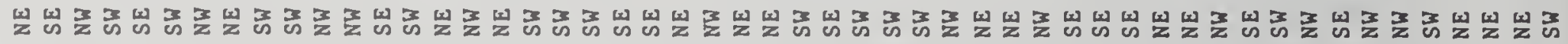

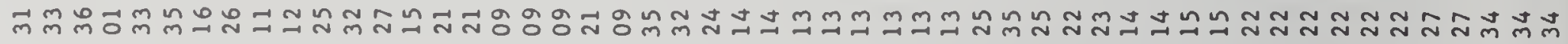

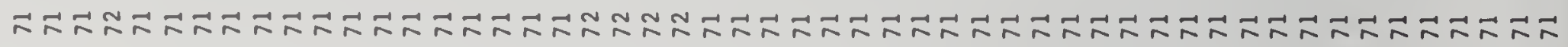

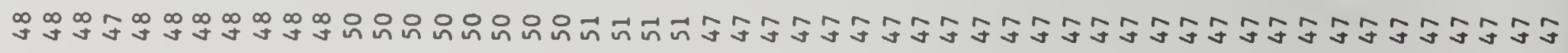

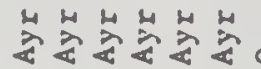

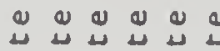

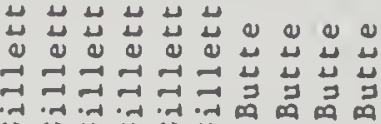

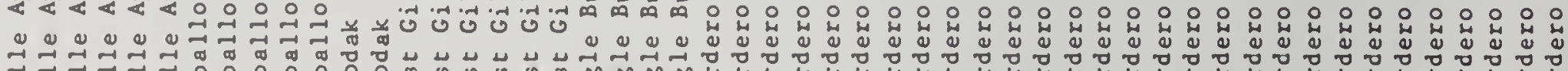

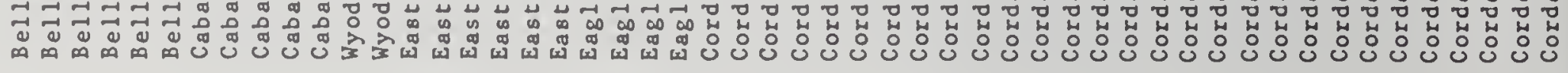

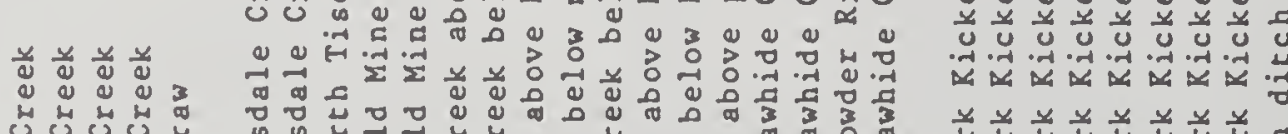

$\begin{array}{lll}3 & 3 \\ 5 & 3 \\ 0 \\ 0\end{array}$

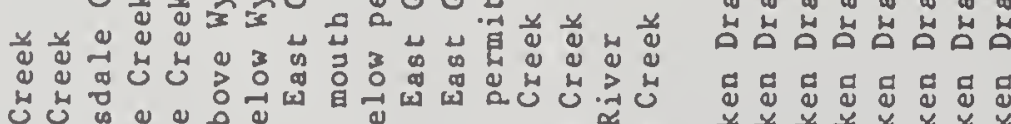

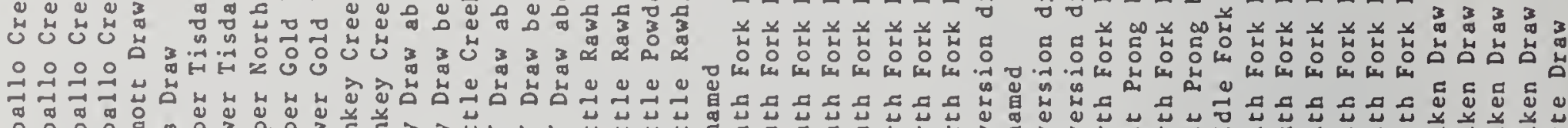
व

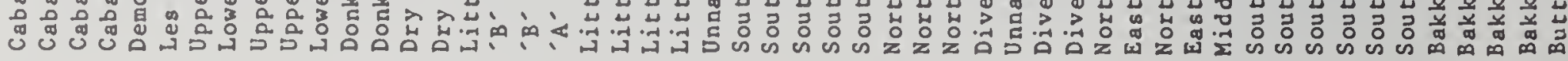
4 건 等

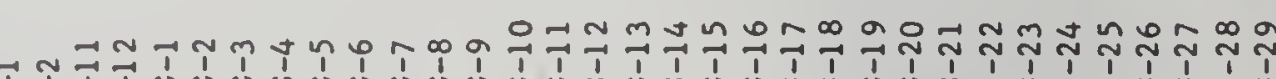

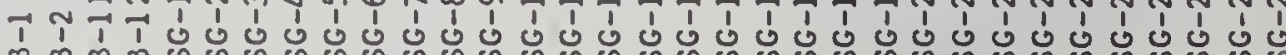

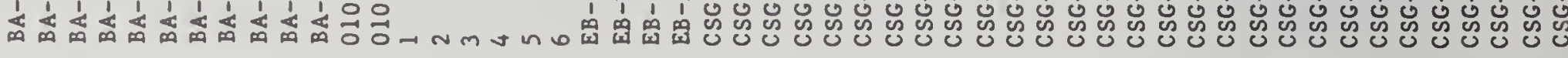

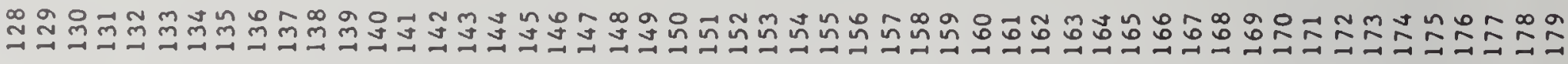




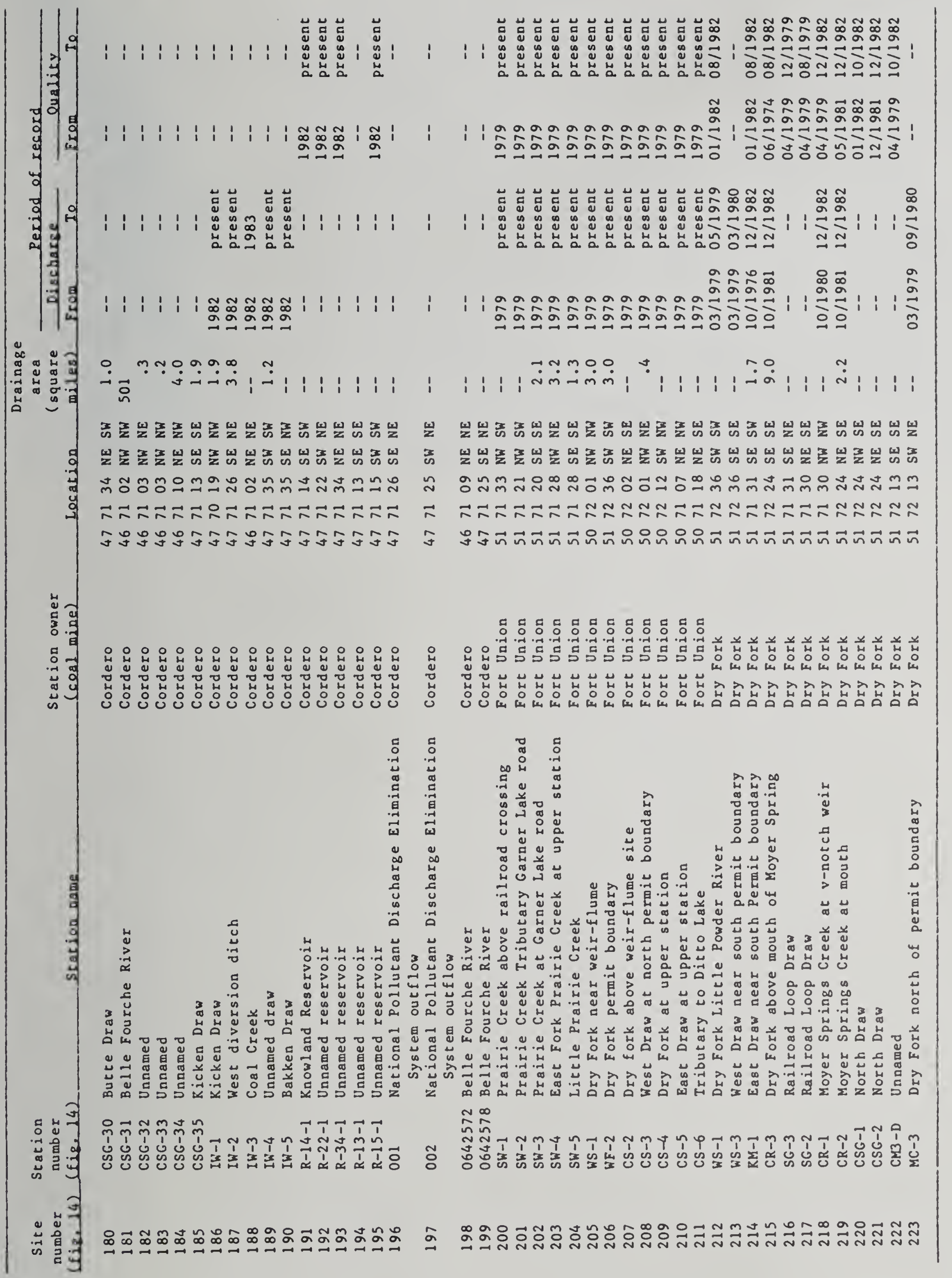





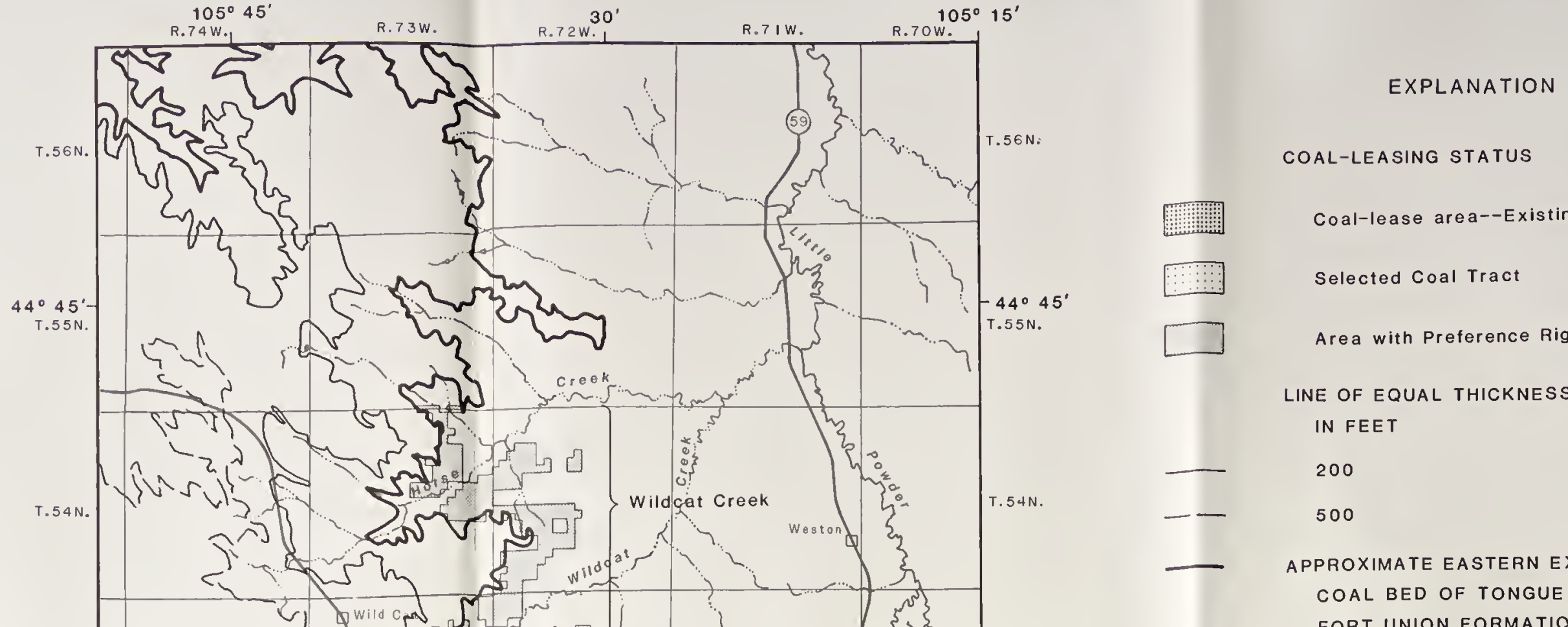

Selected Coal Tract

Area with Preference Right Lease Application

LINE OF EQUAL THICKNESS OF OVERBURDEN. IN FEET

500

APPROXIMATE EASTERN EXTENT OF WYODAK COAL BED OF TONGUE RIVER MEMBER OF FORT UNION FORMATION OR STRATI
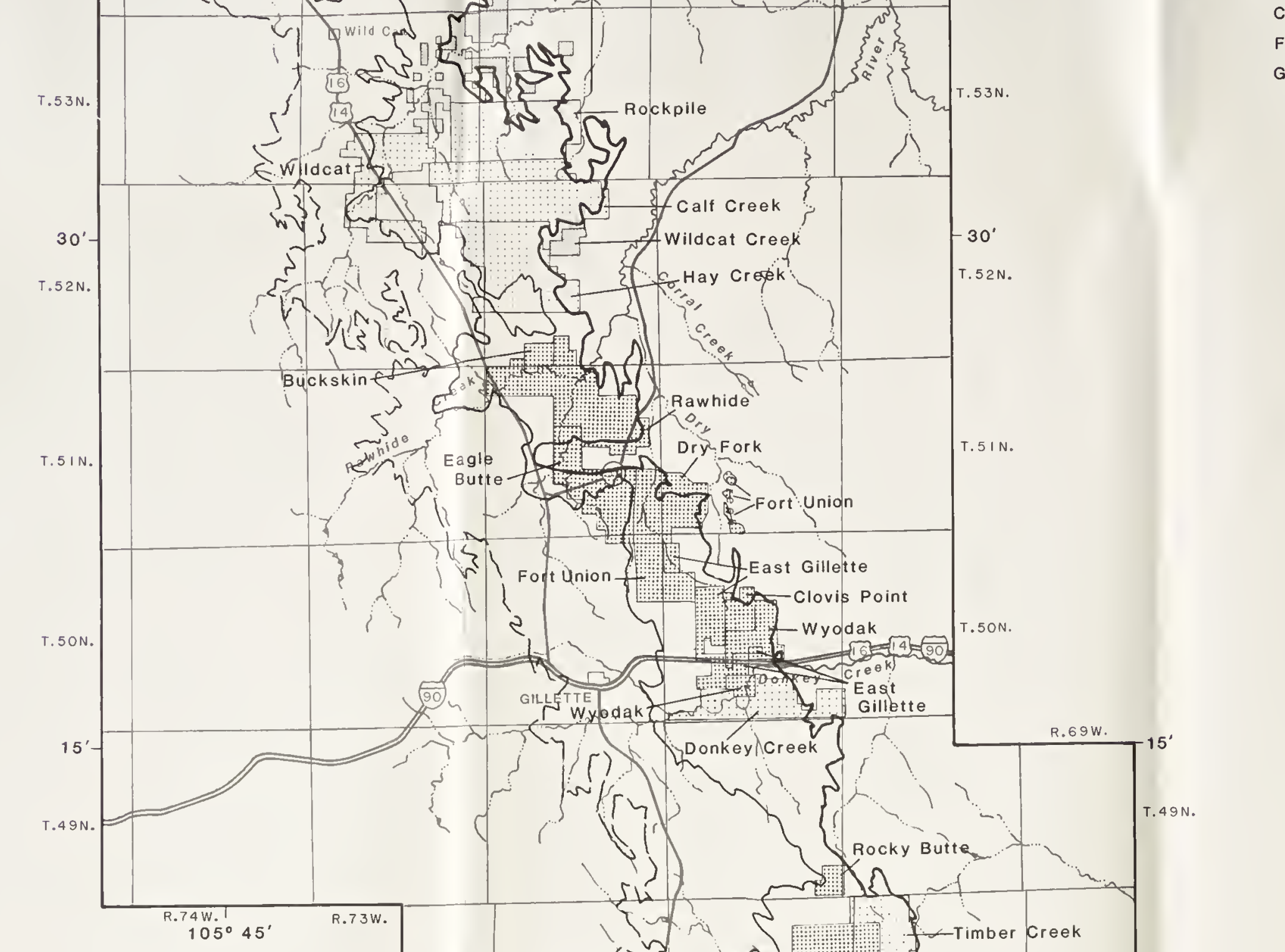

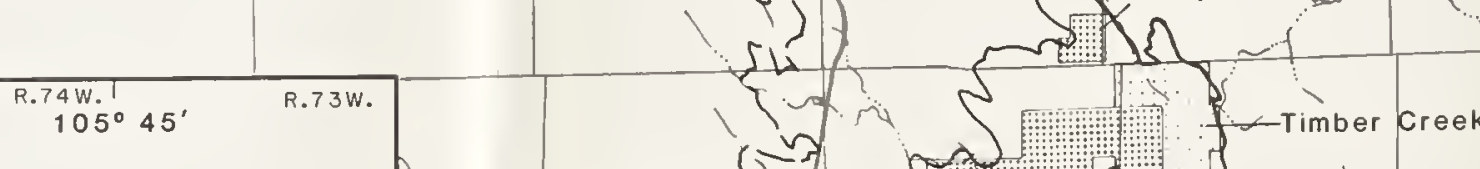

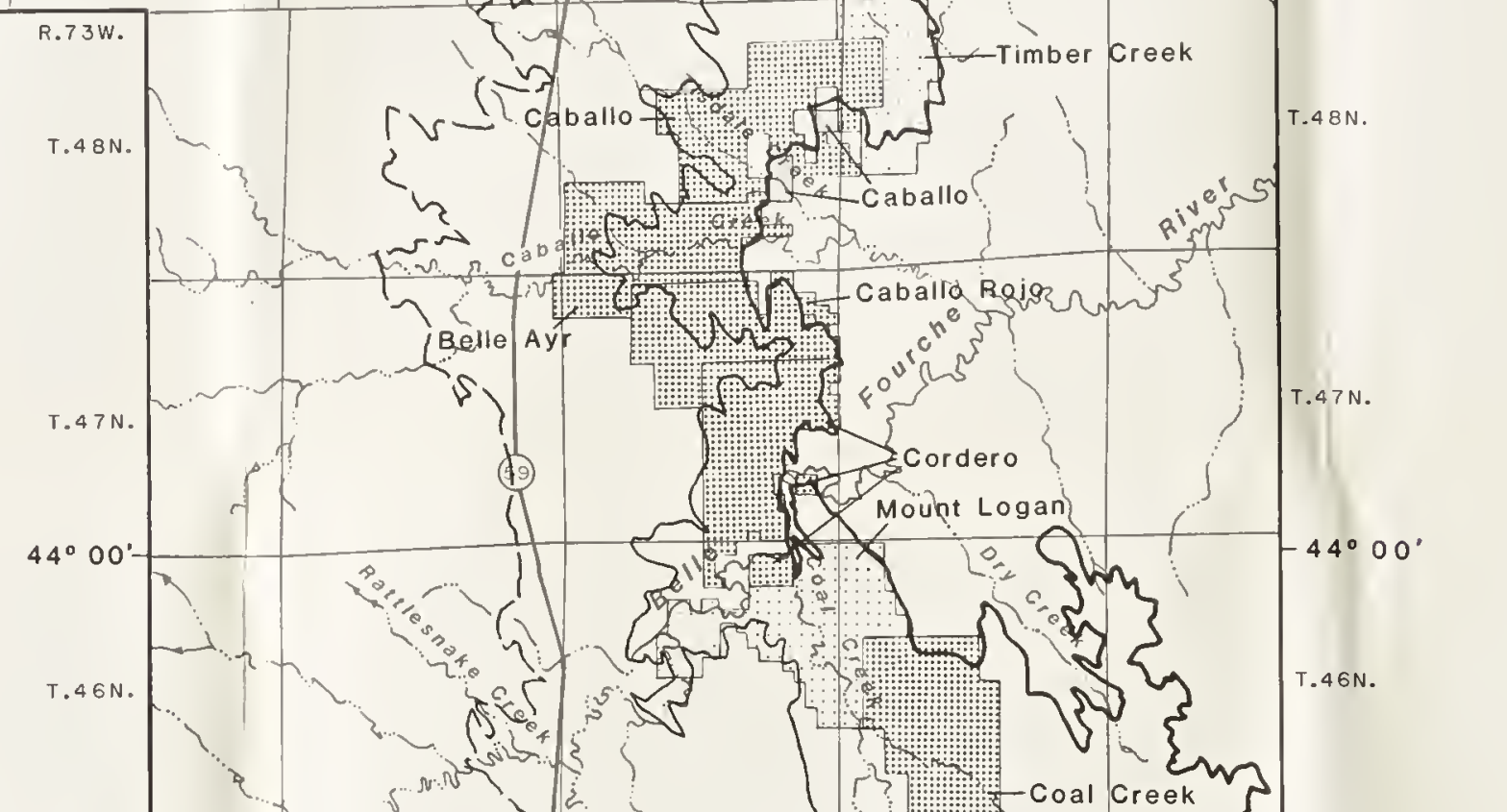

Wh trom mine-permit applications on illo al he Wyoming Deparimont ol EnvironCoal Tracts and Pre Areas tor Selected Coplicaction and Prom Bureau of Land Applications from U.S. Bureau or Land Overburden thickness from R.W. Jones, Wyoming Geological Survey, 1987.

1: $13^{\circ}$
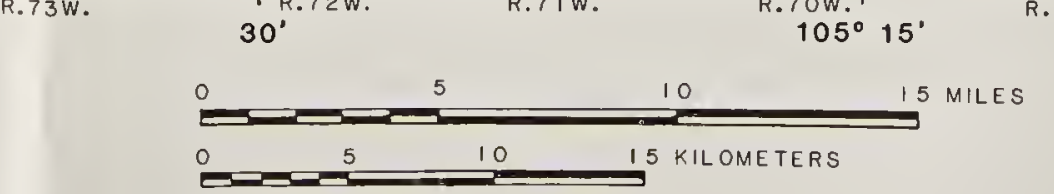

MAP SHOWING STATUS OF COAL LEASING, 1987, AND OVERBURDEN THICKNESS, EASTERN 


\section{GEOLOGY LIBRARY.}

\section{WATER-RESOURCES INVESTIGATIONS REPORT 88-4046 PLATE 1}

\section{EXPLANATION}

COAL-LEASING STATUS

Coal-lease area--Existing and proposed mines

Selected Coal Tract

Area with Preference Right Lease Application

LINE OF EQUAL THICKNESS OF OVERBURDEN, IN FEET

200

500

APPROXIMATE EASTERN EXTENT OF WYODAK COAL BED OF TONGUE RIVER MEMBER OF FORT UNION FORMATION OR STRATIGRAPHICALLY EQUIVALENT COAL BED 

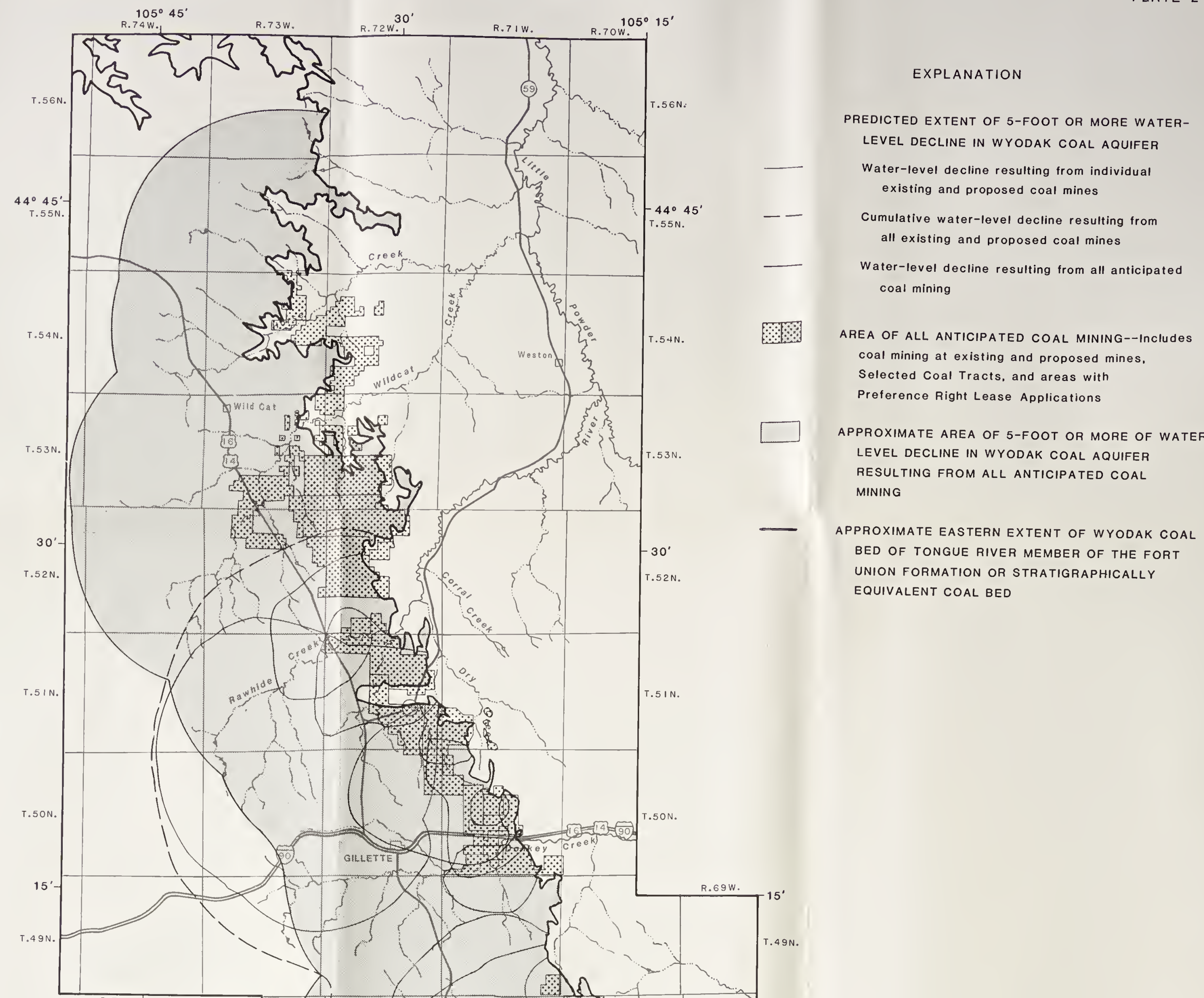

APPROXIMATE EASTERN EXTENT OF WYODAK COAL BED OF TONGUE RIVER MEMBER OF THE FORT UNION FORMATION OR STRATIGRAPHICALLY EQUiVALENT COAL BED

${ }_{1050}^{74 W .1} 45$

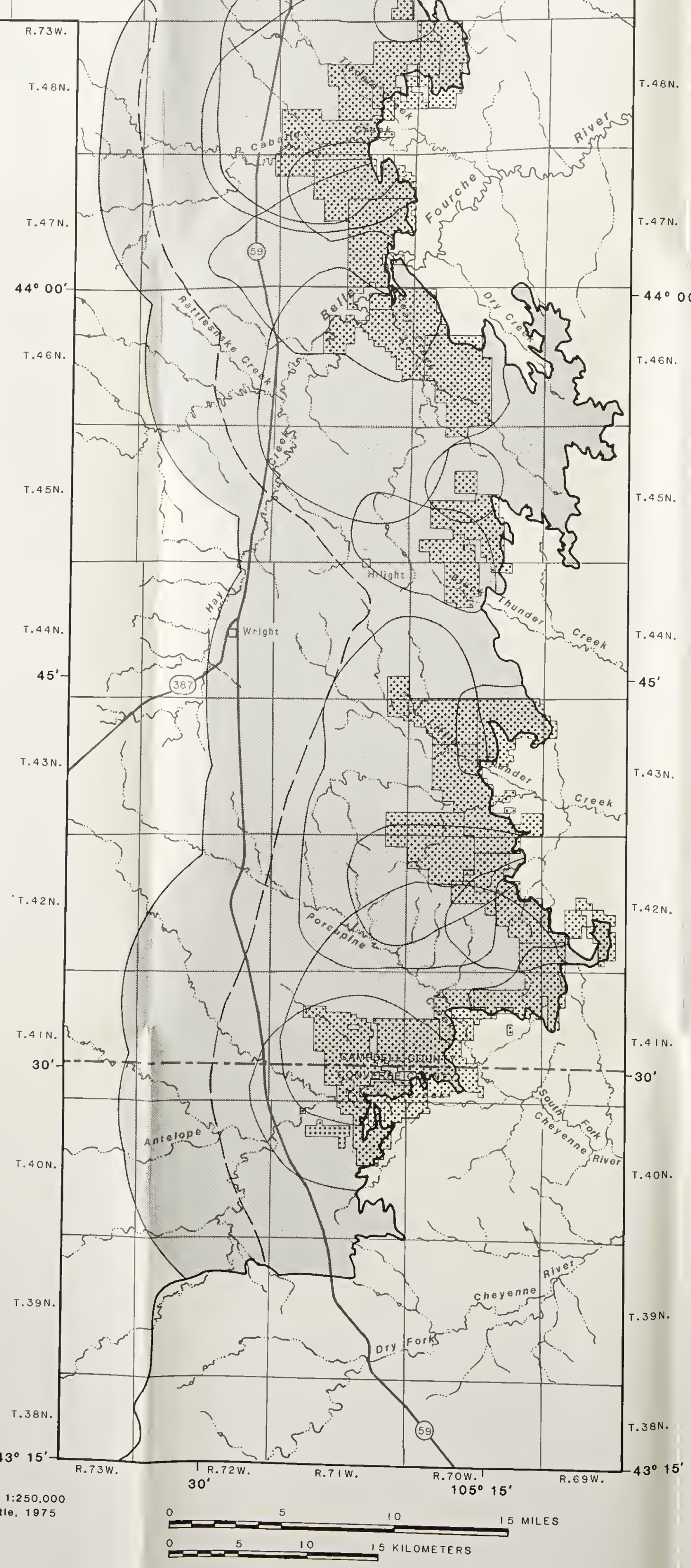

$$
-
$$

$$
\text { o. }
$$

Predicted extent of 5 -foot or more of water-level decline in the Wyodak coal aquifer resulting from axisting and proposed coal mining obtained from Departen applications on file at the Wyoming Department of Environmental Quality, 1987. 


\section{WATER-RESOURCES INVESTIGATIONS REPORT 88-4046 PLATE 2}

\section{EXPLANATION}

PREDICTED EXTENT OF 5-FOOT OR MORE WATERLEVEL DECLINE IN WYODAK COAL AQUIFER Water-level decline resulting from individual existing and proposed coal mines

Cumulative water-level decline resulting from all existing and proposed coal mines

Water-level decline resulting from all anticipated coal mining

AREA OF ALL ANTICIPATED COAL MINING--Includes coal mining at existing and proposed mines, Selected Coal Tracts, and areas with Preference Right Lease Applications

APPROXIMATE AREA OF 5-FOOT OR MORE OF WATERLEVEL DECLINE IN WYODAK COAL AQUIFER RESULTING FROM ALL ANTICIPATED COAL MINING 
DEPARTMENT OF THE INTERIOR Whepared in Cooperation With the U.S. GEOLOGICAL SURVEY DEPARTMENT OF THE INTERIOR
U.S. GEOLOGICAL SURVEY OS. OFFICE OF SURE SURACE MINING

WATER-RESOURCES INVESTIGATIONS REPORT $88-4046$
PLATE 3

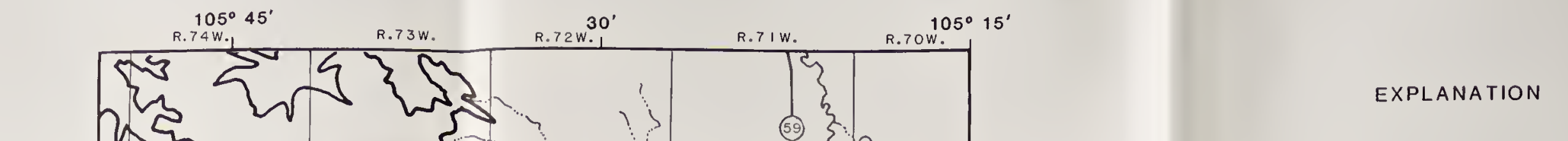

WATER-SUPPLY WELL--Located on map at the center of the quarter-quarter section

Completed in wasatch aquifer

completed in Wyodak coal aquifer

APPROXIMATE AREA OF 5-FOOT OR MORE OF WATER-LEVEL DECLINE IN WYODAK COAL AQUIFER RESULTING FROM ALL ANTICIPATED COAL MINING--Includes coal mining at existing and proposed mines, Selecled Coal Tracts, and areas with Preference Right Lease Applications

APPROXIMATE EASTERN EXTENT OF WYODAK COAL BED OF TONGUE RIVER MEMBER OF FORT UNION FORMATION OR STRATIGRAPHICALLY EQUIVALENT COAL BED

Whation of wells from the Office of the Wyoming State Engineer, 1987.
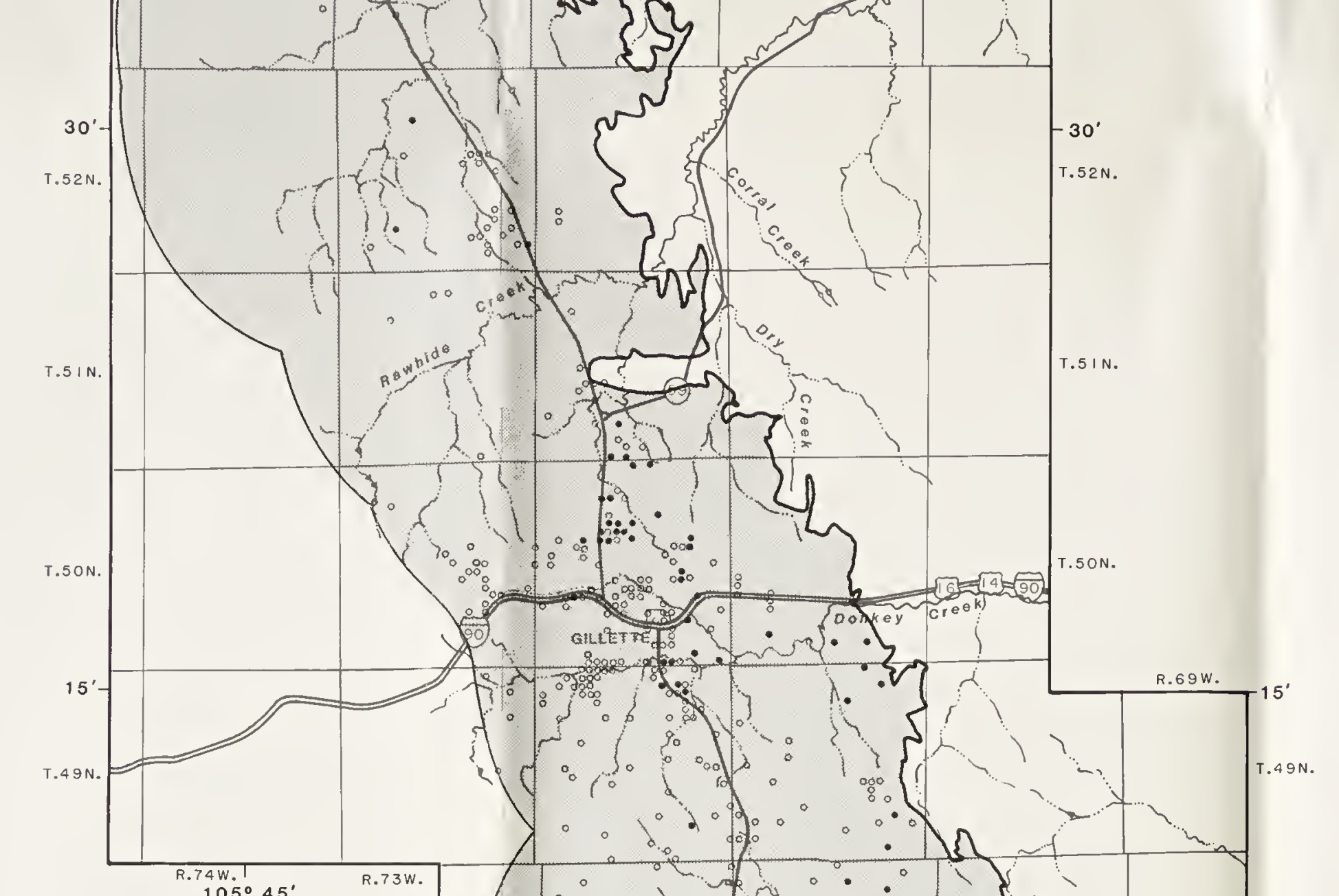

${ }^{R .74 W .1}{ }^{R} 5^{\circ} 45^{\prime}$
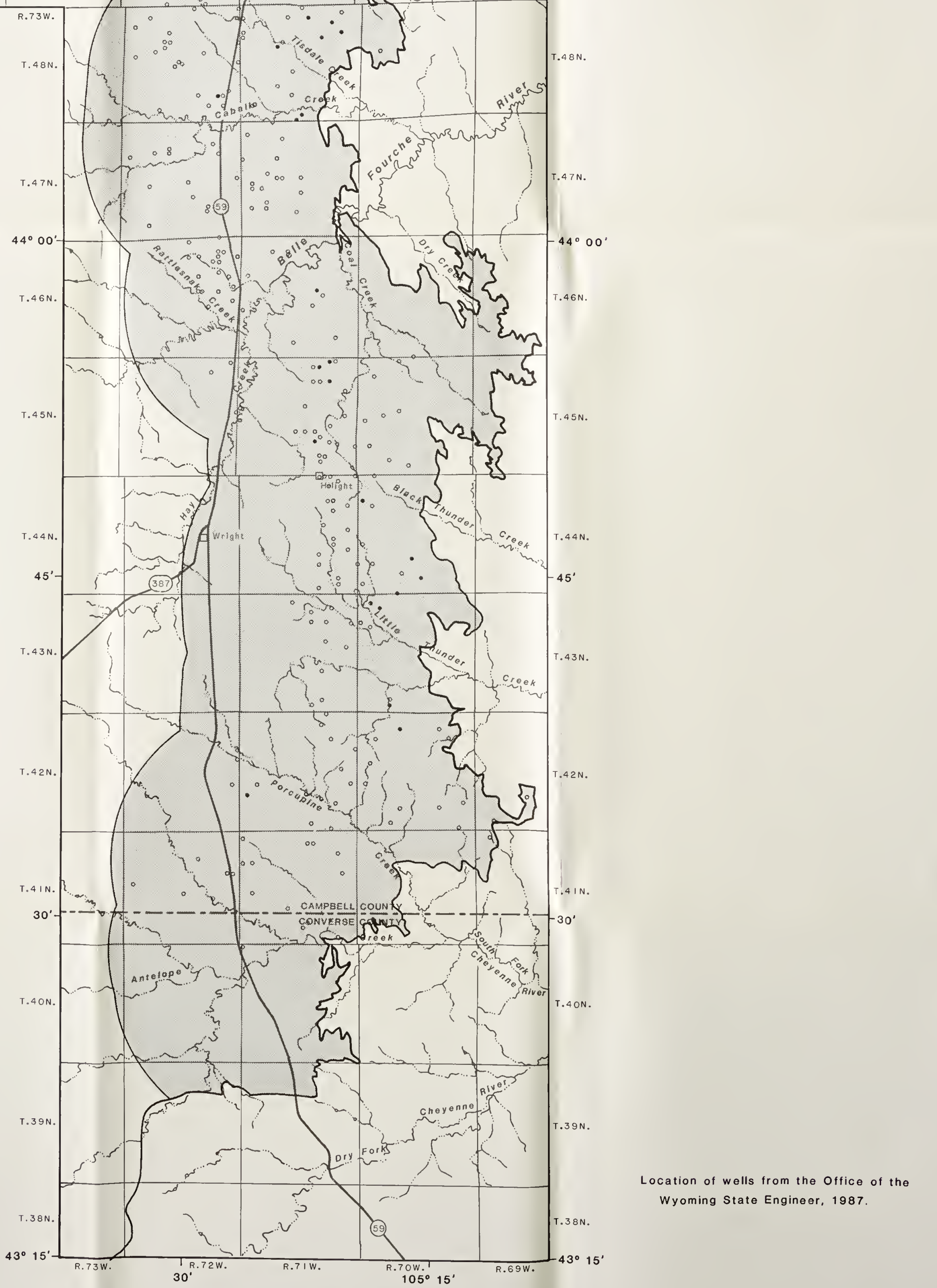

MAP SHOWING LOCATION OF WATER-SUPPLY WELLS COMPLETED IN THE WASATCH AQUIFER AND WYODAK COAL AQUIFER IN THE AREA OF WATER-LEVEL DECLINE RESULTING FROM ALL ANTICIPATED COAL MINING, EASTERN POWDER RIVER STRUCTURAL BASIN, 
WATER-RESOURCES INVESTIGATIONS REPORT 88-4046 PLATE 3

\section{EXPLANATION}

WATER-SUPPLY WELL--Located on map at the center of the quarter-quarter section Completed in Wasatch aquifer Completed in Wyodak coal aquifer

APPROXIMATE AREA OF 5-FOOT OR MORE OF WATER-LEVEL DECLINE IN WYODAK COAL AQUIFER RESULTING FROM ALL ANTICIPATED COAL MINING--Includes coal mining at existing and proposed mines, Selected Coal Tracts, and areas with Preference Right Lease Applications

APPROXIMATE EASTERN EXTENT OF WYODAK COAL BED OF TONGUE RIVER MEMBER OF FORT UNION FORMATION OR STRATIGRAPHICALLY EQUIVALENT COAL BED 
DEPARTMENT OF THE INTERIOR
U.S. GEOLOGICAL SURVEY
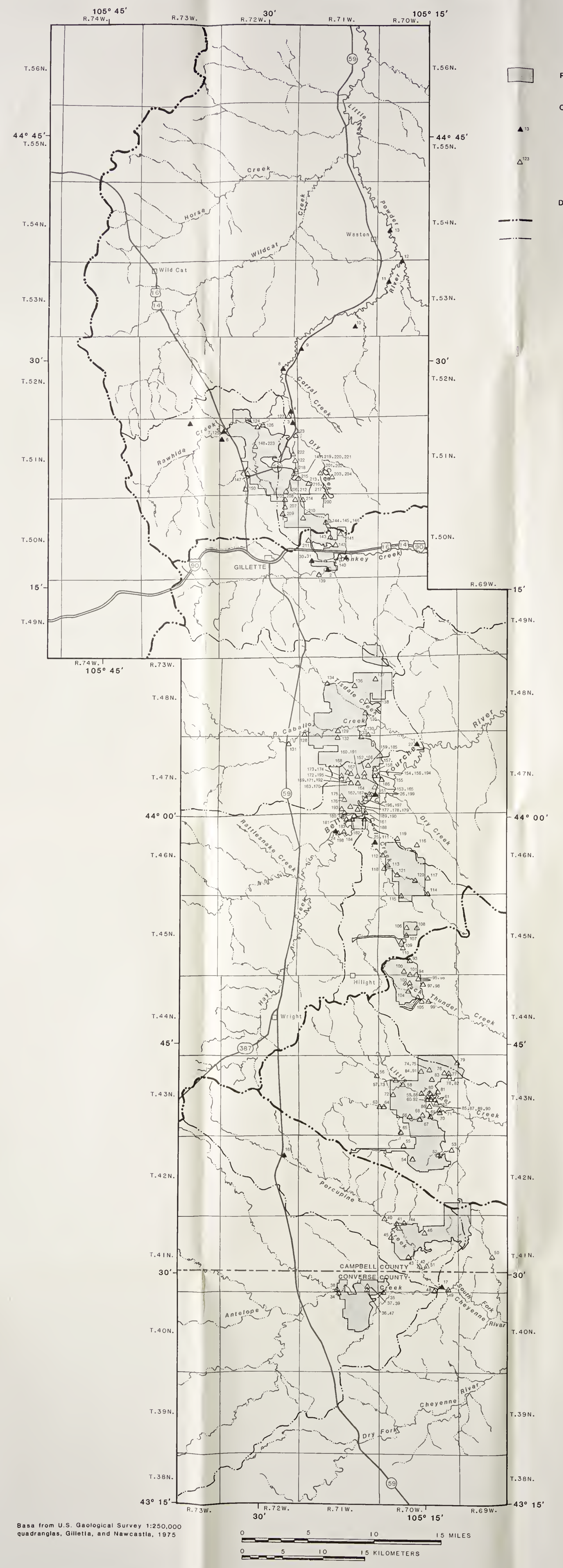

MAP SHOWING PROJECTED MAXIMUM DISTURBED AREAS, LOCATION OF STREAMFLOWGAGING STATIONS AND DRAINAGE-BASIN BOUNDARIES, EASTERN POWDER RIVER STRUCTURAL BASIN, NORTHEASTERN WYOMING. 
WATER-RESOURCES INVESTIGATIONS REPORT 88-4046

PLATE 4

\section{EXPLANATION}

\section{PROJECTED MAXIMUM AREA DISTURBED DURING COAL MINING}

OPERATION OF STREAMFLOW-GAGING STATIONS

U.S. Geological Survey--Numeral is site number listed in table 14

Coal-mining company--Numeral is site number listed in table 33

\section{DRAINAGE BASINS}

Basin boundary

Subbasin boundary 
DEPARTMENT OF THE INTERIOR

WYOMING PEP PARED IN COOPERATION WITH THE
U.S. OFFICE OF SURFACE MINING

U.S. GEOLOGICAL SURVEY
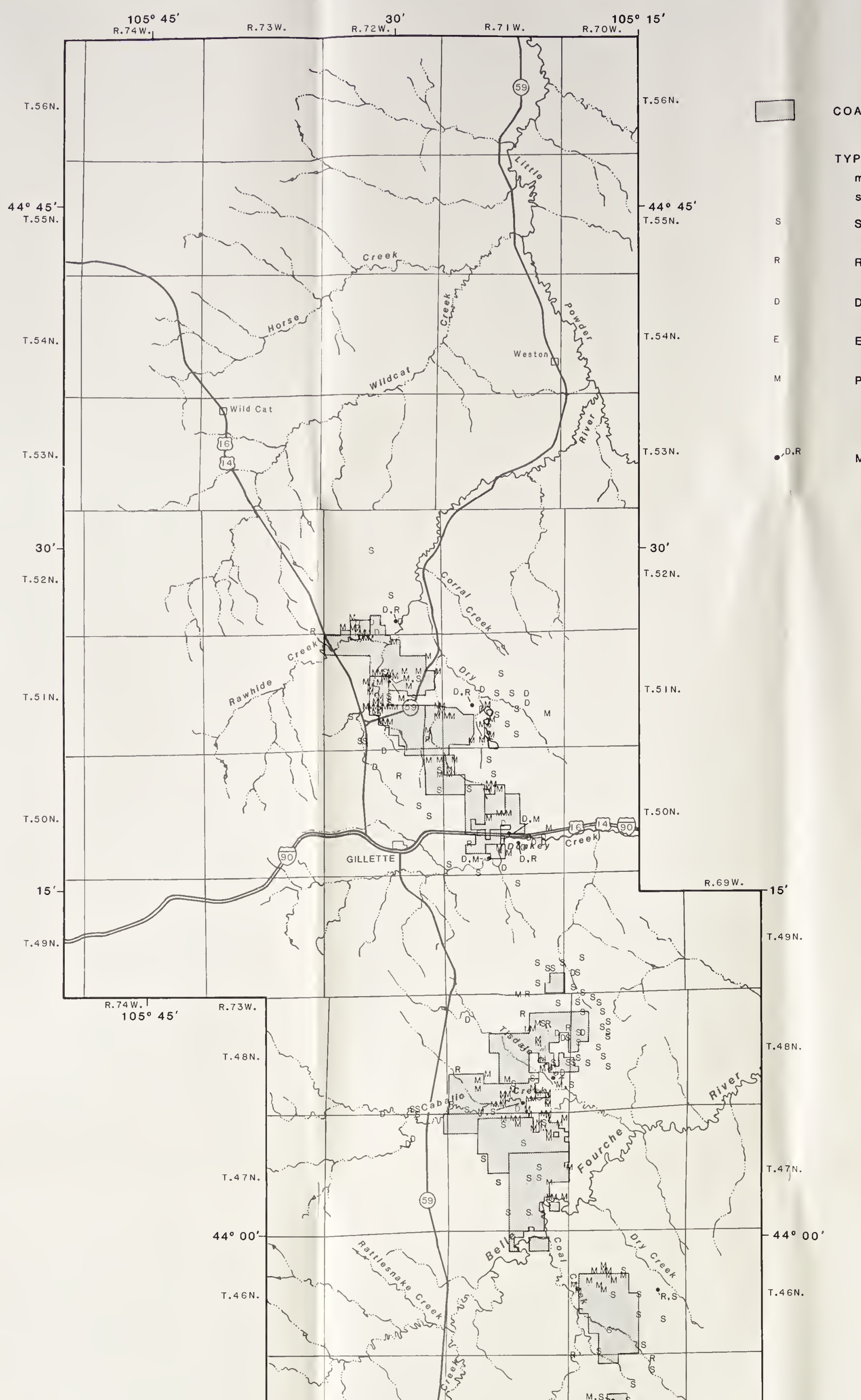

Base trom U.S. Geologicel Survey 1:250,000
quadrangles, Gillette, end Newcestie, 1975

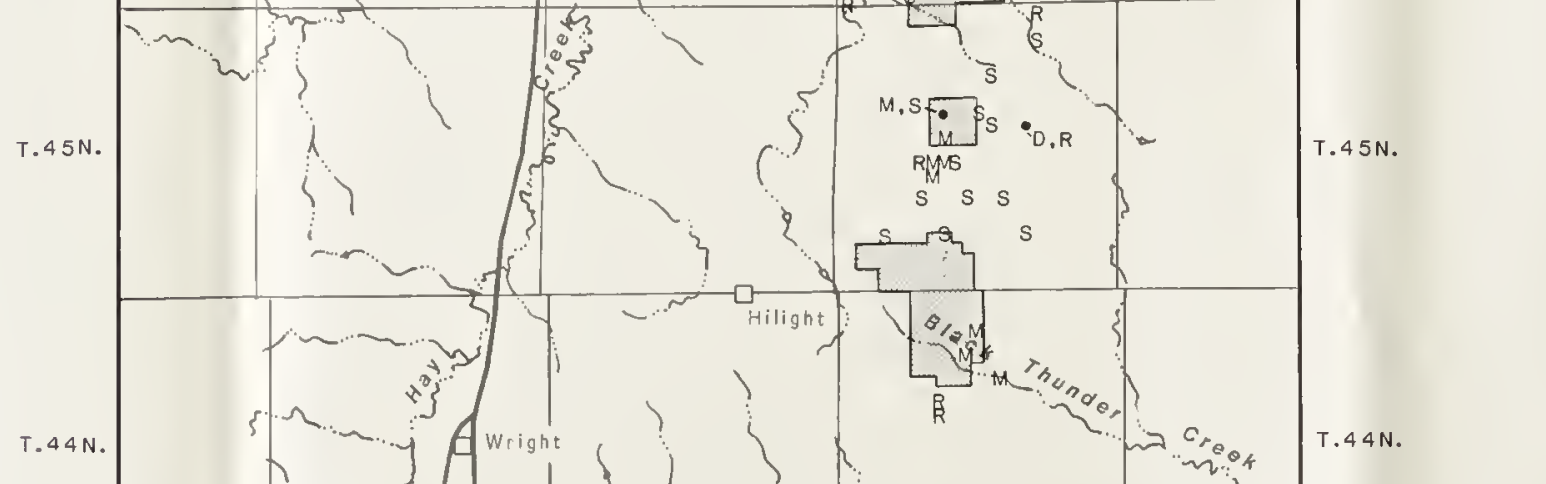

EXPLANATION

\section{COAL-LEASE AREA} map at the center of the quarter-quarter

slock reser

Stock reservoir

Reservoir

Ditch

Enlargement

Permit issued to coal-mining company (primarily for sediment-retention ponds)

water right located in same quarter-quarter section 


\section{WATER-RESOURCES INVESTIGATIONS REPORT 88-4046 PLATE 5}

\section{EXPLANATION}

COAL-LEASE AREA

TYPE OF SURFACE-WATER RIGHT--Located on map at the center of the quarter-quarter section

Stock reservoir

Reservoir

Ditch

Enlargement

Permit issued to coal-mining company (primarily for sediment-retention ponds)

More than one surface-water right located in same quarter-quarter section 




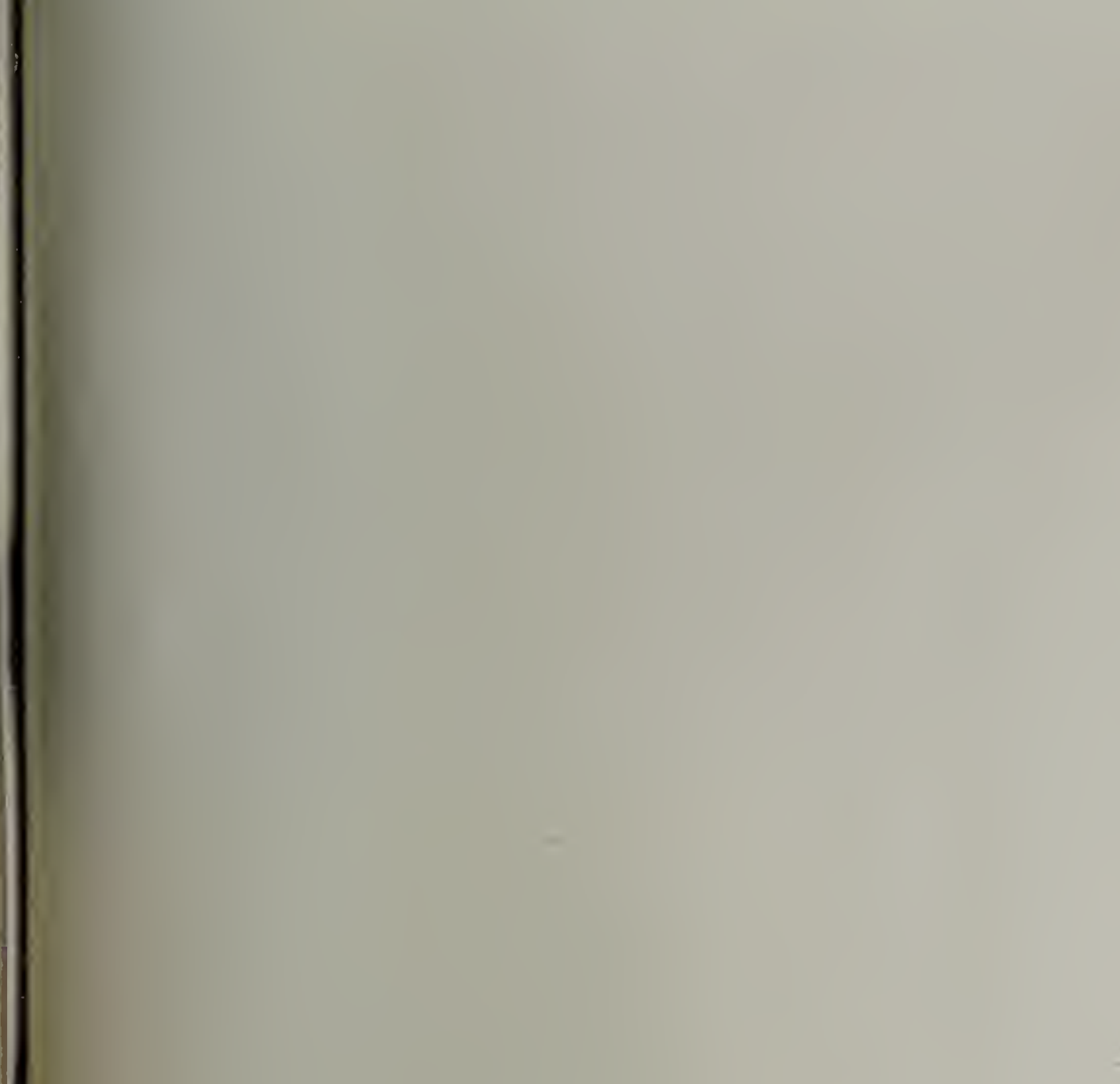


UNIVERSTTY OF ILLINOIS-URBANA

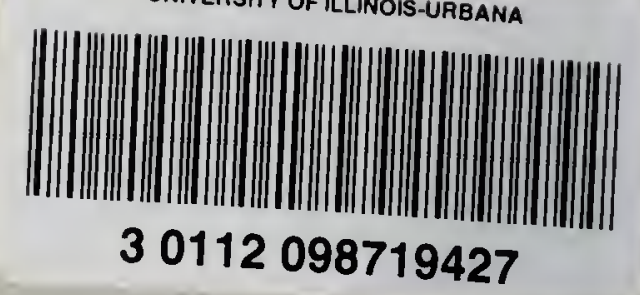

